\author{
UNIVERSIDADE DE SÃO PAULO \\ INSTITUTO DE ESTUDOS BRASILEIROS \\ PROGRAMA DE PÓS-GRADUAÇÃO \\ CULTURA E IDENTIDADES BRASILEIRAS
}

HELENIRA PAULINO

Carlos Oswald: a gravura como obra de arte na primeira metade do século XX no Rio de Janeiro 


\author{
UNIVERSIDADE DE SÃO PAULO \\ INSTITUTO DE ESTUDOS BRASILEIROS \\ PROGRAMA DE PÓS-GRADUAÇÃO \\ CULTURA E IDENTIDADES BRASILEIRAS
}

\title{
Carlos Oswald: a gravura como obra de arte na primeira metade do século XX no Rio de Janeiro
}

\author{
HELENIRA PAULINO
}

Dissertação apresentada ao Programa de PósGraduação Culturas e Identidades Brasileiras do Instituto de Estudos Brasileiros da Universidade de São Paulo, para a obtenção do título de Mestre em Filosofia.

Área de concentração: Estudos Brasileiros

Orientadora: Profa. Dra. Mayra Laudanna

São Paulo

2017 
Paulino, Helenira

Carlos Oswald : a gravura como obra de arte na primeira metade do século XX no Rio de Janeiro / Helenira Paulino -- São Paulo, 2017.

Orientadora : Profa. Dra. Mayra Laudanna.

Dissertação (Mestrado) - Universidade de São Paulo. Instituto de Estudos Brasileiros. Programa de Pós-Graduação em Culturas e Identidades Brasileiras. Área de concentração: Estudos Brasileiros. Linha de pesquisa: Brasil: a realidade da criação, a criação da realidade.

Versão do título para o inglês: Carlos Oswald : etching as art in the first half of the XX century in Rio de Janeiro.

Descritores: 1. Oswald, Carlos, 1882-1971 2. Gravura 3. História da gravura 4. Artes plásticas 5. Artes gráficas 6. Gravura em metal I. Universidade de São Paulo. Instituto de Estudos Brasileiros. Programa de Pós-Graduação II. Título. 
Nome: PAULINO, Helenira.

Título: Carlos Oswald: A gravura como obra de arte na primeira metade do século XX no Rio de Janeiro

Dissertação apresentada ao Instituto de Estudos Brasileiros da Universidade de São Paulo para obtenção de título de Mestre em Filosofia.

Aprovado em:

Banca examinadora

Profa. Dra.

Instituição

Julgamento

Prof. Dr.

Instituição

Julgamento

Prof. Dr.

Instituição

Julgamento 

Aos meus pais, pelo apoio constante. 



\section{AGRADECIMENTOS}

À Profa. Dra. Mayra Laudanna, pela dedicação a este trabalho e por todos os aprendizados que me proporcionou, muito contribuindo para o meu crescimento intelectual e meu desenvolvimento como pesquisadora.

Ao Museu Nacional de Belas Artes/IBRAM/MinC, por possibilitar a pesquisa das obras de Carlos Oswald, bem como o acesso aos documentos do artista guardados pela Instituição.

À Fundação Biblioteca Nacional, por possibilitar o acesso às gravuras de Carlos Oswald guardadas no acervo da Instituição.

À Família Oswald, na pessoa de Maria Clara Monteiro Sobrino Porto, pela gentileza em permitir a reprodução das obras de Carlos Oswald. 



\section{RESUMO}

\section{PAULINO, Helenira. Carlos Oswald: a gravura como arte na primeira metade do século}

XX. 2017. 336p. Dissertação (Mestrado em Filosofia, Área de concentração Estudos Brasileiros) - Instituto de Estudos Brasileiros, Universidade de São Paulo, São Paulo, 2017.

Esta dissertação estuda a gravura de Carlos Oswald (1882 - 1971) tendo em vista os conceitos do próprio artista expostos em seus diversos textos, destacadamente o livro autobiográfico do autor, publicado em 1957, Como me tornei pintor, e os artigos impressos na revista Vozes de Petrópolis. O trabalho evidencia a modernidade desse artista que instala no Rio de Janeiro o ensino da gravura em metal como arte. O conceito que Oswald traz para o país sobre a gravura dista da concepção aqui vigente, visto que, ao menos, até as primeiras décadas do século XX, a gravura é considerada técnica para a reprodução de imagens, sendo arte aplicada à indústria. A fim de demonstrar o que se afirma, analisa-se documentos e textos sobre a Academia Imperial de Belas Artes e sobre o Liceu de Artes e Ofícios, ambas instituições do Rio de Janeiro. É no Liceu que Oswald implanta o ensino da gravura como obra de arte, incialmente em 1914 e, posteriormente, em 1930, sendo responsável pela formação de vários gravadores brasileiros. Nesta pesquisa, demonstra-se, ainda, que a obra gráfica de Oswald, nas duas décadas iniciais de 1900, não é analisada pela maior parte dos jornalistas que tratam das exposições de artes plásticas, o que também evidencia que a gravura não é considerada da mesma maneira que a pintura e a escultura no país. A análise das gravuras do artista é realizada, assim, a partir dessas conceituações, bem como das proposições de Oswald explicitadas em seus escritos. A análise concentra-se nas gravuras do artista pertencentes à coleção do Museu Nacional de Belas Artes/Ibram/MinC e ao acervo da Fundação Biblioteca Nacional - Brasil.

Palavras-chave: Carlos Oswald - Gravura - História da Gravura - Artes Plásticas - Artes Gráficas - Gravura em metal 



\begin{abstract}
PAULINO, Helenira. Carlos Oswald: etching as art in the first half of the $\mathbf{X X}$ century in Rio de Janeiro. 2017. 336p. Dissertação (Mestrado em Filosofia, Área de concentração Estudos Brasileiros) - Instituto de Estudos Brasileiros, Universidade de São Paulo, São Paulo, 2017.

This dissertation studies the etchings of Carlos Oswald (1882-1971) in light of his own concepts disclosed in many of his texts, in particular in the autobiography entitled Como me tornei pintor, published in 1957, and in articles published in the magazine Vozes de Petrópolis. The innovativeness of the artist, who established the teaching of metal etching as art in Rio de Janeiro, is evident. With the goal of demonstrating how Oswald's concept of metal etching as art distanced it self from Brazil's first decades of the XX century firmly established conception of engraving as an art applied to the industry, an analysis of documents and texts about the Academia Imperial de Belas Artes and the Liceu de Artes e Ofícios was performed. Oswald establishes in the Liceu de Artes e Ofícios the teaching of etching as Art, being responsible for the formation of many Brazilian etchers. Here it is also demonstrated that the etchings of Carlos Oswald, during the first two decades of the 1900s, were not evaluated by most art critics for not being considered art. The analysis of the artist etching presented here is based on this above-mentioned conception, as well as in Oswald's own propositions expressed in his texts. The research is centered in etchings belonging to the collections of the Museu Nacional de Belas Artes/Ibram/MinC and the Fundação Biblioteca Nacional - Brasil.
\end{abstract}

Key Works: Carlos Oswald - Engraving - Etching History - Visual Arts - Graphic Arts Metal Etching 



\section{SUMÁRIO}

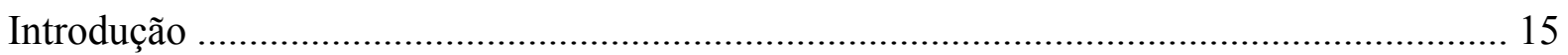

1. A gravura no Rio de Janeiro no final do século XIX e início do século XX ...................... 21

1.1. Gravura na Academia Imperial de Belas Artes …………………………………….... 23

1.2. A gravura no Liceu de Artes e Ofícios .................................................................... 29

2. A recepção crítica das águas-fortes de Carlos Oswald ..................................................... 39

2.1. A crítica da obra de Carlos Oswald nas duas décadas iniciais do século XX ................. 42

2.2. Adalberto Mattos e Renato Almeida: a água-forte como obra de arte ............................. 49

2.3. A gravura como obra de arte: água-forte ………………………………………….... 55

3. O ensino e a divulgação da água-forte como obra de arte ................................................. 61

3.1. A oficina de água-forte do Liceu de Artes e Ofícios: 1914 - 1919 .................................. 61

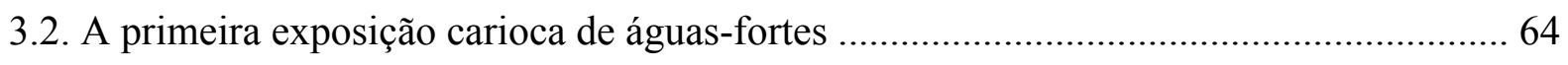

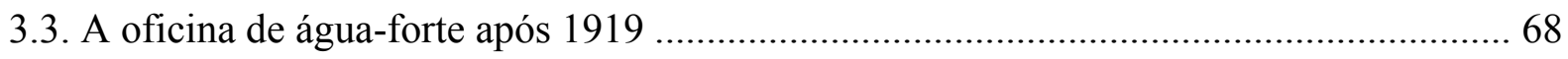

3.4. O curso de artes gráficas da Fundação Getúlio Vargas .................................................. 72

3.5. O Atelier de Arte: a divulgação da gravura à água-forte ……………………………..... 77

4. A obra gráfica de Carlos Oswald: análise e discussão a partir dos conceitos do artista expostos em seus escritos ........................................................................................ 85

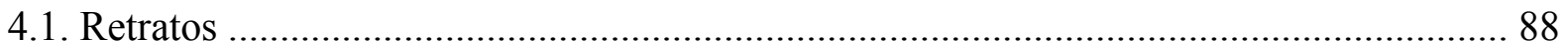

4.2. Cenas com a figura humana: composições ……………………………………….... 100

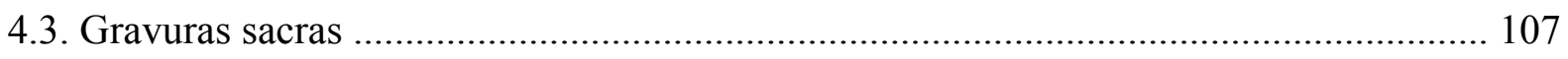

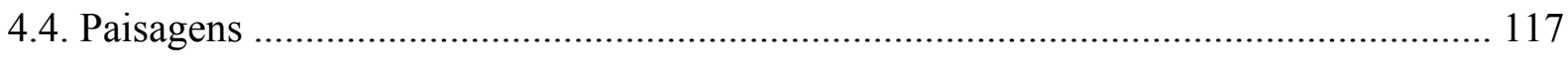

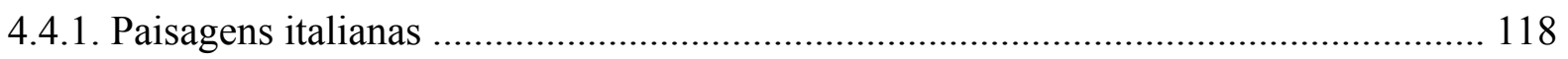

4.4.2. Paisagens brasileiras ...................................................................................... 127

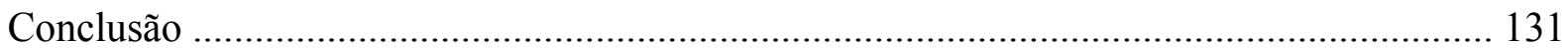

Catalogação das gravuras de Carlos Oswald: obras do Acervo da Fundação Biblioteca

Nacional - Brasil e da coleção do Museu Nacional de Belas Artes/IBRAM/MinC ............. 133

Referências bibliográficas ............................................................................................... 323 



\section{Introdução}

Carlos Oswald (1882 - 1971), brasileiro nascido na Itália, inicia seus estudos de artes plásticas nos primeiros anos do século XX, após completar o curso que lhe confere o diploma de físico-matemático, sem, contudo, continuar a escola que poderia lhe formar como engenheiro. Oswald abandona as ciências exatas em favor das Belas Artes, a qual aprende como aluno livre da Academia de Florença ${ }^{1}$. O artista dedica-se, ao longo de sua carreira, à pintura, ao mural, ao vitral e à gravura, entre outras artes. O presente trabalho discute a sua obra gravada, recorte de sua produção realizado em razão da importância do conjunto dessa arte para a história da gravura brasileira, como demonstrar-se-á.

É na Itália que Carlos Oswald começa a gravar em 1908, após o retorno de sua primeira viagem ao Brasil, realizada em 1906. O artista afirma que ali foi um dos primeiros cultores da água-forte ${ }^{2}$, como obra de arte. A afirmação, embora hiperbolizada, é coerente com a pesquisa de Giorgio Marini sobre a presença de artistas estrangeiros, bem como de italianos, na capital da Toscana nos primeiros anos do século XX que praticam a gravura. Marini afirma que há em Florença, no período, o "renascimento" da água-forte, sendo esta arte ali praticada por alguns gravadores ${ }^{3}$.

O relato de Oswald, presente em sua autobiografia, é a única fonte que informa sobre o seu início entre os ácidos e os metais. Este seu texto, Como me tornei pintor ${ }^{4}$, publicado em 1957, sempre serviu de base para as publicações sequentes sobre o artista, sendo referência central para outras bibliografias, como o livro da filha do pintor - Carlos Oswald (1882 1971): Pintor da Luz e dos Reflexos ${ }^{5}$, que basicamente repete as informações daquele. O texto do gravador é de importância também para este trabalho, visto que nele, além de o artista memorar eventos de sua vida, ele expõe suas ideias e proposições sobre as artes plásticas. Considere-se, ainda, que a autobiografia, antes de ser impressa em volume único, foi publicada como artigos em revista da editora petropolitana Vozes, revista esta que durante anos contou com a colaboração do autor.

\footnotetext{
${ }^{1}$ Para mais dados biográficos sobre Carlos Oswald, ver sua autobiografia, Como me tornei pintor, de 1957 , publicada pela editora Vozes, Petrópolis.

${ }^{2}$ Carlos Oswald, Como me tornei pintor, Petrópolis, Vozes, 1957, p. 25.

${ }^{3}$ Giogio Marini, "L’incisione a Firenze a ridosso della Grande Guerra: spunti per gli esordi di Carlo Sbisà", Trieste, 2014.

${ }^{4}$ Carlos Oswald, op. cit., 1957.

${ }^{5}$ Maria Isabel Oswald Monteiro, Carlos Oswald (1882 - 1971): Pintor da Luz e dos Reflexos, Rio de Janeiro, Casa Jorge, 2000.
} 
Em 1933, Carlos Oswald publica seu primeiro artigo ${ }^{6}$ na Vozes de Petrópolis, periódico católico de cultura, como seu subtítulo informa. Os textos de Oswald, ao menos quarenta e sete artigos impressos até 1956 - incluindo os capítulos de Como me tornei pintor -, abordam, principalmente, a arte sacra, mas tratam também questões das artes plásticas de modo geral, alguns deles referindo-se à água-forte. Há, ainda, notícias de que textos de Oswald são publicados em outros periódicos, fluminenses e paulistas, revistas e jornais tanto ligados à Igreja Católica, quanto laicos ${ }^{7}$.

Os artigos de Oswald na revista petropolitana, bem como sua autobiografia e alguns manuscritos do artista, guardados no Arquivo Histórico do Museu Nacional de Belas Artes/IBRAM/MinC, Rio de Janeiro, são fonte de pesquisa para esta dissertação; visto que o estudo aqui empreendido sobre a obra gráfica de Carlos Oswald tem em conta as proposições desse artista expostas nesses escritos.

Entre as primeiras águas-fortes de Oswald e a publicação de seus textos há, evidentemente, certa distância temporal; mais do que isso, sua autobiografia é memória e, como tal, monumentaliza sua vida e suas atividades profissionais em suas páginas. Não por isso tais escritos deixam de registrar concepções do artista que importam para a análise de suas obras, uma vez que neles lê-se ideias fundamentais do artista sobre as artes plásticas, como se verá. Não se considera que as gravuras de Carlos Oswald sejam demonstrações de suas ideias escritas, visto que não há tradução entre as diferentes artes. Deste modo, recorre-se às proposições do artista, explanadas em seus textos, para evidenciar o que se vê em suas obras de arte plásticas.

Relativamente à sua gravura, de 1908 a 1912, anos nos quais ele realiza suas obras ainda na Europa, Oswald grava cerca de cinquenta matrizes. Nos anos seguintes, já no Brasil, o água-fortista, mesmo que em períodos delimitados, não deixa de fazer essa arte pela qual afirma ter um interesse "congênito" ". Oswald continua sua pesquisa gráfica até a década de 1950, quando realiza gravuras para serem comercializadas pelo Atelier de Arte, editora de artes gráficas, na qual ele é diretor artístico. Na década de 1960, já afetado por doença, quase cego, ele realiza suas últimas águas-fortes e pontas secas, algumas delas publicadas em álbum organizado pela Gravura de Arte Editora (GAE).

\footnotetext{
${ }^{6}$ O primeiro artigo de Oswald na revista Vozes de Petrópolis, publicado no ano de 1933, é uma conferência que ele pronuncia para adentrar no Círculo de Estudos São Norberto: "Arte, Religião e Moral".

${ }^{7}$ O catálogo da exposição póstuma "Carlos Oswald" no Museu Nacional de Belas Artes do Rio de Janeiro, em 1982, apresenta lista realizada por Isabel Oswald Monteiro com indicações de textos do artista publicados em periódicos como o Correio da Noite e o Jornal do Commercio, ambos do Rio de Janeiro.

${ }^{8}$ Carlos Oswald, op. cit., 1957, p. 24.
} 
Embora não seja a intenção desta pesquisa demarcar pioneirismos, é de importância para a história da gravura brasileira reconhecer que Oswald apresenta suas obras impressas a partir de matrizes de metal como obras de arte já nas primeiras décadas do século XX no Brasil. Ele o faz mesmo cercado por concepções de época que entendem a gravura como arte aplicada à indústria. Por essa razão, procurar-se-á neste trabalho evidenciar a importância desse artista que implanta no Rio de Janeiro o ensino da gravura como arte. Conceito moderno visto que afasta a gravura de sua função técnica, que serve apenas à reprodução de imagens diversas, relacionada à tipografia, elevando-a à de obra de arte, para ser exposta em conjunto com a pintura e a escultura. Evidencia-se, ainda, o esforço do artista em instaurar no Liceu de Artes e Ofícios carioca o ensino da calcografia, inicialmente, em 1914 - quando os frequentadores os ateliê são os artistas que Oswald convida para experimentar a água-forte, visto à falta de interesse nessa arte - e, posteriormente, em 1930 - quando a oficina desse estabelecimento reabre e alguns alunos chegam a se formar.

Objetivando esclarecer o que se discute sobre a gravura ser considerada arte aplicada à indústria até, ao menos, as duas primeiras décadas do século XX no Brasil, e explicitar a modernidade de Oswald, foi necessário considerar o ensino da gravura na Academia Imperial de Belas Artes (AIBA) e no Liceu de Artes e Ofícios (LAO), ambas instituições de ensino da então capital do Império no final do século XIX. Na AIBA, a gravura entendida como arte nobre é a gravura de medalhas e pedras preciosas, sendo que as técnicas gráficas não são ensinadas na instituição até décadas depois da Proclamação da República. Já no LAO do Rio de Janeiro, o ensino da gravura, enquanto as diferentes técnicas gráficas como a calcografia e a xilogravura, é planejado por serem essas técnicas necessárias à confecção de livros ilustrados e demais publicações, cuja comercialização poderia trazer recursos financeiros ao estabelecimento filantrópico de ensino. Apesar de essa ser a concepção que fundamenta a implantação da oficina de água-forte no LAO, é, justamente, ali que Oswald ensina os processos de gravação das placas de metal não a artesãos hábeis, mas a artistas.

A análise das notas e dos artigos de jornais do início do século XX que tratam das exposições que Oswald participa ou das que ele realiza também evidencia que a gravura não é considerada da mesma maneira que a pintura e a escultura pelos missivistas que escrevem sobre arte. Por isso, suas gravuras não são discutidas nos periódicos sendo apenas brevemente elogiadas ou censuradas por sua técnica, como "bons" ou "maus" trabalhos. Dois autores, entretanto, são exceção entre os jornalistas, pois analisam, já no final da década de 1910, as gravuras de Oswald e até as qualificam como arte de grande qualidade produzida pelo artista. 
Oswald não apenas implanta o ensino da água-forte no LAO do Rio de Janeiro, como também empreende outras iniciativas para a sua divulgação, como a Primeira exposição carioca de águas-fortes, em 1919, e, nas décadas de 1940 e 1950, participa de clubes de gravura e ministra curso sobre o assunto na Fundação Getúlio Vargas (FGV).

A análise das obras do artista se faz, assim, tendo em vista as concepções destacadas acima sobre a gravura, bem como as proposições de Oswald para a sua arte, como afirmou-se, expostas em seus escritos. Não é escopo deste trabalho analisar todas as suas obras gráficas, uma vez que se opta por destacar os vários recursos plásticos que o artista utiliza para elaborar suas obras. Evidencia-se, por isso, os modos de o artista compor a gravura, os quais destacam o ponto e a linha, elementos que, segundo Oswald, são próprios da gravura. A análise das obras abarca diferentes períodos da produção do gravador, tanto na Itália quanto no Brasil, como também os motivos variados que o artista se utiliza na sua produção, tal como a paisagem, o retrato e a arte sacra.

Este trabalho é realizado a partir de gravuras pertencentes à coleção do Museu Nacional de Belas Artes/IBRAM/MinC e ao acervo da Fundação Biblioteca Nacional - Brasil. Obras estas que estão catalogadas anexo a este trabalho ${ }^{9}$. Destaca-se, entretanto, que a pesquisa realizada na literatura existente sobre o artista e em vários periódicos não revelou a existência de muitas outras gravuras além das aqui apresentadas, sendo possível considerar que a catalogação aqui expressa reúne, certamente, a maior parte da obra gravada de Carlos Oswald.

Relativamente às gravuras de Oswald, é importante saber, ainda, que o artista não marca todas as tiragens realizadas a partir de suas matrizes, sendo impossível totalizar o número de exemplares impressos ou mesmo localizar todas as variações de suas obras. Variações que são vistas tanto no modo de limpar as matrizes para impressão, quanto no emprego de cores distintas, como se discutirá. Por essa razão, para a catalogação aqui realizada, decidiu-se considerar que as obras impressas em cores variadas são obras diferentes das monocromáticas, dada a variação que tal mudança provoca nelas. Esta decisão se apoia na própria argumentação do artista sobre as modificações que ele produz em suas obras:

Várias vezes o repeti [o quadro $A$ Última Ceia], não só para corresponder às encomendas como para satisfazer meu desejo de modificar-lhe o aspecto mundano as tonalidades, os fundos, os tamanhos, procurando melhorar a execução, acentuar os caracteres. Posso afirmar que dificilmente se encontrarão dois exemplares iguais,

\footnotetext{
${ }^{9}$ Ao longo deste trabalho as reproduções das gravuras do artista são indicadas por numeração sequencial que refere as obras da catalogação.
} 
cópias. Todos os que existem feitos por minhas mãos são repetições com variantes, todos assinados, todos, pois, originais. ${ }^{10}$

Embora o artista, no trecho destacado de sua autobiografia, refira-se à sua pintura sacra, ele também procede de modo similar com a gravura, realizando modificações em matrizes e, como afirmou-se, imprimindo obras variadas a partir das mesmas placas. Essas impressões não são "repetições", provas de estado ou de impressão, mas sim todas obras originais, assinadas pelo artista.

Assim, a pesquisa e a análise que se realiza nesse trabalho, longe de ser conclusiva, visto a importância e variedade da obra desse artista, pretende apenas evidenciar a modernidade de Carlos Oswald, sua importância como professor de brasileiros ${ }^{11}$, como também a contribuição desse artista, muitas vezes esquecido pela história das artes, para a gravura deixar de ser entendida somente como obra de reprodução ou "arte menor".

\footnotetext{
${ }^{10}$ Carlos Oswald, op. cit., 1957, p. 57.

${ }^{11}$ A ideia de Oswald como pioneiro da gravura no país apenas enquanto professor foi muito difundida em artigos de periódicos, livros e em verbetes de enciclopédias de artes plásticas, principalmente a partir da década de 1960 e após a sua morte - em 1971. Nesses textos, lê-se que Carlos Oswald foi o primeiro professor de água-forte como arte no Brasil, responsável pela formação de diversos gravadores ao longo da primeira metade do século XX, no Rio de Janeiro. É isso que é normalmente destacado sobre a produção do artista, sendo sua obra gráfica apenas citada e raramente analisada. Localiza-se, inclusive, o livro de Teixeira Leite publicado em 1966, como sendo o primeiro a afirmar categoricamente que a importância de Carlos Oswald para a gravura brasileira é como professor. José R. Teixeira Leite, A gravura brasileira contemporânea, Rio de Janeiro, Ed. Expressão e Cultura, 1966. Segue-se a essa publicação uma série de dicionários de artes plásticas e livros de história da arte brasileira, editados nas décadas de 1970 e 1980, que a utilizam como fonte, como por exemplo o de Roberto Pontual. Cf. Roberto Pontual, Dicionário das Artes Plásticas no Brasil, Rio de Janeiro, Ed. Civilização Brasileira, 1969. Ver também: Walmir Ayala, Dicionário de Artistas Plásticos: arquitetura, escultura, pintura, desenho, gravura, artes aplicadas, Brasília, Instituto Nacional do Livro, MEC, 1973. P. M Bardi, História da arte brasileira: pintura, escultura, arquitetura, outras artes, São Paulo, Ed. Melhoramentos, 1975.
} 



\section{A gravura no Rio de Janeiro no final do século XIX e início do século XX}

A discussão da recepção da produção gráfica de Carlos Oswald no Brasil, por meio da análise de textos encontrados em periódicos que comentam as Exposições Gerais de Belas Artes e as demais exposições coletivas que o artista participa ou mesmo as suas individuais, permite apresentar uma apreciação mais adequada sobre a inscrição da água-forte como obra de arte no Brasil no início do século XX. Os textos sobre arte das décadas de 1900 e 1910, em sua maior parte, apenas citam a gravura, evidenciando que no Brasil, desse período, com poucas exceções, há ausência de análise da gravura como obra de arte. Demonstram ainda que aqueles que defendem a gravura como obra de arte, a divulgam em periódicos que são indiferentes a essa discussão. Menciona-se, por exemplo, os textos de Adalberto de Mattos de meados da década de 1910, bem como os da década seguinte, os quais serão tratados adiante; mas não só, pois também os artigos de Carlos Oswald escritos em periódicos das décadas seguintes, como os da revista Vozes de Petrópolis, ainda tentam demonstrar e defender a arte do metal como obra de arte. Essa concepção moderna, em especial no Brasil da primeira metade do século, afasta a gravura da ideia de técnica reprodutiva de obras de arte, o que lhe conferia a ideia de arte a serviço de alguma coisa. É desta concepção que resulta as expressões utilizadas por alguns historiadores de "arte menor" ou "arte maior" da gravura.

Pretende-se, deste modo, entender a inserção da obra gráfica de Carlos Oswald no início do século no Brasil. Por isso, a análise aqui empreendida faz-se sob dois aspectos: o primeiro investiga a inscrição da gravura nas artes plásticas no Rio de Janeiro entre o final do século XIX e início do XX, o que exige evidenciar as diferentes técnicas e concepções que se colocam sob a palavra gravura; e o segundo analisa a recepção crítica das obras gráficas de Carlos Oswald nas duas primeiras décadas do século XX.

Sem o estudo acerca do conceito sobre gravura nesses anos é impossível entender a inserção da obra gráfica de Carlos Oswald no Brasil e seu esforço para inscrevê-la nas "belas artes” em um país que ainda a entendia como arte ligada tão somente à tipografia.

Objetivando demonstrar o que se afirma, analisam-se alguns documentos oficiais, textos de época, leis e decretos sobre duas instituições de ensino que, de modos e com fins distintos, ocupam-se, a primeira, do ensino das Belas Artes e, a segunda, das artes aplicadas à indústria, tanto na capital do Império, quanto na da República: a Academia Imperial de Belas Artes (AIBA), que após a mudança de governos passa a ser denominada Escola Nacional de Belas Artes (ENBA), e o Liceu de Artes e Ofícios (LAO). 
Analisando-se documentos da AIBA evidencia-se que a gravura que é ensinada na Academia, desde a sua fundação, mesmo que com intermitências, devido à falta de professores ou suspensões da cadeira, como será tratado adiante, é a gravura de medalhas e pedras preciosas; essa sim obra de arte, que junto com a pintura e com a escultura, tem a função de elevar e ensinar as histórias das nações. Por isso, na documentação da AIBA ou da ENBA, a palavra gravura designa, principalmente quando esses documentos se referem às disciplinas ministradas na escola, a gravura de medalhas e a de pedras preciosas, as quais são consideradas "arte nobre".

Porém, quando esses documentos especificam os impressos e publicações presentes na biblioteca da ENBA ou, até mesmo, designam as obras aceitas nas Exposições Gerais de Belas Artes, "gravura" pode referir-se às xilogravuras, litogravuras, gravuras à buril e às águas-fortes de modo geral, mas não como arte.

Relativamente às discussões sobre o ensino da gravura realizadas no Liceu de Artes e Ofícios do Rio de Janeiro, nas últimas décadas do século XIX, essas tratam da gravura enquanto técnica que produz imagens impressas, estas para atenderem a indústria da época. Nos documentos de época sobre o assunto, como naqueles da AIBA e da ENBA, lê-se gravura em madeira, gravura à água-forte, gravura à talho-doce, visto que os diversos trabalhos gráficos são tratados de acordo com os nomes que identificam suas técnicas. Esses trabalhos não recebem apenas a designação "gravura", como serão identificadas essas técnicas quando passam a ser consideradas como arte.

No LAO discute-se, ao menos desde a década de 1870, a implantação do ensino e das oficinas gráficas na instituição, tanto como forma de instrumentalizar a mão de obra, quanto como possiblidade de comércio e, consequente, lucro para o estabelecimento de ensino. Evidencia-se, considerando-se a inscrição da gravura na indústria gráfica nascente na época, que o desejo de firmar o ensino da gravura no LAO, bem como a sua aceitação nas exposições de belas artes, tanto as organizadas pela AIBA, quanto as organizadas pelo LAO, não significa que as xilogravuras, as gravuras a água-forte etc. sejam considerados obras de arte. Pelo contrário, tais obras são artes aplicadas à indústria e, justamente, por isso suas técnicas podem ser ensinadas em escola que visa a formação de profissionais úteis ao desenvolvimento industrial do país. Como demonstrar-se-á, no Brasil, no final do século XIX e início do XX, a gravura é arte aplicada à indústria que tem como fim a reprodução de outras obras de arte ou de imagens no geral, essas sendo cópias ou até originais. As imagens obtidas por meio da gravura podem ser usadas tanto para ilustrar e compor as diversas publicações e periódicos, quanto para a impressão de papeis úteis ao comércio e demais serviços. 
Assim sendo, a tentativa de Carlos Oswald de implantar o ensino de água-forte no Liceu de Artes e Ofícios em 1914 se dá em uma instituição de formação prática e em uma época em que a gravura não é considerada da mesma maneira que as pinturas e as esculturas.

A compreensão dos conceitos acerca da gravura no Rio de Janeiro e, consequentemente, no Brasil na passagem do século XIX para o XX, permite evidenciar que Carlos Oswald, em suas águas-fortes, apresenta uma concepção distinta sobre essa arte da vigente no país. Por isso a falta de análise em periódicos sobre a gravura de Carlos Oswald, ao menos nas duas décadas iniciais do século XX.

\subsection{Gravura na Academia Imperial de Belas Artes}

No relatório sobre os trabalhos da Academia de Belas-Artes do ano de 1882, assinado por Antônio Nicolau Tolentino ${ }^{12}$, então diretor, lê-se um extenso argumento contra a substituição da cadeira de gravura de medalhas e pedras preciosas pela de xilografia. Substituição esta firmada pelo decreto de número 8.802 de 16 de dezembro de $1882^{13}$, que visa implantar no lugar da gravura de medalhas e pedras preciosas a gravura em madeira. No referido relatório, entregue ao Governo Imperial e datado de abril de 1883, Tolentino monta uma oposição entre a gravura - nisto a xilografia, a litogravura, a água-forte, a água-tinta, a gravura à buril - e a gravura de medalhas e pedras preciosas de modo a demonstrar que as disciplinas distinguem-se quanto aos seus fins. No argumento do referido relatório, o autor, embora desconsidere a xilografia como arte, pois ligada às questões do dia-a-dia, como escreve, afirma que se esta for mantida na instituição como proposto no ato do poder executivo, será preciso somar a ela outras "espécies" de técnicas, como a "gravura sobre aço

\footnotetext{
${ }^{12}$ Antônio Nicolau Tolentino, de acordo com os documentos consultados no Acervo Arquivológico do Museu dom João VI, foi diretor da Academia de 1874 a 1888, todavia, Ernesto Gomes Moreira Maia foi diretor interino da instituição ao menos em dois momentos no período em que Tolentino era diretor: em 1884, quando Maia assina o relatório da Academia, e entre 1887 e 1888, quando Tolentino solicita licença médica, e alguns meses antes de seu falecimento. Acervo Arquivológico do Museu D. João VI/ EBA / UFRJ. Disponível em: $<$ http://www.museu.eba.ufrj.br/>. Acesso em: 25/05/2017.

O relatório sobre os trabalhos da Academia no ano de 1882, disponível para consulta, é documento datiloscrito, que se encerra com o nome de Tolentino, não sendo possível confirmar a autoria do mesmo apenas por essa fonte. Antônio N. Tolentino, Relatorio do Director da Academia das Bellas-Artes, 26 abr. 1883, documento datiloscrito. Entretanto, o relatório sobre as atividades da Academia do ano seguinte, 1883, manuscrito e assinado por Ernesto Gomes Moreira Maia em 1884, faz referência ao documento do ano anterior, afirmando que a autoria é de Tolentino. Ernesto G. M. Maia, Academia Imperial das Bellas-Artes, 17 abr. 1884, documento manuscrito.

${ }^{13} \mathrm{O}$ decreto n. 8.802, de 16 de dezembro de 1882, cria na Academia de Belas Artes a cadeira de xilografia fazendo cumprir a Lei n. 3.141, de 30 de outubro de 1882, cujo Art. 2, n. 34 autoriza o governo a substituir a cadeira de gravura de medalhas e pedras preciosas pela de xilografia.
} 
ou cobre e em pedra litográfica" 14 , de sorte que se acrescente uma "seção de gravura" Academia.

Contudo, de acordo com o exposto no relatório, enquanto as diferentes "espécies" de gravuras servem para ilustrar livros, produzir impressos para o comércio, decorar papéis avulsos e reproduzir obras de arte, a gravura de medalhas e pedras preciosas se presta a perpetuar os fatos notáveis da história. Esta gravura possui a nobre tarefa de construir a memória da nação, ao passo que a xilografia e demais técnicas apenas produzem papéis vulgares, de uso cotidiano. Por isso, o diretor argumenta que suprimir a importante cadeira de gravura de medalhas e pedras preciosas do quadro de disciplinas é tornar a Academia de Belas Artes inferior ao que ela já foi ${ }^{16}$, visto que, como a escultura e a pintura, as artes da glíptica e da medalhística produzem os monumentos que erigem a história da nação ${ }^{17}$.

Consequentemente, lê-se no relatório escrito por Tolentino para que se reestabeleça a gravura de medalhas e pedras na Academia, visto ser ela, como parte do curso da Escultura, distante dos "processos e resultados" ${ }^{18}$ da xilografia, não sendo possível, portanto, a substituição de uma cadeira pela outra.

A despeito do relatório sobre os trabalhos do ano de 1882, o Governo Imperial não suprime a cadeira de xilografia da Academia, nem tampouco, manda organizar uma seção de artes gráficas nessa instituição nos anos finais da monarquia. Mas, considere-se, a cadeira de xilografia nunca será preenchida, quer no Império, quer nos cinquenta anos iniciais da República, pois somente na Escola Nacional de Belas Artes, então já subordinada à Universidade do Brasil, as artes gráficas serão aceitas na escola.

\footnotetext{
${ }^{14}$ Antônio Tolentino, op. cit., p.5.

${ }^{15}$ Idem, ibidem.

${ }^{16}$ Em 1882, o cargo de professor da cadeira de gravura de medalhas e pedras preciosas se encontrava vago há mais de dez anos, desde a morte do último lente, José da Silva Santos. Este professor ocupou esse cargo na Academia de 1851 a 1869 , sendo antes disso, de 1840 a 1851, professor substituto. Lê-se nos documentos do Museu D. João VI, que em 1871 foi aberto concurso para a cadeira de gravura de medalhas e pedras preciosas, para o qual dois candidatos se inscrevem: Joaquim José da Silva Guimarães Jr. e Quintino José de Faria. Ambos, no entanto, mesmo que em etapas diferentes, abandonaram o exame antes do seu fim. Em 1873, Guimarães Jr. inicia o concurso, mas o candidato não comparece à terceira prova. Dois desses candidatos solicitam ao Ministério do Império, em 1879, que os nomeiem para ocupar a cadeira ainda vaga, sem a necessidade de concurso, visto as suas experiências anteriores. Não obstante, segundo informa o próprio Tolentino em seu relatório, a vaga de professor para a cadeira ainda estava vazia em 1882. Cf. Quadro 5 - Professores por Disciplina, In: Cybele V. N. Fernandes, “O Ensino de Pintura e Escultura na Academia Imperial das Belas Artes", 2007, disponível em: <http://www.dezenovevinte.net/ensino_artistico/aiba_ensino.htm>. Acesso em 26/05/2017. Cf. Acervo Arquivológico do Museu D. João VI/ EBA / UFRJ. Disponível em: $<$ http://www.museu.eba.ufrj.br/>. Acessado em 25/05/2017.

${ }^{17}$ As diversas moedas cunhadas com os bustos dos monarcas e as medalhas realizadas para as datas comemorativas são monumentos tais quais os grandes conjuntos escultóricos instalados em praças públicas, servindo para a elevação dos personagens escolhidos da nossa história. Ressalta-se, deste modo, a importância das medalhas, moedas e pedras preciosas esculpidas em baixo relevo para a construção da história da nação, mesmo que essa produção seja pouco estudada pela história da arte brasileira.

${ }^{18}$ Antônio Tolentino, op. cit., p. 5.
} 
Entretanto, mesmo que a alteração proposta pelo decreto de dezembro de 1882 não seja concretizada, sabe-se, de acordo com os documentos acessíveis hoje, que em 26 jul. de 1884, em decisão do Ministério dos Negócios do Império, é aprovado o programa do concurso para professor da disciplina de xilografia ${ }^{19}$. Três candidatos - José Martins Gomes Vilas Boas, Quintino José de Faria e Charles Idoux - se inscrevem para o concurso que aconteceu em $1885^{20}$. A documentação, todavia, não permite afirmar se todos os candidatos participam dele e qual o resultado do mesmo, sendo possível apenas saber que a matéria, como afirmou-se, não foi implantada na Academia.

Relativamente à cadeira de gravura de medalhas e pedras preciosas, lê-se, em documentos que datam dos anos de 1887 e 1888, que a congregação de professores solicita ao Governo Imperial, em vários ofícios, que se reconheça o pedido dos docentes para o reestabelecimento dela. Não há, porém, nas coleções de leis, decretos e decisões do Império desses anos qualquer resposta publicada sobre o assunto ${ }^{21}$.

A restituição da cadeira de gravura de medalhas e pedras preciosas ocorre apenas após a Proclamação da República - na agora chamada Escola Nacional de Belas Artes -, instituída pelo decreto n. 983 de 08 de novembro de $1890^{22}$, documento que também aprova seu novo estatuto. Nele, lê-se que a escola é "destinada ao ensino da pintura, da escultura, da arquitetura e da gravura" 23 , sendo esta última matéria a de medalhas e pedras preciosas, como se lê no artigo quarto do mesmo documento. As mudanças realizadas no regimento da instituição nos anos de 1901, 1911, 1915, 1931 e 1933 não alteram o já firmado na última década do século anterior relativamente à medalhística e à glíptica, as gravuras ensinadas na escola.

Embora logo após o 15 de novembro a cadeira de gravura já estivesse restabelecida por lei, como desejava a congregação de professores do Império, somente depois da

\footnotetext{
${ }^{19}$ A decisão do Ministério do Império n ${ }^{\circ} 47$, de 26 de julho de 1884, aprova, com modificações, o programa para o concurso da nova cadeira de xilografia da Academia das Belas Artes. Antes da decisão, o relatório do diretor interino Ernesto Maia, datado abril de 1884, informa ao Governo Imperial que a vaga para professor de xilografia ainda não foi preenchida.

${ }^{20}$ Cf. A documentação Acervo Arquivológico do Museu D. João VI/ EBA / UFRJ sob o verbete "xilografia". Disponível em: <http://www.museu.eba.ufrj.br/>. Acessado em 25/05/2017.

${ }^{21}$ Nas Coleções de Leis do Império do Brasil dos anos de 1887 e de 1888, bem como no último ano da monarquia, não se encontrou nenhuma lei sobre o assunto. As Coleções dos Atos do Poder Executivo e das Decisões dos Ministérios publicadas, que reúnem decretos, avisos e decisões dos mesmos anos, também não apresentam documentos sobre o reestabelecimento da cadeira de gravura de medalhas e pedras preciosas na Academia de Belas Artes.

${ }^{22}$ O decreto n. 983, de 8 de novembro de 1890, que aprova os estatutos para a Escola Nacional de Belas Artes, determina no Título 1, Art. $1^{\circ}$, que "A Academia das Belas-Artes passará a ter denominação de Escola Nacional de Belas-Artes e será destinada ao ensino da pintura, da escultura, da arquitetura e da gravura", esta de pedras e medalhas.

${ }^{23}$ Decreto n. 983 , de 8 de novembro de 1890, Aprova os estatutos para a Escola Nacional de Belas-Artes, Coleção de Leis do Brasil, Rio de Janeiro, 8 nov. 1890.
} 
contratação de Augusto Girardet, em 1892, a vaga de professor para a disciplina é preenchida.

Pouco se sabe sobre esse artista que chega ao Brasil em 1891, podendo-se afirmar, entretanto, que ele ocupa o referido cargo até meados do decênio de $1920^{24}$.

As sucessivas reformas da ENBA, no que concerne à gravura de medalhas e pedras preciosas, como se lê nos citados regimentos, mantêm a orientação de que esse curso visava formar artistas aptos a modelar e esculpir metais e pedras, e isto, até o regimento de 08 de ago. de $1947^{25}$. Nesta reformulação da escola, todavia, o curso de gravura passa a ser entendido de outra forma pois, agora amplo, é "técnico" e prepara, não apenas gravadores de medalhas e pedras preciosas, como também calcógrafos e xilógrafos.

Esse regimento do final do decênio de 1940 determina que as aulas de xilografia, talho-doce e água-forte aconteçam na quinta e última série do curso, após o aluno ter passado pelo aprendizado da cadeira de medalhística e glíptica, entre outras matérias. Talvez seja por essa a razão, a da seriação das disciplinas, que Maria Luiza Luz Távora ${ }^{26}$ afirma que é somente em 1951 que se iniciam na escola as aulas de gravura em metal e em madeira ${ }^{27}$.

Do que se pode verificar, portanto, as artes gráficas, não são ensinadas na Escola Nacional de Belas Artes até a metade do século XX. Todavia, as impressões de gravuras à água-forte e litografias têm lugar certo nessa instituição desde o final do século XIX: na biblioteca. Aliás, o estatuto de 1890, já determina que é função do bibliotecário catalogar as "gravuras e estampas" que ali se guardam, bem como o regimento de 1901 informa que o material colecionado na biblioteca da instituição está em conformidade com os programas

\footnotetext{
${ }^{24}$ Augusto Girardet foi contratado como professor de gravura de medalhas e pedras preciosas da Escola Nacional de Belas Artes pela primeira vez em 1892, sendo que nas duas décadas que se seguem são realizadas renovações sucessivas do seu contrato. Em 1912, o Ministério da Justiça e de Negócios Interiores solicita à escola que seja realizado concurso para a cadeira, de acordo com o que determina o art. 36 da Lei Orgânica do Ensino Superior e do Fundamental na República, aprovada pelo decreto n. 8.659 de 5 de abril de 1911 . As inscrições para o concurso são abertas em junho de 1912. No final desse mesmo ano, Girardet apresenta o programa para o concurso interno dos alunos da escola nessa disciplina. Ele permanece no cargo, ao menos, até meados da década de 1920, segundo o que se lê nos documentos da ENBA, acessíveis no Arquivo do Museu D. João VI/ EBA / UFRJ.

${ }^{25}$ O capítulo III, Do curso de Gravura, do "Regimento da Escola Nacional de Belas Artes" publicado no Diário Oficial da União, em 08 ago. de 1947, inclui no referido curso o ensino das técnicas gráficas: “O ensino e a prática no Curso de Gravura se destinam a formar técnicos, tanto na Gravura de Medalhas e Pedras Preciosas, como no Talho-doce, na Água-forte, na Xilografia e outras modalidades da gravura, dotando-os de conhecimentos científicos e artísticos que os habilitem a atingir alto grau, nas realizações da especialidade".

${ }^{26}$ Maria L. L. Távora, “A gravura artística na Escola Nacional de Belas Artes - anos 50/60: tensões e conquistas na atualização do seu ensino de arte", Belo Horizonte, 2004.

${ }^{27}$ A afirmação de Távora repete o depoimento de Adir Botelho, que consta do livro Gravura Brasileira Hoje Depoimentos, no qual o gravador memora que começou a fazer gravura na ENBA em 1951, no curso, segundo ele, recém-criado de Arte da Propaganda e do Livro, ministrado por Raimundo Cela. Botelho afirma que Cela foi indicado pela Congregação da escola para assumir a disciplina nessa data e que, no ano seguinte, ele passou a ser assistente do docente. Após a morte do artista cearense, Oswaldo Goeldi é contratado, em 1955, para ocupar essa mesma cadeira. Adir Botelho et al., Gravura Brasileira Hoje Depoimentos, Rio de Janeiro, Oficina de Gravura SESC - Tijuca, 1996, pp. 27 - 29.
} 
curriculares e serve às aulas e aos estudos dos alunos, visto que a "biblioteca será de preferência formada de livros, gravuras e estampas relativas às matérias professadas na Escola"28. As gravuras da Academia, como se pode confirmar, reproduzem esculturas e quadros de artistas considerados de importância, assim como florões e outras estampas “decorativas" que, na época, são entendidos como indispensáveis à ornamentação de construções, portanto, estampas que devem ser copiadas pelos alunos, de acordo com os diferentes cursos que a escola oferece.

As sucessivas atas de reuniões dos professores locais mostram que há pedidos de compra de livros e gravuras que servem ao aprendizado dos alunos. Essa documentação, assim como a menção das gravuras nos regimentos da escola, evidencia a importância das reproduções de obras de arte, feitas por meio das técnicas gráficas, para o ensino ${ }^{29}$.

Apesar desses papeis impressos servirem para o exercício da mão, eles são, por vezes, também mostrados em exposições, desde que executados pela "indústria" da época. Os trabalhos realizados em litografia, xilogravura, buril e água-forte são aceitos nas Exposições Gerais de Belas Artes desde 1894, como se lê nos estatutos dessas mostras, no entanto, esses trabalhos não são contemplados com prêmios ${ }^{30}$. A aceitação desses trabalhos nas referidas exposições, que podem ser apresentados por brasileiros e estrangeiros, não é contraditória ao aqui exposto. O jornalista que assina A.V. do periódico A Notícia, em 1909, lembra que "Todas as Belas-Artes, e algumas de suas acessórias e subordinadas se acham representadas

\footnotetext{
${ }^{28}$ O Decreto n. 3.987, de 13 abr. 1901, aprova o regulamento da Escola Nacional de Belas Artes. O capítulo XVII desse regulamento trata das competências do bibliotecário e, em seu Art. 188, afirma que a biblioteca da instituição é destinada a publicações que estejam de acordo com as matérias ensinadas na escola.

${ }^{29}$ A pesquisadora Marianne Farah Arnone, em sua dissertação de mestrado intitulada A gravura como difusora da arte, de 2014, afirma que, desde o início da Academia das Belas Artes, a gravura que foi implementada na instituição foi a de medalhas, "entretanto, as estampas gráficas - como material didático - eram parte integrante de seu sistema de ensino pautado, sobretudo, no exercício da cópia das obras dos 'mais consagrados mestres' que compunham a 'grande tradição artística"”. Antes da pesquisadora, Ricardo A. B. Pereira, no artigo "A ENBA da primeira metade do século XX vista pela obra de alguns dos seus professores - uma gradual transição para o moderno", de 2013, já defendia que a cópia de gravuras impressas era parte integrante do ensino de desenho na AIBA, principalmente para os alunos iniciantes. O próprio artista Carlos Oswald, em sua autobiografia, Como me tornei pintor, de 1957, lembra que, ainda no século XX, a cópia de imagens impressas como exercício de desenho era prática comum no Brasil. O artista afirma, todavia, que em suas aulas no Liceu de Artes e Ofícios, aboliu essa prática. Tanto a fala do artista, quanto os documentos consultados, diferem, portanto, do que defende Arthur Gomes Valle em sua tese de doutoramento sobre os artistas da ENBA na Primeira República, apresentada em 2007, uma vez que o pesquisador afirma que não há evidências materiais que os alunos da escola copiassem imagens impressas no período por ele estudado. Curiosa dúvida de Valle, sabendo-se que ao menos até o decênio de 1940 as escolas de belas artes do Brasil tinham por norma exercitar a mão do futuro artista a partir da cópia de obras impressas.

${ }^{30}$ De acordo com os estatutos da ENBA do começo do século XX, as Exposições Gerais de Belas Artes são atribuições do Conselho Superior de Belas Artes. Elas têm como objetivo a "animação do desenvolvimento artístico no Brasil" e delas podem participar artistas nacionais e estrangeiros. Ao maior prêmio da mostra, o Prêmio Viagem, com duração de dois anos, podem concorrer somente artistas brasileiros, com idade inferior a trinta anos.
} 
por trabalhos de valor e interessantíssimos." ${ }^{, 31}$ na mostra daquele ano. Ele explicita, pois, que são aceitas no certame trabalhos que não são, necessariamente, considerados obras de arte, sendo o evento geral o suficiente para incluir produtos diversos relacionados às "BelasArtes", até os que são reputados como "acessórios". Considere-se que, além das gravuras, desde 1894, são permitidos nas exposições produtos das chamadas artes decorativas, os quais não apresentam, muitas vezes, indivíduos e sim a produção de companhias, que também almejam participar do evento da capital federal para divulgarem sua produção.

Evidencia-se, todavia, que esses trabalhos não possuem o mesmo conceito das pinturas, esculturas e projetos arquitetônicos, visto que estes são "obras de arte" para os regimentos das exposições gerais, enquanto que as gravuras e as artes decorativas são apenas “obras". Ainda mais, esses mesmos documentos estabelecem que essas "obras" não podem concorrer aos maiores prêmios do concurso: ao Prêmio Viagem e à Medalha de Honra.

As pinturas e esculturas concorrem aos prêmios mais cobiçados da exposição, mas a elas é interditado, nos regimentos de 1893 e de $1908^{32}$, de acordo com o Art. $6^{\circ}$, apresentar cópias de outras obras, exceto aquelas que fazem parte do aprendizado do aluno pensionista na Europa, como se sabe, não pelos regimentos, e sim pelos catálogos das exposições gerais ${ }^{33}$. Porém, cópias de outras obras de arte realizadas em gravuras e litografias são aceitas nessas mostras, como consta nos regimentos. Ora, evidencia-se, por isso, que é próprio da gravura ser um exercício de reprodução.

A gravura impressa, obra que serve à reprodução de obras de arte e imagens no geral, não se adequa à preparação de "artistas" até a metade do século XX. A aprendizagem das artes aplicadas ou industriais é própria de outra instituição: o Liceu de Artes e Ofícios. Afinal, esta instituição, de acordo com seus fundadores, é voltada à instrução popular e tem o objetivo de promover a industrialização do país por meio da formação de mão de obra especializada.

\footnotetext{
${ }^{31}$ A.V., "Salão de 1909", A Notícia, Rio de Janeiro, 31 ago. 1909.

${ }^{32}$ Consta no Art. $6^{\circ}$ tanto do "Regimento das Exposições Gerais de Belas Artes", publicado no Diário Oficial da União em 21 jul. 1893, quanto do regimento da mesma exposição, publicado em 14 ago. 1908, a interdição a cópias, nas mostras, de outras obras de arte feitas por meios que não a gravura.

${ }^{33}$ O catálogo da Exposição Geral de Belas Artes, de 1896, publicado pela Escola Nacional de Belas Artes, informa que a pintura Rendição de Breda, de Elyseo Visconti, é a de número 142 da mostra. A tela é a cópia que o artista realizou do quadro de Velázquez, A Rendição de Breda, também conhecido pelo título As lanças. Elyseo pinta essa obra como exercício e para cumprir às exigências de aluno pensionista.
} 


\subsection{A gravura no Liceu de Artes e Ofícios}

Francisco Joaquim Bethencourt da Silva, que em 1856 funda a Sociedade Propagadora de Belas Artes (SPBA), lamenta, no final do século XIX ${ }^{34}$, não ter sido possível instalar oficinas práticas, como as de gravura em madeira, no Liceu de Artes e Ofícios do Rio de Janeiro. Este estabelecimento de ensino, fundado e mantido pela SPBA, tem como objetivo proporcionar às classes do povo o estudo das belas artes enquanto "aplicação necessária aos ofícios e às indústrias", como se lê no estatuto dessa sociedade aprovado pelo Ministro e Secretário de Estado dos Negócios da Agricultura, Comércio e Obras Públicas em 1862. Neste documento consta que a finalidade da agremiação é promover a propagação, o desenvolvimento e o aperfeiçoamento das artes e, para atingir esse fim, ela deve fazer crescer no povo o gosto pelo belo não apenas "como meio de educação, mas também como acessório essencial a todos os ofícios e indústrias manufatureiras" diretor do Liceu insista com seus pares na importância das oficinas práticas, como as de gravura, para esse estabelecimento, objetivando obter dinheiro para auxiliar na manutenção da instituição, cuja conservação cabia prioritariamente à SPBA, sociedade constituída por particulares. Bethencourt da Silva reforça seu argumento acerca da implantação das referidas oficinas considerando que as aulas de talho-doce, água-forte e xilografia já estavam previstas como parte do currículo do Liceu de Artes e Ofícios, pelo seu regulamento interno, desde, ao menos, $1871^{36}$.

\footnotetext{
${ }^{34}$ Trechos de escritos de Bethencourt da Silva são citados por Álvaro Paes de Barros em seu livro O Liceu de Artes e Oficios e Seu Fundador, de 1956; entretanto, o autor não informa as datas, nem origens dos textos de Bethencourt. Sendo poucas as fontes de pesquisa disponíveis sobre o Liceu de Artes e Ofícios do Rio de Janeiro, o livro de Barros, mesmo sem a datação dos escritos, é de importância para se pesquisar a história da instituição. Especificamente sobre a passagem referida, é possível que ela seja do início da década de 1880 , visto que no mesmo período encontra-se relatório do Liceu no qual se lê sobre a necessidade de implantação das oficinas práticas. Álvaro Paes de Barros, O Liceu de Artes e Ofícios e Seu Fundador, Rio de Janeiro, 1956.

${ }^{35} \mathrm{O}$ estatuto da Sociedade Propagadora de Belas Artes, aprovado pelo decreto n. 3.012, de 28 de nov. de 1862, em seu artigo segundo determina que a Sociedade atingirá seus fins por meio da fundação e conservação do Liceu de Artes e Ofícios, da edição de uma revista de arte com estampas e gravuras originais, da implantação de uma biblioteca popular, da organização de conferências e exposições anuais, da promoção de concursos para os alunos do Liceu e até do financiamento de viagens ao exterior aos melhores alunos. Ademais, o estatuto determina que é função da Sociedade se corresponder com outras organizações de mesmo fim para buscar auxílios e esclarecimentos, além de ajudar na instituição de outras sociedades como ela. Esse documento regulamenta que essas atividades serão realizadas de acordo com os recursos pecuniários disponíveis e explicita, no Art. 42, que a manutenção da própria sociedade, bem como a do Liceu são as duas primeiras alíneas para as quais a verba da instituição é dedicada. As oficinas são, assim, uma possibilidade de ganho para a Sociedade, o que será explicitado adiante, bem como apontam que a propagação do "belo", que é função da Sociedade, não se faz da mesma maneira do que na Academia de Belas Artes, visto que no Liceu se ensinam e praticam as belas artes aplicadas às diversas indústrias manufatureiras.

${ }^{36}$ Liceu de Artes e Ofícios do Rio de Janeiro, "Regulamento e Regimento", 1871 citado por Celina M. Murasse, A educação para a ordem e o progresso do Brasil: O Liceu de Artes e Ofícios do Rio de Janeiro (1856-1888), Campinas, 2001, p. 102.
} 
No entanto, embora as aulas do Liceu para adultos e meninos livres ${ }^{37}$ se iniciem em $1858^{38}$, na antiga sala de assembleias e reuniões religiosas da Irmandade do Santíssimo Sacramento, até a primeira década do século XX não há na escola, já então sediada no terreno da antiga Secretaria do Império e da velha Tipografia Nacional, espaço destinado às oficinas a fim de que os alunos produzam manufaturas.

De acordo com o livro comemorativo do centenário da Sociedade Propagadora de Belas Artes de Álvaro Paes de Barros, Bethencourt argumenta que a implantação dos ateliês, como também são chamadas as oficinas, contribuem para que a instrução popular atinja alto grau de qualidade, permitindo a formação de mão de obra especializada para a indústria, que, na época, ainda é manufatureira. Ainda mais, Bethencourt defende que, justamente por fornecer serviços necessários à capital, a instalação das oficinas traria renda para a instituição filantrópica, a qual obtinha seus recursos pecuniários das contribuições obrigatórias dos seus sócios, bem como das doações de benevolentes e do governo ${ }^{39}$.

O diretor explica que, se houvesse o subsídio necessário, a instalação das oficinas de carpintaria, de fundição de tipos, de encadernação, assim como a de gravura em madeira rapidamente proporcionariam à instituição a manutenção de seus custos gerais. Isto viabilizaria, em um segundo momento, a implantação de outras oficinas práticas, já que as listadas destinam-se principalmente à gráfica. Pretendia-se também ateliês de fundição, marcenaria, escultura em madeira e gesso, pintura de ornatos e, entre outros, o de litografia.

As várias oficinas gráficas atenderiam todos os quesitos no que se refere à produção de livros com imagens, visto que Bethencourt entende que, no período, "já não se fazem mais livros de ensino sem gravuras", sendo a "estampa" um "atrativo", tanto para as crianças,

\footnotetext{
${ }^{37}$ A Lei 1.331-A, de 17 de fevereiro de 1854, aprova o regulamento para a reforma do ensino primário e secundário do Município da Corte, no Império. O Art. 69 da lei determina que "Não serão admitidos à matrícula, nem poderão frequentar as escolas: [...] Os escravos". O "Regulamento do Liceu de Artes e Ofícios", publicado em 1871, no Art. 3 afirma que o ensino da escola é gratuito "para todo e qualquer indivíduo - livre ou liberto que não tiver contra si alguma circunstância que torne inconveniente a sua admissão" [grifo nosso]. ${ }^{37}$ Liceu de Artes e Ofícios do Rio de Janeiro, citado por Celina M. Murasse, op. cit., p. 102.

${ }^{38}$ Segundo Barros, o Liceu começou a funcionar somente em março de 1858 , com aulas noturnas para operários, crianças e adultos do sexo masculino, visto que as aulas para mulheres são implantadas somente em 1881 . Álvaro P. Barros, op.cit., p. 9.

${ }^{39} \mathrm{O}$ estatuto da Sociedade, aprovado pelo decreto $\mathrm{n}^{\mathrm{o}} 3.012$, em seu artigo nono, determina que os sócios devem realizar contribuições mensais de mil conto de réis à sociedade. Ficam dispensados dessa obrigação aqueles sócios que lecionam no Liceu, gratuitamente. Celina Murasse afirma que em 1864, o número de sócios da SPBA já havia sido reduzido dos 99 iniciais para 20, portanto, os recursos da associação derivados dessas contribuições também diminuíram. Celina Murasse, op. cit., p. 102. Os estudos sobre a instituição, como o de Murasse, apontam que a manutenção financeira do Liceu aparece como constante preocupação nos relatórios sobre a instituição. Sabe-se que ao longo do Império e da República o governo repassa subsídios à SBPA, contudo, seria preciso pesquisa específica sobre o assunto para concluir se esses créditos eram constantes ou mesmo suficientes à manutenção da escola.
} 
quanto para os adultos ${ }^{40}$. O idealizador do Liceu, conhecendo as publicações ilustradas europeias e norte-americanas, compreende a importância das imagens para o ensino e, consequentemente, o papel fundamental das oficinas gráficas, por isso afirma que a instalação dessas "seria para o Liceu grande fonte de renda, sem contar o gosto que difundiria no povo pela leitura e o grande impulso que daria à instrução popular com a produção de livros ilustrados de baixo custo" $"$.

Considere-se que os "livros ilustrados", que servem à instrução do povo, são também aqueles nos quais as imagens têm a mesma importância que o texto ou superam este, pois a imagem, por vezes, é mais útil para a compreensão do que se ensina. É certo que revistas do século XIX, assim como livros de literatura traziam imagens; no entanto, devem-se considerar os manuais de ensino, aqueles voltados para a educação prática, quer do século XIX como do XX, a exemplo, os da editora italiana Ulrico Hoepli ou os da francesa Roret ${ }^{42}$, entre outros impressos indispensáveis para a aprendizagem na época. Aliás, a título de informação, algumas dessas publicações seguem sendo de importância ainda hoje para a formação técnica.

A ideia de livro ilustrado atenderia não só às necessidades da instituição como também da sociedade em geral. É neste sentido que Bethencourt da Silva a defende, o que exige a implantação de oficinas, ideia que é compartilhada por alguns membros da Sociedade mantenedora do Liceu, além de outros colaboradores, a exemplo do escritor e livreiro Félix Ferreira $^{43}$.

Ferreira, também jornalista, atuante nos últimos trinta anos do século XIX, é um dos articulistas que defende a implantação das oficinas no Liceu, em especial a de gravura em madeira, como se lê no texto ${ }^{44}$ em que comenta a Exposição Geral de Belas Artes $^{45}$ de 1882.

\footnotetext{
${ }^{40}$ F. J. Bethencourt da Silva citado por Barros, op.cit., p. 220.

${ }^{41}$ Idem, Ibidem.

${ }^{42}$ A editora italiana Ulrico Hoepli desde o final do século XIX produziu inúmeros manuais com estampas para o ensino prático que circularam não apenas na Itália, como também no Brasil. Pode-se afirmar o mesmo sobre os Manuels Roret, de editora francesa, que desde meados do século XIX circularam em vários países. Ambas editoras imprimiram títulos que se ocupavam tanto da construção de prédios e sistemas hidráulicos, quanto de práticas técnicas como as da marcenaria ou as da tipografia, chegando, inclusive, a publicarem manuais que ensinavam as damas os penteados da época. A Biblioteca Nacional do Rio de Janeiro possuí em seu acervo títulos da Ulrico Hoepli, prevalecendo publicações do século XX, como o manual Costruzioni idrauliche e idraulica tecnica, basi scientifiche, applicazioni tecniche, studi speciali de Eugenio Campina, publicado em Milão em 1933; também possui publicações da casa francesa, manuais impressos ainda no século XIX, como o Nouveau manuel complet du peintre en bâtiments, du fabricant de couleurs, du doreur, du vernisseur, du vitrier et de l'argenteur de Riffault, publicado em Paris em 1843.

${ }^{43}$ A pesquisadora Marianne Arnone em sua dissertação sobre Félix Ferreira também afirma que o crítico compartilha da opinião de Bethencourt da Silva sobre a relevância das publicações ilustradas, consequentemente da gravura para o ensino. A gravura é, para Ferreira, um meio de reprodução pelo qual se divulga a imagem e, por isso, pode estar a serviço da instrução popular, já que possibilita o aprendizado. Marianne F. Arnone, $A$ gravura como difusora da arte, São Paulo, 2014.

${ }^{44}$ Félix Ferreira, "Pequenas exposições: I - Do Liceu de Artes e Ofícios em 1882", In: Félix Ferreira, Belas Artes: estudos e apreciações, Porto Alegre, Zouk, 2012 [1885], pp.113-127.
} 
Ao citar as xilografias expostas na mostra, o autor afirma que cresce a necessidade de aulas de gravura em madeira na escola do povo, lembrando que esta não é a primeira vez que trata do assunto. Chega até a sugerir que os xilógrafos ${ }^{46}$ que apresentam obras na exposição, Alfredo Pinheiro e José Villas Boas, poderiam ser convidados como professores das oficinas da instituição mantida pela Sociedade Propagadora de Belas Artes; aliás, é a Sociedade que promove essa Exposição Geral. Mais ainda, Félix Ferreira esclarece que também seria do interesse desses artífices, os responsáveis pela tipografia Pinheiro \& Cia, ensinarem àqueles que poderiam se tornar seus "úteis auxiliares"47. Esclarece, com seu artigo, que o ensino das técnicas gráficas é entendido como uma maneira de auxiliar a sociedade brasileira no caminho para a industrialização, sendo a gravura, consequentemente, por ser "arte industrial" necessária para o seu desenvolvimento.

É evidente, pois, que tanto para Bethencourt da Silva quanto para Félix Ferreira, as técnicas de gravura de impressão objetivam a reprodução de imagens e são técnicas que servem às oficinas tipográficas. Por essa razão, o local de ensino da gravura é o Liceu de Artes e Ofícios, escola que prepara os trabalhadores para atender a indústria da época, exigente do trabalho manual.

A defesa do ensino para a formação de mão de obra especializada, na década em que a escravatura foi abolida, como visto, não é assunto apenas de professores e de jornalistas que

\footnotetext{
${ }^{45}$ De acordo com o estatuto da Sociedade Propagadora de Belas Artes é função dessa organização promover exposições de arte para atingir seu objetivo de difundir as artes entre as classes populares. Uma publicação de 1883 sobre os trabalhos da Sociedade e do Liceu reúne, entre outros documentos, o catálogo da Exposição Geral de Belas Artes de 1882, no qual se lê que essa mostra foi possível devido a construção de um novo salão no prédio do Liceu, que pode abrigá-la. Nela são expostos trabalhos que são considerados obras de arte, além pinturas à guache, aquarelas, desenhos e gravuras variados, em geral, cópias de estampas e de gessos, mapas, atlas, desenhos topográficos etc. Cf. "Catálogo dos Trabalhos de Belas Artes da Primeira Exposição Promovida pela S. Propagadora das Belas Artes Em 18 de Março de 1882", In: Sociedade Propagadora de Belas Artes, A Sociedade Propagadora das Bellas-Artes e o Lycêo de Artes e Officios do Rio de Janeiro, Rio de Janeiro, Typographia Hildebrandt, 1883, pp. 176-196. A pesquisadora Alba Carneiro Bielinski, que menciona a exposição de 1882, afirma que participam dela professores do Liceu, membros da SPBA e artistas consagrados. Alba C. Bielinski, "O Liceu de Artes e Ofícios: sua história de 1856 a 1906", 19\&20, jan. 2009.

${ }^{46}$ De acordo com o catálogo da mostra de 1882, os expositores de xilogravura são Alfredo Pinheiro e Villas Boas, que expõem "diversos trabalhos em xilografia e os respectivos clichés em madeira". Os demais expositores de gravura apresentam, em sua maior parte, litografias, em especial, retratos. Destaca-se H. J. Aranha que apresenta um diploma impresso à cores em litografia e um retrato de D. Pedro II feito no "sistema água-forte, gravado em cinco horas"; Antonio Araujo de Souza Lobo mostra "suplementos ilustrados do Pigmeu", jornal dos alunos do Liceu, e Claudio Lomellino de Carvalho expõe um atlas completo do Brasil, organizado e gravado por ele. Cf. Sociedade Propagadora de Belas Artes, op. cit., p.193-194.

${ }^{47}$ Idem, p.118. Relativamente aos xilógrafos que se apresentam na Exposição Geral de 1882, de acordo com o pesquisador Orlando da Costa Ferreira, Alfredo Pinheiro (1858? - após 1901?) era fillho do também xilógrafo Manuel Joaquim da Costa Pinheiro, que estabeleceu a oficina tipográfica, xilográfica e litográfica Pinheiro \& Cia, na qual tanto Alfredo quanto José Martins Gomes Villas Boas trabalhavam. Ambos trabalharam juntos na gravação de mais de cem imagens para a Revista da Exposição Anthropologica Brazileira, publicada em julho de 1882, a partir de desenhos de Huascar de Vergara. Orlando da C. Ferreira, Imagem e letra, São Paulo, EDUSP, 1994, p.183.

${ }^{48}$ Marianne F. Arnone, op. cit., p.58.
} 
escrevem sobre artes: Rui Barbosa, em seu conhecido discurso "O Desenho e A Arte industrial" ${ }^{49}$, demonstra, com uma longa argumentação, ser o ensino prático realizado no Liceu uma causa importante para o desenvolvimento do país. Nesse pronunciamento de 23 de novembro de 1882, por ocasião do Sarau Artístico Literário promovido pelos professores do Liceu em homenagem ao conselheiro Rodolfo de Souza Dantas, Barbosa afirma que "Criar a indústria é organizar a sua educação" ${ }^{, 50}$. Exemplifica essa proposição a partir da experiência europeia, principalmente a inglesa, visto que esta monarquia entende, com as Exposições Universais realizadas a partir da metade do século XIX, que o ensino das artes aplicadas é a causa motriz da excelência da produção de um país e, consequentemente, do sucesso do seu desenvolvimento industrial. Por isso a Inglaterra e outros países europeus, de acordo com Barbosa, implantam as aulas de desenho tanto nas escolas primárias, quanto nas escolas de ensino industrial.

O pesquisador Claudio Amaral ${ }^{51}$ evidencia que nas ideias de Rui Barbosa sobre educação estão inclusas proposições advindas da obra do inglês John Ruskin, autor bastante citado pelo político brasileiro. A partir do pensador britânico, Barbosa entende que o desenho está na base do ensino, sendo, portanto, indispensável à boa execução das diversas profíssões, não só as ligadas às artes industriais. Daí Barbosa sempre defender enfaticamente em seus discursos proferidos no Senado a necessidade imperiosa de se aliar a teoria ao desenho, tal qual se faz nas escolas inglesas.

Assim, o discurso comemorativo de Barbosa sobre o Liceu, além de apontar o ensino do desenho como solução para os problemas financeiros e sociais do país, é um elogio a essa escola e aos sócios fundadores da SPBA, visto que atribui à "iniciativa individual" dos sócios a primazia de um ensino que deveria, por sua importância, estar a cargo do governo imperial.

A importância do desenho para Rui Barbosa não se limita apenas às escolas, uma vez que entende o desenho como capaz de fomentar nas pessoas o gosto pelo belo. $\mathrm{O}$ desenvolvimento dessa "cultura artística", não restrita, portanto, a um pequeno círculo de pessoas, mas acessível a um maior número de indivíduos, além de proporcionar os diversos benefícios à sociedade já referidos, possibilita o aumento do consumo das obras de arte. Barbosa considera que a ampliação do círculo de apreciadores de arte é possível também devido aos "modos de reprodução industrial que se acumulam em nosso tempo: a gravura, a litografia, a fotografia, a helioplastia, a galvanoplastia, a moldagem sob os seus vários

\footnotetext{
${ }^{49}$ Rui Barbosa, “O desenho e A Arte Industrial”, In: Sociedade Propagadora de Belas Artes, op. cit., p. 197-223. ${ }^{50}$ Idem, p. 215.

${ }^{51}$ Cláudio S. Amaral, “Rui Barbosa e John Ruskin: a política do ensino do desenho”, Arquitextos, jun. 2010.
} 
processos" $" 52$ que tornam ampla a circulação dos desenhos, das pinturas e das esculturas consagradas.

Deste modo, o defensor da educação para as diferentes camadas da sociedade considera que há aproximação entre as artes aplicadas e as belas artes, pois afirma que entre elas a diferença se dá por uma "gradação de matizes", visto que não há "divisória insuperável" e que a indústria, no período, usa as mais elevadas habilidades artísticas para seus produtos. Assevera, assim, ser impossível preparar os alunos para as artes aplicadas sem aproximá-los das belas artes. Porém, evidencia que a proximidade entre ambas não significa que não cumpram "papéis" diferentes:

$\mathrm{Na}$ essência, pois, as belas artes e as artes industriais são duas naturezas homogêneas e homorgânicas. Todavia, não se lhes confundem os papéis. Uma olha a efeitos superiores: é o fim de si mesma; paira independente nas regiões do ideal. A outra tende a esparzir o belo nos hábitos mais frequentes da existência humana. Uma não se entrega, senão a uma família necessariamente mais ou menos limitada de espíritos distintos; a outra não se recusa a ninguém. ${ }^{53}$

Fica claro no discurso de Rui Barbosa o que também pode-se depreender em Bethencourt e Ferreira, que a causa defendida é a do ensino que treine a mão de obra nacional nas diversas técnicas artísticas a fim de que os homens e mulheres tornem-se mão de obra eficaz para a indústria do país, com arte. Ao usar a expressão "educação pela arte", Rui Barbosa explicita que a discussão do ensino das artes aplicadas, nelas inclusa a gravura, como se viu, difere dos objetivos do ensino da Academia de Belas Artes.

No artigo "O que vai por aí" ${ }^{4}$, de 1883, Alfredo Júnior apresenta os mesmos argumentos de Bethencourt, de Ferreira e de Barbosa para solicitar publicamente que o governo imperial subsidie a implantação das oficinas no Liceu. O jornalista ainda afirma que se as artes indústrias não progrediram no país, no quarto de século em que a escola esteve aberta, não foi por falta de esforço daqueles que a dirigiam. Entretanto, segundo Júnior, todo esse esforço não proporcionou os resultados esperados à industrialização do país uma vez que as teorias apreendidas nas aulas não foram colocadas em prática devido à falta de oficinas.

O autor deixa claro que as dificuldades que a instituição encontra para a instalação de tamanho benefício são duas: espaço e verba. Mais do que isso, ele avisa que, anos antes, ele

\footnotetext{
${ }^{52}$ Rui Barbosa, op.cit., p. 219.

${ }^{53}$ Idem, p. 207 - 208.

${ }^{54} \mathrm{O}$ artigo de Alfredo Júnior é reimpresso no relatório sobre o Liceu de Artes e Ofícios de 1883. Neste relatório consta que o artigo foi originalmente publicado no "folhetim Cruzeiro", mas não há indicação de datas. Todavia, considerando-se o conteúdo do artigo é possível que ele tenha sido escrito em 1882. Alfredo Júnior, "O que vae por ahi...", In: Sociedade Propagadora de Belas Artes, op. cit., p.135-140.
} 
mesmo já denunciava a falta de espaço desse estabelecimento de ensino, sugerindo ao poder imperial que o realocasse no Convento da Ajuda, edifício este "com terreno espaçoso, muito próprio para as oficinas" ${ }^{, 55}$, e que abrigava apenas algumas freiras, as quais poderiam ser facilmente deslocadas ${ }^{56}$. O jornalista, ao sugerir essa transferência, sem dúvida, está criticando a última locação do LAO, que da Igreja São Joaquim seguiu para o prédio inicialmente reformado para a Secretaria do Império $^{57}$ e que, depois, foi concedido à escola, local, portanto, que além de não ser apropriado para as oficinas, não contava com espaço suficiente para as aulas. Conclui o articulista, assim, pela necessidade de verba, "duas ou três centenas de contos", afirma ele, para se desapropriar as casas vizinhas ao Liceu e para construir no local delas as oficinas. Apesar dos apelos, o Liceu de Artes e Ofícios permanece por cerca de três décadas ${ }^{58}$ sem as reformas necessárias: é o que se pode entender a partir de Álvaro Paes de Barros, que afirma terem sido instaladas as oficinas que atendem às artes gráficas somente no final de 1911.

Relativamente à falta de verbas, o próprio Bethencourt da Silva afirma a necessidade de dinheiro para a implantação das oficinas além do que provinha da Sociedade Propagadora de Belas Artes. Sem dúvida, a Sociedade, de acordo com seu estatuto primeiro, sempre foi mantida por contribuições obrigatórias de seus sócios, mas não só, pois, como pode-se

\footnotetext{
${ }^{55}$ Idem, p. 137.

${ }^{56}$ Alfredo Júnior ainda escreve que o referido convento traria mais proveito ao país sendo uma escola do que "guardando relíquias de uma instituição condenada pelas ideias adiantadas do século". Idem, p. 137. A crítica à Igreja Católica que está explícita na frase do jornalista é própria da época, visto que no final do século XIX, especialmente na década de 1870, o Estado brasileiro passou por momentos de tensão com a instituição religiosa. Além disso, ideias do liberalismo, do positivismo e do cientificismo marcam a intelectualidade brasileira no período, inclusive a imprensa local: essas ideias promovem, grosso modo, a separação entre os poderes do Estado e da Igreja.

${ }^{57}$ Relativamente ao espaço destinado ao Liceu de Artes e Ofícios, a pesquisadora Alba Bielinski afirma que após a sua abertura em 1858 no consistório da Irmandade do Santíssimo Sacramento, ele passou, no ano seguinte, a funcionar na Igreja São Joaquim. Ainda segundo Bielinski, em 1876, à Sociedade é cedido o antigo edifício da Secretaria de Negócios do Estado e dois anos depois, em 1878, é cedido à escola também o prédio vizinho a esse, que é o da antiga Tipografia Nacional. O Liceu inaugura seu novo endereço nos antigos edifícios estatais, no atual Largo da Carioca, em 1878, e ali permanece durante a República. Cf. Alba Bielinski, op. cit. Todavia, Alfredo Júnior, em 1883, menciona apenas que o Liceu, na época, está sediado no prédio que fora incialmente reformado para abrigar a Secretaria, o quê, para o jornalista, foi uma decisão errada. Sobre o edifício da Tipografia Nacional, Junior afirma apenas que foi cogitada a ideia de transferir o Liceu para ele, mas que a construção era muito pequena. Cf. Alfredo Júnior, op. cit.

${ }^{58}$ No governo de Floriano Peixoto, com a Lei n. 191-B, de 30 de setembro de 1893, que fixa a despesa geral da República dos Estados Unidos do Brasil para o exercício de 1894 e dá outras providências, é concedido à Sociedade Propagadora de Belas Artes o domínio útil do terreno do prédio do Liceu, assim como o Estado é autorizado a desapropriar os prédios vizinhos a fim de promover melhorias na escola. Segundo Bielinski, em 1906 é lançada a pedra fundamental para a construção do novo edifício da escola. A construção, contudo, ainda de acordo com a pesquisadora, é iniciada somente em 1910. Apesar dessa informação, não se encontrou documentos que comprovem essas datas, nem a da colocação da pedra fundamental. Sabe-se, apenas, que em 1912 o governo do Marechal Hermes da Fonseca concede, pelo decreto n. 9.919, de 7 dez. 1912, o auxílio de trezentos mil contos de réis ao Liceu de Artes e Ofícios especificamente para a construção de seu novo edifício. O novo prédio do Liceu é inaugurado, ainda segundo Bielinski, somente em 1926.
} 
verificar em diversas leis, há várias subvenções do Estado tanto no período do Império, quanto no da República. Como também é previsto no referido Estatuto, doações podem ser feitas por todas as pessoas da sociedade, além das dos seus sócios e as do governo. Apesar disso, o problema da instalação das oficinas é resolvido somente no início da primeira década do século XX, segundo Barros, devido ao financiamento da firma Pirracini \& Cia, indústria que fabricava máquinas gráficas e fundia tipos.

Destaque-se, aliás, que, a referida firma, representante da Sociedade Augusta de Turim $^{59}$, montou as oficinas e as equipou para atender a carência do país no que se refere à fabricação de livros. Segundo Barros:

[...] foram também adquiridos materiais para litografia, pautação, douração, encadernação e, mais tarde um atelier de água-forte, o primeiro montado nessa cidade, e ainda oficinas de gravura, cerâmica, clitonagem, essa considerada uma das melhores do País, assim como um atelier de xilografia. ${ }^{60}$

Quase trinta anos separam a instalação das oficinas no Liceu de Artes e Ofícios das ideias de Bethencourt da Silva, Félix Ferreira e Rui Barbosa. Todavia, nesse intervalo de tempo, o conceito sobre a gravura em nada modifica-se. Essa constatação se demonstra pelo fato de que as oficinas instaladas em 1911 são as mesmas pretendidas por Bethencourt da Silva antes do fim da monarquia. Além disso, elas são subsidiadas por uma empresa gráfica, que muito teria a ganhar com a formação dos artesãos. Evidencia-se que a organização das oficinas gráficas nada tem de filantropia, pois como bem lembra Alfredo Júnior, ainda em 1883, os “aprendizes são lucrativos", duas vezes inclusive, pois além das oficinas gerarem renda à instituição, os trabalhadores, quando formados, geram mais lucros para seus empregadores.

Segundo o que consta no livro de Barros, as oficinas foram inauguradas no ano da morte de Bethencourt da Silva; cerimônia que, se ocorreu no final de 1911, foi após a eleição da SPBA de setembro, a qual elegeu Francisco Joaquim Bethencourt Filho para diretor do Liceu e para o cargo de $1^{\circ}$ Secretário da SPBA, único cargo perpétuo da associação. Os jornais da época informam que a eleição da nova diretoria da SPBA ocorre após a morte de seu idealizador e que o único sócio fundador ainda vivo, o Dr. Francisco Portella solicita ao

\footnotetext{
${ }^{59}$ A Sociedade Augusta de Turim, empresa italiana, representada por Fernando Pirracini no Brasil, fabrica máquinas gráficas e funde tipos, segundo informa o Almanak Laemmert da Capital Federal de 1914. A importadora pede falência em 1915, que é concedida em 1916. Cf. "Fallencia denegada", O Paiz, Rio de Janeiro, 30 out. 1915. "Fallencia", O Paiz, Rio de Janeiro, 10 ago. 1916.

${ }^{60}$ Álvaro P. de Barros, op.cit., p.143.
} 
Marechal Hermes da Fonseca que presida a Sociedade ${ }^{61}$. No dia das eleições da diretoria, $O$ Século informa que o Marechal visitou as dependências do Liceu, inclusive "as obras para a instalação das oficinas de xilografia, litografia, gravura, água-forte, modelagem e cerâmica"62 . Se o exposto pelos jornais se comprova, pode-se supor que Bethencourt Filho inaugura, em dezembro, as oficinas que foram pleiteadas e viabilizadas ainda na gestão de seu pai.

As razões acima expostas não são as únicas que permitem afirmar que a instituição, ainda na década de 1910, entende a gravura como técnica gráfica a serviço da reprodução de imagens e como processo fundamental para a realização das mais variadas publicações. A revista da Sociedade Propagadora de Belas Artes, Brazil Artístico ${ }^{63}$, publicada em 1911, contém em suas páginas imagens que foram denominadas pelos redatores de "ilustrações e estampas": xilogravuras, litografias, águas-fortes e também fototipias ${ }^{64}$. Os redatores ressaltam a dificuldade de se encontrar bons gravadores e impressores no país e, mais ainda, apontam que os diversos periódicos brasileiros ilustrados já fazem uso dos processos fotomecânicos, abandonando a gravura em madeira e em metal que, outrora, "ilustravam os livros e publicações jornalísticas" ${ }^{65}$. Ora, apesar desses novos meios de reprodução começarem a ser utilizados, os editores da revista se propõem a "Reerguer as artes decaídas, abrindo aos artistas novos horizontes", e concluem: "eis o nosso desideratum"

Considera-se que a palavra "artistas" nesse contexto em nada altera o fato de que a gravura é entendida como arte própria para complementar as publicações, da mesma maneira que no final do século XIX. Mesmo aqueles que defendem as técnicas gráficas artesanais, em detrimento das publicações fotomecânicos, as entendem como técnicas que produzem belas obras para serem encadernadas, publicadas e distribuídas, sendo, portanto, a gravura um meio de reprodução de imagens originais ou de cópias.

Conclui-se que as concepções acerca das oficinas práticas no Liceu de Artes e Ofícios no início do século XX são ainda muito próximas àquelas defendidas no final do Império. Mesmo a ideia de que o Liceu, é o lugar que forma a mão de obra para a indústria brasileira,

\footnotetext{
${ }^{61}$ Cf. "Sociedade Propagadora de Bellas Artes", Jornal do Commercio, Rio de Janeiro, 27 set. 1911.

${ }^{62}$ Cf. "A eleição do Lyceo - Sociedade Propagadora de Bellas Artes”, O Seculo, Rio de Janeiro, 28 set. 1911 , p.3.

${ }^{63}$ O Brazil Artistico, Rio de Janeiro, $1^{\text {o }}$ Trimestre, - 25 mar. 1911.

${ }^{64}$ Sobre as imagens impressas na revista, nota-se que o artista Modesto Brocos tem publicada uma água-forte sua, retrato de Grandjean de Montigny. Diversos pesquisadores, como Orlando da Silva em seu livro A Arte Maior da Gravura, de 1976, atribuem a responsabilidade da compra dos materiais e prensa para a Oficina de Água-forte do Liceu em 1911 a Brocos. Relativamente aos trabalhos que Brocos desempenha, nota-se, o artista é creditado no O Brazil Artistico, entre outros, como encarregado da "parte artística" da revista O Brazil Artistico.

65 “As nossas ilustrações”, In: O Brazil Artistico, Rio de Janeiro, $1^{\text {o }}$ Trimestre, - 25 mar. 1911, p. 309.

${ }^{66}$ Idem, Ibidem.
} 
por meio do ensino do desenho, é ainda presente na instituição, como demonstra o texto "O ensino do desenho no Liceu de Artes e Ofícios" ${ }^{67}$, publicado na revista oficial da SPBA. O ensino do desenho propiciaria, de acordo com o autor F. Silva, "um sensível espírito de observação e de método, e um indiscutível desenvolvimento das faculdades intelectuais" ${ }^{\text {"68 }}$ nos operários, que, obtendo uma melhor instrução, deixariam de realizar apenas cópias dos produtos estrangeiros, para trazer contribuições "originais" aos seus locais de trabalho.

É evidente, portanto, que, em 1911, quando as oficinas gráficas são, finalmente, instaladas no Liceu de Artes Ofícios, a gravura é entendida como arte aplicada à indústria e que o local próprio para seu ensino é essa instituição e não a Escola Nacional de Belas Artes. Carlos Oswald, contudo, tentará dar outro caráter à oficina de água-forte do Liceu, para a qual é nomeado professor em 1913, alguns meses após chegar da Europa, como se discutirá.

\footnotetext{
${ }^{67}$ F. Silva, "O ensino do desenho no Lycêo de Artes e Officios", In: O Brazil Artistico, Rio de Janeiro, $1^{\circ}$ Trimestre, - 25 mar. 1911, p. 271-278.

${ }^{68}$ Idem, p. 271.
} 


\section{A recepção crítica das águas-fortes de Carlos Oswald}

A fim de investigar a inserção da produção gráfica de Carlos Oswald no Brasil, analisa-se como as gravuras do artista são entendidas e comentadas nas colunas de arte dos jornais e revistas do final da década de 1900 e ao longo da década de 1910, período quando o artista expõe tanto nas Exposições Gerais de Belas Artes, quanto nas mostras individuais e coletivas que ele promove e participa no Rio de Janeiro e em São Paulo.

Evidencia-se, todavia, que não se escreve, no início do século XX no Brasil, sobre a "gravura" do artista ou, ainda, sobre suas "gravuras em metal": comentam-se suas "águasfortes". Os textos de periódicos identificam as obras gráficas de Carlos Oswald por sua técnica, certamente para diferenciá-las dos demais trabalhos que se põem sob o termo "gravura" no período, visto que esse termo, como se afirma, serve principalmente para designar a nobre arte das medalhas e da glíptica ensinada na Academia Imperial, depois, Escola Nacional de Belas Artes e as estampas destinadas a ilustrar livros, periódicos e a reproduzir obras de arte.

Mais do que isso, sugere-se que, ao menos para o artista, que também denomina as suas gravuras de "águas-fortes”, a expressão as diferencia das demais gravuras do período que ele evidencia serem "utilitárias", visto que servem como ilustrações, rótulos e reproduções de outras imagens. As suas incisões, todavia, se prestam a outros fins, uma vez que são obras de arte, por isso a necessidade de destaca-las como "águas-fortes de arte" ${ }^{69}$ diferenciação que é importante até a metade do século XX, ao menos no Brasil, como o artista escreve em sua autobiografia.

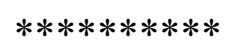

Carlos Oswald ${ }^{70}$ expõe suas águas-fortes pela primeira vez no Brasil em $1909^{71}$, quando as envia da Europa para a $16^{\mathrm{a}}$ Exposição Geral de Belas Artes. A partir desse ano, ele

\footnotetext{
${ }^{69}$ Carlos Oswald, op. cit., 1957, p. 25.

${ }^{70}$ Carlos Julião Jaime Ignacio Alexandre Maria é o filho primogênito do compositor Henrique Oswald e da florentina Laudômia Bombernard Gasperini. De acordo com Maria Isabel Oswald Monteiro, ele foi registrado no Vice Consulado do Império do Brasil em Florença. Maria I. O. Monteiro, "Carlos Oswald”, Henrique Oswald, [s.d]. O próprio Carlos Oswald afirma que foi batizado no Batistério dessa cidade, onde, anos depois, escolheu estudar no Istituto Galileo Galilei "influenciado" pelos "progressos da eletricidade e mecânica". Da instituição obtém o diploma de físico-matemático, visto que desiste de seguir os estudos para formar-se engenheiro. Possivelmente entre 1902 e 1903, matricula-se como aluno livre na Academia de Belas Artes de Florença, frequentando o curso de modelo vivo. Também assiste às aulas de Anatomia Artística da Academia, que eram
} 
expõe suas composições gravadas sobre o metal tanto em Exposições Gerais promovidas pela Escola Nacional de Belas Artes, quanto em mostras individuais que promove e naquelas coletivas que participa e até organiza, a exemplo da Primeira exposição carioca de águasfortes no Liceu de Artes e Ofício, em 1919.

Sabe-se, aliás, que Oswald apresenta águas-fortes nas exposições em conjunto com suas pinturas devido aos breves comentários que aparecem nos jornais. Essas obras do artista não são, pois, completamente ignoradas pelos escritores das colunas de arte; entretanto, são poucos os periódicos que trazem informações sobre a calcografia do artista em comparação com aqueles que mencionam apenas a sua pintura. De modo geral, nos textos em que as águas-fortes são citadas, os comentários dos autores são sucintos e, quando muito, eles apenas dedicam algumas palavras para classificar como boas ou más as composições impressas sobre papel. Tais escritos, portanto, não analisam as águas-fortes que mencionam. Além disso, algumas vezes, essas obras são referidas como "preparações" para a verdadeira arte, que é a pintura. Talvez porque as gravuras sejam entendidas como "simples" desenhos e, como tal, sua função não poderia ser outra que a de esboço ou de estudo para a "arte maior", a pintura. Sendo assim, a leitura dos textos de periódicos que abordam as telas de Carlos Oswald é relevante para a investigação sobre a gravura dele, na medida em que esses artigos, muitas vezes, são construídos de modo a enfatizar a ideia de "progresso" na trajetória do artista. Nesse modelo de argumentação, não há espaço para a análise da gravura, uma vez que ela sequer é obra de arte.

ministradas na Escola de Medicina com os mesmos "cadáveres" usados pelos futuros médicos, como explica o artista. Carlos Oswald, op. cit., p. 9 -10.

${ }^{71}$ Um artigo de 1920 informa que Carlos Oswald expõe gravuras pela primeira vez no Brasil em "1907". Embora esse texto seja assinado por A.M., que, segundo Orlando da Costa Ferreira em seu livro Imagem e Letra, é Adalberto Mattos, portanto, já no decênio de 1920 amigo de Carlos Oswald, a data que se lê em seu texto intitulado "O que é a gravura a água-forte" não se confirma. Adalberto escreve para o magazine Leitura para Todos, em nov. 1920, objetivando divulgar a gravura a água-forte e explicar para o seu leitor como essa técnica é realizada. $\mathrm{O}$ autor também faz breve histórico dessa arte e afirma que os primeiros artistas a dela fazerem uso no Brasil foram Henrique Bernardelli e Modesto Brocos. Carlos Oswald, nesse contexto, exporia suas gravuras em 1907 no Rio de Janeiro. Carlos Oswald em seu livro Como me tornei pintor afirma que só começou a fazer gravura em 1908, no seu retorno do Brasil à Florença, no ateliê do gravador Carl Strauss. Mas ainda: não há registro de gravura de Oswald anterior ao seu contato com Strauss, o que torna a afirmação de Mattos improvável. Costa Ferreira utiliza o texto de Adalberto Mattos para reafirmar o início da gravura à água-forte como arte no país e posicionar Brocos e Bernardelli como os primeiros a fazê-lo; no entanto, o autor, baseandose em outras fontes - possivelmente o livro autobiográfico de Oswald - menciona que esse artista se iniciou na gravura em 1908, corrigindo a afirmação de Mattos, e acrescentando que Oswald expõe gravuras no Brasil em 1913. As críticas das Exposições Gerais de Belas Artes dos vários jornais cariocas confirmam em parte a afirmação de Costa Ferreira, pois evidenciam que nos anos de 1904, 1906, 1907 e 1908, quando Oswald participa do salão, o artista expõe somente pinturas. Contudo, a exposição de Oswald e de Eugênio Latour na Escola Nacional de Belas Artes, em 1913, não parece ser a primeira em que suas gravuras são mostradas no Brasil, visto que em 1909, Amador Bueno, no Jornal do Brasil, Rio de Janeiro, de 04 set. 1909, e o jornalista A.V. do A Notícia, Rio de Janeiro, de 31 ago. 1909, mencionam que o artista apresenta vinte águas-fortes no concurso. 
As águas-fortes de Carlos Oswald não são as únicas gravuras a não serem analisadas pelos jornalistas, visto que além dele outros gravadores, mesmo que poucos, expõem nos salões cariocas ${ }^{72}$. Modesto Brocos y Gomes $(1852$ - 1936), por exemplo, professor da cadeira de desenho figurado na ENBA desde 1891, já apresenta obras gravadas no metal nas exposições gerais nos anos de 1894, 1900, 1901, 1902, 1903 e $1906^{73}$. Esse artista, porém, realiza projeto distinto do de Carlos Oswald com suas gravuras ${ }^{74}$, visto que grava retratos de políticos, artistas e outros homens de importância para a construção da história nacional. Seus retratos, várias encomendas, são destinados às paredes dos gabinetes e corredores do governo e também às publicações impressas com o objetivo de fixar a imagem dos homenageados como heróis nacionais. Mesmo assim, suas águas-fortes, quando expostas nos salões cariocas, também não são analisadas, sendo, apenas, elogiadas ou censuradas.

Ademais, como são poucos os artistas que expõem gravura em metal nas mostras organizadas pela ENBA nesses anos finais do século XIX e inicias do XX, sugere-se que há, no Brasil, pouca compreensão do processo técnico da água-forte, bem como sobre sua

\footnotetext{
${ }^{72}$ Outro artista que apresenta águas-fortes no Brasil no final do século XIX, é o italiano Antonio Piccinni (18461920), pintor e gravador que mora no Rio de Janeiro entre a última década de 1800 e os primeiros anos do século XX. Segundo o Jornal do Commercio, Piccinni expõe, entre outras, a água-forte $O$ Avarento, realizada em 1878. O Museu Nacional de Belas Artes possui um exemplar desta gravura. Piccinni dedica-se a água-forte na Itália, sendo reconhecido pela defesa que faz dela como arte e não apenas como meio de reprodução. Algumas das gravuras que expõe no Brasil no ano de 1895 são elogiadas pela crítica, mas parecem não causar grande impacto no país. Não é possível, todavia, afirmar que as gravuras que esse artista expõe no Brasil sejam todas obras de arte, pois é comum a presença de xilografias, litografias e gravuras em metal na Exposição Geral de Belas Artes que reproduzam pinturas e desenhos de outros artistas ou, ainda, que sejam ilustrações para livros e periódicos. "Notas sobre arte", Jornal do Commercio, Rio de Janeiro, 1 set. 1895, p.2.

${ }^{73}$ No ano de 1894, Brocos apresenta uma água-forte na exposição geral. Cf. Escola Nacional de Belas Artes, Catálogo da Exposição Geral de Belas Artes, Rio de Janeiro, Typographia Hildebrandt, 1894, p. 19. Em 1900, em matéria do Jornal do Commercio, lê-se que "O Sr. Brocos tem na Exposição um bom retrato à água-forte, de uma técnica nervosa e franca, e que seria primoroso se não fosse a mão esquerda". "Notas sobre arte", Jornal do Commercio, Rio de Janeiro, 4 set. 1900, p.3. Sobre o ano de 1901, o missivista registra que o artista aumenta sua coleção de retratos em água-forte com o de Fagundes Varella. Cf. "Notas sobre arte", Jornal do Commercio, Rio de Janeiro, 10 set. 1901, p.3. Em 1902, ele expõe mais quatro retratos, incluindo um de Rodolfo Bernardelli. "Notas de arte", Jornal do Commercio, Rio de Janeiro, 12 set. 1902, p.3. Em 1903, Brocos apresenta entre suas as águas-fortes um retrato do Imperador D. Pedro II. "Notas de arte", Jornal do Commercio, Rio de Janeiro, 13 set. 1903, p.3. Sobre o retrato em água-forte que Modesto Brocos apresenta em 1906, afirma Bueno Amador que "fica longe, mesmo muito longe dos desenhos das suas célebres e artísticas águas-fortes, que com tanta perícia tem cultivado". Bueno Amador, "O Salão de 1906", Jornal do Brasil, Rio de Janeiro, 10 set. 1906.

${ }^{74} \mathrm{De}$ acordo com o que se lê nos periódicos, o pintor espanhol realiza um projeto específico com suas águasfortes: apresenta nos salões retratos gravados que fazem parte de um "grandioso e imperecível monumento que [ele] estava elevando à memória de ilustres brasileiros". "Notas sobre arte", Jornal do Commercio, Rio de Janeiro, 10 set. 1901, p.3. Acrescente-se que, em 1906, um dos retratos expostos por ele, o do constitucionalista José Joaquim Seabra (1855 - 1942), era uma encomenda do governo para a galeria dos titulares da pasta do Interior e Justiça. O jornalista, que comenta a obra, revela que a água-forte é apropriada para essa encomenda por ela ser mais artística e mais duradoura do que a fotografia. Destaca-se que a comparação que o missivista propõe, para justificar a encomenda do estado à Brocos, não é entre a água-forte e a pintura, mas sim entre a gravura e a fotografia, técnica esta considerada meio de reprodução mecânico e com menor durabilidade na época do que a água-forte. "Notas de arte", Jornal do Commercio, Rio de Janeiro, 1 set. 1906, p. 3. Em 1911, Brocos apresenta também um retrato na revista O Brazil Artístico, o de Grandjean de Montegny, que é acompanhado de um texto sobre o construtor e professor da então Academia de Belas Artes. Cf. Sociedade Propagadora de Belas Artes, O Brazil Artístico, Rio de Janeiro, 1911, p. 245.
} 
história. Essas informações não são apresentadas nos textos críticos, porque as gravuras, como se lê em textos dessa época, não são obras de arte. Por isso, os textos do gravador de medalhas e articulista Adalberto Mattos publicados em revistas na década de 1920, por exemplo, se propõem a revelar ao público os "segredos" dessa técnica, objetivando qualificala como parte das Belas Artes e não como arte aplicada à indústria.

\subsection{A crítica da obra de Carlos Oswald nas duas décadas iniciais do século $\mathrm{XX}$}

Carlos Oswald, que nasce e estuda em Florença, envia pinturas ao salão sediado no Rio de Janeiro desde 1904. Neste ano, quando ainda é aluno livre da Academia de Belas Artes florentina, o artista é premiado pelas paisagens expostas na mostra organizada pela Escola Nacional de Belas Artes com a Menção Honrosa de $2^{\circ}$ Grau $^{75}$. Nos anos de 1906 e 1907, período quando reside no Brasil ${ }^{76}$, suas obras também participam dessa exposição, como se lê em notas de periódicos que a registram ${ }^{77}$. Em 1907, Oswald participa ainda do I Salão Livre de Belas Artes $^{78}$ do Museu Comercial, no Rio de Janeiro, com seis pinturas e, em 1908, já de volta à Itália, ele envia novamente para a Exposição Geral de Belas Artes no Rio de Janeiro, ao menos um autorretrato e uma paisagem ${ }^{79}$.

\footnotetext{
${ }^{75}$ Cf. "Exposição das Bellas Artes", Gazeta de Notícias, 12 set. 1904. "Notas de Arte", Jornal do Commercio, Rio de Janeiro, 13 set. 1904, p.3.

${ }^{76} \mathrm{Em}$ sua autobiografia, Carlos Oswald afirma que sua primeira viagem ao Brasil aconteceu no ano de 1906. O pintor chega ao país graças à passagem de navio concedida pelo Cônsul Geral do Brasil em Gênova, amigo de seu pai. Já no Rio de Janeiro, além de participar das Exposições Gerais de Belas Artes, Oswald realiza exposição individual na Escola de Música de Henrique Oswald, Leão Veloso e Francisco Braga, na Av. Rio Branco. Nos meses que passa no Brasil, ele passeia pelas praias e campos cariocas a fim de pintá-las. Percorre além do Rio de Janeiro, Juiz de Fora, cidade na qual se hospeda na casa de Humboldt Fontainha, "pintando paisagens e fazendo pequenos retratos". À relação com a família Fontainha, Oswald atribui o convite que recebe em 1910 para participar da comissão de artistas responsáveis pela decoração do pavilhão brasileiro na Exposição Internacional de Turim de 1911, visto que Humboldt foi o encarregado da organização da mostra. Cf. Carlos Oswald, op. cit., 1957, p. 13-27. José Eduardo Martins, em estudo sobre o músico Henrique Oswald, escreve que o pianista organizou os concertos musicais na mesma exposição universal de Turim, mas a convite do governo paulista. A pesquisa de Martins, baseada nas correspondências da família Oswald, aponta que Carlos retornou do Brasil à cidade florentina em outubro de 1907. José E. Martins, Henrique Oswald: músico de uma saga romântica, 1995, São Paulo, Edusp, p. 86-87.

${ }^{77}$ No ano de 1906, segundo Gonzaga Duque e Amador Bueno, Oswald expõe as pinturas Violinista, Triste e Magdalena; nesse ano, o júri lhe confere a Medalha de $2^{\mathrm{a}}$ Classe. Em 1907, as críticas nos periódicos citam que o artista apresenta um autorretrato, um retrato intitulado com as iniciais "M.B." e um retrato de Henrique Oswald, seu pai. Cf. Gonzaga Duque, "Salão de 1906", Kosmos, Rio de Janeiro, set. 1906. Bueno Amador, "Belas Artes - O Salão de 1906", Jornal do Brasil, Rio de Janeiro, 26 set. 1906, p.2. Gonzaga Duque, "Salão de 1907", Kosmos, Rio de Janeiro, set. 1907. "Escola de Bellas Artes - Salão de 1907 - Vernissage", Correio da Manhã, Rio de Janeiro, $1^{\circ}$ set. 1907.

${ }^{78}$ Em 1907, Oswald participa da primeira exposição do Salão Livre de Belas Artes, no Museu Comercial no Rio de Janeiro, apresentando seis trabalhos, entre eles o jornalista cita um retrato de Francisco Braga e os títulos $A$ Tarde, Guarás e Rosas. Cf. "Os nossos artistas", Gazeta de Notícias, Rio de Janeiro, 13 ago. 1907.

${ }^{79}$ A matéria da Revista da Semana comenta que Oswald expõe um autorretrato no salão de 1908. Amador Bueno menciona, além do autorretrato feito à "maneira antiga", uma "paisagem brasileira". Nesse ano, novamente,
} 
As obras de Carlos Oswald vistas no Brasil nesses anos, todas pinturas, são criticadas quanto às suas cores e luzes e são descritas como monocromáticas ${ }^{80}$ e escuras. Os jornalistas afirmam que o "jovem pintor" segue um "modo antigo" de pintar, sem fontes de luz natural, uma vez que suas pinturas lembram as de Rembrandt ${ }^{81}$. Relativamente à paisagem, observam os amantes da "luz brasileira", que as pinturas do gênero feitas no Rio são extravagantes, fantasiosas e literárias ${ }^{82}$. É o que eles evidenciam nos jornais, visto não conhecerem a pesquisa pictórica de Oswald que na época se propunha a pintar "ao modo de Carrière", portanto, distante da ideia de cópia da natureza. No que concerne aos retratos, os articulistas afirmam que os pintados por ele não parecem "ente humano" e têm a "carnação" como de uma "estátua de marfim" $" 83$. No que se refere à pintura sacra, acerca da tela Magdalena, a capital do país, presa ainda aos conceitos padrões de Academia de Belas Artes, a considera como despojada dos atributos que lhe são próprios ${ }^{84}$, daí afirmarem, por exemplo, que as pinturas de Oswald não explicitam seus títulos. Essas críticas, que bem mostram o gosto da época, acabam, em geral, por afirmar que, apesar dos “defeitos”, Oswald é um jovem promissor.

As gravuras de Oswald apresentadas na Exposição Geral de Belas Artes de 1909, na seção "Gravuras e Litografias", são elas também estranhas aos colunistas de arte do país. Bueno Amador, articulista do Jornal do Brasil que escreve sobre os salões, afirma que esses trabalhos são falhos quanto à composição e também escreve que não condizem com o quê

Oswald não recebe recompensas do concurso. Cf. "O salão de Bellas-Artes”, Revista da Semana, Rio de Janeiro, 18 out. 1908. Bueno Amador, "Bellas-Artes", Jornal do Brasil, Rio de Janeiro, 15 set. 1908, p.4.

${ }^{80}$ Em sua autobiografia, Carlos Oswald lembra ter exposto no Rio de Janeiro um autorretrato "monocromo feito à maneira de Carrière", maneira que ele " procurava imitar e que estava em voga naqueles anos, na Europa". $\mathrm{O}$ artista não especifica, todavia, quando expôs essa pintura. Carlos Oswald, op. cit., 1957, p. 19. Maria Amélia de Toledo B. Piza, em sua tese sobre a obra pintada de Carlos Oswald, afirma que a tela Autorretrato à Carrière foi executada em 1907 no Rio de Janeiro e que o artista realizou uma cópia dela, exposta na Europa, sendo a "original" apresentada no salão de 1907. Cf. Maria A. de T. B. Piza, A Poética da Luz na Obra de Carlos Oswald, Bauru, 2004, p.81. As críticas desse ano da mostra afirmam que, entre outras obras, Oswald expôs um autorretrato ao qual referem-se os jornalistas como "estudo de cabeça". O autor do Jornal do Commercio afirma que "O seu estudo de cabeça, um autorretrato, que tem certas qualidades de modelado, parece um pergaminho velho que tenha sofrido os efeitos de um incêndio". "Notas de Arte", Jornal do Commercio, Rio de Janeiro, 8 set. 1907. As críticas do ano de 1908, também citam um pequeno autorretrato: "É de muito bom desenho, finamente modelado, expressivo e com ambiente. Se há algum senão (e se isto constitui senão) é que lembra um retrato antigo". "O salão de Bellas-Artes", Revista da Semana, Rio de Janeiro, 18 out. 1908. Amador Bueno, também em 1908, elogia o mesmo retrato, afirmando que não conhece o "original". Assim, é possível que o autorretrato feito à maneira do artista Eugéne Carrière seja exposto ou em 1907 ou em 1908 e que os críticos brasileiros desconheçam a referência ao artista francês, considerando apenas que a pintura de Oswald apresenta um modo antigo, com apenas um ponto de luz na composição e sem "luz natural". Bueno Amador, Jornal do Brasil, Rio de Janeiro, 15 set. 1908.

${ }^{81}$ Cf. "Notas de Arte", Jornal do Commercio, Rio de Janeiro, 23 set. 1906.

${ }^{82}$ Cf. Bueno Amador Jornal do Brasil, Rio de Janeiro, 15 set. 1908.

${ }^{83}$ Cf. "Notas de Arte", Jornal do Commercio, Rio de Janeiro, 8 set. 1907.

${ }^{84}$ Cf. Gonzaga Duque, "Salão de 1906", Kosmos, Rio de Janeiro, set. 1906. 
seus títulos expressam ${ }^{85}$. O jornalista acrescenta que as considera de um "exotismo doentio" $\mathrm{e}$, por isso, prefere as pinturas às gravuras do artista, ainda que as pinturas possuam problemas, mas estas, ao menos, segundo Amador, mostram a "maneira pessoal" do artista, característica que o articulista valoriza ${ }^{86}$.

Contudo, se as pinturas de Oswald são aceitas por essa característica que os missivistas intitulam "maneira pessoal", as águas-fortes são, no máximo, consideradas por Amador e pelo jornalista do A Notícia ${ }^{87}$, que também as cita em seu texto, como "boas" enquanto "gravuras". As águas-fortes são "boas", pois técnicas de reprodução, técnica, aliás, que Oswald domina, embora apresente obras no salão. As pinturas, no entanto, são valorizadas pela "maneira pessoal", porque são obras de arte, muito diferentes das composições feitas com incisões, que os articulistas não entendem. As gravuras de Oswald também incomodam os jornalistas por possuírem títulos em francês. Tanto Bueno Amador quanto aquele que assina com as iniciais A.V. repreendem essa escolha e explicitam o desgosto que possuem pelo abandono da "língua de Camões".

Nos três anos seguintes a 1909 não há notícias da participação de Carlos Oswald nas mostras brasileiras. Entre 1910 e 1911, o pintor está encarregado, em conjunto com outros artistas brasileiros, tais como os irmãos Chambelland, os Timothéo da Costa e Eugênio Latour, da decoração do Pavilhão Brasileiro da Exposição Universal de Turim de $1911^{88}$,

\footnotetext{
${ }^{85}$ Cf. Bueno Amador, Jornal do Brasil, Rio de Janeiro, 4 set. 1909.

${ }^{86} \mathrm{O}$ "estilo" ou "maneira" própria de um artista é qualidade ressaltada por vários missivistas do início do século XX que tratam dos salões. Na visão deles, é fundamental que os jovens pintores demonstrem em suas obras, expostas ano a ano, a constituição de uma maneira específica. A matéria do Jornal do Commercio sobre a mostra de 1909, por exemplo, afirma que: "O Sr. Carlos Oswald, que passou por um temperamento exótico, meio desorientado, dotado embora de inata e profunda intuição artística, começa a libertar-se dos seus defeitos - ou a fazê-los esquecer - a impor-se como um artista apenas bastante "diferente" para se constituir uma originalidade. A figura macerada, torturada de sonho da sua Réveuse; o seu Pierrot todo branco, melancólico, dando uma sensação musical de surdina moribunda; o seu Homme au manteau noir, tipo de poeta ou artista doutros tempos, desgrenhado e fatal - são criações acentuadas, essencialmente individuais. A fatura, com o seu cunho de aparência antiga, é, na verdade, nova, porque é própria; os seus mesmos desvios e deficiências não se confundem com a inexperiência comum; e assim também os traços fortes, os efeitos profundos se tornam mais profundos e mais fortes pela sua independência e ineditismo. O Sr. Oswald não tardará de certo em fazer triunfar completamente a sua originalidade." "Notas de arte", Jornal do Commercio, Rio de Janeiro, 7 set. 1909, p. 7.

${ }^{87}$ A.V., A Notícia, Rio de Janeiro, 31 ago. 1909.

${ }^{88}$ De acordo com Carlos Oswald, após deixar o Brasil, em 1907, e de permanecer algum tempo em Florença, em 1909 ele viaja para Munique. Em 1910, já de volta da Alemanha, foi convidado para, em conjunto com outros artistas, decorar as salas do pavilhão brasileiro na Exposição Universal de 1911. Os trabalhos da equipe de artistas, apesar de destinados à Itália, foram realizados em Paris e, posteriormente, transferidos para Turim, visto que se tratavam de painéis para serem "maruflados" nas paredes. Segundo o relatório dos trabalhos da comissão do Brasil na Exposição Universal de Turim-Roma, fazem parte da comissão de "Direção da parte técnica e artística" encarregada da decoração do pavilhão do Brasil: Dr. Jayme Figueira, Julio Antonio de Lima, Aluizio de Almeida Stahlembrecher, D. Georgina de Albuquerque, D. Nicolina Vaz de Assis, Eduardo de Sá, Antonio Parreiras, Manoel Madruga, Carlos Chambelland, Rodolpho Chambelland, Lucilio de Albuquerque, Irmãos Timotheo da Costa, José França, Eugenio Latour, Augusto de Freitas e Carlos Oswald. No mesmo relatório, há menção a Carlos Oswald na descrição do pavilhão brasileiro: "Lateralmente, duas ricas salas, estilo Luiz XV, decoradas pelos artistas irmãos Timotheo da Costa e Carlos Oswaldo [sic], comunicam-se com as quatro
} 
decoração para a qual são realizadas pinturas murais em telas, em Paris, posteriormente, “marufladas” nas paredes do pavilhão na cidade italiana. Só em 1913 o nome de Oswald volta a aparecer nas colunas de arte dos jornais do Brasil, inicialmente nos artigos que comentam sua exposição com Eugênio Latour, no primeiro semestre daquele ano na Escola Nacional de Belas Artes, e, no segundo semestre, na Exposição Geral da mesma escola.

Evidencia-se que há nos textos sobre a obra de Oswald, desse ano de 1913, uma mudança significativa em relação ao que se lê sobre ela nos primeiros anos em que ele expõe no Brasil. No ano de sua volta ao Rio de Janeiro, os jornalistas o celebram como um pintor que explora os "efeitos de luz" e as "cores" em suas pinturas. Essa exaltação é realizada em oposição às suas obras anteriores, pintadas pela crítica como "monocromáticas". Lê-se, por isso, sobre o "progresso" do jovem artista: em texto de 27 de maio de 1913 do Jornal do Commercio $^{89}$, por exemplo, consta que as primeiras pinturas do artista expostas no Brasil demonstram "predileções arcaicas", advindas da frequência de Oswald às galerias florentinas, mas em 1913, segundo o autor, o artista se esforça para criar um estilo pessoal; o Correio da Noite $^{90}$, de alguns dias antes, publica artigo no qual Oswald é descrito como "colorista" e "impressionista", justamente o contraponto com o passado, pois agora, ele está "liberto do academismo e dos ateliês penumbrosos".

As descrições e ideias usadas para caracterizar a pintura de Oswald, nos textos de época, são organizadas de modo a justificarem as mudanças na pintura dele como uma sucessão e superação de fases ${ }^{91}$. Essa progressão faz o artista ascender da condição de aprendiz, portanto, preso aos ensinamentos escolares, ao patamar de artista com "estilo pessoal”, que está a par das pesquisas europeias entendidas, pelos colunistas de arte, como as mais "modernas", tal como o que eles entendem por Impressionismo. Desta maneira, a crítica

pequenas salas angulares...". Cf. Antônio de P. A. Resende, Relatorio sobre os trabalhos da Commissão do Brazil na Exposição Turim-Roma de 1911 e propaganda do café no estrangeiro, Turim, 1911, p. 94. Na "Relação de trabalhos de Carlos Oswald", na autobiografia do artista, há também a seguinte referência sobre essa decoração: "Painéis decorativos - 5 painéis, 2,00 x 2,00m - Pintura à cera, intitulados: "A Dança", "Música no Trabalho", "Música na Natureza", "Música no Mar", "Música no Amor"; executados em Paris para o Pavilhão Brasileiro na Exposição Internacional de Turim, Itália". Cf. Carlos Oswald, op. cit., 1957, p.209.

89 "Notas de arte", Jornal do Commercio, Rio de Janeiro, 27 maio 1913.

90 “A Exposição Oswald na Escola de Bellas Artes”, Correio da Noite, Rio de Janeiro, 23 maio 1913, p.1.

${ }^{91}$ Nos artigos sobre a Exposição Geral de Belas Artes de 1913, a crítica acerca das diferentes "maneiras" da obra de Oswald é clara, visto que o jornalista de O Imparcial se aventura a explicar as "graves mudanças" desse "nobre" pintor identificando três maneiras de pintar no desenvolvimento da obra dele: na primeira são ressaltadas as "massas pesadas" e o "ambiente pouco iluminado", fase na qual o pintor ainda está afastado da "sua verdadeira meta" e é atrapalhado pelas "influências acadêmicas"; a segunda e a terceira maneiras, segundo o jornalista, se diferenciam apenas pelos gêneros das pinturas e revela a "verdade" do artista, a cor. A segunda maneira é a das "telas decorativas" que representam os bois nas praias toscanas, com fatura simples e original. A última é a dos quadros de gênero que representam nus e cenas cotidianas com iluminações artificiais. É esta a maneira, para o autor, que revela "o belo temperamento alegre e sensual de Carlos Oswald" e é "seu melhor encanto". "O ‘salon’ de 1913 - Carlos Oswald - Luiz Cristhophe”, O Imparcial, Rio de Janeiro, 9 set. 1913. 
da pintura de Carlos Oswald é feita de modo a evidenciar as melhoras consecutivas do "jovem promissor" 92 .

Nota-se que a ideia de "progresso" presente nesses textos não é restrita a Oswald, trata-se de uma ideia presente nos demais escritos sobre arte no Brasil nas primeiras décadas do século XX. Estes textos são construídos de modo a demonstrarem os "avanços" dos jovens artistas, visto que essas exposições, em especial as Gerais de Belas Artes, são "a prova do movimento artístico" ${ }^{93}$ do país, como explicita o colunista do A Notícia em 1913.

Dentro desse modelo de texto, voltado primordialmente à pintura e pautado na ideia de progresso dos artistas, não há espaço para a água-forte, visto que essa técnica, como se viu, nem obra de arte é. Assim, os artigos que citam essa produção o fazem ou para sugerir que Carlos Oswald abandone outros processos artísticos, no caso a calcogravura, a fim de concentrar-se em uma só arte, a pintura, ou para tecer comentários breves, elogiosos e sumários sobre as águas-fortes de Oswald, sem analisá-las.

Relativamente ao conselho dado a Oswald, para que ele opte pela pintura, a ideia do “jovem promissor" parece sugerir que enquanto aprendiz, ou "artista moço", é permitido a ele as experiências diversas. É frente a essa ideia, que distingue a pintura como arte e a gravura como "arte aplicada" ou "arte aplicada à indústria", que alguns críticos chegam até a elogiar a “polifonia" de técnicas utilizadas por Oswald. Dois artigos exemplificam o exposto, a saber, o do Jornal do Commercio de 27 de maio de 1913, no qual se lê um elogio seguido de conselho:

Mais do que uma simples referência merecem suas águas-fortes, em que o artista revela qualidades de vigor, de audácia e de claro-escuro e produz obras de bastante valor.

Mas... completa o jornalista:

O Sr. Carlos Oswald na atual exposição afirma-se um artista dotado de qualidades valiosas e de rara energia de trabalho: há nele o estofo de um verdadeiro pintor! Mas é preciso, a bem do seu futuro, que abandone todas as experiências com formas de arte para que não se sinta fortemente levado e que trace definitivamente a estrada que tem

\footnotetext{
${ }^{92}$ Entre o momento inicial da obra de Oswald e aquele no qual ele é descrito como "jovem pintor" há a volta do artista para a Europa, entre 1908 e 1913. Período este que é entendido, por alguns missivistas, como uma viagem de estudos, uma vez que isto é o esperado para a carreira de vários dos artistas do país. Assim, diversos textos não informam corretamente que Oswald é nascido na Itália e não está ali estudando temporariamente, mas sim, residindo. Por isso, nesses mesmos textos, lê-se que em 1913 ele está de "volta" ao Rio de Janeiro, como outros brasileiros que viajam para conhecer as escolas e museus europeus.

93 “A Noticia no Salon”, A Notícia, Rio de Janeiro, 3 set. 1913.
} 
de trilhar, para que não esbanje inutilmente as suas forças e não prejudique o elemento vital de sua arte. $^{94}$

Conselho similar é dado por M. Nogueira da Silva a Carlos Oswald. No capítulo "Dois Grandes Artistas"95 de seu livro Artistas de Hoje, Nogueira da Silva comenta a mostra de 1913 de Oswald e de Latour na ENBA. Pelo que se lê em seu livro, a arte é, para ele, o resultado da interpretação da "natureza" pelo espírito do artista, que a sente e, depois, a fixa, por meio da técnica, na obra. Assim, é pela distinção entre os modos de sentir que o articulista explica as diferenças existentes entre os artistas. No texto no qual trata especificamente de Oswald e Latour, ele explicita que há dois modos de interpretar a "impressão fugaz da natureza": alguns artistas apenas a percebem e produzem uma arte mais "realista", mais próxima à vida, visto que se trata de uma emoção mais branda; outros, porém, são acometidos por afetações mais violentas e sofrem a natureza, por isso produzem uma arte mais fantasiosa. Oswald está, para Silva, nesse segundo grupo de artistas, enquanto Latour está no primeiro.

Deste modo, Nogueira da Silva não admite que alguém que "sofra a natureza" e domine o desenho e a perspectiva, como Oswald, possa dedicar-se à "febre de ineditismo e bizarrismo", ou seja, possa estar desviado dos "supremos intuitos da arte" e gaste tempo e energia com a "moda do novo". Logo, o articulista não entende porque Oswald, "artista vibrátil" e "preocupado com a beleza", faz monotipias e outras experiências com materiais. As águas-fortes apresentadas na exposição são até elogiadas, porém, mesmo sendo o artista o "nosso mais distinto água-fortista" ${ }^{96}$, Nogueira da Silva o aconselha a concentrar-se em um "só processo", que - pelo que se depreende dos demais artigos do livro - é a pintura.

Quando não é sugerido a Carlos Oswald que abandone suas águas-fortes, essas são entendidas pelos jornalistas como "estudos". O missivista do artigo "A propósito do "Salão de 1913 "' 97 , por exemplo, afirma conhecer a obra de Oswald não apenas das telas apresentadas no Salão, mas também das "pastas, que o artista guarda em sua oficina". O autor do artigo, A.V., é o mesmo que, em 1909, menciona as águas-fortes de Oswald na Exposição Geral de Belas Artes daquele ano. No texto de 1913, o jornalista discute as representações de animais realizadas em pintura e em escultura e comenta a obra de alguns artistas que expõem no salão. Ao final do artigo, menciona as obras de Carlos Oswald que representam os bois usados no transporte do mármore nas praias toscanas. É nesse contexto que cita as águas-fortes do artista

\footnotetext{
94 “Notas de arte", Jornal do Commercio, Rio de Janeiro, 27 maio 1913.

${ }^{95}$ M. Nogueira da Silva, "Dois grandes Artistas", In: M. Nogueira da Silva, Artistas de Hoje, Rio de Janeiro, Ed. Brasileira Lux, 1925, p. 91-115.

${ }^{96}$ Idem, p. 114.

${ }^{97}$ A.V., "Á proposito do 'Salão de 1913"”, Suplemento d'A Notícia, Rio de Janeiro, 18 out. 1913.
} 
como "estudos gráficos". Aliás, as reproduz nas páginas do jornal com a legenda "estudo", reforçando a noção presente no texto de que esses trabalhos seriam preparações para a arte: a pintura.

Os repetidos elogios às águas-fortes de Carlos Oswald, que aparecem em alguns textos da década de 1910, não são suficientes para ampliar a discussão sobre ela. Muito menos a qualificam como algo além de técnica que serve a outras artes, como a pintura, visto que esses artigos não apresentam nenhuma reflexão, nem trazem informações novas para os leitores sobre a água-forte ou outra gravura em metal. A coluna "Notas de Arte", do Jornal do Commercio, em 16 de agosto de $1914^{98}$, por exemplo, menciona que Carlos Oswald apresenta no salão daquele ano águas-fortes, águas-tintas e pontas secas junto com sua pintura, comentando que esses trabalhos têm uma nota pessoal e uma imaginação sonhadora. A mesma coluna, no ano seguinte, afirma que as águas-fortes do artista, únicas gravuras nessa técnica expostas no Salão de 1915, são “interessantes e finas" ${ }^{99}$. Sobre a Exposição Juventas ${ }^{100}$, também de 1915, lê-se que Oswald é "severo na água-forte, guardando sempre aquela simplicidade do desenho". Considere-se: não raro a gravura é entendida como um modo de se reproduzir desenhos, e isso ainda ao longo dos primeiros 30 ou 40 anos do século XX no Brasil.

Mesmo sobre a exposição individual do artista no Liceu de Artes e Ofícios em 1916, lê-se apenas que "Como água-fortista já o sabemos artista completo" ${ }^{101}$. O comentário sumário revela que não há nada a ser discutido sobre uma técnica que, segundo o missivista, o artista já domina. Para essas obras não se coloca a crítica de arte, tal como é feita em relação às pinturas do artista. Estas, identificadas por seus títulos, são analisadas em relação a obras de outros artistas, sendo relevante comentar o modo como são pintadas.

Os textos de periódicos, assim, nada revelam sobre as obras gráficas expostas nos anos iniciais do século XX, evidenciam que elas podem, no máximo, ser consideradas como produtos de uma técnica que é bem ou mal repetida por aquele que a pratica. A gravura é indiferente aos colunistas de arte. Conhece-se, entretanto, artigo de 1916, do Jornal do Commercio $^{102}$, que trata da Exposição Geral, no qual essa indiferença é substituída pela surpresa. O jornalista, demonstrando que é incomum a presença de três expositores de águaforte na mostra, afirma que os jovens Carlos Oswald, Argemiro Cunha e Adalberto Mattos

\footnotetext{
98 "Notas de arte", Jornal do Commercio, Rio de Janeiro, 16 ago. 1914, p.6.

99 "Notas de arte", Jornal do Commercio, Rio de Janeiro, 15 ago. 1915, p.2.

100 "Notas de arte - Exposição Juventas", A Notícia, Rio de Janeiro, 16 out. 1915.

101 "Inaugurou-se hontem a exposição de pintura Carlos Oswald", Gazeta de Notícias, Rio de Janeiro, 24 maio 1916.

102 "Notas de arte”, Jornal do Commercio, Rio de Janeiro, 26 ago. 1916, p.6-7.
} 
bem fazem em se dedicar a essa arte, que, na Europa, pode adquirir preços elevados. A afetação do missivista em relação às águas-fortes revela a pouca familiaridade que se tem com a técnica, daí o autor evidenciá-la como "novidade".

Nos anos seguintes, não há mudanças quanto à recepção das obras gráficas nos jornais e revistas, que, entre 1917 e 1918, aliás, pouco mencionam as águas-fortes do agora pintor, representante de sua geração ${ }^{103}$, como escrevem, Carlos Oswald. Menciona-se que há alguns artigos de periódicos de São Paulo, do final da década de 1910 e início da de 1920, que registram as vendas de obras, tanto de pinturas, quanto de gravuras e até desenhos, das exposições de Carlos Oswald naquela cidade $^{104}$. Todavia, não se percebe nesses textos mudanças em relação aos periódicos cariocas, visto que mesmo em artigo do jornal $A$ Gazeta, que destaca no título a pintura e a gravura na mostra de Oswald em São Paulo, em 1923 “A exposição do pintor e agua-fortista Carlos Oswald" ${ }^{105}$-, são escritos os costumeiros elogios, sem análise ou mesmo explicação para os leitores sobre o que são "as belas e difíceis águasfortes".

Há somente dois artigos na década de 1910 que se apresentam como exceções ao que aqui se expõe. Na década seguinte apenas mais três publicações sobre a água-forte a analisam como obra de arte nos periódicos cariocas. Esses artigos, todavia, não contradizem o que se afirma sobre a ausência de análise da água-forte e sobre a indiferença em relação a essa arte, que é entendida como "arte aplicada".

\subsection{Adalberto Mattos e Renato Almeida: a água-forte como obra de arte}

Adalberto Mattos ${ }^{106}$ publica, em 1916, um artigo no jornal $A$ Época, possivelmente por ocasião da exposição individual de Carlos Oswald no Liceu de Artes e Ofícios, no qual além de discutir a pintura daquele que, como ele, é professor na escola do povo, escreve sobre

\footnotetext{
${ }^{103}$ Cf. "Notas de Arte - Exposição Oswald", Jornal do Commercio, São Paulo, 25 jan. 1918. Cf. Rodrigo Octavio Filho, "O 'Salão' de 1918”, Revista do Brasil, São Paulo, nov. 1918, p.305-310.

${ }^{104}$ Diversas notas registram as vendas da mostra. Cf. "Exposição Carlos Oswald", Correio Paulistano, São Paulo, 21 jan. 1923. "Exposição Carlos Oswald", A Gazeta, São Paulo, 24 jan. 1923. No encerramento da exposição, anuncia-se que foram vendidos vinte e três quadros a óleo, dezoito águas-fortes, onze sanguíneas e um desenho a pastel. "Exposição Carlos Oswald", Correio Paulistano, São Paulo, $1^{\circ}$ fev. 1923.

105 "A exposição do pintor e agua-fortista Carlos Oswald”, A Gazeta, São Paulo, 11 dez. 1923.

${ }^{106}$ Adalberto Pinto de Mattos (1888-1966) escreve para periódicos na década de 1920, especialmente para aqueles da sociedade anônima $O$ Malho, tais como Illustração Brasileira e Leitura para todos, artigos sobre a arte brasileira. $\mathrm{O}$ autor, que também era gravador de medalhas e pedras preciosas formado pela ENBA e, portanto, ex-aluno de Augusto Girardet, escreveu tanto sobre a arte mais difundida no período, a pintura, quanto sobre a escultura, a gravura em medalhas, a cerâmica e a gravura à água-forte. No livro sobre o Liceu de Artes e Ofícios de Álvaro Paes de Barros, lê-se que Adalberto Mattos foi aluno dessa escola, concomitantemente à sua formação na ENBA, e, a partir de 1908, tornou-se professor de desenho do Liceu.
} 
suas águas-fortes ${ }^{107}$. Ao contrário dos demais artigos do período, no texto encontram-se vários parágrafos sobre a "arte do branco e negro". Nestes, Mattos revela que as "pessoas" não entendem porque Carlos Oswald "não dá às suas chapas aquela minúcia" encontrada nas águas-fortes de gravadores como o italiano Antonio Piccinni e o austríaco Ferdinand Schumtzer. Enfatiza que estes dois gravadores, como outros, usam apenas "a ponta do riscador e do buril" para fazer suas imagens. Explicita, assim, que tais "pessoas" conhecem apenas obras gravadas nas quais o contraste entre o branco e o preto, bem como os meios tons, são unicamente realizados por hachuras entrecruzadas, tal como determinam os manuais práticos sobre gravura, destinados à arte da reprodução.

Carlos Oswald, contudo, afirma Mattos, explora "novos métodos" para realizar suas obras. Nelas, os claros e escuros são obtidos também pelo emprego de "truques", comuns aos água-fortistas modernos, os quais proporcionam "belos efeitos". O medalhista explica que os panos e o palmo da mão, normalmente usados para retirar o excesso de tinta durante a entintagem da matriz, são utilizados pelos água-fortistas modernos para criar finas veladuras e áreas limpas na matriz que, ao ser impressa, tem seus cinzas, brancos e escuros formados por linhas e também por manchas de tinta. Essas veladuras feitas na impressão e, portanto, não gravadas na chapa, são fundamentais para a realização das águas-fortes de Oswald, pois as linhas, essas sim, incisões corroídas pelo ácido, são sintéticas. O autor, em diversas passagens do texto, evidencia que esse modo de proceder é uma novidade, "moderno", e, enfatiza, não está "escrito nos manuais"108.

O próprio Carlos Oswald afirma que a gravura "aprende-se na oficina fazendo e vendo fazer [...] as teorias são boas só nos livros, a prática é que [faz] o grande mestre." E acrescenta: "Eu nunca li nenhum manual de gravura e no entanto... o que aqui está foi feito unicamente com a experiência da oficina" ${ }^{\text {109 }}$. A ênfase na experimentação e descobertas ao se fazer gravuras e não na técnica apreendida a partir de manuais é fundamental na argumentação, tanto de Mattos quanto de Oswald, para divulgar a água-forte como obra de arte, visto que, para tanto, é preciso afastá-la da concepção de processo que é repetido a partir de textos técnicos e, até, distanciá-la das imagens publicadas em livros e revistas que o público conhece e identifica como "gravuras". Ao ressaltar que as águas-fortes de Oswald são realizadas com métodos modernos, Mattos as destaca da vulgaridade dos impressos e as qualifica como obras de arte que são realizadas a partir de "maneiras pessoais" do artista.

\footnotetext{
${ }^{107}$ Adalberto Mattos, "Impressões de Arte”, A Epoca, Rio de Janeiro, 27 jun. 1916.

${ }^{108}$ Idem, ibidem.

${ }^{109}$ Idem, ibidem.
} 
Outra ideia recorrente nos artigos de Mattos é que a água-forte é "pouca divulgada entre nós" ${ }^{110}$, tanto que a aquisição da Biblioteca Nacional de uma coleção de gravuras de Carlos Oswald ${ }^{111}$, com exemplares definitivos e provas de estado, é justificada na fala do artista da seguinte maneira:

Felizmente estas [as águas-fortes] agora vão para lugar seguro, para a Biblioteca Nacional, que adquiriu uma coleção com todos os documentos e "estados" para a boa realização das cópias; é uma coleção interessante, onde os que não têm noção do que é a arte da água-forte podem ver como se faz uma chapa e que ela é mais difícil do que parece à primeira vista. ${ }^{112}$

A venda é de interesse de acordo com o que se lê, para tornar o processo de realização de uma água-forte conhecido e acabar com os preconceitos em relação a essa arte, que tem suas características próprias e difere, assim, de qualquer outra técnica gráfica.

Em novembro de 1920, Adalberto Mattos publica novo artigo intitulado "O que é a gravura a água-forte" ${ }^{\prime 113}$, no qual são descritos os materiais e as ferramentas empregados na água-forte, dadas receitas de mordentes e de vernizes e também é explicado como se faz uma obra com esse processo do início ao fim. A publicação esclarecer como se faz uma água-forte é coerente com a hipótese de que é preciso tornar conhecida a arte dos metais: evidenciando seu processo, demonstra-se, além de sua complexidade, a diferença que ela possui em relação às técnicas de reprodução mecânica, advindas dos processos fotográficos, com as quais a água-forte é, por vezes, confundida. As "explicações", portanto, servem para demonstrar o processo usado pelos artistas a fim de que aqueles que ainda não conhecem a água-forte possam aprender sua técnica, estudá-la, quer dizer, olhar os “mestres”, para, posteriormente, adotar seu modo próprio de gravar:

A água-forte é a Arte mais pessoal que imaginar se possa. Cada um traça como entende, porém quando já é senhor de todas as manhas existentes. Antes é conveniente estudar como os mestres aconselham, para adquirir a ginástica precisa. ${ }^{114}$

\footnotetext{
${ }^{110}$ Idem, ibidem.

${ }^{111}$ A fala do artista informa também que, nesse ano de 1916, a Biblioteca Nacional adquire uma coleção de águas-fortes suas. Essa informação é coerente com a que se encontra no livro de Registro da Biblioteca Nacional do ano de 1916, preservado pela Divisão de Iconografia da Fundação Biblioteca Nacional, no qual se lê, ao menos em dois processos no mesmo ano, um de 28 de julho e outro de 30 de dezembro, que a biblioteca paga ao artista por diversas águas-fortes, tanto exemplares definitivos, quanto provas de estado.

${ }_{112}$ Carlos Oswald, citado por Adalberto Mattos, "Impressões de Arte", A Epoca, Rio de Janeiro, 27 jun. 1916.

113 A.M., "O que é a gravura a água-forte", Leitura para todos, Rio de Janeiro, nov. 1920.

${ }^{114}$ Idem, ibidem.
} 
Junto ao texto de Mattos são impressas imagens que mostram desenhos das ferramentas, da prensa e dos demais processos descritos. É também reproduzida como exemplo de uma água-forte, obra assinada com o monograma do artista italiano Felice MelisMarini. Observa-se que os clichês que ilustram o artigo de Mattos são iguais aos que foram publicados no manual Hoepli ${ }^{115}$, publicado em 1916, cujo autor é o referido Melis-Marini, artista que procura explicar aos principiantes os "segredos da técnica de incisão" de maneira moderna, distante, portanto de manuais como os de Abraham Bosse e outros que ensinavam como representar madeiras, tecidos, peles em gravações.

Imagem 1: Clichês do manual de Água-forte de Felice Melis-Marini.
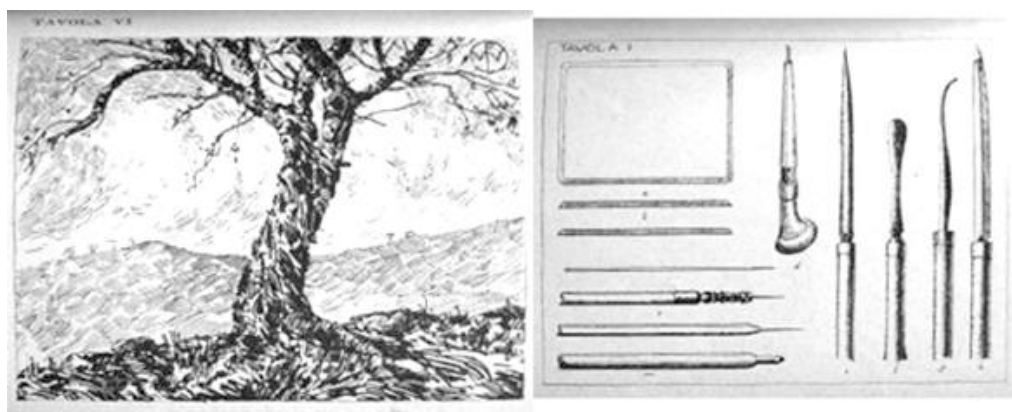

Fonte: Felice Melis-Marini, L'Acquaforte: Manuale Pratico con 10 tavole e 15 prove originali, Milão, 1916.

Disponível em: http://ilmercantediebay.altervista.org/acquaforte.html. Acesso: 12/05/2017.

Imagem 2: Ilustrações do artigo de Adalberto Mattos, "O que é a gravura a água-forte”.
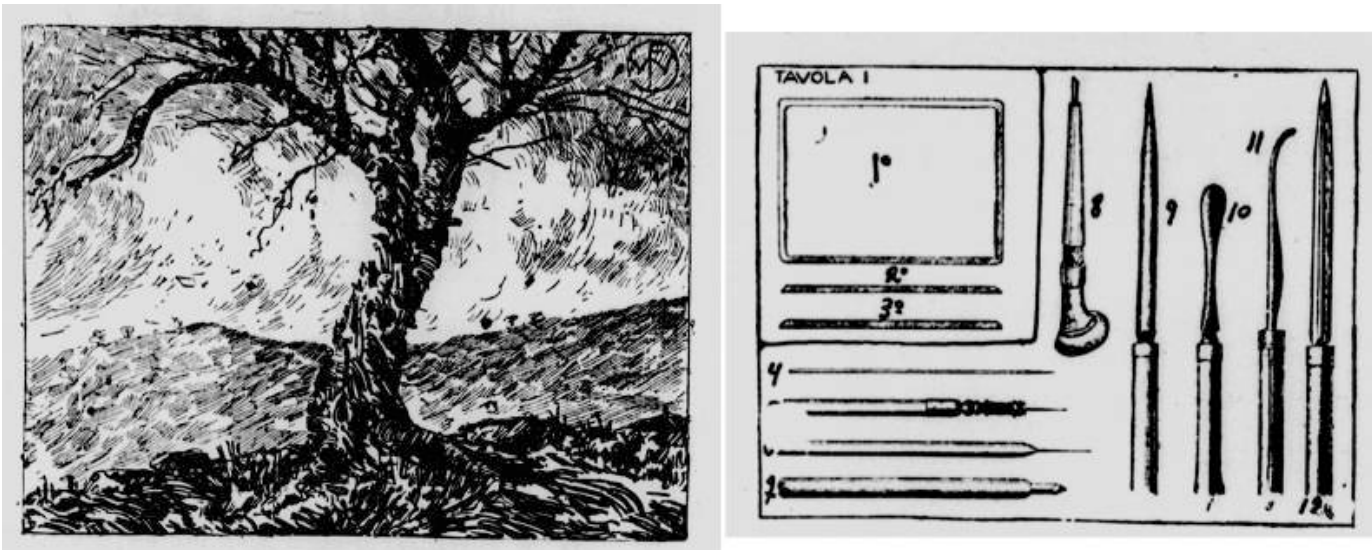

Prova de uma chapa.

Fonte: A.M., “O que é a gravura a água-forte”, Leitura para todos, Rio de Janeiro, nov. 1920. Disponível em:

Hemeroteca Digital, Fundação Biblioteca Nacional.

\footnotetext{
${ }^{115}$ Felice Melis-Marini, L'Acquaforte: Manuale Pratico con 10 tavole e 15 prove originali, Milão, 1916.
} 
Adalberto de Mattos, no texto da Leitura para todos, não se ocupa somente dos processos técnicos, uma vez que ele aborda também a história da água-forte no Brasil. No texto consta que Modesto Brocos e Henrique Bernardelli foram os primeiros a se arriscarem nas artes dos metais no Rio de Janeiro. Brocos, segundo Mattos, inaugura a prática da águaforte no país quando aqui chega em 1891 e Bernardelli começa a praticá-la em 1900. Todavia, o testemunho de Mattos é de que o modo de proceder desses artistas é "velho", já estabelecido pelos manuais e, portanto, contrastante com a novidade que Carlos Oswald apresenta. Aliás, para encerrar seu texto, Mattos destaca peremptoriamente a Primeira exposição carioca de água-forte, organizada por Oswald, realizada no ano de 1919 no Liceu de Artes e Ofícios, afirmando que "A realização de tão interessante exposição marcará o início do renascimento de uma nova era para a Arte Brasileira" $" 116$.

Os artigos de Adalberto Mattos publicados em 1922 e 1926, respectivamente, na Illustração Brasileira ${ }^{117}$ e na Para todos ${ }^{118}$, comentam a mostra carioca de águas-fortes de 1919, inclusive nomeiam os expositores. O texto publicado em 1926 é, na verdade, reimpressão daquele de 1922, e difere deste somente no modo de publicação, visto que foi dividido em dois números da revista, e nas imagens que apresenta. Enquanto o artigo da Illustração Brasileira traz reproduções das águas fortes, possivelmente, expostas em 1919 e realizadas na oficina de água-forte do Liceu de Artes e Ofícios, o da Para todos apresenta reproduções de pintura que em nada se relacionam com o escrito: evidentemente, não se trata de imagens que ilustram o texto, trata-se apenas de obras que o editor imprimiu no periódico. Mas, o que importa destacar é o conhecimento de Mattos sobre a gravura, que procura evidenciar desde Maso Finiguerra, Albert Dürer, Parmigianino, Rembrandt até gravadores italianos ${ }^{119}$ e ingleses do século XIX, alguns até membros das associações de águas-fortistas que começam a surgir na Europa nesse século. Obviamente, não é possível identificar quais são as referências bibliográficas que Mattos utiliza para compor seu texto, no entanto, sua pesquisa é significativa, o que muito contribui para a divulgação da água-forte, especialmente as de Oswald e de outros brasileiros que a praticam na oficina do Liceu como obras de arte.

Renato Almeida, o segundo autor que escreve nos periódicos sobre a água-forte, trata apenas da obra de Carlos Oswald e não cita a produção dos outros artistas que, poucos meses

\footnotetext{
${ }^{116}$ A.M., "O que é a gravura a água-forte", Leitura para todos, Rio de Janeiro, nov. 1920.

${ }^{117}$ Adalberto Mattos, “A gravura à água-forte no Rio de Janeiro”, Illustração Brasileira, Rio de Janeiro, dez. 1922.

${ }^{118}$ Adalberto Mattos, “A gravura à 'Agua-forte' no Rio de Janeiro”, Para todos, Rio de Janeiro, 25 set. 1926. Adalberto Mattos, “A gravura à Agua-forte”, Para todos, Rio de Janeiro, 02 out. 1926.

${ }^{119}$ Mattos cita Luigi Conconi (1852-1917), Tranquillo Cremona (1837-1878), Pio Joris (1843 - 1921), Sebastiano De Albertis (1828 - 1987), Uberto Dell'Orto (1848 - 1895) e Vittore Zanetti Zilla (1864 - 1946). Adalberto Mattos, “A gravura à água-forte no Rio de Janeiro”, Illustração Brasileira, Rio de Janeiro, dez. 1922.
} 
após a publicação de seu artigo, expõem no Liceu na primeira exposição coletiva de gravura no Rio de Janeiro. Em "Um artista interior (Carlos Oswald)" "120 são inclusive reproduzidas as gravuras Concerto, Cyprestes, Pierrot e Visitação ${ }^{121}$, conforme as legendas as nomeiam, de Carlos Oswald. Nesse artigo, Renato Almeida afirma que o pintor nascido no final do século XIX é um artista que está "dentro das tendências de seu tempo", visto que mais lhe interessa um pretexto qualquer para explorar o jogo cromático nas telas, do que os velhos temas "rebuscados". Para Almeida, Oswald se afasta das antigas diretivas que determinam o que deve ser pintado e como fazê-lo e está próximo do pensamento de um crítico como Camille Mauclair ${ }^{122}$, a quem Almeida cita diversas vezes, afirmando até que o artista, tal como o francês que escreveu sobre o Impressionismo, sabe que "pintar é pensar em cores".

Apesar dessas referências à pintura, o texto de Almeida é sobre a água-forte de Carlos Oswald, pois o autor vê nela a "forma de arte [...] mais preciosa" do artista. Qualifica a águaforte como um "gênero de gravura" que é próprio dos espíritos recolhidos. Toda a argumentação do texto, fundamentada nas ideias de Mauclair, trata Carlos Oswald como "um isolado", isto é, como artista de extrema sensibilidade que se afasta das amarguras cotidianas para criar uma arte elevada espiritualmente. O isolamento, segundo Almeida a partir de Mauclair, permite ao artista, mesmo sofrendo a vida, mostrar a beleza encontrada na natureza, sua fonte de "inspiração".

Renato de Almeida não só reproduz gravuras de Oswald em seu artigo, como também as analisa em comparação com a produção de outros gravadores e pintores, tais como Francis Seymour Haden e Eugène Carriére. Mais ainda, Almeida qualifica a água-forte como arte representante "do tempo" e própria daqueles artistas sensíveis e elevados, como Oswald, a quem, evidentemente, elogia.

Considere-se que a concepção da água-forte como arte representativa do tempo, ou seja, da passagem do século XIX para o XX, não é presente somente em Almeida. No entanto, no Brasil, não se encontra discurso semelhante, enquanto na Europa já no século XIX há discursos que assim a entendem. Leem-se textos de artistas italianos, ou de ingleses e franceses, membros das associações de água-fortistas, que definem a arte dos metais como arte rápida, sintética e simples, por isso, própria da época. Tais escritos, evidentemente, também objetivam defender a gravura como parte das Belas Artes, em meio a instituições e

\footnotetext{
${ }^{120}$ Renato Almeida, "Um artista interior (Carlos Oswald)", O Malho, Rio de Janeiro, 04 out. 1919.

${ }^{121}$ A água-forte Visitação é referida também pelos títulos A Visitação ou Maria e Sta Isabel. Concerto também tem como título Tocando Debussy. Cyprestes é conhecida ainda por A Musas ou Dança Clássica ou Coroa de Ciprestes.

${ }^{122}$ Camille Mauclair é pseudônimo de Séverin Faust (1872-1945) autor de, entre outros livros, L'Art en Silence, publicado em 1901, em Paris, e de estudos sobre Claude Monet e os Impressionistas.
} 
concepções que ainda a entendem como arte aplicada à indústria, mas isso no XIX: ressalta-se que na França e na Inglaterra os textos que argumentam pela água-forte como obra de arte datam da segunda metade de 1800 e, na Itália, esses artigos são das primeiras décadas de $1900^{123}$.

\subsection{A gravura como obra de arte: água-forte}

Os textos de periódicos comentados até aqui, tanto aqueles que apenas citam as obras gráficas de Carlos Oswald, quanto aqueles que a analisam, utilizam a expressão "água-forte" para referir as gravuras em metal do artista. Estas, todavia, não são apenas "águas-fortes", uma vez que ele também realiza águas-tintas e pontas secas, técnicas que raramente são nomeadas nos periódicos. Esta constatação permite sugerir que a referida expressão não é usada exclusivamente para identificar a obra à técnica, mas é também uma generalização de alguns processos de gravura em metal, podendo incluir procedimentos como a água-tinta e a ponta-seca.

Os documentos estudados sobre a gravura no Brasil no final do século XIX e início do XX, bem como a análise da recepção da obra gráfica de Carlos Oswald nas duas décadas iniciais de 1900, permitem afirmar que "água-forte” é usada em detrimento da palavra "gravura", utilizada para designar impressos, visto que as acepções de "gravura" são por demais amplas, podendo a palavra referir diferentes técnicas e trabalhos. Entretanto, não é possível afirmar que os missivistas e críticos no Brasil utilizam a expressão "água-forte" para identificar as gravuras que são obras de arte, uma vez que não a consideram dessa maneira. Diferente, portanto, de Carlos Oswald e daqueles que divulgam sua obra, Adalberto Mattos e Renato de Almeida, pois, certamente, esses três autores reconhecem que a expressão "águaforte" ${ }^{" 124}$ identifica técnica gráfica que, desde meados do século XIX, na Europa, é usada por

\footnotetext{
${ }^{123} \mathrm{Na}$ Inglaterra, o discurso de Francis Seymour Haden perante a Academia Real de Belas Artes, publicado em 1862, defende a gravura como arte. Francis Seymour Haden, The relative claims of etching and engraving to rank as fine arts, and to be represented as such in the Royal Academy of Arts, London, Matchim and Son, 1883. $\mathrm{Na}$ França, as várias publicações da Sociedade de Água-Fortistas trazem textos que também abordam o assunto, ver: Société des Aqua-fortistes, Eaux-Fortes modernes: originales et inédites, Paris, 1862 - 1863. Société des Aqua-fortistes, Eaux-Fortes modernes, Paris, 1864. Já na Itália, artigos publicados na revista Emporium divulgam as exposições de gravura e analisam essa arte no início do século XX, ver: Luigi Giovanola, "Acqueforti ed Acquafortisti: Vico Viganò", Emporium, Bergamo, Itália, mar. 1912, pp. 195-212. Raffaele Calzini, "Esposizioni e Concorsi: La Mostra Nazionale dell'Incisione", Emporium, Bergamo, Itália, mar. 1915, pp.181-191. R. Chiminelli, "Acqueforti ed Acquafortisti: Emanuele Brugnoli”, Emporium, Bergamo, Itália, nov. 1922, pp. 262-275. Roberto Papini, "Stampe Moderne D’Ogni Paese Alla Mostra di Firenze”, Emporium, Bergamo, Itália, jun. 1927, pp.338-356.

${ }^{124} \mathrm{~A}$ expressão em português, água-forte, é equivalente à eau-forte em francês, acquaforte em italiano e etching em inglês.
} 
artistas que pretendem realizar obras de arte "originais" e não cópias de pinturas, esculturas e desenhos.

No discurso de Francis Seymour Haden perante a Society of Arts na Inglaterra, pronunciado em 1883, por exemplo, lê-se que o uso da palavra etching, equivalente à águaforte, é feito pelo gravador para designar não o processo técnico ou as pessoas que o realizam, mas para distinguir duas práticas, visto que entende a água-forte como:

Todas as formas de gravação em metal, seja a ponta-seca, o buril, a maneira negra, ou a água-tinta, ou quaisquer outras formas que o artista possa escolher, usadas como meio de expressão original são entendidas, para o propósito deste texto, como inclusas no termo comum "água-forte"; e as mesmas formas, quando não usadas para o propósito da expressão original, estão inclusas no termo comum "gravura". ${ }^{125}$

Seymour Haden, presidente da Society of painter-etchers, inclui sob o termo gravura as obras gráficas que afirma como não "originais", visto que elas reproduzem obras de arte. Além disso, defende que esses trabalhos são realizados a partir de "fórmulas" repetidas pelos gravadores de modo mecânico. Por isso, para ele, na produção dessas imagens a inteligência de quem as faz não está ativa, não havendo nelas identidade alguma. Sendo assim, conclui Haden, gravura é ofício muito diferente, pois, da água-forte, que é obra de arte. Com essa arte, os artistas, com suas inteligências "acordadas", produzem trabalhos com identidade própria. Os água-fortistas, também denominados de painter-engravers por Seymour Haden, empregam técnicas que são suas e não repetem modos de gravar já estabelecidos.

Anos antes do discurso de Haden, na França, uma também Société des Aqua-fortistes é fundada para publicar e comercializar as águas-fortes realizadas pelos vários gravadores. A partir de 1863, a Sociedade publica volumes anuais que reúnem as águas-fortes dos sócios, as quais também são vendidas em tiragens mensais. As publicações anuais são introduzidas por textos de críticos que elevam a água-forte e a elogiam em detrimento da fotografia, técnica que começa a suplantar a gravura na reprodução de obras de artes e é entendida como mecânica, logo, fora das Belas Artes, pelos defensores da água-forte.

Théophile Gautier, no primeiro número da publicação ${ }^{126}$, define cada água-forte como um “desenho original” e ressalta que essa arte é rápida e fácil. Antes de Seymour Haden,

\footnotetext{
${ }^{125}$ Tradução livre do inglês: "All forms of engraving on metal, whether by the etching needle, the burin, by mezzotint, or aquatint, or whatever other forms the artist may choose as a means of original expression, are to be understood, for the purposes of the present paper, as included in the common term 'etching'; and like forms, when not used for the purposes of original expression, as included in the common term "engraving"'. Francis Seymour Haden, op. cit., 1883.

${ }^{126}$ Société des Aqua-fortistes, Eaux-Fortes modernes: originales et inédites, Paris, 1862 - 1863.
} 
Gautier já afirma que na água-forte cada artista inventa sua maneira, não havendo recomendações quanto aos modos de fazer, nem quanto aos gêneros, sendo, portanto, cada água-fortista livre para mostrar toda sua "originalidade". Gautier ainda revela que a:

[...] a Sociedade de Agua-fortistas foi fundada precisamente para combater a fotografia, a litografia, a água-tinta, a gravura cujas hachuras cruzadas têm um ponto no meio; em uma palavra, o trabalho regular, automático, sem inspiração que deteriora a própria ideia de $\operatorname{artista}^{127}$

A referência às "hachuras cruzadas com um ponto no meio" demonstra que esses gravadores franceses se posicionam contra as obras gráficas realizadas a partir dos manuais e tratados, os quais informam como cada tipo de superfície - pano, pele, madeira - deve ser representada por meio das hachuras. Certamente, essa é uma das razões pelas quais a águaforte é caracterizada como uma gravura simples e rápida, mas também complexa, uma vez que Gautier afirma que cada linha marcada no verniz deve ser significativa, exigindo do gravador "uma certeza no traço".

Nos textos que introduzem as publicações da Sociedade francesa ano a ano, não se encontra a generalização da expressão água-forte, como há no pronunciamento de Haden. Entretanto, é explicito nesses escritos que ela é "arte original e verdadeiramente moderna" 128.

Não se afirma que Carlos Oswald, Adalberto Mattos e Renato Almeida escrevam necessariamente a partir das concepções inglesas ou francesas sobre a água-forte, visto que, salvo Almeida que até cita um crítico francês em seu texto e o gravador Seymour Haden, os demais autores não costumam referir suas fontes, nem mencionam a sociedade francesa ou o água-fortista inglês. No entanto, em documento datiloscrito, intitulado A água-forte no Rio de Janeiro, encerrado com o nome de Carlos Oswald, provavelmente do início da década de 1950, lê-se que:

Este gênero de gravura à água-forte que os franceses chamam de "gravure d'art" ou "eau-forte d'artiste" e que nós chamamos "água-forte original", começou no Rio de Janeiro de uma maneira esporádica no princípio do nosso século. ${ }^{129}$

\footnotetext{
127 Tradução livre do francês: "la Société des Aqua-Fortistes s'est fondée précisément pour combattre la photographie, la lithographie, l'aqua-tinte, la gravure dont les hachures recroisées ont un pont au milieu; en un mot, le travail régulier, automatique, sans inspiration qui dénature l'idée même de l'artiste". Théophile Gautier, "Un mot sur l'eau-forte", In: Société des Aqua-fortistes, op. cit., 1862 - 1863.

${ }^{128}$ W. Bürger, "Un mot sur l'eau-forte", In: Société des Aqua-fortistes, Eaux-Fortes modernes, Paris, 1864.

${ }^{129}$ O documento datiloscrito está no Fundo de Carlos Oswald no Arquivo Histórico do Museu Nacional de Belas Artes e parece ser uma versão de um artigo publicado na revista Vozes de Petrópolis em maio de 1955 com o título "A Oficina de Gravura a Água-forte". Trechos desse documento também são encontrados em outros escritos publicados de Carlos Oswald, tal como sua autobiografia. O documento é provavelmente do início da década de 1950 porque menciona a Bienal de São Paulo e o Atelier de Arte, este último inciativa para a
} 
O documento, que apresenta trechos de outros artigos assinados e publicados por Carlos Oswald, indicia, deste modo, que o artista reconhece que a expressão "água-forte", ainda que acrescida de termos que a qualificam como "original” ou própria dos artistas, é uma distinção para as gravuras assim denominadas.

Acrescente-se que a Itália, país no qual Oswald estuda arte e conhece a água-forte com o americano, de ascendência germânica, Carl Strauss ${ }^{130}$, em 1908, vive o "renascimento" da gravura, como afirmam os textos da revista Emporium na década de 1910. Alguns artigos dessa publicação ilustrada, que circula na Itália entre 1895 e 1964, analisam as obras gráficas de artistas do país, bem como comentam e criticam as exposições de gravura italiana realizadas em Milão, Florença e até Londres nas décadas inicias do século XX. Ressalta-se que nesses artigos a expressão água-forte não é usada como uma generalização para as técnicas de gravura em metal, visto que os diversos processos são nomeados para descrever as obras discutidas pelos autores. Porém, assim como na Inglaterra e na França, os críticos discutem a água-forte, e demais processos gráficos, como obras de arte.

O escritor Raffaele Calzini afirma, em texto sobre a Mostra Nazionale dell'Incisione $^{131}$, organizada pela Associazione Acquafortisti e Incisori ${ }^{132}$ em Milão em 1915, que a água-forte deve ser "um fim em si mesma" e não deve se prestar a ser um meio. O autor defende que essa arte deve ser considerada e realizada a partir de suas próprias características, não devendo ser utilizada pelos artistas como simples meio para registrar seus desenhos. Evidentemente, Calzini escreve após a saída de Oswald da Itália, contudo, seu texto revela que desde o início do século XX diversos artistas italianos e também estrangeiros que residiam em cidades como Florença, praticam a água-forte e participam de um movimento de renovação da gravura no país.

A ideia de que a Itália vive, no início do século XX, o "renascimento" da gráfica, em especial da água-forte, não está presente somente no texto de Calzini de 1915, mas também

divulgação e comercialização da água-forte da qual Carlos Oswald participa e que acontece entre 1950 e 1952. Carlos Oswald, A água-forte no Rio de Janeiro, documento datiloscrito, s.d., Arquivo Histórico do Museu Nacional de Belas Artes/Ibram/MinC, Rio de Janeiro.

${ }^{130} \mathrm{O}$ pesquisador Giorgio Marini afirma que em Florença, na primeira década de 1900, vivem alguns águafortistas anglo-saxões que participam do movimento de renovação da gravura na Itália. Assim, a presença do estrangeiro Carl Strauss na cidade, com quem Oswald aprendeu gravura, não é isolada no período. Cf. Giogio Marini, op. cit., 2014. Aliás, Carlo Strauss, como o artista é chamado por Raffaele Calzini, expõe na mostra nacional de gravura em Milão em 1914, sendo caracterizado pelo crítico como desenhista puro, mas excessivamente analítico. Raffaele Calzini, "Esposizioni e Concorsi: La Mostra Nazionale dell'Incisione", Emporium, Bergamo, Itália, mar. 1915, pp.181-191.

${ }^{131}$ Idem, Ibidem.

${ }^{132} \mathrm{Na}$ Itália, a associação de água-fortistas e gravadores, presidida pelo artista Vico Veganò, foi fundada no início do século XX. 
em outros artigos da mesma revista datados ao longo das décadas de 1910 e $1920^{133}$. O pesquisador Giorgio Marini, em artigo de $2014^{134}$, reafirma a existência desse movimento pela gravura na Itália, nas três primeiras décadas do século XX, e escreve que ele é estimulado pela divulgação dessa arte nas revistas especializadas e nas exposições, além de ser sustentado por uma política de aquisição de gravuras contemporâneas pelos museus do país, como a galeria Uffizi. Contudo, observe-se que na Itália, no referido período, é também travada a luta pelo reconhecimento da gravura como arte, uma vez que as associações, artistas e críticos estão, nos textos de periódicos e nas exposições, defendendo uma posição que, pelo que se lê, ainda não é consenso na sociedade italiana.

Sendo assim, quando Carlos Oswald afirma em sua autobiografia que foi um dos primeiros cultores da água-forte e que participou do renascimento dessa arte, tanto em Florença, quanto no Brasil, ele se coloca junto a um movimento maior, que ocorre na Itália, mas que não é fenômeno isolado ao país. Portanto, a insistência do artista em denominar suas gravuras como águas-fortes, as posiciona como distintas das demais gravuras "utilitárias", como Oswald as denomina, produzidas e conhecidas no Brasil.

\footnotetext{
${ }^{133}$ Cf. Luigi Giovanola, "Acqueforti ed Acquafortisti: Vico Viganò", Emporium, Bergamo, Itália, mar. 1912, pp. 195-212. Cf. R. Chiminelli, "Acqueforti ed Acquafortisti: Emanuele Brugnoli”, Emporium, Bergamo, Itália, nov. 1922, pp. 262-275. Cf. Roberto Papini, "Stampe Moderne D’Ogni Paese Alla Mostra di Firenze", Emporium, Bergamo, Itália, jun. 1927, pp.338-356.

${ }^{134}$ Giorgio Marini, op. cit.
} 



\section{O ensino e a divulgação da água-forte como obra de arte}

\subsection{A oficina de água-forte do Liceu de Artes e Ofícios: 1914 - 1919}

A oficina de água-forte do Liceu de Artes e Ofícios do Rio de Janeiro, principalmente no que tange aos seus primeiros anos de existência, é assunto abordado por poucos estudos que tratam da história da gravura brasileira, entre os quais, o livro de Orlando da Silva, $A$ arte maior da gravura, e o artigo de Maria Luisa Luz Tavora, "A gravura no Liceu de Artes e Ofícios" $" 135$. As informações que se leem nesses trabalhos são encontradas em duas principais fontes: o livro comemorativo dos cem anos do Liceu de Artes e Ofícios, de Álvaro Paes de Barros $^{136}$, publicado em 1956, e o livro autobiográfico de Carlos Oswald ${ }^{137}$. Considere-se, todavia, que mesmo na publicação de Barros, as informações sobre o funcionamento da oficina baseiam-se em escritos de Oswald. No livro do, na época, diretor da referida instituição de ensino, o subcapítulo "Carlos Oswald e a gravura à 'água-forte' do Liceu” é semelhante ao artigo do gravador e professor publicado em 1955 na revista Vozes de Petrópolis, "A Oficina de Gravura à Água-forte"138. Mais ainda, pode-se dizer que o escrito de Barros altera apenas a primeira pessoa do discurso de Oswald para a primeira pessoa do plural.

Os escritos acima mencionados sobre a oficina reafirmam a informação dada pelo próprio Oswald, a saber, de que ele é contratado pela Sociedade Propagadora de Belas Artes em 1914 para ser professor do Liceu ${ }^{139}$. Entretanto, lê-se no Correio Paulistano de 29 de julho de 1913, que o pintor "recém-chegado" da Europa já nesse ano é nomeado professor do $\mathrm{LAO}^{140}$. Apesar da divergência das datas, sabe-se que as inscrições para as aulas de água-forte oferecidas por Oswald são abertas em março de $1914^{141}$.

Em seu artigo de 1955, Oswald escreve que o cargo de professor de gravura em metal, anteriormente a sua chegada, é oferecido ao artista Modesto Brocos y Gómez pela Sociedade

\footnotetext{
${ }^{135}$ No livro de Orlando da Silva, A arte maior da gravura, de 1976, consta algumas informações sobre a Oficina de água-forte do Liceu. O artigo "A gravura no Liceu de Artes e Ofícios - RJ: tensão entre métier e meio expressivo" de Maria Luisa Luz Tavora, publicado em 2007, nos Anais do $16^{\circ}$ Encontro da Anpap, é outra pesquisa que aborda o assunto.

${ }^{136}$ Cf. Álvaro P. de Barros, "Carlos Oswald e a gravura à 'água-forte' do Liceu”, In: Álvaro P. Barros, op.cit., pp. $328-334$.

${ }^{137}$ Carlos Oswald, op. cit., 1957.

${ }^{138}$ Cf. Carlos Oswald, “A oficina de gravura à água-forte”, Vozes de Petrópolis, Petrópolis, maio jun. 1955, pp. $257-262$.

${ }^{139}$ Carlos Oswald, op. cit., 1957, p.44.

${ }^{140}$ Cf. "Registro de Artes - Carlos Oswald", Correio Paulistano, São Paulo, 29 jul. 1913.

${ }^{141}$ Cf. "Lyceu de Artes e Officios", Correio da Manhã, Rio de Janeiro, $1^{\circ}$ mar. 1914.
} 
mantenedora da escola, pois, segundo Oswald, não existiam outros artistas, além de Brocos, especializados nessa arte no país. Não se sabe se Brocos recebe esse convite; no entanto, o pintor e gravador espanhol grava sobre o metal desde o final do século XIX, tendo exposto, inclusive, suas gravações em ácidos na Europa. Ainda sobre esse artista, professor da Escola Nacional de Belas Artes, pode-se dizer, a partir de fontes secundárias, que ele orienta as compras dos materiais necessários à montagem da oficina no Liceu em 1911, assim como a prensa $^{142}$. Mesmo podendo ser a data da compra dos materiais para a oficina inferida pelo gravador Orlando da Silva, quando Carlos Oswald começa a trabalhar naquele estabelecimento, ele encontra o ateliê montado com prensa elétrica vinda da Alemanha e materiais e ferramentas importados da França: placas de cobre, buris, raspadores e brunidores.

Contudo, inicialmente, poucos alunos frequentam as aulas de água-forte, visto que, como Oswald afirma, desconhece-se essa arte no país e, mais, lembra o professor, que aqueles que demonstram algum interesse, se assustam com o trabalho árduo necessário para a realização das obras. Não por isso o artista deixa de gravar ou de divulgar a água-forte de arte e, como ele memora, desde o início de sua carreira de professor tenta "evangelizar" a todos para praticar "bem ou mal as artes plásticas" ${ }^{143}$, isto é, tenta convencer artistas a experimentarem a água-forte. É essa a solução, aliás, dada por Oswald para o problema da baixa frequência da oficina: ele incentiva e leva para a escola profissionalizante artistas e professores da Escola Nacional de Belas Artes para conhecerem a gravação de chapas e a impressão delas. É o que se vê em fotografia do álbum de Nogueira da Silva ${ }^{144}$, datada de 1914, na qual Adalberto Mattos, Arthur Timótheo e Carlos Chambelland se reúnem em torno de uma prensa elétrica e observam, nas mãos do professor formado em Florença, uma prova de uma de suas águas-fortes junto a sua respectiva matriz [Imagem 3]. Além desses artistas, outros ainda riscam placas de metal no Liceu: Henrique Bernardelli, Antonino Mattos, Argemiro Cunha, José Cordeiro, Ernesto Francisconi, João Timótheo da Costa, Pedro Bruno etc. ${ }^{145}$. A propósito, o articulista do Jornal do Commercio ${ }^{146}$ de 1916, com surpresa, como já

\footnotetext{
${ }^{142}$ Tanto Oswald quanto Barros que, como se afirmou, segue o primeiro, asseveram que esses materiais e máquina são adquiridos na Europa a partir de lista realizada por Modesto Brocos, sem, contudo, memorar uma data para isto. Carlos Oswald escreve que Brocos "se encarregou de fazer a lista do material necessário para a montagem de uma moderna oficina de gravura a água-forte". Cf. Carlos Oswald, "A oficina de gravura à águaforte", Vozes de Petrópolis, Petrópolis, maio jun. 1955, p. 258. Orlando da Silva é quem afirma que a compra desses materiais é realizada em 1911, por Modesto Brocos, na França e na Alemanha. Cf. Orlando da Silva, op. cit., 1976, p.77.

${ }^{143}$ Carlos Oswald, op. cit., 1957, p. 96.

${ }^{144}$ M. Nogueira da Silva, Álbum de fotografias de artistas brasileiros e estrangeiros, [1920]. Acervo Fundação Biblioteca Nacional.

${ }^{145}$ Carlos Oswald, “A oficina de gravura à água-forte”, Vozes de Petrópolis, Petrópolis, maio jun. 1955, p. 259.

146 "Notas de arte", Jornal do Commercio, Rio de Janeiro, 26 ago. 1916, p.6-7.
} 
mencionado no capítulo anterior, cita as águas-fortes de Argemiro Cunha, Adalberto Mattos e Oswald na Exposição Geral de Belas Artes, possivelmente obras gravadas no Liceu. Lê-se ainda, em texto da década de 1920, de Adalberto Mattos, outros nomes, hoje desconhecidos, que passam pelas bacias de ácido do Liceu, tais como Giuseppe Gargaglione, Ricardo Bevilacqua, José Arthur Bevilacqua e Córa Nympha Ferreira França ${ }^{147}$.

Imagem 3 - Oficina do Liceu de Artes e Ofícios, 1914. Na legenda da fotografia lê-se os nomes dos artistas: A. Timótheo, Ad. Mattos, C. Chambelland e C. Oswald, e o local e data, "Rio, 1914".

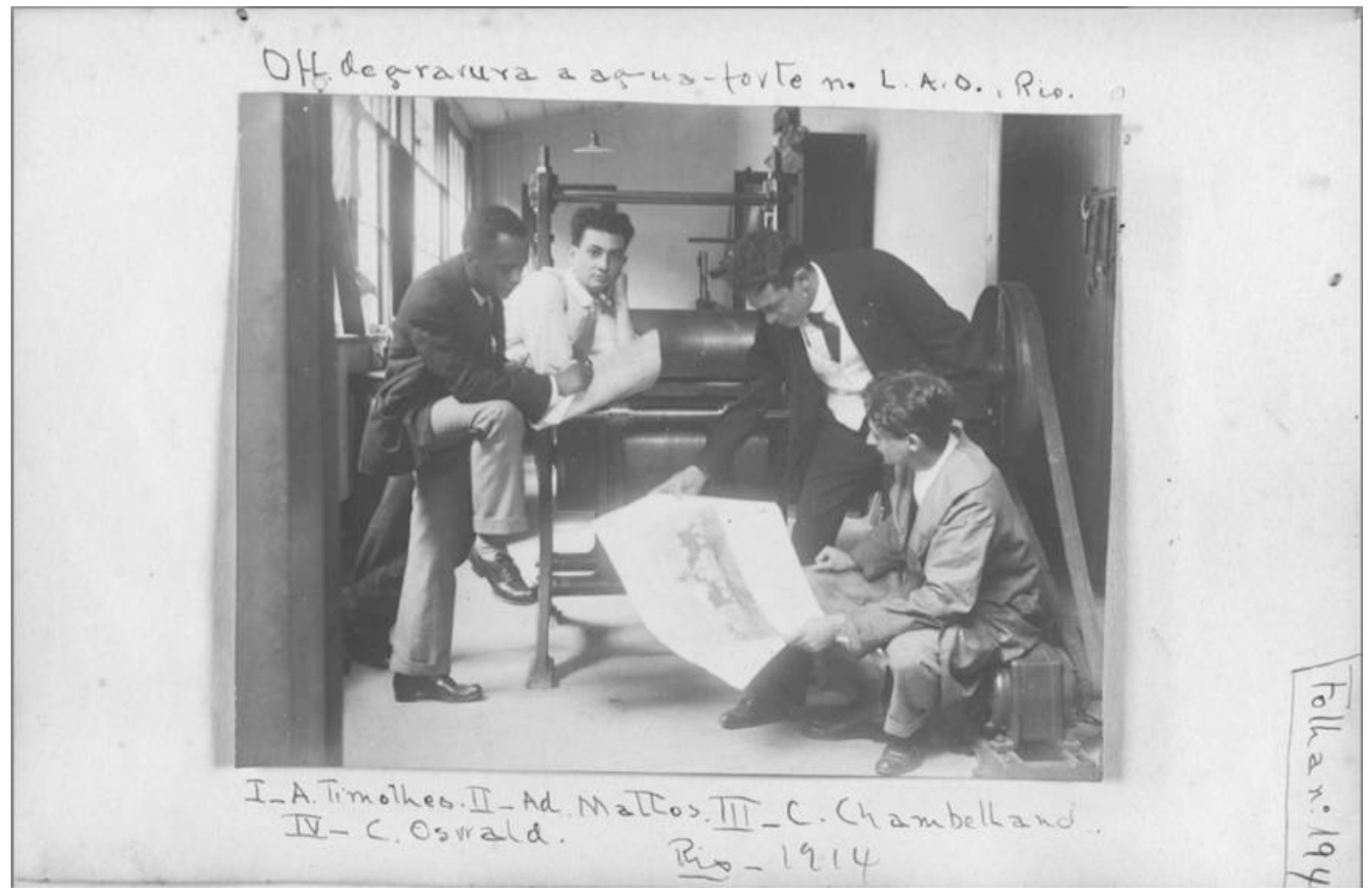

Fonte: Imagem retirada do álbum do crítico Nogueira da Silva, doado para a Fundação Biblioteca Nacional em 1932. Acervo Digital da Fundação Biblioteca Nacional.

Carlos Oswald afirma encontrar na oficina - certamente devido ao equipamento -, “campo admirável para desenvolver" as suas "atividades gráficas"148: é o que se lê tanto em sua autobiografia, quanto no seu artigo da Vozes de 1955. Embora Oswald memore o ateliê do Liceu de maneiras distintas, ora destacando, em sua autobiografia, que "ninguém se interessava pela água-forte naquele tempo", ora afirmando, de modo grandiloquente, a "grande pujança nos primeiros anos" de existência da "Escola Carioca de Água-forte do Liceu

\footnotetext{
${ }^{147}$ A.M., "O que é a gravura a água-forte", Leitura para todos, Rio de Janeiro, nov. 1920.

${ }^{148}$ Idem, p. 44.
} 
de Artes e Ofícios" ${ }^{149}$; ele evidencia em seus textos o desinteresse que encontra no Rio de Janeiro para o ensino da água-forte na década de 1910 e demonstra as dificuldades e o esforço para a implantação da arte da gravura no país. Os escritos do professor e gravador monumentalizam, assim, a oficina como sendo o local a partir do qual a ideia da água-forte como arte se propaga.

A importância da oficina nesses anos, portanto, não deve ser desconsiderada, sabendose da necessidade existente para se elevar a "gravura" - como entendemos hoje - à categoria de arte, uma vez que na época, a "gravura" considerada arte com "a" maiúsculo é a de medalhas. Entretanto, apesar de alguns alunos, pintores e escultores consagrados, bem como amigos do artista, músicos e intelectuais gravarem ocasionalmente matrizes em metal, nos primeiros anos da "Escola Carioca de Água-forte" não é formada turma de gravadores no Rio de Janeiro. Mesmo assim, já em 1919, os trabalhos lá feitos são reunidos e divulgados na Primeira exposição carioca de águas-fortes, mostra organizada por Oswald no próprio prédio do Liceu.

\subsection{A primeira exposição carioca de águas-fortes}

No final de 1919 é aberta a Primeira exposição carioca de águas-fortes, promovida pela Sociedade Propagadora de Belas Artes, mostra que é divulgada em algumas notas elogiosas de periódicos cariocas. O caricaturista J. Carlos ${ }^{150}$, com humor, também comenta a exposição, revelando não o seu sucesso, mas evidenciando o desconhecimento do público em relação à técnica: na página de $O$ Jornal, vê-se um ébrio que, polidamente, demanda ao porteiro da mostra onde é a exposição de "água-forte", sabendo-se que a "gravura" é pouco conhecida como "arte", mas não a aguardente [Imagem 4].

A exposição, entretanto, é lembrada como de importância nos textos da década de 1950 de Carlos Oswald, mostra que é o resultado do trabalho realizado na oficina do Liceu, visto que os anos de divulgação da gravura na escola do povo "culminam" nessa exposição. Sabe-se, porém, que ela foi montada com trabalhos dos "alunos" de Oswald e de outros inscritos, artistas nacionais e estrangeiros, desde que residentes no país; além disso, como também se lê em periódicos, essa mostra oferece prêmios "honoríficos e pecuniários" ${ }^{151}$.

\footnotetext{
${ }^{149}$ Carlos Oswald, Carlos Oswald, "A oficina de gravura à água-forte”, Vozes de Petrópolis, Petrópolis, maio jun. 1955 , p. 259.

${ }^{150}$ J. Carlos, "Velho Amador", O Jornal, Rio de Janeiro, 22 nov. 1919.

151 "Primeira Exposição Carioca de Gravura a agua forte", Correio da Manhã, Rio de Janeiro, 30 out. 1919.
} 
Imagem 4: Caricatura de J. Carlos publicada no O Jornal, Rio de Janeiro, em 22 de novembro de 1919.

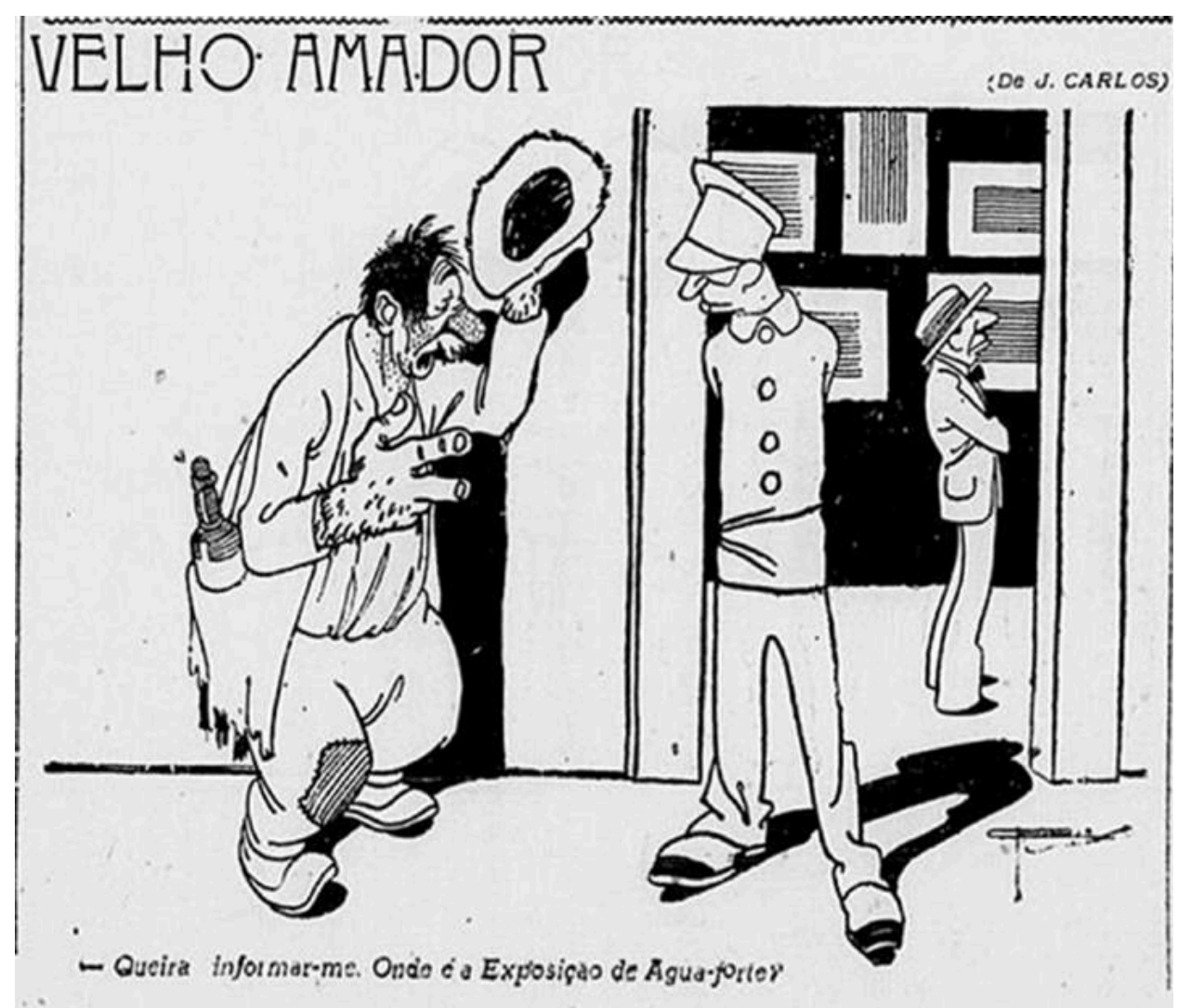

Fonte: O Jornal, Rio de Janeiro, 22 nov. 1919. Disponível em: Hemeroteca Digital, Fundação Biblioteca Nacional

Na edição de O Paiz, de 24 de novembro de 1919, é impressa lista dos expositores ${ }^{152}$, a maior parte deles, tal como os "alunos" da oficina, são artistas formados pela Escola Nacional de Belas Artes, pintores e escultores, mas há também aqueles que já gravam, seja em metal, madeira ou pedra, com mais experiência, como Modesto Brocos, Raimundo Cela, Antonio Valle Souza Pinto e Calixto Cordeiro. Além dos nomes daqueles que já se sabe frequentadores da oficina do LAO, lê-se no jornal que Altino de Moraes, Armando Magalhães Corrêa, Augusto Bracet, Floraspe Renzetti, Georges Bloow, Helios Seelinger, Isaltino Barbosa, Mário Nery, Maria Silva, Mario Tullio, Paulo Mazzuchelli, Rodolfo Chambelland, além de Adalberto Mattos, têm gravuras na exposição. Carlos Oswald é quem mostra maior número de trabalhos, quarenta e quatro, enquanto os demais participantes expõem de um até

\footnotetext{
${ }^{152}$ A matéria afirma que expuseram águas-fortes: Adalberto Mattos, Altino de Moraes, Antonio Valle Souza Pinto, Antonino Mattos, Argemiro Cunha, Armando Magalhães Corrêa, Arthur Timótheo da Costa, Augusto Bracet, Calixto Cordeiro, Carlos Oswald, Córa Ferreira França, Ernesto Francisconi, Floraspe Renzetti, Georges Bloow, Helios Seelinger, Henrique Bernardelli, Isaltino Barbosa, João Timótheo da Costa, José Cordeiro, Mário Nery, Maria Silva, Mario Tullio, Modesto Brocos, Paulo Mazzuchelli, Pedro Bruno, Raimundo Cela e Rodolfo Chambelland. J.M., "Bellas-Artes - Exposição Águas-fortes", O Paiz, Rio de Janeiro, 24 nov. 1919.
} 
quatro trabalhos, é o que se lê no periódico do Rio de Janeiro, no qual o missivista revela estar surpreso com o "sucesso" da mostra, mas não só, pois ele também confessa estar "pasmo" com essa arte que, até então, para ele, era desconhecida.

A mostra que surpreende o missivista tem obras organizadas em cinco seções - talho doce, água-forte, água tinta, ponta seca e monotipia - não apresentando, portanto, somente águas fortes. De acordo com matéria do $A$ Noite, que divulga as inscrições para o certame, as gravuras expostas devem ser "originais ou reproduções de obras de arte de real valor"153. $\mathrm{O}$ fato de se ler em periódico que também são aceitas cópias de obras na mostra, desde que de "real valor", pode causar estranhamento. Todavia, como se sabe, para ser artista - ao menos até o decênio de 1940 -, um dos exercícios necessários é a cópia de obras de arte. Aliás, qualquer aluno da Escola Nacional de Belas Artes que recebia prêmio viagem tinha obrigação de enviar cópia de obra de artista consagrado, trabalho que, comumente, era apresentado em exposição de Belas Artes. Do que é possível entender, não se trata de se aceitar na exposição de águas-fortes a reprodução técnica de obra para impressão em livros ou em outros veículos de divulgação ou de se receber gravuras destinadas à indústria da época, mesmo porque estes trabalhos, litografias, foram expostos separadamente.

No mesmo dia da inauguração da exposição de águas-fortes, é aberta ao público, também em um salão do Liceu, a Primeira exposição carioca artístico-industrial de litografia. Dela participam cerca de vinte e oito expositores ${ }^{154}$, entre estes estão litógrafos de profissão e também companhias gráficas, como a Imprensa Nacional, que apresentam suas produções ao público. Pelo que consta nos jornais, alguns dos artistas que expõe gravuras de arte na sala contígua do Liceu $^{155}$, também expõem litografias, inclusive o próprio Carlos Oswald $^{156}$. Tal informação não é surpreendente, uma vez que os gravadores podem tanto dedicar-se a produzir obras de arte, quanto obras aplicadas à indústria. É significativo, entretanto, que a exposição organizada por Carlos Oswald seja divulgada e apresentada ao público separadamente da mostra de gravuras artísticas-industriais, mesmo que ambas

\footnotetext{
153 "Primeira exposição carioca de gravura a agua forte", A Noite, Rio de Janeiro, 19 out. 1919.

${ }^{154}$ A comissão organizadora da mostra é composta por Calixto Cordeiro, Raul Pederneiras, Valle de Souza Pinto, Delfim da Camara e Coronel Leite Ribeiro. Segundo o jornal expõem: Carlos Oswald, Helios Seelinger, Luiz Peixoto, Pedro Peres, Argemiro Cunha, José Cordeiro, Ernesto Francisconi, Marcio Nery, Hermogenes Marques, Mario Tullio, Isaltino Barbosa, Antonino Mattos, Córa Ferreira França, Adalberto Mattos, Raul Deveza, Oswaldo Teixeira, Marel Soutello, Maurício Tobim, Alvaro Marins, Paulo Mazzuchelli, Arthur Lucas, Antonio Valle de Souza Pinto, Raul Pederneiras, Calixto Cordeiro. As seguintes companhias gráficas também participam: Imprensa Nacional, Pimenta de Mello \& C., Villas Boas \& C., Felippe Borgonova \& C.. "Exposição Carioca de Lithographia", O Jornal, Rio de Janeiro, 3 nov. 1919.

${ }^{155}$ Chega-se a essa conclusão a partir da leitura dos textos de periódicos que noticiam as duas mostras. É possível, entretanto, que os jornalistas misturem os nomes dos artistas que expõem em cada exposição.

${ }^{156}$ Conhece-se uma litografia de Carlos Oswald, realizada em 1915, que representa folha de fumo (Fig. 77). O artista também realizou, ao longo dos anos, litografias para ilustrar livros.
} 
aconteçam concomitantemente no Liceu de Artes e Ofícios. O fato evidencia a intenção de distinguir e afastar as águas-fortes, e demais técnicas de gravura aceitas na mostra de Carlos Oswald, das litografias, estas entendidas, como o título dessa exposição demonstra, como próprias das artes aplicadas.

Portanto, essa primeira exposição de águas-fortes divulga ao público carioca gravuras como obras de arte, distinguindo-as dos demais trabalhos gráficos que circulam nos periódicos, livros, folhetos avulsos ou servem para confecção de embalagens, diplomas etc. Contudo, apesar dos jornais da época publicarem breves notas em suas páginas sobre a exposição, nesses breves textos, não se leem análises ou críticas das obras expostas, evidenciando que, para a maior parte dos jornalistas, a água-forte ou permanece desconhecida ou não é considerada assunto das colunas de arte.

Em 1922, todavia, Adalberto Mattos, um dos expositores de 1919, ao divulgar a águaforte em matéria impressa na Illustração Brasileira, memora esse certame e cita artistas que dele participam, tais como Pedro Bruno, Modesto Brocos e Henrique Bernardelli. O objetivo de Mattos, em seu artigo, é apresentar ao seu leitor os artistas que realizam água-forte no país, chegando inclusive a reproduzir algumas das gravuras que comenta nas páginas da revista ${ }^{157}$. Possivelmente, todos os artistas enumerados por Mattos são expositores da referida mostra de 1919, ainda que o artigo não deixe claro se o pianista Alfredo Oswald, os pintores Leopoldo Gotuzzo, José Pereira Dias Júnior e Morel Soutello dela participem. De qualquer maneira, o texto de Mattos explicita que diversos artistas experimentam a água-forte nos primeiros anos da oficina e alguns deles, como Argemiro Cunha e Antonino Mattos dedicam-se com maior interesse a essa nova arte, gravando várias matrizes.

Nessa empreitada de se divulgar a arte da água-forte contribui a revista Illustração Brasileira. Por exemplo, águas-fortes dos dois últimos artistas referidos são reproduzidas no periódico meses antes da publicação do artigo citado do medalhista. Aliás, entre 1920 e 1922, além das gravuras de Argemiro e Antonino, são reproduzidas em diferentes edições da revista águas-fortes de Carlos Oswald, Pedro Weingartner, Pedro Bruno e do próprio Adalberto Mattos ${ }^{158}$. Tais gravuras não são publicadas como ilustrações ou complementos para os

\footnotetext{
${ }^{157}$ As seguintes obras são reproduzidas no artigo: Ruínas de Adalberto Mattos, Velha Árvore de Antonino Mattos, Retoque e Porta do Forte do Castelo de Argemiro Cunha, La Moquerie de Alfredo Oswald, Barcos de Pedro Bruno, Risonha de Dias Júnior, Velho Tronco de Maria Silva, Retrato de Grandjean de Montigny de Modesto Brocos, Retrato de Leopoldo Miguez e detalhe do Diploma do Instituto Nacional de Música de Henrique Bernardelli e Claustro em Florença e Bois na Praia de Carlos Oswald. Cf. Adalberto Mattos, "A gravura à água-forte no Rio de Janeiro", Illustração Brasileira, Rio de Janeiro, dez. 1922.

${ }^{158} \mathrm{Na}$ edição de setembro de 1920 da Illustração Brasileira são reproduzidas as águas-fortes Porta do Morro do Castelo (1918) de Argemiro Cunha e Remorso (1917) de Pedro Weingartner. Illustração Brasileira, Rio de Janeiro, set. 1920. Em outubro do mesmo ano é impressa Árvores (1919) de Antonino Mattos. Illustração
} 
$\operatorname{textos}^{159}$, e muito menos como imagens que reproduzem outras obras de arte, elas são impressas como trabalhos assinadas por artistas, com destaque. Considere-se que, com a exceção das gravuras de Carlos Oswald, as águas fortes dos demais artistas são datadas entre 1916 e 1919, não sendo, assim, improvável que tais obras sejam resultado do trabalho realizado no Liceu de Artes e Ofícios. Essa hipótese é endossada pelo fato de que essas mesmas imagens aparecerem, entre outras, no artigo de Mattos de 1922 que elogia a oficina de água forte do Liceu.

\subsection{A oficina de água-forte após 1919}

Após a exposição de 1919, o Liceu de Arte e Ofícios decide fechar a oficina de águaforte. A decisão, segundo Carlos Oswald, é motivada pela construção da nova ala da escola, próxima à Rua 13 de Maio ${ }^{160}$. Mesmo parecendo estranho que uma reforma provoque o fim das aulas de gravura em metal e o desmonte da prensa elétrica que lá estava, essa é a justificava que se lê nos textos de Oswald e no de Barros que, como se constata, mormente reafirma o discurso do artista. Sabe-se que por causa dessa "crise", como escreve Oswald em sua autobiografia, as aulas de água-forte ministradas no Liceu são interrompidas por dez anos, só retornando por volta de 1930.

De fato, é provável que a Sociedade Propagadora de Belas passe por "crise" financeira nos anos de 1920, pois ela contrai mais de um empréstimo para realizar a referida reforma, chegando, inclusive, a emitir debêntures em 1925, a fim de obter mais verba para concluir as novas instalações do estabelecimento ${ }^{161}$. Esses empréstimos, ainda em 1939, não estão

Brasileira, Rio de Janeiro, out. 1920. No mês seguinte, outra gravura de Argemiro, No Estaleiro, é publicada na revista. Illustração Brasileira, Rio de Janeiro, nov. 1920.

Ao longo de 1921 são reproduzidas as gravuras de Carlos Oswald: Brincando com a chama, Gravador Trabalhando - também conhecida como Gravador Adalberto Mattos , Porta Romana, Bois à Beira do Mar intitulada pelo artista Bois carregando madeira na praia da Toscana -, Cabeça de São João Batista - também denominada de Cristo ou Yocahanann. Illustração Brasileira, Rio de Janeiro, edições de jan. 1921, fev. 1921, mar. 1921, abr. 1921, jun. 1921.

Em abril de 1921, é reproduzida na revista também a gravura Pescadores de Pedro Bruno. Illustração Brasileira, Rio de Janeiro, abr. 1921. Em dezembro de 1921, a obra do próprio Adalberto Mattos, Velho Tronco (1919) é publicada. Illustração Brasileira, Rio de Janeiro, dez. 1921. Em abril do ano seguinte, outra gravura de Argemiro Cunha, Árdua Faina, é apresentada aos leitores. Illustração Brasileira, Rio de Janeiro, abr. 1922.

Considere-se que o artista e escritor Adalberto Mattos colabora com a Illustração Brasileira, desde ao menos outubro de 1920, sendo possível, assim, que seja ele quem promova a divulgação das obras gráficas nas edições do periódico.

${ }_{159}$ Apenas o retrato de Elysio de Carvalho, em água-forte, feito por Carlos Oswald, é impresso junto a texto do autor que homenageia, em agosto de 1922, na Illustração Brasileira.

${ }^{160}$ Carlos Oswald, op. cit., 1957, p.45.

${ }^{161} \mathrm{O}$ decreto $\mathrm{n}^{\mathrm{o}} 16.967$, de $1^{\circ}$ de julho de 1925, concede à Sociedade Propagadora de Belas Artes o direito de emitir "debêntures", para resgate de empréstimo emitido para a construção do edifício do Liceu de Artes e 
quitados pela Sociedade ${ }^{162}$, que mesmo com aportes de cotas de caridade do governo, parece não ter verba suficiente para manter suas instalações. A falta de recursos e espaços adequados para a instalação da oficina de água-forte é, sem dúvida, um dos motivos pelos quais ela permanece fechada durante a década de 1920.

Nesses anos em que a prensa da oficina está desmontada, Oswald afirma que utiliza a prensa da Biblioteca Nacional para imprimir suas matrizes. Contudo, não há informações exatas sobre a continuidade das aulas de água-forte em outros lugares públicos que não o Liceu. Possivelmente, Oswald passe a dar aulas somente em sua residência, pois, como ele mesmo relembra, seu ateliê foi local importante para o ensino da gravura ${ }^{163}$.

A oficina do Liceu é reaberta em 1930, data registrada nos escritos de Oswald como o início do real desenvolvimento da água-forte como obra de arte no país, uma vez que ele afirma: "Pondo de lado os primeiros catorze ou quinze anos de trabalhos e lutas, só por volta de 1930 começou a minha 'turma' a aparecer e firmar-se"164. Essa "turma", agora alunos e não mais artistas consagrados, são jovens que se interessam pela gravura em metal. Sem delimitar datas, Oswald afirma que diversos estudantes passaram por suas aulas, a maior parte deles vindos da Escola Nacional de Belas Artes que, como se sabe, não tem curso de gravura até a metade do século XX. O professor cita como seus aprendizes: Hans Steiner, Poty Lazzarotto, Ceurio de Oliveira, Percy Lau, Henrique Bicalho Oswald, Claudio Corrêa e Castro, Renina Katz, Segismundo Pinto Martins, Misabel Pedroza, J. J. Mendes, Escobar Filho, Alexandre d'Almeida, Jerônimo Ribeiro, Jeronymo Jardim, José D'Ávila, Deborah R. Mosakovicove, Lizete Almeida, Maria Laura Radspieler e Leda Ciarla.

Esse grupo de interessados na gravura, de acordo com os relatos de Oswald e de alguns de seus alunos, aprende a técnica convivendo com a falta de materiais prontos, pois não encontrados para a compra. Após o término das placas, vernizes e ferramentas importados da Europa que estavam no Liceu, os frequentadores das aulas de água-forte se deparam com a ausência de materiais do gênero produzidos no Brasil. Assim, é condição da produção de gravuras em metal no país, a preparação, pelos próprios artistas, dos materiais básicos. Esses jovens se veem obrigados a conseguir no comércio local os substitutos ou as matérias primas

\footnotetext{
Ofícios, publicado no Diário Oficial da União, Rio de Janeiro, em 4 jul. 1925.

${ }^{162}$ O decreto-lei $\mathrm{n}^{\circ} 1.604$, de 14 de setembro de 1939, autoriza o Prefeito do Distrito Federal a contratar com a Sociedade Propagadora das Belas Artes a cessão de benfeitorias de sua propriedade nas condições que menciona, publicado no Diário Oficial da União, Rio de Janeiro, em 16 set. 1939. Com esse decreto a prefeitura do Rio de Janeiro passa a ser encarregada dos encargos do empréstimo por debêntures, mas a ela são concedidas as benfeitorias construídas no terreno do Liceu de Artes e Ofícios pela Sociedade.

${ }^{163}$ Carlos Oswald também escreve que monta em seu ateliê a prensa que "herdou" de Henrique Bernardelli; todavia, isso deve ter acontecido após a morte do pintor, ocorrida em 1936.

${ }^{164}$ Carlos Oswald, op. cit., 1957, p. 96.
} 
que podem ser transformados para a realização das gravuras: placas comuns de metal devem ser polidas para servirem de matrizes, agulhas comuns são presas a cabos de pincéis para construírem pontas secas, asfaltos e ceras são misturados para a preparação dos vernizes etc. Essa condição, portanto, necessária ao trabalho na oficina, passa a ser memorada por Oswald, na década de 1950, e por outros pesquisadores da gravura brasileira, como uma qualidade daqueles que riscam matrizes no país, uma vez que eles tinham de dominar todo o processo de produção da gravura. A propósito, o problema da falta de materiais nacionais adequados às artes gráficas e mesmo às outras artes, como a pintura, é relatado por diversos artistas ainda nas décadas mais avançadas do século XX. O próprio Carlos Oswald, em 1953, participa de comissão, em conjunto com Iberê Camargo, que se reúne com o presidente Getúlio Vargas para solicitar a revisão das taxas de importação de materiais artísticos, visto ser a importação indispensável frente a má qualidade dos produtos nacionais ${ }^{165}$.

Poty Lazzarotto escreve em carta datada da década de 1940, enviada de Paris para Oswald, que faz litografias e algumas xilografias na França, mas não "gravura", pois encontra um ateliê "muito mal aparelhado" e resolve aproveitar seu tempo de "melhor maneira"166. Poty elogia seu professor, mas a crítica que faz ao ateliê parisiense não significa que no Brasil existissem mais recursos para se fazer gravura do que na capital francesa.

Carlos Oswald afirma, em seu texto da Vozes de 1955, que a oficina de água-forte é alocada, em 1930, em uma pequena sala provisória, voltada para o pátio interno da escola. Barros, que repete Oswald, amplifica essa afirmação do artista e escreve que as aulas de águaforte, ainda em 1956, acontecem na mesma saleta de $1930^{167}$, portanto, aparentemente, não provisória. Orlando da Silva lembra que, em 1942, a Oficina está em uma sala onde só cabe a prensa, que embora elétrica, tem de ser rodada à mão, e completa a informação escrevendo que não há materiais disponíveis para fazer nada além de ponta-seca ${ }^{168}$. Poty, depois de seu estágio na Europa, envia de São Paulo, isso já na década de 1950, carta a Carlos Oswald na qual informa sobre o curso de gravura que oferece no Museu de Arte. Na correspondência,

\footnotetext{
${ }^{165}$ Cf. "Em favor das belas artes”, A Manhã, Rio de Janeiro, 3 fev. 1953.

${ }^{166}$ Napoleon Potyguara Lazzarotto, Carta para Carlos Oswald, Paris, set. 194X. Arquivo Histórico Museu Nacional de Belas Artes/Ibram/MinC, Rio de Janeiro. Supõe-se o decênio de 1940 para carta, porque Poty viaja para Paris em 1946 e lá permanece um ano.

${ }^{167}$ Carlos Oswald escreve no artigo: "Finalmente, por iniciativa do professor Eurico Alves, a máquina foi provisoriamente armada numa saleta dando para o pátio interno do Liceu." Carlos Oswald, "A oficina de gravura à água-forte”, Vozes de Petrópolis, Petrópolis, maio jun. 1955, p.259. Barros altera a afirmação, no ano seguinte, para: "Finalmente por intervenção do professor Eurico Alves, a maquinaria foi provisoriamente armada numa saleta, dando para o pátio interno do Liceu, onde ainda se acha”. Álvaro Paes de Barros, op. cit., p.330.

${ }^{168}$ Depoimento de Orlando da Silva publicado no livro Adir Botelho et al, op. cit., pp. 48-50. Maria Luisa Luz Tavora, possivelmente a partir de relatos de artistas, também afirma que o local destinado à Oficina, em sua reabertura, é uma pequena sala ao lado dos banheiros, onde os alunos, sem muito espaço, conseguiam apenas imprimir suas chapas. Maria Luisa L. Tavora, op. cit., 2007, p 384.
} 
Poty afirma que se o professor encontrasse tão boas condições no Rio de Janeiro quanto as que ele encontra no seu ateliê recém montado naquela instituição paulistana, a sua luta pela água-forte teria sido mais fácil ${ }^{169}$. Oswald no artigo de 1955 , afirma que, entre as décadas de 1930 e 1950, o número de interessados nas aulas de água-forte cresceu e foi preciso mudar o ateliê de lugar, dessa vez, para uma sala maior que a anterior e melhor iluminada, mas não especifica a data, tampouco escreve sobre questões técnicas, o que é sugerido na referida carta de Poty.

Carlos Oswald, em seus escritos, nunca atribui os problemas enfrentados pela oficina de água-forte à falta de apoio do Liceu de Artes e Ofícios ou a qualquer outro problema porventura existente na instituição. Ao contrário, o artista sempre elogiou a inciativa da Sociedade Propagadora de Belas Artes em manter o ensino da água-forte na escola. Entretanto, é impossível não reconhecer que o ensino de gravura tal como é previsto no final do século XIX e início do XX pelos fundadores da Sociedade é muito diferente daquele implantado por Carlos Oswald. Enquanto os primeiros visavam a formação de artesãos para as firmas gráficas, o segundo almejava a formação de artistas que, conhecedores da técnica, produzissem obras de arte. Esta foi a prática adotada nos cursos que Oswald ofertou na oficina que dirigia, direção que se confirma a partir de relatos de seus alunos e dele próprio ${ }^{170}$.

Entretanto, Carlos Oswald denuncia, explicitamente, a falta de incentivo à gravura por parte de outra instituição: a Escola Nacional de Belas Artes. Tanto em sua autobiografia, quanto em seu texto da Vozes, de 1955, o gravador se indigna com o fato de que até a década de 1950 a gravura não é oficialmente ensinada naquele estabelecimento voltado às Belas Artes. A ausência dessa cadeira na escola se não demonstra que, ao mesmo até o final da década de 1940 no Brasil, essa arte ainda encontrava dificuldades para ser aceita como obra de arte, tal como o era a pintura e a escultura, ao menos indicia que a gravura não era compreendida, visto que a mesma só passa a ser discutida em periódicos pouco antes do início do decênio de 1950. Ao romper desses anos, aliás, a mudança é total, mesmo porque incentivada pelo próprio governo.

\footnotetext{
${ }^{169}$ Napoleon Potyguara Lazzarotto, Carta para Carlos Oswald, datada "São Paulo, jul. 195X”. Arquivo Histórico Museu Nacional de Belas Artes/Ibram/MinC, Rio de Janeiro. Supõe-se que a carta seja da década de 1950, pois nesses anos Poty ministra curso de gravura no MASP.

${ }^{170}$ Se esta posição gerou conflitos com a escola, não se encontram documentos ou relatos que os confirmem. Tavora aponta em seu texto uma tensão entre duas diferentes concepções da gravura no Liceu: a que se voltava para os ofícios e a que era ensinada na oficina de água-forte. Ressalta-se, porém, que as afirmações da estudiosa são baseadas em relatos após a saída de Carlos Oswald da escola, principalmente, nos relatos de Orlando da Silva. Além disso, a autora argumenta que as más condições da oficina também demonstram essa relação conflituosa entre a direção da instituição e os professores. Maria L. L. Tavora, op. cit., 2007.
} 
O ensino da água-forte é questão que implica mudança de conceito, tanto daqueles que trabalham, de maneira geral, com as Belas Artes, quanto do público, até o momento que o governo passa a entender que essa arte pode representar, por questões diversas, que não é o escopo deste trabalho, o Brasil no exterior. Até o final dos anos de 1940, artistas e públicos têm de ser informados e educados na nova concepção sobre a gravura: de que ela não é apenas técnica que faculta a ilustração de revistas e livros, mas que é processo próprio aos artistas. Portanto, Carlos Oswald não ensina apenas a técnica da água-forte, ele divulga uma ideia com seu trabalho de professor. Nessa empreitada da oficina de água-forte do Liceu ele permanece até, provavelmente, meados da década de 1940. Após a sua aposentadoria, a oficina não é extinta, permanecendo seu filho, Henrique Bicalho Oswald, como professor. Darel Valença lembra, aliás, que no final dos anos de 1940, quando ele procura o Liceu para experimentar a gravura em metal, o professor já é Henrique, o Lilico ${ }^{171}$. A oficina funciona ainda na década de 1950, mesmo após a ida de Lilico para à Europa, em gozo de prêmio viagem, época que o ex-aluno, Orlando da Silva, assume a função de professor.

Ressalta-se, contudo, que a oficina do Liceu não é o único local no qual Carlos Oswald dá aulas na década de 1940: em 1946, ele ensina água-forte em outra instituição de ensino, a Fundação Getúlio Vargas.

\section{4. O curso de artes gráficas da Fundação Getúlio Vargas}

Consta no folheto de divulgação do curso de Desenho de propaganda e de artes gráficas da Fundação Getúlio Vargas, segundo Maria Luisa Luz Távora ${ }^{172}$, que essas aulas são destinadas “aos profissionais em atividade em empresas gráficas particulares, em institutos oficiais ou paraestatais que mantém serviços nesses ramos de desenho técnico”, e, ainda de acordo com a pesquisadora, lê-se no mesmo folheto que artistas, estudantes de desenho e de pintura também podem se matricular nessas aulas. O curso da Fundação Getúlio Vargas é voltado, portanto, para a formação do trabalhador especializado nas atividades que necessitam do desenho e da gráfica, nisto, incluso, os artistas, que, como se sabe, trabalham em atividades afins para se sustentarem.

Tomás de Santa Rosa, organizador do curso, em carta datada de 19 de janeiro de 1946, convida Carlos Oswald para ser um dos “instrutores” das aulas na Fundação:

\footnotetext{
${ }^{171}$ Depoimento do artista Darel Valença publicado no livro Adir Botelho et al, op. cit., 1996.

${ }^{172}$ Maria Luisa L. Tavora, "Experiência Moderna: gravura no curso de Desenho de Propaganda e de Artes Gráficas - Fundação Getúlio Vargas 1946”, 2012, p. 1610.
} 
A Fundação Getúlio Vargas, no desejo de desenvolver entre nós, o gosto e o estudos das artes gráficas, encarregou-me de organizar um "atelier" livre, onde se pudesse com um [sic] boa "equipe" ministrar aos jovens interessados no problema o ensino necessário de suas técnicas.

Num empreendimento desta natureza, não poderia esquecer o seu nome.

E, eis a razão desta carta, afim de consulta-lo se pode aceitar esse encargo. ${ }^{173}$

Enquanto Santa Rosa oferece o trabalho a Oswald, afirmando que o curso prevê um "ateliê livre" para o estudo das diferentes artes gráficas, o folheto oficial, novamente de acordo com Távora, divulga que as aulas na FGV objetivam "dar aos conhecedores do desenho básico, o domínio seguro do desenho de propaganda e artes gráficas, especialização que, dia a dia, se torna mais necessária, em face do avanço da técnica da publicidade" ${ }^{\natural 74}$. Apesar da aparente incongruência encontrada sobre os objetivos da iniciativa, não é possível esquecer que, na época, era oportuno que o futuro publicitário conhecesse as artes gráficas; mais ainda, que o artista pudesse participar da crescente indústria de livros ilustrados dessa época $^{175}$. O ateliê livre proposto a Oswald não é excrescência, ao contrário, inscreve-se à proposta do curso. Santa Rosa, em nova carta a Carlos Oswald, de 14 de fevereiro, mostra-se entusiasmado quanto às questões publicitárias, pois as entende como chave para a atração de alunos. Para dar início às aulas, previstas já para março de 1946, Rosa solicita a Oswald que o auxilie com os preparativos: pede uma lista de materiais necessários a um grupo de doze alunos e pergunta se o gravador pode lhe enviar rapidamente uma indicação para a compra de uma prensa ${ }^{176}$.

Além de Oswald, são convidados como professores Axl Leskoschek, Annah Levy e Silvio Signorelli. Tavora ${ }^{177}$ afirma que Santa Rosa dá as aulas de Composição Decorativa e de Técnica de Publicidade; Oswald ensina a água-forte, Leskoschek, a xilografia, Signorelli, a litografia, todos as três técnicas de gravura, de acordo com o impresso que divulga o curso, inclusas na área de Desenho Aplicado, e Annah Levy, encarregada das aulas de História da

\footnotetext{
${ }^{173}$ Santa Rosa ainda informa a Oswald que é previsto que os "instrutores", tal como denomina os professores, ministrem três aulas semanais de duas horas, mas isso pode ser revisto, como escreve, de acordo com a necessidade de cada ensino. Acrescenta que as aulas acontecerão em Botafogo, "no antigo Colégio Aldridge". Tomás de Santa Rosa, Carta para Carlos Oswald, Rio de Janeiro, 19 jan. 1946. Arquivo Histórico Museu Nacional de Belas Artes/Ibram/MinC, Rio de Janeiro.

${ }^{174}$ Maria L. L. Tavora, op. cit., 2012, p. 1610.

${ }^{175}$ Sobre o trabalho de artistas feitos para livros e revistas ver o artigo de Carla Fernanda Fontana, "O Desenho de Letras em Capas de Livros: Edgar Koetz e a Seção de Desenho da Livraria do Globo de Porto Alegre", publicado na revista Livro, $\mathrm{n}^{\circ}$ 5, 2016; o trabalho de conclusão de curso da mesma autora intitulado $O$ Ateliê de Desenho da Livraria do Globo, ECA-USP, 2004 e sua dissertação de mestrado apresentada à FFLCH, USP, 2010, intitulada O trabalho de Poty Lazzarotto como Ilustrador.

${ }^{176}$ Tomás de Santa Rosa, Carta para Carlos Oswald, Rio de Janeiro, 14 fev. 1946. Arquivo Histórico Museu Nacional de Belas Artes/Ibram/MinC, Rio de Janeiro.

${ }^{177}$ Maria Luisa L. Tavora, op. cit., 2012.
} 
Artes e das Artes Gráficas. Apesar do impresso sugerir restrições - desenho aplicado -, do que se sabe por depoimentos publicados, as aulas do artista austríaco Leskoschek, que estava no Brasil fugindo do nazismo, e do brasileiro nascido em Florença, Carlos Oswald, procuravam principalmente despertar a criatividade dos alunos ${ }^{178}$.

Durante os sete meses de duração do curso, que, segundo afirma o jornalista Antonio Bento, se inicia em maio de 1946 e se encerra em novembro do mesmo ano, não foi possível encontrar notícia. Em 1947, porém, dois jornais cariocas apresentam diversas matérias sobre as aulas de gravura da Fundação Getúlio Vargas devido a exposição promovida pela instituição com os trabalhos dos alunos. Segundo Antonio Bento, que escreve para o Diário Carioca, nessa mostra se apresentam vinte e dois alunos, embora, como afirma o redator, mais pessoas frequentam as aulas da Fundação ao longo de $1946^{179}$. O crítico elogia a qualidade dos trabalhos expostos, bem como a iniciativa do pintor Santa Rosa e dos outros professores, que ensinam os alunos de acordo com as "orientações estéticas" deles:

[...] a turma de expositores é de primeira ordem, comparada com o que se conhece nas amostras análogas da Escola Nacional de Belas Artes ou do Liceu de Artes e Ofícios. É evidente que não se produziu nenhum milagre. Os progressos realizados pelos alunos do Curso decorrem da hábil orientação de seus professores, que lhe deram, antes de tudo, inteira liberdade no que diz respeito à expressão artística e à orientação estética adotada. Cada aluno podia fazer o que bem quisesse, limitando-se os professores a guia-lo no emprego da técnica adotada, no desenho como na gravura. Foi não só respeitada como cultivada a personalidade do aluno. Por esse motivo, não se vê na exposição nenhum Santa Rosa-Mirim ou qualquer Leskoschek-Junior, fenômeno tão comum nos cursos daqui como nos da Europa. É essa a primeira lição a tirar-se da excelência da pedagogia artística adotada no Curso da "Fundação Getúlio Vargas. ${ }^{180}$

Para elogiar o trabalho realizado na fundação, Bento menospreza o ensino de outras instituições, inclusive o do Liceu, sugerindo que as obras ali produzidas e expostas não são de boa qualidade; certamente fala da gravura voltada para a indústria. No mesmo artigo, o crítico afirma que, antes do curso de sete meses da Fundação, a gravura era prática restrita a poucos:

[...] o Curso da "Fundação Getúlio Vargas" veio democratizar no Rio o ensino das técnicas diversas de gravura. Só isso constitui uma revolução. Outrora, quem sabia fazer no Brasil água-forte, xilogravura e água-tinta podia ser considerado verdadeiro bruxo. Os alunos desse Curso, após sete meses de ensino, já estão utilizando com

\footnotetext{
${ }^{178}$ Sobre Leskoschek ver “Axl Leskoschek e seus alunos: Brasil/1940-1948”. Curadoria Frederico Morais; texto Frederico Morais. Rio de Janeiro, Galeria de Arte Banerj, 1985. Acerca de Carlos Oswald é dispensável referência, uma vez que as mesmas estão indicadas ao longo deste trabalho.

${ }_{179}$ Antonio Bento, "O curso da 'Fundação Getúlio Vargas"”, Diário Carioca, Rio de Janeiro, 13 fev. 1947.

${ }^{180}$ Idem, ibidem.
} 
desembaraço processos técnicos que eram antigamente o privilégio de meia dúzia de artistas. $^{181}$

A discussão sobre o curso e, consequentemente, sobre o ensino da gravura se alonga por algumas semanas no Diário Carioca e também no Correio da Manhã devido a notícia de que, mesmo com o sucesso da exposição, a Fundação decide encerrar o ensino das artes gráficas em suas dependências. A notícia ultraja Antonio Bento e Mário Pedrosa, crítico que também se coloca a favor do ensino das técnicas gráficas.

Pedrosa lembra Bethencourt da Silva, ao tentar explicitar para aqueles que decidem sobre os rumos da fundação, que o ensino da gravura enquanto técnica é fundamental para o desenvolvimento da indústria editorial nascente no país. Mais do que isso, o crítico argumenta que o ensino das artes, mesmo que pareça "desinteressado", é essencial para as indústrias do país, uma vez que é necessário formar mão de obra com conhecimentos "artesanais" amplos e não restrita aos conhecimentos técnicos reduzidos:

[...] por decisão, ao que parece irrevogável, dos donos da Fundação, esse curso que Santa Rosa e outros devotados monges das artes no Brasil dirige, vai acabar[.] Em seu lugar, o sr. Simões Lopes quer criar um inócuo curso chamado de "desenho industrial" onde os alunos aprenderão a fazer desenhos geométricos ao tira-linhas. Não sabem os donos desses 300 milhões de cruzeiros do patrimônio fabuloso que é a Fundação, que ensinar artes gráficas reais, ensinar praticamente, artesanalmente, a toda uma geração de jovens brasileiros as diversas espécies de gravura além do desenho livre, da aquarela, da monotipia, etc. é muito mais útil do que limitar-se a ensinar desenho industrial a pessoas inteiramente broncas ou inocentes do que seja desenho artístico ou sem a menor noção do que seja uma disciplina artesanal prévia. ${ }^{182}$

É evidente, a partir desse texto, que Mário Pedrosa, em 1947, não defende o ensino da gravura enquanto arte, mas sim como arte aplicada à indústria. $\mathrm{O}$ crítico considera as artes gráficas como essenciais para a produção de livros e, por isso, entende que o país precisa formar hábeis técnicos:

As indústrias gráficas brasileiras não poderão expandir-se em quantidade e qualidade sem técnicos, isto é, concretamente, sem uma boa equipe de artífices gravadores.

Por sua vez, a gravura, sob todas as formas e gêneros, é o maior campo de desenvolvimento para aquelas indústrias. Suspender, portanto, o Curso de Artes Gráficas sob o pretexto de que "arte" não interessa para a indústria, é o mesmo que fechar escolas de piloto sob a alegação de que o país precisa é de desenhistas de mapas geográficos. Por esse critério, o Brasil não carece de uma escola onde se ensine

\footnotetext{
${ }^{181}$ Idem, Ibidem.

${ }^{182}$ Mario Pedrosa, "Selvageria a la Goering”, Correio da Manhã, Rio de Janeiro, 21 fev. 1947.
} 
a arte fotográfica porque é mais prático obter-se gente que saiba usar mecanicamente a máquina, pô-la mais ou menos em foco e tocar com o dedo. ${ }^{183}$

Antonio Bento afirma que o curso da Fundação propiciou a formação de "gravadores como não se conhece outra no Brasil”. E, ecoando Pedrosa, também defende a necessidade de se formar artesãos que dominem seu ofício, e acrescenta que o curso de Santa Rosa faz o que a Escola Nacional de Belas Artes não consegue, uma vez que ali não se ensinam essas técnicas:

todos reconhecem a necessidade do funcionamento do Curso, que permitiu a possibilidade da existência de um "atelier" livre para o ensino de artes plásticas no Rio. Desse "atelier" poderão sair artesãos verdadeiros e uma geração de gravadores como não se conhece outra no Brasil, graças a Santa Rosa e aos professores Carlos Oswald e Leskoschek. A necessidade do Curso é incontestável, dada a deficiência do ensino na Escola de Belas Artes. ${ }^{184}$

Carlos Oswald, em documento datiloscrito, no qual escreve sobre a água-forte no Rio de Janeiro, provavelmente datado do início da década de 1950, também se indigna com o fechamento do curso, mas, diferentemente de Mário Pedrosa e Antonio Bento, demonstra outro entendimento sobre o fato:

No fim do ano uma exposição concorridíssima patenteou as classes intelectuais a utilidade e eficiência daqueles cursos que, no entanto, foram inexplicavelmente suprimidos pelos dirigentes da instituição com a excusa sibilina de que a gravura de arte não é própria para o povo! ${ }^{185}$

A diferença entre a argumentação de Carlos Oswald e a de Pedrosa está, evidentemente, tanto no conceito sobre a gravura, quanto nos objetivos desse ensino. Diferente do crítico de arte, Oswald nunca pretendeu o ensino da água-forte como técnica a serviço do mercado editorial. Mais do que isso, sua indignação avança, pois, segundo é possível concluir de seus escritos, o artista revolta-se diante da posição das autoridades de não incentivarem o ensino da arte, com "a" maiúsculo, para a população. De qualquer modo, tanto Oswald quanto os autores referidos defendem o curso de artes gráficas da Fundação; estranho é, todavia, que para fazê-lo, Bento e Pedrosa, numa argumentação hiperbólica, obliterem o ensino realizado por tantos anos no Liceu de Artes e Ofícios. Estranhamento inicial, pois,

\footnotetext{
${ }^{183}$ Idem, Ibidem.

${ }^{184}$ Antonio Bento, “Desaparecerá o curso da F.G.V?”, Diário Carioca, Rio de Janeiro, 14 fev. 1947.

${ }^{185}$ Carlos Oswald, A água-forte no Rio de Janeiro, s.d., p.3. Documento datiloscrito, Arquivo Histórico Museu Nacional de Belas Artes/Ibram/MinC, Rio de Janeiro.
} 
como se sabe, técnica. Assim, eles argumentam que o ensino da água-forte, da xilografia e da litografia é uma novidade no Rio de Janeiro, além de afirmarem que esses conhecimentos sobre a gráfica são restritos a alguns "entendidos" que não desejam compartilhá-los. Mário Pedrosa escreve:

Até agora, a gravura era um mistério só para meia dúzia de entendidos que o guardavam a sete chaves. A água-forte tinha o privilégio das coisas raras e desconhecidas.

Esse ou aquele sujeito que tinha uma prensa para a gravura ou conhecia o segredo do ácido para a água-forte se mantinha em geral, numas reticências de iniciado quando algum leigo ou algum jovem mais curioso o interrogavam sobre aqueles técnicos. Agora, Carlos Oswald, Santa Rosa e Leskoscheck acabaram com o mistério, e o segredo está aberto para quem quiser vir e aprender. ${ }^{186}$

Antonio Bento, ainda, critica as gravuras realizadas no país até então pela falta de "precisão gráfica":

Não exagero reafirmando que esse Curso constitui uma revelação. Sabe-se que a gravura contemporânea não goza de boa fama artística. Atribui-se o fato a influência da pintura impressionista, cujo objetivos plásticos são antagônicos ou opostos à arte do gravador que exige antes de tudo precisão gráfica. Santa Rosa submeteu seus alunos a um rigoroso aprendizado. Todos são obrigados a desenhar rapidamente para exercitar a mão (...). Os seus alunos têm de gravar rapidamente sob as vistas experimentadas de Carlos Oswald e de Leskochek ${ }^{187}$

Os dois articulistas que defendem a continuidade do curso de artes gráficas, muito bem intencionados, engradecem o curso organizado por Santa Rosa, mas não evidenciam os esforços de Carlos Oswald e de seus ex-alunos para divulgarem a arte da gravura.

\subsection{O Atelier de Arte: a divulgação da gravura à água-forte}

A divulgação da água-forte como obra de arte é tarefa não apenas dos escritos de Carlos Oswald e de suas aulas no Liceu, mas como também das exposições de gravura. Em carta de 6 de agosto de 1948, Hans Steiner demonstra que, como o professor Oswald ensina, é preciso "instruir" o público e os jornalistas sobre a água-forte para propagá-la e comercializála:

\footnotetext{
${ }^{186}$ Mario Pedrosa, “Curso de Desenho e Artes Gráficas”, Correio da Manhã, Rio de Janeiro, 15 fev. 1947.

187 Antonio Bento, "Uma geração de gravadores”, Diário Carioca, Rio de Janeiro, 16 fev. 1947.
} 
Estou aqui neste Porto Alegre frio metido na minha Exposição de Arte Gráfica e experimentando todos os prazeres e toda a monotonia de tal coisa. Devo dizer que o papel de empresário desempenhei corretamente. Procurei e tive muita propaganda, depois uma critica entusiasta. (...) Recebo muita visita de professores, estudantes, e gráficas comerciais. Amanhã e depois vou ter na minha "galeria" as turmas do $3^{\circ}$ e $4^{\circ}$ ano do Inst. de Belas Artes, para eles receber [sic] explicações sobre esta técnica. Também tenho exposto algumas chapas e ferramentas, $1^{\circ}$ est., como vê professor fiel à escola, aos nossos princípios, estou assim trazendo uma exposição instrutiva ao Sul do Brasil, para propaganda da Arte Gráfica.

(...) Isto de ter dado caráter instrutivo à exposição, está trazendo algum prejuízo comercial. Tem gente bem rica indagando se então outro também pode ter a mesma coisa. Pacientemente explico o que sei à respeito da origem da Gravura, e eu mesmo sei de casos que não venceram o seu egoísmo. ${ }^{188}$ [grifo nosso]

Hans Steiner deixa claro que a propaganda é indispensável à arte, principalmente no caso da gravura, daí ele escrever que bem desempenhou seu papel de "empresário". Particularizando a arte do metal, o ex-aluno de Oswald evidencia que o problema é ainda maior, pois essa arte além de enfrentar o desconhecimento do público, lida com os preconceitos dos consumidores que, evidentemente, não entendem ainda o fato dela poder se multiplicar.

Essa ideia de que a arte deve destinar-se a mais de um colecionador, por sua multiplicação, é da gravura. Por isso, não é de se estranhar que Carlos Oswald, no final da década de 1940, colabore e participe de clubes que promovem a gravura, quer para a sua simples divulgação, quer para a sua comercialização.

O Clube dos Glifófilos, sediado na galeria carioca de Calvino Filho, que tem curta duração, somente de 1946 a 1949, é uma dessas associações que tem como objetivo a divulgação e a venda de gravuras, tanto assim que se propõe a conferir a cada um dos seus cem sócios algumas gravuras por ano. Apesar de Oswald datar a existência do clube já na segunda metade do decênio de 1940, os jornais apenas divulgam o empreendimento no ano de 1949, quando algumas notas afirmam que são seus sócios Carlos Oswald, Cândido Portinari, Hans Steiner, Amilcar Regis do Nascimento, Valdemar Paixão, Amauri Catrambi, Fayga Ostrower, Poty Lazzarotto, Carlos Geier, entre outros ${ }^{189}$.

Em março de 1949, o Diário Carioca ${ }^{190}$ noticia a distribuição entre os sócios dos Glifófilos de uma gravura de Carlos Oswald, além de afirmar que o artista, junto a Portinari, é

\footnotetext{
${ }^{188}$ Hans Steiner, Carta para Carlos Oswald, Porto Alegre, 06 ago. 1948. Arquivo Histórico Museu Nacional de Belas Artes/Ibram/MinC, Rio de Janeiro.

189 “As Artes”, Diário Carioca, Rio de Janeiro, 10 fev. 1949. Outra nota no Correio da Manhã informa, a pedido de Lívio Abramo, que apesar dele ter sido citado como integrante do clube, ele não o é e ainda se posiciona contrariamente aos objetivos da associação, os quais julga não serem do interesse da gravura brasileira. Cf. "Clube dos Glifófilos", Correio da Manhã, Rio de Janeiro, 17 abr. 1949, p. 15.

190 "As Artes", Diário Carioca, Rio de Janeiro, 18 mar. 1949.
} 
da direção artística da associação, a qual tem como responsável financeiro, Calvino Filho. A obra que Oswald realiza para o clube é Uma rua no Bingen Petrópolis (Fig. 159.A), de 1949, com tiragem de cem exemplares. Esta obra, entretanto, não é a única editada nesse ano por essa organização, sendo divulgadas em breves notas nos periódicos também obras de Carlos Geier, Poty, Percy Lau e Hans Steiner, realizadas especialmente para o clube ${ }^{191}$. Apesar da edição das tiragens das cinco gravuras dos artistas referidos, o Club dos Glifófilos, segundo afirma Oswald, não consegue se manter por muito tempo, sendo, aparentemente, encerrado nesse mesmo ano de 1949.

Em 1950, Peter Morris ${ }^{192}$ funda o Atelier de Arte (AA), empresa descrita por Oswald como uma grande oficina de água-forte com oito prensas, na qual são produzidas tiragens de gravuras para serem vendidas pelo correio por todo o Brasil ${ }^{193}$. Carlos Oswald é diretor artístico do empreendimento em conjunto com seu ex-aluno José Silveira D’Ávilla, seu filho Henrique Oswald e Ludwig Hesshaimer, gravador austríaco radicado no Rio de Janeiro. Oswald não se encarrega apenas da gerência da parte "artística" do referido empreendimento - possivelmente selecionando gravuras para a comercialização -, ele também realiza, entre 1951 e 1952, novas águas-fortes para o Atelier, além de reimprimir para a instituição algumas de suas obras antigas. Apesar da demanda a Oswald, o Atelier de Arte divulga e negocia gravuras, entre outros gravadores, de Hans Steiner, Darel Valença, Percy Lau, Poty Lazzarotto, José D’Ávila, Raimundo Cela, Henrique Oswald, é o que se pode concluir ao se consultar os documentos do Fundo Carlos Oswald do Arquivo Histórico do Museu Nacional de Belas Artes, no qual há listas com valores e nomes dos gravadores, com preços de gravuras e anotação sobre a porcentagem cabida ao "Atelier" 194.

Sabe-se que na década de 1950, no Brasil, alguns clubes de gravura, fora os aqui mencionados, são organizados em Porto Alegre, São Paulo, Santos e Recife, como afirma Aracy Amaral em seu livro Arte para quê? ${ }^{195}$, no qual a autora também refere brevemente

\footnotetext{
191 "Letras e Artes”, A Noite, Rio de Janeiro, 9 maio 1949. “As Artes”, Diário Carioca, Rio de Janeiro, 24 jun. 1949.

${ }^{192}$ Em nota de 26 de set. 1951, no Jornal do Commercio, Peter Morris é citado como diretor da Canadian Radium Copporation of Brazil. Cf. "Várias Notícias", Jornal do Commercio, Rio de Janeiro, 26 set. 1951. Nos anos seguintes, seu nome volta a ser citado algumas vezes nos jornais, sempre relacionado à empresa da qual continua a ser diretor e que passa a ser nomeada de Radium Indústria e Comércio Americano S.A.. A Radium fabrica materiais para sinalização, como tintas e pigmentos luminosos, tubos e lâmpadas ultravioletas, além de equipamento para impressão em cores pelo processo de silkscreen. Cf. "Inaugurada fábrica que é única na América", Tribuna da Imprensa, Rio de Janeiro, $1^{\circ}$ ago. 1955.

${ }_{193}$ Carlos Oswald, op. cit., 1957, p.98.

${ }^{194}$ Documentos manuscritos, guardados pelo fundo de Carlos Oswald do Arquivo Histórico do Museu Nacional de Belas Artes, apresentam listas com valores e nomes dos gravadores, designando os preços das gravuras, a porcentagem do "Atelier" e o montante devido a cada artista.

${ }^{195}$ Aracy Amaral, Arte para quê? A preocupação social na arte brasileira 1930 - 1970, Nobel, São Paulo, 1984.
} 
uma associação de mesmo tipo organizada no Rio de Janeiro em $1956^{196}$. Contudo, diferente do Atelier de Arte, que não possuí orientação política, Amaral afirma que os clubes que estuda são baseados no Taller de Gráfica Popular do México e pretendem a gravura como instrumento na luta popular. É evidente, pelo que se lê em entrevista de José D’Ávilla, um dos organizadores do empreendimento com Morris, que o engajamento do Atelier de Arte é outro. D’Ávilla considera a gravura como obra de arte que se multiplica, daí seus valores serem inferiores ao de uma pintura, ideia que também os clubes de gravuras de direção política dos anos de 1950 defendem. A ideia de "democratização" é, sem dúvida, a palavra que os une. Todavia, enquanto para os clubes de gravura, como o de Porto Alegre, a democracia implica a política, para os artistas do AA a "democratização" significa colocar ao alcance de muitos a arte da gravura, ou, como se dizia na época, vulgarizá-la. No Jornal do Brasil, que entrevista D’Ávila, lê-se:

Agora ele [D'Ávila] e Carlos Oswald, o grande pintor que é uma das mais puras glórias da arte no Brasil, uniram-se para criar o "Atelier de Arte", com que vão tentar a vulgarização entre nós da gravura.

[...]. Qual a razão do Atelier de Arte? [...]

Se quisermos tirar o povo das rotineiras preocupações das contingências da vida, devemos ampliar lhe os horizontes, levar-lhe a cultura, aprimorar the a sensibilidade, dando-lhe um objeto mais elevado, um interesse maior para a luta, para a vida.

$[\ldots]$

resolvi lançar-me na luta por uma maior difusão da obra de Arte, isto é, levá-la ao povo ou melhor, democratizá-la, tirando-a do ambiente restrito, de um pequeno número formado de snobs ou mesmo de sinceros apreciadores.

$[\ldots]$

Enquanto o público se contentar com simples estampas policrômicas, reproduzidas mecanicamente, e de má qualidade, ou com as [?] folhinhas de armazém não haverá nunca uma consciência da importância da Arte e dos benefícios que ela traz ao indivíduo em particular, bem como à harmonia social.

Pensávamos então, em organizar com artistas de real valor um Atelier, num sistema cooperativo que pudesse facilitar ao público, bons trabalhos no campo das Artes plásticas. Como seria possível ao povo adquirir obras de Arte, se estas em geral custam elevados preços para o nosso nível de vida, e não ser possível ao próprio artista realizar bons trabalhos de valor artístico por preços acessíveis?

Surgiu-nos então a ideia de iniciarmos o nosso movimento com a "água-forte. Sabido como é que a importância artística não consiste no tamanho nem no valor da matéria com que é elaborado, e sendo a "água-forte" um meio de grandes possibilidades de expressão [...] seria ainda possível vendê-las por preços acessíveis a qualquer pessoa

\footnotetext{
${ }^{196}$ Aracy afirma, a partir do depoimento de Paulo Werneck, em 1982, que o clube de gravura do Rio de Janeiro foi fundado por "influência" de Carlos Scliar e organizou, no diretório acadêmico da Escola Nacional de Belas Artes, a exposição "Gravuras Mexicanas" em 1956. Cf. Idem, p. 186.

197 "Democratização da Arte", Jornal do Brasil, Rio de Janeiro, 12 fev. 1952.
} 
Infelizmente a empreitada comercial de Morris pela água-forte não tem sucesso, visto que as coleções de gravuras enviadas por correio ou não são aceitas pelos potenciais compradores ou não são pagas. Carlos Oswald, em sua autobiografia lembra que avisa Morris que "só com águas-fortes" não se obtém lucro suficiente para manter e justificar o "grande capital"198 empenhado na oficina. Oswald sabe que na década de 1950 ainda não é possível ter mercado para as artes gráficas no Brasil, mesmo porque, como se sabe, é nesse decênio que o comércio artístico começa a crescer no país.

Em 1952, ano em que se iniciam as aulas de gravura na Escola Nacional de Belas Artes, Peter Morris solicita que Oswald fale com Georgina de Albuquerque para que a referida escola adquira parte das ferramentas do AA, a fim de sanar um pouco do seu prejuízo financeiro. As perdas pecuniárias, contudo, são compensadas pelo sucesso moral ${ }^{199}$ da iniciativa, segundo afirma na mesma correspondência o investidor entusiasta da água-forte. Considere-se que, antes de fechar, o Atelier de Arte promove exposição de águas-fortes, em parceria com a oficina do Liceu de Artes e Ofícios, no Museu Nacional de Belas Artes ${ }^{200}$, da qual Carlos Oswald e vários de seus alunos participam.

Em 1952, ano do término do Atelier, Raymundo de Castro Maya cria a Sociedade os amigos da gravura, associação melhor sucedida que as suas antecessoras, que funciona por mais de dez anos e edita obras de Henrique Oswald, Hans Steiner, Ahmés de Paula Machado, Fayga Ostrower, Poty Lazzarotto, Oswaldo Goeldi, Percy Lau, Darel Valença Lins, Livio Abramo, entre outros ${ }^{201}$.

Moacyr Padilha, no mesmo ano de 1952, jornalista que certamente conhecia gravura, escreve artigo intitulado "Carlos Oswald, o Apóstolo da Gravura Artística no Brasil”, que é publicado no Diário de Pernambuco. Padilha afirma que há uma presença maior da gravura nos salões e exposições, decorrente do maior interesse dos jovens artistas por essa arte. No entanto, ressalta que esses jovens desconhecem a luta percorrida até aquele momento:

Muitos, senão a esmagadora maioria, ignoram a origem desse salutar movimento artístico, cuja crônica poderia ser escrita através da narração das árduas lutas que assinalam os quarenta anos de batalha travada pelo mestre Carlos Oswald desde que

\footnotetext{
${ }^{198}$ Carlos Oswald, op. cit., 1957, p.96.

${ }^{199}$ Peter Morris, Carta para Carlos Oswald, Rio de Janeiro, 7 jul. 1952. Arquivo Histórico Museu Nacional de Belas Artes/Ibram/MinC, Rio de Janeiro.

200 “Exposição de Águas-fortes", Correio da Manhã, Rio de Janeiro, 30 maio 1952.

${ }^{201}$ Os Museus Castro Maya retomaram a Sociedade Os Amigos da Gravura em 1992. Cf. Os amigos da gravura. In MUSEUS Castro Maya. Rio de Janeiro: IBRAM, 2017. Disponível em: < http://museuscastromaya.com.br/museu-da-chacara-do-ceu/exposicao-do-museu-da-chacara-do-ceu/os-amigosda-gravura/>. Acesso em: 10 mar. 2017.
} 
fundou em modesta sala do Liceu de Artes e Ofícios do Rio de Janeiro a primeira oficina de água-forte no Brasil. ${ }^{202}$

Padilha, genro de Oswald, celebra o resultado do trabalho do artista e ressalta que a "moda" pela gravura contagia no Rio de Janeiro aqueles que se interessam pelo "negócio" nas artes:

Após quase quarenta anos de trabalho em prol da disseminação, pelo ensino, da gravura artística no Brasil, pode dizer-se que Carlos Oswald venceu a batalha. Possuir hoje uma água-forte na parede vai-se tornando quase moda... E quando a moda ganha corpo... Stendhal dizia de sua geração - "ils ne croient à rien qu'à la mode" poderíamos perguntar em que acreditam os nossos contemporâneos senão nela mesmo? No caso da expansão das artes gráficas em nosso país não poderíamos deixar de reverenciar também s. excia. a moda. Ela é em boa parte responsável pelo surto no Rio de organizações destinadas exclusivamente a explorar comercialmente o "negócio", imprimindo e vendendo milhares de gravuras. ${ }^{203}$

Padilha, na década de 1950, não é o único a "celebrar" a maior popularidade da gravura; em sua autobiografia, Oswald também se entusiasma com o reconhecimento que essa arte começa a receber nesses anos. Assim, suas memórias, mesmo que por vezes de modo hiperbólico, registram as suas atividades na oficina de água-forte e a divulgação que realiza da gravura como arte, chegando a afirmar que, após todo esse trabalho, em 1957, a gravura se impõe e que "todos lhe dão o mesmo valor que se concede à pintura, escultura"204.

Na década de 1960, outros clubes de gravura são formados, não com a direção política da maior parte do dos anos de 1950, antes com objetivos que se aproximam mais do extinto AA, como aquele organizado em 1963 pela Sociedade dos Amigos do Museu Nacional de Belas Artes do Rio de Janeiro que, segundo informa Teixeira Leite, deveu-se à iniciativa de Orlando da Silva, ex-aluno de Oswald ${ }^{205}$.

Entretanto, nas décadas de 1950 e 1960, anos de maior difusão da gravura em comparação com os anteriores, Carlos Oswald, aposentado do Liceu e já com problemas de visão, participa de poucas exposições e, tal como já se lê nos textos sobre o curso da Fundação Getúlio Vargas, seu trabalho em prol da gravura passa despercebido pelos críticos de arte que a comentam. No debate promovido pelo Museu de Arte Moderna do Rio de Janeiro em 1956 sobre as artes gráficas, por exemplo, que é relatado em periódico ${ }^{206}$, quase não se menciona Carlos Oswald, visto que são os artistas "modernos", como Oswaldo Goeldi

\footnotetext{
${ }^{202}$ Moacyr Padilha, "Carlos Oswald, o Apóstolo da Gravura Artística no Brasil”, Diário de Pernambuco, Pernambuco, 6 jan. 1952.

${ }^{203}$ Idem, Ibidem.

${ }^{204}$ Carlos Oswald, op. cit., 1957, p.25.

${ }^{205}$ J. R. Teixeira Leite, “Clubes de Gravura”, Diário de Notícias, Rio de Janeiro, 29 ago. 1963.

${ }^{206}$ Vera Tormenta, "Os gravadores discutem acaloradamente", Para todos, Rio de Janeiro, 1 nov. 1956.
} 
e Lívio Abramo, os memorados como os iniciadores das artes gráficas no Brasil. O mesmo se afirma nos depoimentos de gravadores brasileiros para o Jornal do Brasil, quando o crítico Ferreira Gullar ${ }^{207}$ organizou um inquérito sobre a gravura, no final de 1957 e início de 1958. Nesses artigos, que transcrevem as falas dos artistas, não há depoimento de Oswald e ele é apenas lembrado por seus alunos mais próximos, como Darel Valença.

Essa situação se altera após a morte do gravador, em 1971, quando exposições póstumas o celebram como "iniciador da água-forte" no Brasil. Sabe-se, a partir de documentos, textos de periódicos e referências bibliográficas, que Carlos Oswald realiza cerca de oitenta exposições, entre as coletivas e as individuais, em vida. Em vinte e quatro delas há notícias de que o artista mostra águas-fortes, estas normalmente apresentadas ao público em conjunto com a sua pintura e, raramente, expostas sozinhas. Após a morte de Carlos Oswald são realizadas, ao menos, vinte e três mostras, também entre individuais e coletivas, nas quais suas obras são mostradas. Em dezesseis dessas exposições é provável que apenas as gravuras do artista sejam expostas. As mostras póstumas contribuem, portanto, para fixarem a imagem do artista como o professor de uma "geração de gravadores brasileiros" e como iniciador do ensino da gravura em metal no país.

${ }^{207}$ Entre 1957 e 1958 o Jornal do Brasil publica série de depoimentos de gravadores organizados por Ferreira Gullar, o primeiro deles é o de Oswaldo Goeldi. 



\section{A obra gráfica de Carlos Oswald: análise e discussão a partir dos conceitos do artista expostos em seus escritos}

Carlos Oswald, em seu livro publicado em 1957, afirma que a gravura é a mais espiritual das artes plásticas, uma vez que suas técnicas são baseadas em elementos abstratos: o ponto e a linha. Segundo o autor, as outras artes, a pintura e a escultura, lidam diretamente com a matéria, mas não a gravura, uma vez que ela exige que o artista explicite "suas ideias e sentimentos por meio de abstrações: o ponto sem dimensões e a linha com uma só dimensão" 208 . Por essas características Oswald a considera “arte espiritual”, distante, portanto, da matéria que a pintura e a escultura tanto necessitam. Daí sua predileção pela gravura, arte que, como escreve, "satisfazia os [seus] íntimos desejos de exprimir com a máxima simplicidade [seus] estados de alma"209.

Considerando que a gravura serve-se de elementos abstratos, distantes, por isso, dos sólidos e das superfícies, o artista também entende que ela, particularmente a água-forte, é sintética por excelência. Esta proposição é explicitada pelo fato de que na gravura todos os problemas da representação - as formas, os volumes, as luzes, as cores - devem ser resolvidos somente com o ponto e com a linha; por essa razão, o gravador tem de, necessariamente, construir sua obra a partir de um processo de síntese. Assim, para Oswald, a gravura se opõe à “exagerada policromia" ${ }^{210}$ de certas manifestações artísticas europeias do final do século XIX e início do XX, o que não a afasta da modernidade deste último século, pois ela mantem-se distante de todos os elementos supérfluos à obra; proposta, como se sabe, de importância na época.

A síntese ou o "sintetismo", como escreve Oswald, é proposição que ele tem para a sua obra, o que não implica no abandono da figuração e da profundidade. Considerar esses elementos nas composições importa, visto que em suas gravuras veem-se figuras cujos contornos fundem-se com o fundo, assim como perspectivações diversas para a construção da profundidade. Modernidades, embora ele continue a figurar, como, aliás, muitos modernos europeus dos anos 1910, 1920, 1930 etc. Para o artista, como se depreende de seus escritos, a

\footnotetext{
${ }^{208}$ Carlos Oswald, op. cit., 1957, p. 44.

${ }^{209}$ Idem, ibidem.

${ }^{210}$ Carlos Oswald escreve: "Sei que em todo o mundo o despertar do interesse pela gravura nasceu e se desenvolveu no nosso século, pelas razões que todos conhecem: 'sintetismo', em oposição à exagerada policromia dos pós-impressionistas; entusiasmo pela ressureição desta arte que tinha sido morta pelos processos mecânicos derivantes da fotografia”. Idem, p. 96.
} 
arte tem de se "comunicar" com o público, daí a insistência na figuração, ainda que como síntese ${ }^{211}$.

Sendo assim, não é a cópia da natureza, paisagens ou pessoas, o que motiva a pesquisa gráfica de Oswald, podendo-se afirmar ainda o mesmo relativamente às suas pinturas de cavalete ou murais e os seus vitrais ${ }^{212}$. Aliás, a "cópia da realidade", como ele escreve na revista Vozes de Petrópolis, é realizada pela fotografia e, exatamente por isso, ela é técnica mecânica e não arte. A imagem fotográfica não é, para o autor, produto obtido por uma operação de síntese realizada pelo homem, sendo mero "espelho" do real. Ela produz até "verdade científica", mas não "estética":

Dizia-me noutro dia um meu conhecido "entendido de arte": "Só depois da invenção da máquina fotográfica é que os pintores compreenderam os movimentos das pernas dos cavalos em corrida. Veja, os antigos desenhavam convencionalmente o alternar rítmico das patas, os modernos agrupam as quatro pernas num facho apertado que dá a impressão de o animal estar suspenso no ar." - "Mas, disse eu, o Sr. já percebeu este instante com seus próprios olhos?" - "Não, isto é impossível, só a objetiva apanha as frações de segundos".

Vê-se aí claramente o engano: o olho humano tem vida e sintetiza numa só várias imagens que se sucedem rapidamente, de maneira que forma uma 'visão psíquica' que nada tem de fotográfico. A objetiva diz a verdade, mas não é uma 'verdade estética' porque não pode ser percebida a olho nu. ${ }^{213}$

A própria apreensão do mundo pelo olho humano, para Oswald, é síntese, que não pode ser realizada pela máquina fotográfica. Mais do que isso, o verossímil da arte não coincide com as "verdades" científicas, sendo o artista responsável por representar o que concerne à percepção humana. Relativamente à observação da paisagem, por exemplo, depreende-se de trecho do texto de Oswald de 1957, que ela é a apreensão das constantes mudanças que sofre a natureza:

[...] o [João] Batista [da Costa] virava a cabeça, atraído pela paisagem, e ficava parado, olhando o suceder-se maravilhoso do panorama. Eu calado, ele caladíssimo. Que havíamos de fazer? Ambos paisagistas, embebidos do milagre visual que

\footnotetext{
${ }^{211}$ As questões relativas à síntese são de importância para Oswald, aparecendo proposições sobre o assunto em seus diversos textos. Para ele, o corpo humano é a "síntese de toda a criação", não apenas no sentido de que a figura reúne formas que estão também na natureza, mas também de modo amplo, Oswald escreve que "sendo o homem alma e corpo, a síntese de toda a natureza, nada se pode pensar de mais nobre no campo plástico e tornase ridículo preferir [a ele] figuras abstratas, ocas, que nada dizem ao nosso espírito". Idem, p. 48.

${ }^{212}$ Sobre a arte do vitral ver: Carlos Oswald, "Técnicas de Arte: o Vitral", Vozes de Petrópolis, Petrópolis, set. dez. 1949.

${ }^{213}$ Carlos Oswald, “Arte Abstrata”, Vozes de Petrópolis, Petrópolis, set. dez. 1948, p. 664.
} 
presenciávamos, absorvidos e distraídos pela contínua mudança das formas, das cores, das distâncias, dos tons... ${ }^{214}$

Essas alterações que o artista vê sem os moldes acadêmicos - que fixam modos de compor, disposição de luz, entre outras questões compositivas - também são evidenciadas na passagem do artigo "A beleza da matéria”, no qual Oswald explicita uma de suas observações acerca das cores ao descrever o cortiço de lavadeiras próximo à sua casa:

É um encanto para os meus olhos de pintor passar por aquele lugar, que a qualquer outra pessoa talvez cause desagrado. Iluminados pelo sol, aqueles panos de várias cores, movimentados pelo vento, destacando-se sobre o fundo variado e pitoresco dos casebres, formam um quadro magnífico de tons finíssimos ou, às vezes, de contrastes violentos. $^{215}$

Se a própria observação do mundo é síntese, como afirma Oswald, uma vez que o homem percebe as mudanças consecutivas da natureza e as "unifica" em imagem única, a representação desta imagem pelo artista é exigente de síntese, visto que ele interpreta a natureza e a "traduz" em formas, cores, luzes etc. No caso do gravador, ainda mais, pois ele tem à sua disposição apenas os elementos abstratos; sua tarefa só pode ser, assim, resultado de extrema simplificação, afastada, portanto, da ideia de cópia. É evidente, deste modo, o entendimento que o artista tem dessa arte, sintética por excelência. Acrescenta-se que a incisão gravada, seja esta feita diretamente pela ponta na matriz, seja pela mordedura do ácido, é essencial para a elaboração das formas, assim como o ponto é necessário para a confecção dos cinzas, dos contrastes, da intensificação das luzes, da cor etc.

Enquanto para Carlos Oswald a linha e o ponto são elementos essenciais para a gravura, isto não se destaca em manuais dessa arte desde o século XVIII. Esses textos tratam da gravura de reprodução, aquela que é feita para estampar a pintura e a escultura em impressos, portanto, convenções que estabelecem modos de gravar que constroem com traços combinados de formas diversas vários tipos de superfícies e materiais. De acordo com o tratado de água-forte de Abraham Bosse ${ }^{216}$, por exemplo, as carnes humanas devem ser representadas com linhas cruzadas de modo a formarem losangos. As hachuras assim dispostas podem servir tanto para construir as peles masculinas, quanto as femininas, desde que a "doçura" da carne da mulher, como escreve Bosse, seja traduzida em incisões gravadas

\footnotetext{
${ }^{214}$ Carlos Oswald, op. cit., 1957, p. 71.

${ }^{215}$ Carlos Oswald, “A Beleza da Matéria”, Vozes de Petrópolis, Petrópolis, jan. fev. 1947, p. 54.

${ }^{216}$ Abraham Bosse, Tratado da gravura à água forte, e a buril, e em maneira negra com o modo de construir as prensas modernas e de imprimir em talho doce, Lisboa, 1801, p. 69 e p. 78.
} 
muito próximas e o corpo masculino, mais forte, seja feito por hachuras distanciadas. Ainda sobre as maneiras de gravar, nesse manual, que foi traduzido para o português por José Joaquim Viegas Menezes, lê-se que terrenos, paredes, troncos de árvores devem ser gravados com linhas trêmulas e que, nessas figurações, é possível misturar linhas cruzadas que formam losangos com aquelas que delineiam quadrados.

Há vários outros exemplos, neste e em outros manuais práticos de gravura de reprodução que, evidentemente distanciam-se das concepções de Carlos Oswald. Para ele, como a gravura não é simples técnica de reprodução, mas arte, as linhas não têm funções específicas, por isso podem servir para construir rostos, sombras, fundos etc. Mais ainda, a linha, diferentemente de muitas gravuras de reprodução, na maior parte da produção de Oswald não tem a função de contorno, uma vez que os diferentes objetos são elaborados pelo encontro de incisões variadas, arranjadas em múltiplas combinações. Esse tipo de resolução da forma pode ser bem observado nos retratos que o artista grava sobre o metal ao longo de sua carreira.

\subsection{Retratos}

Entre 1914 e 1915, Oswald grava os retratos dos compositores Richard Wagner e Carlos Gomes, este último, vulto da ópera brasileira, é água-forte que representa a cabeça do compositor de perfil. Desta obra, o acervo da Fundação Biblioteca Nacional possui dois exemplares, ambos integrados à instituição em 1916, sendo que, embora as duas impressões tenham o monograma do artista gravado, em uma delas também há a assinatura de Oswald, à lápis, fora da mancha, assim como a data "1915" (Fig. 73.A). As duas provas de C. Gomes não são impressas da mesma maneira: a datada (Fig. 73.A) é impressão mais escura do que a outra e tem uma veladura sobre toda a superfície; na gravura não datada (Fig. 73.B), a veladura, quase imperceptível, acentua o movimento do cabelo. Nesta impressão ocorrem áreas mais claras que na anterior, evidenciando as incisões que elaboram as formas.

A diferença das duas impressões evidencia que o resultado da obra depende, manifestamente, do modo como o artista deseja realizar a limpeza da matriz. Essa afirmação é possível visto que o próprio Oswald escreve que há muitas maneiras de trabalhar a tinta na placa, as quais possibilitam impressões de efeitos diversos:

É que há mil modos para dispor a tinta sobre o metal e uma mesma chapa pode dar dezenas de efeitos diferentes, conforme o impressor dispuser as leves camadas de 
tinta. Tirando-a completamente nos lugares que deseja apareçam brancos, deixandoos, com grande arte e elegância, em outros lugares para envolver o entrelaçado dos traços, afim de obter leves tons de "lavis" (ligeiras sombras), ou intensos planos de preto fechado. ${ }^{217}$

É o que se vê em várias de suas obras, como nas duas impressões de Carlos Gomes, cujos diferentes resultados provêm dos modos distintos de limpar a matriz.

Em ambas as gravuras, a representação de Gomes é terminada por uma linha horizontal, traçada de uma margem à outra da mancha, que rompe a figuração, do próprio compositor, para iniciar outra, da inscrição de seu nome, hiperbolizando, com isso, a personalidade apresentada. A obra é, em parte, elaborada por linhas cruzadas que definem volumes e formas, principalmente nas áreas de sombra, embora, por vezes, esse recurso também seja utilizado em zonas mais claras. A variação de cinzas na impressão é obtida, tecnicamente, pelo cruzamento das hachuras, por vezes feitas por linhas bastante próximas, como nas áreas escuras, por vezes a partir de linhas mais separadas. A variação da profundidade dos traços, que permite a impressão de tons de cinzas diversos, é resultado dos banhos de ácido, banhos estes com tempos distintos, sendo que os de maior duração possibilitam a impressão das linhas mais escuras.

Há na obra incisões curtas e descontínuas, sem cruzamento, que constroem áreas claras, mas as áreas totalmente iluminadas são aquelas onde não há gravações. Linhas curvas conferem forma e movimento ao cabelo e ao bigode da figura, estas, como as demais linhas, são gravadas em traços dispostos com variações de distâncias. Relativamente ao cabelo, esse movimento é intensificado pelo cruzamento das linhas na parte inferior dele.

Uma linha ziguezagueante emerge do fundo da composição no canto inferior direito e segue para a lateral esquerda do observador, conduzindo o olhar do observador para o primeiro plano, ao mesmo tempo que funde o fundo à figura. A fusão da figura com seu entorno também ocorre na lateral esquerda superior pelo prosseguimento de algumas linhas que ao construírem o entorno constroem os cabelos, promovendo, por isso, a dissolução dos limites da forma. Esse recurso ocorre em algumas áreas da obra, justamente porque as linhas são elementos quer do fundo, quer da figura, sem distinção.

A intersecção das linhas que constroem a figura com aquelas que compõem as sombras também ocorre em Richard Wagner (Fig. 63.A). Nesta água-forte, Wagner é representado de perfil e, bem como na imagem anterior, a figuração é terminada na linha que a separa do nome gravado. Nesta obra, o chapéu do artista alemão fusiona-se com a área que

${ }^{217}$ Carlos Oswald, op. cit., 1957, p. 304. 
o cerca, visto que as linhas cruzadas na extremidade da aba possuem gravação similar àquelas das linhas que compõem o fundo: apenas alguns trechos do objeto se diferenciam do espaço que o cerca, sugerindo, assim, a sua forma.

$\mathrm{O}$ acervo da Fundação Biblioteca Nacional possui, além de Richard Wagner (Fig. 63.A), o primeiro e o segundo estados dessa gravura. Estas provas auxiliam para a compreensão de como Oswald realiza essa obra e, como se verá, outras. No primeiro estado (Fig. 63.C), o perfil já está todo gravado na matriz: as diferentes incisões constroem as formas com os mesmos recursos de cruzamento das linhas e variação das mordeduras do ácido, como referido em Carlos Gomes. São evidentes neste estado as linhas em ziguezagues que começam a compor a área ao redor da figura ao mesmo tempo que elaboram a parte inferior direita e esquerda. No estado subsequente (Fig. 63.D), parte das linhas em ziguezagues, na extremidade direita do observador, é coberta por linhas que cruzam as anteriores, local que é trabalhado posteriormente, como evidencia a prova seguinte, justamente para que a impressão da tinta seja mais densa que as demais. O mesmo ocorre na lateral esquerda. Estas áreas sobrepostas evidenciam as camadas da composição e favorecem o efeito de fusão da figura com o fundo.

Destaca-se que a representação da cabeça de Wagner já está resolvida desde o primeiro estado da obra, por isso, pode-se dizer, que nas provas posteriores, Oswald intensifica o contraste de claro-escuro e integra a figura com a área que a cerca. Nesse processo, até partes do rosto de Wagner são escurecidas, sugerindo a fusão de parte da pálpebra e da testa com o chapéu. Tal escolha do artista demonstra que mais importante do que enfatizar a fisionomia do retratado, é construir na obra uma atmosfera densa, a qual é caracterizada pelas áreas escuras em oposição às claras.

$\mathrm{Na}$ obra final de Richard Wagner, as luzes são fundamentais para acentuar o movimento sugerido pelas linhas que formam o cabelo e a enorme costeleta que segue até o pescoço. Luzes estas, assim como a gola da camisa, que dramatizam a composição.

As resoluções observadas nestas obras, Carlos Gomes e Richard Wagner, de 1914 e 1915, também podem ser encontradas em retratos realizados por Oswald em anos posteriores, tais como o do compositor Jean-Philippe Rameau. Esses tipos, consagrados pela história, devem trazer os caracteres que os distingam: em Gomes, cabelo, bigode e maxilar protuberante; em Wagner, nariz avantajado e costeletas destacadas.

Em Rameau (Fig. 80.A), obra de 1919, os caracteres que identificam o músico são os cabelos em cachos, gravados por incisões curvas e delgadas que destacam as mechas em rolos ritmicamente dispostos; a cabeça inclinada e o foco de luz que nela incide revelam a forma 
oval e alongada do rosto, bem como o nariz fino que caracterizam o músico francês. $\mathrm{O}$ contraste de claro e escuro na imagem enfatiza os caracteres destacados da personalidade.

Em Gomes, Wagner, Rameau e outros entende-se que Oswald não busca reproduzir a fisionomia dos compositores, mas seus tipos, como se destacou, e, em geral, pode-se dizer que o artista privilegia nas obras a construção de contrastes obtidos pela alternância do claro e do escuro e o destaque para aspectos da figura que a distinguem. Esses caracteres figurados são comuns às representações desses compositores em pinturas e esculturas realizadas por diversos artistas. Rameau, por exemplo, tem necessariamente, nas várias obras que o retratam, cabelos em cachos e nariz fino ${ }^{218}$.

Outros tipos gravados por Carlos Oswald indicam que o artista segue essa mesma direção, no sentido de destacar caracteres. Também é de se considerar que Oswald serve-se de soluções técnicas que se assemelham para construir a personagem e o seu entorno.

$\mathrm{Na}$ água-forte Beethoven (Fig. 78.B), de 1919, as pouquíssimas incisões que desenham o cabelo na parte superior promovem a fusão dele com o seu entorno, diferentemente das três gravuras anteriores, nas quais a fusão é obtida pela intersecção de linhas. Nesta obra do pianista de Bonn, o rosto é representado de três quartos e prevalece na imagem o espaço em branco do papel, que é parte da composição, assim como em Leonardo (Fig. 127.A), de 1935, gravura na qual o vulto do artista florentino assoma do vazio da mancha. Os limites que eventualmente poderiam ser feitos por linhas, não o são, daí a sugestão de que a figura emerge do papel: o alto da cabeça e a barba não são delimitados por linhas; a área em torno da figura não tem hachuras, sendo a sombra do lado direito do observador realizada por poucas linhas cruzadas. Oswald constrói com as mesmas incisões, nítidas e limpas, as partes do rosto, cabelos, sombras e entorno.

No primeiro estado da água-forte Chopin (Fig. 79.B), de 1919, embora a figura também assome do fundo, a composição, pelo contrário, é elaborada por muitas incisões. Diferente da maior parte das obras que se conhece, nesta há alteração da figura representada entre o primeiro estado e a obra. Na prova primeira, o rosto tem formas que divergem das encontradas na outra. Nesta última (Fig. 79.A) vê-se as modificações na boca, no queixo, no pescoço, na pálpebra e até mesmo na maça do rosto, que se torna mais arredondada, se comparada com a anterior. Além disso, no primeiro estado da água-forte (Fig. 79.B) há ausência total de linhas de contorno, enquanto no estado definitivo (Fig. 79.A), parte do

\footnotetext{
${ }^{218}$ A figura de Rameau pintada na segunda metade do século XVIII e atribuída à Jacques-André Aved, por exemplo, possui os mesmos caracteres representados na gravura de Oswald. Cf. Collections du Musée des Beaux-arts de Dijon, Portrait présumé de Jean-Philippe Rameau, disponível em: http://mbacollections.dijon.fr/ow4/mba/voir.xsp?id=00101-451\&qid=sdx_q0\&n=2\&e=. Acesso em 12/09/2017.
} 
pescoço ganha contorno. Este destaca a cabeça do fundo, ao mesmo tempo que faz com que ela provenha dele, mesmo porque toda a composição é trabalhada para isso. Na obra pertencente à coleção do Museu Nacional de Belas Artes (Fig. 79.A) até a área destinada ao nome do compositor contribui para que a figura erga-se da mancha, uma vez que todo o entorno dela e a área onde é gravada a escritura recebem o mesmo tratamento. Também contribui para a unidade observada na obra, a maneira como a matriz é limpa, em círculo, o que acentua o movimento construído pelas incisões.

A integração da figura com a mancha impressa é vista também em uma das últimas obras de Carlos Oswald, seu Autorretrato (Fig. 175.A), gravado em 1964. Conhece-se desta obra somente impressões póstumas, de 1978, talvez realizadas pelo gravador Orlando da Silva. Em 1969, Silva ${ }^{219}$ realiza catalogação das gravuras de Oswald, na qual esse autorretrato é listado por ele, dramaticamente, como sendo a última obra do artista; além disso, Silva afirma que esse trabalho é realizado especialmente para a editora Gravura de Arte (GAE). Sabe-se que na década de 1960, Oswald, já parcialmente cego, risca algumas matrizes para o álbum que é lançado pela GAE, o qual é formado por cinco de suas obras ${ }^{220}$; seu retrato, todavia, não consta dessa publicação.

Oswald representa a si mesmo de óculos com uma das lentes escura e a cabeça reclinada em três quatros. Não há linhas de contorno e o mesmo tratamento que é dado às linhas que elaboram, simultaneamente, as formas e as sombras do rosto, é presente também no entorno da figuração: as incisões são largas e aprofundadas, resultando, na impressão, linhas escuras e espessas. Não parece haver diferença na gravação das linhas, visto que na impressão não há gradação de tons, sendo possível que a matriz tenha passado por poucos banhos de ácido. Apesar de não se observar nessa imagem a variedade de cinzas presentes em outras obras do artista, entende-se que o modo que ele utilizou para compor este trabalho é semelhante aos demais, como a intersecção das partes da composição, as linhas ziguezagueantes etc.

A construção da forma pela variação das linhas justapostas e cruzadas não é, todavia, o único recurso plástico encontrado nos tipos e retratos de Oswald, uma vez que em Autorretrato (Fig. 125.E) de 1935, por exemplo, é justamente a linha de contorno que constrói

\footnotetext{
${ }^{219}$ Orlando da Silva, Carlos Oswald o gravador - Catálogo “raisonné”, Rio de Janeiro, Gravura de Arte Editora, 1969.

${ }^{220}$ O álbum Carlos Oswald cinco gravuras originais, realizado em 1964, reúne as gravuras Bois a noite (1910), Trecho de Procissão (1955), Paisagem com palmeiras (1964), Dia chuvoso em Petrópolis (1964) e Ponte no Bingen (1964). Ele foi publicado pela Gravura de Arte Editora em 1964 e impresso por Orlando da Silva. Um exemplar da publicação, do total de uma tiragem cem cópias, pertence ao acervo da Fundação Biblioteca Nacional.
} 
o perfil do artista. Esta linha, que a princípio poderia ser pensada como divisória entre a figura e o fundo, ao analisá-la, vê-se que ela é somente linha, por isso acentuada por banho: as soluções que resolvem o fundo são as mesmas utilizadas para o rosto. $\mathrm{Na}$ impressão, identificada como primeiro estado, por alguém que não o $\operatorname{artista}^{221}$, evidencia-se que o recurso de intersecção entre o rosto e o fundo é realizado pelo gravador de modo diverso dos anteriormente aqui destacados.

Insiste-se em destacar os modos como Carlos Oswald trabalha justamente para chamar atenção do espectador de que o artista, por trabalhar a composição, distancia-se de obras que distinguem a figura e o fundo. É esse pensamento plástico, que relaciona as partes entre si, indispensável, como o próprio artista destaca em diferentes pontos de seu livros: as luzes de uma obra, a relação dos objetos que compõem uma obra, os valores etc. Os "fatores", como escreve, de uma composição, pintura, gravura etc.

Do Autorretrato de 1935 conhece-se, ainda, outra impressão, assinada pelo artista, na qual, áreas escuras colocadas em partes específicas da cabeça promovem a construção do volume nesse trecho da figuração (Fig. 125.A). Embora a impressão da gravura anteriormente referida (Fig. 125.E) possa ser entendida como um primeiro estado, pois assim assinalada na margem do papel, como se afirmou, é marcação de alguém que não o artista. Afirmação que se sustenta por duas razões simples: a primeira, é que não se trata da letra de Carlos Oswald; a segunda, é que a impressão aqui identificada sob o número "125.E” tem a linha de contorno do perfil mais acentuada do que a outra impressão. Essa linha vista na obra 125 é gravada por novo banho que a aprofunda, sendo o inverso impossível. Assim sendo, o retrato do artista assinado no papel (Fig. 125.A) é impressão anterior àquela em que há menos volumes evidenciados (Fig. 125.E).

É certo que não se localizam impressões das gravuras de Oswald com título e assinatura do artista gravados a fim de determinar as obras tidas como finais, posteriores àquelas "avant la lettre" 222 , mas isso não é necessitante em sua produção, visto que, por vezes, após terminar uma gravação e uma impressão, ele a retoma. Esse é o caso da gravura que retrata Franz Liszt. O compositor húngaro é figurado em duas obras, ambas com o monograma do artista e a data "1915" gravados na lateral direita da mancha. Franz List (Fig.

\footnotetext{
${ }^{221}$ A obra possui anotação manuscrita, no canto inferior direito do papel, "1 $1^{\circ}$ estado". Contudo, a caligrafia é distinta das demais anotações encontradas em outras provas de estado e de impressão do acervo, as quais entende-se serem feitas pelo artista. Assim, é provável que a impressão seja inferida como um primeiro estado. 222 “Essas provas são conhecidas com o termo 'avant la lettre', pois os antigos água-fortistas franceses, depois de terminar completamente uma chapa, costumavam gravar, na margem inferior dela, o título, o nome do gravador, etc. Só então a chapa estava pronta para a edição." Carlos Oswald, "Água-forte", Vozes de Petrópolis, Petrópolis, maio jun. 1945, p. 303.
} 
74), assim grafado, ingressa no acervo da Fundação Biblioteca Nacional em 1916. Nesta obra, grande parte da mancha é ocupada pela figuração do cabelo, o qual é construído por poucas linhas curvas. Estas, dispostas esparsamente e em ritmos alternados, têm seu movimento acelerado pelas luzes sugeridas na composição. Ao pé do cabelo, note-se, é principalmente a tonalidade cinza que, ao mesmo tempo que o sugere o apaga, tornando-o uma massa informe: massa e cabelo, por assim dizer, fusionam-se.

Na outra versão dessa obra ${ }^{223}$, feita a partir da mesma placa, há modificações gravadas que devem ser destacadas. Embora, como dito, Oswald retome algumas matrizes após a assinatura, nesta gravura de Franz Liszt (Fig. 75) a retomada, supõe-se, tenha sido feita para atender encomenda. Hipótese plausível considerando-se que as modificações evidenciam soluções que tornam o tipo mais adequado ao gosto de compradores de retratos-tipo. Nesta obra, a limpeza da matriz com o palmo ou os panos, apesar de ainda destacar áreas mais claras na composição, não contribui de maneira tão intensa para evidenciar o movimento das mechas como na outra, a Fig. 74. Mesmo se tratando de obra adequada, na Fig. 75, como na anterior, os caracteres que identificam o compositor estão presentes: linhas de expressão, nariz adunco, boca com o canto caído, o que dá seriedade ao tipo, e, evidentemente, as verrugas de Liszt.

Enquanto na primeira obra Oswald privilegia composição que ressalta os contrastes de claro e escuro e o movimento dos cabelos da figura, na segunda, ele a resolve acrescentando mais linhas para delinearem os fios, adiciona a vestimenta e, na impressão, clareia o rosto tornando-o mais óbvio. Obra, por assim dizer, mais vendável, visto que tipo figurado conforme gosto corrente, sem extravagâncias. A hipótese que se levanta deve-se, em parte, a uma carta datada de 1955, na qual seu ex-aluno Hans Steiner refere o retoque de "traços cansados" que faz na matriz dessa obra para imprimi-la. Ora, traços cansados, como se sabe, são rebaixamentos decorrentes das várias impressões ${ }^{224}$.

\footnotetext{
${ }^{223}$ A obra pertence à coleção do MNBA e, de acordo com a catalogação do museu, ela foi adquirida em 1963, proveniente diretamente do artista, assim como a maior parte das gravuras de Carlos Oswald pertencentes a essa coleção. A data da aquisição é posterior, portanto, a da obra Franz List do acervo da Fundação Biblioteca Nacional.

${ }^{224}$ A gravura que retrata Franz Liszt é referida em correspondência entre Hans Steiner e Carlos Oswald, datada de 20 de abril de 1955. Neste documento, Steiner afirma que imprimiu uma prova da gravura e não "resistiu" à vontade de retocar "umas partes do fundo falhadas na mo[r]sura e avivar alguns traços cansados na parte extrema do queixo [...] mais algumas linhas no baixo do nariz". Steiner afirma, porém, que na "chapa não houve alteração nenhuma, apenas algumas reformas que estão perfeitamente na compreensão de quem [a] executou". A carta evidencia um trabalho de restauro da placa já gasta, o que pode indicar ou contínua tiragem ou retomada da matriz para nova tiragem em ano posterior. Hans Steiner, Carta para Carlos Oswald, datada "Teresópolis, 20 abr. 1955". Arquivo Histórico do Museu Nacional de Belas Artes/Ibram/MinC, Rio de Janeiro.
} 
Nestas duas obras de Liszt há recursos plásticos que se encontram em outras gravuras já analisadas e, a indicada sob o número 75, assemelha-se, por exemplo, ao retrato de $H$. Oswald, o qual também tem parte da vestimenta representada mais definida do que nas demais gravuras consideradas.

H. Oswald (Fig. 114.A), de 1933, é obra adquirida no mesmo ano pelo Instituto de Educação para integrar a galeria de compositores brasileiros desse estabelecimento de ensino $^{225}$. Talvez, como se supõe acerca da gravura de Liszt, trabalho feito por encomenda. Nesta obra, diferente das demais, o retrato de seu pai é construído por água-tinta e água-forte; no entanto, há recursos como os das linhas ziguezagueantes que elaboram tanto o ombro, quanto o espaço que o cerca, que são encontradas em outras gravuras anteriormente analisadas. Os focos de luzes no rosto do pianista destacam algumas das características do retratado, tal como se vê em fotografias dele: a cabeça calva com a testa larga, o nariz alongado, o bigode e a barba desalinhados devido aos fios brancos. Os olhos de Henrique Oswald, embora na sombra, salientados apenas por pequenos brancos, sugerem olhar distante, típico de artistas, intelectuais etc. Estas mesmas características estão presentes em outra gravura que Carlos Oswald retrata o músico, seu pai.

Na obra de 1914, vê-se igualmente o olhar vago de Henrique Oswald (Fig. 64.A) cuja expressão, tanto nesta quanto na obra de 1933, sugere introspecção, caráter importante para a distinção do tipo como artista que se preocupa profundamente com sua obra e não com as questões prosaicas do cotidiano ${ }^{226}$. Na impressão de 1914 chama a atenção o fato de a figura estar representada até pouco abaixo da linha da cintura; as suas formas feitas por hachuras e não por contornos, evanescem no sentido vertical, dando destaque para o rosto. Não é por essa

\footnotetext{
${ }^{225}$ Carlos Oswald na catalogação parcial de suas obras, anexa à sua autobiografia (1957), lista a gravura $\mathrm{H}$. Oswald como realizada em 1933. No mesmo ano, o artista afirma que realiza outros retratos de músicos, sem, entretanto, mencionar que se trata de encomendas. Carlos Oswald, op. cit., 1957, p. 224. Periódico carioca noticia que em novembro de 1933 é inaugurada a "Sala de Músicos" do Instituto de Educação, com galeria de retratos de compositores brasileiros já falecidos em água-forte, todas elas de Oswald. A nota cita os seguintes retratos: Pe. José Maurício, Francisco Manoel, Alexandre Levy, Carlos Gomes, Leopoldo Miguez, Alberto Nepomuceno, Glauco Velasquez, Luciano Gallet e H. Oswald. Cf. "A inauguração da galeria de compositores brasileiros já falecidos no Instituto de Educação", Correio da Manhã, Rio de Janeiro, 25 nov. 1933.

${ }^{226}$ Alguns pontos da breve biografia que Carlos Oswald publica sobre Henrique, em 1945, destacam o caráter do artista e de sua obra: "As características da arte de Henrique Oswald são a genialidade dos pensamentos sempre elegantes e com atitudes originais, a variedade da harmonia e a clareza que não fraqueia nem nos enredos mais complicados das partes, o perfeito equilíbrio entre os diversos instrumentos. A grande ideia nunca fica sacrificada aos efeitos superficiais e de mera virtuosidade. Sua música eleva a um plano superior exprimindo uma serenidade doce que somente aqui e ali é interrompida por uns gemidos nostálgicos". Em outro trecho desse artigo, Oswald escreve: "Henrique Oswald, verdadeiro temperamento de artista e além disso muito nervoso e impressionável, não era tipo para governar um estabelecimento como o Instituto Musical [...] Henrique Oswald que vivia e 'pensava musicalmente', que era a negação do 'homem prático', não podia se sentir bem num lugar onde tudo dependia da responsabilidade do diretor." Carlos Oswald, "Artistas Cristãos: II) Henrique Oswald e seu filho Alfredo", Vozes de Petrópolis, Petrópolis, jan. fev. 1945, p. 67 e p. 71.
} 
razão que o tratamento do terço inferior da mancha deva ser desconsiderado: as linhas que elaboram os dedos do pianista são prolongadas de modo a construir o entorno da figura.

Essa ideia de introspecção que pode ser observada em Henrique Oswald, artista cristão, como escreve seu filho ${ }^{227}$, também é encontrada em Pe. José Maurício (Fig. 121.A), embora de modo distinto. No retrato do brasileiro nascido no século XVIII, a noção de introspecção é sugerida pelos olhos cerrados do compositor, também padre, e talvez possa ser entendida como modo de sugerir a veneração e a fé, próprias dos religiosos. O caráter religioso do autor de diversas músicas sacras é ainda identificado pelo colarinho que se vê, o qual sugere ser de uma batina. Nesta gravura, resolvida por água-tinta e água-forte, a área gravada pelos pontos completa o trabalho feito pelas linhas, visto que a sobreposição dos dois processos de gravação resulta, na impressão, em zonas cinzas e escuras. A água-tinta ressalta na obra os contrastes de claro e escuro construído também pelas linhas.

Diferente dessa solução de água-tinta, são as resoluções encontradas nas obras Alexandre Levy (Fig. 120.A) e Glauco Velasquez (Fig. 119.A), ambas de 1933. Nestas, linhas de contorno delgadas delimitam o espaço que é preenchido pela área gravada com a águatinta; alguns traços são usados apenas para evidenciar o movimento dos fios de cabelo das figuras ou para reforçar poucas sombras. Nestas duas gravuras, Oswald evidencia aspectos dos retratados - em Velasquez, os bigodes, as sobrancelhas e os cabelos escuros, bem como a gravata borboleta e o paletó; em Levy, os bigodes, o rosto pontudo e a rosa na lapela do paletó - que também aparecem em fotografias dos compositores. Assim, esses trabalhos parecem partir de uma motivação diversa, no caso, as fotografias que consagraram esses artistas.

De modo semelhante, as obras Francisco Braga (Fig. 117.A), Francisco Manoel (Fig. 118.A) e Alberto Nepomuceno (Fig. 115), de 1933, também parecem evidenciar caracteres que são vistos em fotografias ou em outras representações dos compositores. As três gravuras apresentam, ainda, semelhanças no modo como são executadas: os bustos são construídos inteiramente pela água-tinta, a qual estabelece as formas, as sombras e os fundos. Nestas obras, a água-tinta não mais preenche forma delimitada por linha ou auxilia a água-forte na construção dos claros-escuros, ela, como em um desenho em aguada, confecciona a composição pela sobreposição e encontro de áreas gravadas por mordeduras do ácido com durações maiores ou menores. Assim, da mesma maneira que Oswald aproveita as variações que são próprias da água-forte para elaborar suas obras, ele também utiliza aquelas próprias

\footnotetext{
${ }^{227}$ No mesmo artigo da revista Vozes, posteriormente reproduzido como anexo no livro de Oswald de 1957, o autor enfatiza o caráter cristão de seu pai. Idem.
} 
da água-tinta, ou seja, a possibilidade de elaborar a composição pela gravação de áreas com profundidades distintas, que na impressão, resultam em tons variados ${ }^{228}$.

A água-tinta, para Oswald, serve também para construir a cor. A relação da água-tinta com a cor, todavia, não é necessitante, mas possível, visto que há gravuras do artista feitas com ela e impressas em preto ou em uma só cor. Sendo Oswald o próprio impressor da maior parte de suas gravuras, o artista, ao imprimir obras com matizes distintos, não está "testando" cores para obter prova final, mas produzindo obras diferentes, como entende-se que as gravuras Alberto Nepomuceno o são: a pertencente ao acervo da FBN (Fig. 115) é impressa em marrom e a obra que é parte da coleção do MNBA, em cores. Ambas são exemplares finais, assinadas pelo artista, sem nenhuma marcação manuscrita que as identifiquem como "provas de impressão". O que se pretende dizer é que Oswald faz pesquisas plásticas inclusive em relação às cores e suas relações. Impressões de diferentes cores em Oswald não significam necessariamente provas de estados, experimentações para se chegar a uma obra final. Em sua produção, como já se procurou distinguir, encontram-se obras finais impressas em preto e branco assim como em cores.

Assim entendendo-se a pesquisa plástica de Oswald, destaque-se que isso pode ocorrer inclusive em retratos que são possíveis encomendas, como os destinados à galeria de músicos brasileiros do Instituto de Educação. Embora esses trabalhos de 1933 mantenham algumas das resoluções encontráveis em outras composições de retratos, estes não apresentam a fusão acentuada da figura com o fundo ou a personagem que assoma da mancha, como ocorre nos vultos de Richard Wagner (Fig. 63.A), Leonardo (Fig. 127.A) e Beethoven (Fig. 78.B). Quanto à disposição da luz, apesar de Oswald conservar focos de luz diversos nos retratos de 1933, ele prioriza o destaque no rosto, evidenciando a fisionomia dessas duas últimas personalidades. O mesmo não acontece em uma gravura como a de Franz List (Fig. 74), aquela do acervo da Fundação Biblioteca Nacional, uma vez que o que é evidenciado pela luz é o movimento dos cabelos da figura ou em Richard Wagner (Fig. 63.A), na qual algumas áreas do perfil do compositor estão escurecidas.

Oswald enumera três modos distintos de se produzir retratos, para encomendas ou não. O primeiro modo é executar a figura a partir de uma única fotografia do modelo; o segundo, maneira já mais adequada à arte, é o artista ter à sua disposição várias fotografias e observar a pessoa, mesmo que de maneira rápida e fortuita; o terceiro é estudar aquele a quem se retrata

\footnotetext{
${ }^{228}$ Sobre o processo da água-tinta, Carlos Oswald escreve que ele promove a gravação de "superfície de pontinhos minúsculos que ao olhar dará a impressão de um tom igual, cheio. Por meio de pinceladas de asfalto o artista obterá as graduações que deseja, como na água-forte". Carlos Oswald, “Água-forte”, Vozes de Petrópolis, Petrópolis, maio jun. 1945, p. 303.
} 
do natural em diversas poses e várias vezes. Esses modos de execução são diferentes, segundo Oswald, sendo aquele que é feito a partir de uma fotografia considerado cópia, portanto, sem valor artístico. Entretanto, mesmo julgando que o melhor modo de se realizar um retrato seja pelo estudo aprofundado do modelo, Oswald afirma que algumas vezes não trabalhou com essas condições, já que, nem sempre, foi possível se orientar pelas proposições artísticas ideais $^{229}$.

Entende-se, a partir dessas colocações de Oswald, que seu objetivo artístico é a síntese, como na paisagem, que depende de observações diversas, ou, pode-se dizer, de observações que se modificam, necessárias justamente para que o artista faça uma síntese do objeto que representará, não uma cópia. As várias poses de um modelo são necessárias não para copiar as suas partes, mas para apreender as relações entre elas, das formas, das luzes, das sombras, visto que elas não são dadas por doutrinas. Para Oswald, a cópia não é arte; por conseguinte, gravar um retrato a partir de uma única imagem não permite ao artista chegar a uma obra que possa "transmitir" ou "comunicar" ao público o "caráter" de quem se retrata. Este sim é o objetivo de Oswald para as suas gravuras que representam pessoas.

$\mathrm{O}$ artista não pretende com suas obras fixar a personalidade particular do indivíduo, mas sim compor com linhas e pontos os caracteres do retratado, evidenciando o que o identifica. Ainda mais, Oswald afirma que nas obras dos compositores, pretende representar "plasticamente a característica [das] composições musicais" 230 e assevera em "muitos outros vultos [procura] desenhar dando mais atenção ao complexo de suas obras do que a seu caráter físico" ${ }^{231}$.

Por esse motivo, ao escrever sobre a gravura Carlos Gomes, por exemplo, Oswald afirma que deseja representar nela o caráter leonino do compositor - bem exposto no vasto cabelo e no perfil assertivo da figura. Sobre Liszt, escreve que "revive" o compositor húngaro em "água-forte que pelos traços enérgicos, as asperezas de seu rosto (verrugas, rugas e outros acidentes que [acentua] de propósito), nos dão a impressão de suas movimentadas 'Rapsódias",232. Já a gravura que mostra Beethoven, o compositor é retratado com os olhos cerrados e a cabeça inclinada, justamente para evocar o "silêncio". Esse caráter também é explicitado em outra gravura, de mesmo título, de 1935 (Fig. 128.A), na qual vê-se o compositor junto de figura que leva o dedo à boca, cessação de ruído. Nessa composição, Oswald faz a alegoria do Silêncio para destacar a surdez do músico.

\footnotetext{
${ }^{229}$ Carlos Oswald, op. cit., 1957, p. 114.

${ }^{230}$ Idem, p. 111.

${ }^{231}$ Idem, p. 112.

${ }^{232}$ Idem, ibidem.
} 
O caráter é, como acima destacado, o que o Oswald julga ser fundamental nas obras que figuram pessoas, tanto que ele pode ser explicitado por alegoria, ainda que só se conheça esse recurso em Beethoven.

Considere-se que Oswald não grava apenas vultos das artes, na década de 1910, ele realiza, por exemplo, Sonho (Fig. 53.A), ponta $\operatorname{seca}^{233}$ de 1912 realizada na Itália ${ }^{234}$, que representa cabeça em escorço que ocupa toda a mancha impressa. Há nela variação nas hachuras que elaboram as formas, sendo a incisão gravada, como em outras obras do artista, elemento essencial da composição. Na obra, linhas escuras, em curvas e arabescos, servem de moldura ao rosto cinza; elas sugerem sustentar a cabeça ao mesmo tempo que a integram com o fundo. A figura parece, deste modo, imersa no emaranhado de linhas, também sugerindo, pelos olhos fechados, o devaneio próprio de quem se entrega ao sonho.

A intersecção das linhas da cabeça com o entorno é ainda mais intensa em Poeta (Fig. 54.A $)^{235}$. Nesta gravura de 1913 não é possível distinguir se os traços curvos, dispostos dinamicamente, que cercam o rosto e o pescoço, figuram o cabelo ou se eles fazem parte das linhas que estabelecem o espaço. Essas curvas funcionam como espécie de transição entre a cabeça bem delineada por finas incisões e a área da qual ela assoma, como se as partes do rosto surgissem da massa informe. Linhas inclinadas cobrem parte das curvas e avançam na metade inferior da obra, quase inteiramente ocupada por bloco que sugere os ombros e o colo da figura. É desse bloco que se eleva o pescoço inclinado que sustenta a cabeça e a projeta para frente. Ao redor do pescoço, hachuras dispostas em segmentos curvos sugerem a noção de um movimento circular ritmado. A solidez e estabilidade da figuração da cabeça e do pescoço contrastam com a movimentação agitada sugerida pelas linhas que os cercam.

No acervo da FBN encontram-se três impressões diferentes de Poeta $^{236}$, cada uma delas evidencia, como em Carlos Gomes, que o resultado da obra é dependente do modo

\footnotetext{
${ }^{233}$ Sobre a ponta seca, Oswald escreve que: “[...] os traços são executados por uma agulha ao invés do buril, e a tinta é presa mais pelas asperidades laterais ("rebarbas") produzidas pela agulha do que pela profundidade dos riscos. O claro-escuro da ponta seca é dos mais bonitos. O preto é aveludado, intenso e o traço pode começar finíssimo e acabar alargado, esbatido, quente". Carlos Oswald, “Água-forte”, Vozes de Petrópolis, Petrópolis, maio jun. 1945, p. 302.

${ }^{234}$ De acordo com o que se lê em anotação manuscrita na obra pertencente ao acervo da Fundação Biblioteca Nacional.

${ }^{235}$ Também de acordo com anotação manuscrita na obra, pertencente ao acervo da Fundação Biblioteca Nacional, ela foi realizada já no Rio de Janeiro em 1913.

${ }^{236}$ Uma das obras Poeta (Fig. 54.A) é adquirida pela Fundação Biblioteca Nacional em 1916, proveniente de compra realizada diretamente do artista; a segunda (Fig. 54.B) é registrada na nova catalogação do acervo da instituição em 1962, mas é parte da coleção antes dessa data; a terceira (Fig. 54.C) é, provavelmente, impressão póstuma, feita a partir da matriz de zinco que também pertence ao acervo. Apesar de ser desconhecida a data de registro na instituição dessa última obra, é possível que ela seja parte de conjunto de impressões realizadas na década de 1970, a partir das matrizes que integram o acervo da biblioteca em 1975 e 1976. Essas impressões póstumas estão reunidas tanto em pasta de obras do artista, quanto são usadas como "capas" para armazenar suas
} 
como o artista escolhe limpar a matriz. Assim, uma das impressões (Fig. 54.A) ressalta a nitidez das linhas que elaboram a figura e o fundo, totalmente integrados, revelando a variação de cinzas e pretos. Já na outra (Fig. 54.B), são os contrastes dramáticos do claroescuro que são acentuados. Em ambas as impressões da gravura, o artista utiliza a veladura, ainda que de modos distintos, para produzir uma atmosfera na composição. A terceira prova (Fig. 54.C) supõe-se ser impressão póstuma justamente devido ao modo como foi impressa: de modo geral, mais clara, sem os contrastes de claro escuro "violentos" e a riqueza de cinzas que são típicas das impressões de época.

As diversas impressões que se encontram das gravuras de Oswald demonstram que o artista não segue a convenção estabelecida em 1960 de que todas as cópias de uma mesma tiragem devem ser iguais ${ }^{237}$, mais do que isso, ele não considera que a obra final é resultado apenas das incisões e retículas gravadas, sendo o modo de limpeza da matriz importante para se obter efeitos diversos.

\subsection{Cenas com a figura humana: composições}

Os retratos e tipos de Carlos Oswald não são os únicos em que a figura humana é representada em destaque na obra do artista. Na década de 1910, no Rio de Janeiro, Oswald grava cenas, que denomina de "composições" ${ }^{238}$; nestas obras as figuras humanas são mostradas em conjunto com objetos. Gravuras estas que diferem de águas-fortes produzidas na Itália, nas quais figuras femininas são retratadas em atividades domésticas e íntimas, como em Mulher bordando (Fig. 8.A), de 1908, Toilette (Fig. 21.A) e En cousant (Fig. 20), estas duas de 1909. Enquanto nas "composições" de Oswald da primeira metade da década de 1910 os objetos são bastante trabalhados, assim como os corpos e os rostos, nas obras de 1908 e 1909, as mulheres são definidas a partir de poucas linhas, de modo bastante sintético.

\footnotetext{
respectivas matrizes. Relativamente à obra Poeta registrada em 1962 (Fig. 54.B), lê-se, no canto inferior direito do papel, anotação que sinaliza dúvida quanto ser essa obra primeiro estado da gravura. A caligrafia dessas palavras é distinta daquela encontrada em outras gravuras pertencentes a esse mesmo acervo. Estas provas possuem anotações, sem sinais de interrogação, que marcam os primeiros e segundos estados das obras, além de, por vezes, apresentarem indicações para a gravação e para a impressão. Supõe-se, por essa razão, que nessas gravuras lê-se a caligrafia do artista, diferente da encontrada na impressão de Poeta.

${ }_{237}$ Carlos Oswald realiza quase a totalidade de sua obra gravada antes do $3^{\circ}$ Congresso Internacional de Artistas de Vienna, em 1960, que convencionou o que é uma "gravura original" e estabeleceu as regras para a numeração das tiragens, provas de estado e provas de artista. Portanto, em suas obras, o artista não segue as convenções que são comuns na contemporaneidade e, mais do que não numerar e assinar suas provas de estado e cópias de tiragem segundo tais regras, o artista não considera que todas as obras impressas a partir de uma mesma matriz devem ser iguais.

${ }^{238}$ Carlos Oswald, op. cit., 1957, p. 44.
} 
Na água-forte O gravador Adalberto Mattos (Fig. 62.A), de 1914, o artista é representado em mesa de trabalho, no exercício de sua profissão, em conjunto com seus instrumentos, como buris, lupa, lima e espécie de torno ${ }^{239}$. Note-se que os objetos figurados são do gravador, mas daquele que trabalha com medalhas e pedras preciosas. Aliás, é essa a profissão de Adalberto Mattos, embora, como se sabe, ele realiza algumas águas-fortes ${ }^{240}$.

Nessa obra, embora possa se identificar Adalberto, Oswald procura evidenciar a profissão do gravador. Nesta gravura são utilizados diferentes recursos para a construção das formas, muitos já considerados em tipos e retratos analisados, como, por exemplo, a fusão do corpo com o espaço no qual ele se insere, como se observa na lateral direita dessa obra. Destaca-se a variedade de linhas que elaboram os objetos e o ateliê: traços com comprimentos e direções diversos, tanto dispostos paralelamente, quanto cruzados; linhas claras e escuras, finas e espessas. Ainda mais, a distância entre a gravação das linhas estabelece ora áreas densas e, na impressão, escuras, como aquela sob o braço do gravador, ora rarefeitas e iluminadas, como na lateral da caixa que guarda os buris.

Mattos é representado de perfil, olhando através da lupa, com as pálpebras baixas e a cabeça inclinada em direção ao trabalho. Assim como o rosto, as mãos e os braços de Mattos são destacados pela luz, esta, no entanto, não é distribuída pela composição a partir de um único ponto; como se vê, Oswald utiliza pontos de luz variados para evidenciar as figurações que são de importância: o gravador e seus instrumentos de trabalho.

Sem dúvida, o destaque para o instrumental importa no caso desta gravura, mas não é possível esquecer que quando Oswald escreve sobre a água-forte ele afirma que a gravura é processo realizado quase inteiramente pela mão, pouco influindo a máquina, no caso a prensa, que só participa no final do processo ${ }^{241}$. Essa argumentação no texto de Oswald é necessária, visto que o artista objetiva demonstrar a importância da gravura como arte e não como técnica, justamente o que a diferenciada dos processos de reprodução fotográficos, nos quais, como ele destaca, a máquina tem maior participação do que o homem.

Em Tocando Debussy ou Concerto (Fig. 65.A) o que se destaca, diferentemente da gravura anterior, não são as alegorias de uma profissão, nem mesmo a pessoa retratada,

\footnotetext{
${ }^{239} \mathrm{O}$ objeto representado sob as mãos do artista é um pequeno torno usado para segurar a peça sobre o a qual o gravador trabalha com o buril.

${ }^{240}$ Adalberto Mattos também realiza algumas águas-fortes, como visto, expostas na Primeira Exposição Carioca de Águas-fortes, em 1919, no Liceu de Artes e Ofícios, mas profissionalmente é gravador de medalhas e pedras preciosas.

${ }^{241}$ Oswald escreve sobre a água-forte: "Como se vê, só no fim é que intervém a máquina, máquina primitiva. Isso demonstra que a gravura à água-forte é processo completamente artístico. Tudo é executado pela mão do autor, tal qual, por exemplo, uma pintura à óleo, e só para a passagem da chapa para o papel é que se torna necessária a máquina”. Carlos Oswald, “Água-forte”, Vozes de Petrópolis, Petrópolis, maio jun. 1945, p. 304.
} 
Oswald afirma que nessa composição de "assunto musical", como em outras, sua intenção é “exprimir plasticamente" a música ${ }^{242}$. Certamente por isso vê-se na gravura apenas a moça ao piano com pássaro nele pousado. Os focos de luz destacam os braços da musicista e suas mãos, bem como as teclas do instrumento e a partitura.

O conjunto de provas de estado ${ }^{243}$ dessa gravura registra as gravações sucessivas na matriz. No primeiro estado da gravura (Fig. 65.C), na margem direita do papel, lê-se anotação manuscrita que refere as misturas do mordente e os tempos dos banhos de ácido para áreas específicas da imagem. O artista, como se lê em seu planejamento, mostra que as linhas abertas no verniz pela agulha são gravadas pelo ácido em etapas sucessivas. Sobre o processo da água-forte Oswald escreve em artigo:

Para obter as diversas graduações dos riscos, desde os mais leves até os mais fortes e escuros, o artista tira a chapa do ácido e cobre as partes que têm de ficar claras com uma camada de verniz de asfalto. Coloca a chapa de novo no ácido para aprofundar as outras partes, e repete o mesmo processo de cada vez até que seja alcançada a profundidade desejada. ${ }^{244}$

O texto de Oswald e as provas de estado de Tocando Debussy possibilitam a afirmação, já sugerida na análise da gravura Wagner, que, já no primeiro estado da gravação, as figurações, mesmo que em linhas gerais, já estão resolvidas; os estados sucessivos da obra servem ao gravador para abrir luzes, inscrever sombras, enfim, elementos compositivos que produzem o que chamamos de atmosfera.

Os estados da obra que sucedem a primeira prova (Fig. 65.D, 65.E, 65.F e 65.G) demonstram que o artista opta por tornar mais densas partes da gravura, tal como o fundo, no qual, gradualmente, as distâncias entre as linhas cruzadas diminuem, resultando, na impressão final, em zona escura na qual pequenos espaços não gravados entre as hachuras, pontos de luz, concentram-se, somente, sobre o piano. O instrumento musical também é escurecido ao longo desse processo. Os diferentes estados evidenciam não apenas os banhos de ácido sucessivos, como também o acréscimo de incisões na matriz. Estas tanto completam algumas figurações, quanto acentuam as sombras e áreas escuras. Novas linhas são usadas, ainda, para tornarem menos nítidas formas que eram visíveis no início do trabalho, como a do pássaro, o

\footnotetext{
${ }^{242}$ Mesmo referindo-se à pintura, a partir da qual a gravura é realizada, Oswald escreve que seu público "nunca comunicou ter dúvidas de que a melodia que a moça toca não seja do mestre moderno francês". Carlos Oswald, op. cit., 1957, p. 109.

${ }^{243} \mathrm{O}$ acervo da Fundação Biblioteca Nacional tem importante conjunto de impressões da gravura: a compra realizada pela instituição em 1916, diretamente do artista, incluiu além da obra que se supõe definitiva, impressa em marrom, cinco provas de estado que registram as sucessivas gravações realizadas sobre a matriz.

${ }^{244}$ Carlos Oswald, “Água-forte”, Vozes de Petrópolis, Petrópolis, maio jun. 1945, p. 302.
} 
qual pode ser visto em detalhes nas primeiras provas e, a partir do quarto estado da gravura (Fig. 65.F), é coberto por hachuras que, na impressão, o tornam uma massa cinza.

Assim, a partir das provas de Tocando Debussy, pode-se afirmar que a cada alteração o artista repensa a composição da obra, sabendo-se que para Oswald são as relações que interessam, como destacou-se. A busca pelo contraste intenso do claro-escuro, o destaque de certas partes da composição pela luz ou o inverso, tornam menos fortes formas que, em estados anteriores, eram nítidas e até mesmo claramente delineadas.

Anteriormente a esta obra, Oswald realiza pintura intitulada Tocando Debussy, a qual tem as mesmas formas representadas, ainda que inversas, da gravura. Esta, considere-se, não é reprodução gráfica de um original a óleo, como poder-se-ia supor, pois, como já se destacou, para Oswald isso não se coloca, mesmo porque ele pensa suas gravuras a partir de linhas e pontos e não a partir de pinceladas. Uma "variação", por assim dizer, da sua própria obra, como se evidencia em trecho de texto do artista no qual ele analisa as diferenças entre a pintura A ceia de Emaús (1648) de Rembrandt e a gravura do artista holandês que trata do mesmo assunto ${ }^{245}$ :

Sou pintor-gravador e quase sempre as minhas gravuras são tiradas de quadros meus, e assim pelo que sei operam quase todos os artistas-gravadores, pois consideram a gravura de arte como sendo um ramo das belas artes, e Rembrandt, por exemplo, não quis copiar seu quadro com o buril, mas executar um novo exemplar, "variante" do precedente a óleo, porém independente como composição e possuindo todos os requisitos de "bela arte original". Aliás é facílimo se persuadir do que escreve comparando os dois trabalhos. A água-forte apenas foi inspirada pelo quadro, mas não é dele cópia nem estudo. ${ }^{246}$

Portanto, é evidente que Oswald não considera que as suas gravuras, mesmo baseando-se em composições anteriormente pintadas, sejam cópias. As gravuras são obras que possuem resoluções distintas das telas a óleo, visto o respeito que o artista tem quanto ao que é específico de cada arte e, ainda mais, o apreço que ele tem pela arte dos metais, a mais espiritual das artes, por isso mesmo distante dos processos de reprodução. Considere-se

\footnotetext{
${ }^{245}$ Carlos Oswald realiza a sua análise a partir de reprodução da pintura de Rembrant, publicada em livro sobre o Museu do Louvre, de série de M. Armand Dayot, "Les grands Musées du Monde illustré en coleurs". A pintura a qual Oswald se refere é a $A$ Ceia de Emaús ou Os peregrinos de Emaús, pertencente à coleção do Louvre e datada de 1648. Cf. Rembrandt et la figure du Christ, Musée du Louvre, disponível em: < http://rembrandt.louvre.fr/fr/html/r13.html >, acesso em 2/09/2017. Já a gravura, é possível que Oswad refira a obra Cristo em Emaús, de 1654, que tem mesmo assunto da pintura, mas composição distinta dessa. Cf. Centro Cultural do Banco do Brasil, Rembrandt e a arte da gravura, Brasília, 2002, p. 68.

${ }^{246}$ Carlos Oswald, A "Ceia de Emaus" de Rembrandt, s/d. Documento datiloscrito pertencente ao Arquivo Histórico do Museu Nacional de Belas Artes/Ibram/MinC, Rio de Janeiro.
} 
também que mesmo nas pinturas, Oswald realiza versões com alterações das composições, de Tocando Debussy, por exemplo, existem, ao menos, duas obras diferentes ${ }^{247}$.

Mimma ou Brasileira vestida de japonesa (Fig. 56.A), 1914, também é obra na qual o artista serve-se da figura feminina para realizar a composição. Desta água-forte o acervo da FBN possui três provas de estado, além da obra final, a partir das quais se pode observar o escurecimento e o apagamento de parte da composição de modo mais intenso do que aquele observado em Tocando Debussy.

No primeiro estado da gravura (Fig. 56.C), como ocorre em outras provas de obras analisadas, todos os elementos da composição, objetos e figura, já estão gravados por incisões variadas. Vê-se, atrás do torso feminino, duas lanternas japonesas penduradas, além de fundo ornado com motivos florais. No segundo estado (Fig. 56.D), as ornamentações são menos perceptíveis, uma vez que são cobertas por linhas que cruzam aquelas gravadas anteriormente, resultando, na impressão, em área mais escura. Os contrastes de claro-escuro nesta prova, de modo geral, também são acentuados e as lanternas japonesas permanecem destacadas pela luz. No terceiro estado (Fig. 56.E) os motivos florais do fundo quase não são mais visíveis, visto que toda essa área da composição é coberta por outras incisões; as lanternas também são interseccionadas por linhas, tornando-se figurações menos destacadas do fundo. No estado final da gravura (Fig. 56.A) não é mais possível ver os arabescos e flores, nítidos no primeiro estado; além disso, os diversos objetos, tais como as lanternas e a poltrona têm seus contornos interseccionados pelas linhas das demais figurações, o que rebaixa as definições das formas vistas na primeira prova. O trabalho de acréscimo de linhas e as sequentes gravações da matriz não promovem apenas o escurecimento na impressão das figurações do entorno da modelo, visto que as formas do rosto e do torso também são gradualmente escurecidas. Essas

\footnotetext{
${ }^{247}$ Maria Amélia B. de Toledo Piza afirma que a pintura Tocando Debussy foi realizada por Oswald em 1910 , sendo retocada posteriormente, em data não explicitada pela autora. Ela afirma que a obra original possuía representação do pássaro apoiado no piano, o que não é visto na obra pertencente ao acervo do Liceu de Artes e Ofícios, dai concluir, que a pintura foi modificada. Maria A. B. T. Piza, A poética da luz na obra de Carlos Oswald, Bauru, 2004, p. 119. Duas reproduções dessa mesma pintura são conhecidas, uma na revista italiana Emporium, em maio de 1913 e outra na Illustração Brasileira, de outubro de 1925. A reprodução da revista Emporium é em preto e branco e, com dificuldade, é possível ver nela o pássaro apoiado no piano; destaca-se que essa obra contém assinatura do artista no canto inferior esquerdo da tela. A outra reprodução, na revista brasileira, é imagem em tricromia; nesta é possível ver com clareza o pássaro, mas a assinatura do artista está localizada no canto superior direito da tela. A revista informa que a obra reproduzida pertence ao acervo da Sociedade Propagadora de Belas Artes, como se sabe, mantenedora do Liceu. Cf. Giulio Caprin, "Arte contemporânea: Giovani ritrattisti toscani", Emporium, Bergamo, maio 1913, p. 368. Carlos Oswald, "Tocando Debussy", Illustração Brasileira, Rio de Janeiro, out. 1925. A essas informações, acrescenta-se o fato de que Carlos Oswald escreve na catalogação de suas obras que da tela Tocando Debussy, realizada em 1910, existe uma repetição "sem o periquito" que pertence, em 1957, ao autor. Sendo assim, é difícil precisar no conjunto da obra Oswald, e não apenas relativamente à sua gravura, quantas versões existem de cada composição ou ainda se o artista modifica uma mesma tela ou matriz para produzir obra distinta. Cf. Carlos Oswald, op. cit., 1957, p. 208.
} 
gravações realizadas promovem o volume da figura e destacam o quimono. A parte de baixo da mancha permanece, todavia, com poucas gravações, área de luz.

A comparação entre o primeiro estado da gravura com a obra final que se conhece, evidencia que as gravações sucessivas também constroem a profundidade na imagem. $\mathrm{Na}$ primeira prova, a composição é plana, sendo que todas as figurações parecem apenas sobrepostas. O acréscimo de incisões e os vários banhos de ácido, que aprofundam linhas, possibilitam obter uma impressão com variações de cinzas e pretos, que sugerem uma atmosfera à imagem, construindo a profundidade do espaço.

Oswald, ao escrever sobre as obras que realiza nos primeiros anos da década de 1910, registra a sua pesquisa como sendo a dos "efeitos de luz". Segundo o próprio artista, ele pinta tanto nus, quanto composições diversas com figuras femininas a fim de explorar os contrastes produzidos pela iluminação natural e a artificial, como a de lanternas e velas ${ }^{248}$. Apesar de o artista escrever sobre sua pesquisa pictórica, a partir da análise de suas gravuras, pode-se afirmar que também na água-forte ele explora tais efeitos; todavia, nessa arte, a pesquisa com a luz não é feita somente com a cor, mas também pela exploração dos brancos, cinzas e pretos obtida na impressão. Deste modo, em Mimma a representação da irmã transvestida em japonesa é um motivo para a pesquisa com os pontos de luz variados, que estabelecem espaços e atmosferas na imagem.

Brincando com a chama (Fig. 72.A), de 1915, é outra composição na qual Oswald pesquisa a luz provinda de fontes variados, mas, no caso desta gravura feita em água-forte e água-tinta a impressão é em cores. O artista afirma sobre esta gravura que, como outras, ela é realizada a partir de pintura de mesmo título, de 1913, a qual ele afirma ser "efeito de luz"249. A obra representa perfil feminino refletido em espelho; a figura estende a mão na direção do objeto que a ilumina - "uma vela acesa!" -, o qual não é figurado na composição, apenas sugerido: o que se vê na gravura é a projeção da luz tanto sobre os objetos representados, quanto sobre o braço, o colo e o rosto da figura. Esse não é, entretanto, o único ponto de luz da composição, visto que as costas e cabeça representadas também têm áreas claras, ainda que com menor intensidade.

Dessa gravura conhece-se além da obra final (Fig. 72.A), o primeiro estado (Fig. 72.E) e três exemplares que, de acordo com as anotações manuscritas, são provas de impressão das matrizes que formam a obra (Fig. 72.B, 72.C e 72.D). Apesar das matrizes não serem conhecidas, afirma-se, a partir das referidas provas e da catalogação do artista, que a gravura é

\footnotetext{
${ }^{248}$ Carlos Oswald, op. cit., 1957, p. 42.

${ }^{249}$ Idem, p. 210.
} 
resultado da impressão sobreposta de três placas. Estas, contudo, não são usadas por Oswald de modo a obter tricromias, pois, ao menos, nas obras que se conhece, o artista opta por usar somente as cores vermelha e azul, como na obra do acervo da FBN (Fig. 72.A).

A prova em que se lê a anotação de Oswald, "chapa claro escuro", (Fig. 72.B) é impressão da matriz com a gravação em água-forte e em ponta seca dos objetos e figuras representados. Não é possível identificar, entretanto, se essa mesma matriz também é gravada em água-tinta ou se a prova é resultado da sobreposição da impressão de todas as placas que compõem a gravura, entintadas em preto. Esta prova explicita a solução dada por Oswald para a representação das formas: as linhas, sem serem contornos, apenas pela variação dos cruzamentos e direções, estabelecem as formas como em outras obras do artista; as áreas gravadas pela água-tinta colaboram na disposição das luzes e das sombras.

A prova com a anotação manuscrita "chapa vermelha" (Fig. 72.D) é a impressão da matriz com área gravada em água-tinta sobreposta àquela que estabelece as hachuras gravadas. As linhas são impressas em preto, enquanto que a água-tinta é impressa em vermelho e amarelo. Nesta prova, Oswald, portanto, mistura duas cores em uma única matriz. Já a prova marcada como "chapa azul" (Fig. 72.C), parece ser impressão parcial de placa somente gravada pela água-tinta, impressa em azul. As provas marcadas como "chapa vermelha” (Fig. 72.D) e "chapa azul” (Fig. 72.C), evidenciam que a água-tinta além de servir para destacar as luzes e as sombras, é responsável pela cor que a imagem recebe. Tal resolução da composição é coerente com a afirmação de Carlos Oswald sobre o processo da água-tinta que, para o artista, permite a produção de uma gravura em cores, visto que ele escreve que a água-tinta faculta "executar provas coloridas de maior beleza"250.

Entretanto, considere-se que não são somente as áreas gravadas pela água-tinta as quais permitem a cor na obra, visto que as provas e o primeiro estado de Brincando com a chama (Fig. 72.E) são os únicos, dos exemplares conhecidos da gravura, nas quais as linhas são impressas em preto, pois nas obras "finais" também estas são entintadas em vermelho. O artista opta, assim, por solução que atenua os contrastes de claro-escuro construído por pretos, para evidenciar as relações entre os meios tons obtidos pela sobreposição do vermelho e do azul.

Oswald pesquisa nas diferentes provas de impressão, as relações de cor possíveis para a obra. Se em uma pintura seria necessário que o artista fizesse várias versões da tela para modificar seus aspectos quanto aos matizes empregados, o gravador tem à sua disposição

\footnotetext{
${ }^{250}$ Carlos Oswald, “Água-forte”, Vozes de Petrópolis, Petrópolis, maio jun. 1945, p. 303.
} 
matrizes e tintas variadas que lhe permitem explorar as relações tonais, sem ter de iniciar todo o processo novamente. Daí a importância das diferentes impressões para Oswald, obras que podem ser diversas.

\subsection{Gravuras sacras}

Carlos Oswald tem vasta produção em arte sacra, tanto como pintor, quanto como gravador. O artista afirma que inicia suas obras de assunto religioso por volta de 1915, com a decoração da "Sala dos Párocos" do Palácio São Joaquim, no Rio de Janeiro. Porém, ele também escreve que a encomenda não foi propriamente de "arte sacra", mas de "arte cívicoreligiosa" $^{251}$, uma vez que os murais representam a primeira missa no Rio de Janeiro e a Batalha das Canoas, assuntos, como de costume, escolhidos pelo diretor do Instituto Histórico e Geográfico Brasileiro. Ainda de acordo com Oswald, estas pinturas, por memorarem fatos notáveis, seguem a "verdade história", como ele escreve, composta segundo relatos e documentos que tratam do tema. Estas diferem da arte que é somente sacra, uma vez que a arte sacra, embora esteja a serviço da religião, não é exigente de rigor "histórico", por isso mesmo possibilita maior liberdade de invenção. Para o artista, a arte sacra deve inspirar a devoção dos fieis, mas os tipos nela representados não precisam portar vestimentas de época ou ter o desenho de suas fisionomias orientado pela etnia do personagem, nem as cenas precisam ser representadas figurando os supostos locais geográficos em que elas aconteceram $^{252}$. Ainda mais, como escreve Oswald em sua autobiografia, o artista, ao representar uma passagem bíblica, tem de necessariamente imaginar os detalhes da obra e “completar" a cena, visto que os textos das escrituras não são minuciosos nas suas descrições ${ }^{253}$.

No mesmo ano em que pinta os murais do Palácio São Joaquim, Oswald grava Cristo (Fig. 69.A $)^{254}$, ponta seca com cabeça masculina. Esta tem cabelos e barba longos que cercam e determinam a oval que forma o rosto; a testa larga, as sobrancelhas próximas aos olhos, uma

\footnotetext{
${ }^{251}$ Sobre os murais da Sala dos Párocos no Palácio São Joaquim, Oswald escreve que "Embora esses murais não sejam propriamente arte sacra, mas arte cívico-religiosa, eles representam o primeiro marco de minha série de pinturas sacras". Carlos Oswald, op. cit., 1957, p. 47.

252 "Numa obra de arte plástica cristã, nunca se deve procurar sua fidelidade histórica, nunca se ela deve [sic] considerar documento cronológico, nem pretender que sua composição, sua indumentária, e que os tipos raciais representados estejam de acordo com a realidade histórica nela representada. Nunca se deve pronunciar a palavra 'anacronismo', numa obra de arte cristã." Carlos Oswald, "Arte Cristã", Vozes de Petrópolis, Petrópolis, jan. fev. 1944, p. 76.

${ }^{253}$ Carlos Oswald, op. cit., 1957, p. 104.

${ }^{254}$ A obra pertencente ao acervo da FBN tem anotação manuscrita "1915/Rio", mas em sua catalogação Oswald afirma que a gravura é de 1914. Oswald, op. cit., 1957, p. 211.
} 
delas levemente arqueada, os olhos abertos - que deixam entrever quase toda a íris com ponto branco -, o nariz alongado e fino, a boca serrada coberta por bigode sugerem expressão severa à figura. A obra é impressa com veladura sobre toda a superfície, o que torna as linhas pouco nítidas e imprimem um tom geral cinza escuro, com exceção da testa e do nariz que são destacados por focos de luz.

Sabe-se da existência de outros dois exemplares desta gravura ${ }^{255}$ (Fig. 69.B e 69.C), que são impressos de modo distinto da obra descrita anteriormente. Estas impressões aparentam linhas mais nítidas e contraste mais acentuado que na impressão de número 69.A, efeito provavelmente obtido por limpeza mais acentuada da matriz com os "panos". Estas obras são intituladas de Cabeça de São João Batista. A alteração do título é feita pelo próprio artista que, na catalogação de suas obras, dá à gravura tanto o nome de Cristo, quanto de Iocahanann ${ }^{256}$, adaptação para o português de Yochanan ou Yohanan, nome do apóstolo João Baptista. Essa dupla intitulação não é arbitrária, uma vez que Carlos Oswald, católico fervoroso e conhecedor da liturgia cristã, defende em seus escritos na revista Vozes de Petrópolis, muitos dos quais dedicados ao tema da arte sacra, que a arte quando a serviço da religião, segue cânones estabelecidos pela liturgia cristã e tem como limitação os dogmas da Igreja, mas, representam tipos. Portanto, Oswald só é autorizado a afirmar que uma mesma representação é tanto um, quanto outro personagem bíblico, porque há aproximações e similitudes na construção dos dois tipos.

Segundo narram os livros do Evangelho, João Baptista é quem "prepara o caminho" para Jesus. Sua concepção é anunciada pelo anjo Gabriel a seu pai, como a de Jesus é anunciada pelo mesmo anjo à Maria. O nascimento do filho de Zacarias e Isabel - prima de Maria -, pouco antes do de Cristo, também é um milagre, pois Isabel, em idade avançada, não conseguia conceber antes da anunciação. Na vida adulta, João Baptista prega no deserto da Judéia, batizando aqueles que se convertem à fé cristã e se arrependem de seus pecados. É ele, inclusive, quem batiza Jesus ${ }^{257}$. As várias imagens de São João Baptista o representam

\footnotetext{
${ }^{255}$ Obras conhecidas por reprodução em catálogo. Cf. Paulo L. Vergolino, Carlos Oswald: o resgate de um mestre, Caixa Cultural Brasília, Curitiba, 2011, p. 60 - 61.

${ }^{256}$ Oswald, op. cit., 1957, p. 211.

${ }^{257}$ No Novo Testamento, nos livros do Evangelho, Lucas 7, versículo 24 a 29, consta que Jesus fala à multidão sobre João Baptista; em trecho da passagem, lê-se: "Um profeta? Sim, eu digo a vocês, é mais que profeta. Este é aquele a respeito de quem está escrito: 'Enviarei o meu mensageiro à tua frente; ele preparará o teu caminho diante de ti'”. No livro do Evangelho, João 1, versículo 23 a 27, lê-se diálogo entre João Baptista e seus discípulos: "João respondeu com as palavras do profeta Isaías: 'Eu sou a voz do que clama no deserto: 'Façam um caminho reto para o Senhor'. Alguns fariseus que tinham sido enviados interrogaram-no: 'Então, por que você batiza, se não é o Cristo, nem Elias, nem o Profeta?' respondeu João: 'Eu batizo com água, mas entre vocês está alguém que vocês não conhecem. Ele é aquele que vem depois de mim, e não sou digno de desamarrar as correias de suas sandálias"'. Ainda de acordo com diversas passagens dos livros do Evangelho, João vive no
} 
quando criança, com cajado e halo na cabeça, algumas vezes com a alegoria do carneiro ao lado; quando adulto, ele é figurado vestido em peles de animais e com cabelos compridos ou encaracolados, com cajado na mão, que pode estar envolto por alegoria da escritura sagrada, o carneiro também pode ser apresentado ao lado do apóstolo.

Deste modo, João Baptista, assim como Jesus, é representado por figura masculina com cabelos compridos. A tipologia das duas personagens é semelhante, tanto pelas aproximações entre suas histórias, quanto por ser João Baptista "precursor" de Cristo na tarefa de propagar a fé cristã. Como a representação de Oswald se reduz à cabeça da figura e nela não há alegoria que é conferida a somente um dos tipos, o que, evidentemente, impediria a dupla titulação, ela pode ser tanto um quanto o outro personagem bíblico.

A Visitação é gravura de Oswald do mesmo período que a anterior e representa duas cabeças de perfil. A obra tem outro título que explicita que ela simboliza os tipos de Maria e de Sta Isabel (Fig. 70.A) ${ }^{258}$, uma a mãe de Jesus e a outra de João Baptista. Elas, entretanto, não podem compartilhar uma única figuração, visto que são identificadas pela caracterização dos rostos, um mais jovem que o outro. Acrescenta-se que, nesse caso, os dois títulos da obra servem para indiciar a passagem bíblica a qual ela se refere.

No Evangelho, Lucas 1:23-80, é narrada a passagem da Anunciação. O anjo, depois de contar para Maria sobre a sua concepção, também fala sobre Isabel que, mesmo infértil, espera um filho, o qual receberá o nome de João. Depois da Anunciação, Maria visita Isabel e quando a virgem se aproxima de sua prima, a criança no ventre dela se mexe. A velha mulher, então, sente-se repleta pelo Espírito Santo, entoando um cântico à Maria. Essa é a passagem conhecida como a Visitação. A história é habitualmente representada nas imagens sacras pelo encontro de duas figuras femininas, sendo uma mais velha do que a outra, os corpos são representados em pé ou sentados, visto que, muitas vezes, a gestação de Isabel, e por vezes, também a de Maria, são simbolizadas por barriga protuberante; há, inclusive, representações em que os fetos, dentro das mulheres, são figurados.

tempo do rei Herodes e por ele é aprisionado por pregar que o soberano não poderia viver com sua cunhada, Herodias. Tendo sido João Baptista já encarcerado, o rei, encantado pela filha de Herodias, Salomé, concede à jovem o direito de lhe pedir algo. Por vingança, Herodias pede à sua fillha que solicite a cabeça de João Baptista degolada em um prato. Herodes atende o pedido de Salomé e João Baptista é executado. As várias imagens de São João Baptista figuram episódios centrais da vida do apóstolo: ele criança, representado junto com o Menino Jesus e a Virgem, por vezes, também com sua mãe, Isabel; já adulto, vestido com peles, pregando no deserto; no batismo de Cristo, nas águas do Rio Jordão; e na sua morte, representada tanto instantes antes da sua degola pelos guardas de Herodes, quanto por cena na qual sua cabeça é colocada no prato para ser entregue à Salomé.

${ }^{258}$ O exemplar da gravura pertencente ao acervo da FBN tem o título da obra e a data e local "1915 (Rio)" manuscritos na obra. 
Oswald, em sua gravura, reduz a cena à cabeça de perfil das duas figuras. Não se vê nenhum cenário ou paisagem na composição, somente linhas paralelas que estabelecem forma triangular na frente dos perfis. Os corpos das mulheres não são representados, pois os caracteres dos tipos - a expressão nos rostos e a diferença de idade - são resolvidos com na gravação das cabeças. Reconhece-se Isabel porque ela é a figura com linhas de expressão marcadas, que indicam ser ela mais velha do que a outra mulher. Maria tem perfil mais delicado e menos marcado por linhas. Além disso, Oswald as diferencia pela luz: o rosto de Isabel é envolto por área escura, enquanto o de Maria, por zona clara, visto que ela é a Virgem, a Nossa Senhora. Ambas as figuras, com as pálpebras rebaixadas, cabeças inclinadas para baixo e partes do rosto delineadas têm expressões serenas, que podem sugerir a devoção de ambas.

Embora a obra de Oswald represente caracteres fundamentais para a distinção dos tipos, novo e velho, as figuras não carregam qualquer outra alegoria que as identifiquem, tal como a aproximação entre as duas mulheres e a gravidez de, ao menos, uma delas. A união das duas figuras é resolvida pela forma triangular gravada entre elas, que sugere essa ligação. Apesar disso, é indispensável o título da obra, na verdade, os títulos, para que se entenda a qual passagem bíblica essa gravura refere.

A questão do título não é secundária, pois é um recurso utilizado por Oswald para hiperbolizar a composição sacra e identificar o que ela simboliza. O próprio artista afirma, em seus escritos sobre o assunto, que diversos outros artistas, figurativos, poderiam fazer arte sacra se apenas alterassem os títulos de suas obras profanas e acrescentassem a elas alguns símbolos, cobrindo, evidentemente, partes nuas das figuras, para estar de acordo com as delimitações da liturgia. As obras assim caracterizadas poderiam ser transformadas de profanas a sacras, uma vez que possuiriam os atributos necessários para tornarem-se composições cristãs.

Assim, também na gravura Caim e Abel, o título cumpre a sua função de sinalizar para o observador os tipos que ela representa. A obra, de 1925, refere passagem do Velho Testamento que narra o assassinato de Abel por seu irmão, após Deus preterir a oferenda de Caim em favor da do pastor $^{259}$ (Fig. 89). A passagem bíblica é representada em diversas imagens sacras, nas quais vê-se a cena de luta entre os dois irmãos. Eles são, habitualmente, figurados com os corpos entrelaçados, sendo que Abel está caído e Caim, por cima dele,

\footnotetext{
${ }^{259}$ A história dos dois irmãos é narrada no Antigo Testamento, Gêneses 4: 1-16. Caim, lavrador, e Abel, pastor, são filhos de Adão e Eva. Já adultos, os dois irmãos fazem uma sacrifício à Deus: Caim oferece os produtos de seu trabalho com a terra e Abel, uma de suas ovelhas. Deus prefere o animal aos vegetais, ficando Caim enfurecido com o irmão. Ele, então, decide matar Abel, o que faz quando estão os dois no campo.
} 
defere o golpe fatal. A luta é ambientada em diferentes cenários, nos quais podem aparecer a ovelha, oferenda de Abel a Deus ou apenas a fogueira na qual o sacrifício é realizado.

$\mathrm{Na}$ gravura de Oswald o assassinato é representado quase sem as alegorias que tipificam a referida cena: um corpo masculino, com o torso esticado horizontalmente, segura em uma das mãos objeto que parece enfincado em uma ovelha. Desta, vê-se somente a cabeça, que está colocada sobre pilha de toras de madeira, como numa fogueira. O segundo corpo masculino é posto de cócoras, próximo às pernas da figura estirada horizontalmente, na sua frente. Todo o espaço ao redor das figuras é composto por incisões que, embora não representem objetos ou paisagem, constroem o "cenário" para a ação: do canto superior direito da mancha se propagam linhas concêntricas circulares, que sugerem céu ou atmosfera. Os círculos abrem-se tanto que chegam à interseccionar as linhas cruzadas diagonalmente, que demarcam o terreno sobre o qual os corpos se assentam. Linhas convexas também são gravadas no canto inferior esquerdo da mancha, próximas ao corpo disposto horizontalmente. Este, aliás, parece engolido por todas essas linhas que o cercam e o comprimem. O encontro das diferentes linhas, as do terreno com aquelas do alto da imagem, circulares, forma "linha de horizonte" irregular e entrecortada. O que possibilita alguma impressão de profundidade na imagem é a disposição das linhas que formam o entorno das figuras e a disposição no espaço dessas. Contudo, a interseção do "solo" com o "céu" faz com que o fundo avance, o que provoca alteração na percepção da profundidade, dinamizando a composição.

Reconhece-se a figura caída no chão como a de Abel, evidentemente, devido à sua posição e também pela associação desse corpo com o da ovelha, figura esta destacada pela luz. Caim é a outra figura, que contrasta com a de Abel tanto pela sua disposição em eixo vertical, quanto por ser escura. Não há, propriamente, uma cena de luta, os dois corpos se encontram, mas parecem mais sobrepostos do que entrelaçados. O que sugere a tensão e movimento na imagem são as linhas que constroem o espaço, o estiramento do corpo de Abel e a relação perpendicular entre as figuras.

Evidencia-se ainda que, numa mesma imagem, Oswald simboliza tanto o assassinato de Abel, quando o sacrifício que o antecede, uma vez que na lateral esquerda do observador, vê-se o pastor deferindo golpe contra a cabeça da ovelha, já na fogueira e, do lado oposto da obra, o corpo de Caim, em vias de se inclinar sobre o de Abel, movimento sugerido pela posição de suas pernas e pés. Embora a posição dos corpos masculinos seja de importância para a construção da narrativa, o que é fundamental para se identificar a passagem bíblica é a ovelha: é ela que, associada ao corpo masculino, identifica Abel e, por oposição, reconhece-se Caim. Assim, são, justamente, a ovelha e o título da obra que enfatizam que a composição 
representa o que, de acordo com o Antigo Testamento, é o primeiro assassinato entre os homens. Não fossem esses recursos que identificam os tipos e a cena, as duas figuras masculinas poderiam fazer parte de alguma representação profana, se lembrarmos o próprio escrito de Oswald sobre arte sacra.

Nas décadas de 1920, 1930 e 1940, Oswald continua a gravar imagens sacras com a mesma inventividade, sendo que algumas são obras que simbolizam passagens bíblicas e outras são alegorias de santos da Igreja Católica. Em 1946, o artista realiza importante conjunto de gravuras que simbolizam as quatorze estações da Via Sacra. Obra que Oswald envia, inclusive, ao Papa Pio XII, por intermédio da Sociedade Brasileira de Arte Cristã, da qual foi um dos fundadores no mesmo ano de 1946.

Essas estações da Via Sacra narram a condenação de Cristo à morte, seu martírio com a cruz e a ressureição. Oswald escreve que, além das gravuras, realizou diversas obras com o mesmo assunto, a maior parte delas pinturas encomendadas para a decoração de Igrejas. As águas-fortes e água-tintas da Via Sacra, todavia, não são realizadas para um único cliente e, pode-se sugerir, apresentam uma solução aos párocos que desejam decorar seus templos com obras de arte, mas não possuem o capital para empregar em pinturas ${ }^{260}$. Considere-se que, em seus escritos na revista Vozes de Petrópolis, Oswald ressalta que as gravuras devem ser usadas na decoração sacra, uma vez que são obras de arte. Aliás, mais baratas que as telas ou murais, as gravuras têm qualidade incomparável a das reproduções de pinturas e esculturas, estas, imagens sem valor artístico, de acordo com o autor.

Oswald resolve as estações da Via Sacra (Fig. 136 a Fig. 156), de modo sintético, destacando apenas o que é mais representativo de cada estação. A $12^{\text {a }}$ estação (Fig. 154.A) é água-forte que representa o torso de Jesus pregado na cruz; embora só se veja parcialmente o corpo e a cruz, o artista os ressalta hiperbolizando a cena, "a morte de Jesus": em destaque, no canto superior direito da mancha, um enorme prego cravado no centro da palma da mão; na lateral esquerda, o corpo de Cristo com musculatura enrijecida e iluminado; a cabeça pendendo para trás e coroada com espinhos e, acima da cabeça, a inscrição "INRI". Signos indispensáveis para esse episódio bíblico, os quais são intensificados pelo artista devido ao tratamento austero e regular produzido pelas incisões de todos os elementos da composição: corpo, cruz, céu, chão. A tensão da cena é intensificada na construção do céu, este elaborado por linhas curvas que estabelecem um ritmo, o qual, devido às suas variações de tamanho, sugere a profundidade da cena.

\footnotetext{
260 "Várias igrejas adotaram [a Via Sacra] para seu interior, como, por exemplo, a capela do monumento a Nossa Senhora de Fátima, em Petrópolis. Vários Bispos do Brasil a adquiriram”. Carlos Oswald, op. cit., 1957, p. 231.
} 
Como se pode observar nesse conjunto de gravuras, Oswald sintetiza a cena de cada estação, resumindo-a aos seus signos indispensáveis; sínteses, portanto, pois assim o artista entende e faz sua produção, distante da cópia e avesso aos excessos de detalhes, como se lê em seus escritos.

Além das suas Vias Sacras, Oswald considera como obras de grande sucesso as suas Últimas Ceias. A primeira das obras que recebe esse título, uma pintura, é realizada em 1918 para a Igreja do Brás, em São Paulo, para atender a encomenda do Conde de Lara ${ }^{261}$. Após essa obra que atende um pedido, Oswald pinta outra Última Ceia, mas com alterações ou como ele costuma escrever: faz uma "variação" de sua própria obra ${ }^{262}$. No início do decênio de 1920, do que se pode entender a partir da documentação primária, a Casa Stheli Frères comercializa tricromias da tela de $1918^{263}$.

A Última Ceia (Fig. 88.A) gravada, obra possivelmente de 1923, é trabalhada de modo minucioso por Oswald: as linhas em cruzamentos e disposições variadas elaboram os diferentes objetos e constroem o espaço no qual o jantar ocorre. As luzes que iluminam a cena provêm de várias direções, mas a luz da cena, por assim dizer, a que une a composição e destaca o que se narra na escritura é a que se inicia na figura à direita, sentada, e se estende até a figura de Cristo, à esquerda. Essa luz que desenha uma elipse destaca os apóstolos, unindo-os; mas uma das figuras quebra esse movimento e separa-se do conjunto, quer por estar de costas para o observador e de pé na composição, quer por ter seu manto trabalhado em tons escuros, diferente dos demais. Além disso, essa figura que parece opor-se ao objetivo dos discípulos tem à sua frente duas chamas de lamparinas que a evidenciam, ainda mais, como destoante do grupo.

Oswald escreve em sua autobiografia sobre a Última Ceia. Apesar da descrição do artista referir-se à pintura, ela elucida a representação da cena, a mesma que se vê na gravura, ainda que nesta a posição das figuras seja inversa daquela.

Jesus acabava de pronunciar aquelas fatídicas palavras: "Alguém de vós há de me trair'. Todos os apóstolos se levantam aterrorizados, deixam seus bancos e se aproximam de Jesus que, sentado na extremidade da mesa, vê-se rapidamente cercado

\footnotetext{
${ }^{261}$ Além da afirmação do artista, nota em periódico comprova a data da encomenda da decoração da igreja pelo Conde de Lara a Carlos Oswald. Cf. "Centenario da parochia do Braz”, Correio Paulistano, São Paulo, 31 jan. 1918.

${ }^{262}$ Carlos Oswald, op. cit., 1957, p. 57.

${ }^{263}$ A Última Ceia é a primeira das pinturas do artista a ser reproduzida e comercializada pela casa suíça, que também imprime em tricromias outras pinturas sacras do autor, como Sagrado Coração de Jesus e Senite paroultos Venire ad me. Cf. "A repercussão da obra de um artista patrício no estrangeiro", Gazeta de Notícias, Rio de Janeiro, 12 jun. 1927.
} 
pelos discípulos que exclamam: 'Serei eu, Senhor?'. João, à direita, segura o braço do Salvador e $\mathrm{O}$ olha com intensidade. Pedro, no primeiro plano, é visto de costas apoiando as mãos na mesa, e presa de súbita emoção; atrás do Senhor, de pé, André, irmão de Pedro, sente-se aniquilado. Seguem-se, da direita para a esquerda: Bartolomeu elevando o olhar ao alto; ao lado, bem por cima de João, Tiago Maior segura abismado a cabeça entre as mãos e, encostado no seu irmão João, fita o olhar aflito no Mestre. Continuando para a esquerda, aparecem Filipe e Simão, este último apoia a cabeça sobre os ombros do precedente esforçando-se para se aproximar mais de Jesus. Vem logo o evangelista Mateus que levanta a mão como que protestando e, sentados, pertinho, os primos do Senhor, Judas Tadeu e Tiago Menor. Todos estes discípulos, quase que eletrizados, dirigem seus olhares na direção de Jesus procurando compreender-lhe as misteriosas palavras. Distraídos de tudo em volta de si, não reparam em Judas Iscariotes que, levantando-se repentinamente, arrasta a toalha e entorna o cálice de vinho que se derrama na mesa. Aqui temos expresso com evidente realismo um duplo símbolo: primeiro, é o Sangue do Redentor que se torna perdido para o traidor, segundo, é a massa escura dele que, como diabólica sombra, tapa a Luz da Verdade representada pela lâmpada a óleo. O único discípulo que se apercebe da traição é, naturalmente, Tomé que, sempre desconfiado, como o demonstraria mais tarde em relação à Ressureição, sentado na extremidade esquerda da mesa, olha com o rabo dos olhos os movimentos de Judas Iscariotes. ${ }^{264}$

A descrição do artista de sua própria obra evidencia como cada objeto e figura representados cumprem uma função na narrativa. Nota-se que as expressões dos apóstolos marcam suas reações ao pronunciamento de Jesus e são componentes importantes para a construção da cena. Por essa razão, destaca-se que a arte sacra, tal como Oswald a pratica, exige do artista conhecimento quanto aos modos de representação de expressões da face. Conhecimentos estes difundidos nas escolas de arte e em textos diversos, os quais ensinam como devem ser desenhadas as partes do rosto para figurar determinadas paixões ${ }^{265}$. Oswald, aluno livre da Academia de Florença, mesmo que não por meio dos textos, conhece esses modos de representação e deles faz uso para compor suas obras que são simbólicas, o que não implica, entretanto, na aderência do gravador e pintor aos demais preceitos e doutrinas fixados, visto as proposições modernas da sua gravura.

O trecho do texto de Oswald explicita, ainda, que ele utiliza os elementos plásticos, principalmente o contraste de claro e escuro e os focos de luz para evidenciar partes da composição, mais do que isto, a oposição entre a luz e a sombra marca a oposição entre Jesus e Judas, seu traidor.

\footnotetext{
${ }^{264}$ Carlos Oswald, op. cit., 1957, p. 58-59.

${ }^{265} \mathrm{Um}$ desses textos, ilustrado com as fisionomias desenhadas de acordo com as diferentes paixões é o de Charles Le Brun, Conference de Monsier Le Brun premier peintre du Roy de France, chancelier et directeur de l'Academie de Peinture et Sculpture, Paris, 1698.
} 
Essa gravura de Oswald não é a única que representa a passagem bíblica da Última Ceia; no conjunto da obra do artista há, pelo menos, duas outras composições a partir do mesmo tema: em uma delas vê-se Jesus e os apóstolos em pé, em torno da mesa (Fig. 108.A) realizada em 1932, na outra, datada de 1958 ou 1959, obra feita a partir da de 1923, Jesus está sentado à direita do observador e novamente Judas é a figura que traja manto escurecido (Fig. 172).

A Última Ceia (Fig. 108.A) de 1932 simboliza outro momento do jantar de Jesus com seus doze apóstolos: ela representa a passagem na qual Jesus reparte o vinho entre seus discípulos, simbolizando seu sangue ${ }^{266}$. A gravura tem solução simples: as formas são construídas por linhas de contorno e incisões mínimas são delineadas para determinar o espaço no qual se desenvolve a cena; a água-tinta é usada para definir as luzes e sombras do espaço e construir, de modo simples, a volumetria das figuras. Ao centro da composição, o cálice, Jesus o entrega a seu discípulo: síntese da cena representada.

O primeiro estado da obra (Fig. 108.B) demonstra que todas as figuras e objetos são gravados a água-forte e só depois o artista ocupa-se da água-tinta. Oswald não altera o modo de trabalhar esta gravura por ela atender a temas sacros. Ademais, também nas gravuras sacras, o artista trabalha com cores variadas na impressão, alterando os efeitos da obra por meio das relações tonais, como se observa na obra impressa em vermelho dessa $A$ Última Ceia (Fig. 109).

Carlos Oswald realiza gravuras com tema sacro até a década de 1950, sendo que, entre 1950 e 1952, ele grava essas obras especificamente para o Atelier de Arte, do qual, como visto, é diretor artístico. Esse local objetivava, segundo afirma o artista, a divulgação da arte da água-forte, por isso mesmo as gravuras eram impressas em grandes tiragens para serem comercializadas. O historiador Orlando da Silva afirma, ao tentar retraçar a biografia de Carlos Oswald, que vários exemplares das gravuras impressas no Atelier são perdidas em incêndio $^{267}$. Sendo assim, entre as gravuras de Oswald desses anos, certamente várias delas feitas para esse local, estão algumas que alegorizam santos católicos, como a Cabeça de São Francisco (Fig. 166), o Sto. Antônio (Fig. 160). Entre outras desses anos há as que trazem a alegoria do Menino Jesus.

Destaque-se a figuração em Oswald: relativamente à representação de corpos nas imagens sacras, o artista afirma que diversas vezes usou como modelos seus filhos e parentes. Na composição de a Última Ceia, por exemplo, aquela pintada em 1918 e gravada em 1923

\footnotetext{
266 "Este cálice é a nova aliança no meu sangue, que derramado por vós". Evangelho, Lucas 22: 20.

${ }^{267}$ Orlando da Silva, op. cit., 1969.
} 
(Fig. 88.A), Oswald escreve que um mesmo filho foi modelo para vários dos apóstolos e, inclusive, para Jesus ${ }^{268}$. Assim, em seus escritos, ele justifica a necessidade do modelo não para reprodução do retratado, mas devido à complexidade dos problemas plásticos impostos ao artista que mantém a figuração, proposição válida não apenas para a representação do corpo, como também para os demais objetos e seres da natureza:

[...] a nossa arte clássica necessita de "modelos" devido à complexidade dos fatores que intervêm na execução de uma obra, fatores que se entrechocam e se influenciam uns aos outros, como, por exemplo, os reflexos, o modelado, os planos e valores e mil coisas que tornam impossível trabalhar de memória. [...]. Nós não copiamos a natureza, mas a interpretamos, escolhemos o que nos interessa, mas sempre precisamos ter a natureza real perante os olhos. Podemos com um moço pintar uma figura de mulher ou de velho, porém nunca inventar sem ter estudado o claro-escuro, a forma, as cores, do natural. ${ }^{269}$

O uso no trecho da expressão "arte clássica" ou ainda, como em outras passagens do texto de 1957, da expressão "arte tradicionalista", não concerne à arte ensinada e produzida segundo modelos fixados ${ }^{270} \mathrm{em}$ academias, além de não contradizer a modernidade que se afirma sobre as soluções das gravuras de Oswald. Para o autor, segundo se depreende de seus vários escritos, "arte clássica" ou "tradicionalista" é aquela que mantém as proporções e relações entre as formas apreendidas na observação do mundo. Essas relações devem ser figuradas sem excessos de deformações, pois, se assim for, dificultará a compreensão das formas pelo público ${ }^{271}$.

Embora a ideia da importância da observação do "natural" na passagem destacada esteja relacionada à arte sacra, ela não é particular desse gênero, pois Oswald considera fundamental o domínio das "academias" - o estudo do nu era denominado "academia" nas escolas de arte no início do século XX no Brasil - para qualquer artista, siga ele as mais

\footnotetext{
${ }^{268}$ Carlos Oswald, op. cit., 1957, p. 53.

${ }^{269}$ Idem, ibidem.

${ }^{270}$ Uma das proposições de Oswald para o ensino do desenho é abolir a cópia de estampas, mesmo nas primeiras lições dos aprendizes. Nas suas aulas do Liceu de Artes e Ofícios, o artista, de acordo com o que ele escreve, implanta um ensino baseado na observação direta de objetos. Idem.

${ }^{271}$ Em outro trecho de sua autobiografia, Oswald escreve que "nossa arte tradicionalista é baseada sempre nas proporções da natureza e nada podemos fazer de original se não estudarmos de antemão o modelo vivo". Idem, p.83. A oposição entre a fotografia e a pintura realizada por Oswald ajuda a compreender o que significa para o autor a manutenção das proporções da natureza: "A fotografia é um espelho que nada explica, a obra de arte pictórica deve ser uma interpretação do real, uma síntese, em que são eliminados todos os detalhes inúteis, que distraem da compreensão da beleza pura, mas deve ao mesmo tempo ficar fiel às proporções da natureza, permanecer nos limites de suas leis, não deformar". Carlos Oswald, "A Beleza da Matéria", Vozes de Petrópolis, Petrópolis, jan. fev. 1947, p. 55.
} 
variadas orientações de "estilo", como escreve ${ }^{272}$. Por isso, para a realização de diversas obras profanas Oswald também faz uso de modelos, como se destacou em Mimma e em outras obras, que, sem serem retratos, partem de poses de familiares do artista. Como ele afirma, o uso do modelo serve somente para a apreensão das relações entre os elementos plásticos, por isso é possível fazer, a partir de uma mesma referência, qualquer representação, alterando a expressão da figura e acrescendo outros aspectos a ela.

Por isso, o filho do artista pode lhe servir de modelo para que ele pinte ou grave diferentes figuras, como a de santos. Segundo Oswald, como se lê em seus escritos sobre arte sacra na revista católica Vozes de Petrópolis, a arte sacra é funcional ${ }^{273}$ e está a serviço da religião, mas, como se destacou, ele também a entende como afeita à imaginação, pois exige do artista a complementação de suas narrativas ${ }^{274}$. A arte sacra, mesmo tendo as delimitações dos dogmas da Igreja quanto à representação do nu, por exemplo, segundo o artista, ela possibilita maior invenção do que outras composições, como as obras históricas, como se afirmou, e mais liberdade do que algumas proposições artísticas orientadas pela militância política, como Oswald entende ser o que se denomina de "arte social",275.

\subsection{Paisagens}

Até agora analisou-se gravuras de Carlos Oswald nas quais a figura humana é de importância para a composição, seja nas obras sacras, seja nas profanas. Boa parte da produção gráfica do artista, todavia, também abarca a paisagem. As árvores da Toscana, as cenas da praia de Forte dei Marmi e a cidade de Florença são presentes em suas gravuras desde 1908, ano que Oswald aprende a água-forte com o americano Carl Strauss ${ }^{276}$. Já no Brasil, Oswald continua a gravar paisagens, e raramente com construções, talvez sendo a única exceção a gravura intitulada Fachada da Igreja de Santo Antônio (Fig. 105 e Fig. 106), realizada em 1930. Nas décadas de 1920, 1930 e 1940, Oswald grava vistas do Rio de Janeiro e de Petrópolis, várias delas apresentando pontos conhecidos das duas cidades, como a Pedra

\footnotetext{
${ }^{272}$ Lembra-se da proposição de Oswald sobre o corpo humano ser a síntese de todas as formas. Assim, dominar o desenho da figura é dominar o desenho dos demais objetos e seres da natureza.

${ }^{273}$ Carlos Oswald, "A Sociedade Brasileira de Arte Cristã", Vozes de Petrópolis, Petrópolis, set. out. 1947, p. 616.

${ }^{274}$ Carlos Oswald, op. cit., 1957, p. 104.

${ }^{275}$ Sobre a concepção de Oswald de "Arte social" ver: Carlos Oswald, "Problemas da Arte Cristã", Vozes de Petrópolis, Petrópolis, maio jun. 1947.

${ }^{276}$ Sobre as aulas com esse gravador, Oswald escreve: "Estávamos no ano 1908. Conhecera um grande águafortista americano de origem alemã, Carl Strauss, que tinha o atelier bem pertinho do meu, na 'Porta Romana' [...] Foi Strauss meu guia único, pois não frequentei a aula de gravura na Academia." Carlos Oswald, op. cit., 1957, p. 24.
} 
da Gávea, o Jardim Botânico e a Serra dos Órgãos. No entanto, considere-se, para Oswald a construção de paisagens interessa como relações de luzes, cores e formas e não como cópia dessas vistas, como se lê em trecho de sua autobiografia:

$\mathrm{Na}$ paisagem eu não via os objetos em sua valorização humana, não me importava saber se estava pintando eucaliptos ou ciprestes, se os verdes das planícies eram do capim ou do trigo, se os claros provinham de rochas ou de grupos de casas; numa palavra, eu não queria fazer o "retrato" parecido das plantas e dos elementos todos que constituem e que se chama "paisagem"; eu queria transmitir aquela sensação maravilhosa que despertava em mim a hora do crepúsculo, ou a harmônica sucessão dos planos e das cores, o "meu estado de alma" enfim. ${ }^{277}$

Para Oswald a obra de arte não é cópia, mas sim a síntese do que ele, como artista, pode dar a conhecer ao espectador. A síntese, como processo realizado somente pelo homem, implica necessariamente na "humanização" da obra, como escreve Oswald em artigo para a revista Vozes $^{278}$. Mais do que isso, como matemático que era, ele considera que toda arte é sempre uma abstração, visto o processo pelo qual ela é realizada. Assim, na gravura, a arte mais espiritual, também a paisagem tem de ser confeccionada somente pelos elementos mais abstratos: linhas e pontos. Desta maneira, como processo de abstração próprio do homem, a paisagem não é isenta de subjetividade, sendo sempre obra confeccionada por artista que deseja “comunicar" algo. Este "algo", entretanto, não é exigente de símbolos, como nas obras sacras, sendo que as obras podem, simplesmente, registrar a beleza percebida pelo artista na natureza ${ }^{279}$. Entende-se, portanto, que o "estado de alma" que Oswald afirma transmitir em suas paisagens relaciona-se com o desejo de evidenciar que a composição é resultado da sua percepção e das suas escolhas, não sendo, por isso, reprodução de uma determinada vista, tal como um “cartão postal”, mas imagem que é, por si mesma, uma abstração.

\subsubsection{Paisagens italianas}

Oswald conta que da cidade Forte dei Marmi, por exemplo, lhe interessava o aspecto branco do lugar, visto no mármore carregado pelas carroças, nas praias da referida cidade

\footnotetext{
${ }^{277}$ Idem, p. 47-48.

${ }^{278}$ Carlos Oswald, “Arte Abstrata”, Vozes de Petrópolis, Petrópolis, set. dez. 1948, p. 665.

${ }^{279}$ No artigo "A beleza da matéria" Oswald evidencia seu entusiasmo pela observação das relações de cor, luz e forma mesmo nas paisagens e cenas mais simples e corriqueiras. $\mathrm{O}$ autor escreve que valoriza as coisas por sua beleza "em si" e não pela função ou significação que possam ter. Carlos Oswald, "A Beleza da Matéria", Vozes de Petrópolis, Petrópolis, jan. fev. 1947.
} 
litorânea, nos bois etc. ${ }^{280}$. O artista também refere o estudo que realiza dos bois, afirmando que lhe importava apreender a anatomia dos animais e registrar seus movimentos ${ }^{281}$. Desses seus estudos e observações conhecem-se algumas gravuras feitas entre 1909 e 1912.

Em Novicello in restauro (Fig. 40.A e Fig. 41), de 1910, vê-se uma carroça, à esquerda do observador, dirigida por figura masculina e conduzida por dois bois; o conjunto é colocado à frente de um navio tombado no chão, com as velas rebaixadas. No lado esquerdo do casco do navio, está esboçado um toldo branco e, no lado direito da composição, em linha circular, há panos estendidos num varal. A cadeia de montanhas iniciada à esquerda do observador segue em perspectiva até quase a margem direita da composição, desenhando uma inclinada. Essa mesma perspectivação é acentuada pela disposição do barco, a qual é quebrada justamente pela disposição dos dois bois que puxam a carroça e as roupas estendidas no varal. Sob o toldo branco, quase imperceptível, esboça-se uma figura, assim como entre as roupas também há outra figura. Esses corpos são extremamente sintéticos, construídos por poucas incisões. São esses poucos traços que também estabelecem as vestimentas da figura que dirige a carroça, a única realmente em destaque na obra, visto que as outras duas quase não são percebidas, por serem realizadas com as mesmas linhas que constroem as sombras do navio, no caso da figura sob o toldo, e a mesma marcação que constrói as elevações que se vê por entre os panos do varal, na figura da direita. Os bois, diferente das figuras gravadas, têm as formas robustas destacadas pelas luzes incidentes em seus corpos, assim como também se destacam, pelo contraste, seus cascos e suas cabeças.

A área abaixo da linha de três quartos da composição tem apenas alguns pontos gravados, poucos traços e formas, além do pano estendido no varal, na lateral direita da gravura. A carroça, o navio tombado, as figuras e os bois concentram-se em faixa horizontal na metade da mancha, sendo o último terço da composição ocupado pela cadeia de montanhas e pelo céu.

As obras conhecidas de Novicello in restauro são impressas em marrom (Fig. 40.A) e em vermelho (Fig. 41). Em ambas, a luz destaca algumas partes da composição - os bois, a vela do navio, as montanhas - que colaboram para a construção da profundidade em torno do eixo oblíquo. Note-se, ainda, que os diferentes focos de luz evidenciam outras figurações, como os panos e, na impressão em vermelho, também a camisa do carroceiro, salientando esses objetos. As diferenças entre as duas obras, impressas em vermelho e marrom,

\footnotetext{
280 “O interessante naquelas praias são os bois brancos que carregam blocos de mármore ou pilhas de lajes brancas. Tudo é branco - o pó das ruas, os muros das casas construídas com pedras em conjunto com mármores, os telhados de chapas de mármore, etc." Carlos Oswald, op. cit., 1957, p. 35.

${ }^{281}$ Idem, Ibidem.
} 
evidenciam que algumas dessas luzes são obtidas pelo artista devido à limpeza da matriz com os panos. Assim, a veladura que cobre toda a superfície pode ser mais ou menos densa e, até inexistente, nas áreas em que o artista escolhe destacar pela luz.

Bois e carroças são figurados em todas as cenas gravadas nas praias da Toscana, acompanhados, muitas vezes, de representações de grandes navios. É o que é observado na água-forte e agua-tinta impressa em cores Bois descansando (Fig. 38.A), de 1910. Na metade inferior da composição, à esquerda do observador, vê-se dois bois próximos à carroça, a qual é apenas em parte gravada pelo artista, o que sugere a continuidade da cena para além dos limites da mancha. Os corpos dos bois são construídos pelo contraste entre as áreas claras e escuras que os formam. Na metade superior da composição, à direita do observador, é figurado o navio, o qual parece ser habitado por algumas figuras fantasmagóricas. Sobre seu casco escuro contrasta uma grande massa clara, que é a vela rebaixada. A forma deste tecido enfatiza oblíqua que é continuada pelas cordas que o seguram; estas linhas ascendem até a margem superior da gravura. Note-se que os bois, do modo como estão dispostos na imagem, também fazem parte da oblíqua construída pela vela e cordas. Bois e carroças, no entanto, são separados do navio por cerca que, partindo da metade da lateral direita da mancha, segue, mesmo que desvanecendo gradualmente, até o fundo da composição. A profundidade da imagem é acentuada por esse eixo construído pela cerca, que se encontra com a linha de horizonte, marcada pela junção do céu, com o solo.

Anotações na margem do papel da prova de impressão dessa gravura ${ }^{282}$ indicam que essa obra é resultado da sobreposição de três matrizes, as quais, de acordo com as mesmas anotações, são entintadas, cada uma, com mais de uma cor. Na prova (Fig. 38.B) as matrizes impressas estão levemente fora de registro, o que possibilita sugerir que uma das placas contém as linhas que confeccionam as formas e as outras duas são águas-tintas que servem para estabelecer as áreas de cor. Tanto a prova de impressão, quanto as anotações do artista explicitam que ele não segue "regra", habitualmente difundida, de que em uma gravura colorida cada chapa recebe somente uma cor, que sobreposta a outras placas impressas por outras cores, formam as diferentes tonalidades da obra. Ainda mais, a mistura de cores sugerida nas anotações e vista na prova dessa obra, não é aquela que se encontra no exemplar da gravura pertencente à Biblioteca, aqui identificada como Fig. 38.A. Isto, porém, não é

\footnotetext{
${ }^{282} \mathrm{O}$ acervo da FBN possui dois exemplares da gravura, um deles é assinado e intitulado pelo artista, à lápis, fora da mancha, no papel (Fig. 38.A); o outro é, possivelmente, uma prova de impressão, visto que tem anotação manuscrita que parece orientar a entintagem da matriz (Fig. 38.B).
} 
contraditório com o conjunto da obra de Oswald, pois ele realiza experimentações com os matizes, como visto, imprimindo obras finais variadas.

Nas gravuras de Forte dei Marmi referidas, o artista explora a cor como elemento da composição, pesquisando matizes e luzes que estabelecem efeitos variados nas obras. Esta resolução com cores não é, entretanto, a única usada pelo artista para representar as paisagens da Toscana. Há gravuras impressas somente em preto, nas quais Oswald explora as relações de claro-escuro, promove o apagamento das formas e organiza as figurações de acordo com fugas diversas para estabelecer o espaço na paisagem, como destacado nas obras já referidas. Três dessas gravuras, aliás, são apresentadas na Exposição Anual de Munique no Glaspalast, de julho a outubro de 1910. No catálogo oficial da mostra lê-se que as composições figuram no certame como obra única, possivelmente assim inscritas pelo $\operatorname{artista~}^{283}$. Supõem-se serem reunidas na mesma moldura as gravuras: Bois carregando madeiras na praia da Toscana (Fig. 24.A), Bois puxando um navio (Fig. 27.A) e Carregando mármores (Fig. 35.A).

Como nas demais gravuras do artista que representam os bois ao lado dos homens, nestas obras, o corpo humano é construído por poucas linhas que delineiam membros, torso e cabeça, mas não rostos. Nestas gravuras expostas em Munique, ao contrário das obras já referidas, os corpos não se fundem com o entorno, sendo confeccionados de maneira a acentuar uma verticalidade que os bois não possuem. Este tipo de resolução da figura humana é visto também em outras gravuras com bois, o que possibilita afirmar que não se trata de retrato, mas sim de tipo, no caso, o do trabalhador local.

Em Bois carregando madeiras na praia da Toscana (Fig. 24.A), de 1909, Oswald representa dois grupos de bois junto a trabalhadores. Estes grupos estão dispostos de modo a enfatizar a horizontal da composição, justamente a que separa a praia do mar. Atrás deles, observa-se o mar com um barco à esquerda e o céu, resolvido por pontos, sem formas. As três partes da composição são distintas, mesmo porque trabalhadas de modos diversos: o céu é faixa gravada pela água-tinta, na qual se vê pequenos pontos não gravados; o mar têm formas curvas não gravadas que se contrapõem às áreas mais escuras que formam a água; já o solo, os bois e os homens são compostos por massas escuras e algumas linhas.

A comparação do primeiro estado da gravura com a obra terminada permite afirmar que é a água-tinta que estabelece o contraste de claro-escuro entre as três partes da imagem. Embora no primeiro estado da obra já exista uma gravação de água-tinta que auxilia na construção dos corpos dos trabalhadores e dos bois, nele as linhas ainda estão destacadas e

\footnotetext{
${ }^{283}$ Münchener Künstlergenassenchaft, Offizieller Katalog der Münchener Jahres-Ausstellung, Munique, 1910, p. 140 .
} 
são elas que delimitam as formas, inclusive as das ondas do mar (Fig. 24.B). Nesta prova, não ocorrem os contrastes de claro-escuro tão intensos quanto na obra final, apenas algumas partes do mar e das figuras, bem como o céu, são mais claros do que o restante da imagem. Já na impressão da obra finalizada (Fig. 24.A), observa-se que a água-tinta cobre as formas antes definidas pelas linhas, escurecendo a parte da frente da composição de modo que o fundo, composto por mar e céu, seja destacado. O mar é, na obra final, elaborado pelo encontro de áreas cinzas claras com áreas mais iluminadas, o papel. Nota-se, ainda, que não há distinção entre o modo de gravar a água da do barco à vela, como também não há linhas que separam essas duas figurações. A embarcação parece assomar da água, como uma onda que se eleva.

Note-se que as medidas da obra final (Fig. 24.A) indicam que ela tem tamanho menor do que a impressão que é primeiro estado (Fig. 24.B). Essa alteração sugere que a matriz da gravura foi recortada entre uma impressão e outra. A modificação da placa não é insignificante para a composição, pois a área entorno dos bois, pessoas e carroça é reduzida, o que estreita o campo de visão e aproxima a cena do observador.

Em Bois puxando um navio ${ }^{284}$ (Fig. 27.A) destaca-se que a relação entre as figuras constrói a profundidade na imagem: a disposição dos diferentes objetos, animais e pessoas, bem como seus tamanhos variados, conduz o olhar do observador até o fundo da composição e sugere a profundidade do espaço. Nesse sentido, cada forma é significativa para a composição como um todo. Acrescenta-se que os bois, enfaticamente inclinados na lateral esquerda do observador, sugerem a noção de força para promover o deslocamento do navio. Até mesmo as marcas no solo que partem da margem inferior da mancha e seguem até o boi inclinado auxiliam para sugerir a ideia de esforço observada na obra.

Embora em artigos de periódicos Carlos Oswald não discorra sobre a importância de formas que não representam objetos, em sua autobiografia o artista sinaliza que elabora em suas obras "sombras misteriosas"285. Essa afirmação em conjunto com a análise das gravuras do artista, possibilita a sugestão de que as sombras, e também outras marcas que se veem em algumas de suas obras, são de importância para as suas composições, não sendo apenas áreas escuras ou acidentes do terreno. Essas formas são figuras que têm um papel nas composições,

\footnotetext{
${ }^{284}$ Oswald afirma que a gravura foi "inspirada" no quadro Supremo esforço e que também realizou uma repetição dela em 1950, a pedido do Atelier de Arte, visto que, como afirma, a matriz original foi perdida. Carlos Oswald, op. cit., 1957, p. 208 e p. 234. Breve comparação entre as obras, no entanto, evidencia que nenhuma delas é exatamente repetição da outra. A relação da gravura com a pintura é apenas pela figuração, que é similar, contudo, as soluções plásticas dadas pelo artista para as composições, pintada e gravada, são diferentes. Relativamente à gravura de 1950, O Supremo esforço (Fig. 165), ela é realizada em formato retangular e não quadrado, como a obra de 1909, o que promove outra disposição dos elementos representados e, consequentemente, profundidade muito diferente; a obra de 1950, é ainda impressa em verde.

${ }^{285}$ Carlos Oswald, op. cit., 1957, p. 48.
} 
pois destacam ou evidenciam aspectos da imagem, equilibram pesos, dinamizam e sugerem profundidade para as cenas.

Na gravura Carregando mármores (Fig. 35.A), de 1910, a sombra gravada embaixo dos bois e carroças de madeira - figurações dispostas em eixo que enfatiza a horizontal na metade da obra - mais do que ser a projeção de outras formas no terreno, parece figurar uma forma, também ela objeto representado na composição. Ainda mais, é ela que dinamiza toda a composição, separando, por assim dizer, frente e fundo, alto e baixo. Na metade inferior da obra, faixas escuras, paralelas entre si e inclinadas em relação à margem inferior da composição sugerem a passagem da carroça figurada de costas pelo terreno. Essas marcas no solo contribuem para a construção da profundidade. Na gravura, que é também intitulada pelo artista de Impressão ${ }^{286}$, destaca-se a luz, ou o branco da imagem, vista tanto em partes da carroça, homens e bois, quanto na grande área inferior da composição.

Sombras e marcas no solo são figuradas como objetos ainda em outras gravuras de Oswald de Forte Dei Marmi, tais como nas obras intituladas Carregando Mármore (Fig. 48), Forte dei Marmi, Carrara (Fig. 49), de 1912, e Bois (Forte de Marmi, Carrara) (Fig. 25.A), de 1909. Destaca-se que nestas obras os bois, homens e carroças são organizados pelo artista na metade superior da mancha, sendo a metade inferior resolvida como grande área clara. Sugere-se, assim, que nessas obras também o papel, enquanto área de luz, pode ser considerado como elemento que compõem a imagem.

Embora outras paisagens de Oswald, dos seus últimos anos da Itália, não utilizem o papel como recurso para evidenciar a luz; as "sombras misteriosas" aparecem em outras composições do artista desses anos, tal como Luar. Nesta gravura (Fig. 12.A) formas irregulares no terreno do bosque são elaboradas por linhas cruzadas. Estas, como supostas "sombras", são mais escuras do que o resto do solo e parecem ser projeções das árvores. Contudo, ao se observar essa obra, vê-se que não se trata de sombras, mas de figuração que, disposta obliquamente, sugere a irregularidade do terreno e ressalta a profundidade do espaço, esta construída pelas fugantes que sugerem caminho aberto no meio de um bosque. Aliás, é de se considerar que as copas das árvores são resolvidas por marcações simples, que sugerem tufos, e as mais distantes, por hachuras e por zonas cinzas. Os troncos delineados por linhas grossas e escuras são finos, verticais, irregulares, e se espalham pelo espaço, contribuindo para a construção da profundidade da imagem.

\footnotetext{
${ }^{286}$ O exemplar da obra pertencente ao acervo da FBN é intitulado pelo artista, à lápis, no papel de "Impressão".
} 
A mesma resolução dada à vegetação em Luar é observada em Estudo de Árvores (Fig. 13.A). No grupo das árvores que se vê na frente da composição, linhas em pequenas curvas indicam os tufos de folhas que se ordenam ritmicamente, em eixos, por assim dizer, perpendiculares às verticais dos troncos. Estas árvores são dispostas em intervalos regulares iniciado no canto inferior esquerdo e seguem para a direita do observador. Atrás desse primeiro grupo, é colocado, em paralelo, outro conjunto de troncos, irregulares e retorcidos, cujas copas são indicadas por hachuras e algumas linhas circulares. $\mathrm{O}$ eixo oblíquo formado pelos dois grupos de árvores é acentuado por área escura no terreno, forma que atravessa o terço inferior da composição, da esquerda para a direita do observador.

A resolução da paisagem pela ordenação rítmica das figurações também é encontrada em outras gravuras de Oswald dos mesmos anos, como em Árvores nos arredores de Florença (Fig. 16.A). Nesta obra, troncos dispostos em intervalos regulares estabelecem linha inclinada, que parte do canto inferior esquerdo para a lateral direita do observador, esses troncos têm sombras que destacam horizontais perpendiculares às árvores. Essa área da composição é espaço organizado de modo distinto daquele observado do outro lado da mureta. Nessa parte, à esquerda do observador, a paisagem, construída por linhas delgadas e algumas massas escuras, é organizada em fuga diferente a dos troncos vistos no lado direito da composição. Em uma mesma imagem Oswald elabora dois espaços distintos e, simplesmente, os justapõe.

As paisagens que têm como motivos os arredores de Florença mais do que registrar a natureza italiana são gravuras nas quais o artista explora recursos para elaborar o espaço e as formas que as compõem. As linhas são, como nas demais obras do artista, destacadas como elementos primários que confeccionam as formas e, antes de serem linhas de contorno ou de preenchimento, são linhas compositivas; bem como as sombras, como visto, que não são projeções das formas das árvores, pois são objetos que também servem à composição.

Outro recurso para a organização do espaço na obra é, ainda, observado em água-forte e água-tinta de 1909, que Oswald intitula tanto de As musas ou Dança Clássica, como Coroa de Ciprestes (Fig. 33.A). Nela vê-se grupo de árvores sob o qual seis figuras femininas, também arranjadas em conjuntos, são colocadas. A organização das copas das árvores, ritmicamente justapostas, sugerem elipse que ocupa três quartos superiores da composição. É essa elipse que sugere a bidimensionalidade da justaposição das copas, a qual é quebrada devido à disposição dos troncos das árvores que as sustêm.

A disposição das figuras femininas, assentadas no terreno, replica a das coníferas: recostada no tronco da única árvore que não faz parte da elipse, é colocada figura também 
sozinha, que tal como a árvore, é construída por área escura com pouca variação de tons; três grandes ciprestes estão na frente da composição, aquele à esquerda do observador é colocado no um terço da largura da mancha, o do meio, localiza-se quase na metade da mancha, e o da direita, está pouco depois da linha dos dois terços. Entre estas árvores estão os grupos femininos: um trio que dança à esquerda e uma dupla que parece tocar um instrumento à direita. Note-se que a conífera do centro está tanto do lado da mulher que dança, quanto do lado de uma das mulheres sentadas, esta parece recostar as costas na árvore.

A posição desse tronco central na obra é de importância, pois estabelece um "jogo" entre a ilusão de profundidade e a planificação da imagem. Ao mesmo tempo que a posição dessa conífera indica que as mulheres dançam ao lado dela, o fazendo em terreno que se estende para o fundo, ela também indica que os dois grupos de mulheres que a cercam estão num mesmo plano. Esta percepção, contudo, não é reafirmada pela posição desses grupos no terreno, visto que eles não estão alinhados, mas sim, colocados um pouco acima do outro, sugerindo que as dançarinas estão à frente das musicistas. Logo, a profundidade, tal como nas copas das árvores em relação aos seus troncos, é continuamente sugerida para ser, em seguida, desfeita.

Além de Oswald ter como motivação para suas gravuras as praias e bosques da Toscana, o artista também grava vistas da cidade florentina. Ponte Vecchio, de 1910, representa a famosa ponte sobre o Arno e os prédios em torno dela. No primeiro estado da obra (Fig. 34.B), observa-se que, com linhas e hachuras, Oswald elabora a vista, a qual deixa entrever, apenas, dois dos três arcos que sustentam a passagem sobre o rio. As diversas edificações, tanto aquelas da ponte, quanto as do seu entorno, são confeccionadas de modo a destacar a continuidade entre elas. Partes das construções são apenas indicadas por algumas incisões, assim como, a continuidade da cidade e do rio, depois da ponte, é sugerida por hachuras vistas entre os arcos, tanto aqueles sobre a ponte, quanto os embaixo dela.

Na obra final (Fig. 34.A), há o escurecimento de todas as construções e do rio, sugerindo que todas essas figurações e, até mesmo, parte do céu e as pessoas, formam uma massa contínua, escura, que contrasta com as áreas de luz: os arcos da ponte e parte do céu. Estas luzes são abertas na matriz pelo artista com o brunidor, uma vez que no primeiro estado essas mesmas áreas possuíam incisões. Oswald abre luzes evidenciando, assim, na composição a ideia de ponte em arco. Acrescente-se que o artista, ao brunir partes da matriz, elabora imagem na qual a luz entre os arcos sugere uma profundidade que parece sem limites. A gravura não é, portanto, reprodução de uma vista, mas obra de arte que destaca ideias e 
percepções, assim sendo, o referente da paisagem pode ser até apagado para hiperbolizar o que se destaca na composição.

Assim como Ponte Vecchio se afasta da ideia da gravura como reprodução de vistas para serem divulgadas como cartões postais ou em publicações, as composições que Oswald realiza a partir da observação de esculturas também distam do conceito da gravura como meio a serviço da reprodução de obras arte. Em 1909, o gravador realiza três obras que figuram esculturas localizadas na Piazza della Signoria em Florença, uma delas apresenta escultura de Giambologna (1529 - 1603), o Rapto das Sabinas (1574 até 1582), e as duas outras mostram parte da Fonte de Netuno (1565 até 1574), de Bartolomeo Ammannati (1511 - 1592). Estas últimas obras, no entanto, não mostram a figura central do chafariz, mas dois grupos escultóricos que se localizam na murada da fonte octogonal, esculturas em bronze que representam sátiros e nereides realizadas, possivelmente, também por Giambologna.

Embora em Na praça da Signoria (Fig. 32.A), em Chafariz da Piazza della Signoria (Fig. 31.A) e em Coin de la place de La Seignorie (Fig. 30.A) as esculturas estejam sempre em destaque, seja pela posição, seja pela iluminação, há nas composições representações que evidenciam o entorno dos monumentos, por isso, vê-se nessas obras a cidade que cerca as esculturas.

Diferente ainda das gravuras que reproduzem obras de arte, feitas de acordo com os manuais, essas três composições não ressaltam as qualidades do bronze e do mármore, materiais das esculturas, pelo modo como as linhas são arranjadas, ao contrário, as matérias dos objetos representados não são diferenciados pela gravação. Mais do que isso as esculturas apresentam-se como continuidade da murada da fonte e do pedestal sobre os quais se apoiam. Em Rapto das Sabinas, outro título da obra aqui identificada como Fig. 32.A, as três figuras em serpertinata são fundidas com a base da obra, mas não só, visto que os corpos também estão unidos pelas hachuras que elaboram toda a sombra. Oswald não destaca detalhes da obra, mas sim evidencia o movimento construído pelo escultor, dramatizando-o com a fusão dos corpos. A mesma dramaticidade também é vista nas duas obras que representam os grupos escultóricos ao redor da Fonte de Neptuno, pois as sombras e as luzes enfatizam as partes do corpo e suas posições. Também nessas obras Oswald não se atém a figurar todas as formas que as compõem, visto que apenas indica os blocos modelados. Observa-se, por exemplo, que em Coin de la place de La Seignorie (Fig. 30.A) nem o rosto do sátiro, nem o peixe sob a mão da nereide são detalhados, sendo apenas, esse último, forma irregular a qual a coxa e a mão da figura mitológica se fundem. 
$\mathrm{Na}$ revista Illustração Brasileira ${ }^{287}$, de 1924, são publicados alguns desenhos de Oswald, não datados, que representam vistas da praça florentina. Dois deles correspondem às composições de Chafariz da Piazza della Signoria e de Coin de la place de La Seignorie. É possível que esses desenhos sejam os apontamentos do artista para a realização daquelas gravuras, o que não significa simples transposição. Destaca-se este aspecto, visto que muitas vezes supõe-se ser a gravura apenas uma forma de se reproduzir desenhos. Mesmo naqueles anos da primeira metade do século XX isso não se coloca para a produção de Oswald. A gravura é obra de arte que tem de ser resolvida pelo ponto e pela linha.

\subsubsection{Paisagens brasileiras}

No Brasil, Oswald continua a gravar paisagens ${ }^{288}$, mesmo que o número de obras com esse motivo seja, comparativamente, menor do que aquelas realizadas na Itália. Isto não significa afirmar, entretanto, como alguns historiadores o fazem, que a produção gráfica italiana do artista seja mais importante do que a aqui realizada, visto que o gravador continua a sua pesquisa com os elementos que são próprios da gravura, mesmo que com temas diferentes. Em 1914, portanto, no ano seguinte à sua chegada ao país, ele realiza $A$ grande bananeira (Fig. 55.A) e O galinheiro (Fig. 57.A). As provas de estado dessas gravuras (Fig. 55.C, Fig. 55.D e Fig. 57.D) evidenciam que, assim como nos retratos, nos primeiros estados das obras todas as figurações já estão elaboradas. Nas provas subsequentes vê-se que Oswald trabalha os contrastes de claro-escuro e as relações entre as partes da composição a fim de promover a integração entre elas e também a construção de uma atmosfera para a obra. Para tanto, ele utiliza vários recursos, muitos dos quais já mencionados, como o da fusão da figuração com seu entorno - seja pela intersecção das linhas, seja pelo escurecimento da obra - ou o apagamento de partes da imagem quer pelo acréscimo de linhas gravadas quer pelo aprofundamento das linhas por novos banhos de ácido.

Em 1925 , Oswald grava série de paisagens nas quais, como seus títulos indicam, são representados vistas do Rio de Janeiro e da serra petropolitana: Pedra de Itapuca, Icaraí (Fig. 90), Teresópolis (Fig. 91.A), Corcovado (Fig. 94), Praia de Botafogo (Fig. 98.B) e Gávea (Fig. 95.A e Fig. 96). Gávea é obra na qual a célebre pedra carioca é representada atrás de grupos de palmeiras e folhagens, que Oswald elabora com cortes que sugerem que a

\footnotetext{
${ }^{287}$ Carlos Oswald, "Praça da Senhoria”, Illustração Brasileira, Rio de Janeiro, set. 1924.

${ }^{288}$ No Brasil Oswald realiza poucas composições nas quais figura animais, conhece-se $O$ galinheiro (Fig. 57.A), de 1915, e Bois molestados pelas moscas, de 1935.
} 
vegetação emoldura a formação rochosa. Conhece-se diferentes versões dessa obra, nas quais as duas matrizes que a compõem - hoje pertencentes à coleção do MNBA - são impressas tanto em cores (Fig. 95.A e Fig. 97), quanto em preto (Fig. 96). A partir da análise dessas obras, afirma-se que em uma das placas o artista elabora as vegetações, o terreno sobre o qual essas se assentam e as linhas que delineiam o morro. Note-se, contudo, que tais linhas só são vistas na impressão póstuma realizada por Roberto e Marcello Grassmann em $1979^{289}$ (Fig. 95.B), uma vez que nas demais obras, impressas possivelmente pelo artista, a formação rochosa é uma grande área gravada, na qual não se veem as linhas. Na segunda placa são gravados o céu, no qual se sobressaem as nuvens, a pedra e a parte inferior da mancha, área gravada em água-tinta que é usada para imprimir o solo.

A divisão das figurações em duas matrizes permite ao artista explorar diferentes maneiras de imprimir a obra. Todavia, essa separação nas placas não parece objetivar somente a sobreposição das várias cores, visto que Oswald não realiza, necessariamente, a entintagem de uma placa com uma única cor. Na obra identificada sob o número 95.A, por exemplo, o artista usa, ao menos, três cores diferentes na placa que contém o céu gravado, sendo esta matriz impressa sobre aquela que contém as árvores, estas entintadas com uma única cor. Assim sendo, sugere-se que Oswald divide as figurações nas matrizes de modo a auxiliar a composição da obra: em uma placa ele grava, majoritariamente, as palmeiras e folhagens compõem a "frente" da paisagem, na outra, o artista grava a vista que se vê de longe.

Esse modo de organizar a composição, por figurações que se adicionam em matrizes diferentes, é usado também em Teresópolis. Esta obra é realizada em duas placas, as quais podem ser entintadas em cores variadas, resultando em impressão colorida (Fig. 91.A). Evidencia-se que outra versão da gravura, pertencente à coleção do MNBA, é uma impressão de somente uma das matrizes (Fig. 93), esta obra explicita que, nessa matriz, estão gravados todo o trecho da Serra dos Órgãos, bem como o céu, as vegetações e as variações topográficas observadas nos primeiros planos da imagem, os quais também são vistos na obra 91.A. Assim sendo, sugere-se que a segunda matriz, que termina de compor a obra 91.A, contém a gravação da árvore observada na frente da imagem, de algumas vegetações e de formas irregulares - supostas sombras - observados na metade esquerda da obra. Figurações que, mais uma vez, são colocadas como na "frente" da obra, emoldurando a formação rochosa. E como na gravura anteriormente referida, tais vegetações são impressas em uma única cor. A

\footnotetext{
${ }^{289}$ O gravador, Marcello Grassmann, e o impressor, Roberto Grassmann, realizam tiragem póstuma de gravuras de Carlos Oswald reunidas em álbum da editora Graphus, publicado em São Paulo no ano de 1979, intitulado "Carlos Oswald: gravuras". A tiragem das obras só é realizada após análise cuidadosa das matrizes a fim de pesquisar as cores usadas pelo próprio artista em suas impressões.
} 
vista da paisagem, emoldurada pelas árvores da frente da imagem, é impressa em três cores diferentes, essas dispostas sobre a placa de modo a acentuar uma passagem gradual e sutil entre elas.

Esse modo de compor a paisagem, pela sobreposição de figurações e espaços, sugere que o artista opera tal qual numa colagem, adicionando as camadas que constituem a obra. Este recurso não é observado apenas nas obras impressas em cores, com duas matrizes, mas também em outras gravuras, mesmo que realizadas por uma única placa. Nestas obras, as diferentes figuras, mais próximas ao espectador, também servem de "moldura" para a vista que se observa ao "fundo" da composição, é o que se observa em Palmeiras na Tijuca (Fig. 133), Pão de Açúcar (Fig. 113) e Velhas Figueiras (Fig. 103.A e Fig. 104).

Entre essas obras realizadas a partir da observação de vistas do estado do Rio, destacase ainda a gravura Velhas Figueiras (Fig. 103.A e Fig. 104), na qual vê-se árvores que se sobrepõem à silhueta da Serra dos Órgãos. Na obra a resolução dada por Oswald às partes da vegetação se aproxima da solução encontrada nas árvores florentinas, visto que os tufos de folhas são elaborados por formas pontiagudas, que são repetidas para compor a copa das árvores. Vê-se, ainda, que linhas verticais delineiam os cipós que escorrem dos galhos e que os troncos são elaborados por linhas curtas paralelas, linhas cruzadas e curvas; até mesmo os pequenos arbustos são formas repetidas com variações. Ainda mais, a silhueta da cadeia de montanhas, ao fundo, é figura plana confeccionada por traços curtos e próximos, dispostos verticalmente, os mesmos que, mais espaçados e na horizontal, elaboram o céu. Oswald evidencia, deste modo, que as figuras, quaisquer que sejam, são sempre, na gravura, realizadas por linhas e pontos, abstrações.

Portanto, é desnecessário tentar encontrar correspondência exata na realidade para as figurações observadas nas gravuras de Oswald, sendo estranho que o também professor de gravura Orlando da Silva, afirme, por exemplo, que Velhas Figueiras é a representação das árvores do Passeio Público do Rio de Janeiro com a Serra dos Órgãos ${ }^{290}$. A afirmação revela tentativa de olhar a obra de Oswald como o retrato da observação, o que, como explicitou-se, não é coerente com suas proposições plásticas, tanto aquelas de suas obras gravadas, quanto as evidenciadas em seus textos.

As últimas imagens gravadas por Oswald, justamente, paisagens, realizadas em 1964, como Dia chuvoso em Petrópolis (Fig. 177.A) e Ponte no Bingen (Fig. 178.A) são composições elaboradas somente por linhas em cruzamentos, direções e tamanhos diversos.

${ }^{290}$ Orlando da Silva, op. cit., 1969. 
Como nas demais gravuras do artista, observa-se que figuras, corpos, árvores, rochas, montanhas e solo são todos realizados pela mesma matéria, aquela que Oswald escreve ser própria do gravador, os elementos mais abstratos, o ponto e a linha. 


\section{Conclusão}

Como demonstrou-se, a gravura não é considerada arte no Brasil, tal qual a pintura e a escultura, ainda nas décadas finais do século XIX e iniciais do XX. Seu ensino, embora a cadeira de xilografia seja até decretada como parte da Academia Imperial de Belas Artes na década de 1880 - cadeira que não chega a ser instaurada na instituição imperial -, só é parte da então Escola Nacional de Belas Artes na segunda metade do século XX. É no Liceu de Artes e Ofícios do Rio de Janeiro, como instituição voltada à formação da mão de obra para oficinas e indústrias, que a instalação das oficinas gráficas é planejada, mesmo que com dificuldades, nas duas últimas décadas do século XIX. O ensino da gravura é idealizado pelos fundadores do Liceu como prática útil e possível de render lucros ao estabelecimento, visto que possibilitaria a produção de impressos e publicações diversos.

Embora sejam essas concepções que promovem a compra dos equipamentos e montagem do espaço da oficina de água-forte no LAO, Carlos Oswald, convidado para ali ensinar, implanta, incialmente em 1914, contudo sem grupos de alunos, e, posteriormente, em 1930, o ensino da gravura em metal como obra de arte. Oswald ensina artistas que começam a conhecer e a praticar essa arte. O professor respeita, como ele e seus alunos memoram, as escolhas de cada um, visto que cabia a ele apenas ensinar a calcografia e orientar os jovens dentro de suas próprias proposições plásticas, uma vez que não se pretendia ali formar técnicos hábeis, mas sim artistas conscientes do processo e das características da gravura em metal.

A concepção de Carlos Oswald sobre a gravura é, portanto, moderna, distante do conceito de técnica que serve para reproduzir imagens diversas para serem encadernadas ou distribuídas em papeis avulsos. A insistência do artista em expor as suas gravuras ao lado de suas pinturas em exposições, promover mostras coletivas dessa arte, ensinar e escrever textos sobre o assunto colabora para a divulgação desse conceito. Entende-se, contudo, a dificuldade dessa tarefa, uma vez que os textos de periódicos que abordam os assuntos relativos às artes plásticas nas duas décadas iniciais do século XX evidenciam que aqueles que se ocupam de comentar as exposições não entendam a gravura como obra de arte. Esses missivistas apenas tecem breves elogios ou censuras a esses trabalhos, sem analisá-los, com a exceção, como visto, de poucos autores, como Adalberto Mattos.

Ressalta-se ainda que não apenas as iniciativas de Carlos Oswald para propagar a gravura demonstram a sua modernidade, como também suas próprias águas-fortes, águas- 
tintas e pontas secas. Estas evidenciam que o artista utiliza recursos diversos que o distanciam de proposições fixadas, ensinadas nas escolas e, no caso da gravura, divulgadas em manuais.

As obras gráficas de Oswald mostram paisagens, retratos e obras sacras e, a princípio, poderia se supor, pelos temas, que o artista estaria alinhado a ideias que preconizam a reprodução do real de acordo com modelos. No entanto, como evidenciou-se, o artista apresenta obra que valoriza a pesquisa da gravura enquanto arte com características próprias. Ele a destaca como "arte espiritual" e sintética, porque realizada a partir dos elementos mais abstratos - o ponto e a linha.

Oswald entende, assim, a gravura como obra de arte que é, por essência, uma abstração e pretende em seus retratos, como destacou-se, construir o caráter dos tipos e pessoas; suas paisagens evidenciam as relações entre os aspectos que compõem a imagem as luzes, cores, formas -; suas gravuras sacras inspiraram a devoção nos fieis e, mesmo seguindo a liturgia cristã, exploram com inventividade as passagens bíblicas e a elaboração dos tipos.

Embora nem todas as obras do artista apresentem os mesmos recursos plásticos, destaca-se que Oswald muitas vezes funde a figura com o espaço que a cerca e constrói a imagem de modo a considerar as relações entre as partes da composição. Esta, ainda, não é organizada de acordo com um único ponto de fuga, mas tem profundidade construída por fugas diversas e pela organização das figuras na imagem. Assim, suas gravuras explicitam recursos variados para elaboração das obras nas quais, ainda que a profundidade se mantenha, há, por vezes, alusão à planificação da imagem. Ainda mais, a cor e a luz são elementos que compõem a obra, aspectos explorados pelo artista nas variadas impressões que ele realiza de suas gravuras.

Entende-se, deste modo, que a contribuição deste trabalho, por meio da análise das obras do artista a partir de suas ideias e da pesquisa sobre a gravura em metal no Brasil nas primeiras décadas do século XX, é evidenciar a modernidade de Carlos Oswald, tanto nas suas obras, quanto no esforço que ele empenha para divulgar e ensinar a água-forte como obra de arte. Reconhece-se, ainda, a necessidade da continuação deste estudo de modo a abarcar também as pinturas do artista e suas demais produções nas artes plásticas, para, assim, explicitar, de maneira ampla, a contribuição dele para a história da arte brasileira. 


\section{Catalogação das gravuras de Carlos Oswald: obras do Acervo da Fundação Biblioteca Nacional - Brasil e da coleção do Museu Nacional de Belas Artes/IBRAM/MinC}

\section{Índice}

TÍTULO: são registrados o(s) título(s) dado(s) pelo autor, manuscritos na obra e também aqueles referidos na catalogação das obras de Carlos Oswald, anexa à sua autobiografia, Como me tornei pintor, publicada em 1957.

VARIANTE: são registrados o(s) títulos(s) encontrado(s) nas catalogações de museus e na literatura.

DATA: são marcadas as datas anotadas nas obras, tanto gravadas na matriz, quanto manuscritas no papel. Quando essas informações não constam na obra, são registradas as datas presentes na catalogação realizada pelo próprio artista. Impressões póstumas são datadas de acordo com o ano da impressão das mesmas e não da gravação da matriz.

TÉCNICA: é referida a técnica de gravura em metal com a qual a obra foi realizada.

MEDIDAS: é registrado o tamanho da obra em centímetros, tanto da mancha, quanto do papel, quando há essa informação.

IMPRESSÃO: é anotada a cor em que a obra foi impressa, visto a variação dos matizes usados pelo artista nas suas impressões a partir das mesmas matrizes. As impressões póstumas também são referidas.

MATRIZ: é anotado o material da placa que serve de matriz à obra.

MEDIDAS DA MATRIZ: são referidas as medidas em centímetros da placa.

ASSINATURA: é registrado o local e formato da assinatura do artista na obra.

ACERVO ou COLEÇÃO ao qual a obra pertence. 
PROVENIÊNCIA: é registrada a pessoa que vendeu ou doou a obra para a insituição, bem como a data. Quando não há essas informações é registrado o ano de entrada da obra nas coleções. FONTE: referência bibliográfica da qual a imagem e as informações sobre ela foram retiradas, quando se conhece a obra apenas por reprodução.

FOTOGRAFIA: crédito das imagens das obras pertencentes à coleção do Museu Nacional de Belas Artes/IBRAM/MinC.

LITERATURA: referências bibliográficas dos catálogos de exposições, artigos e notas de periódicos e textos variados nos quais a obra é mencionada ou reproduzida.

Fig.: indica o número e exemplar da obra do qual a imagem é reprodução. A mesma marcação é usada na catolagação e nos capítulos da dissertação para referir as obras.

As informações quanto a data, técnica, medidas, matriz, assinatura e proveniência das obras pertencentes ao Museu Nacional de Belas Artes/IBRAM/MinC provêm da catalogação realizada pelo museu. A reprodução das imagens dessa coleção é autorizada pela instituição pelo protocolo SGI - IBRAM 01441.001633/2017-65.

As informações sobre as obras do Acervo da Fundação Biblioteca Nacional - Brasil foram recolhidas em pesquisa na instituição. As reproduções das imagens desse acervo foram realizadas pela autora, com a autorização da Família Oswald, na pessoa da Sra. Maria Clara Monteiro Sobrino Porto, detentora dos direitos autorais das obras.

A numeração das obras nesta catalogação seguiu ordem cronológica, mas não indica a ordem de realização das mesmas pelo artista, visto que além dessa informação não ser verificável, não é de interesse para esta pesquisa.

A subdivisão das obras em itens, marcados por letras (A, B, C etc.), registra provas de estado e de impressão, além de exemplares diferentes pertencentes à coleção do Museu Nacional de Belas Artes/IBRAM/MinC e ao acervo da Fundação Biblioteca Nacional. Em algumas obras também foram referidos outros exemplares encontrados em reproduções, pertencentes a coleções particulares, e impressões póstumas.

Considerou-se que impressão de uma mesma matriz em cores é obra diferente da impressão monocromática. Sendo essas obras em cores, variações, elas possuem numerações distintas daquelas monocromáticas. Na catalogação não são repetidas as informações sobre as matrizes dessas obras. A literatura só é repetida quando apresenta informações diferentes. 


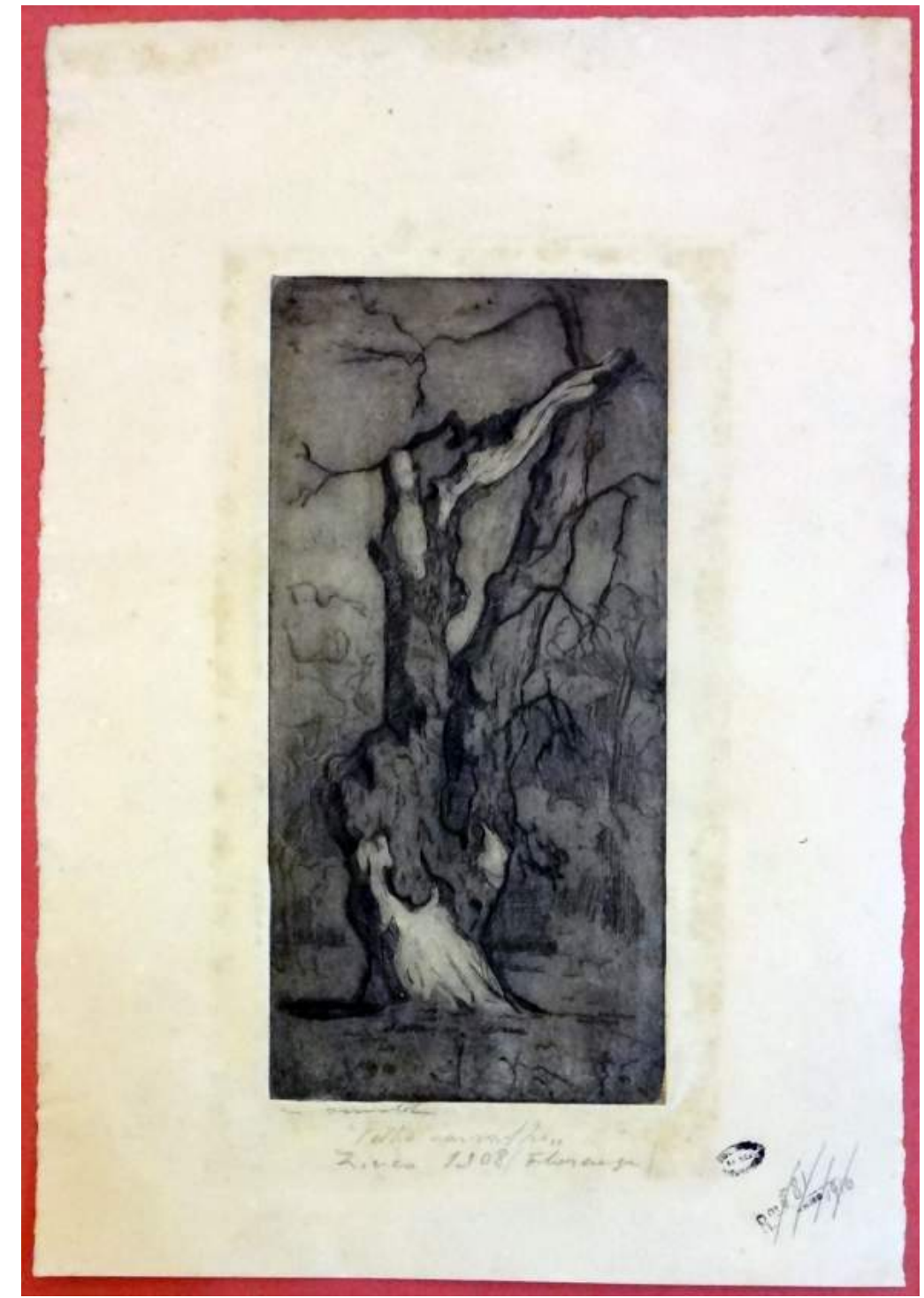

Fig. 1. A

1. TÍTULO: Velho carvalho. VARIANTE: Carvalho.

A. DATA: 1908. TÉCNICA: Água-forte. MEDIDAS: 21 x $10 \mathrm{~cm}$ (mancha), 32,1 x $22 \mathrm{~cm}$ (papel). IMPRESSÃO: em preto. MATRIZ: zinco. ASSINATURA: "C. Oswald" no canto inferior esquerdo do papel. ACERVO Fundação Biblioteca Nacional. PROVENIÊNCIA: Carlos Oswald, compra, 1916.

B. DATA: 1976. TÉCNICA: Água-forte. IMPRESSÃO: póstuma, em preto. MATRIZ: zinco. Sem assinatura. ACERVO Fundação Biblioteca Nacional. PROVENIÊNCIA: registrada no acervo em 1976. [Dois exemplares]

C. [matriz] DATA: 1908. TÉCNICA: Água-forte. MATRIZ: zinco. ACERVO Fundação Biblioteca Nacional. PROVENIÊNCIA: registrada no acervo em 1976.

LITERATURA: Felix, Illustração Brasileira, RJ, 1/6/1913, p. 181 (artigo expo.); Oswald, 1957, p. 206 (ref., afirma ser a primeira gravura do artista); Silva, 1969 (ref.). 


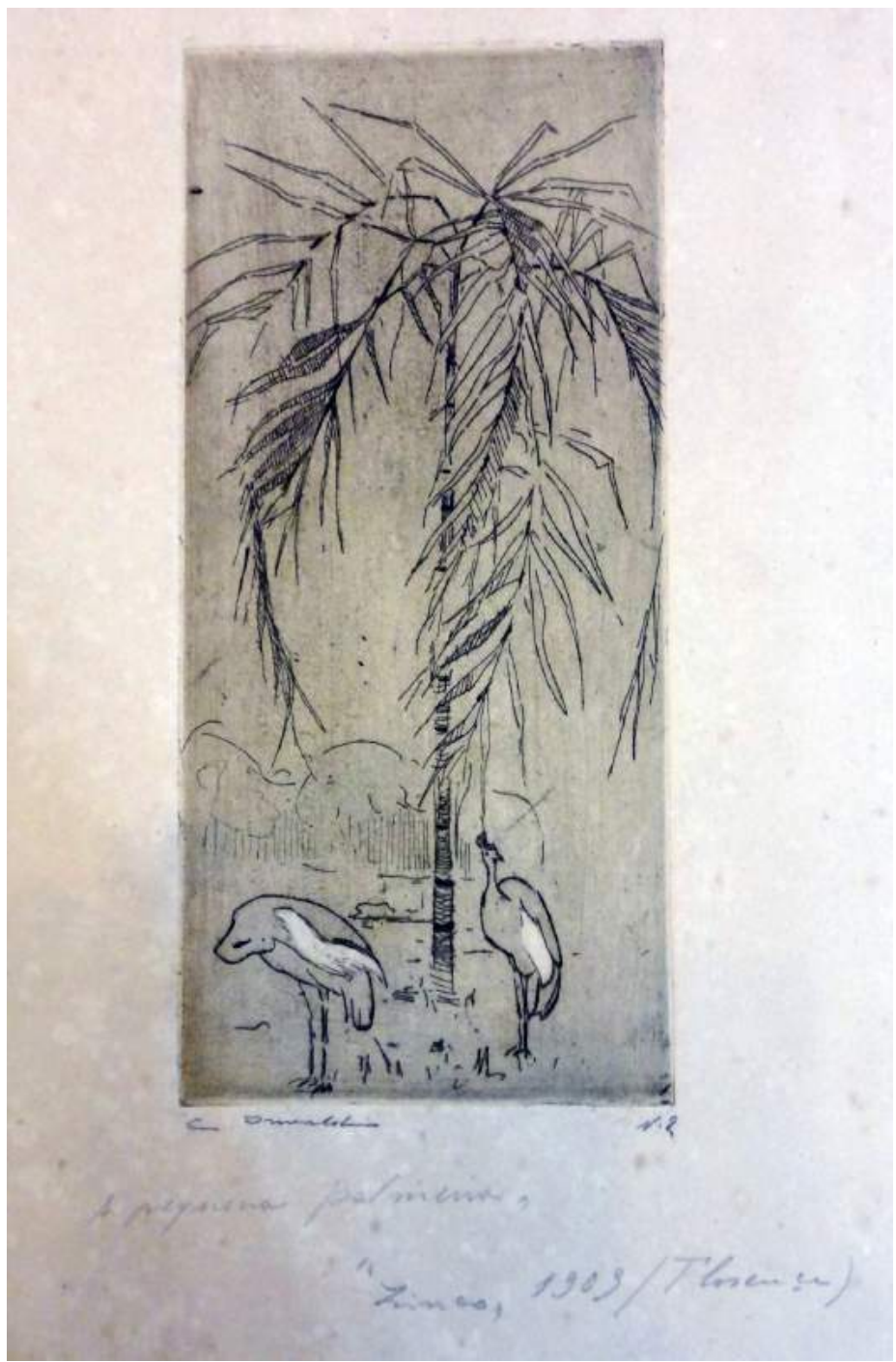

Fig. 2. A

2. TÍTULO: A pequena palmeira. VARIANTE: Palmeira.

A. DATA: 1909. TÉCNICA: Água-forte. MEDIDAS: 21 x $10 \mathrm{~cm}$ (macha), 49,1 x 34 cm (papel). IMPRESSÃO: em preto. MATRIZ: zinco. MEDIDAS DA MATRIZ: 21 x $10 \mathrm{~cm}$. ASSINATURA: "C. Oswald" no canto inferior esquerdo do papel. ACERVO Fundação Biblioteca Nacional. PROVENIÊNCIA: Carlos Oswald, compra, 1916.

B. DATA: 1908. TÉCNICA: Água-forte. MEDIDAS: 21 x $10 \mathrm{~cm}$ (macha), 24,5 x $16 \mathrm{~cm}$ (papel). IMPRESSÃO: em preto. MATRIZ: zinco. MEDIDAS DA MATRIZ: 21 x $10 \mathrm{~cm}$. ASSINATURA: "C. Oswald” no papel. COLEÇÃO Museu Nacional de Belas Artes/IBRAM/MinC. PROVENIÊNCIA: Carlos Oswald, compra 1963.

C. [matriz] DATA: 1908. TÉCNICA: Água-forte. MATRIZ: zinco. MEDIDAS DA MATRIZ: 21 x $10 \mathrm{~cm}$. Sem assinatura. COLEÇÃO Museu Nacional de Belas Artes/IBRAM/MinC. PROVENIÊNCIA: Maria Isabel Oswald Monteiro, doação, 1982.

LITERATURA: Felix, Illustração Brasileira, RJ, 1/6/1913, p. 181 (artigo, referida com o título “Palmeira"); Silva, 1969 (ref., datada 1908); Oswald, 1957, p. 206 (ref., datada 1908, afirma ser a segunda gravura feita pelo artista). 


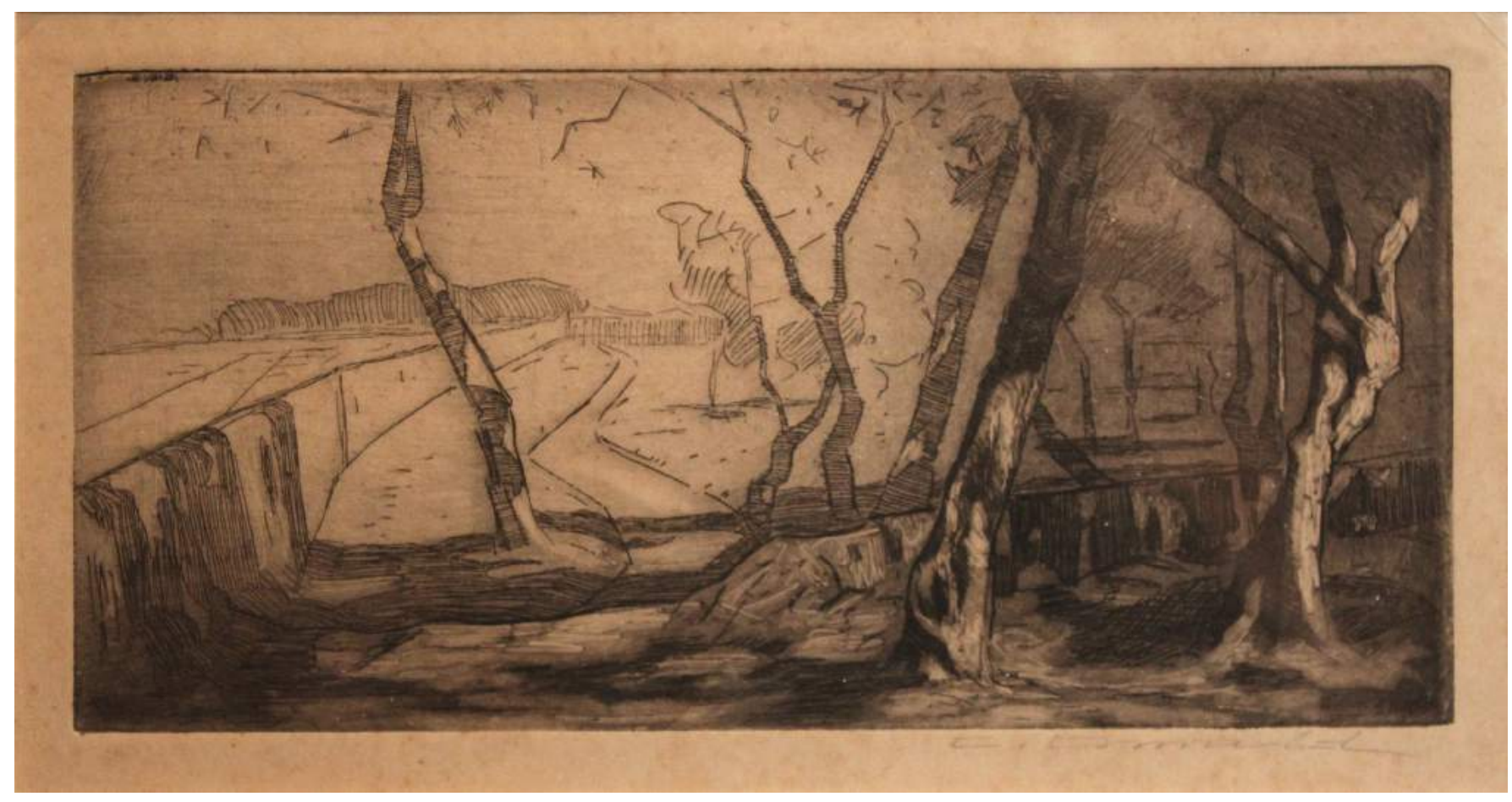

Fig. 3.A

\section{TÍTULO: Oliveiras.}

A. DATA: 1908. TÉCNICA: Água-forte. MEDIDAS: 12,1 x 20,9 cm (mancha), 13,6 x 27 cm (papel). IMPRESSÃO: em preto. MATRIZ: zinco. ASSINATURA: “C. Oswald” no canto inferior direito do papel. COLEÇÃO Museu Nacional de Belas Artes/IBRAM/MinC. PROVENIÊNCIA: Carlos Oswald, compra, 1963. FOTOGRAFIA: Acervo Museu Nacional de Belas Artes/IBRAM/MinC.

B. DATA: 1976. TÉCNICA: Água-forte. IMPRESSÃO: póstuma, em preto. MATRIZ: zinco. Sem assinatura. ACERVO Fundação Biblioteca Nacional. PROVENIÊNCIA: registrada em 1976 no acervo. [Dois exemplares]

C. [matriz] DATA: 1908. TÉCNICA: Água-forte. MATRIZ: zinco. Sem assinatura. ACERVO Fundação Biblioteca Nacional. PROVENIÊNCIA: registrada em 1976 no acervo.

LITERATURA: Oswald, 1957, p. 206 (ref.); Silva, 1969 (ref.). 


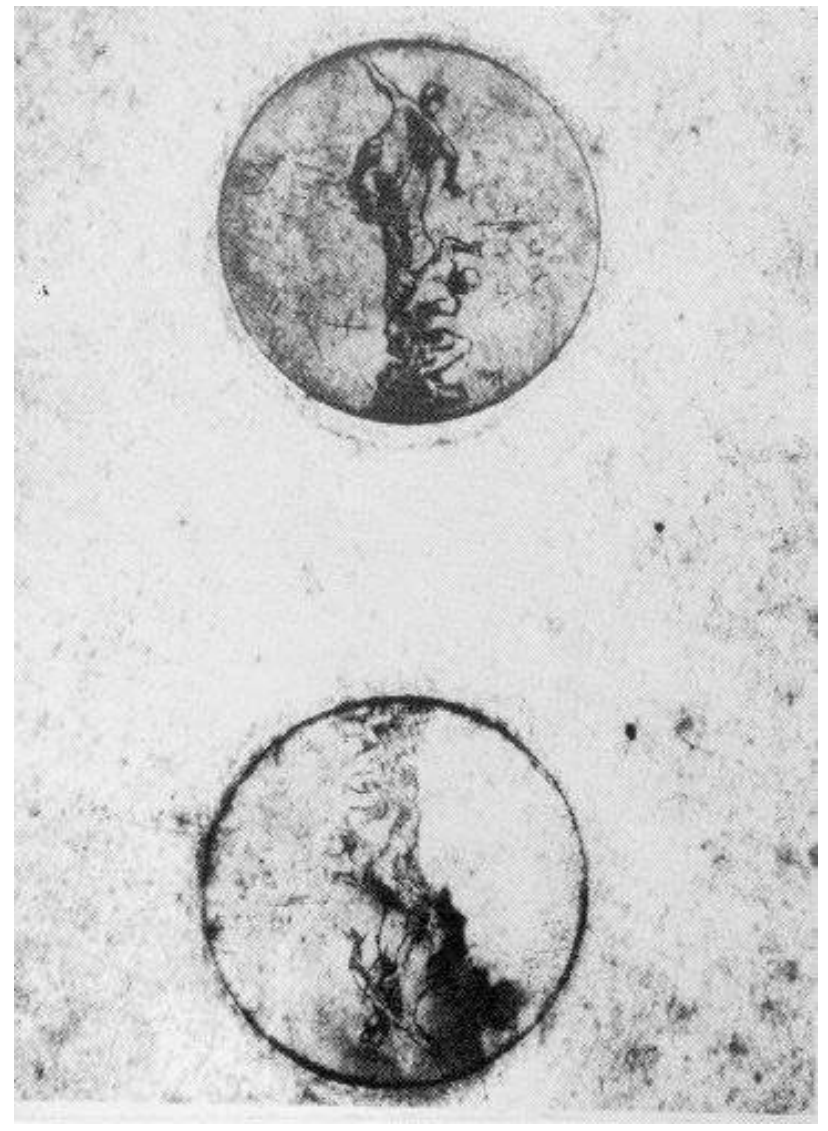

Fig. 4

4. TÍTULO: Rapto das Sabinas.

DATA:1908. TÉCNICA: Água-forte. MEDIDAS: $3 \mathrm{~cm}$ de diâmetro (mancha), 10,4 x 6,9 cm (papel). IMPRESSÃO: em preto. MATRIZ: cobre, moeda aplainada. Sem assinatura. COLEÇÃO Museu Nacional de Belas Artes/IBRAM/MinC. PROVENIÊNCIA: Maria Isabel Oswald Monteiro, doação, 1982. FOTOGRAFIA: Acervo Museu Nacional de Belas Artes/IBRAM/ MinC.

LITERATURA: Silva, 1969 (ref.). 


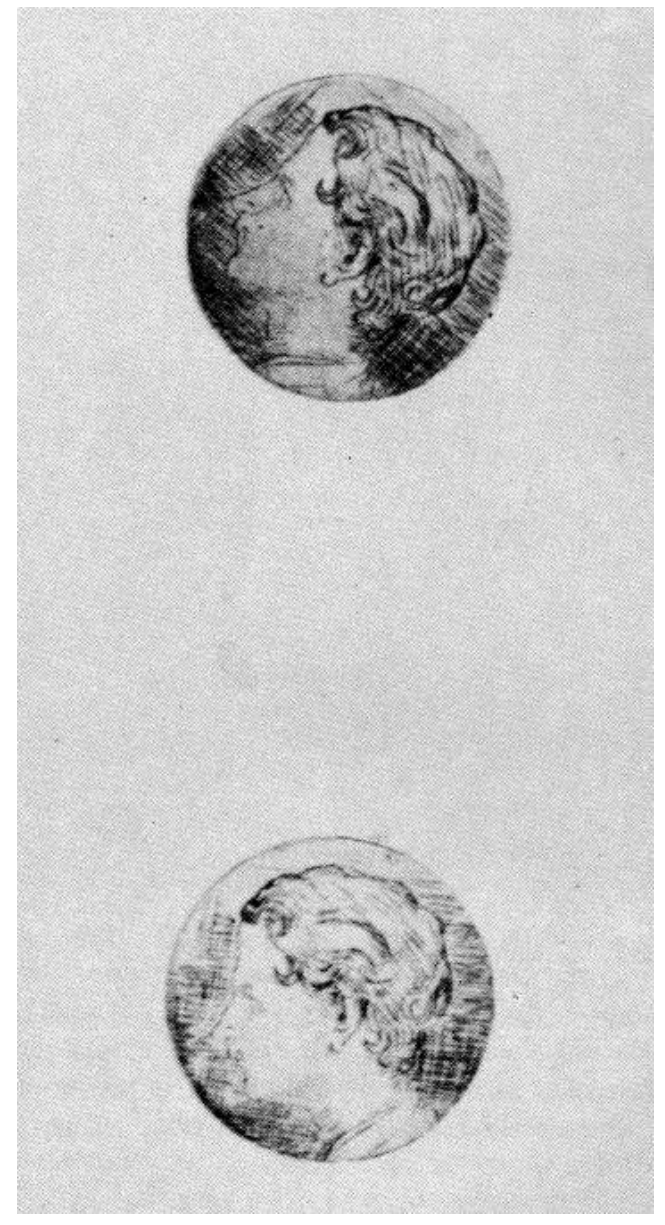

Fig. 5

5. TÍTULO: Alfredo Oswald.

DATA: 1908/1909. TÉCNICA: Água-forte. MEDIDAS: 2,9 x 2,9 cm de diâmetro (mancha); 24,5 x $14 \mathrm{~cm}$ (papel). IMPRESSÃO: em preto. MATRIZ: cobre, moeda aplainada. ASSINATURA: "C. Oswald" duas vezes no mesmo lado no canto inferior direito do papel. COLEÇÃO Museu Nacional de Belas Artes/IBRAM/MinC. PROVENIÊNCIA: Carlos Oswald, compra, 1963. FOTOGRAFIA: Acervo Museu Nacional de Belas Artes/IBRAM/MinC.

LITERATURA: Silva, 1969 (ref.). 


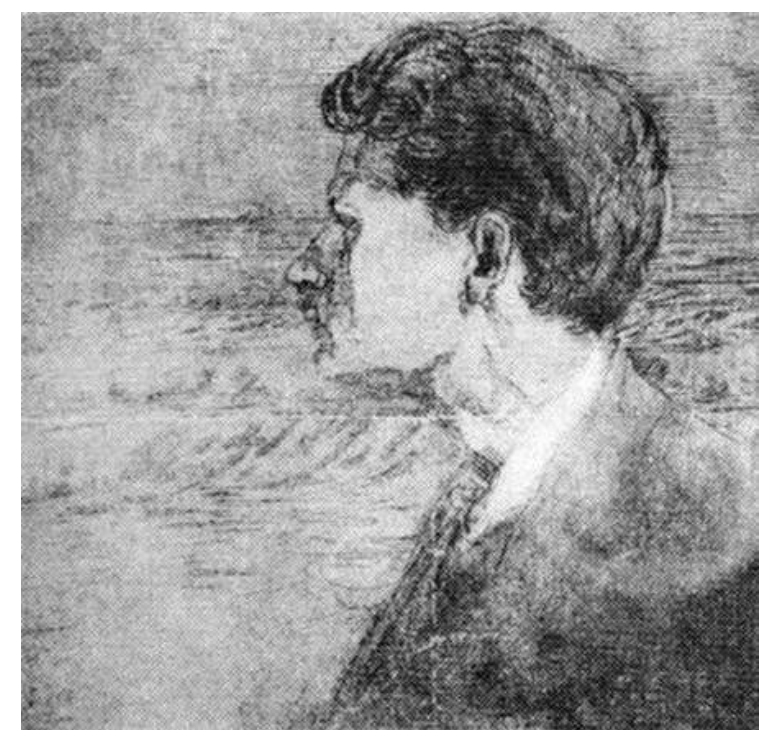

Fig. 6

6. TÍTULO: Autorretrato.

DATA: 1908. TÉCNICA: Água-forte. MEDIDAS: 16 x 16,7 cm (mancha); 31,6 x $21 \mathrm{~cm}$ (papel). IMPRESSÃO: em preto. ASSINATURA: "C. Oswald" no papel e também no canto inferior esquerdo da mancha. COLEÇÃO Museu Nacional de Belas Artes/IBRAM/MinC. PROVENIÊNCIA: Carlos Oswald, compra, 1963. FOTOGRAFIA: Acervo Museu Nacional de Belas Artes/IBRAM/MinC.

LITERATURA: Silva, 1969 (ref.). 


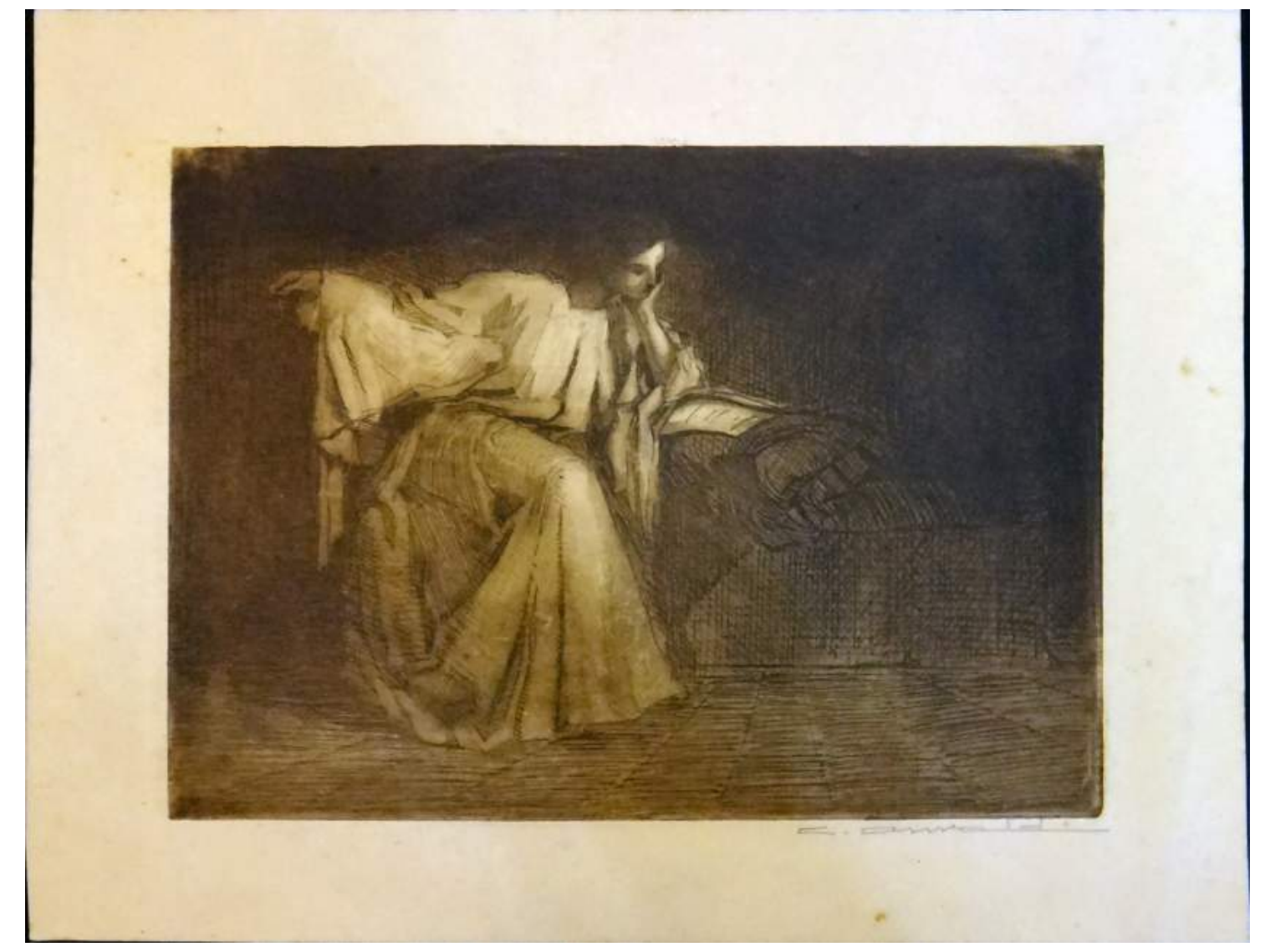

Fig. 7.A

7. TÍTULO: En lisant. VARIANTE: Lendo.

A. DATA: 1908. TÉCNICA: Água-forte. MEDIDAS: 18 x 24 cm (mancha). IMPRESSÃO: em marrom. MATRIZ: zinco. ASSINATURA: "C. Oswald” no canto inferior direito do papel. ACERVO Fundação Biblioteca Nacional. PROVENIÊNCIA: registrada no acervo em 1940.

B. DATA: 1908. TÉCNICA: Água-forte. MEDIDAS: 18 x 24 cm (mancha), 24,2 x 36,3 cm (papel). IMPRESSÃO: de época, em preto. MATRIZ: zinco. ASSINATURA: "C. Oswald" no canto inferior direito do papel. COLEÇÃO Museu Nacional de Belas Artes/IBRAM/MinC. PROVENIÊNCIA: Carlos Oswald, compra, 1963.

C. DATA: 1976. TÉCNICA: Água-forte. IMPRESSÃO: póstuma, em preto. MATRIZ: zinco. Sem assinatura. ACERVO Fundação Biblioteca Nacional. PROVENIÊNCIA: registrada no acervo em 1976. [Dois exemplares.].

D. [matriz] DATA: 1908. TÉCNICA: Água-forte. MATRIZ: zinco. ACERVO Fundação Biblioteca Nacional. PROVENIÊNCIA: registrada no acervo em 1976.

LITERATURA: Silva, 1969 (ref.). 


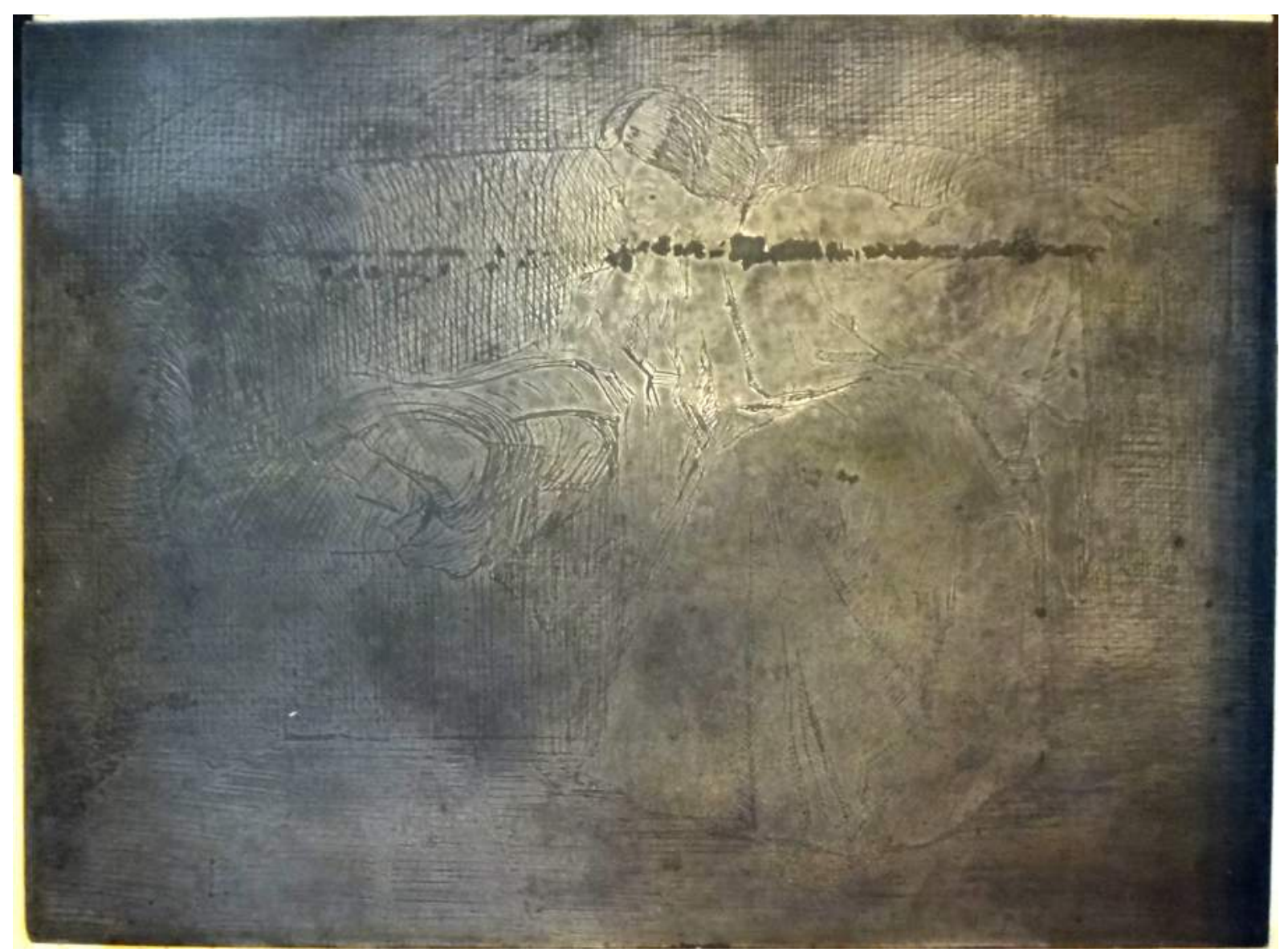

Fig. 7.D 


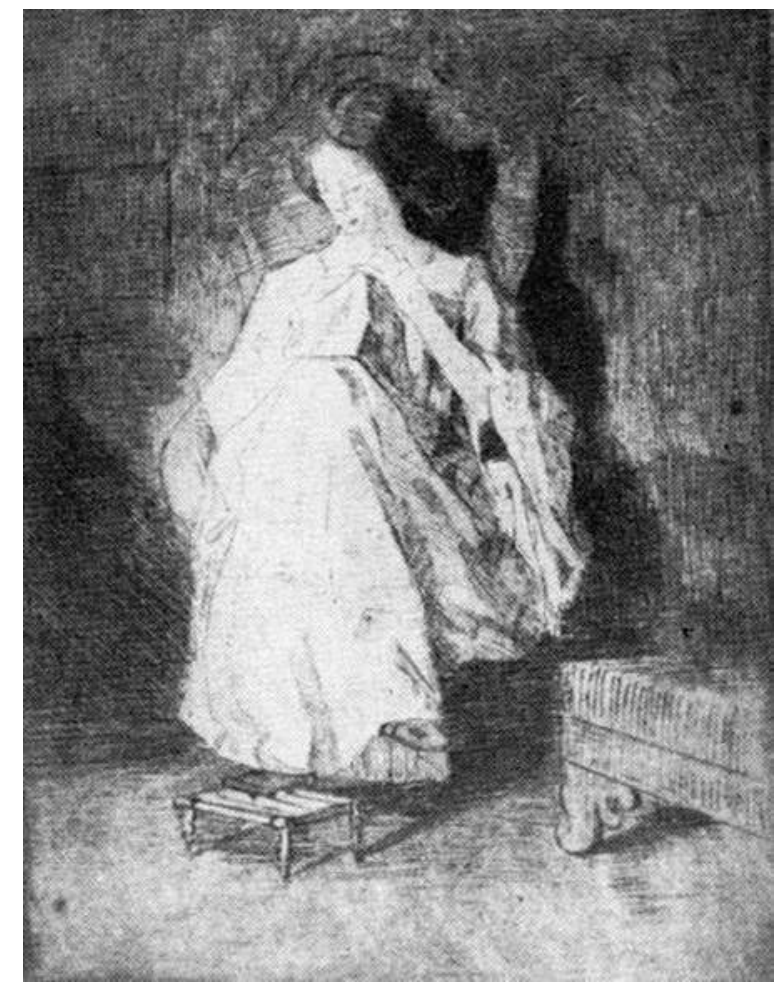

Fig. 8.A

8. TÍTULOS: Mulher bordando; Cosendo. VARIANTE: Bordando sozinha.

A. DATA: 1908. TÉCNICA: Água-forte. MEDIDAS: 19,7 x 15,1 cm (mancha), 23,1 x 18,5 cm (papel). IMPRESSÃO: em preto. MATRIZ: zinco. ASSINATURA: "C. Oswald” no canto inferior direito do papel. COLEÇÃO Museu Nacional de Belas Artes/IBRAM/MinC. PROVENIÊNCIA: Carlos Oswald, compra, 1963. FOTOGRAFIA: Acervo Museu Nacional de Belas Artes/IBRAM/MinC.

B. DATA: 1976. TÉCNICA: Água-forte. IMPRESSÃO: póstuma, em preto. MATRIZ: zinco. Sem assinatura. ACERVO Fundação Biblioteca Nacional. PROVENIÊNCIA: registrada no acervo em 1976. [Dois exemplares.].

C. [matriz] DATA: 1908. TÉCNICA: Água-forte. MATRIZ: zinco. ACERVO Fundação Biblioteca Nacional. PROVENIÊNCIA: registrada no acervo em 1976.

LITERATURA: Oswald, 1957, p. 206 (ref.); Silva, 1969 (ref.). 


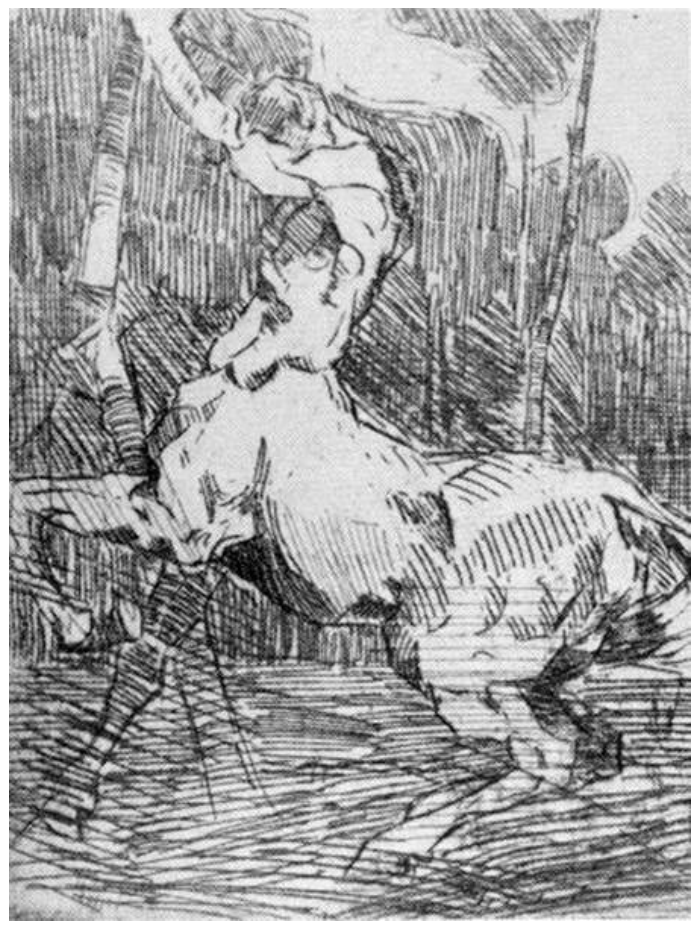

Fig. 9.A

9. TÍTULOS: O centauro; Centauro.

A. DATA: 1908. TÉCNICA: Água-forte. MEDIDAS: 19,5 x $15 \mathrm{~cm}$ (mancha), 27 x 21,6 cm (papel). IMPRESSÃO: em preto. MATRIZ: zinco. ASSINATURA: "C. Oswald” no papel. COLEÇÃO Museu Nacional de Belas Artes/IBRAM/MinC. PROVENIÊNCIA: Carlos Oswald, compra, 1963. FOTOGRAFIA: Acervo Museu Nacional de Belas Artes/IBRAM/MinC.

B. DATA: 1976. TÉCNICA: Água-forte. IMPRESSÃO: póstuma, em preto. MATRIZ: zinco. Sem assinatura. ACERVO Fundação Biblioteca Nacional. [Dois exemplares.]

C. [matriz] DATA: 1908. TÉCNICA: Água-forte. MATRIZ: zinco. Sem assinatura. ACERVO Fundação Biblioteca Nacional. PROVENIÊNCIA: registro no acervo em 1976.

LITERATURA: Oswald, 1957, p. 206 (ref.); Silva, 1969 (ref.). 

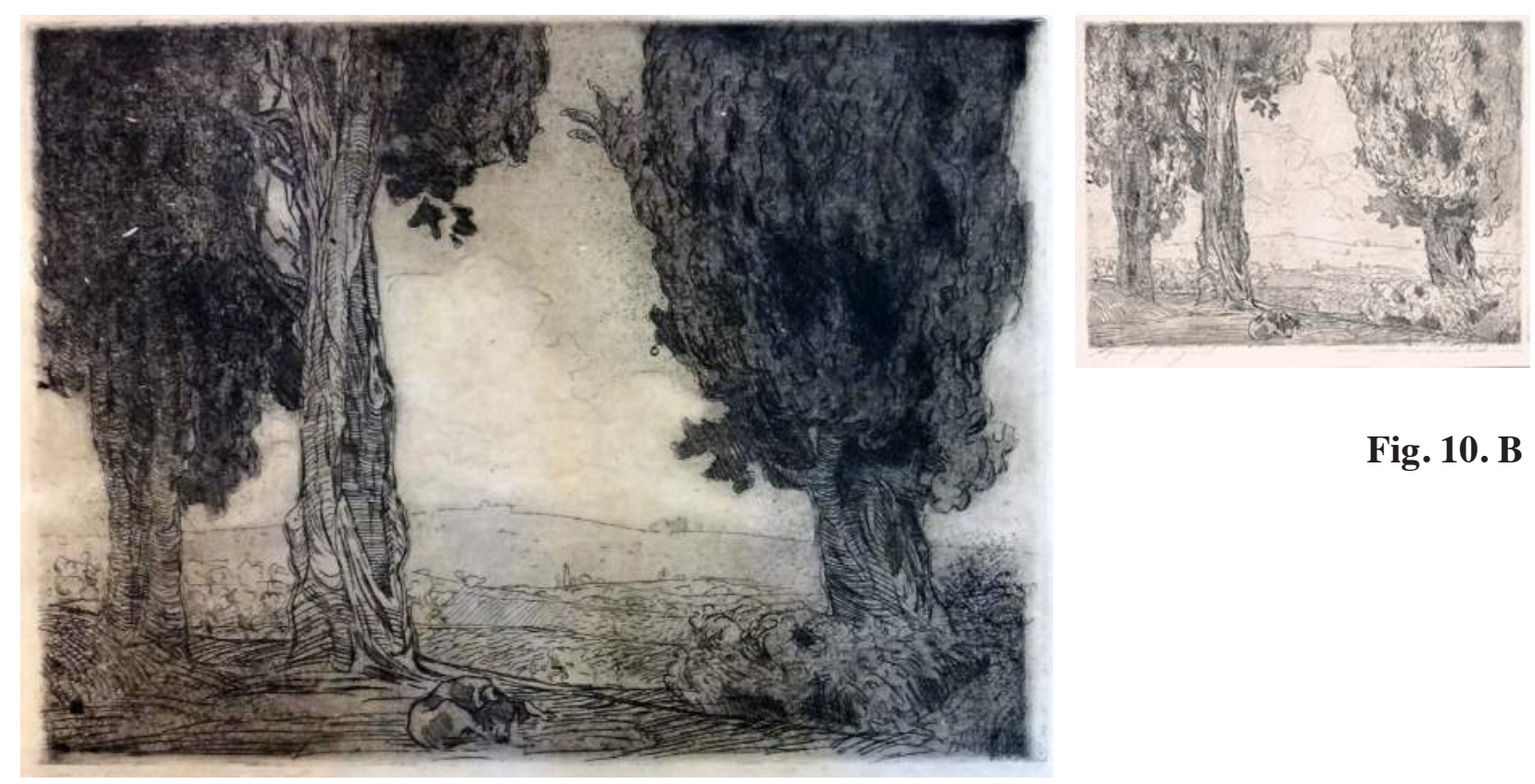

Fig. 10. B

Fig. 10. A

10. TÍTULO: Ciprestes. VARIANTE: Pirineus.

A. DATA: 1909. TÉCNICA: Água-forte. MEDIDAS: 18 x 24,5 cm (mancha), 28,5 x 45,5 cm (papel). IMPRESSÃO: em preto. ASSINATURA: “C. Oswald" no canto inferior esquerdo do papel. ACERVO Fundação Biblioteca Nacional. PROVENIÊNCIA: Carlos Oswald, compra, 1916.

B. DATA: 1909. TÉCNICA: Água-forte. MEDIDAS: 17,5 x $24 \mathrm{~cm}$ (mancha), 27 x $37 \mathrm{~cm}$ (papel). IMPRESSÃO: em preto. ASSINATURA: “C. Oswald” no canto inferior direito do papel. COLEÇÃO particular. FONTE: Evandro Carneiro Leiloeiro, disponível em: <http://www. evandrocarneiroleiloes.com/145675? artistId=88060> , acesso em 13/8/2017.

C. DATA: 1908. TÉCNICA: Água-forte. MEDIDAS: 17,8 x 24,2 cm (mancha); 28,7 x 37,2 cm (papel). IMPRESSÃO: em preto. ASSINATURA: "C. Oswald" no canto inferior direito do papel. COLEÇÃO Museu Nacional de Belas Artes/IBRAM/MinC. PROVENIÊNCIA: Carlos Oswald, compra, 1963.

LITERATURA: Felix, Illustração Brasileira, RJ, 1/6/1913, p. 181 (artigo); Illustração Brasileira, RJ, 4/1921, p. 26 (artigo); Oswald, 1957, p. 207 (ref., datada 1908); Silva, 1969 (ref., datada 1908); Exp. Carlos Oswald: o resgate de um mestre, Caixa Cultural, Brasília/Curitiba, 2011, p.16 (rep.). 


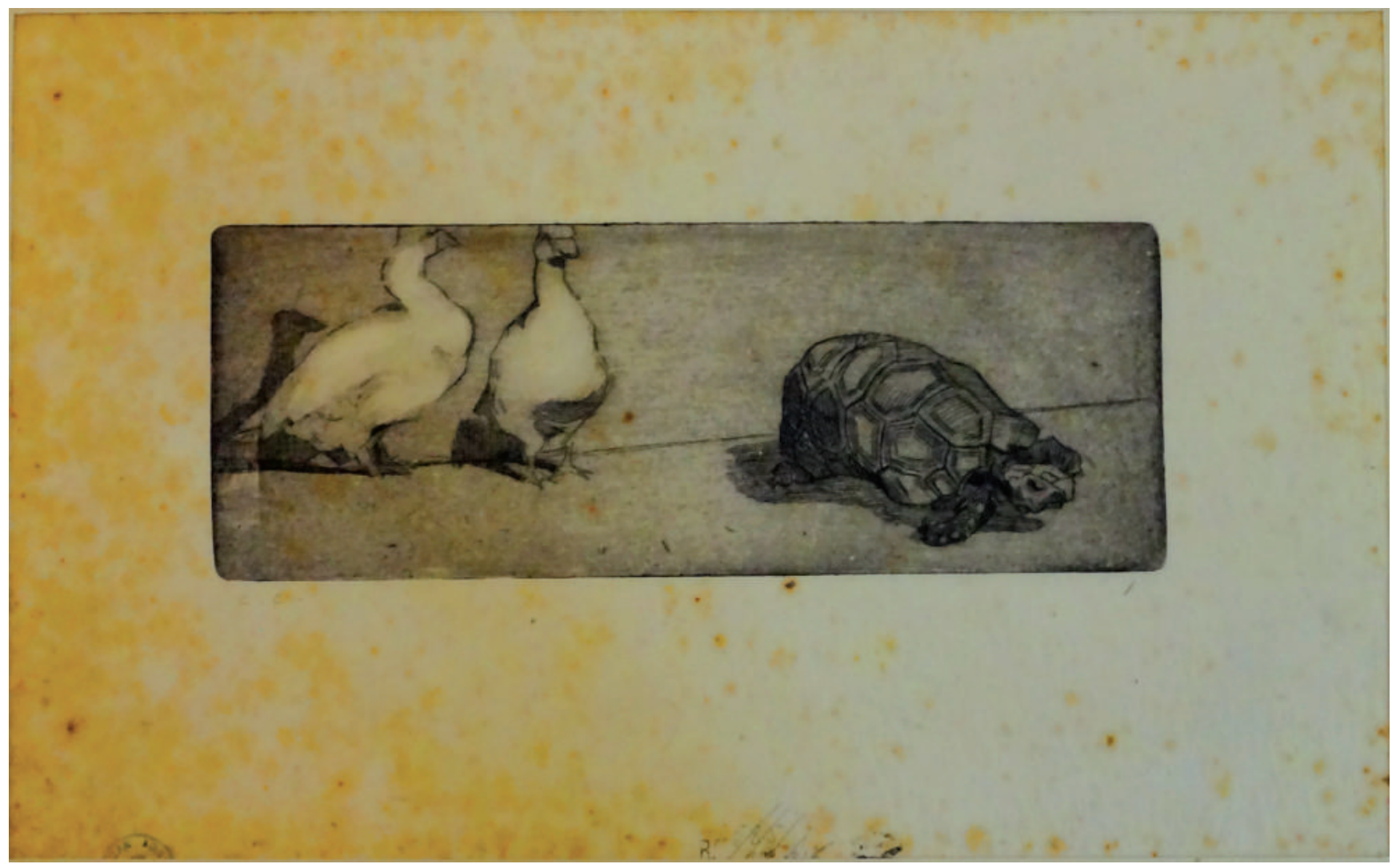

Fig. 11.A

11. TÍTULO: Contrastes. VARIANTE: Tartaruga e Patos.

A. DATA: 1909. TÉCNICA: Água-forte. MEDIDAS: 8 x 23cm (mancha). IMPRESSÃO: em preto. MATRIZ: zinco. ASSINATURA: monograma "CO" no canto inferior esquerdo do papel. ACERVO Fundação Biblioteca Nacional. PROVENIÊNCIA: Carlos Oswald, compra, 1916. B. DATA: 1908. TÉCNICA: Água-forte. MEDIDAS: 8,3 x 21,9 cm (mancha), 19,1 x 29,7 cm (papel). IMPRESSÃO: em preto. MATRIZ: zinco. ASSINATURA: "C. Oswald” no papel. COLEÇÃO Museu Nacional de Belas Artes/IBRAM/MinC. PROVENIÊNCIA: Carlos Oswald, compra, 1963.

C. DATA: 1976. TÉCNICA: Água-forte. IMPRESSÃO: póstuma, em preto. MATRIZ: zinco. ACERVO Fundação Biblioteca Nacional. PROVENIÊNCIA: registrada no acervo em 1976. [Três exemplares].

D. [matriz] DATA: 1908. TÉCNICA: Água-forte. MATRIZ: zinco. ACERVO Fundação Biblioteca Nacional. PROVENIÊNCIA: registrada no acervo em 1975.

LITERATURA: Silva, 1969 (ref., datada 1908). 


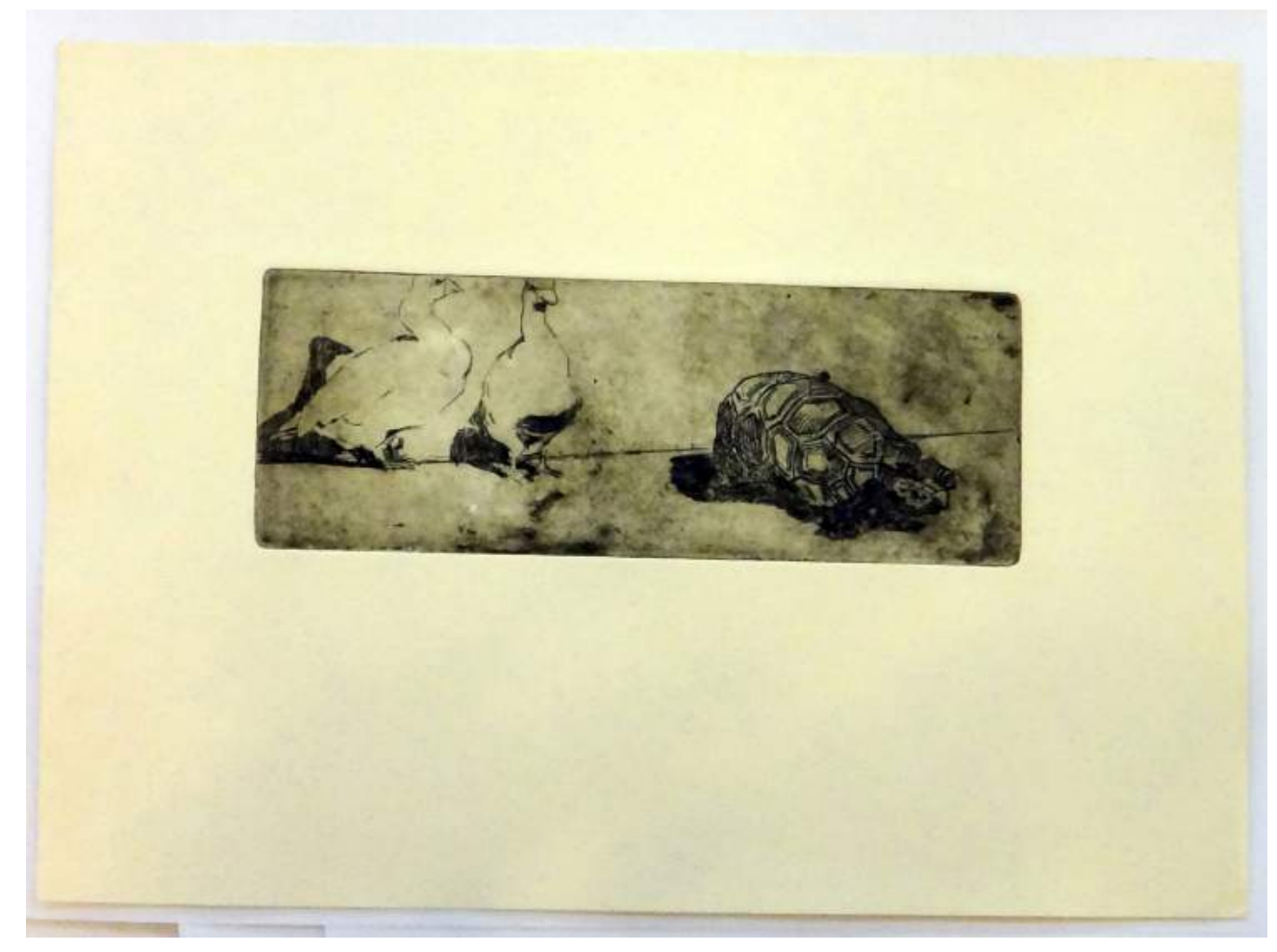

Fig. 11.C

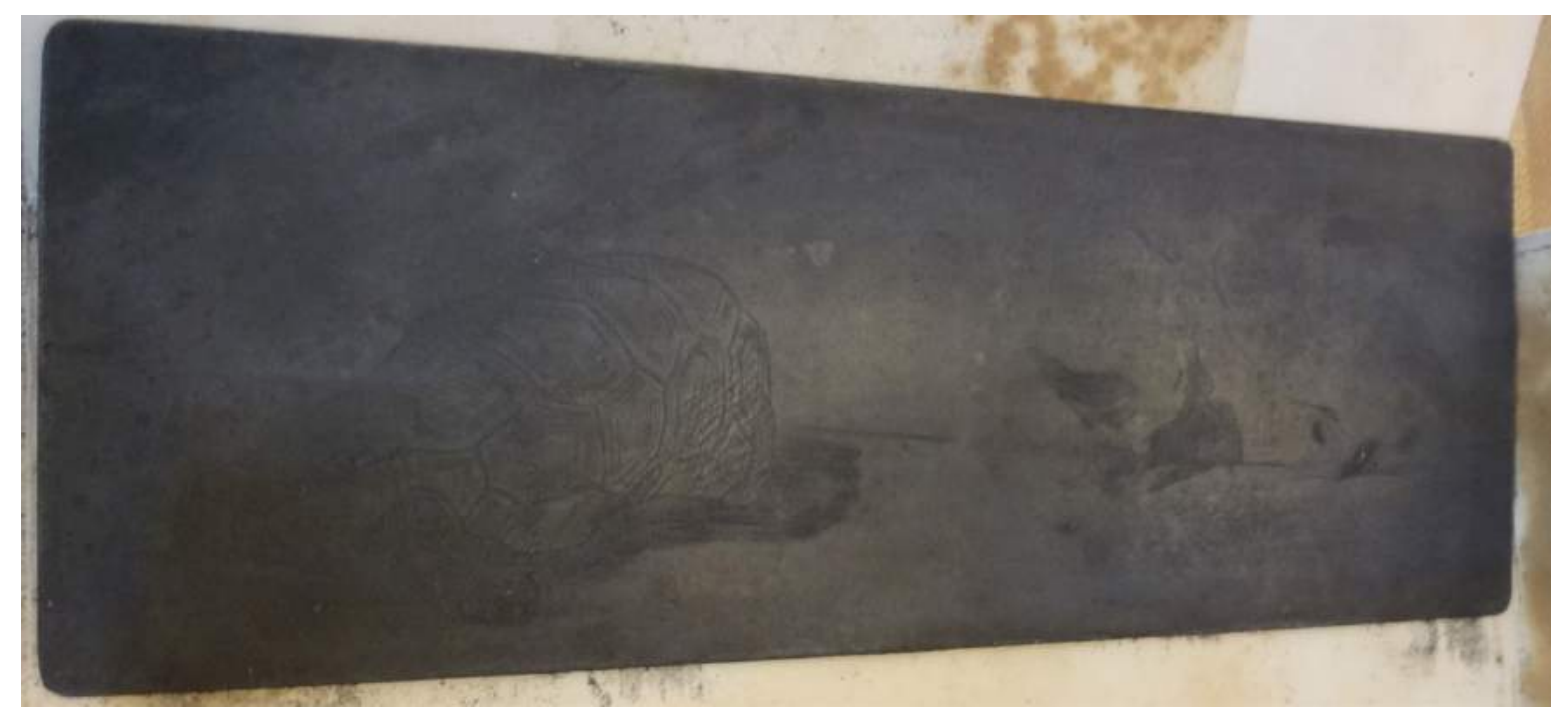

Fig. 11.D 


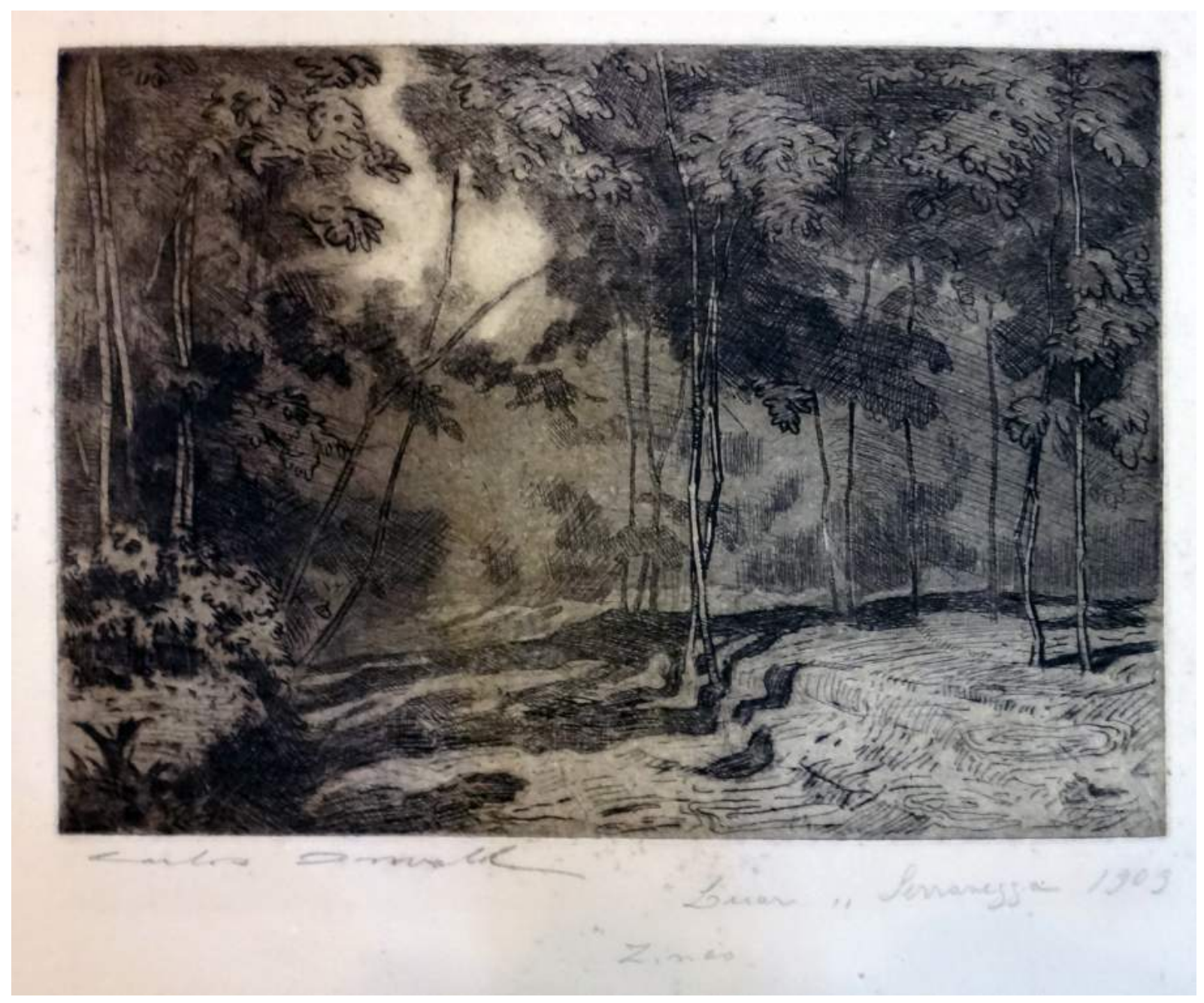

Fig. 12.A

12. TÍTULOS: Luar; Um bosque.

A. DATA: 1909. TÉCNICA: Água-Forte. MEDIDAS: 17,1 x 25 cm (mancha), 33 x 47,5 (papel). IMPRESSÃO: em preto. ASSINATURA: "C. Oswald" no canto inferior esquerdo do papel. ACERVO Fundação Biblioteca Nacional. PROVENIÊNCIA: Carlos Oswald, compra, 1916.

B. DATA: 1908. TÉCNICA: Água-Forte. MEDIDAS: 17,7 x 24,9 cm (mancha); 25 x 35,1 cm (papel). IMPRESSÃO: em preto. ASSINATURA: "C. Oswald" no canto inferior direito do papel. COLEÇÃO Museu Nacional de Belas Artes/IBRAM/MinC. PROVENIÊNCIA: Carlos Oswald, compra 1963.

LITERATURA: Oswald, 1957, p.206 (ref.); Silva, 1969 (ref.); Exp. Carlos Oswald: o resgate de um mestre, Caixa Cultural, Brasília/Curitiba, 2011, p.17 (rep.); Exp. Gravura: Arte Brasileira do Século XX, Itaú Cultural, São Paulo, 2000, p. 39 (rep.). 

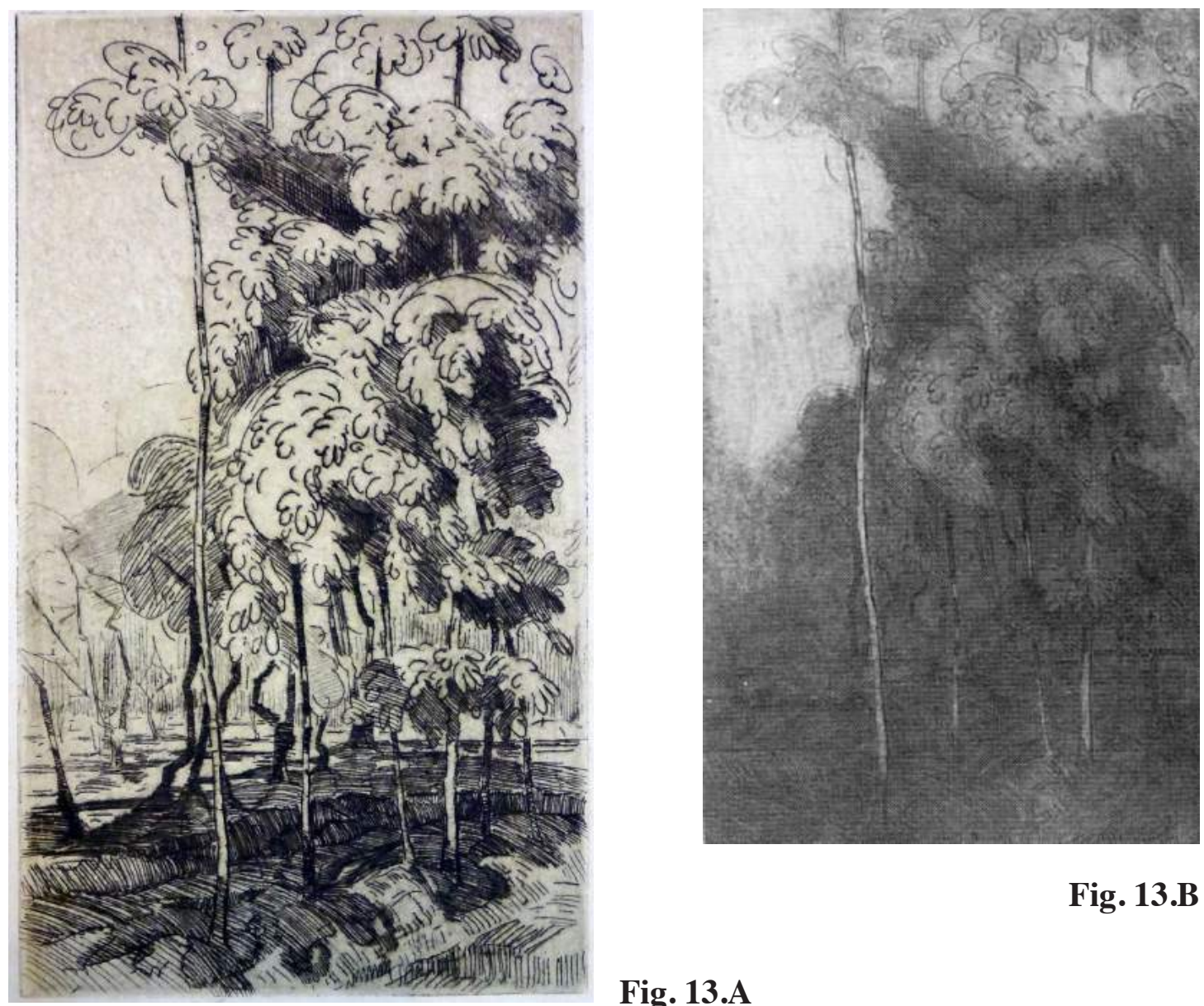

Fig. 13.B

Fig. 13.A

13. TÍTULO: Estudo de árvores. VARIANTE: Árvores; Florentinas.

A. DATA: 1909. TÉCNICA: Água-Forte. MEDIDAS: 24 x 14 cm (mancha), 39,7 x 28,4 cm (papel). IMPRESSSÃO: em preto. MATRIZ: zinco. ASSINATURA: "C. Oswald” no canto inferior esquerdo do papel. ACERVO Fundação Biblioteca Nacional. PROVENIÊNCIA: Carlos Oswald, compra, 1916.

B. DATA: 1909. TÉCNICA: Água-forte. MEDIDAS: 23,7 x 13,9 cm (mancha), 32,6 x 28,1 cm (papel). IMPRESSÃO: em preto. MATRIZ: zinco. ASSINATURA: “C. OSWALD” no canto inferior direito do papel. COLEÇÃO Museu Nacional de Belas Artes/IBRAM/MinC. PROVENIÊNCIA: Carlos Oswald, compra, 1963. FOTOGRAFIA: Acervo Museu Nacional de Belas Artes/IBRAM/MinC.

C. DATA: 1975. TÉCNICA: Água-Forte. IMPRESSSÃO: póstuma, em preto. MATRIZ: zinco. ACERVO Fundação Biblioteca Nacional. PROVENIÊNCIA: registrada no acervo em 1975. [Dois exemplares.]

D. [matriz] DATA: 1909. TÉCNICA: Água-Forte. MATRIZ: zinco. ACERVO Fundação Biblioteca Nacional. Sem assinatura. PROVENIÊNCIA: registrada no acervo em 1975.

LITERATURA: Silva, 1969 (ref.). 


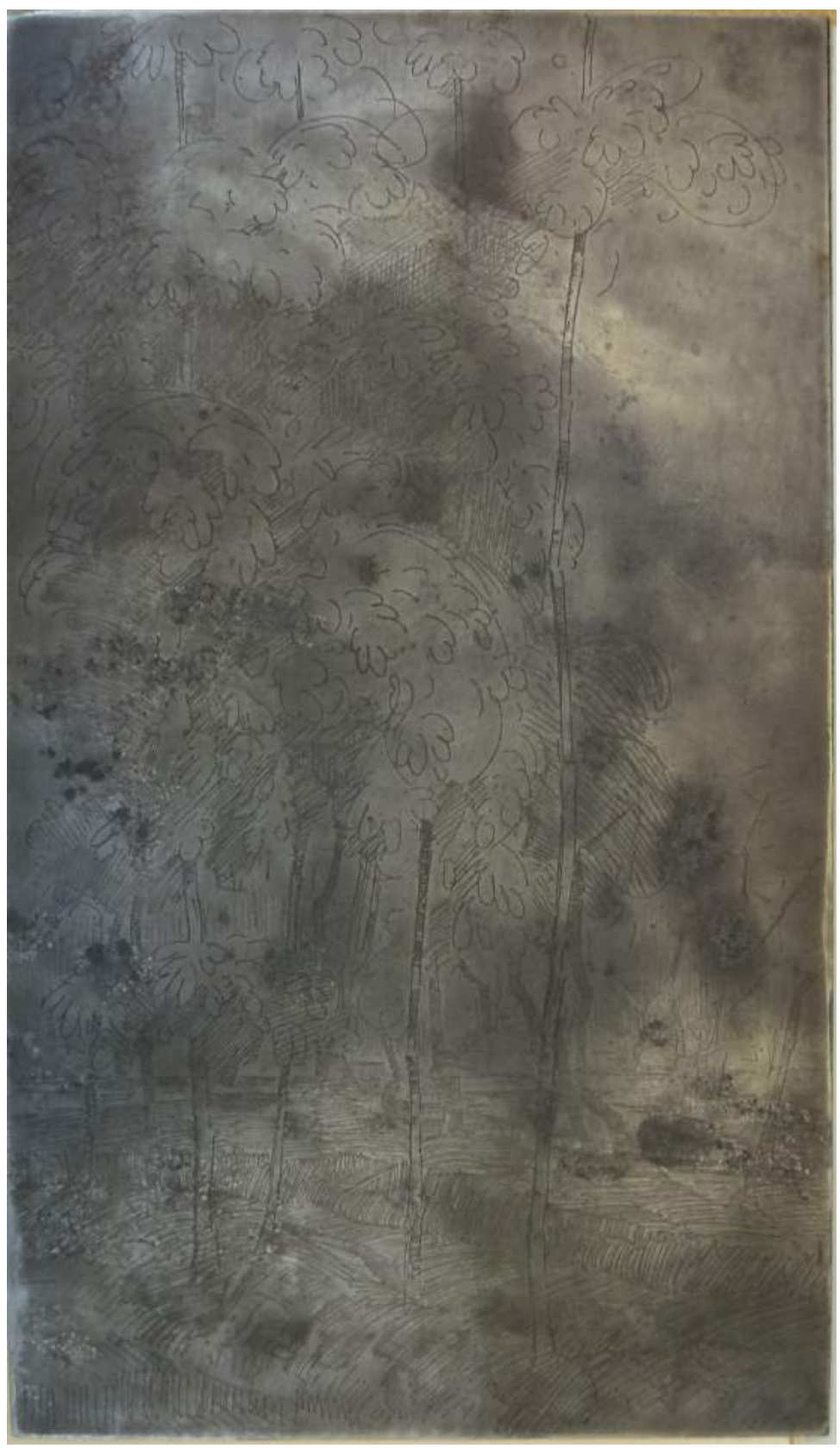

Fig. 13.D 

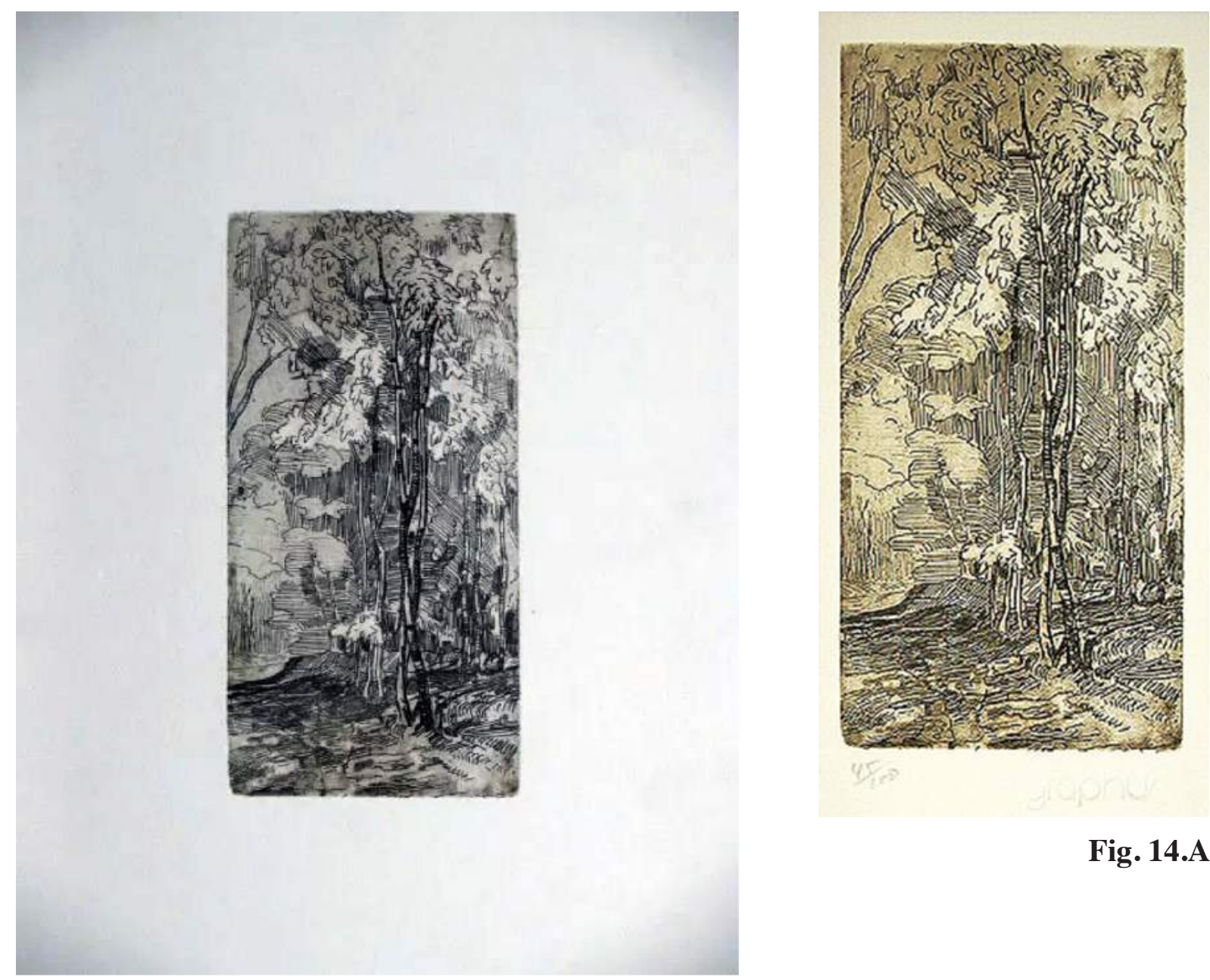

Fig. 14.A

Fig. 14.B

14. [Sem título]. VARIANTE: Bosque. [Obra provável de 1909/1910]

A. DATA: 1979. TÉCNICA: Água-forte. IMPRESSÃO: póstuma, em marrom, por Marcello Grassmann e Roberto Grassmann. Sem assinatura. FONTE: Carlos Oswald: gravuras, Graphus, 1979.

B. DATA: 1979. TÉCNICA: Água-forte. IMPRESSÃO: póstuma, em preto. Sem assinatura. FONTE: Mercado Livre, disponível em: < https://produto.mercadolivre.com.br/MLB889906252-carlos-oswald-gravura-quadro-arte-moderna-brasileira-2-_JM\#redirectedFromParent>, acesso em: 24/8/2017.

LITERATURA: Buti, Letycia, 2000, p. 61 (rep.). 


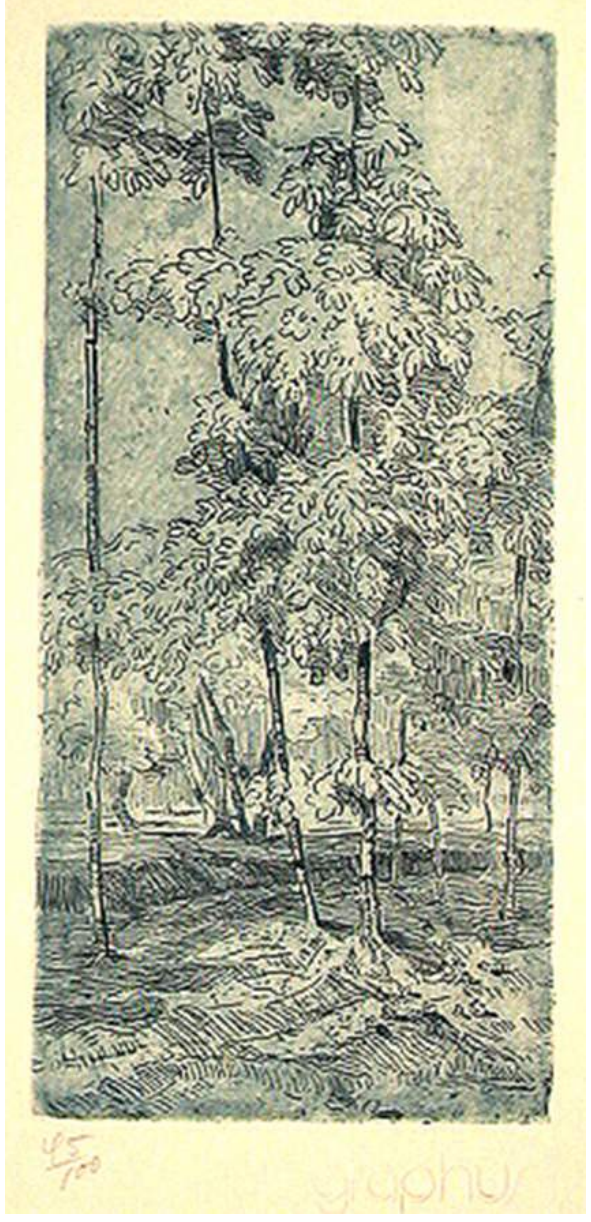

Fig. 15

15. [Sem título]. [Obra provável de 1909/1910]

DATA: 1979. TÉCNICA: Água-forte. MEDIDAS: 21,2 x 9,8 cm. IMPRESSÃO: póstuma, em azul, por Marcello Grassmann e Roberto Grassmann. Sem assinatura. FONTE: Carlos Oswald: gravuras, Graphus, 1979.

LITERATURA: Buti, Letycia, 2000, p. 65 (rep.). 


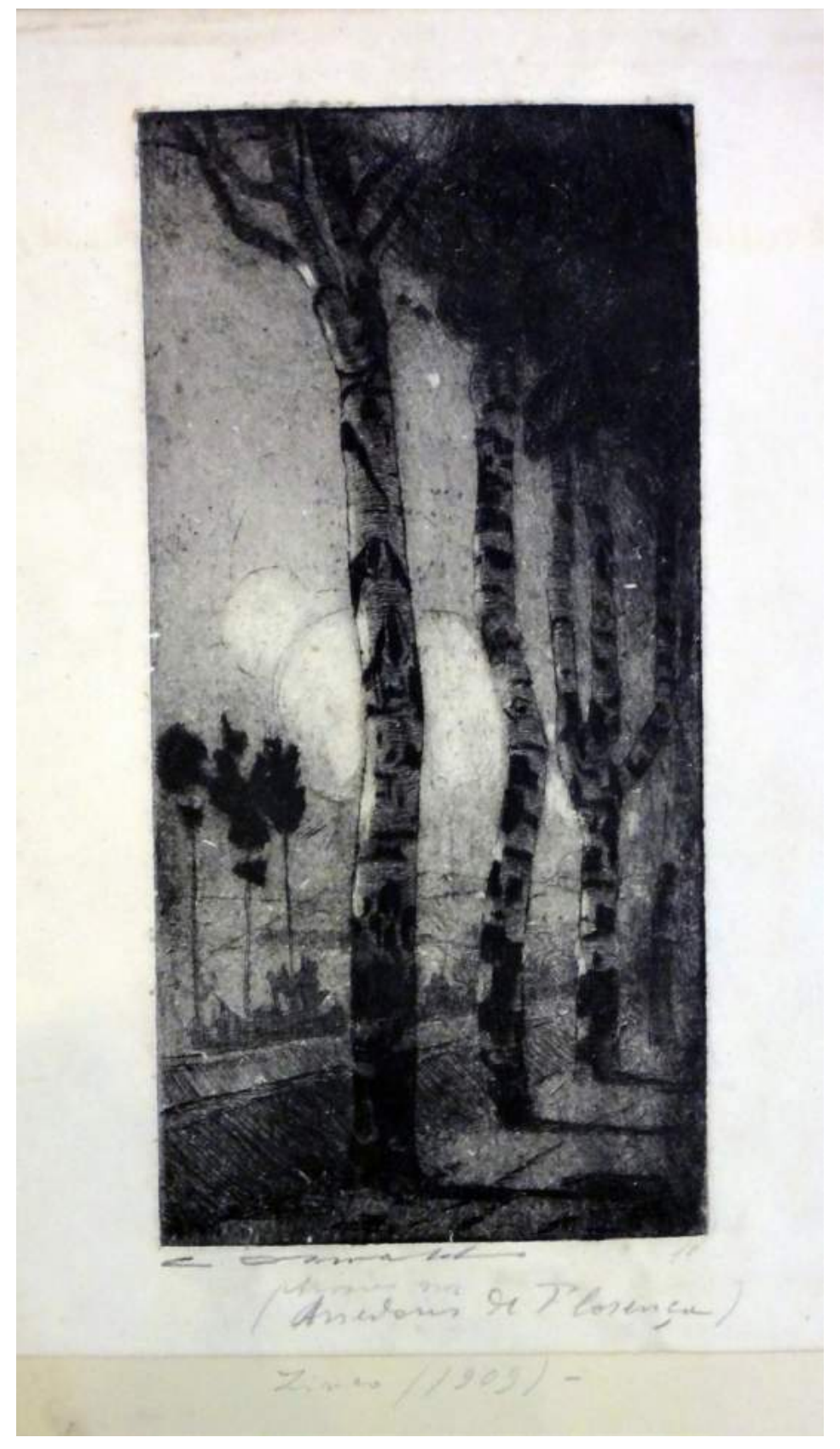

Fig. 16.A

16. TÍTULO: Árvores nos arredores de Florença. VARIANTE: Árvores em Florença.

A. DATA: 1909. TÉCNICA: Água-forte e água-tinta. MEDIDAS: 25 x 12cm (mancha), 43,5 x 30,5 cm (papel). IMPRESSÃO: em preto. MATRIZ: zinco. MEDIDAS DA MATRIZ: 25,1 x 13,2 cm. ASSINATURA: "C. Oswald" no canto inferior esquerdo do papel. ACERVO Fundação Biblioteca Nacional. PROVENIÊNCIA: registrada no acervo em 1916.

B. DATA: 1979. TÉCNICA: Água-forte e água-tinta. IMPRESSÃO: póstuma, em azul, por Marcello Grassmann e Roberto Grassmann. MATRIZ: zinco. MEDIDAS DA MATRIZ: 25,1 x 13,2 cm. Sem assinatura. FONTE: Carlos Oswald: gravuras, Graphus, 1979.

C. DATA: 1979. TÉCNICA: Água-forte e água-tinta. IMPRESSÃO: póstuma, em laranja, por 

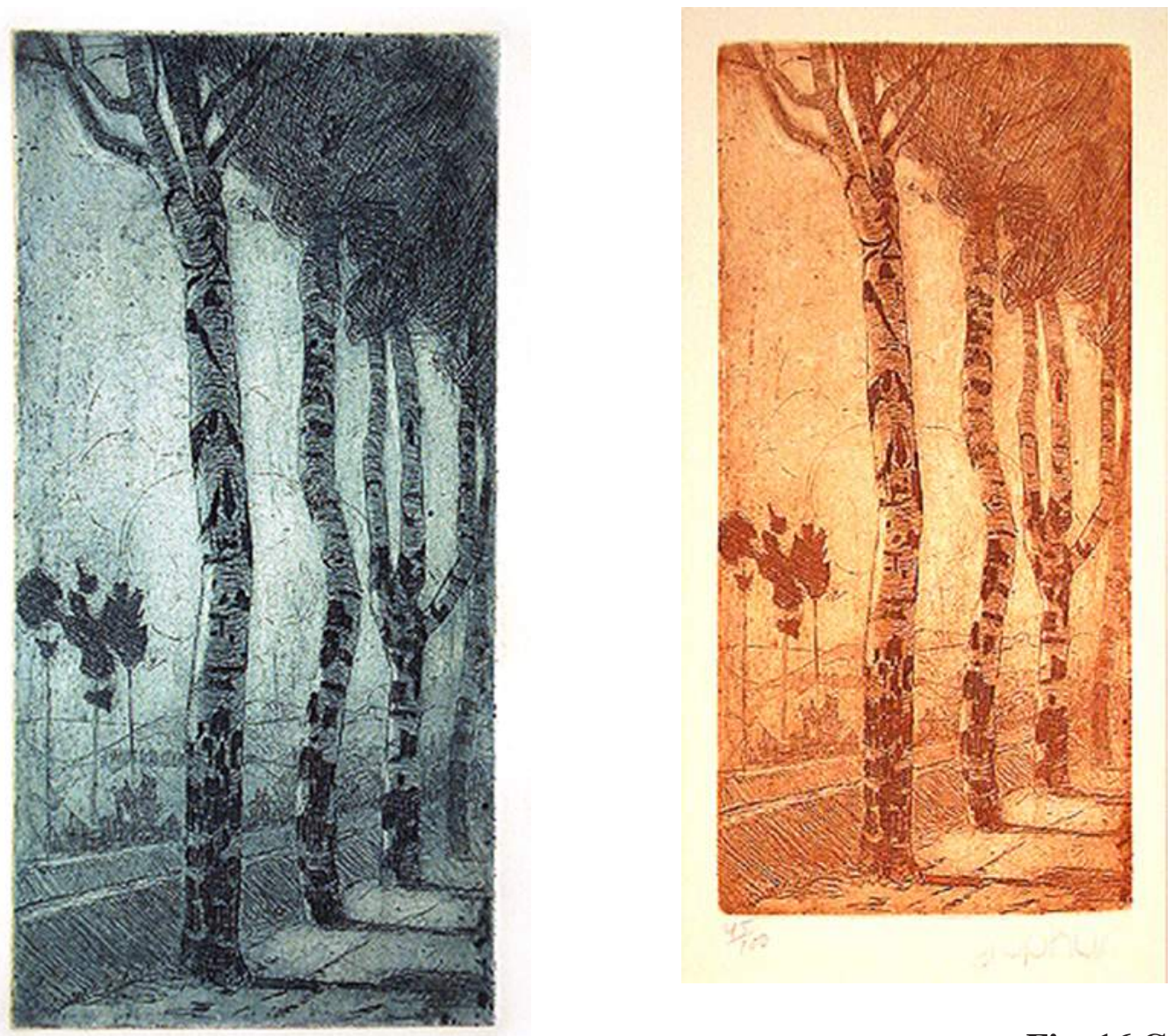

Fig. 16.C

Fig. 16.B

Marcello Grassmann e Roberto Grassmann. MATRIZ: zinco. MEDIDAS DA MATRIZ: 25,1 x 13,2 cm. Sem assinatura. FONTE: Carlos Oswald: gravuras, Graphus, 1979.

D. [matriz] DATA: 1909. TÉCNICA: Água-forte e água-tinta. MATRIZ: zinco. MEDIDAS DA MATRIZ: 25,1 x 13,2 cm. Sem assinatura. COLEÇÃO Museu Nacional de Belas Artes/ IBRAM/MinC. PROVENIÊNCIA: Maria Isabel Oswald Monteiro, doação, 1982. [Com a obra "Um nu" gravada no verso].

LITERATURA: Silva, 1969 (ref.); Buti, Letycia, 2000, p. 63 (rep.). 
17. TÍTULO: Um nu. [Não se conhece a impressão da obra]

[matriz] DATA: 1909. TÉCNICA: Água-forte. MATRIZ: zinco. MEDIDAS DA MATRIZ: 25,1 x 13,2 cm. Sem assinatura. COLEÇÃO Museu Nacional de Belas Artes/IBRAM/MinC. PROVENIÊNCIA: Maria Isabel Oswald Monteiro, doação, 1982. Com a obra "Árvores nos arredores de Florença” gravada no verso. FONTE: Museu Nacional de Belas Artes.

LITERATURA: Silva, 1969 (ref.).

18. TÍTULO: Paisagem de Florença [Não se conhece a impressão da obra]

[matriz] DATA: 1909. TÉCNICA: Água-forte. MATRIZ: zinco. MEDIDAS DA MATRIZ: 24,8 x 15,7 cm. Sem assinatura. COLEÇÃO Museu Nacional de Belas Artes/IBRAM/MinC. PROVENIÊNCIA: Maria Isabel Oswald Monteiro, doação, 1982. Com a obra "Na praça da Signoria" gravada no verso. FONTE: Museu Nacional de Belas Artes.

LITERATURA: Silva, 1969 (ref.).

19. TíTULO: Mulher estudando [?]. [Não se conhece a impressão da obra]

TÉCNICA: Água-forte. MATRIZ: zinco. Sem assinatura. ACERVO Fundação Biblioteca Nacional. PROVENIÊNCIA: registrada no acervo em 1976. [Obra gravada no verso de "O centauro"]. FONTE: Fundação Biblioteca Nacional. 


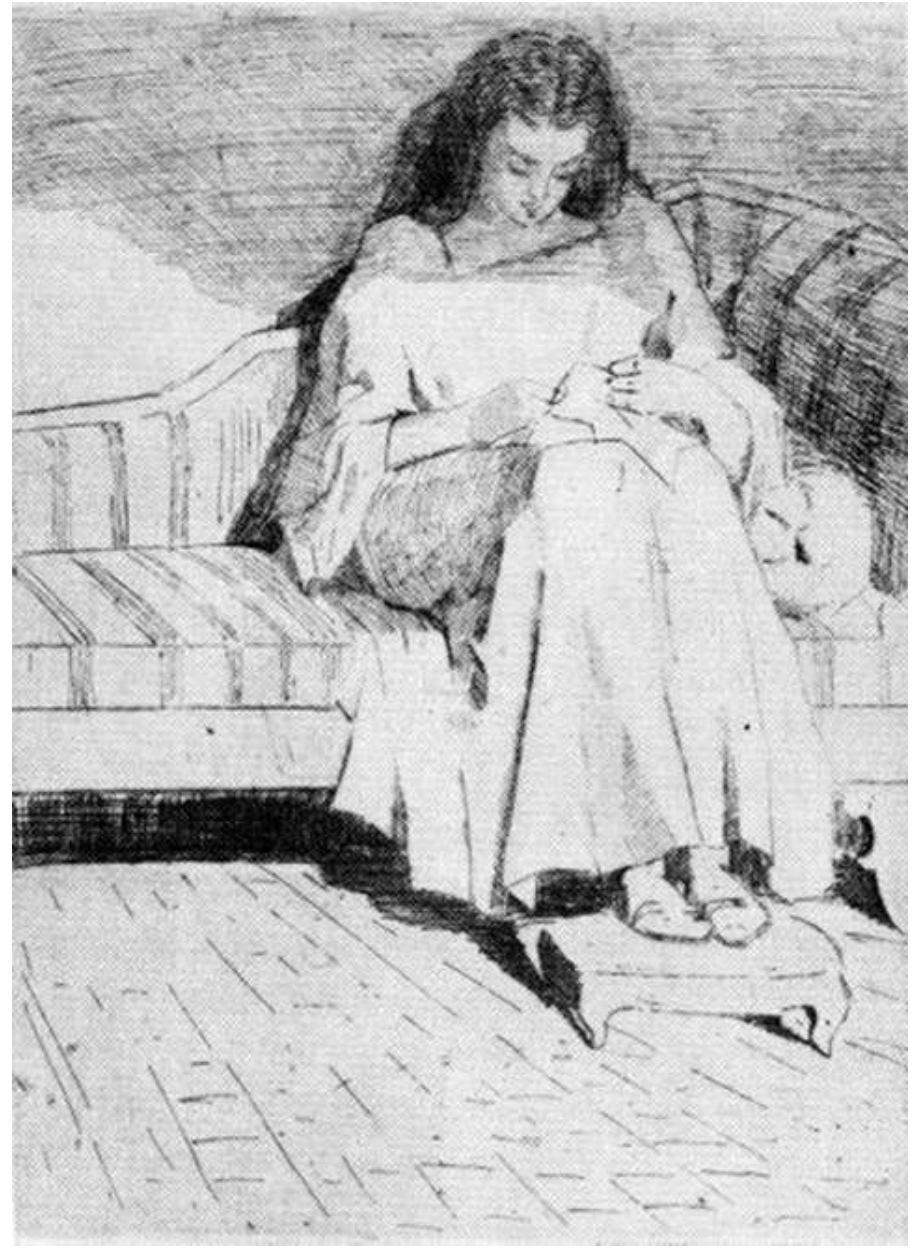

Fig. 20

20. TÍTULO: En cousant. VARIANTE: Costurando.

DATA: 1909. TÉCNICA: Água-forte. MEDIDAS: 24 x 17,7 cm (mancha), 36,1 x 24,1 cm (papel). IMPRESSÃO: em preto. ASSINATURA: "C. Oswald" no papel. COLEÇÃO Museu Nacional de Belas Artes/IBRAM/MinC. PROVENIÊNCIA: Carlos Oswald, compra, 1963. FOTOGRAFIA: Acervo Museu Nacional de Belas Artes/IBRAM/MinC.

LITERATURA: Amador, Jornal do Brasil, RJ, 4/9/1909 (nota expo.); Silva, 1969 (ref.). 


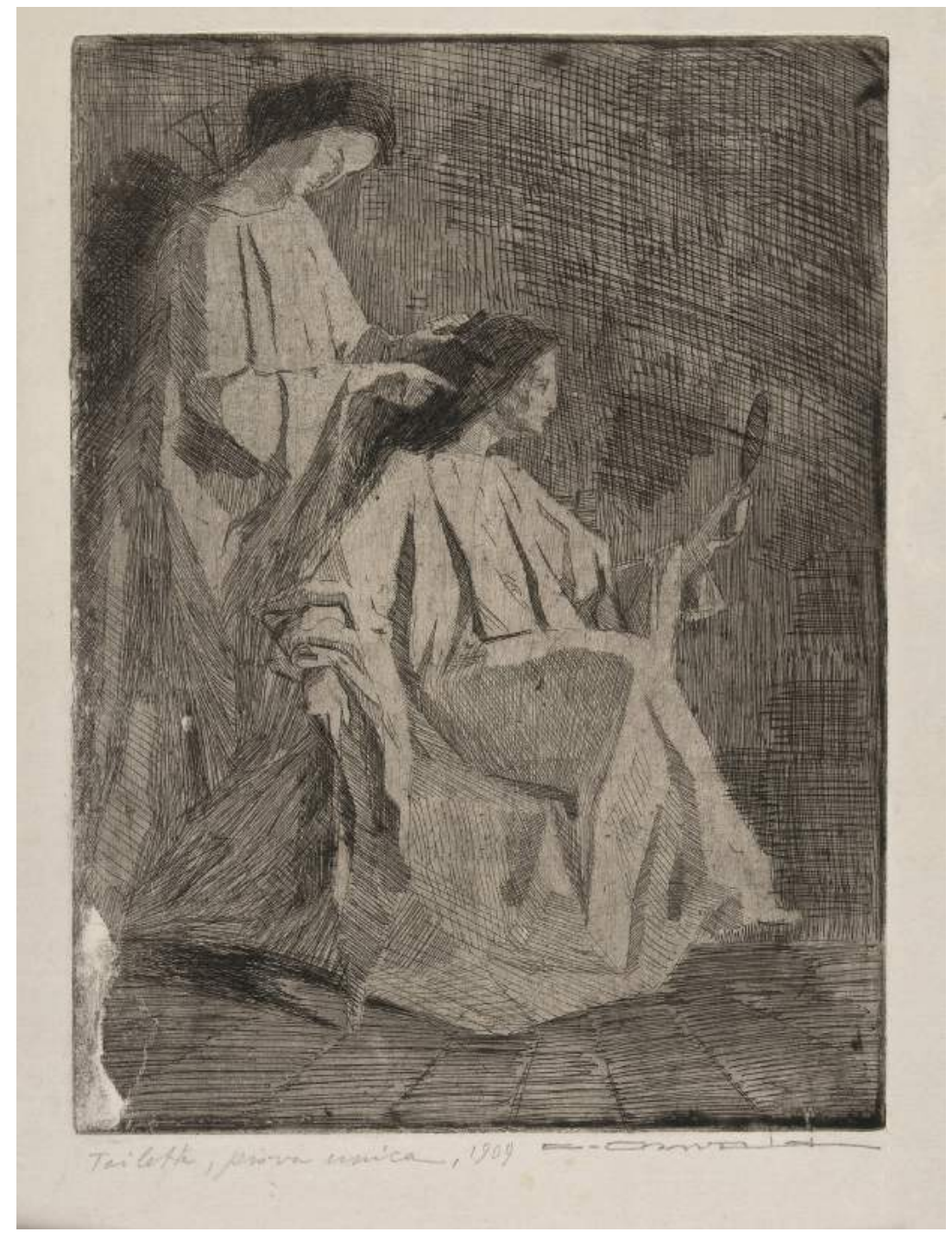

Fig. 21.A

21. TÍTULO: Toilette. VARIANTES: Toalete; Moças se penteando.

A. DATA: 1909. TÉCNICA: Água-forte. MEDIDAS: 24,7 x 18,1 cm (mancha); 35 x 27,2 cm (papel). IMPRESSÃO: em preto. MATRIZ: zinco. MEDIDAS DA MATRIZ: 24 x $18 \mathrm{~cm}$. ASSINATURA: "C. Oswald" no canto inferior direito do papel. COLEÇÃO Museu Nacional de Belas Artes/IBRAM/MinC. PROVENIÊNCIA: Carlos Oswald, compra, 1963. FOTOGRAFIA: Acervo Museu Nacional de Belas Artes/IBRAM/MinC.

B. [matriz] DATA: 1909. TÉCNICA: Água-forte. MATRIZ: zinco. MEDIDAS DA MATRIZ: 24 x $18 \mathrm{~cm}$. Sem assinatura. COLEÇÃO Museu Nacional de Belas Artes/IBRAM/MinC. PROVENIÊNCIA: Maria Isabel Oswald Monteiro, doação, 1982.

LITERATURA: Amador, Jornal do Brasil, RJ, 4/9/1909 (artigo expo.); Silva, 1969 (ref.); Exp. Carlos Oswald: o resgate de um mestre, Caixa Cultural, Brasília/Curitiba, 2011, p. 28 (rep.). 


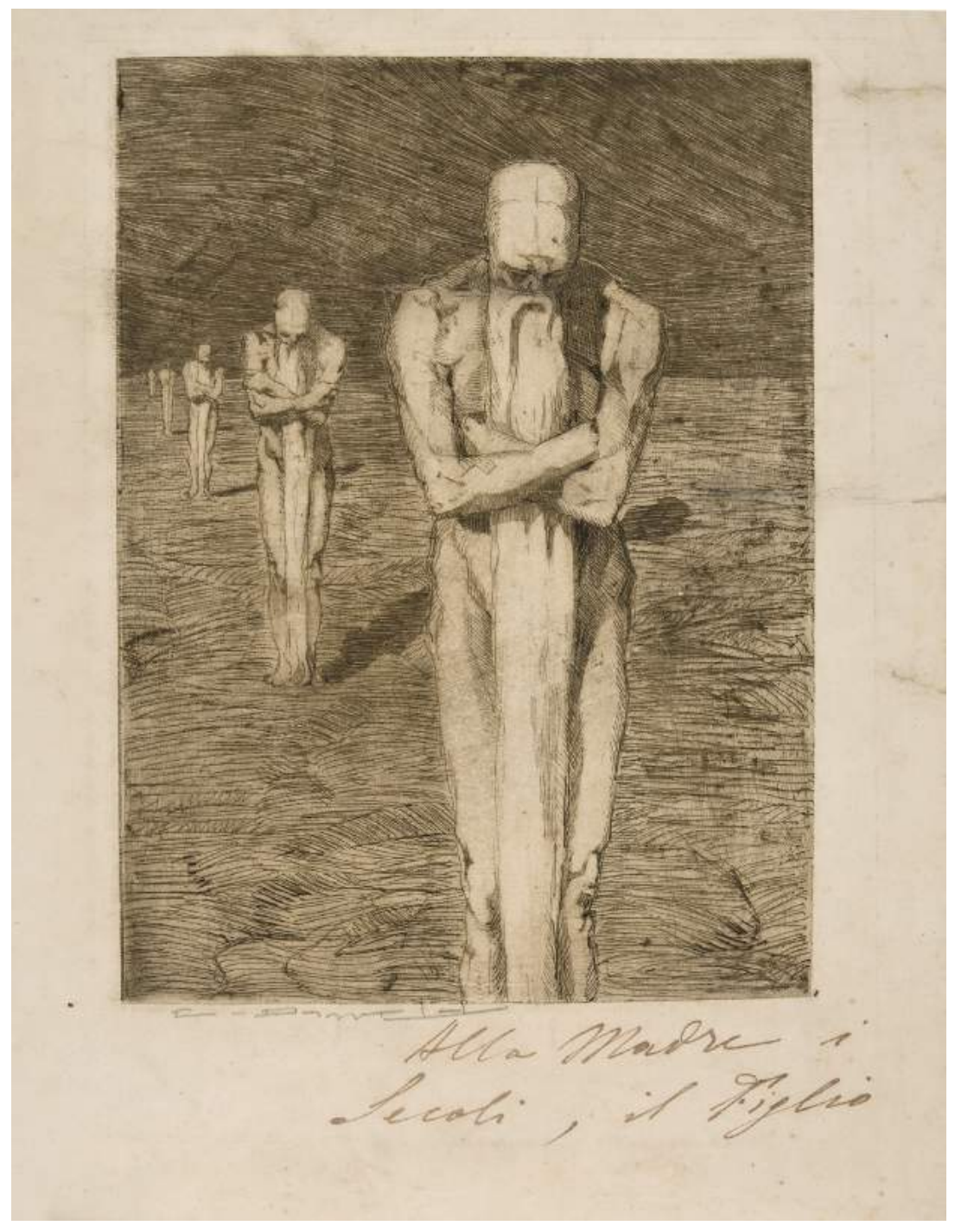

Fig. 22

22. TÍTULO: Alla madre i secoli, il figlio [A mãe os séculos, o filho]. VARIANTE: Os séculos.

DATA: 1909[?]. TÉCNICA: Água-forte. MEDIDAS: 24,5 x 26,5 cm (mancha), 38 x 26,5 cm (papel). IMPRESSÃO: em preto. ASSINATURA: "C. Oswald" no canto inferior esquerdo do suporte. COLEÇÃO Museu Nacional de Belas Artes/IBRAM/MinC. PROVENIÊNCIA: Carlos Oswald, compra, 1963. FOTOGRAFIA: Acervo Museu Nacional de Belas Artes/IBRAM/ MinC.

LITERATURA: Amador, Jornal do Brasil, RJ, 4/9/1909 (artigo expo.); Silva, 1969 (ref.); Exp. Carlos Oswald: o resgate de um mestre, Caixa Cultural, Brasília/Curitiba, 2011, p. 31 (rep.). 


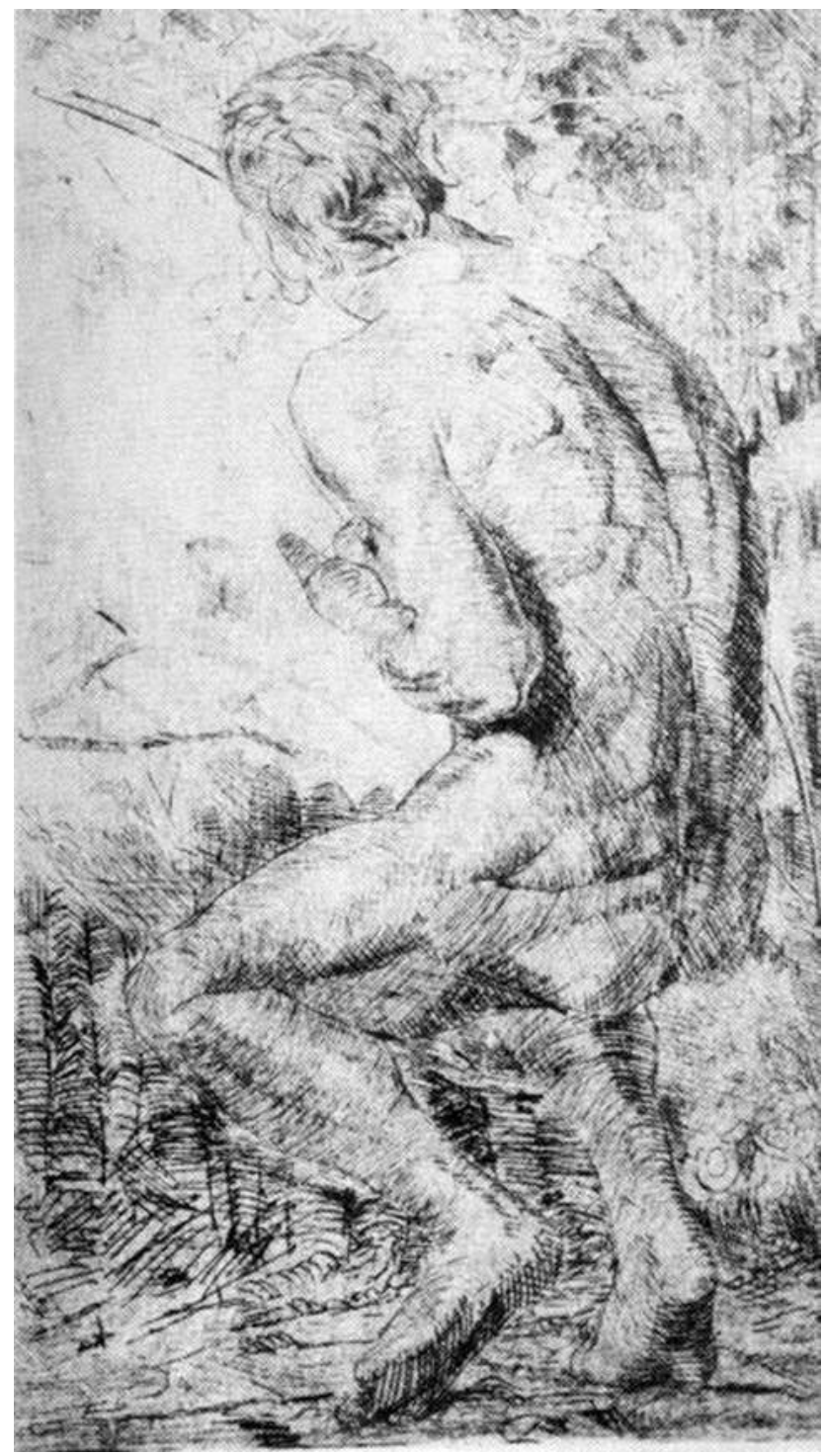

Fig. 23

23. TÍTULO: [Fauno]. VARIANTE: Fauno.

DATA: 1909. TÉCNICA: Água-forte. MEDIDAS: 22 x 17,5 cm (mancha), 29,2 x 22 cm (papel). IMPRESSÃO: em preto. ASSINATURA: "C. Oswald" no canto inferior direito do papel. COLEÇÃO Museu Nacional de Belas Artes/IBRAM/MinC. PROVENIÊNCIA: Carlos Oswald, compra, 1963. FOTOGRAFIA: Acervo Museu Nacional de Belas Artes/IBRAM/MinC.

LITERATURA: Silva, 1969 (ref.). 


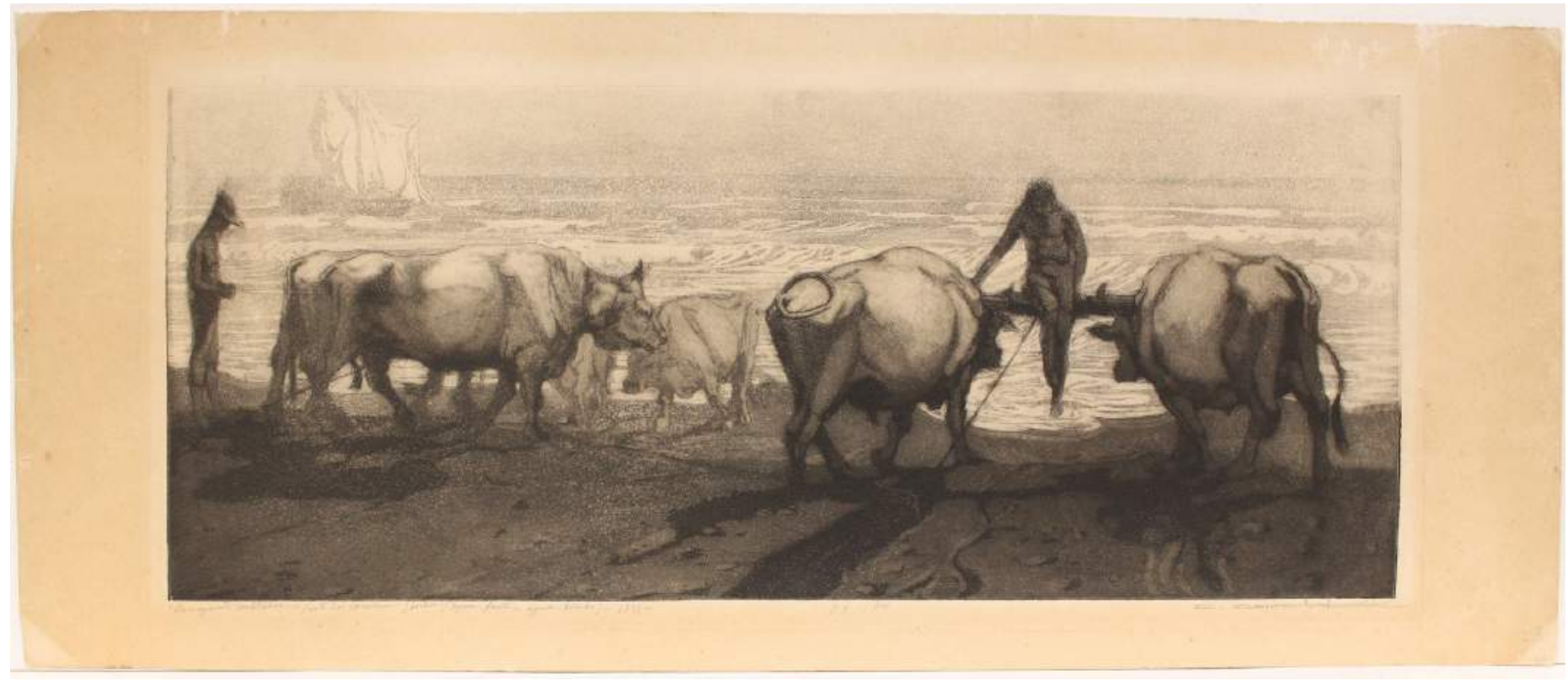

Fig. 24.A

24. TÍTULOS: Bois carregando madeiras na praia da Toscana, Itália; Carregando madeiras. VARIANTES: Bois carregando madeira; Na praia do Tirreno; Bois à beira do mar.

A. DATA: 1909. TÉCNICA: Água-forte e água-tinta. MEDIDAS: 22,2 x 54,4 cm (mancha); 28,6 x 68 cm (papel). IMPRESSÃO: em preto. MATRIZ: zinco. MEDIDAS DA MATRIZ: 22,5 x $42 \mathrm{~cm}$. ASSINATURA: "C. Oswald" no canto inferior direito do papel. COLEÇÃO Museu Nacional de Belas Artes/IBRAM/MinC. PROVENIÊNCIA: Carlos Oswald, compra, 1963. FOTOGRAFIA: Acervo Museu Nacional de Belas Artes/IBRAM/MinC.

B. [1 $1^{\circ}$ estado] DATA: 1909. TÉCNICA: Água-forte e água-tinta. MEDIDAS: 25,5 x $61 \mathrm{~cm}$ (mancha), 35 x 69,5 cm (papel). IMPRESSÃO: em preto. MATRIZ: zinco. MEDIDAS DA MATRIZ: 22,5 x $42 \mathrm{~cm}$. Sem assinatura. ACERVO Fundação Biblioteca Nacional. PROVENIÊNCIA: Carlos Oswald, compra, 1916.

C. [matriz] DATA: 1909. TÉCNICA: Água-forte e água-tinta. MATRIZ: zinco. MEDIDAS DA MATRIZ: 22,5 x $42 \mathrm{~cm}$. Sem assinatura. COLEÇÃO Museu Nacional de Belas Artes/IBRAM/ MinC. PROVENIÊNCIA: Maria Isabel Oswald Monteiro, doação, 1992. 


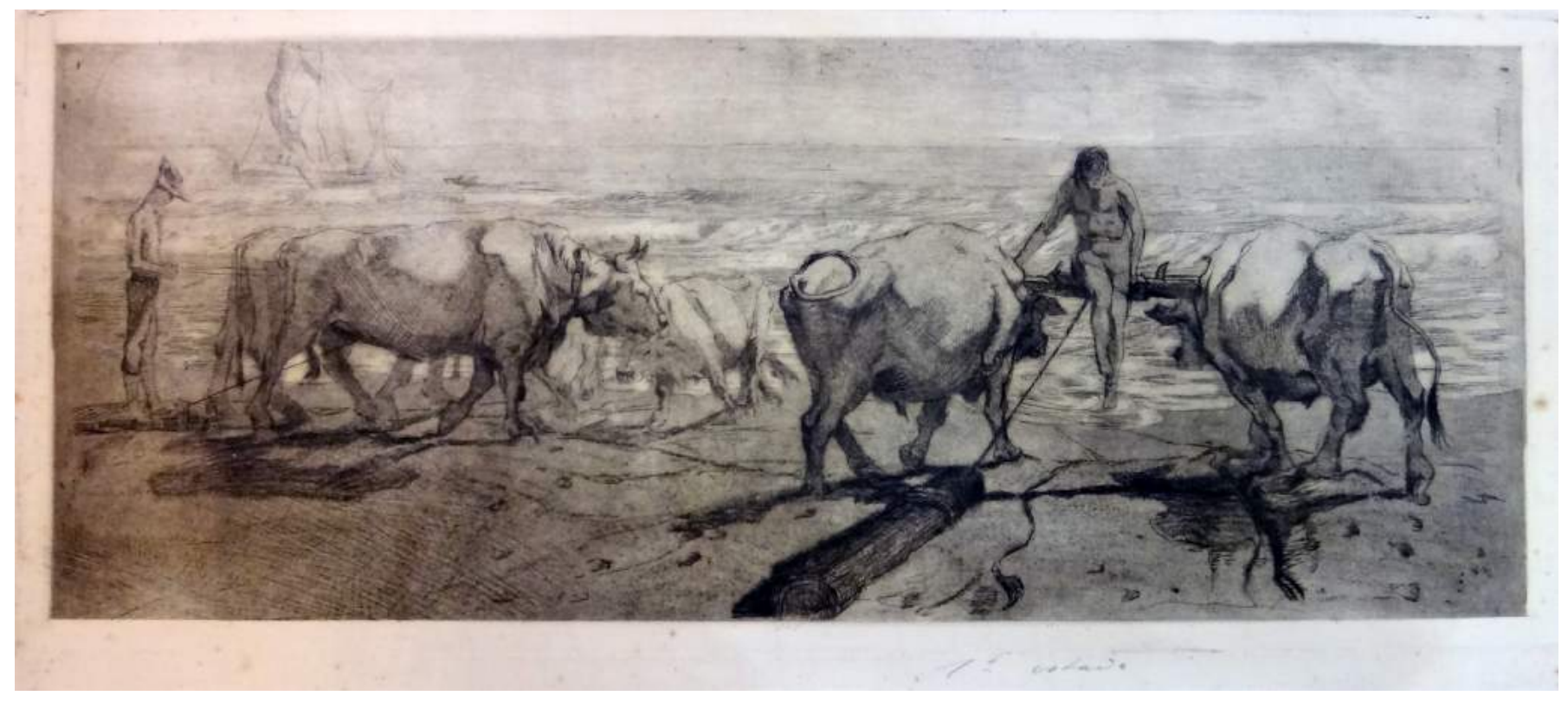

Fig. 24.B

LITERATURA: Exp. anual de Munique, Glaspalast, jul. 1910, p. 140 (ref.); A.V., A Notícia, RJ, 18/10/1913 (rep.); Correio Paulistano, SP, 21/1/1923 (nota expo.); Revista do Brasil, SP, 2/1918, p. 175 (rep.); Illustração Brasileira, RJ, 3/1921, p.26-27 (rep.); Almeida, O Malho, RJ, 4/10/1919 (artigo); Oswald, 1957 (rep., afirma que a gravura foi exposta em Munique); Silva, 1969 (ref.); Exp. Carlos Oswald: o resgate de um mestre, Caixa Cultural, Brasília/Curitiba, 2011, p.26 (rep.). 


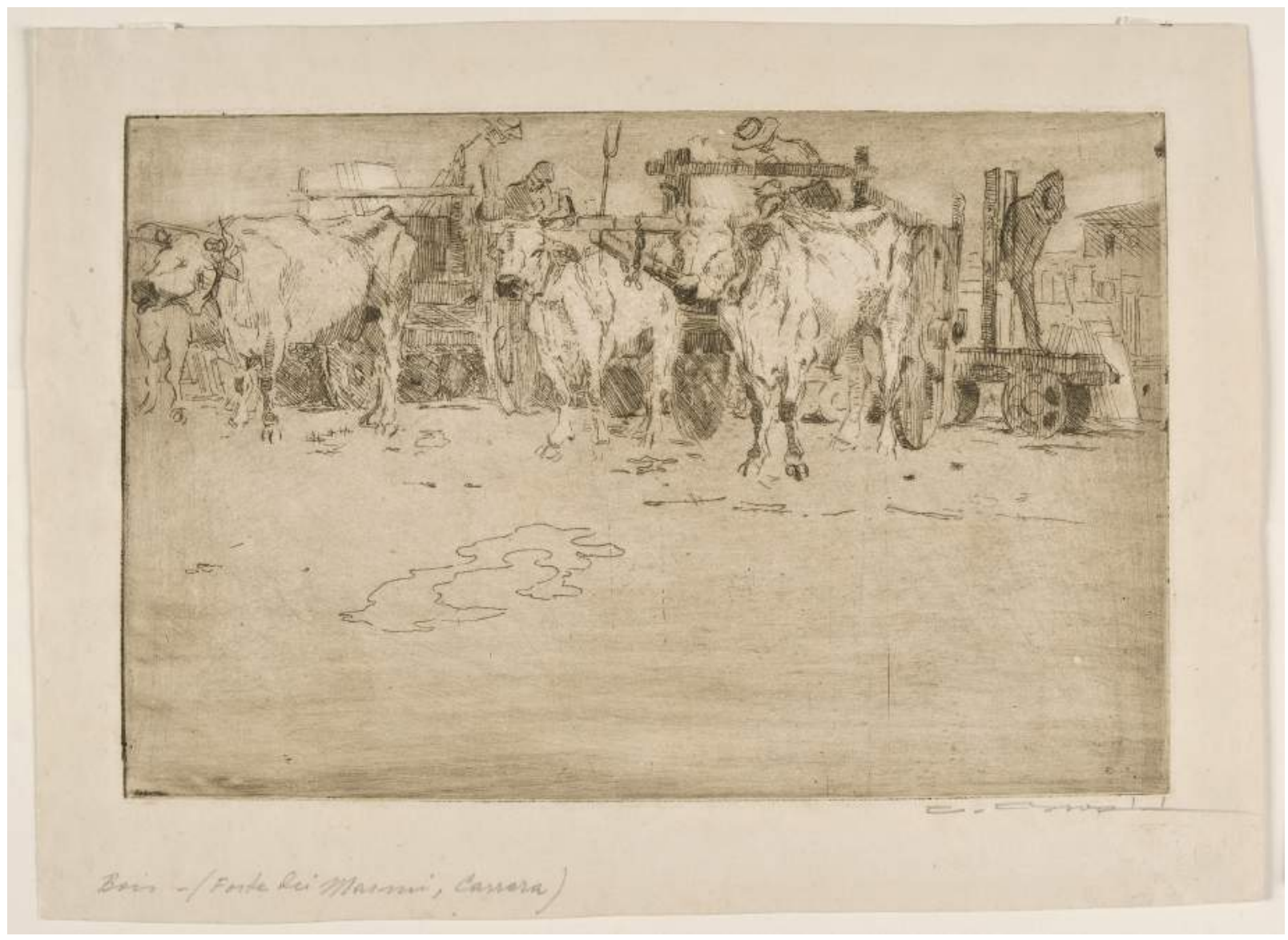

Fig. 25.A

25. TÍTULO: Bois (Forte dei Marmi, Carrara). VARIANTE: Dois carros de bois.

A. DATA: 1909. TÉCNICA: Água-forte. MEDIDAS: 17 x 26,5 cm (mancha); 22,5 x 31,2 cm (papel). IMPRESSÃO: em preto. MATRIZ: latão. MEDIDAS DA MATRIZ: 27,1 x 17,5 cm. ASSINATURA: "C. Oswald" no canto inferior direito do papel. COLEÇÃO Museu Nacional de Belas Artes/IBRAM/MinC. PROVENIÊNCIA: Carlos Oswald, compra, 1963. FOTOGRAFIA: Acervo Museu Nacional de Belas Artes/IBRAM/MinC.

B. [matriz] DATA: 1909. TÉCNICA: Água-forte. MATRIZ: latão. MEDIDAS DA MATRIZ: 27,1 x 17,5 cm. Sem assinatura. COLEÇÃO Museu Nacional de Belas Artes/IBRAM/MinC. PROVENIÊNCIA: Maria Isabel Oswald Monteiro, doação, 1982.

LITERATURA: Silva, 1969 (ref.); Exp. Carlos Oswald: o resgate de um mestre, Caixa Cultural, Brasília/Curitiba, 2011, p. 19 (rep.). 
26. TÍTULO: Carro de bois (?).

A. [matriz] DATA: 1909. TÉCNICA: Água-forte e ponta seca. MATRIZ: latão. MEDIDAS DA MATRIZ: 27,1 x 17,5 cm. Sem assinatura. COLEÇÃO Museu Nacional de Belas Artes/ IBRAM/MinC. PROVENIÊNCIA: Maria Isabel Oswald Monteiro, doação, 1982. FONTE: Museu Nacional de Belas Artes.

B. DATA: 1986. TÉCNICA: Água-forte e ponta seca. MEDIDAS: 17,5 x 27,1 cm (mancha); 26 x 35,5 cm (papel). IMPRESSÃO: póstuma. MATRIZ: latão. MEDIDAS DA MATRIZ: 27,1 x 17,5 cm. COLEÇÃO Museu Nacional de Belas Artes/IBRAM/MinC. PROVENIÊNCIA: registrada na coleção em 1986. FONTE: Museu Nacional de Belas Artes.

LITERATURA: Silva, 1969 (ref.). 


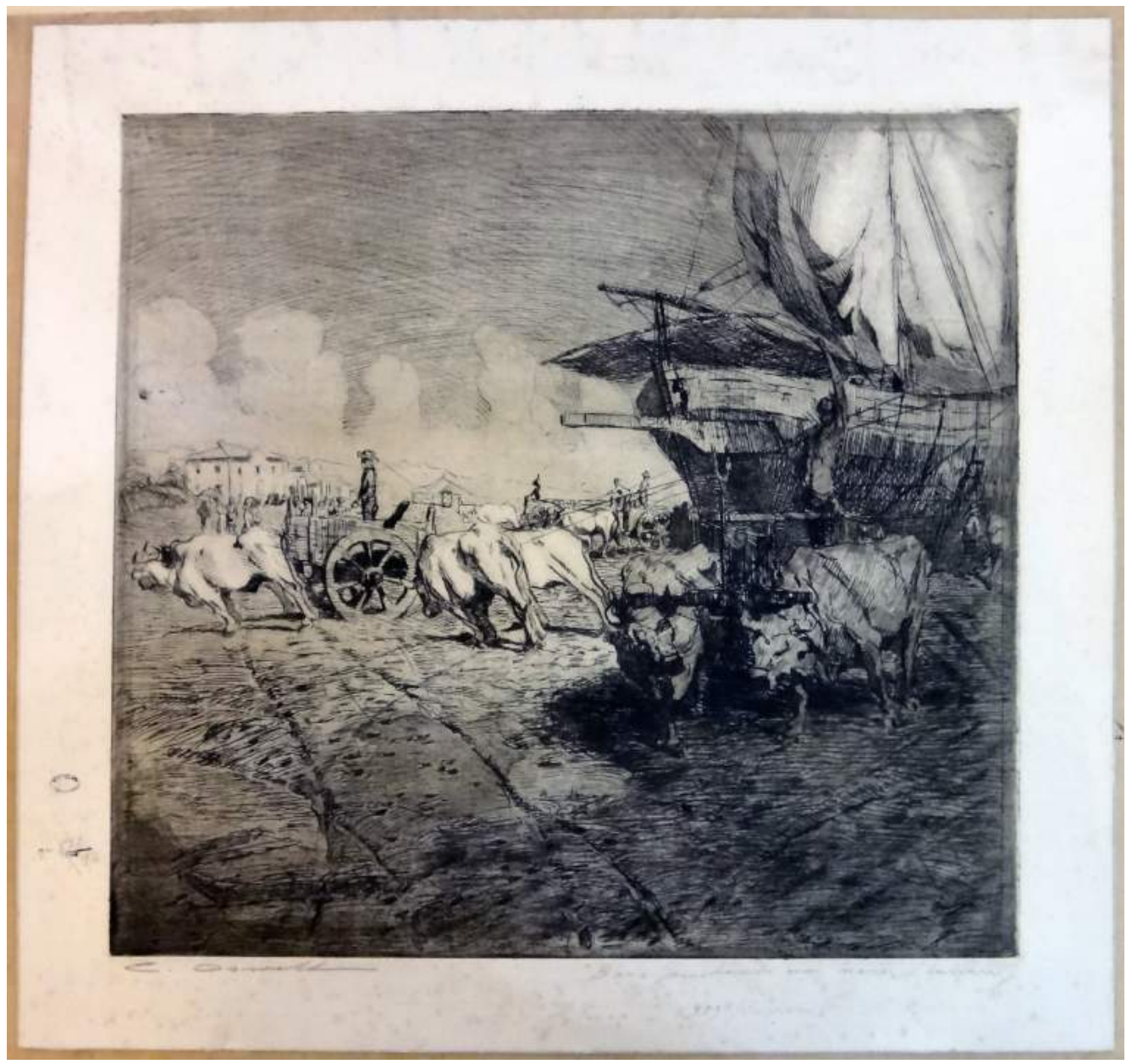

Fig. 27.A

27. TÍTULOS: Bois puxando um navio; O último esforço (na praia de Forte dei Marmi, Itália); Bois carregando um barco. VARIANTE: Supremo esforço.

A. DATA: 1909. TÉCNICA: Água-forte. MEDIDAS: 37,7 x 40,4 cm (mancha), 46 x 48,8 cm (papel). IMPRESSÃO: em preto. ASSINATURA: "C. Oswald" no canto inferior esquerdo do papel. ACERVO Fundação Biblioteca Nacional. PROVENIÊNCIA: Carlos Oswald, compra 1916.

B. DATA: 1909. TÉCNICA: Água-forte. MEDIDAS: 37,9 x 41,6 cm (mancha); 48,4 x 52,3 cm (papel). IMPRESSÃO: em preto. ASSINATURA: "C. Oswald" no canto inferior esquerdo do papel. COLEÇÃO Museu Nacional de Belas Artes/IBRAM/MinC. PROVENIÊNCIA: Carlos Oswald, compra, 1963.

LITERATURA: Exp. anual de Munique, Glaspalast, jul. 1910, p. 140 (ref.); A Gazeta, SP, 24/1/1923 (nota expo.); Oswald, 1957, p. 208 (ref. e rep., afirma que foi exposta em Munique); Silva, 1969 (ref.); Silva, 1976, p. 78 (ref.); Exp. Carlos Oswald: o resgate de um mestre, Caixa Cultural, Brasília/Curitiba, 2011, p. 21 (rep.). 


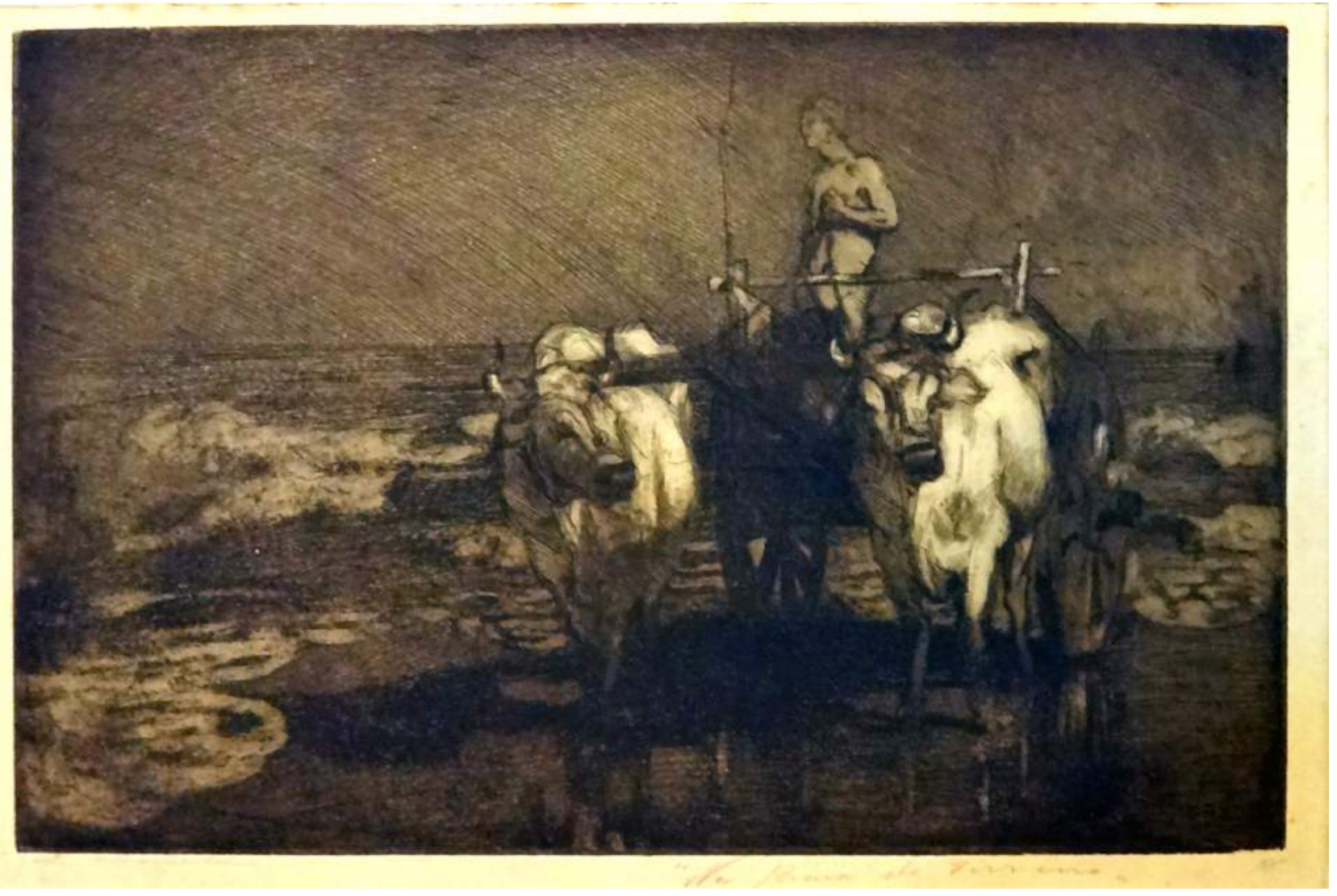

Fig. 28.A

28. TÍTULO: Na praia do Tirreno; Bois na praia; Bois a noite.

A. DATA: 1910. TÉCNICA: Água-forte e água-tinta. MEDIDAS: 25 x 39 cm (mancha). IMPRESSÃO: em marrom. ASSINATURA: "C. Oswald" no canto inferior esquerdo do papel. ACERVO Fundação Biblioteca Nacional. PROVENIÊNCIA: Carlos Oswald, compra, 1916.

B. DATA: 1969. TÉCNICA: Água-forte e água-tinta. MEDIDAS: 25 x 39 cm (mancha). IMPRESSÃO: póstuma, por Orlando da Silva. Sem assinatura. ACERVO Fundação Biblioteca Nacional. PROVENIÊNCIA: registrada no acervo em 1970.

C. DATA: 1964. TÉCNICA: Água-forte e água-tinta. MEDIDAS: 25 x $39 \mathrm{~cm}$ (mancha). IMPRESSÃO: em preto. ACERVO Fundação Biblioteca Nacional. PROVENIÊNCIA: registrada na coleção em 1970. Esta obra pertence ao álbum "Carlos Oswald cinco gravuras originais", impresso pela Gravura de Arte Editora, em 1964.

LITERATURA: Correio Paulistano, SP, 8/2/1918 (nota); Illustração Brasileira, RJ, 12/1922, p. 71 (rep.); Correio Paulistano, SP, 1/2/1923 (nota); Oswald, 1957, p. 207 (ref. e rep.); Silva, 1969 (ref.); Exp. A moderna gravura brasileira, Biblioteca Nacional, RJ, 1974, p. 15-16 (ref.); Silva, 1976, p. 78 (ref.). 


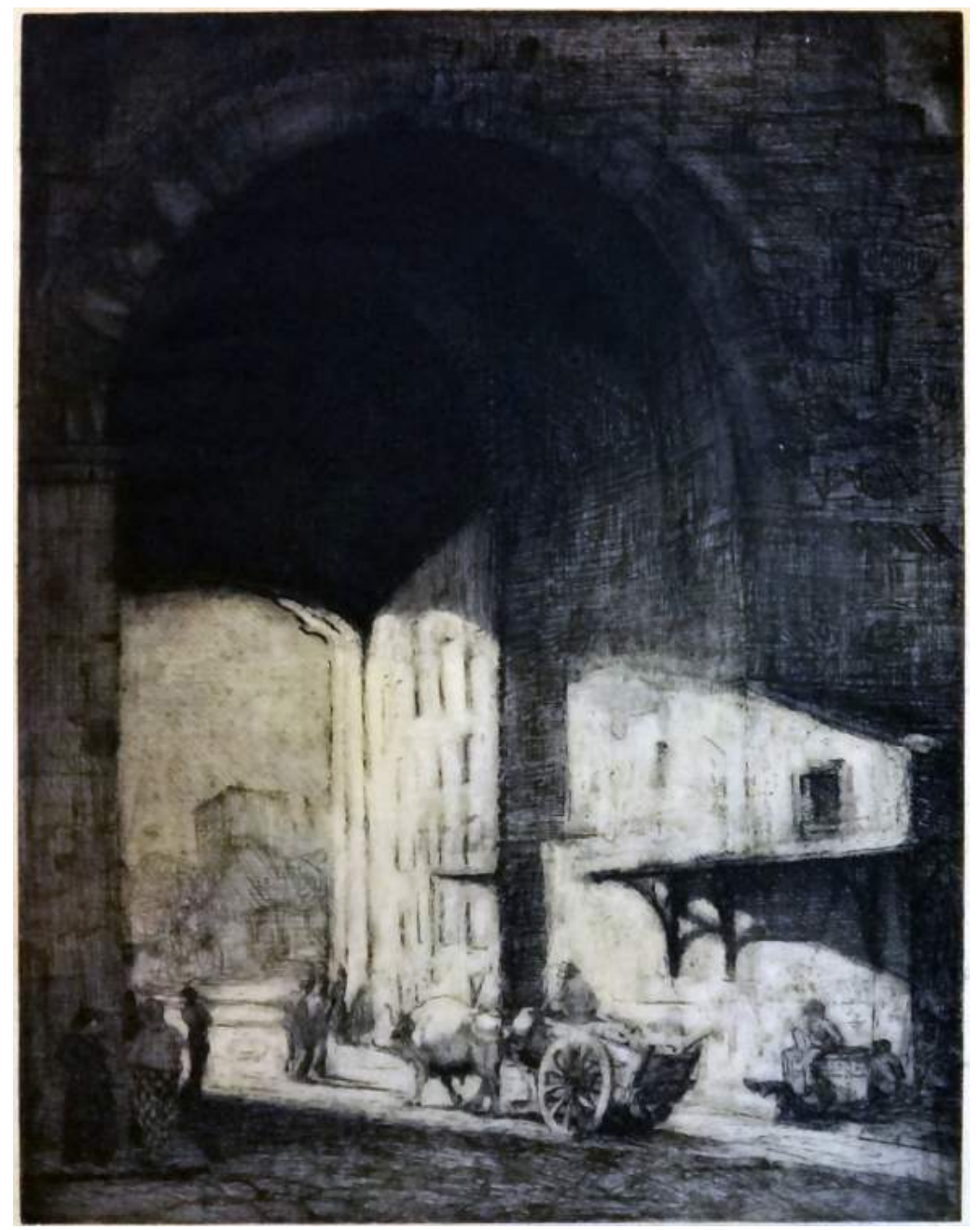

Fig. 29.A

29. TÍTULO: Porta Romana.

A. DATA: 1909. TÉCNICA: Água-forte. MEDIDAS: 42 x 33 cm (mancha), 66,4 x 50,1 cm (papel). IMPRESSÃO: em preto. ASSINATURA: "C. Oswald" no canto inferior esquerdo do papel. ACERVO Fundação Biblioteca Nacional. PROVENIÊNCIA: Carlos Oswald, compra, 1916.

B. DATA: 1911. TÉCNICA: Água-forte. MEDIDAS: 42,3 x 32,8 cm (mancha); 55,8 x 43,2 cm (papel). ASSINATURA: "C. Oswald" no canto inferior direito do papel. COLEÇÃO Museu Nacional de Belas Artes/IBRAM/MinC. PROVENIÊNCIA: Carlos Oswald, compra, 1963.

LITERATURA: O Paiz, RJ, 7/7/1916 (nota); Correio Paulistano, SP, 8/2/1918 (nota); Almeida, O Malho, RJ, 4/10/1919 (artigo); Illustração Brasileira, RJ, 3/1921, p. 25 (rep.); Illustração Brasileira, RJ , 4/1921, p. 26 (artigo); Correio Paulistano, SP, 21/1/1923 (nota); Correio Paulistano, SP, 12/12/1923 (nota); Oswald, 1957, p. 209 (ref. e rep., datada 1911); Silva, 1969 (ref.); Silva, 1976, p. 78 (ref.); Exp. Carlos Oswald: o resgate de um mestre, Caixa Cultural, Brasília/ Curitiba, 2011, p. 32 (rep.). 


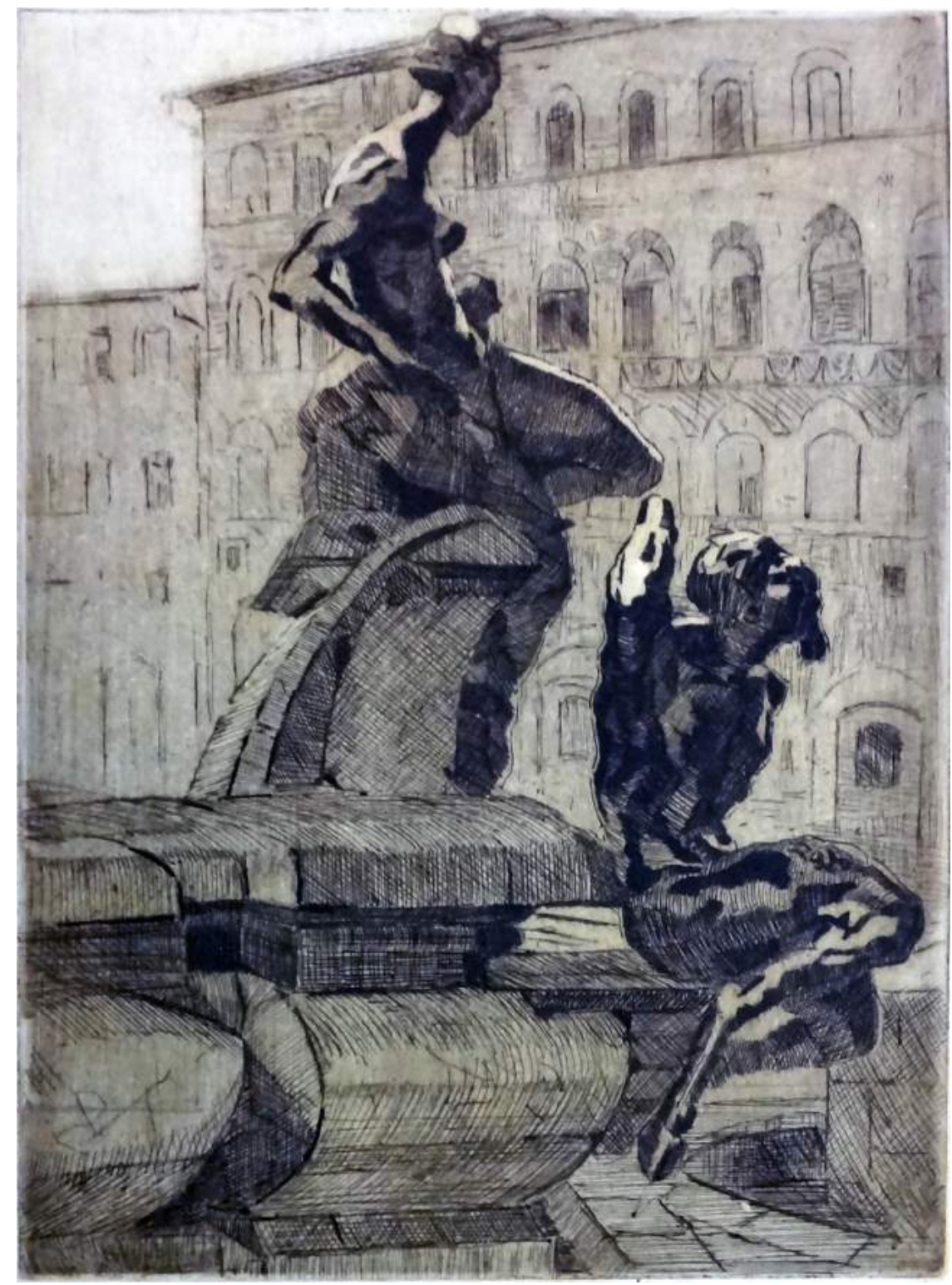

Fig. 30.A

30. TÍTULOS: Coin de la place de La Seignorie (Florence); Florentinas Chafariz. VARIANTE: Centaure, L'Amazone.

A. DATA: 1909. TÉCNICA: Água-forte. MEDIDAS: 25,2 x 18,5 cm (mancha). IMPRESSÃO: em preto. ASSINATURA: "C. Oswald" no canto inferior direito do suporte. ACERVO Fundação Biblioteca Nacional. PROVENIÊNCIA: registrada no acervo em 1916.

B. DATA: 1909. TÉCNICA: Água-forte. MEDIDAS: 25,2 x 18,5 cm (mancha), 29,5 x 21,7 cm (papel). IMPRESSÃO: em preto. ASSINATURA: “C. Oswald” no canto inferior direito do suporte. COLEÇÃO Museu Nacional de Belas Artes/IBRAM/MinC. PROVENIÊNCIA: Carlos Oswald, compra, 1963.

LITERATURA.: Amador, Jornal do Brasil, RJ, 4/9/1909 (artigo); Exp. Carlos Oswald: o resgate de um mestre, Caixa Cultural, Brasília/Curitiba, 2011, p. 25 (rep.). 


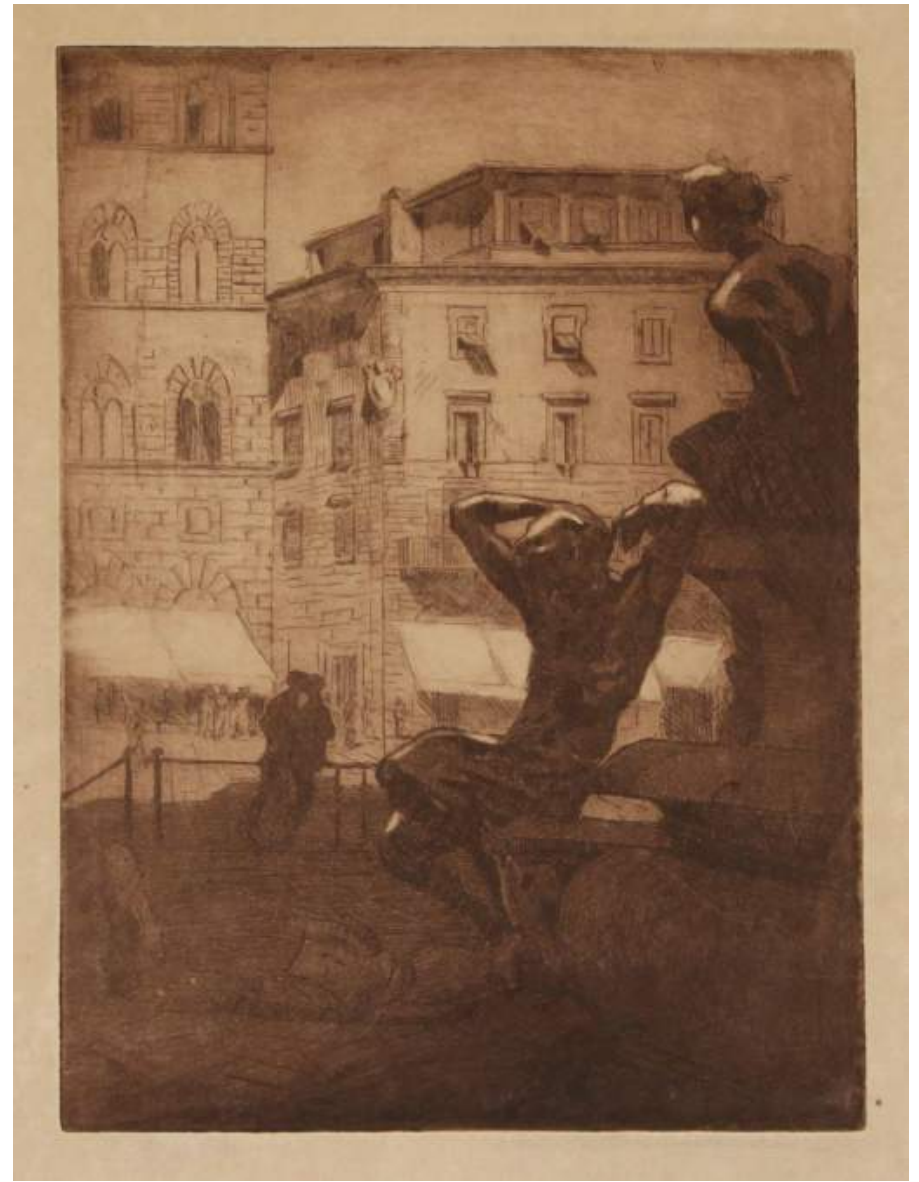

Fig. 31.A

31. TÍTULOS: Chafariz da Piazza della Signoria, Florença, Itália. VARIANTES: Piazza della Signoria; Praça da Senhoria - Florença.

A. DATA: 1909. TÉCNICA: Água-forte e água-tinta. MEDIDAS: 25 x 17,8 cm (mancha); 47,1 x 32,4 cm (papel). IMPRESSÃO: em marrom. MATRIZ: zinco. MEDIDAS DA MATRIZ: 24 x $18 \mathrm{~cm}$. ASSINATURA: "C. Oswald” no canto inferior direito do papel. COLEÇÃO Museu Nacional de Belas Artes/IBRAM/MinC. PROVENIÊNCIA: Elyette Cunha Costa, doação, 2005. FOTOGRAFIA: Acervo Museu Nacional de Belas Artes/IBRAM/MinC.

B. DATA: 1909. TÉCNICA: Água-forte e água-tinta. MEDIDAS: 24,5 x $18 \mathrm{~cm}$ (mancha); 33,5 x $25 \mathrm{~cm}$ (papel). IMPRESSÃO: em sépia. MATRIZ: zinco. MEDIDAS DA MATRIZ: 24 x $18 \mathrm{~cm}$. ASSINATURA: "C. Oswald" no canto inferior direito papel. COLEÇÃO particular. FONTE: Evandro Carneiro Leiloeiro, disponível em: <http://www.evandrocarneiroleiloes. com/145675 ?artistId=88060> , acesso em 13/8/2017.

C. [matriz] DATA: 1909. TÉCNICA: Água-forte e água-tinta. MATRIZ: zinco. MEDIDAS DA MATRIZ: 24 x $18 \mathrm{~cm}$. Sem assinatura. COLEÇÃO Museu Nacional de Belas Artes/IBRAM/ MinC. PROVENIÊNCIA: Maria Isabel Oswald Monteiro, doação, 1992.

LITERATURA: Illustração Brasileira, RJ, 9/1924, (rep.); Silva, 1969 (ref.). 


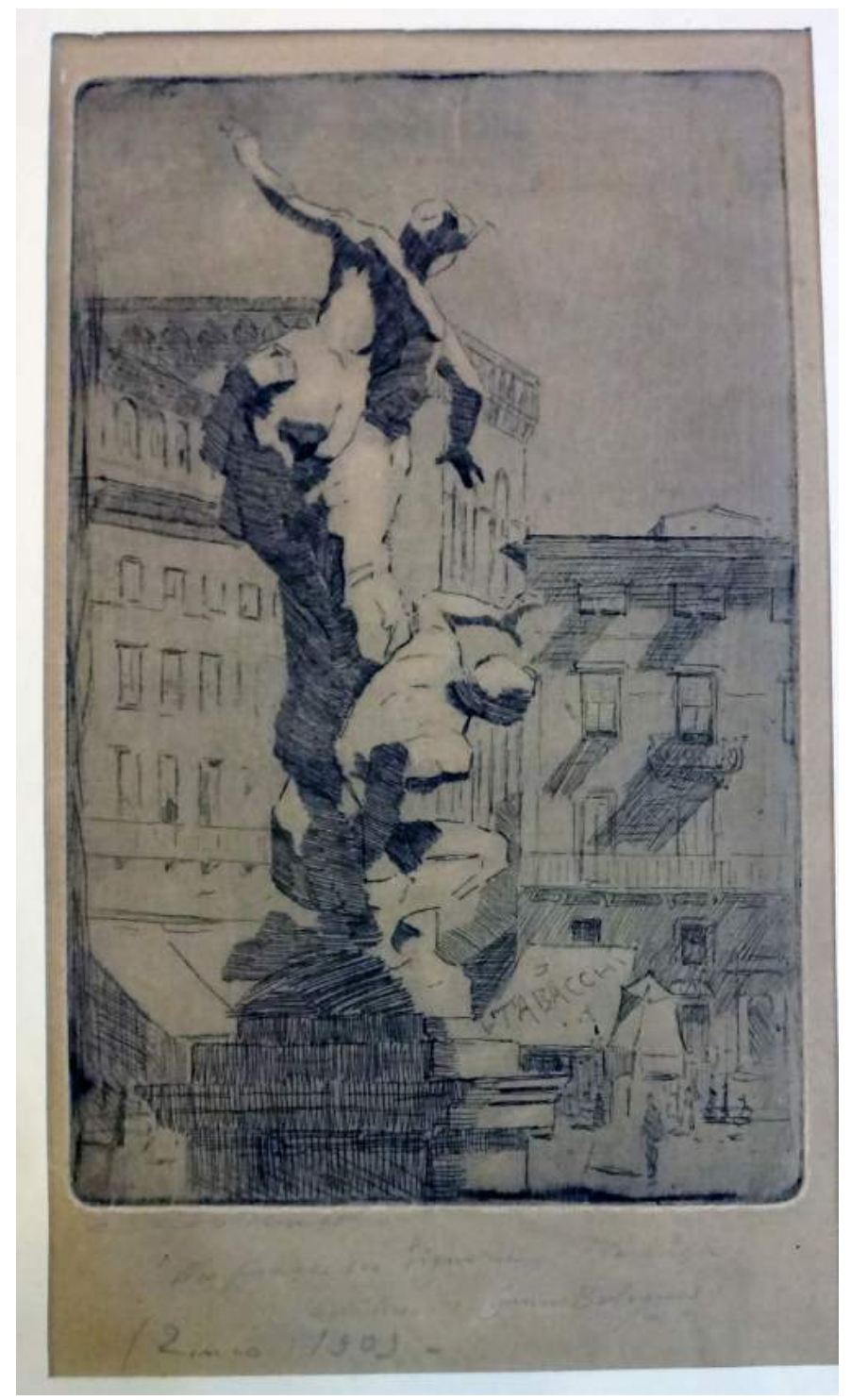

Fig. 32.A

32. TÍTULOS: Na praça da Signoria; Rapto das Sabinas. VARIANTE: Le rapt des sabines.

A. DATA: 1909. TÉCNICA: Água-forte. MEDIDAS: 24,7 x 15,5 cm (mancha), 38 x 23,2 cm (papel). IMPRESSÃO: em preto. MATRIZ: zinco. MEDIDAS DA MATRIZ: 24,8 x 15,7 cm. ASSINATURA: "C. Oswald” no canto inferior esquerdo do papel. ACERVO Fundação Biblioteca Nacional. PROVENIÊNCIA: a obra é integrada ao novo registro do acervo em 1962, mas ingressa na instituição antes dessa data.

B. [matriz] DATA: 1909. TÉCNICA: Água-forte. MATRIZ: zinco. MEDIDAS DA MATRIZ: 24,8 x 15,7 cm. Sem assinatura. COLEÇÃO Museu Nacional de Belas Artes/IBRAM/MinC. PROVENIÊNCIA: Maria Isabel Oswald Monteiro, doação, 1982.

LITERATURA: Amador, Jornal do Brasil, RJ, 4/9/1909 (artigo); Oswald, 1957, p. 207 (ref.); Silva, 1969 (ref.). 


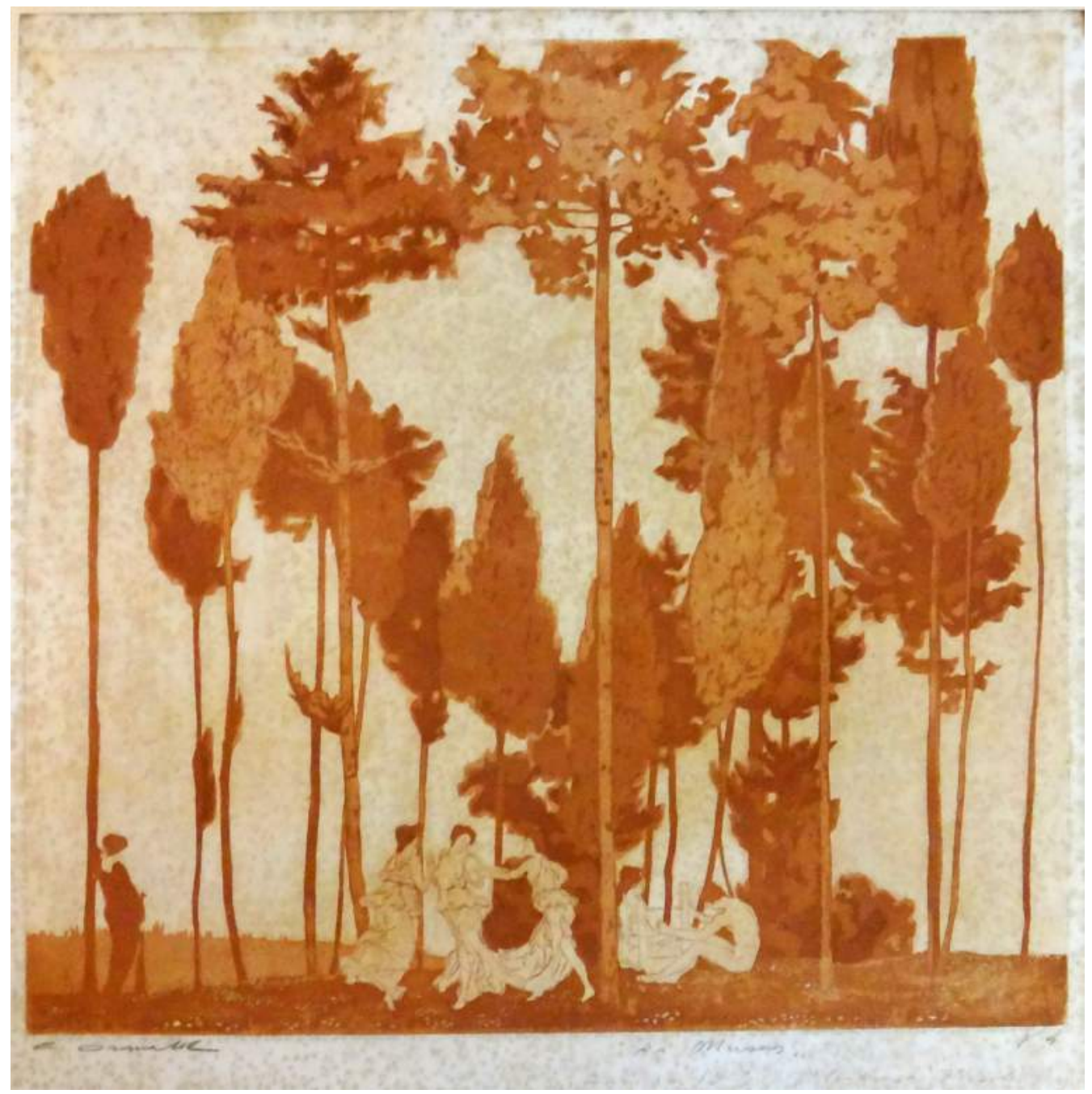

Fig. 33.A

33. TÍTULOS: As Musas; Dança clássica; Coroa de Ciprestes. VARIANTES: Guirlanda dos Ciprestes; Ciprestes.

A. DATA: 1909. TÉCNICA: Água-forte e água-tinta. MEDIDAS: 38 x 40,5 cm (mancha), 49,7 x $71 \mathrm{~cm}$ (papel). IMPRESSÃO: em laranja. MATRIZ: zinco. MEDIDAS MATRIZ: 38,2 x 41 cm. ASSINATURA: "C. Oswald" no canto inferior esquerdo do papel. ACERVO Fundação Biblioteca Nacional. PROVENIÊNCIA: Carlos Oswald, compra, 1916.

B. DATA: 1910. TÉCNICA: Água-forte e água-tinta. MEDIDAS: 38,8 x 40,3 cm (mancha); 40 x $42 \mathrm{~cm}$ (papel). IMPRESSÃO: em laranja. MATRIZ: zinco. MEDIDAS MATRIZ: 38,2 x $41 \mathrm{~cm}$. ASSINATURA: "C. Oswald" no papel. COLEÇÃO Museu Nacional de Belas Artes/ IBRAM/MinC. PROVENIÊNCIA: Carlos Oswald, compra, 1963.

C. DATA: 1979. TÉCNICA: Água-forte e água-tinta. IMPRESSÃO: póstuma, em marrom, por Marcello Grassmann e Roberto Grassmann. MATRIZ: zinco. MEDIDAS MATRIZ: 38,2 x 41 cm. Sem assinatura. FONTE: Carlos Oswald: gravuras, Graphus, 1979. 


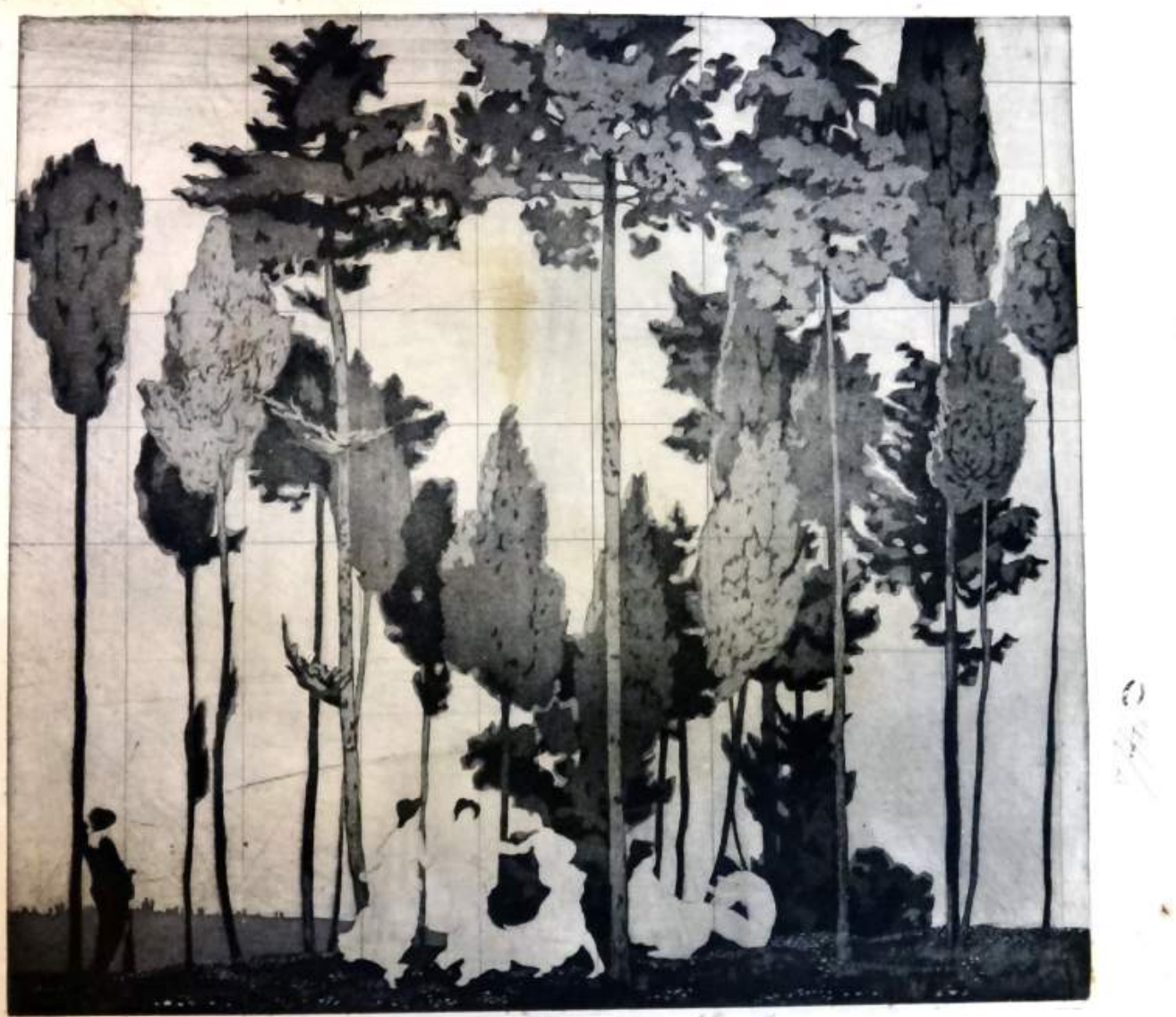

Fig. 33.D

D. [1 $1^{\circ}$ estado] DATA: 1909. TÉCNICA: Água-forte e água-tinta. MEDIDAS: 38 x 41,7 cm (mancha), 41,7 x $51 \mathrm{~cm}$ (papel). IMPRESSÃO: em preto, com intervenções à lápis no papel. MATRIZ: zinco. MEDIDAS MATRIZ: 38,2 x $41 \mathrm{~cm}$. Sem assinatura. ACERVO Fundação Biblioteca Nacional. PROVENIÊNCIA: Carlos Oswald, compra, 1916.

E. [matriz] DATA: 1909. TÉCNICA: Água-forte e água-tinta. MATRIZ: zinco. MEDIDAS MATRIZ: 38,2 x $41 \mathrm{~cm}$. Sem assinatura. COLEÇÃO Museu Nacional de Belas Artes/IBRAM/ MinC. PROVENIÊNCIA: Maria Isabel Oswald Monteiro, doação, 1982.

LITERATURA: Felix, Illustração Brasileira, RJ, 1/6/1913, p. 181 (artigo); Almeida, O Malho, RJ, 4/10/1919 (artigo, rep.); Correio Paulistano, SP, 21/1/1923 (nota); Oswald, 1957, p. 207 (ref. e rep.); Silva, 1969 (ref.); Artistas gravadores do Brasil, 1984, p. 18 (rep.); Exp. Carlos Oswald: o resgate de um mestre, Caixa Cultural, Brasília/Curitiba, 2011, p. 20 (rep.). 


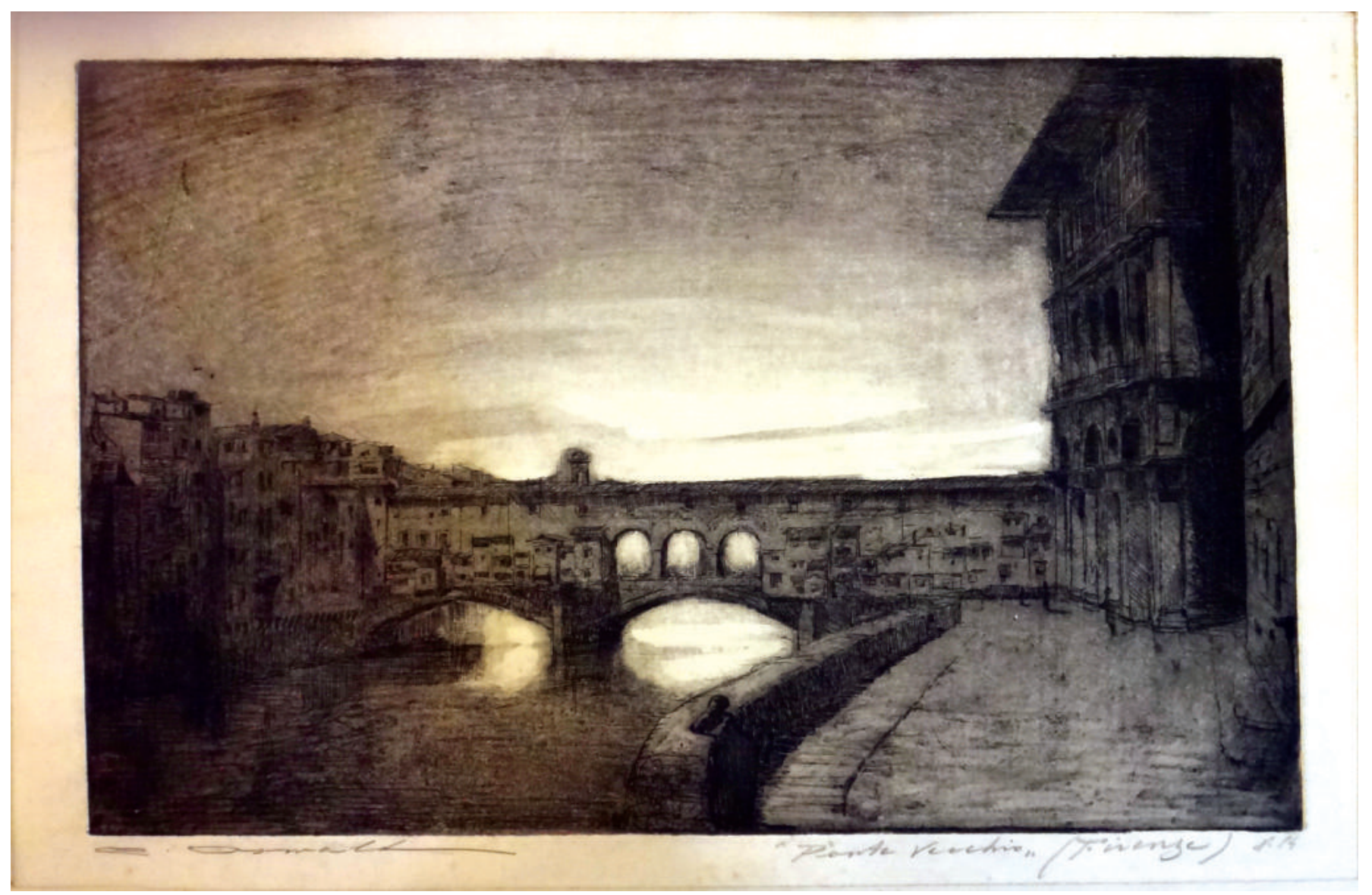

Fig. 34.A

34. TÍTULO: Ponte Vecchio. VARIANTE: Velha ponte.

A. DATA: 1910. TÉCNICA: Água-forte. MEDIDAS: 21,5 x 34 cm (mancha), 36,4 x 57,5 cm (papel). IMPRESSÃO: em preto. ASSINATURA: "C. Oswald" no canto inferior esquerdo do papel. ACERVO Fundação Biblioteca Nacional. PROVENIÊNCIA: Carlos Oswald, compra, 1916.

B. [1 $1^{\circ}$ estado] DATA: 1909. TÉCNICA: Água-forte. MEDIDAS: 21,5 x 34 cm (mancha), 33,1 x 45,7 cm (papel). IMPRESSÃO: em preto. ASSINATURA: “C. Oswald” no canto inferior esquerdo do papel. ACERVO Fundação Biblioteca Nacional. PROVENIÊNCIA: Carlos Oswald, compra, 1916. 


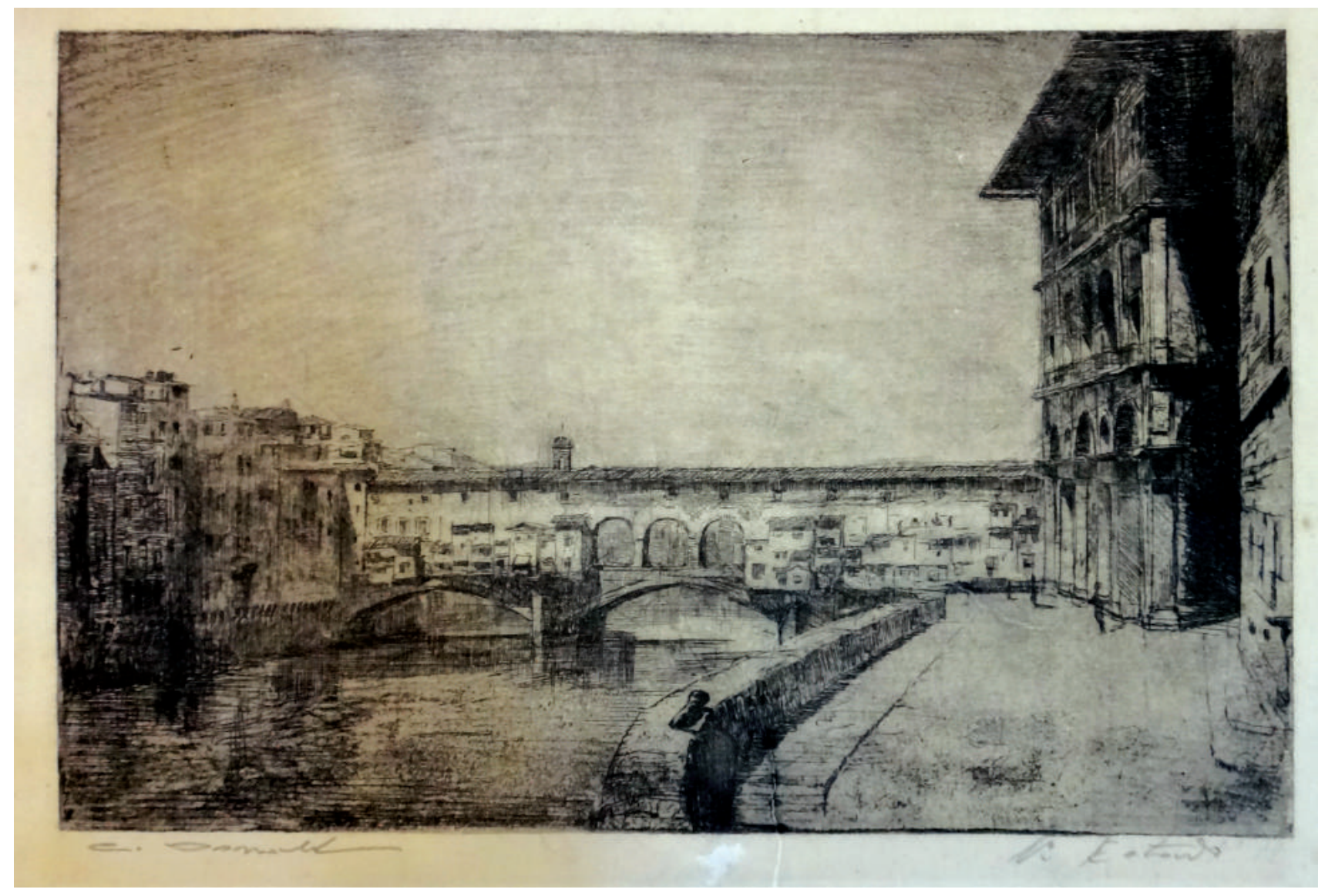

Fig. 34.B

C. DATA: 1909. TÉCNICA: Água-forte. MEDIDAS: 21,9 x 33,5 cm (mancha); 34,3 x 50,7 cm (papel). IMPRESSÃO: em preto. ASSINATURA: "C. Oswald" no papel. COLEÇÃO Museu Nacional de Belas Artes/IBRAM/MinC. PROVENIÊNCIA: Carlos Oswald, compra, 1963.

D. DATA: 1909. TÉCNICA: Água-forte. MEDIDAS: 21,9 x 33,3 cm (mancha); 34,3 x 51,1 cm (papel). IMPRESSÃO: em preto. ASSINATURA: "C. Oswald” no canto inferior direito do papel. COLEÇÃO Museu Nacional de Belas Artes/IBRAM/MinC. PROVENIÊNCIA: José Lucas Oswald, compra, 1968.

LITERATURA: O Paiz, RJ, 7/7/1916 (nota); A Gazeta, SP, 24/1/1923 (nota);

Oswald, 1957, p. 210 (ref., datada 1912); Silva, 1969 (ref., datada 1912); Exp. Carlos Oswald: o resgate de um mestre, Caixa Cultural, Brasília/Curitiba, 2011, p. 15 (rep.). 


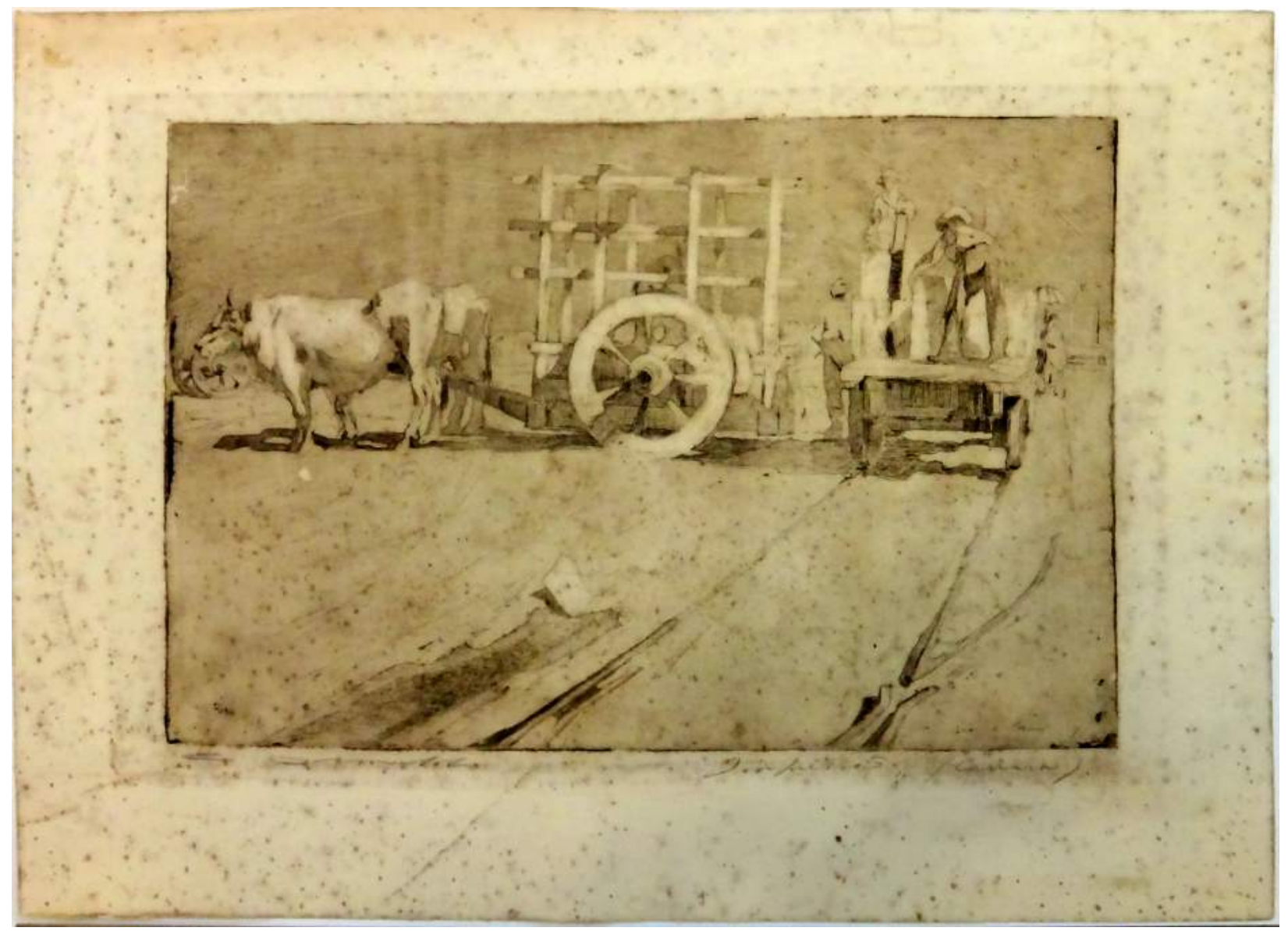

Fig. 35.A

35. TÍTULOS: Impressão (Carrara); Carregando mármores. VARIANTES: Bois carregando mármores; Carrara transporte de mármores.

A. DATA: 1910. TÉCNICA: Água-forte e água-tinta. MEDIDAS: 24,2 x $37 \mathrm{~cm}$ (mancha). IMPRESSÃO: em preto. MATRIZ: latão. ASSINATURA: “C. Oswald” no canto inferior esquerdo do papel. ACERVO Fundação Biblioteca Nacional. PROVENIÊNCIA: Carlos Oswald, compra, 1916.

B. DATA: 1910. TÉCNICA: Água-forte e água-tinta. MEDIDAS: 24,2 x 37 cm (mancha), 39,7 x 55,5 cm (papel). IMPRESSÃO: em preto. MATRIZ: latão. ASSINATURA: "C. Oswald" no canto inferior direito do papel. Coleção Museu Nacional de Belas Artes/IBRAM/MinC. PROVENIÊNCIA: Carlos Oswald, compra, 1963. [Exemplar com a anotação manuscrita: "Carregando mármores Forte dei Marmi 1910. Prova única exposta no 'Glassplast' [sic] de Munich em 1909 e Salon de Paris 1911']

C. [matriz] DATA: 1910. TÉCNICA: Água-forte e água-tinta. MATRIZ: latão. Sem assinatura. ACERVO Fundação Biblioteca Nacional. 


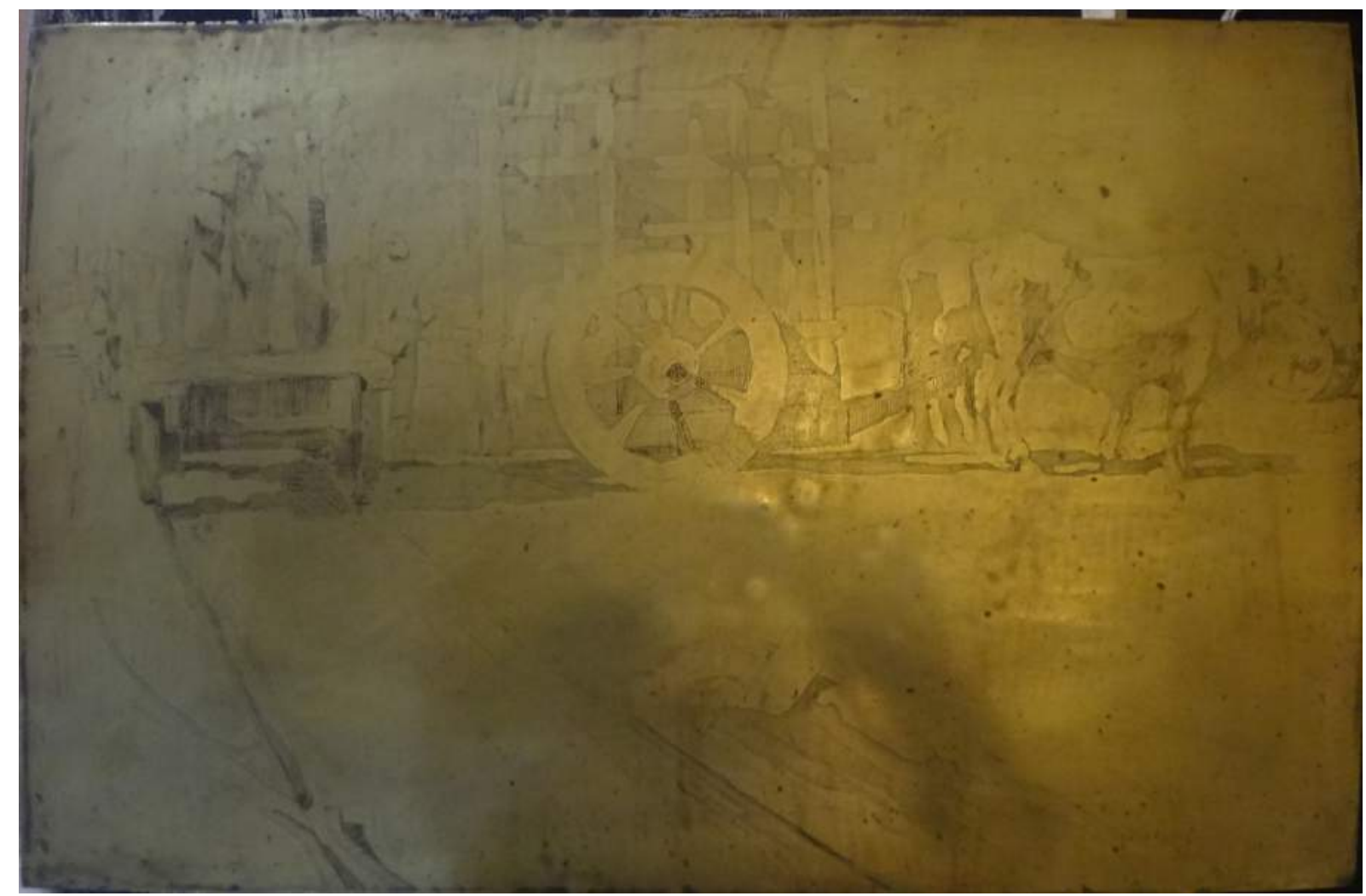

Fig. 35.C

LITERATURA: Exp. anual de Munique, Glaspalast, jul. 1910, p. 140 (ref.); Oswald, 1957, (rep., afirma que a gravura foi exposta em Munique), ref. p. 208 (ref., datada 1909); Silva, 1969 (ref.); Exp. Carlos Oswald: o resgate de um mestre, Caixa Cultural, Brasília/Curitiba, 2011, p. 24 (rep.). 


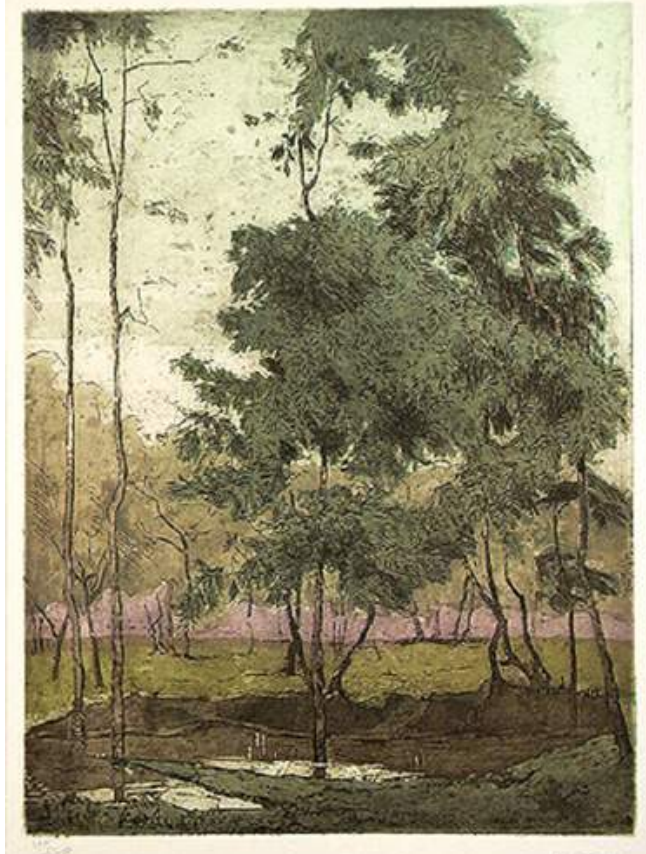

Fig. 36.D

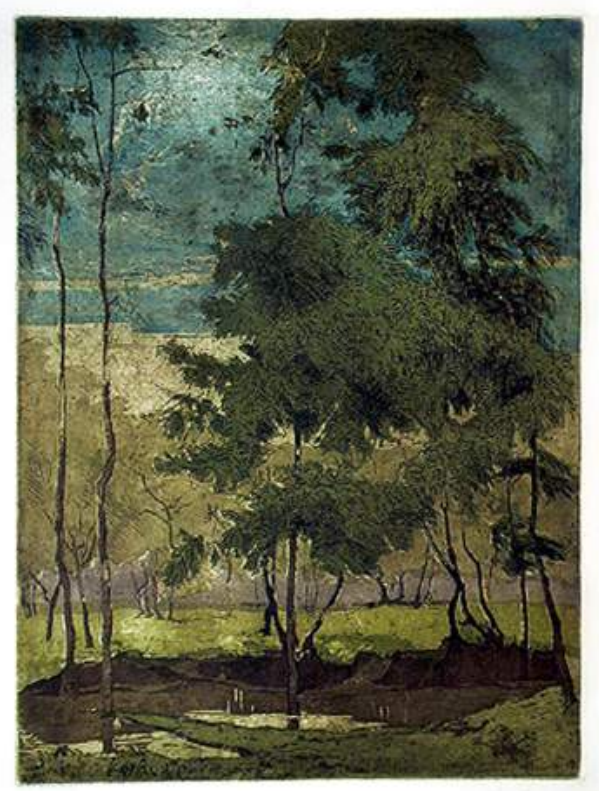

Fig. 36.E

36. TÍTULO: Árvores [no lago Ammersee, Bavaria] [?].

A. [matriz] DATA: 1910. TÉCNICA: Água-forte e água-tinta. MATRIZ: zinco. MEDIDAS DA MATRIZ: 38,1 x 28,1 cm. Sem assinatura. COLEÇÃO Museu Nacional de Belas Artes/ IBRAM/MinC. PROVENIÊNCIA: Maria Isabel Oswald Monteiro, doação, 1982.

B. [matriz] DATA: 1910. TÉCNICA: Água-tinta. MATRIZ: zinco. MEDIDAS DA MATRIZ: 38,1 x 28,1 cm. Sem assinatura. COLEÇÃO Museu Nacional de Belas Artes/IBRAM/MinC. PROVENIÊNCIA: Maria Isabel Oswald Monteiro, doação, 1983.

C. [matriz] DATA: 1910. TÉCNICA: Água-tinta e relevo. MATRIZ: zinco. MEDIDAS DA MATRIZ: 38,1 x 28,1 cm. Sem assinatura. COLEÇÃO Museu Nacional de Belas Artes/IBRAM/ MinC. PROVENIÊNCIA: Maria Isabel Oswald Monteiro, doação, 1983.

D. DATA: 1979. TÉCNICA: Água-forte, água-tinta e relevo. IMPRESSÃO: póstuma, em cores, por Marcello Grassmann e Roberto Grassmann. MATRIZ: zinco. MEDIDAS DA MATRIZ: 38,1 x 28,1 cm. Sem assinatura. FONTE: Carlos Oswald: gravuras, Graphus, 1979.

E. DATA: 1979. TÉCNICA: Água-forte, água-tinta e relevo. IMPRESSÃO: póstuma, em cores, por Marcello Grassmann e Roberto Grassmann. MATRIZ: zinco. MEDIDAS DA MATRIZ: 38,1 x 28,1 cm. Sem assinatura. FONTE: Carlos Oswald: gravuras, Graphus, 1979.

LITERATURA: Artistas gravadores do Brasil, 1984, p. 22 (rep., impressão de 1979); Buti, Letycia, 2000, p. 49 (rep.). 


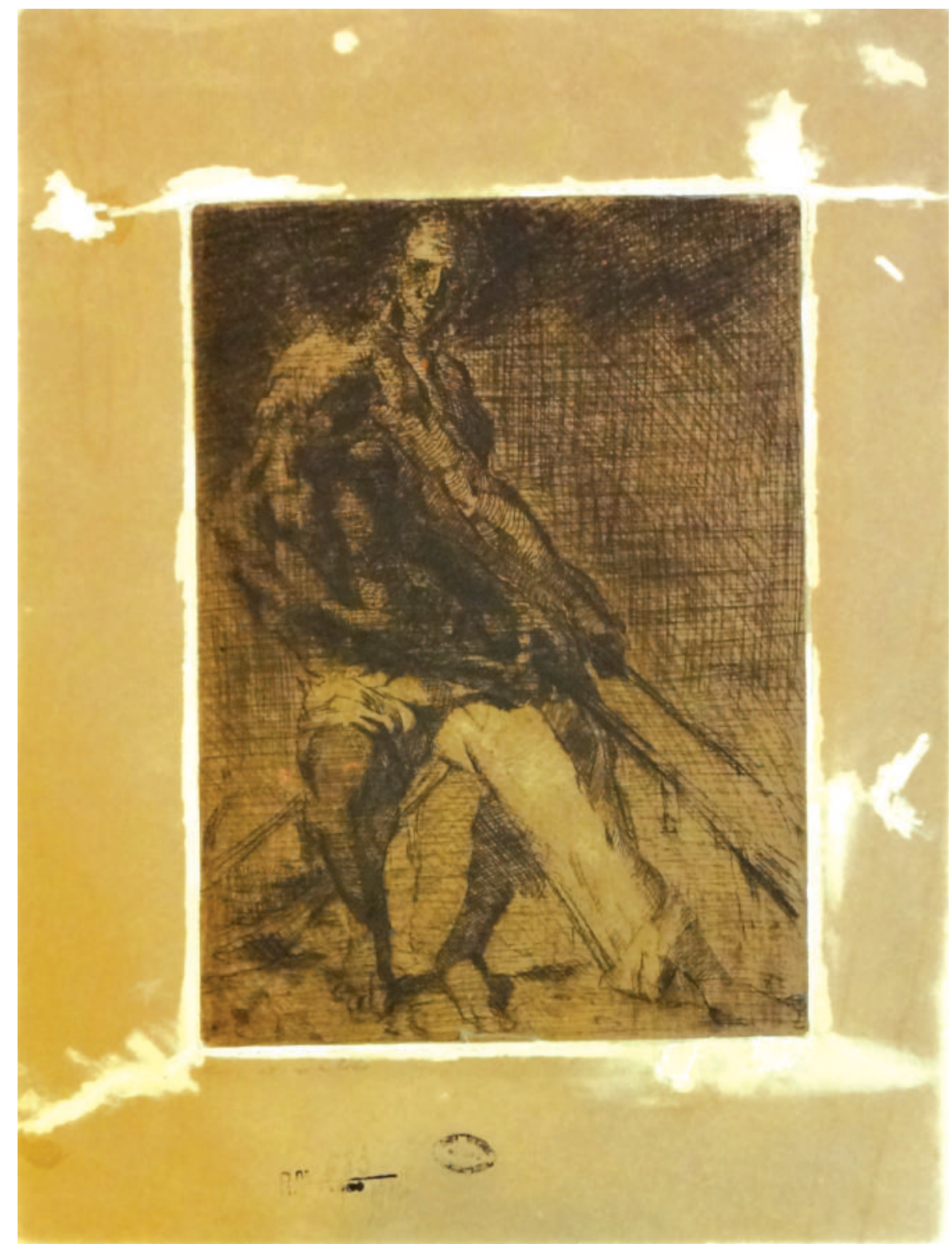

Fig. 37.A

37. TÍTULO: Pescadores [?]. VARIANTE: Pescadores puxando a rede.

A. DATA: 1910. TÉCNICA: Água-forte. MEDIDAS: 17,5 x $13 \mathrm{~cm}$ (mancha), 28 x 21,3 cm (papel). IMPRESSÃO: em preto. ASSINATURA: "C. Oswald" no canto inferior esquerdo do papel. ACERVO Fundação Biblioteca Nacional. PROVENIÊNCIA: Carlos Oswald, compra, 1916.

B. DATA: 1910. TÉCNICA: Água-forte. MEDIDAS: 17,2 x 12,6 cm (mancha); 32,6 x 24 cm (papel). IMPRESSÃO: em preto. ASSINATURA: “C. Oswald” no canto inferior esquerdo do papel. COLEÇÃO Museu Nacional de Belas Artes/IBRAM/MinC. PROVENIÊNCIA: Carlos Oswald, compra, 1963. [Exemplar com anotações para impressão]

LITERATURA: Silva, 1969 (ref.); Exp. Carlos Oswald: o resgate de um mestre, Caixa Cultural, Brasília/Curitiba, 2011, p. 30 (rep.). 


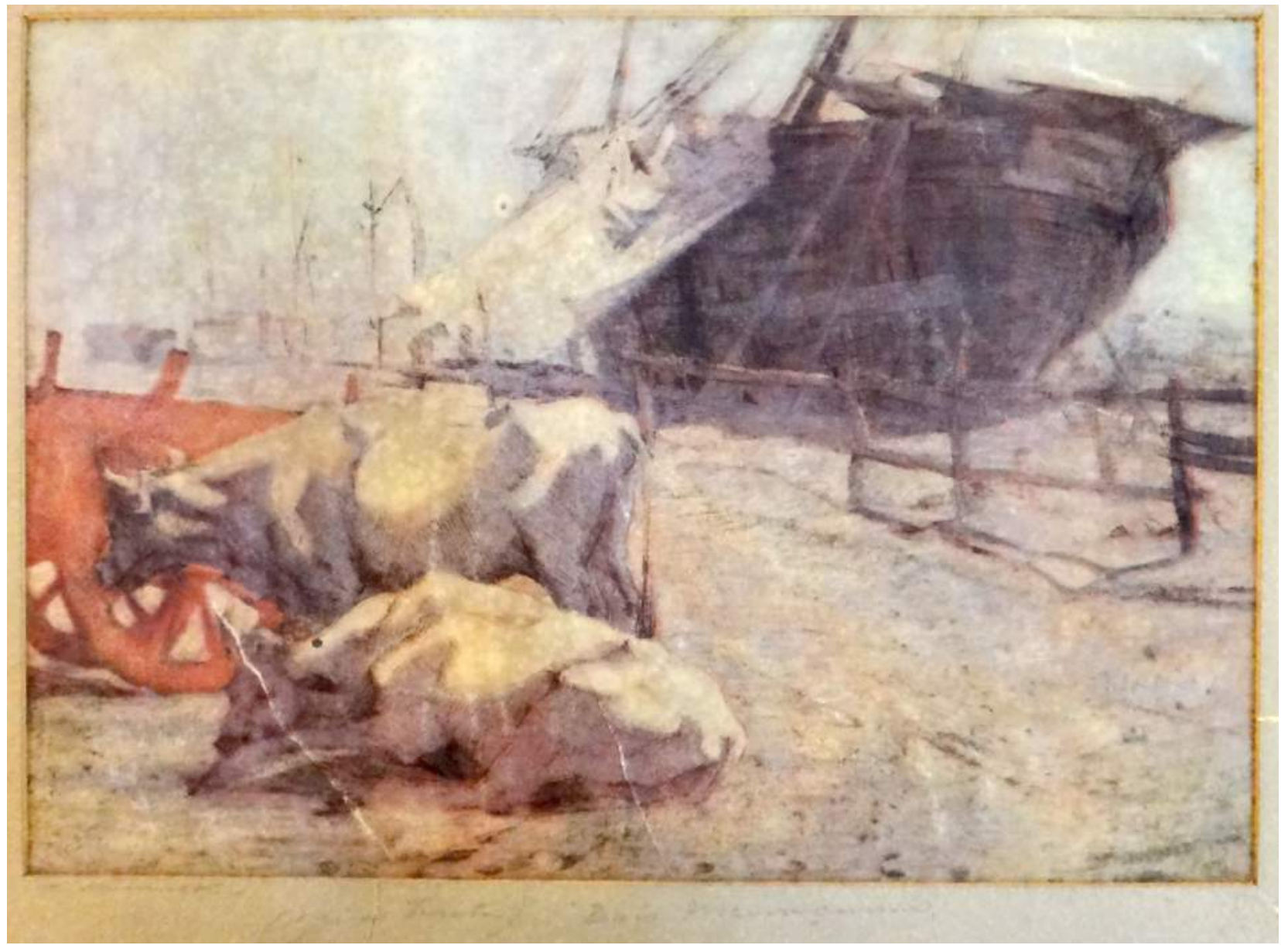

Fig. 38.A

38. TÍTULO: Bois descansando.

A. DATA: 1910. TÉCNICA: Água-forte e água-tinta. MEDIDAS: 22,5 x $32 \mathrm{~cm}$ (mancha). IMPRESSÃO: em cores. ASSINATURA: "C. Oswald" no canto inferior esquerdo do papel. ACERVO Fundação Biblioteca Nacional. PROVENIÊNCIA: Carlos Oswald, compra, 1916. B. [prova de impressão] DATA: 1910. TÉCNICA: Água-forte e água-tinta. MEDIDAS: 22,5 x $32 \mathrm{~cm}$ (mancha), 37,6 x $52 \mathrm{~cm}$ (papel). IMPRESSÃO: em cores. Sem assinatura. ACERVO Fundação Biblioteca Nacional. PROVENIÊNCIA: Carlos Oswald, compra, 1916. [Prova com anotações manuscritas que orientam a impressão, algumas palavras ilegíveis: "1º Ultramar (?), [duas palavras ilegíveis] // lilla, Terra gialla (barca, bois) // $2^{\circ}$ Gantini (?), branco (ceo) // terra gialla (bois) $/ / 3^{\circ}$ preto, ultramar (limpo tudo)]

LITERATURA: Correio Paulistano, SP, 8/2/1918 (nota); Oswald, 1957, p. 208 (ref., afirma que a gravura tem três matrizes); Silva, 1969 (ref.). 


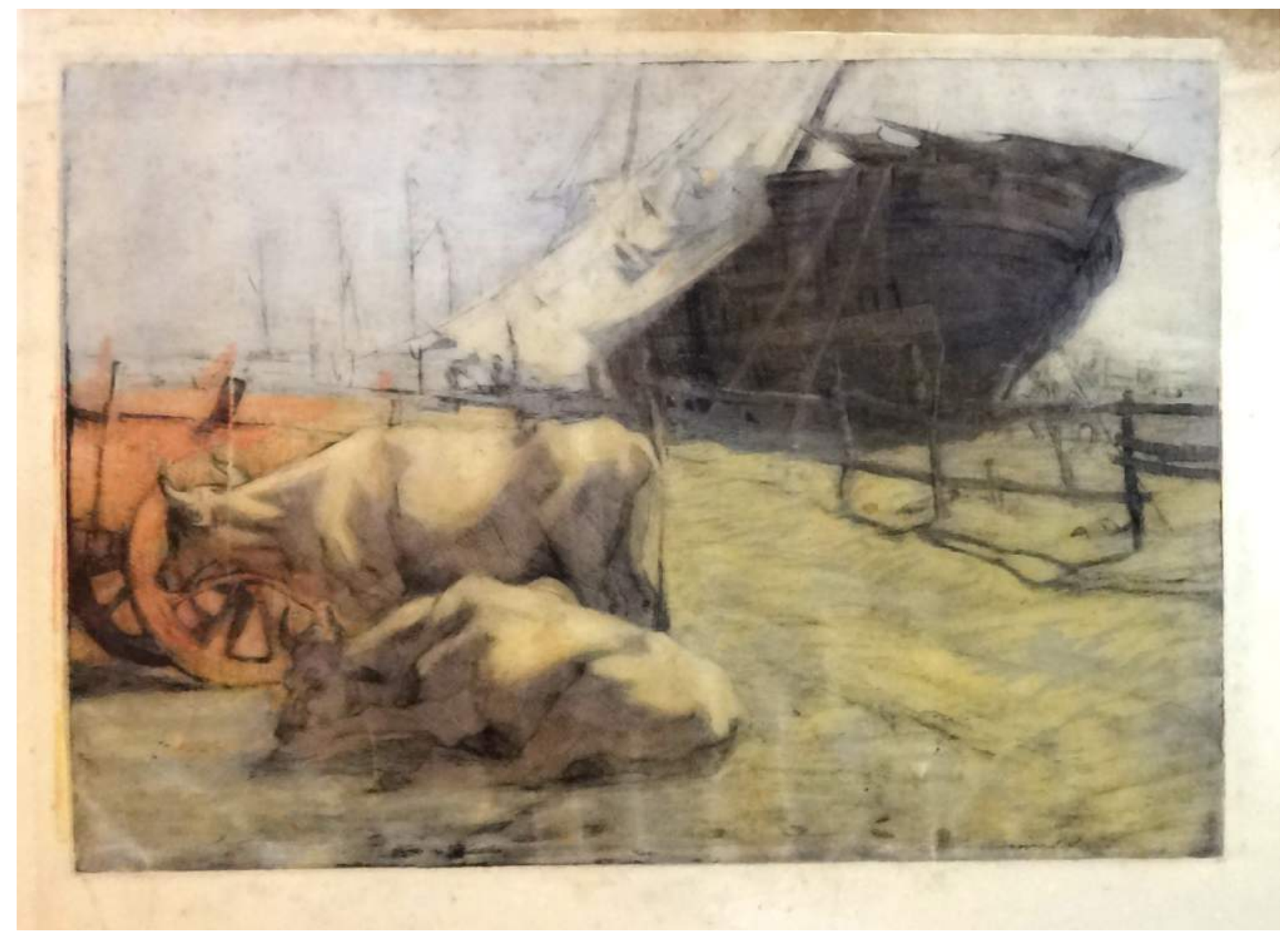

Fig. 38.B

39. TÍTULO: Bois descansando.

DATA: 1910. TÉCNICA: Água-forte e água-tinta. MEDIDAS: 22 x $32 \mathrm{~cm}$ (mancha), 31,5 x 45,7 cm (papel). IMPRESSÃO: em preto. MATRIZ: zinco. ASSINATURA: "C. Oswald" no canto inferior direito do papel. COLEÇÃO Museu Nacional de Belas Artes/IBRAM/MinC. PROVENIÊNCIA: Carlos Oswald, compra, 1963.

LITERATURA: Correio Paulistano, SP, 8/2/1918 (nota); Oswald, 1957, p. 208 (ref., afirma que a gravura tem três matrizes); Silva, 1969 (ref.); Exp. Carlos Oswald: o resgate de um mestre, Caixa Cultural, Brasília/Curitiba, 2011, p. 18 (rep.). 


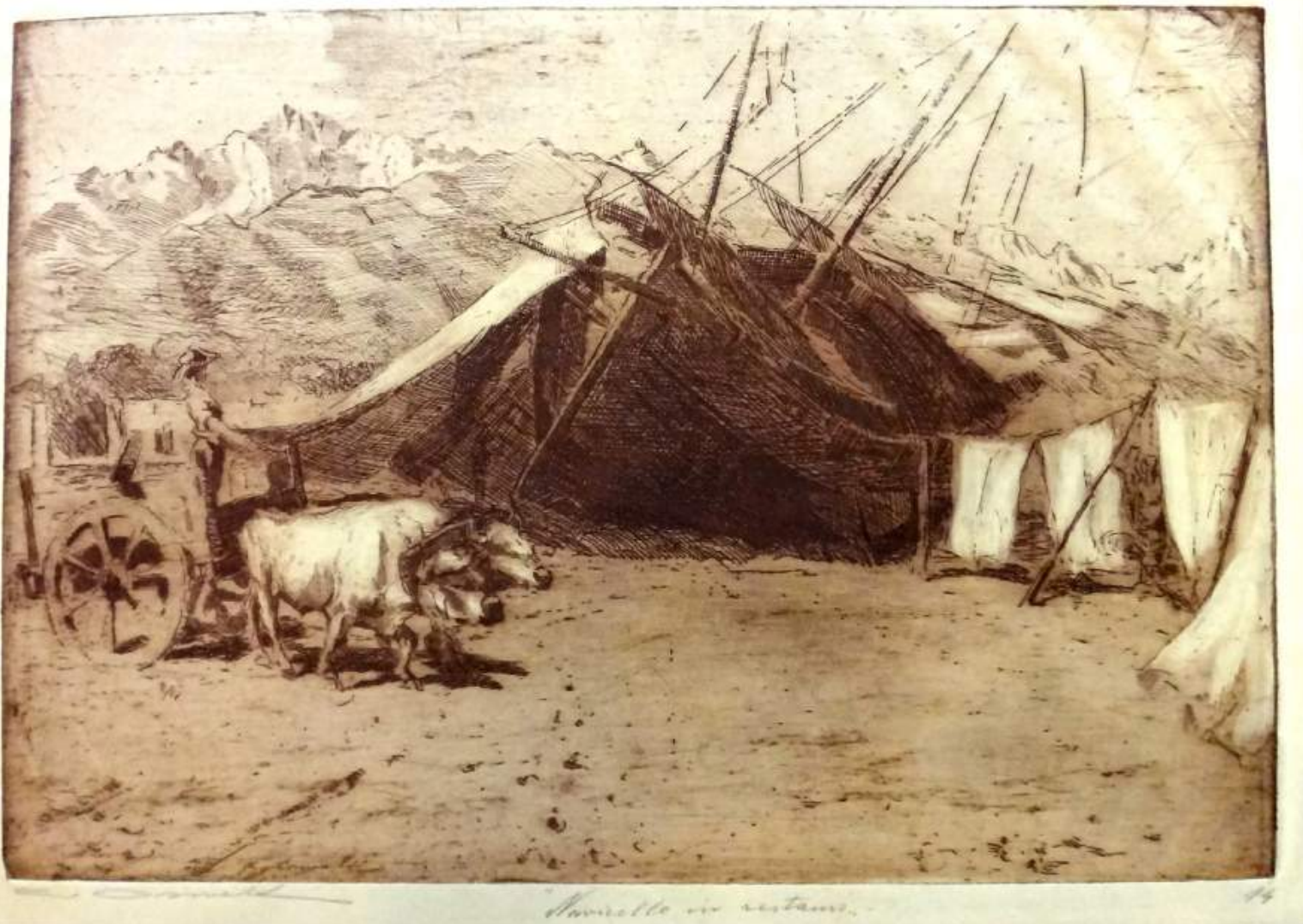

Fig. 40.A

40. TÍTULOS: Velho barco; Novicello in restauro. VARIANTES: Velho navio na praia do Forte dei Marmi; Velho navio em restauro; Barca em concerto.

A. DATA: 1910. TÉCNICA: Água-forte. MEDIDAS: 24 x 36 cm (mancha). IMPRESSÃO: em marrom. MATRIZ: zinco. MEDIDAS DA MATRIZ: 24,2 x 36,3 cm. ASSINATURA: "C. Oswald" no canto inferior esquerdo do papel. ACERVO Fundação Biblioteca Nacional. PROVENIÊNCIA: Carlos Oswald, compra, 1916.

B. [matriz] DATA: 1910. TÉCNICA: Água-forte. MATRIZ: zinco. MEDIDAS DA MATRIZ: 24,2 x 36,3 cm. Sem assinatura. COLEÇÃO Museu Nacional de Belas Artes/IBRAM/MinC PROVENIÊNCIA: Maria Isabel Oswald Monteiro, doação, 1992.

LITERATURA: Correio Paulistano, SP, 8/2/1918 (nota); Oswald, 1957, p. 208 (ref., datada 1909); Silva, 1969 (ref.); Silva, 1976, p. 78 (ref.). 


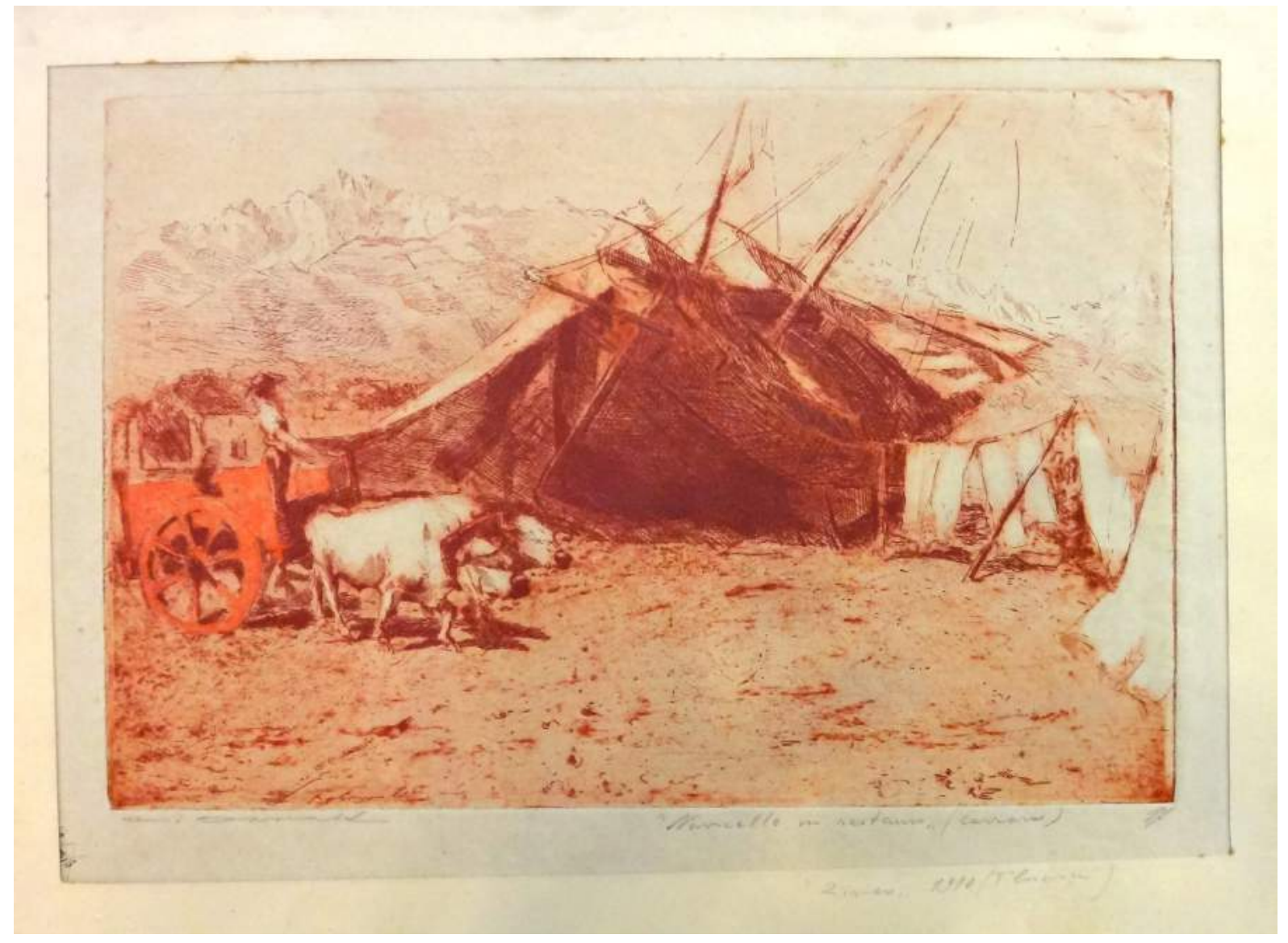

Fig. 41

41. TÍTULOS: Velho barco; Novicello in restauro. VARIANTES: Velho navio na praia do Forte dei Marmi; Velho navio em restauro; Barca em concerto.

DATA: 1910. TÉCNICA: Água-forte. MEDIDAS: 24 x $36 \mathrm{~cm}$ (mancha). IMPRESSÃO: em vermelho. MATRIZ: zinco. MEDIDAS DA MATRIZ: 24,2 x 36,3 cm. ASSINATURA: "C. Oswald" no canto inferior esquerdo do papel. ACERVO Fundação Biblioteca Nacional. PROVENIÊNCIA: Carlos Oswald, compra, 1916. 


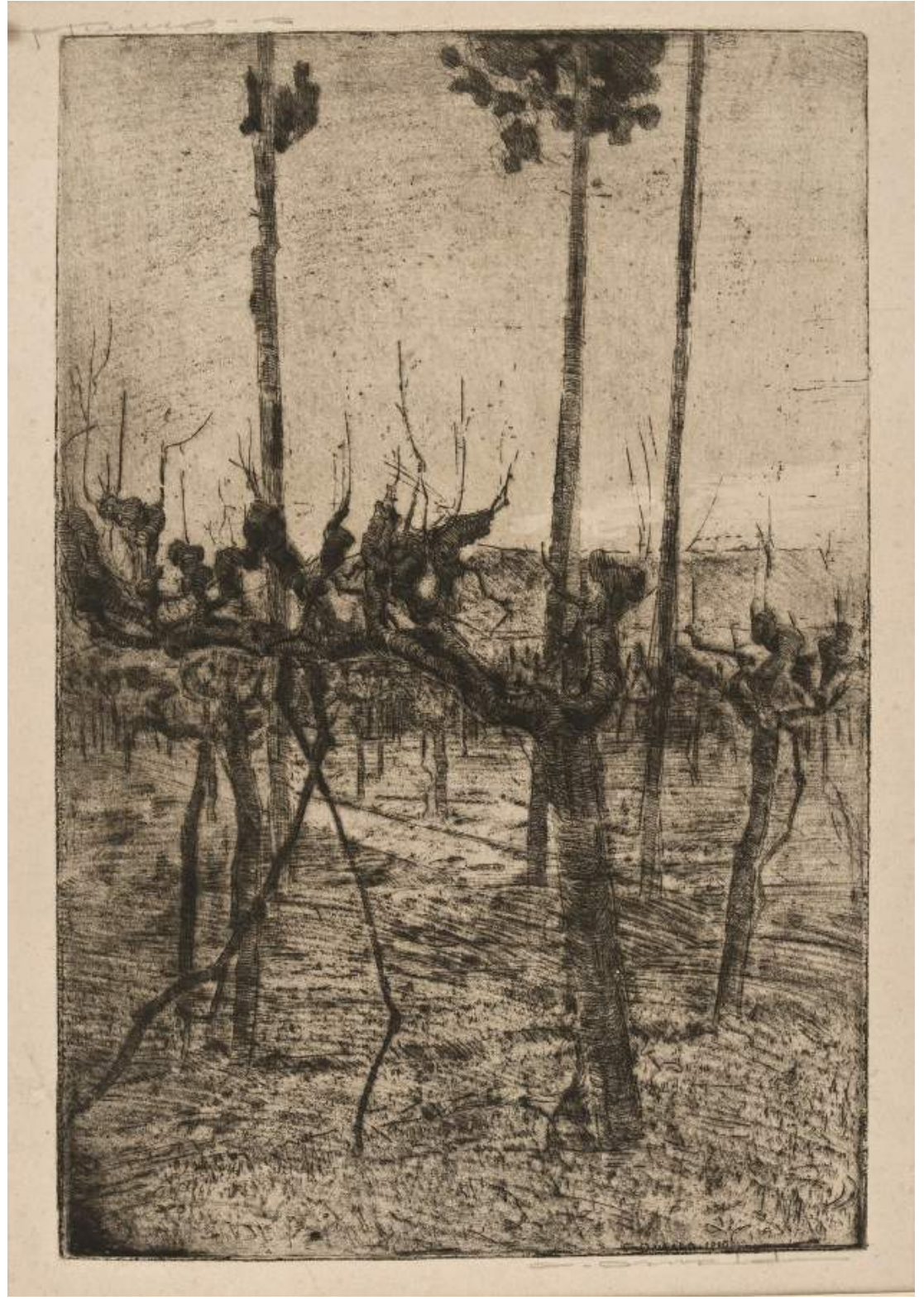

Fig. 42.A

42. TÍTULO: Árvores em Pietti.

A. DATA: 1910. TÉCNICA: Água-forte e verniz-mole. MEDIDAS: 33,4 x 21,7 cm (mancha), 46 x $34 \mathrm{~cm}$ (papel). IMPRESSÃO: em preto. MATRIZ: zinco. ASSINATURA: "C. Oswald" no canto inferior direito do suporte. "C. Oswald" no canto superior esquerdo. COLEÇÃO Museu Nacional de Belas Artes/IBRAM/MinC. PROVENIÊNCIA: Carlos Oswald, compra, 1963. FOTOGRAFIA: Acervo Museu Nacional de Belas Artes/IBRAM/MinC.

B. DATA: 1976. TÉCNICA: Água-forte e verniz-mole. IMPRESSÃO: póstuma, em preto. MATRIZ: zinco. ACERVO Fundação Biblioteca Nacional. PROVENIÊNCIA: registrada em 1976 no acervo. [Dois exemplares] 


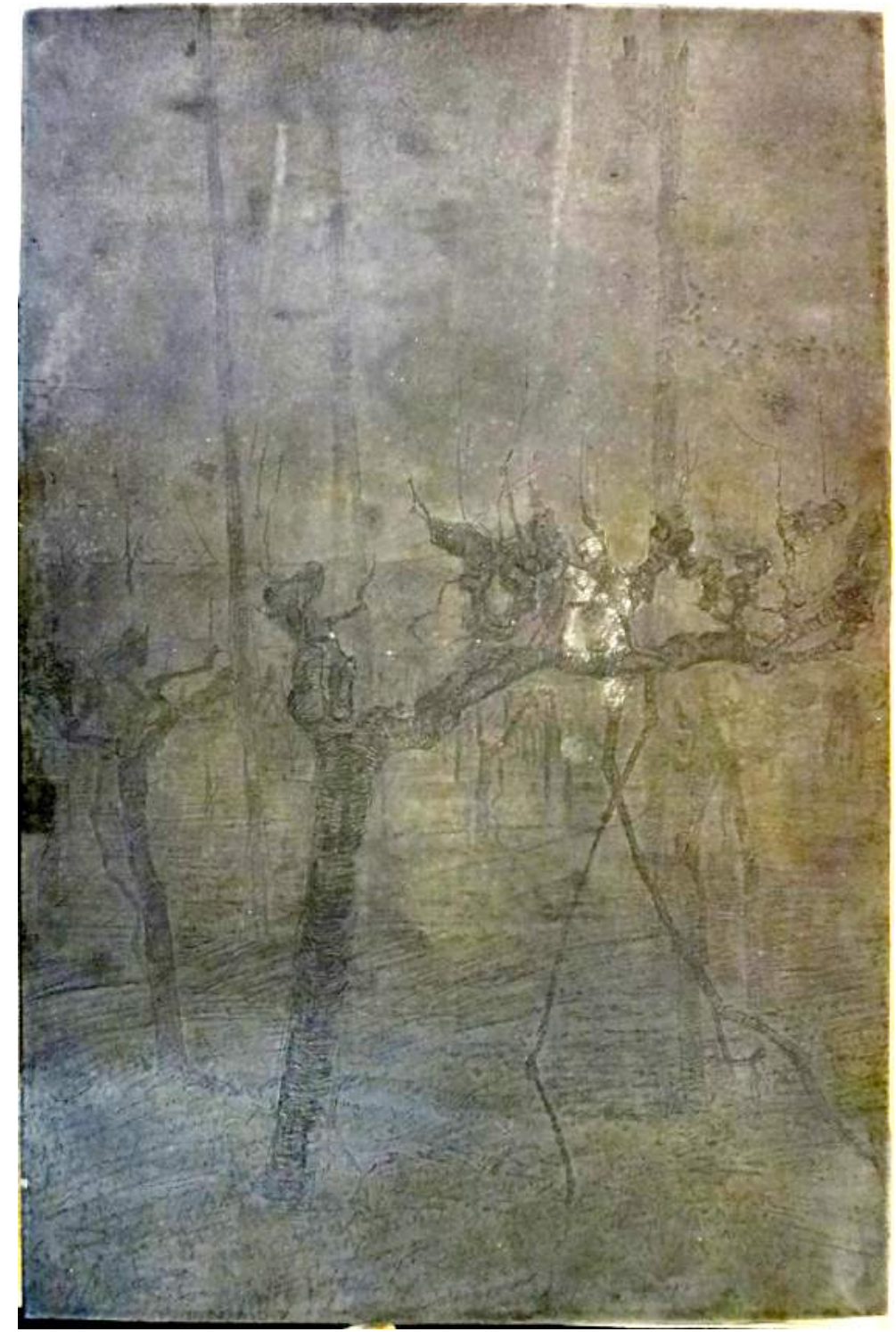

Fig. 42.C

C. [matriz] DATA: 1910. TÉCNICA: Água-forte e verniz-mole. MATRIZ: zinco. Sem assinatura. ACERVO Fundação Biblioteca Nacional. PROVENIÊNCIA: registrada em 1976 no acervo.

LITERATURA: Silva, 1969 (ref.); Exp. Carlos Oswald: o resgate de um mestre, Caixa Cultural, Brasília/Curitiba, 2011, p. 29 (rep.). 


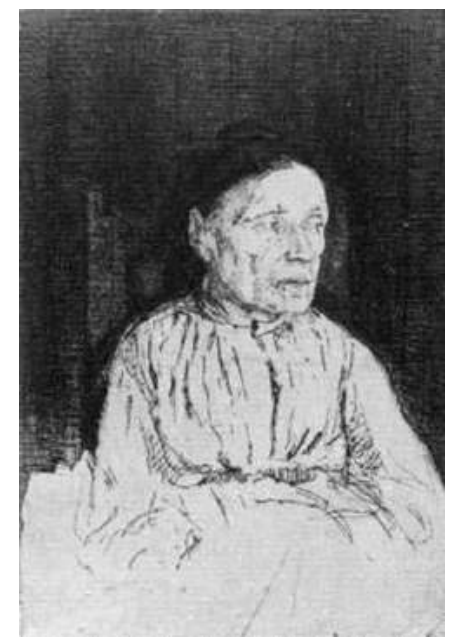

Fig. 43
43. TÍTULOS: Minha tia-avó; Avôs. VARIANTE: Zia Beppa.

DATA: 1910. TÉCNICA: Água-forte e água-tinta. MEDIDAS: 20,7 x 14 cm (mancha); 29,6 x 22,1 cm (papel). IMPRESSÃO: em preto. ASSINATURA: "C. Oswald" no papel. COLEÇÃO Museu Nacional de Belas Artes/IBRAM/MinC. PROVENIÊNCIA: Carlos Oswald, compra, 1963. FOTOGRAFIA: Acervo Museu Nacional de Belas Artes/IBRAM/MinC.

LITERATURA: Oswald, 1957, p. 208 (ref.) ; Silva, 1969 (ref.).

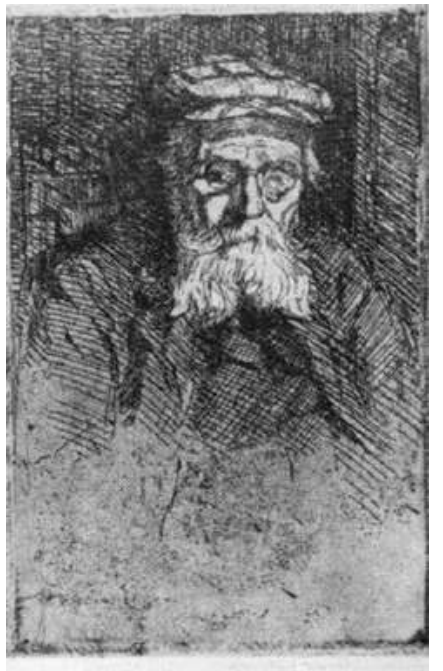

Fig. 44
44. TÍTULOS: Meu avô; Avôs. VARIANTES: O avô.

DATA: 1910. TÉCNICA: Água-forte. MEDIDAS: 19,7 x 13,1 cm (mancha); 32,8 x 23,9 cm (papel). IMPRESSÃO: em preto. ASSINATURA: "C. Oswald” no papel. COLEÇÃO Museu Nacional de Belas Artes/IBRAM/MinC. PROVENIÊNCIA: Carlos Oswald, compra, 1963. FOTOGRAFIA: Acervo Museu Nacional de Belas Artes/IBRAM/MinC.

LITERATURA: Oswald, 1957, p. 208 (ref.); Silva, 1969 (ref.). 


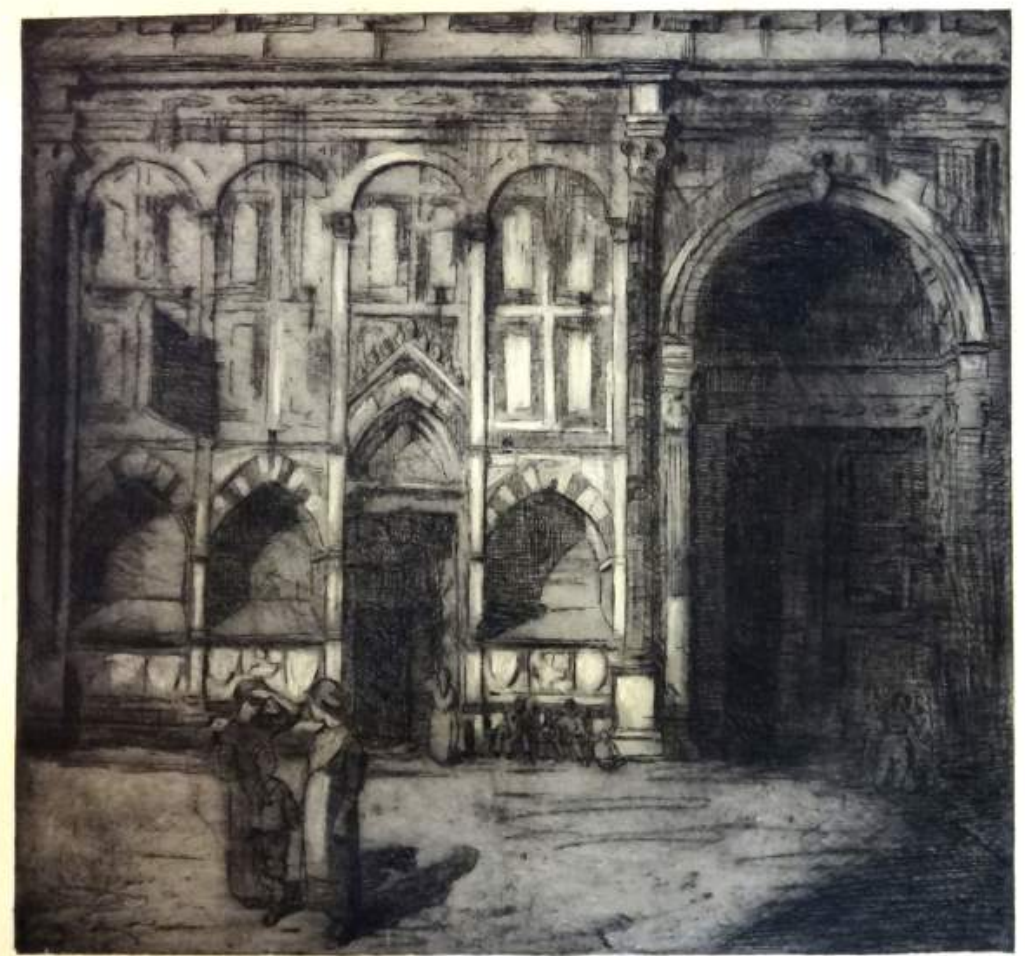

Fig. 45.A

45. TÍTULOS: Velha Igreja; Santa Maria Novella; Trecho de fachada. VARIANTES: Trecho de velha igreja; Trecho de fachada da antiga Matriz.

A. DATA: 1910. TÉCNICA: Água-forte e verniz mole. MEDIDAS: 38 x $40 \mathrm{~cm}$ (mancha), 54,2 x 67,7 cm (papel). IMPRESSÃO: em preto. ASSINATURA: "C. Oswald" no canto inferior esquerdo do papel. ACERVO Fundação Biblioteca Nacional. PROVENIÊNCIA: Carlos Oswald, compra, 1916.

B. DATA: 1912. TÉCNICA: Água-forte e verniz mole. MEDIDAS: 37,7 x 40,2 cm (mancha); 45,9 x 47,6 cm (papel). IMPRESSÃO: em preto. ASSINATURA: "C. Oswald" no canto inferior direito do papel. COLEÇÃO Museu Nacional de Belas Artes/IBRAM/MinC. PROVENIÊNCIA: Carlos Oswald, compra, 1963.

LITERATURA: A Gazeta, SP, 24/1/1923 (nota); Oswald, 1957, p. 208 (ref.); Silva, 1969 (ref.); Exp. Carlos Oswald: o resgate de um mestre, Caixa Cultural, Brasília/Curitiba, 2011, p. 33 (rep.). 


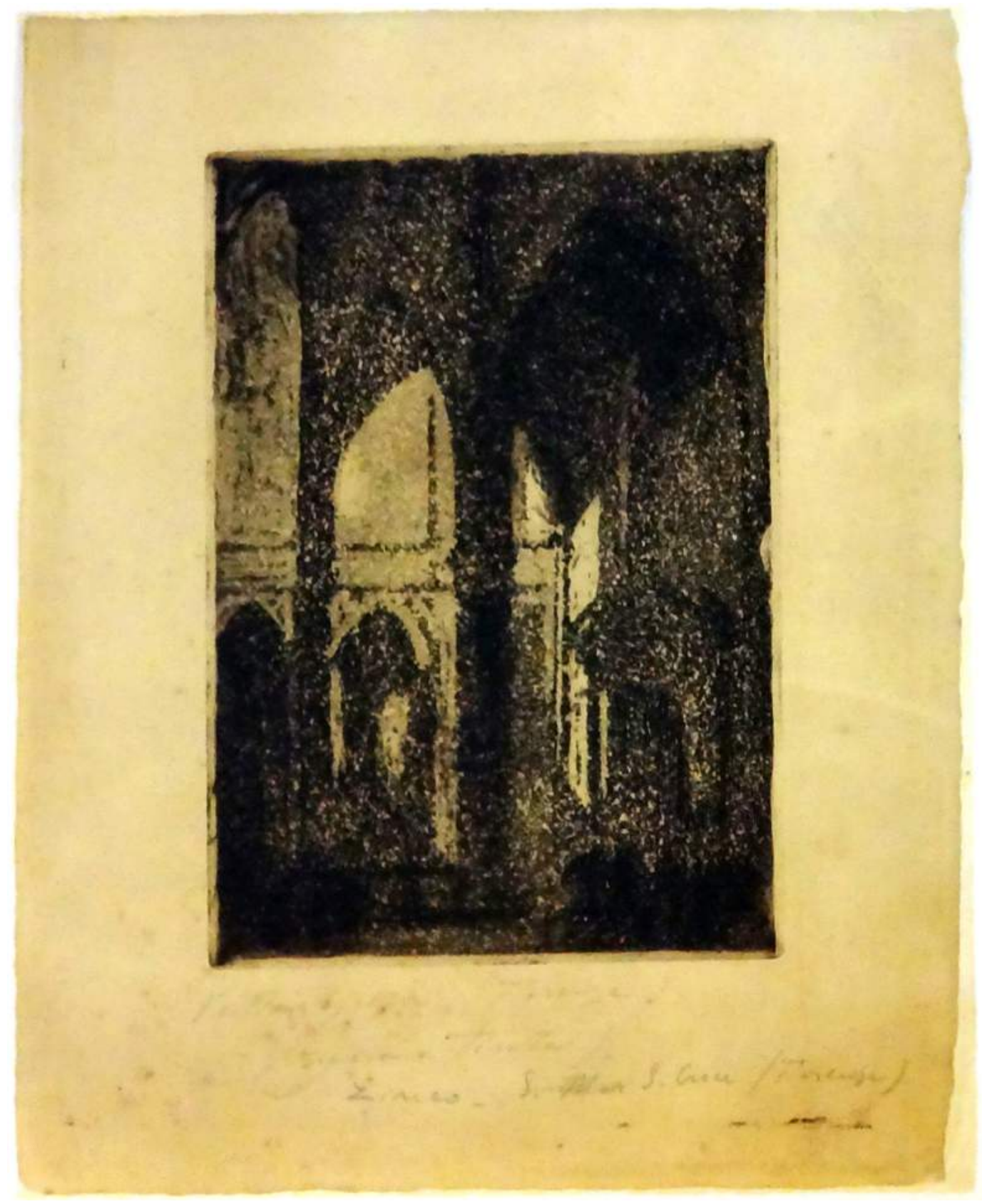

Fig. 46

46. TÍTULO: Velha Igreja.

TÉCNICA: Água-tinta. MEDIDAS: 20 x 14 cm (mancha). IMPRESSÃO: em preto. Sem assinatura. ACERVO Fundação Biblioteca Nacional. PROVENIÊNCIA: registrada no acervo em 1980. 


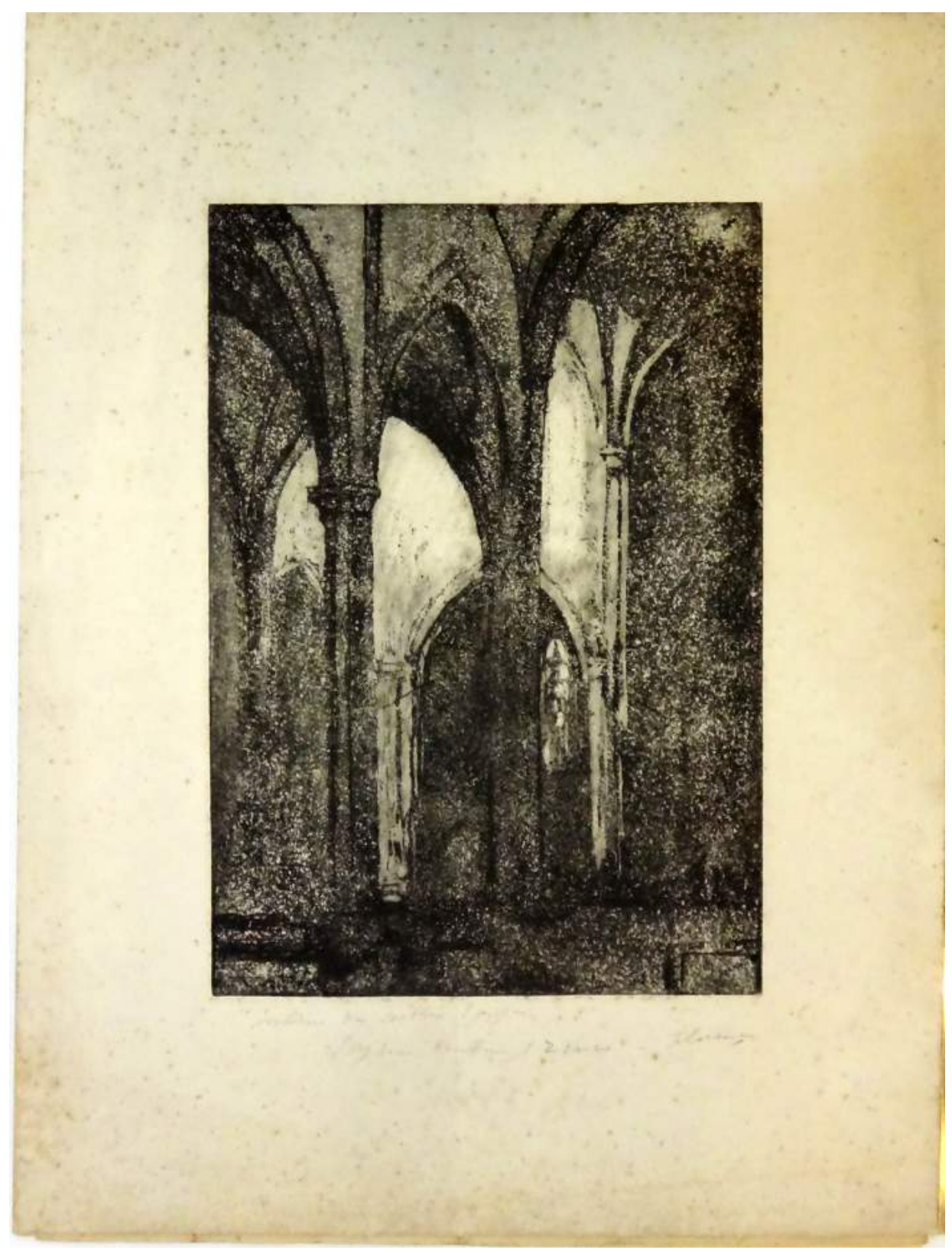

Fig. 47

47. TÍTULO: Interior de Velha Igreja.

TÉCNICA: Água-tinta e água-forte. MEDIDAS: 33 x 21 cm (mancha). IMPRESSÃO: em preto. Sem assinatura. ACERVO Fundação Biblioteca Nacional. PROVENIÊNCIA: registrada no acervo em 1980. 


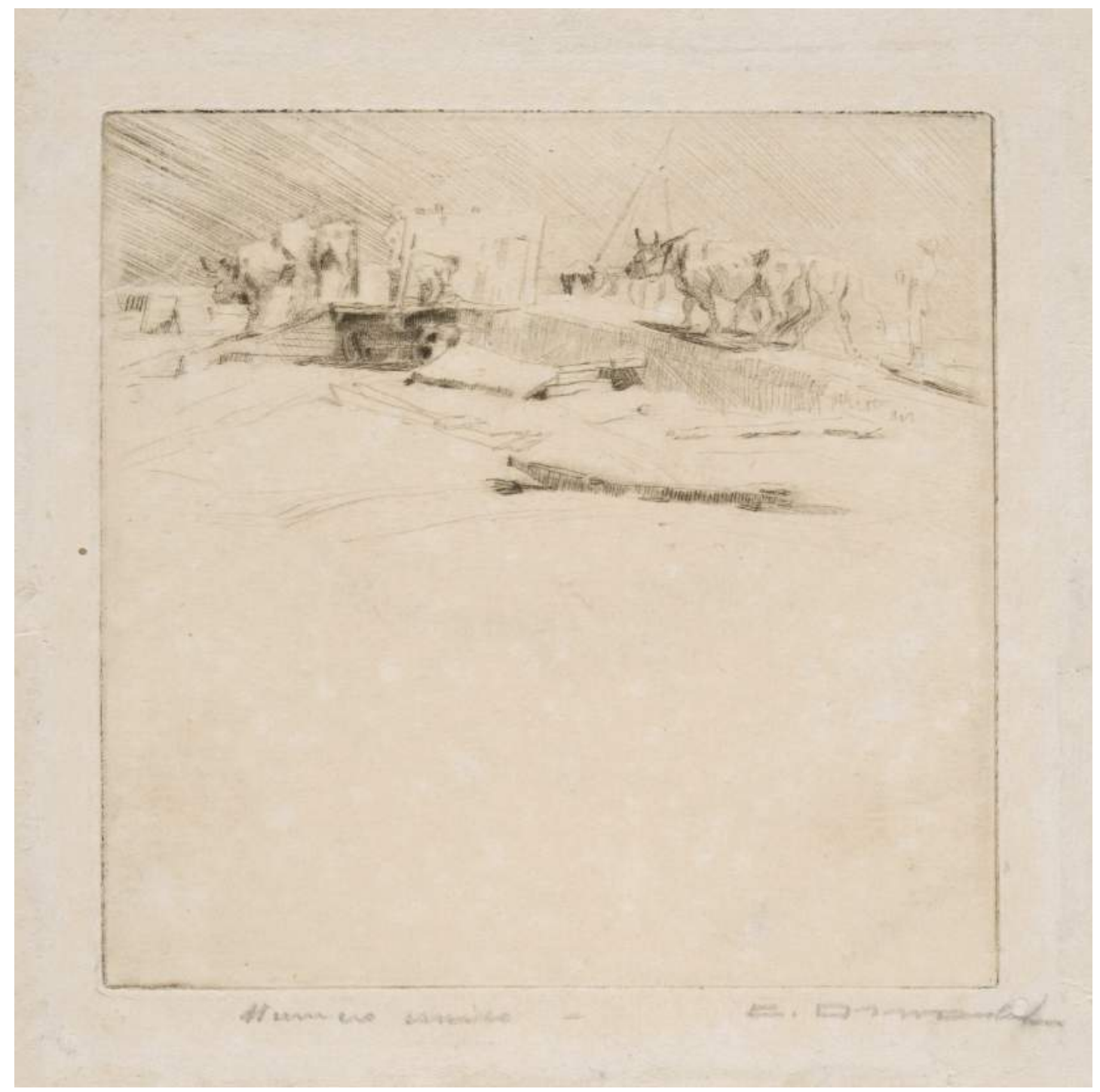

Fig. 48

48. TÍTULO: Carregando mármore. VARIANTE: Pequeno Carregando mármore.

DATA: 1912. TÉCNICA: Ponta seca. MEDIDAS: 12,3 x 12,5 cm (mancha); 29,3 x 21,5 cm (papel). IMPRESSÃO: em preto. ASSINATURA: "C. Oswald" no canto inferior direito do papel. COLEÇÃO Museu Nacional de Belas Artes/IBRAM/MinC. PROVENIÊNCIA: Carlos Oswald, compra, 1963. FOTOGRAFIA: Acervo Museu Nacional de Belas Artes/IBRAM/MinC.

LITERATURA: Silva, 1969 (ref.); Exp. Carlos Oswald: o resgate de um mestre, Caixa Cultural, Brasília/Curitiba, 2011, p. 22 (rep.). 


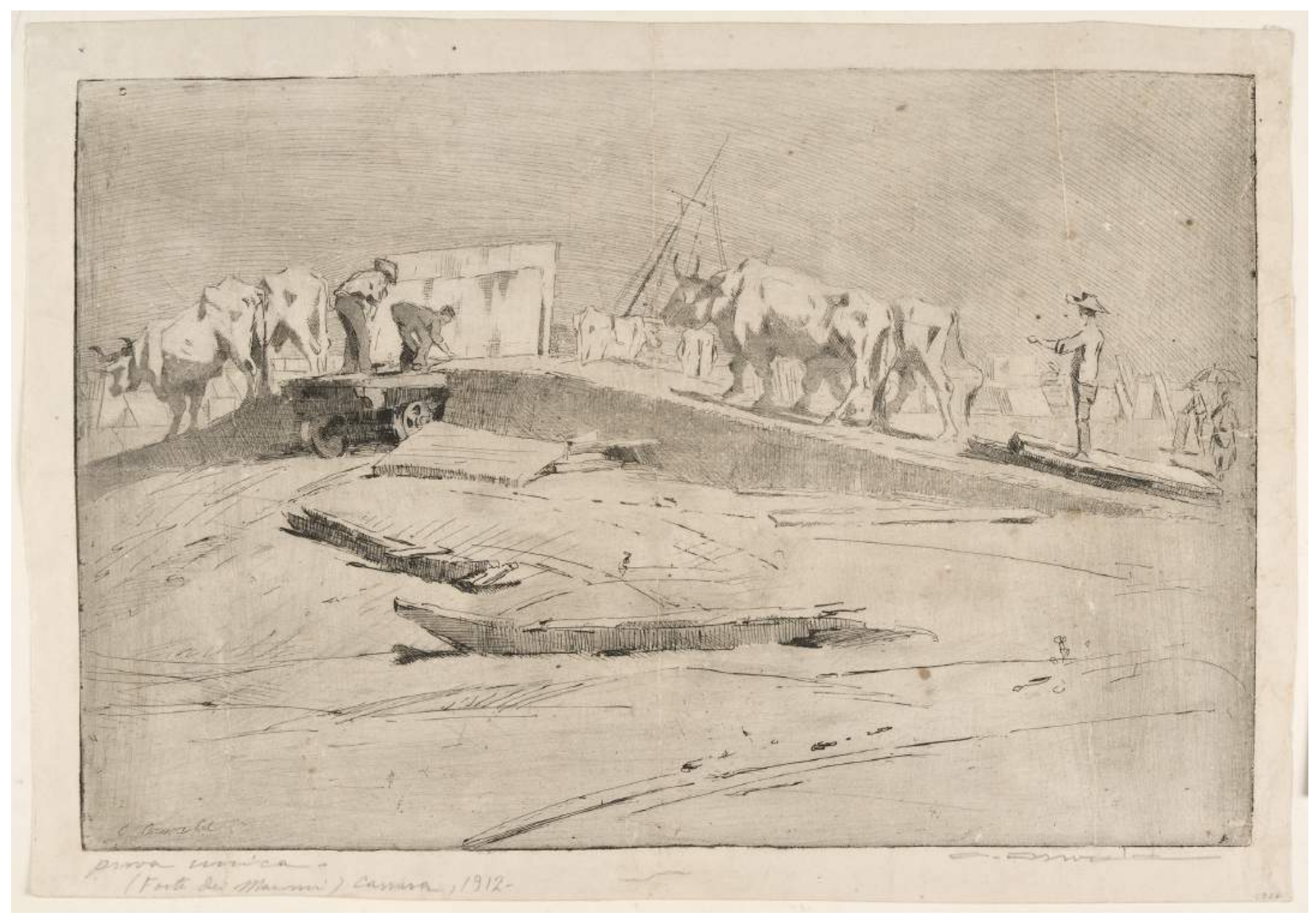

Fig. 49

49. TÍTULO: Forte dei Marmi, Carrara. VARIANTE: Carregando mármore.

DATA: 1912. TÉCNICA: Água- forte e água-tinta. MEDIDAS: 23,7 x 36,5 cm (mancha); 27 x 39,3 cm (papel). IMPRESSÃO: em preto. ASSINATURA: "C. Oswald" no canto inferior esquerdo da mancha e no canto inferior direito do papel. COLEÇÃO Museu Nacional de Belas Artes/IBRAM/MinC. PROVENIÊNCIA: Carlos Oswald, compra, 1963. FOTOGRAFIA: Acervo Museu Nacional de Belas Artes/IBRAM/MinC.

LITERATURA: Silva, 1969 (ref., datada 1909); Silva, 1976. p. 78 (ref.); Exp. Carlos Oswald: o resgate de um mestre, Caixa Cultural, Brasília/Curitiba, 2011, p. 23 (rep.). 


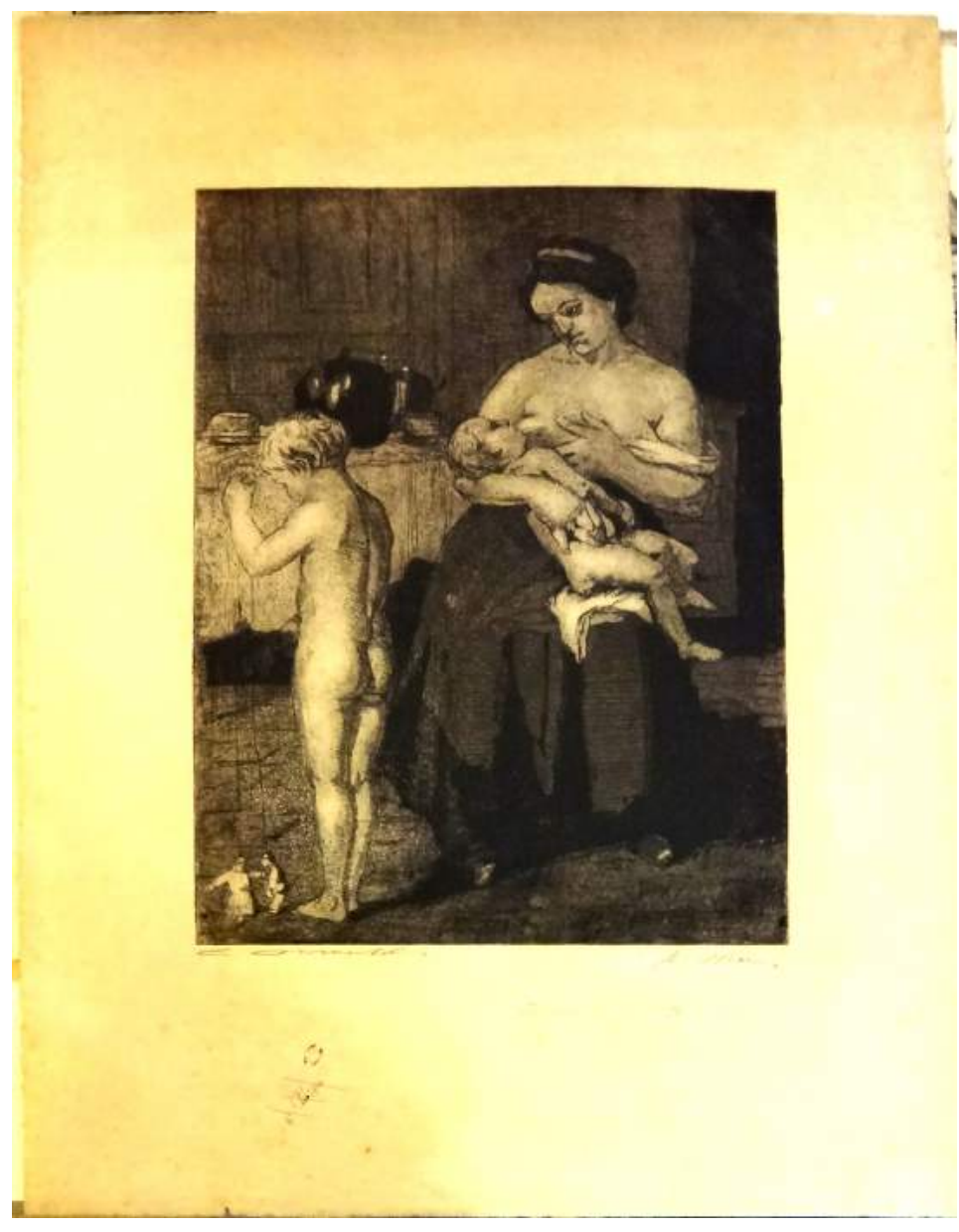

Fig. 50.A

50. TÍTULO: A mãe. VARIANTE: Maternidade.

A. DATA: 1913. TÉCNICA: Água-forte e água-tinta. MEDIDAS: 39,5 x 29,8 cm (mancha), 63 x $48 \mathrm{~cm}$ (papel). IMPRESSÃO: em preto. MATRIZ: zinco. MEDIDAS DA MATRIZ: 39,8 x 30 cm. ASSINATURA: "C. Oswald" no canto inferior esquerdo do suporte. ACERVO Fundação Biblioteca Nacional. PROVENIÊNCIA: Carlos Oswald, compra, 1916.

B. [matriz] DATA: 1911. TÉCNICA: Água-forte e água-tinta. MATRIZ: zinco. MEDIDAS DA MATRIZ: 39,8 x $30 \mathrm{~cm}$. ASSINATURA: monograma “CO”. COLEÇÃO Museu Nacional de Belas Artes/IBRAM/MinC. PROVENIÊNCIA: Maria Isabel Oswald Monteiro, doação, 1982.

LITERATURA: Silva, 1969 (ref.).

51. TÍTULO: A mãe. VARIANTE: Maternidade.

DATA: 1911. TÉCNICA: Água-forte e água-tinta. MEDIDAS: 39,5 x 29,9 cm (mancha); 52,5 x $40 \mathrm{~cm}$ (papel). IMPRESSÃO: em vermelho e azul. MATRIZ: zinco. MEDIDAS DA MATRIZ: 39,8 x $30 \mathrm{~cm}$. ASSINATURA: "C. Oswald" e o monograma "Co" no canto inferior direito do papel. COLEÇÃO Museu Nacional de Belas Artes/IBRAM/MinC. PROVENIÊNCIA: Carlos Oswald, compra, 1963. 


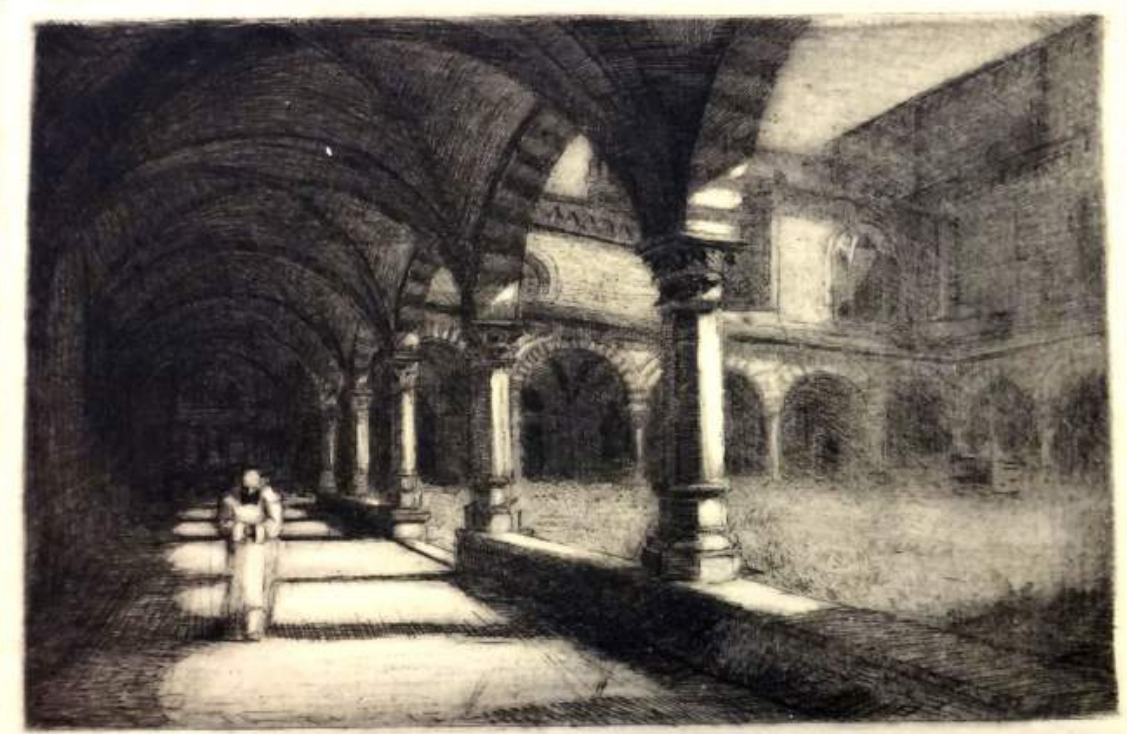

Fig. 52.A

52. TÍTULOS: Velho Claustro; Claustro da Igreja de S. Maria Novella (Florença). VARIANTES: Claustro de Santa Maria Novella; Claustro em Florença.

A. DATA: 1912. TÉCNICA: Água-forte. MEDIDAS: 24 x $33 \mathrm{~cm}$ (mancha). IMPRESSÃO: em preto. MATRIZ: zinco. MEDIDAS DA MATRIZ: 24,1 x 35,6 cm. ASSINATURA: "C. Oswald" no canto inferior esquerdo do papel. ACERVO Fundação Biblioteca Nacional. PROVENIÊNCIA: Carlos Oswald, compra, 1916.

B. [matriz] DATA: 1912. TÉCNICA: Água-forte. MATRIZ: zinco. MEDIDAS DA MATRIZ: 24,1 x 35,6 cm. Sem assinatura. COLEÇÃO Museu Nacional de Belas Artes/IBRAM/MinC. PROVENIÊNCIA: Maria Isabel Oswald Monteiro, doação, 1982.

LITERATURA: Illustração Brasileira, RJ, 1/6/1913, p. 181 (rep.); Illustração Brasileira, RJ, 12/1922, p. 72 (rep.); Correio Paulistano, SP, 12/12/1923 (nota); Oswald, 1957, p. 210 (ref.); Silva, 1969 (ref.). 


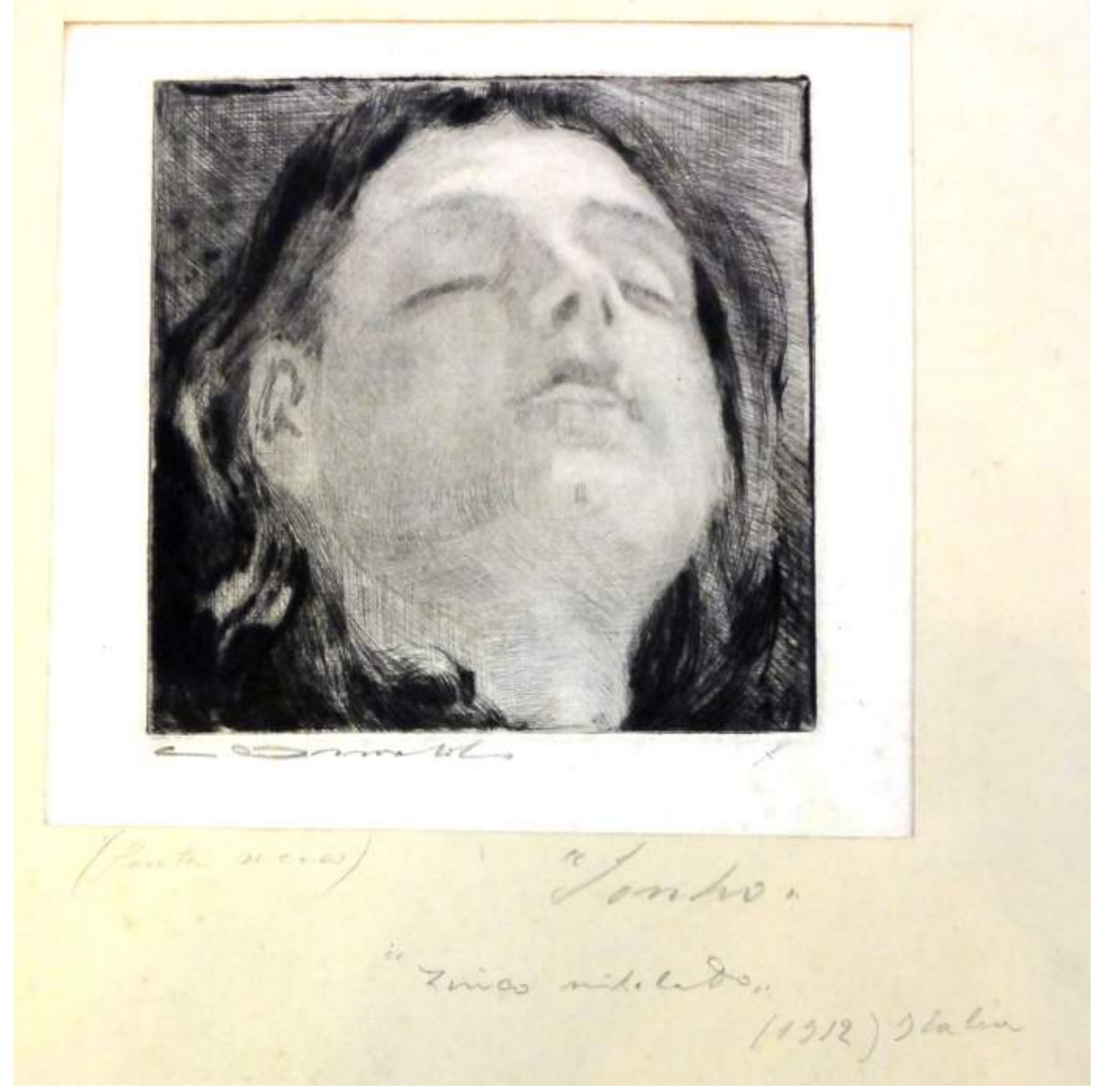

Fig. 53.A

\section{TÍTULO: Sonho.}

A. DATA: 1912. TÉCNICA: Ponta seca. MEDIDAS: 12,5 x 12, $5 \mathrm{~cm}$ (mancha), 24,6 x 24,5 cm (papel). IMPRESSÃO: em preto. ASSINATURA: "C. Oswald" no canto inferior esquerdo do papel. ACERVO Fundação Biblioteca Nacional. PROVENIÊNCIA: Carlos Oswald, compra, 1916.

B. DATA: 1912. TÉCNICA: Ponta seca. MEDIDAS: 12,5 x 12, $5 \mathrm{~cm}$ (mancha), 15,4 x 15,5 cm (papel). IMPRESSÃO: em preto. ASSINATURA: "C. Oswald" no canto inferior esquerdo do papel. COLEÇÃO Museu Nacional de Belas Artes/IBRAM/MinC. PROVENIÊNCIA: Carlos Oswald, compra, 1963.

LITERATURA: Felix, Illustração Brasileira, RJ, 1/6/1913, p. 182 (rep., artigo); Oswald, 1957, p. 210 (ref.); Silva, 1969 (ref.); Exp. Carlos Oswald: o resgate de um mestre, Caixa Cultural, Brasília/Curitiba, 2011, p. 36 (rep.). 


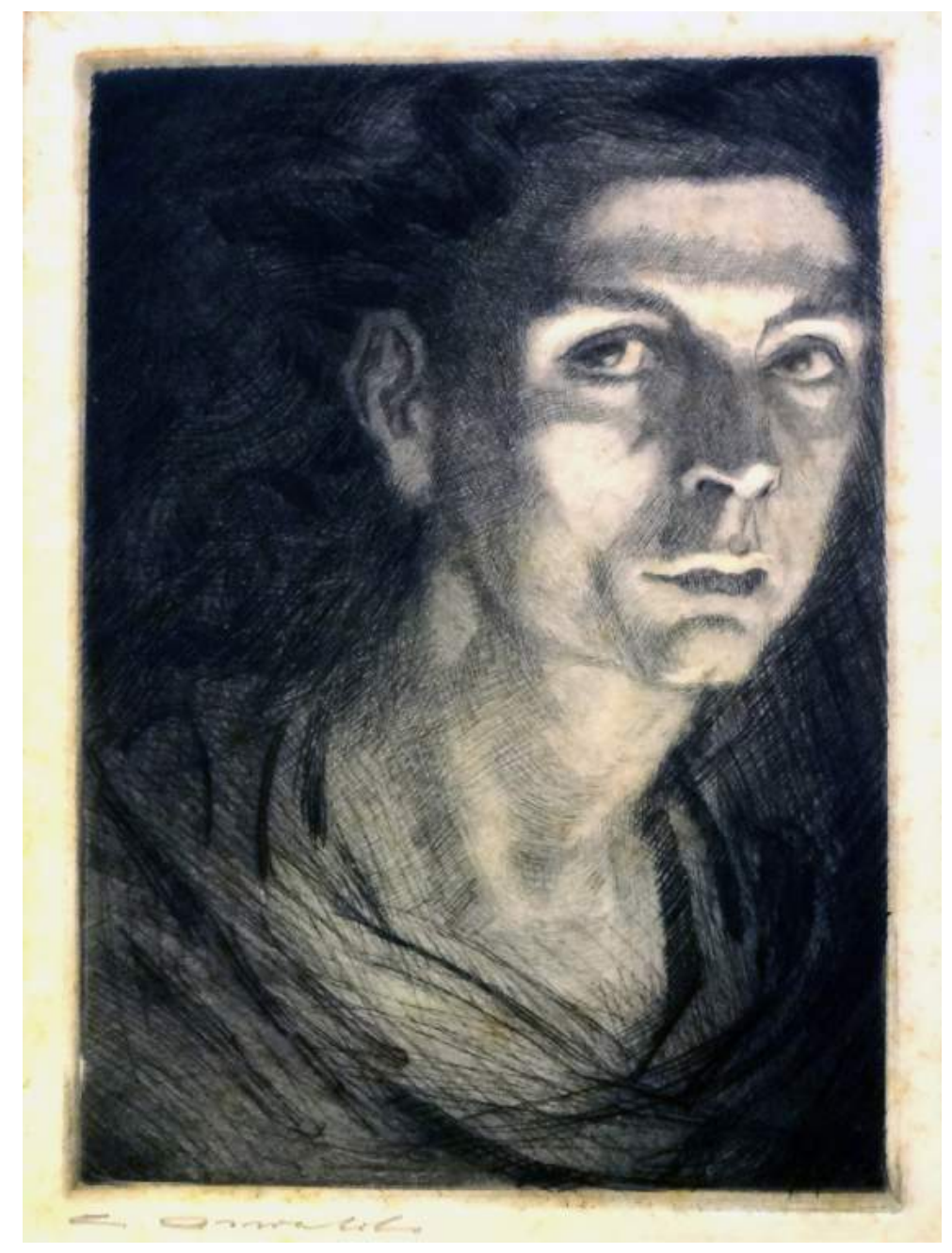

Fig. 54. A

54. TÍTULO: Poeta. VARIANTES: Cabeça de Poeta; O Poeta.

A. DATA: 1913. TÉCNICA: Ponta seca. MEDIDAS: 19,7 x $14 \mathrm{~cm}$ (mancha), 32,5 x $25 \mathrm{~cm}$ (papel). IMPRESSÃO: em preto. MATRIZ: cobre. ASSINATURA: "C. Oswald" no canto inferior esquerdo do papel. ACERVO Fundação Biblioteca Nacional. PROVENIÊNCIA: Carlos Oswald, compra, 1916.

B. [1 estado?] DATA: 1913. TÉCNICA: Ponta seca. MEDIDAS: 19,7 x $14 \mathrm{~cm}$ (mancha), 37,5 x $27 \mathrm{~cm}$ (papel). IMPRESSÃO: em preto. MATRIZ: cobre. Sem assinatura. ACERVO Fundação Biblioteca Nacional. PROVENIÊNCIA: obra registrada no acervo em 1962, mas com indicação de que faz parte da coleção antes dessa data.

C. TÉCNICA: Ponta seca. MEDIDAS: 19,7 x 14 cm (mancha). IMPRESSÃO: possível impressão póstuma, em preto. MATRIZ: cobre. Sem assinatura. ACERVO Fundação Biblioteca Nacional. PROVENIÊNCIA: sem registro no acervo.

D. [matriz] DATA: 1913. TÉCNICA: Ponta seca. MATRIZ: cobre. Sem assinatura. ACERVO Fundação Biblioteca Nacional.

LITERATURA: O Paiz, RJ, 7/7/1916 (nota); Correio Paulistano, SP, 8/2/1918 (nota); O Jornal, RJ, 23/12/1921 (nota); Silva, 1969 (ref.). 

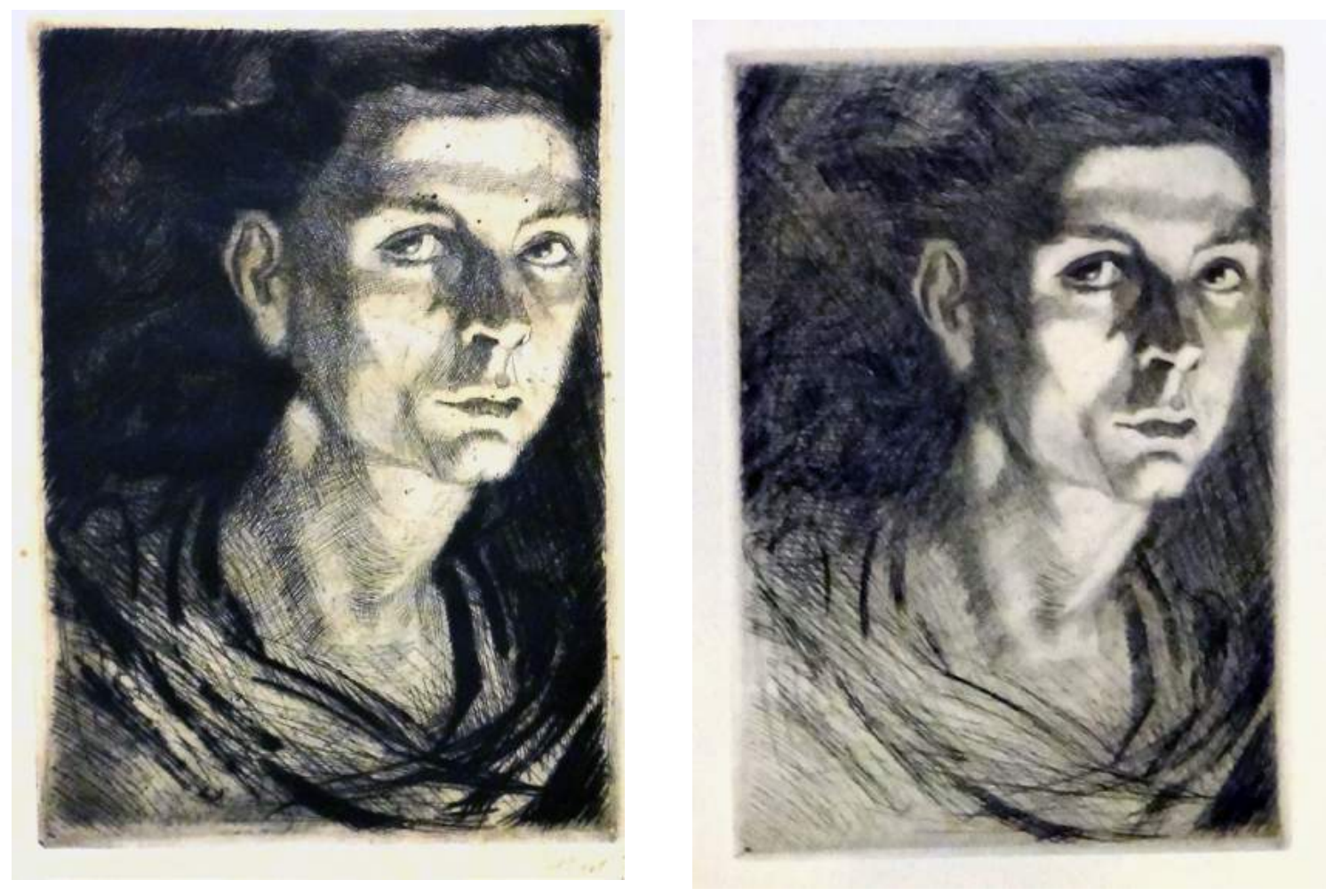

Fig. 54. B

Fig. 54.C

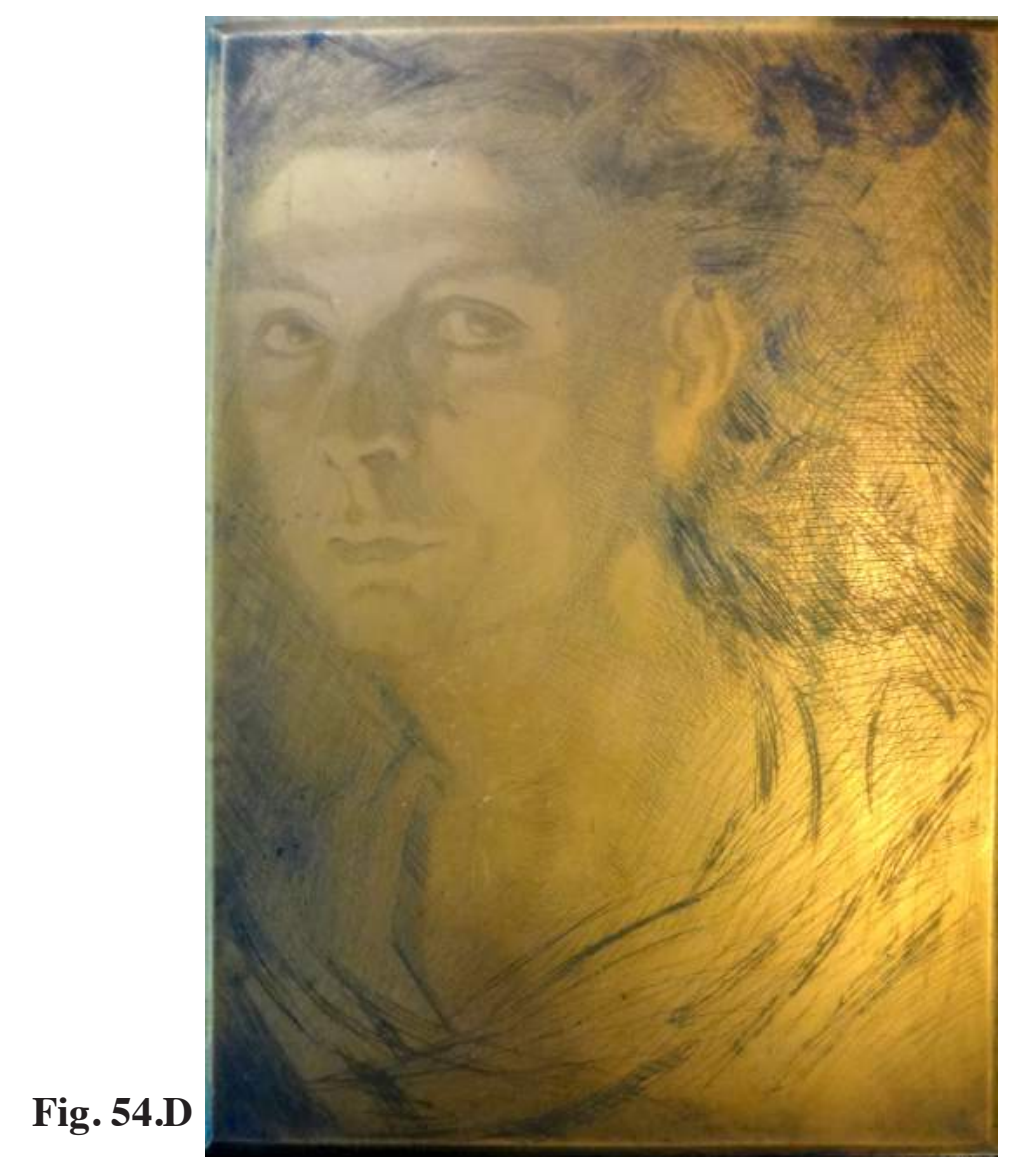


Fig. 55. A

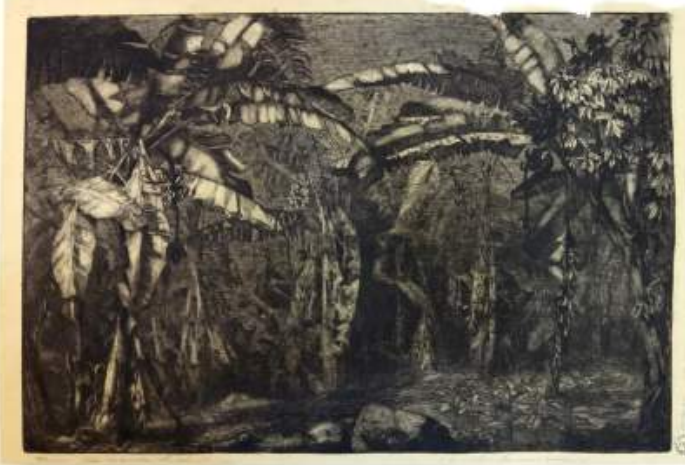

55. TÍTULO: A grande bananeira. VARIANTE: Bananeiras.

A. DATA: 1914. TÉCNICA: Água-forte. MEDIDAS: 39,5 x 59,7 cm (mancha); 42,6 x 63 cm (papel). IMPRESSÃO: em preto. MATRIZ: zinco. MEDIDAS DA MATRIZ: 40,1 x 60,5 cm. ASSINATURA: "C. Oswald" no canto inferior esquerdo do papel, monograma "CO" no centro da margem inferior da mancha. ACERVO Fundação Biblioteca Nacional. PROVENIÊNCIA: Carlos Oswald, compra, 1916. [No verso dessa gravura está impresso o diploma do Instituto Nacional de Música realizado por Henrique Bernardelli].

B. DATA: 1914. TÉCNICA: Água-forte. MEDIDAS: 39,5 x 59,6 cm (mancha); 48,4 x $66 \mathrm{~cm}$ (papel). IMPRESSÃO: em marrom. MATRIZ: zinco. MEDIDAS DA MATRIZ: 40,1 x 60,5 cm. ASSINATURA: "C. Oswald" no papel, monograma "CO" no centro da margem inferior da mancha. COLEÇÃO Museu Nacional de Belas Artes/IBRAM/MinC. PROVENIÊNCIA: Carlos Oswald, compra, 1963.

C. [1 ${ }^{\circ}$ estado] DATA: 1914. TÉCNICA: Água-forte. MEDIDAS: 39,5 x 59,7 cm (mancha); 48 x $63 \mathrm{~cm}$ (papel). IMPRESSÃO: em preto. MATRIZ: zinco. MEDIDAS DA MATRIZ: 40,1 x 60,5 cm. ASSINATURA: monograma "CO" no centro da margem inferior da mancha. ACERVO Fundação Biblioteca Nacional. PROVENIÊNCIA: Carlos Oswald, compra, 1916.

D. [2 $2^{\circ}$ estado] DATA: 1914. TÉCNICA: Água-forte. MEDIDAS: 39,5 x 59,7 cm (mancha); 47,7 x 63 cm (papel). IMPRESSÃO: em marrom. MATRIZ: zinco. MEDIDAS DA MATRIZ: 40,1 x 60,5 cm. ASSINATURA: monograma "CO" no centro da margem inferior da mancha. ACERVO Fundação Biblioteca Nacional. PROVENIÊNCIA: Carlos Oswald, compra, 1916. E. [matriz] DATA: 1914. TÉCNICA: Água-forte. MATRIZ: zinco. MEDIDAS DA MATRIZ: 40,1 x 60,5 cm. ASSINATURA: monograma "CO" no centro da margem inferior. COLEÇÃO Museu Nacional de Belas Artes/IBRAM/MinC. PROVENIÊNCIA: Maria Isabel Oswald Monteiro, doação, 1982.

LITERATURA: O Paiz, RJ, 7/7/1916 (nota); Correio Paulistano, SP, 21/1/1923 (nota); Correio da Manhã, RJ, 6/12/1935 (nota); Oswald, 1957, p. 210 (ref.); Silva, 1969 (ref.); Exp. A gravura brasileira na coleção Mônica e George Kornis, Caixa Cultural, RJ, PR, BA, DF, SP, 2007/2008, p. 23 (rep.); Exp. Carlos Oswald: o resgate de um mestre, Caixa Cultural, Brasília/Curitiba, 2011, p. 55 (rep.). 


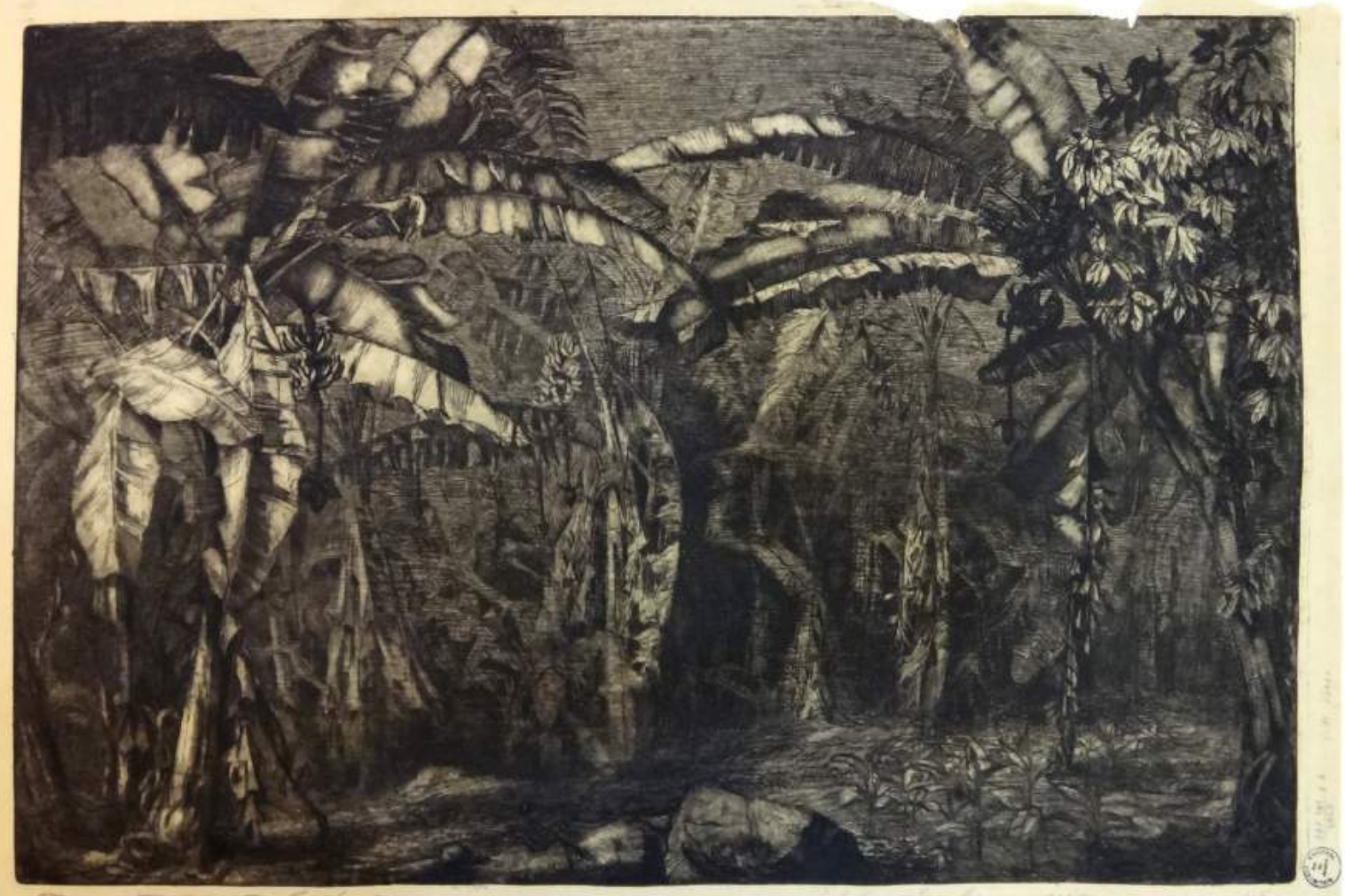

Fig. 55. A

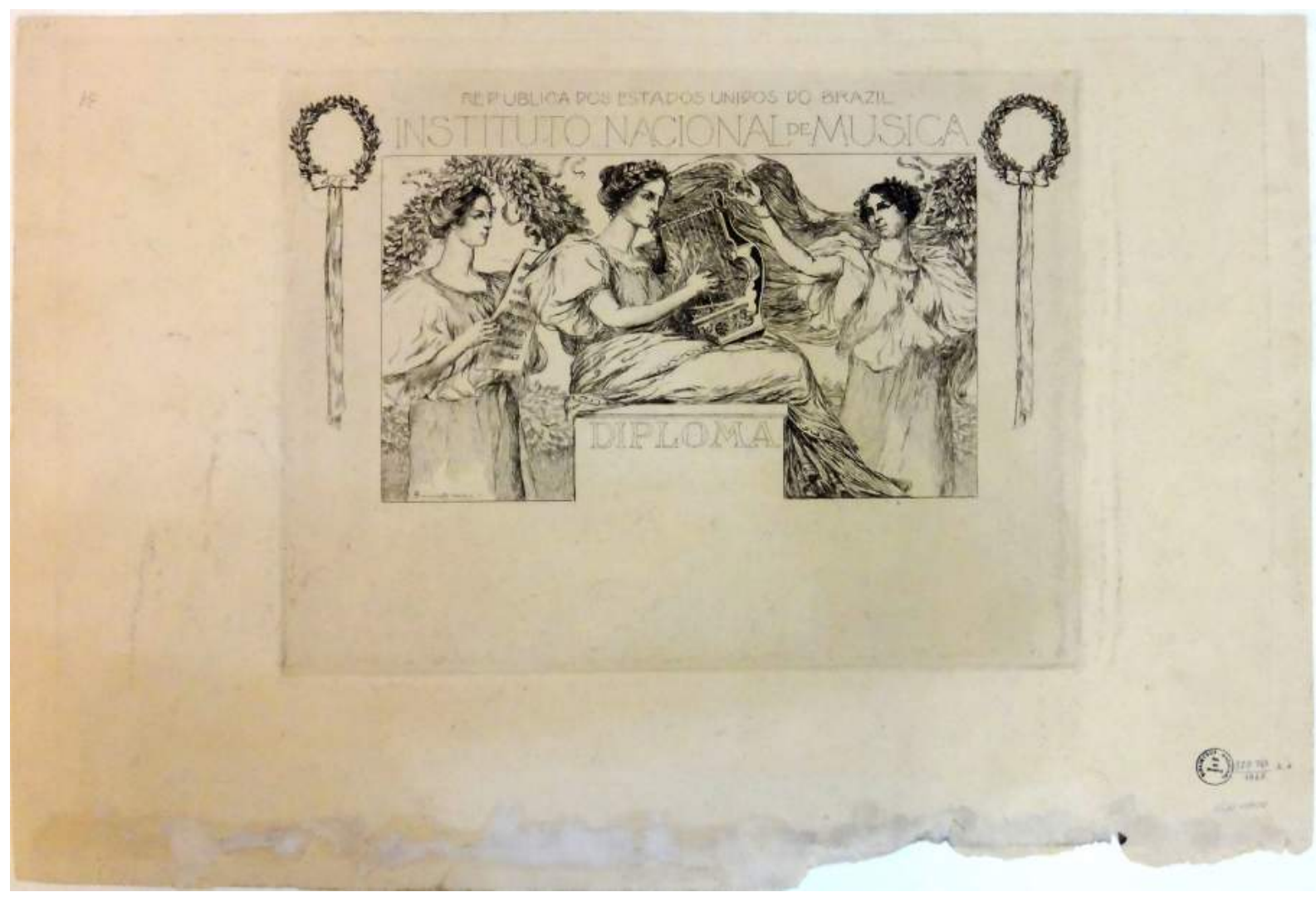

Fig. 55. A

[verso] 


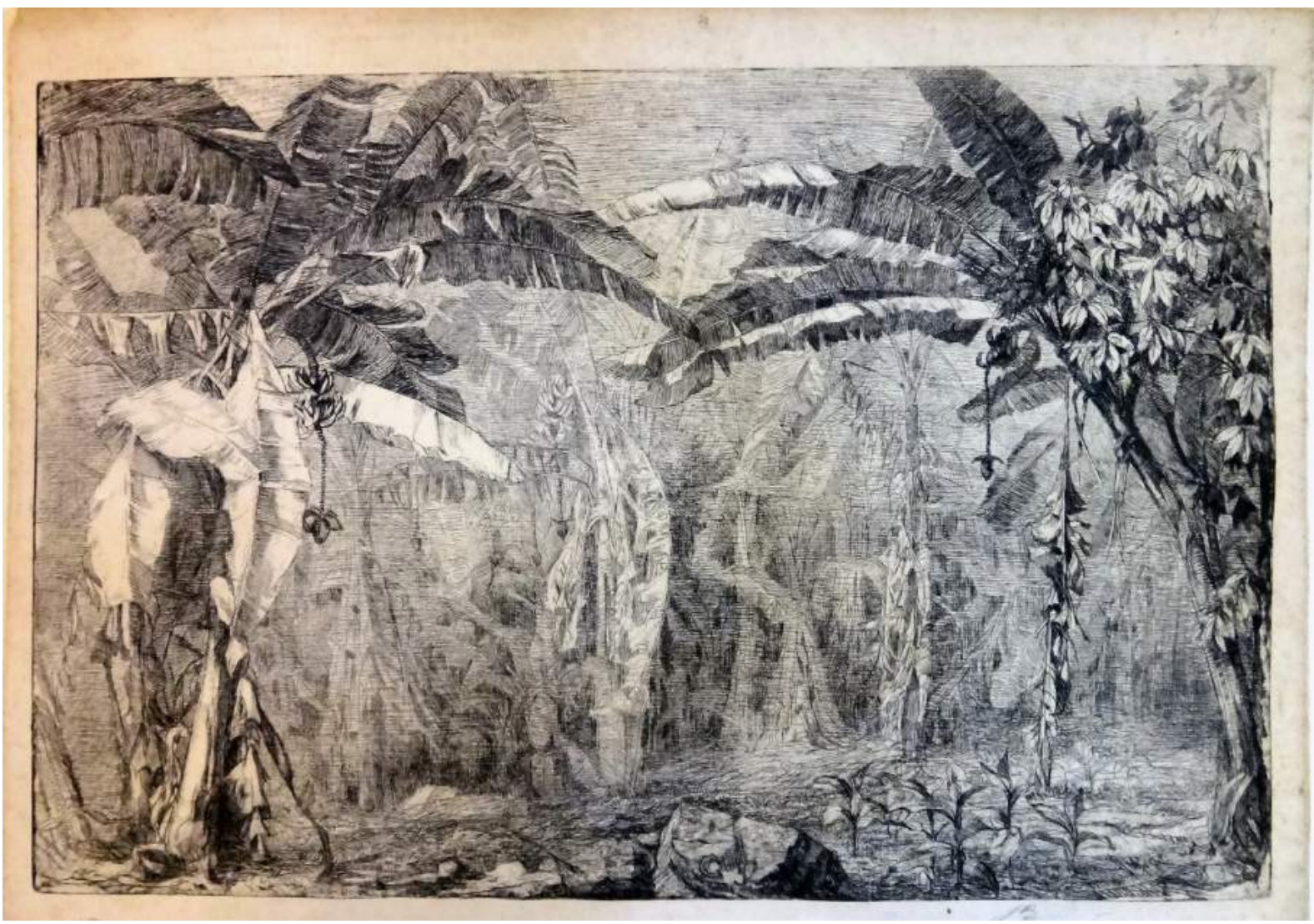

Fig. 55. C

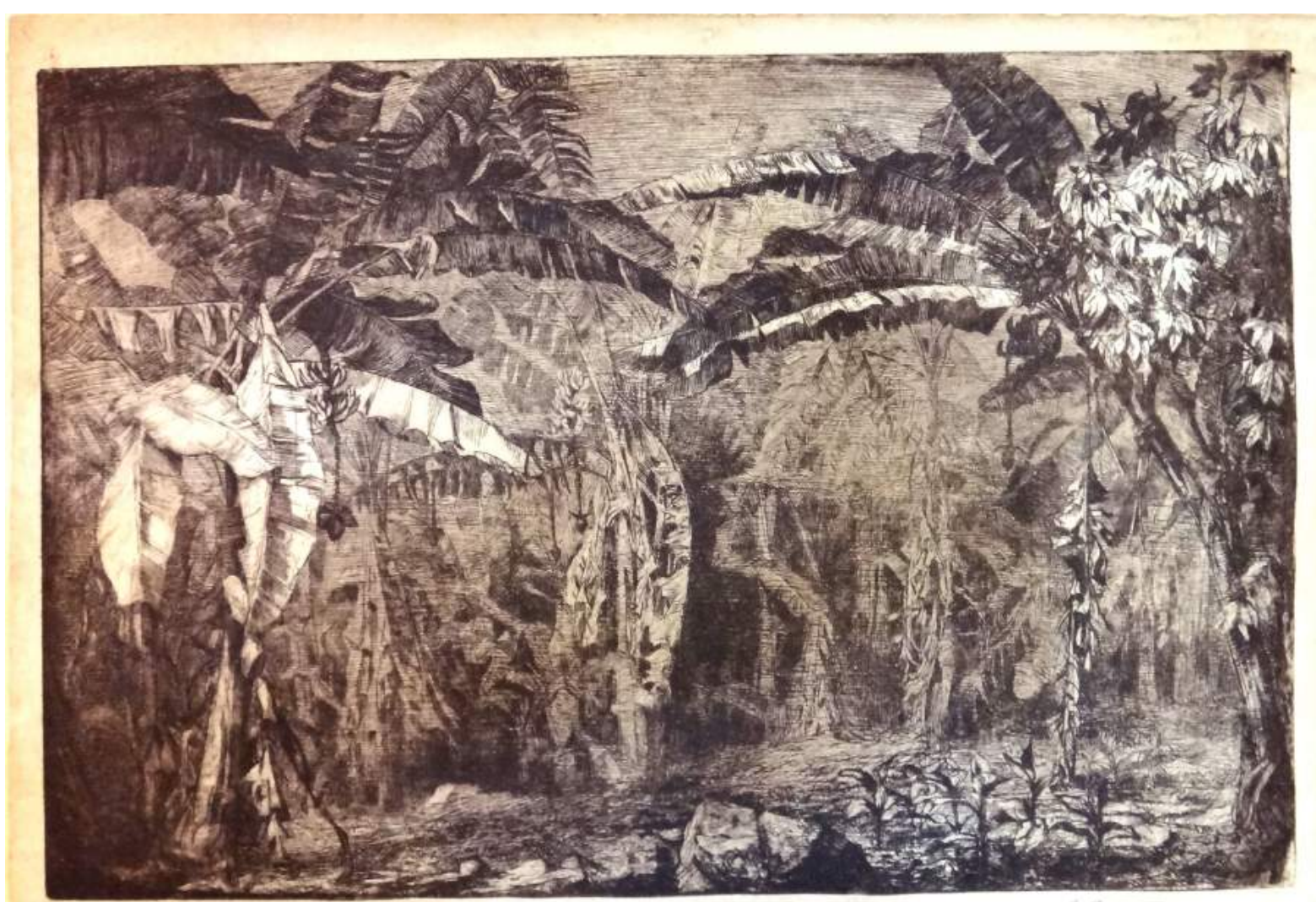

Fig. 55. D 
Fig. 56.A

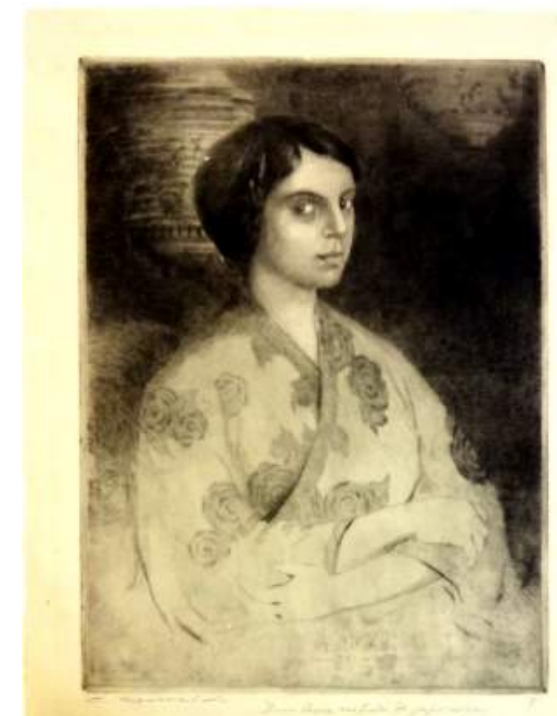

56. TÍTULOS: Mimma; Brasileira vestida de japonesa. VARIANTE: Em kimono; Mulher com quimono chinês.

A. DATA: 1914. TÉCNICA: Água-forte. MEDIDAS: 27,5 x $20 \mathrm{~cm}$ (mancha), 32 x 25,5 cm (papel). IMPRESSÃO: em preto. ASSINATURA: "C. Oswald" no canto inferior esquerdo do papel, "C. Oswald scultp" no canto inferior esquerdo da mancha. ACERVO Fundação Biblioteca Nacional. PROVENIÊNCIA: Carlos Oswald, compra, 1916.

B. DATA: 1914. TÉCNICA: Água-forte. MEDIDAS: 27 x 19,7 cm (mancha); 44 x 32,9 cm (papel). IMPRESSÃO: em preto. ASSINATURA: “C. Oswald” no canto inferior direito do papel, "C. Oswald scultp” no canto inferior esquerdo da mancha. COLEÇÃO Museu Nacional de Belas Artes/IBRAM/MinC. PROVENIÊNCIA: Carlos Oswald, compra, 1963.

C. [1 $1^{\circ}$ estado] DATA: 1914. TÉCNICA: Água-forte. MEDIDAS: 27,5 x $20 \mathrm{~cm}$ (mancha), 34,6 x $26 \mathrm{~cm}$ (papel). IMPRESSÃO: em preto. ASSINATURA: “C. Oswald scultp” no canto inferior esquerdo da mancha. ACERVO Fundação Biblioteca Nacional. PROVENIÊNCIA: Carlos Oswald, compra, 1916.

D. [2 estado] DATA: 1914. TÉCNICA: Água-forte. MEDIDAS: 27,5 x $20 \mathrm{~cm}$ (mancha), 31 x 24,5 cm (papel). IMPRESSÃO: em preto. ASSINATURA: “C. Oswald scultp" no canto inferior esquerdo da mancha. ACERVO Fundação Biblioteca Nacional. PROVENIÊNCIA: Carlos Oswald, compra, 1916.

E. [3º estado] DATA: 1914. TÉCNICA: Água-forte. MEDIDAS: 27,5 x $20 \mathrm{~cm}$ (mancha), 34 x 26,5 cm (papel). IMPRESSÃO: em preto. MATRIZ: cobre. ASSINATURA: "C. Oswald scultp" no canto inferior esquerdo da mancha. ACERVO Fundação Biblioteca Nacional. PROVENIÊNCIA: Carlos Oswald, compra, 1916.

LITERATURA: Correio Paulistano, SP, 12/12/1923 (nota); Silva, Para todos, RJ, 16/11/1956 (ref.); Oswald, 1957, p. 211 (ref.); Silva, 1969 (ref.). 


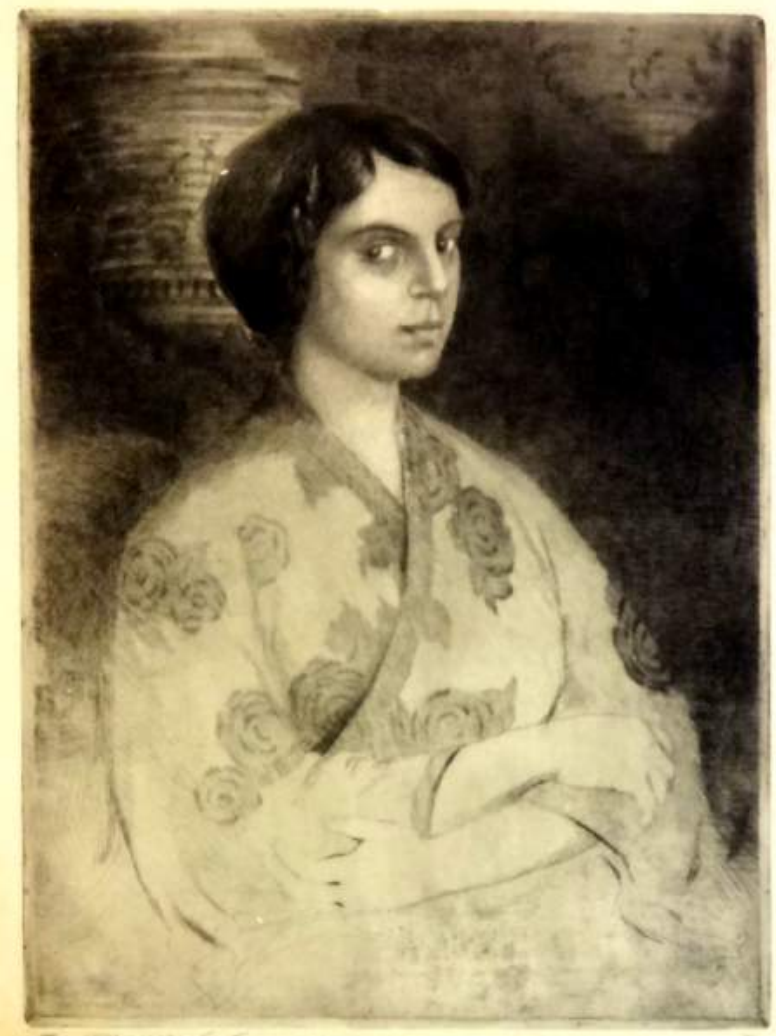

Fig. 56.A

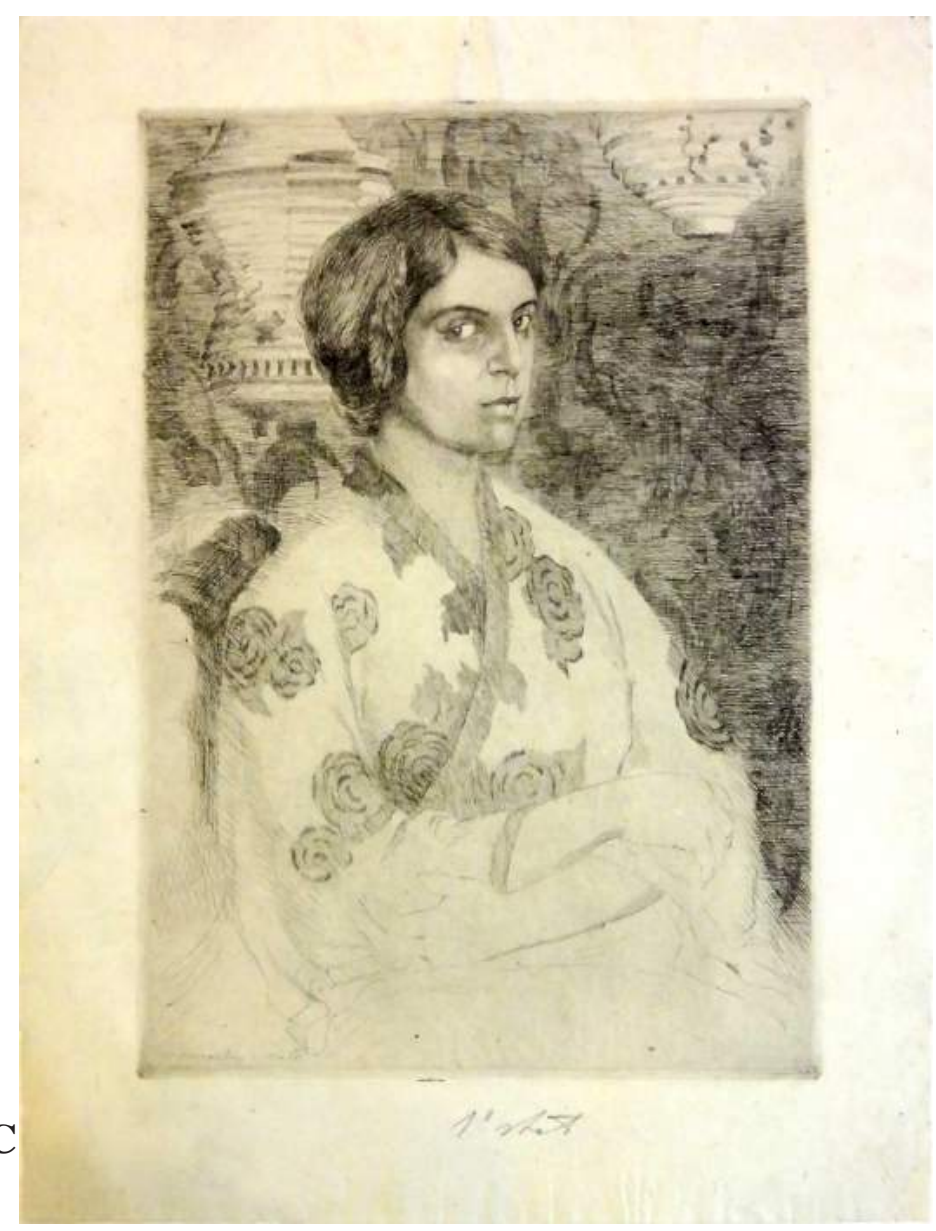




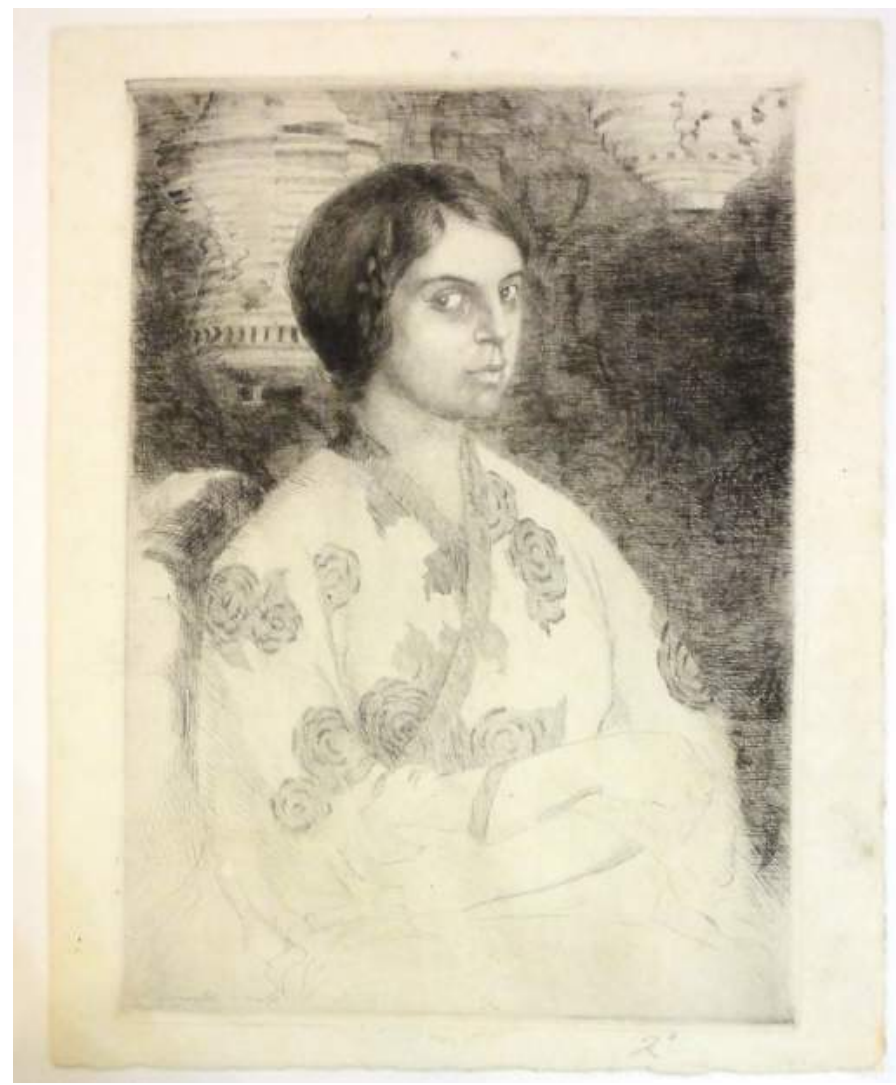

Fig. 56.D

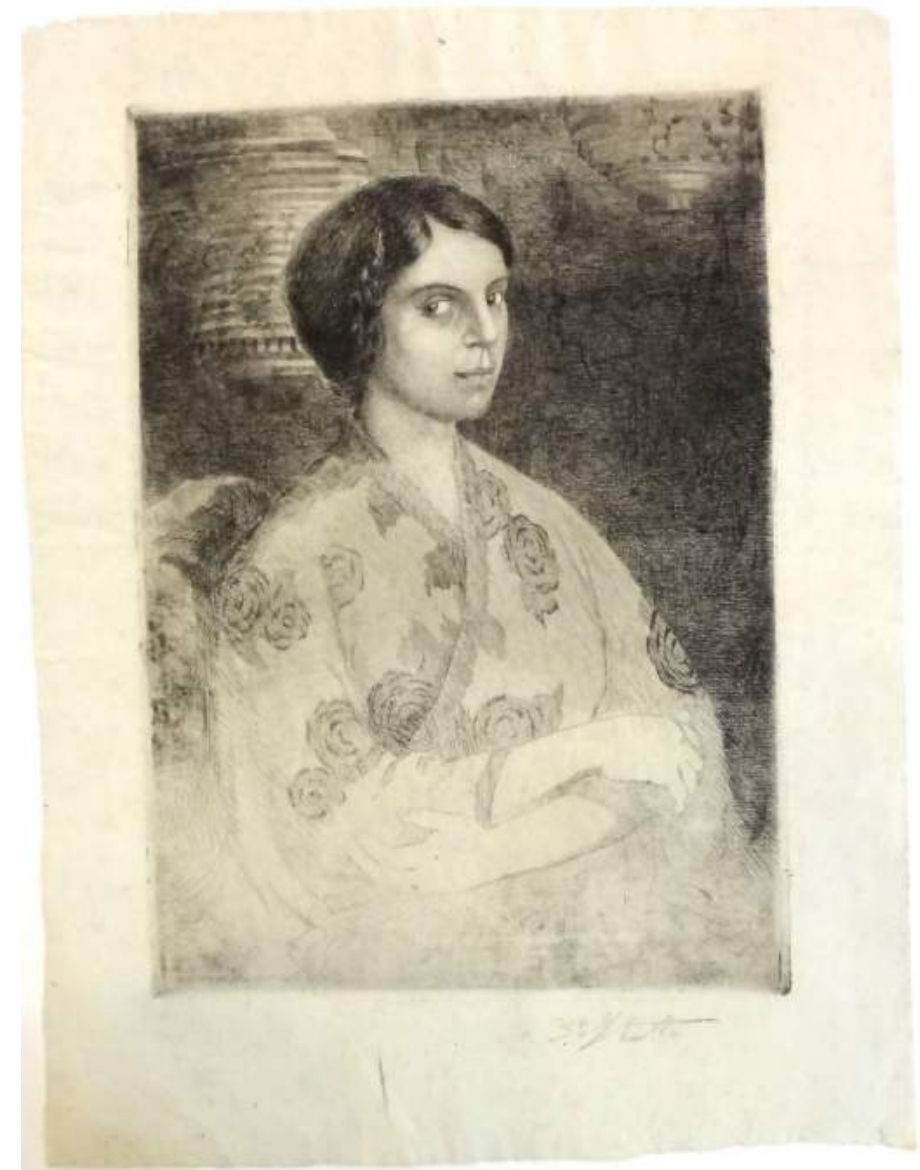

Fig. 56.E 


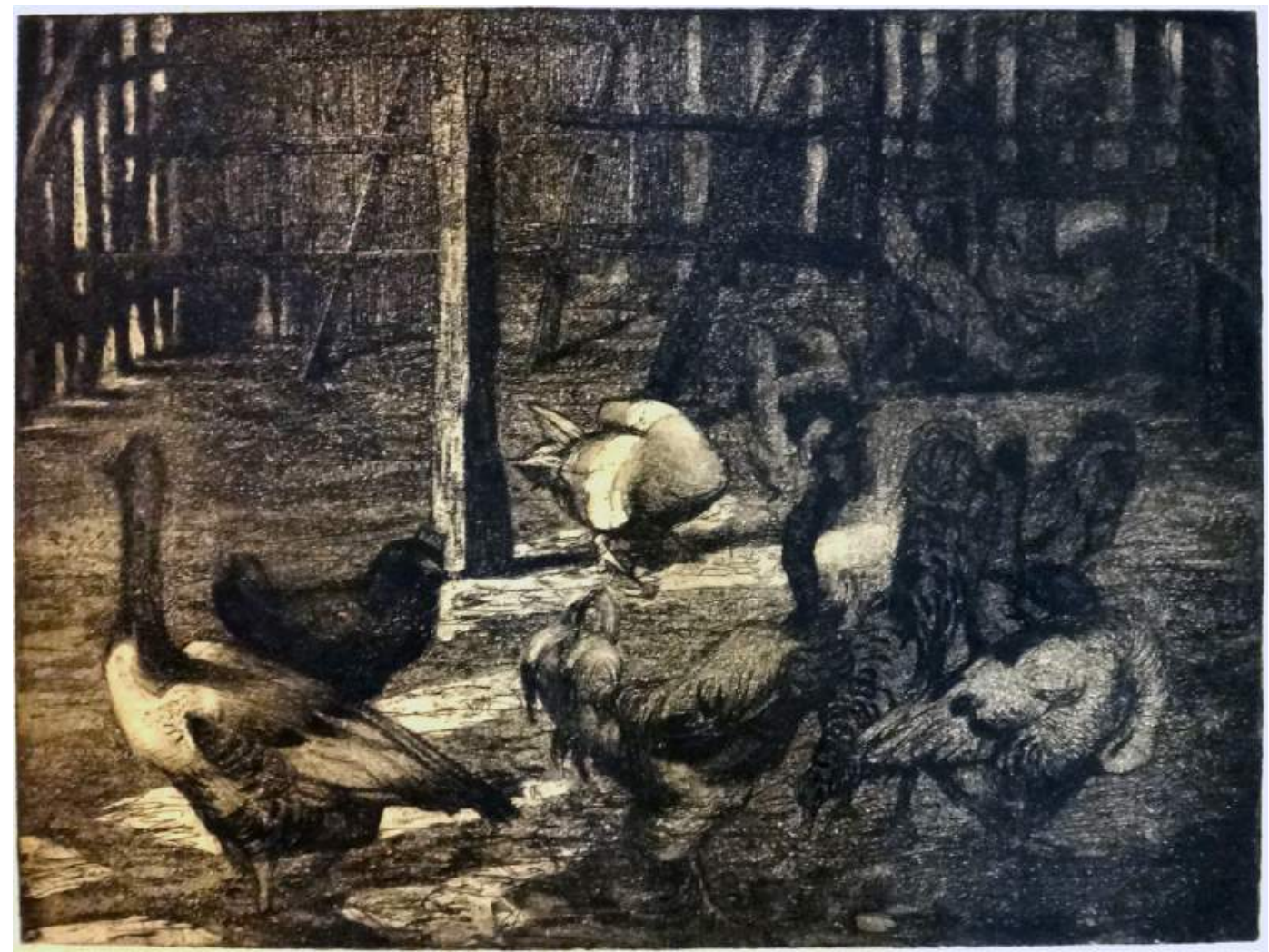

Fig. 57.A

57. TÍTULO: O Galinheiro. VARIANTE: No Galinheiro.

A. DATA: 1914. TÉCNICA: Água-forte e água-tinta. MEDIDAS: 30 x 39,5 cm (mancha), 45,6 x $57 \mathrm{~cm}$ (papel). IMPRESSÃO: em preto. MATRIZ: zinco. ASSINATURA: "C. Oswald" no canto inferior esquerdo do papel. ACERVO Fundação Biblioteca Nacional. PROVENIÊNCIA: Carlos Oswald, compra, 1916.

B. DATA: 1915. TÉCNICA: Água-forte e água-tinta. MEDIDAS: 29,5 x 29,7 cm (mancha); 47,6 x 32,4 cm (papel). IMPRESSÃO: em marrom. MATRIZ: zinco. ASSINATURA: “C. Oswald" no canto inferior direito do papel. COLEÇÃO Museu Nacional de Belas Artes/IBRAM/ MinC. PROVENIÊNCIA: Carlos Oswald, compra, 1963.

C. DATA: 1976. TÉCNICA: Água-forte e água-tinta. IMPRESSÃO: póstuma, em preto. MATRIZ: zinco. ACERVO Fundação Biblioteca Nacional. PROVENIÊNCIA: registrada em 1976 no acervo. [Dois exemplares]

D. [1 $1^{\circ}$ estado] DATA: 1914. TÉCNICA: Água-forte. MEDIDAS: 30 x 39,5 cm (mancha), 45,5 X 57,5 cm (papel). IMPRESSÃO: em preto. MATRIZ: zinco. Sem assinatura. ACERVO Fundação Biblioteca Nacional. PROVENIÊNCIA: Carlos Oswald, compra, 1916.

E. [matriz] DATA: 1914. TÉCNICA: Água-forte e água-tinta. MATRIZ: zinco. Sem assinatura. ACERVO Fundação Biblioteca Nacional. PROVENIÊNCIA: registrada no acervo em 1975.

LITERATURA: Silva, 1969 (ref.); Exp. Carlos Oswald: o resgate de um mestre, Caixa Cultural, Brasília/Curitiba, 2011, p. 38 (rep.). 


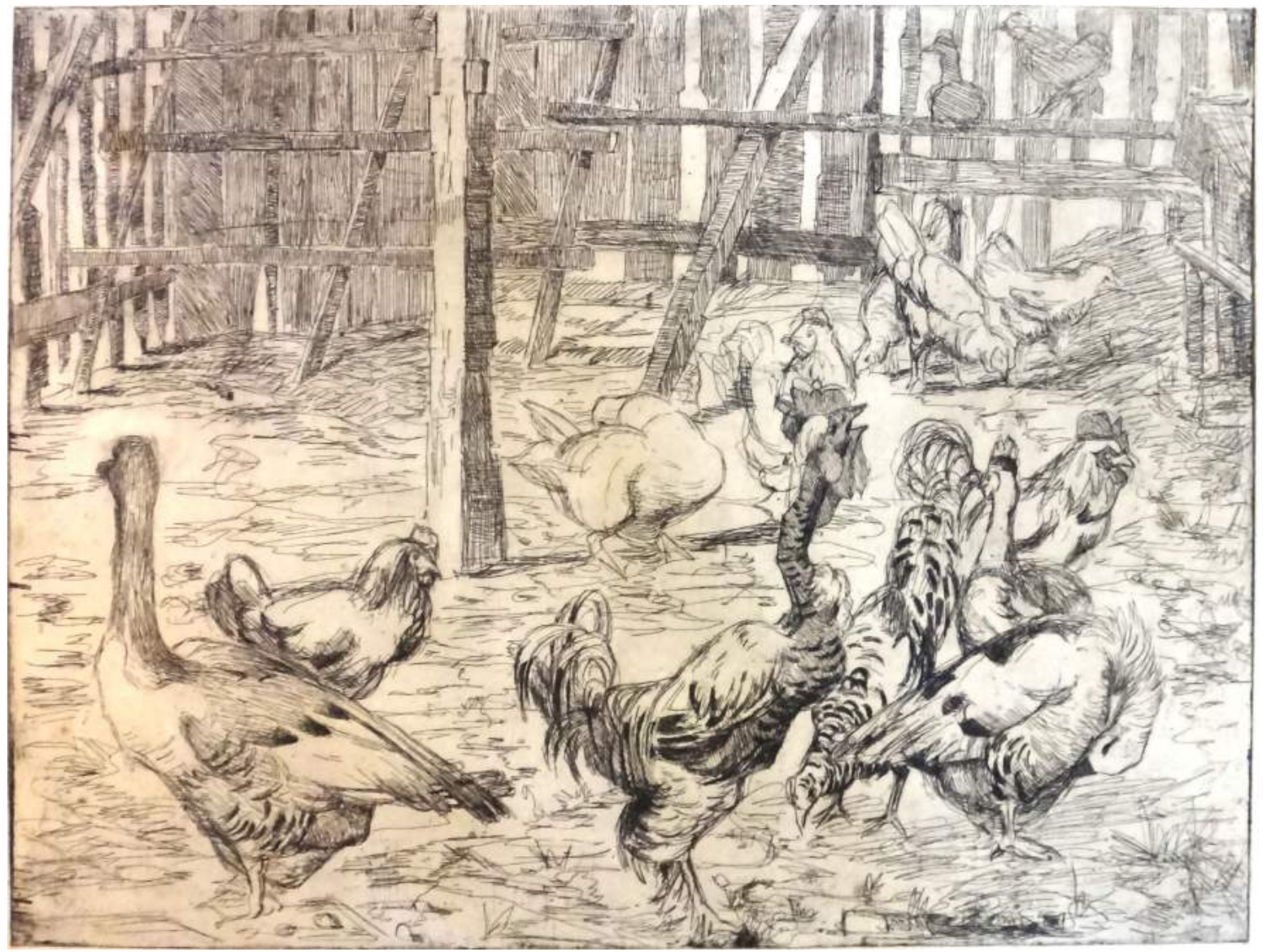

Fig. 57.D

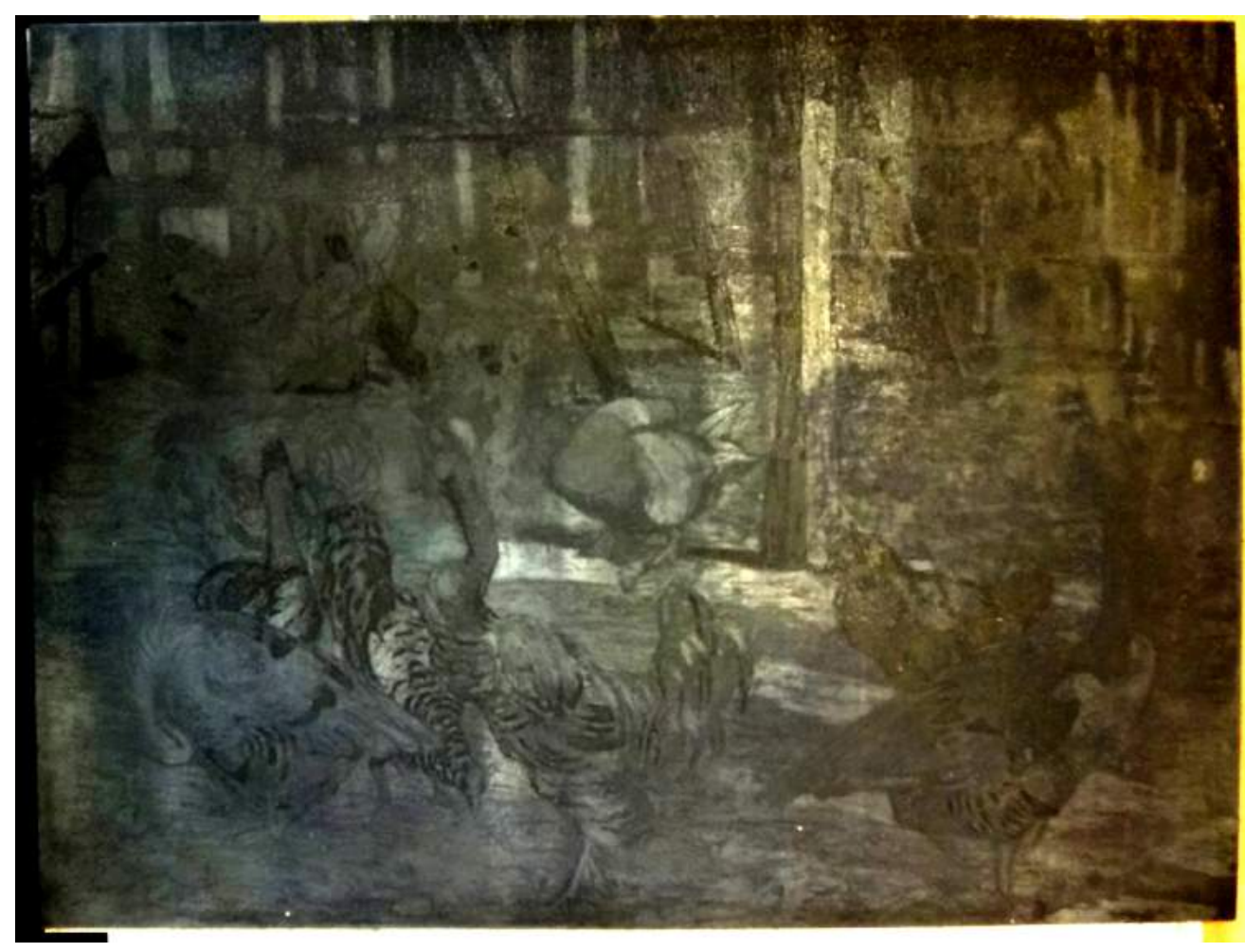

Fig. 57.E 


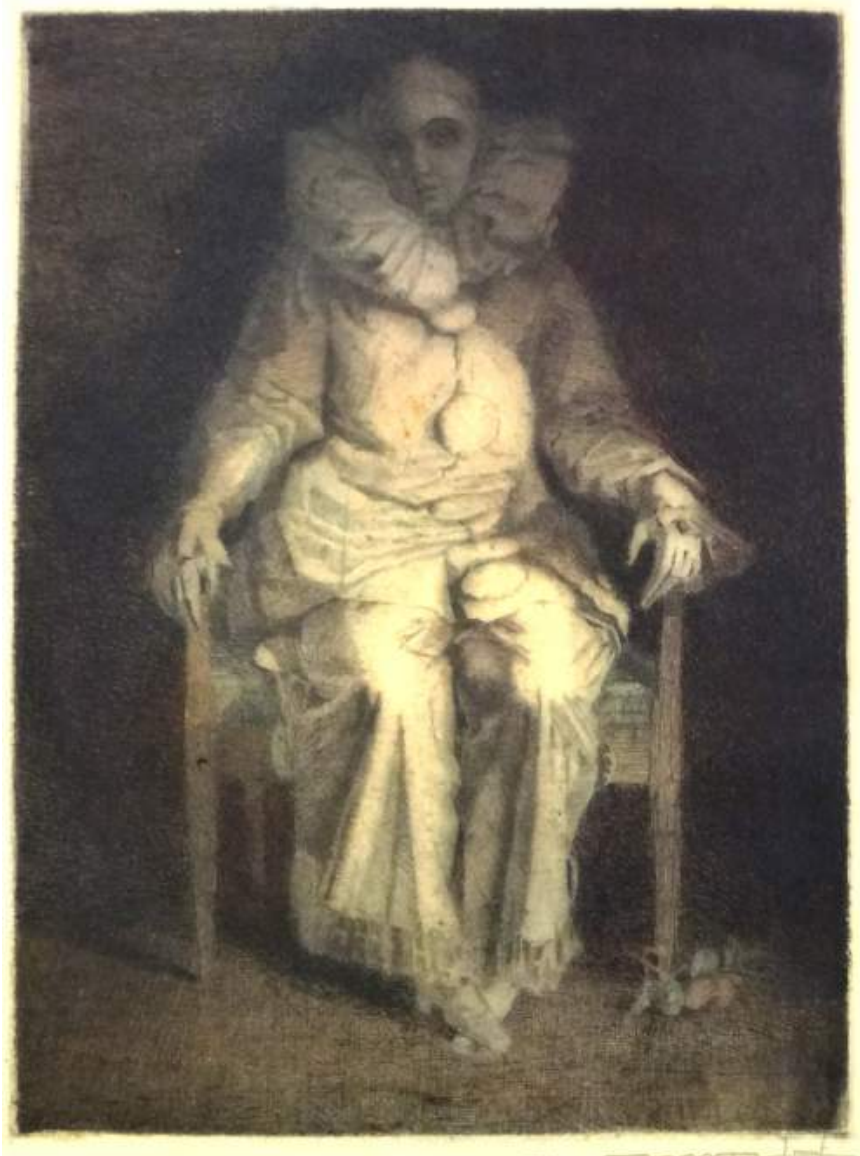

Fig. 58

58. TÍTULO: Pierrot. VARIANTE: Pierrot fatigue; Colombina.

DATA: 1909 [?]/1914 [?]. TÉCNICA: Água-forte. MEDIDAS: 27 x 20 cm (mancha), 36,1 x 25,5 cm (papel). IMPRESSÃO: em preto, áreas em azul e magenta. ASSINATURA: "C. Oswald" no canto inferior direito do papel. ACERVO Fundação Biblioteca Nacional. PROVENIÊNCIA: registrada no acervo em 1940.

59. TÍTULO: Pierrot. VARIANTE: Pierrot fatigue; Colombina.

DATA: 1909 [?]/1914 [?]. TÉCNICA: Água-forte. MEDIDAS: 27,5 x 19,8 cm (mancha); 47,9 x 32,8 cm (papel). IMPRESSÃO: em preto. ASSINATURA: “C. Oswald" no canto inferior direito do papel. COLEÇÃO Museu Nacional de Belas Artes/IBRAM/MinC. PROVENIÊNCIA: Carlos Oswald, compra, 1963.

LITERATURA: Amador, Jornal do Brasil, RJ, 4/9/1909 (artigo, referida com o título "Pierrot Fatigué"); Correio Paulistano, SP, 8/2/1918 (nota); Revista do Brasil, SP, 2/1918, p. 173 (artigo, rep.); Almeida, O Malho, RJ, 4/10/1919 (artigo, rep.); A Manhã, RJ, 13/5/1927 (nota); Exp. Seventy-five Latin American Prints, Corcoran Gallery, EUA, 1944; Oswald, 1957, p. 211 (ref.); Silva, 1969 (ref.). 


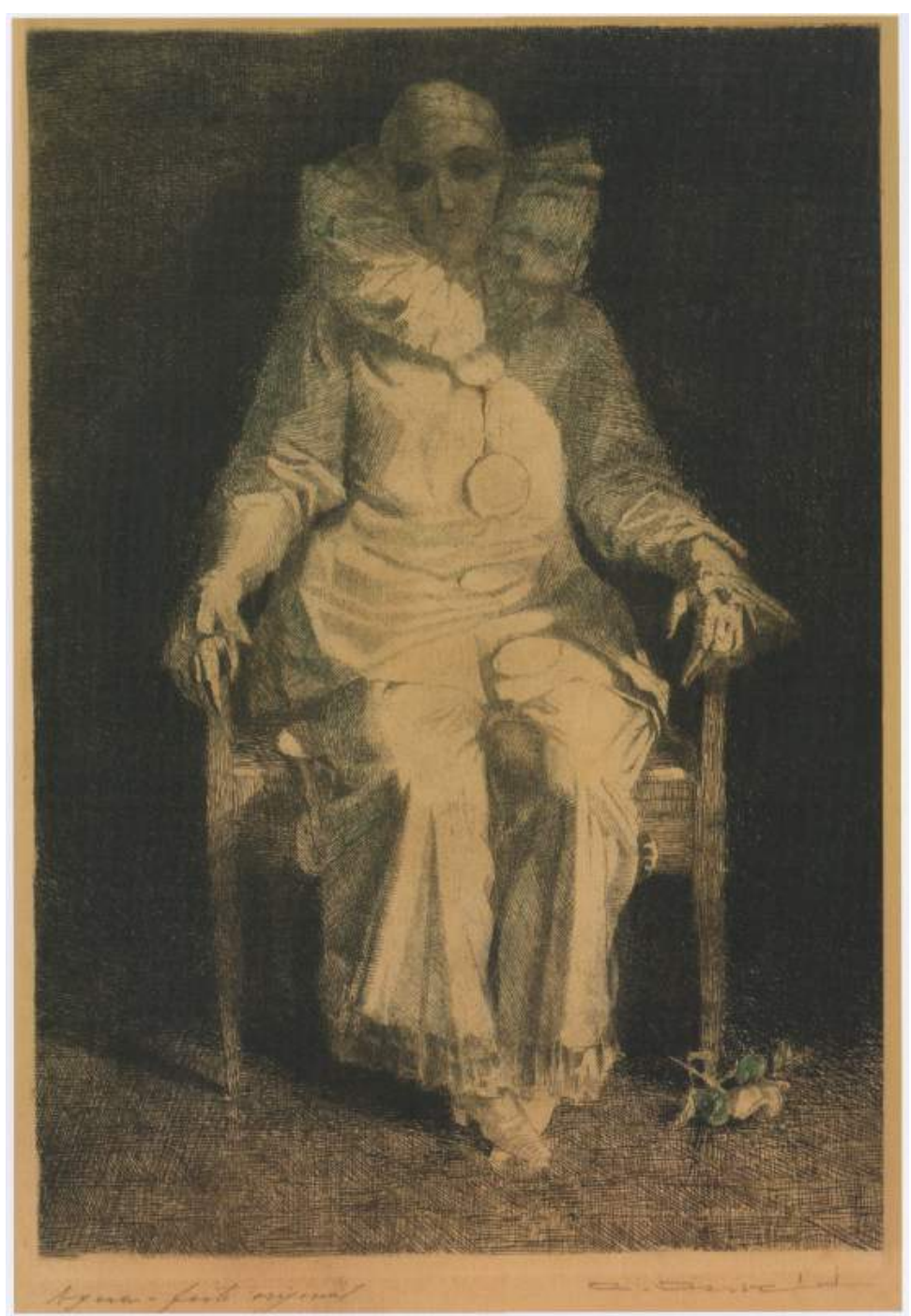

Fig. 60

60. TÍTULO: Pierrot. VARIANTE: Pierrot fatigue; Colombina.

DATA: 1909 [?]/1914 [?]. TÉCNICA: Água-forte. MEDIDAS: 27,2 x 19,3 cm (mancha). IMPRESSÃO: em preto com algumas áreas em azul. ASSINATURA: "C. Oswald" no canto inferior direito do papel. COLEÇÃO Ana Cristina e Luiz Carlos Moreira. FONTE: Vergolino, 2011, p. 57.

LITERATURA: Amador Bueno, Jornal do Brasil, RJ, 4/9/1909 (artigo expo.); Correio Paulistano, SP, 8/2/1918 (nota); Revista do Brasil, SP, 2/1918, p. 173 (artigo, rep.); Almeida, O Malho, RJ, 4/10/1919 (artigo, rep.); A Manhã, RJ, 13/5/1927 (nota); Exp. Seventy-five Latin American Prints, Corcoran Gallery, EUA, 1944; Oswald, 1957, p. 211 (ref.); Silva, 1969 (ref.); Exp. Carlos Oswald: o resgate de um mestre, Caixa Cultural, Brasília/Curitiba, 2011, p. 57 (rep.). 


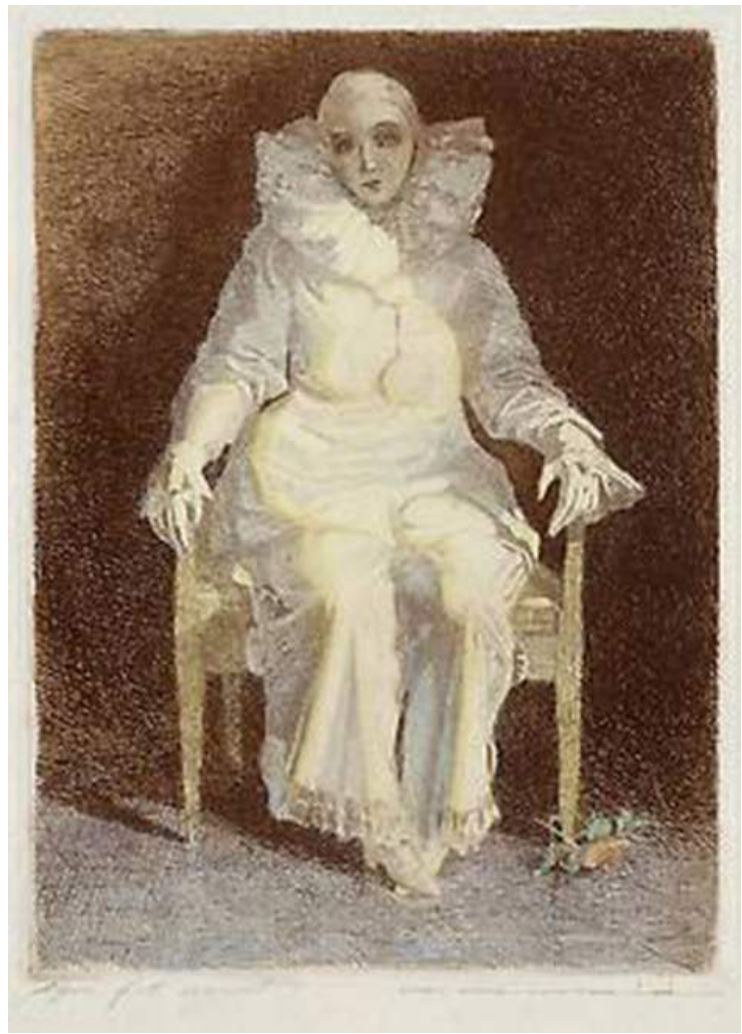

Fig. 61

61. TÍTULO: Pierrot. VARIANTE: Pierrot fatigue; Colombina.

DATA: 1909 [?]/1914 [?]. TÉCNICA: Água-forte. MEDIDAS: 27 x 20 cm (mancha), 37,5 x $27 \mathrm{~cm}$ (papel). IMPRESSÃO: em cores. ASSINATURA: "C. Oswald” no canto inferior direito do papel. COLEÇÃO particular. FONTE: Evandro Carneiro Leiloeiro, disponível em: <http:// www.evandrocarneiroleiloes.com/145675? artistId=88060> , acesso em 13/8/2017. 


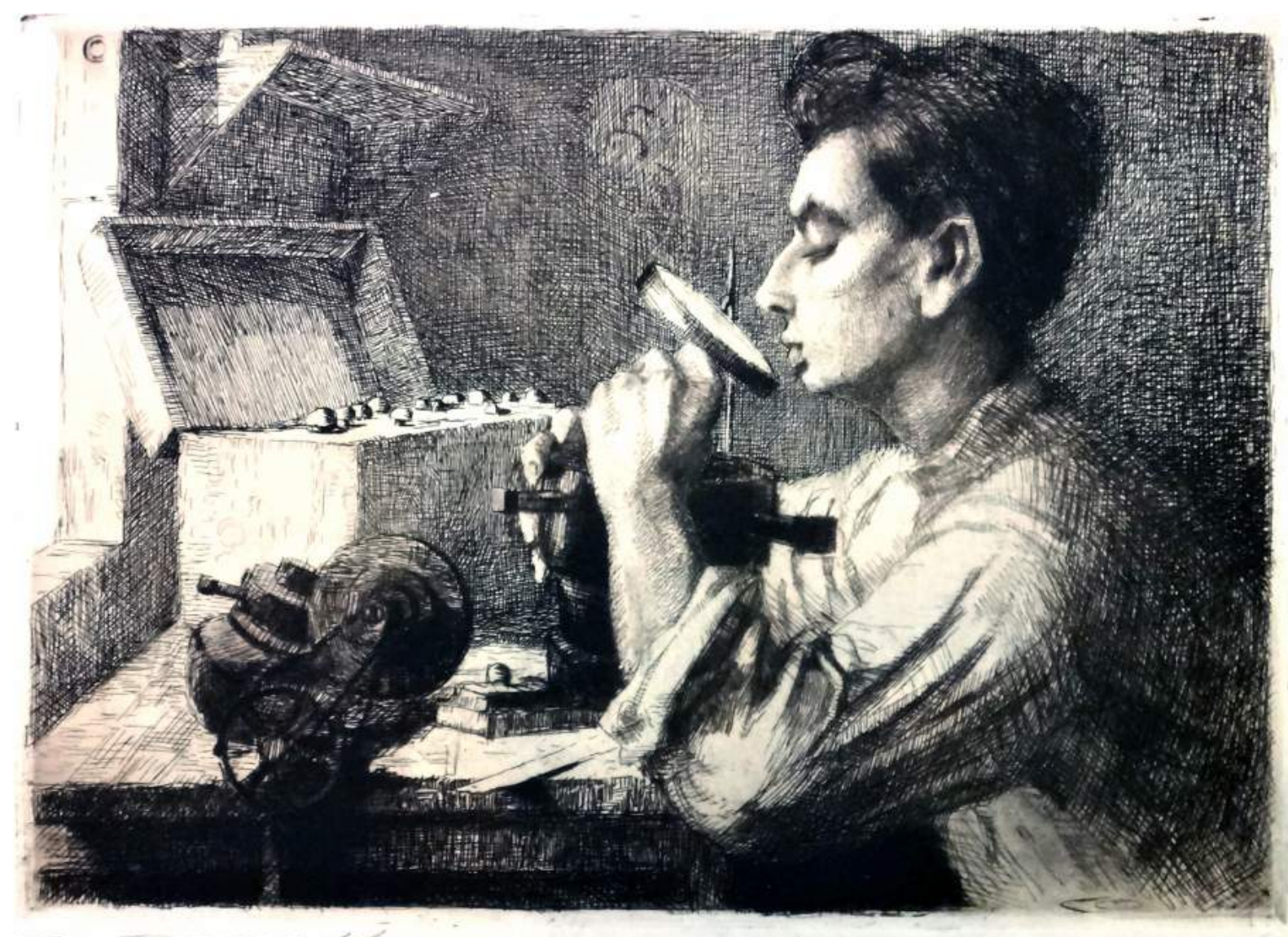

Fig. 62. A

62. TÍTULOS: O gravador Adalberto Mattos; Adalberto Mattos, gravador; Adalberto Mattos; Retrato de Adalberto Mattos.

A. DATA: 1914. TÉCNICA: Água-forte. MEDIDAS: 20 x 27,5 cm (mancha), 32,3 x 50 cm (papel). IMPRESSÃO: em preto. ASSINATURA: monograma "CO” no canto superior esquerdo da mancha, "C. Oswald" no canto inferior esquerdo do papel. ACERVO Fundação Biblioteca Nacional. PROVENIÊNCIA: Carlos Oswald, compra, 1916.

B. DATA: 1914. TÉCNICA: Água-forte. MEDIDAS: 20 x $27 \mathrm{~cm}$ (mancha), 25,3 x 29,7 cm (papel). IMPRESSÃO: em preto. ASSINATURA: monograma "CO" no canto superior esquerdo da mancha, "C. Oswald" no canto inferior direito do papel. COLEÇÃO Museu Nacional de Belas Artes/IBRAM/MinC. PROVENIÊNCIA: Carlos Oswald, compra, 1963.

LITERATURA: Illustração Brasileira, RJ, 2/1921, p. 10 (rep.); Oswald, 1957, p. 212 (ref.); Silva, 1969 (ref.); Exp. Carlos Oswald: o resgate de um mestre, Caixa Cultural, Brasília/Curitiba, 2011, p. 43 (rep.). 


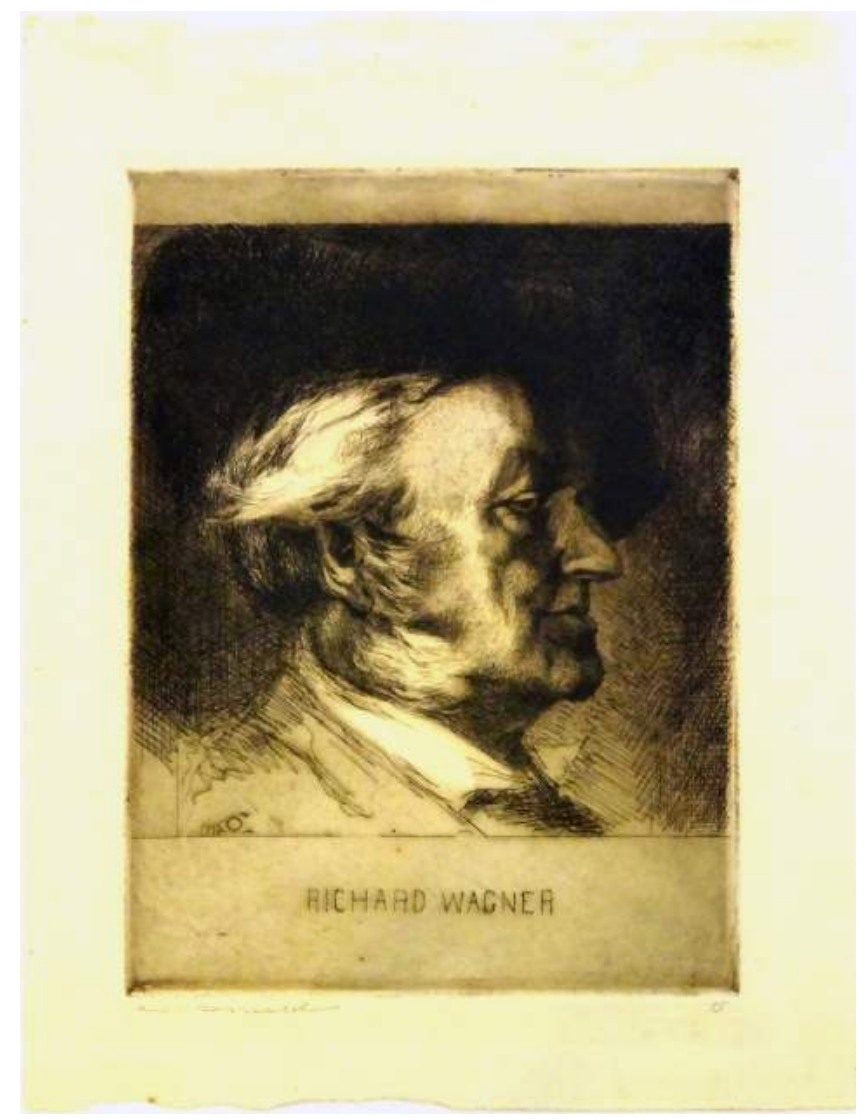

Fig. 63. A

63. TÍTULOS: Richard Wagner; Wagner.

A. DATA: 1914. TÉCNICA: Água-forte. MEDIDAS: 27,5 x $20 \mathrm{~cm}$ (mancha), 36,3 x $27 \mathrm{~cm}$ (papel). IMPRESSÃO: em preto. ASSINATURA: monograma “CO” próximo à margem esquerda da mancha, "C. Oswald" no canto inferior esquerdo do papel. ACERVO Fundação Biblioteca Nacional. PROVENIÊNCIA: Carlos Oswald, compra, 1916.

B. DATA: 1914. TÉCNICA: Água-forte. MEDIDAS: 27,8 x 19,6 cm (mancha), 32,8 x 23,6 cm (papel). IMPRESSÃO: em preto. ASSINATURA: monograma "CO" próximo à margem esquerda da mancha, "C. Oswald" no papel. COLEÇÃO Museu Nacional de Belas Artes/ IBRAM/MinC. PROVENIÊNCIA: Carlos Oswald, compra, 1963.

C. [1º estado] DATA: 1914. TÉCNICA: Água-forte. MEDIDAS: 27,8 x 19,6 cm (mancha), 33 x 22,5 cm (papel). IMPRESSÃO: em preto, com intervenção em grafite. ASSINATURA: monograma “CO” próximo à margem esquerda da mancha. ACERVO Fundação Biblioteca Nacional. PROVENIÊNCIA: Carlos Oswald, compra, 1916.

D. [2 estado] DATA: 1914. TÉCNICA: Água-forte. MEDIDAS: 27,8 x $20 \mathrm{~cm}$ (mancha), 45 x $29 \mathrm{~cm}$ (papel). IMPRESSÃO: em preto. ASSINATURA: monograma "CO 1914” próximo à margem esquerda da mancha. ACERVO Fundação Biblioteca Nacional. PROVENIÊNCIA: Carlos Oswald, compra, 1916.

LITERATURA: O Paiz, RJ, 7/7/1916 (nota); Almeida, O Malho, RJ, 4/10/1919 (artigo); O Jornal, RJ, 23/12/1921 (nota); Gomes, Correio da Manhã, RJ, 8/12/1935 (nota); Oswald, 1957, p. 216 (ref., datada 1919); Silva, 1969 (ref., datada 1915). 


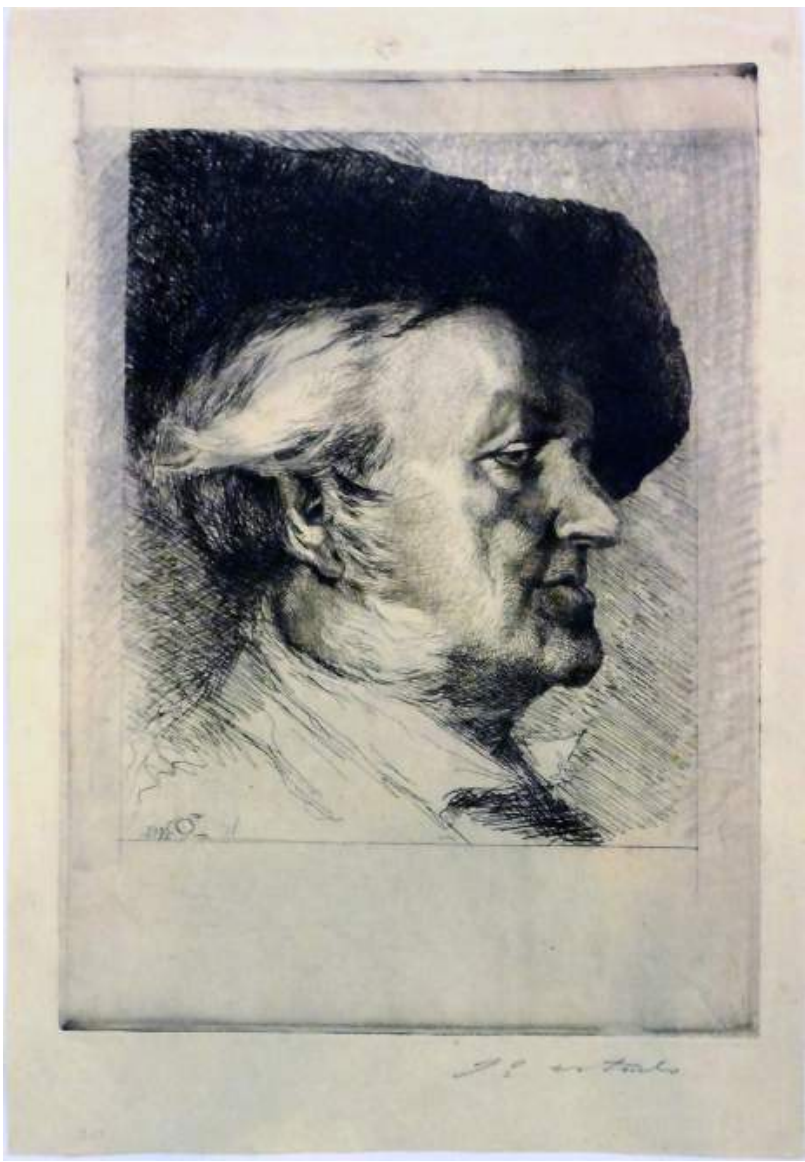

Fig. 63. C

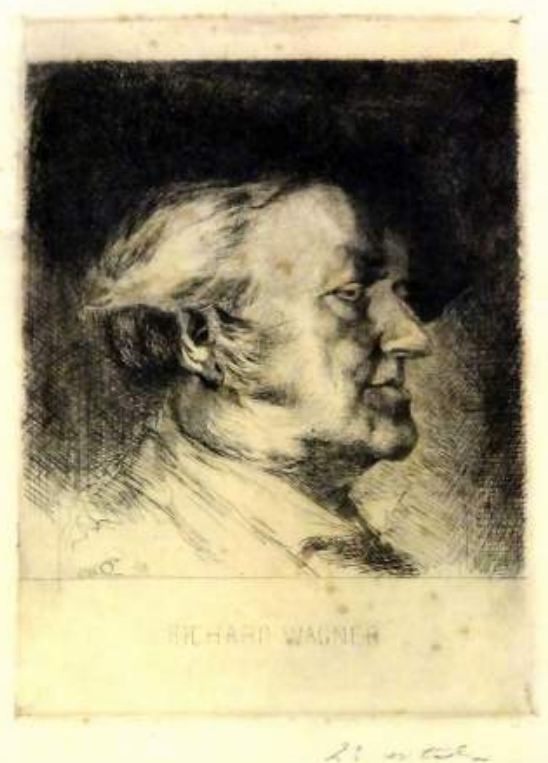

Fig. 63. D 


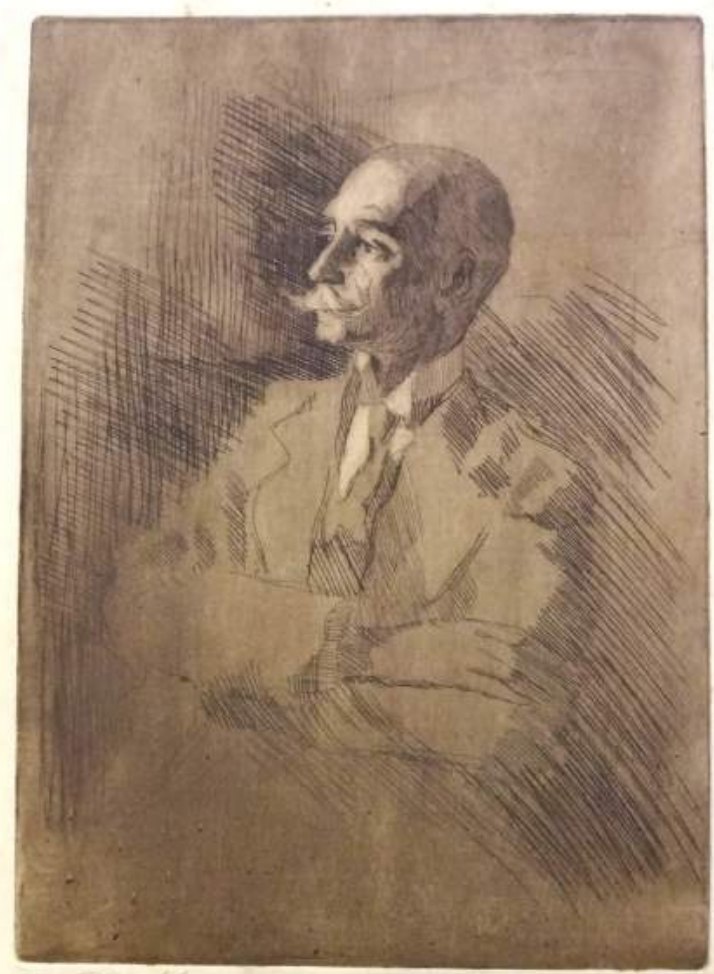

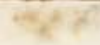

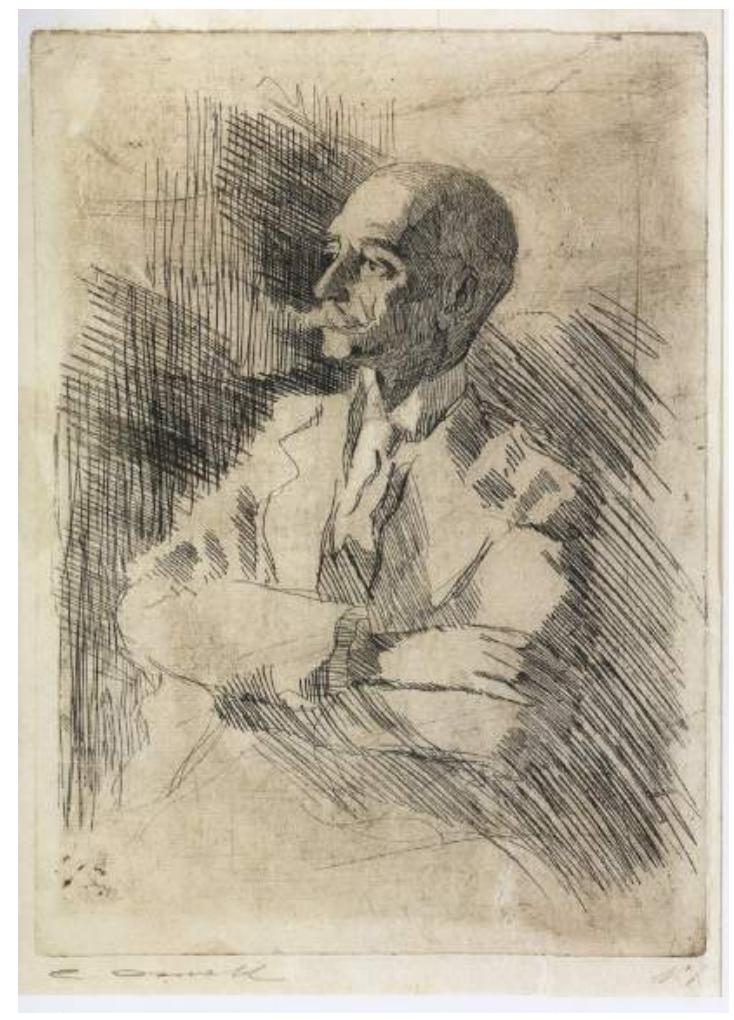

Fig. 64.C

Fig. 64.A

64. TÍTULOS: H. Oswald; Henrique Oswald.

A. DATA: 1914. TÉCNICA: Água-forte. MEDIDAS: 27,8 x $20 \mathrm{~cm}$ (mancha), 45,7 x 28,5 cm (papel). IMPRESSÃO: em preto com fundo em marrom. ASSINATURA: "C. Oswald" no canto inferior esquerdo do papel. ACERVO Fundação Biblioteca Nacional. PROVENIÊNCIA: Carlos Oswald, compra, 1916.

B. DATA: 1915. TÉCNICA: Água-forte. MEDIDAS: 27,8 x 19,7 cm (mancha); 31,8 x 23,7 cm (papel). IMPRESSÃO: em preto. ASSINATURA: "C. Oswald” no canto inferior direito do papel. COLEÇÃO Museu Nacional de Belas Artes/IBRAM/MinC. PROVENIÊNCIA: Carlos Oswald, compra, 1963.

C. DATA: 1915. TÉCNICA: Água-forte. MEDIDAS: 27,8 x 19,7 cm (mancha). IMPRESSÃO: em preto. ASSINATURA: "C. Oswald" no canto inferior esquerdo do papel. COLEÇÃO Melina e Fábio Eleres. FONTE: Vergolino, 2011, p. 45.

LITERATURA: O Paiz, RJ, 7/7/1916 (nota); Correio Paulistano, SP, 8/2/1918 (nota); Oswald, 1957, p. 212 (ref., datada 1914); Silva, 1969 (ref.); Exp. Carlos Oswald: o resgate de um mestre, Caixa Cultural, Brasília/Curitiba, 2011, p. 45 (rep.). 
65. TÍTULOS: Concerto; Tocando Debussy. VARIANTE: Tocando piano; Menina ao piano; Pianista.

A. DATA: 1915. TÉCNICA: Água-forte. MEDIDAS: 20 x 27,5 cm (mancha), 27,5 x 36,5 cm (papel). IMPRESSÃO: em marrom. ASSINATURA: "C. Oswald” gravado no centro da margem inferior da mancha, "C. Oswald" no canto inferior esquerdo do papel. ACERVO Fundação Biblioteca Nacional. PROVENIÊNCIA: Carlos Oswald, compra, 1916.

B. DATA: 1914. TÉCNICA: Água-forte. MEDIDAS: 19,6 x 27,5 cm (mancha). IMPRESSÃO: em preto. ASSINATURA: "C. Oswald" gravado no centro da margem inferior da mancha, "C. Oswald" no canto inferior direito do papel. COLEÇÃO Josafá Vilarouca Jr. FONTE: Vergolino, 2011, p.40.

C. [1 $1^{\circ}$ estado] DATA: 1914/1915. TÉCNICA: Água-forte. MEDIDAS: 20 x 27,5 cm (mancha), 25,2 x 35,5 cm (papel). IMPRESSÃO: em preto. Sem assinatura. ACERVO Fundação Biblioteca Nacional. PROVENIÊNCIA: Carlos Oswald, compra, 1916. [Prova com anotações na margem direita relativamente à gravação da matriz, algumas palavras incompreensíveis: "1a tinta // (vino - mancha) [?] // Ac. $15^{\circ} / / 10 \mathrm{~m} / / 2$ a tinta // (vestido) // Ac. 15\% // 10m// 3a tinta // [palavra ilegível]// come sofia [?] // + Ac. 25\% // 5m]

D. [2 estado] DATA: 1914/1915. TÉCNICA: Água-forte. MEDIDAS: 20 x 27,5 cm (mancha), 25,4 x 34 cm (papel). IMPRESSÃO: em preto. Sem assinatura. ACERVO Fundação Biblioteca Nacional. PROVENIÊNCIA: Carlos Oswald, compra, 1916.

E. [3º estado] DATA: 1914/1915. TÉCNICA: Água-forte. MEDIDAS: 20 x 27,5 cm (mancha), 26,5 x 29,5 cm (papel). IMPRESSÃO: em preto. Sem assinatura. ACERVO Fundação Biblioteca Nacional. PROVENIÊNCIA: Carlos Oswald, compra, 1916.

F. [4 estado] DATA: 1914/1915. TÉCNICA: Água-forte. MEDIDAS: 20 x 27,5 cm (mancha), 27 x 35,6 cm (papel). IMPRESSÃO: em preto. ASSINATURA: “C. Oswald” no centro da margem inferior da mancha. ACERVO Fundação Biblioteca Nacional. PROVENIÊNCIA: Carlos Oswald, compra, 1916.

G. [5º estado] DATA: 1914/1915. TÉCNICA: Água-forte. MEDIDAS: 20 x 27,5 cm (mancha), 27,1 x 36 cm (papel). IMPRESSÃO: em preto. ASSINATURA: "C. Oswald” no centro da margem inferior da mancha. ACERVO Fundação Biblioteca Nacional. PROVENIÊNCIA: Carlos Oswald, compra, 1916.

LITERATURA: Correio Paulistano, SP, 8/2/1918 (nota); Almeida, O Malho, RJ, 4/10/1919 (artigo, rep.); Correio Paulistano, SP, 1/2/1923 (nota); Silva, Para todos, RJ, 16/11/1956 (ref.); Oswald, 1957, p. 211 (ref. e rep., datada 1914); Silva, 1969 (ref., datada 1914); Exp. Carlos Oswald: o resgate de um mestre, Caixa Cultural, Brasília/Curitiba, 2011, p. 40 - 41 (rep.). 


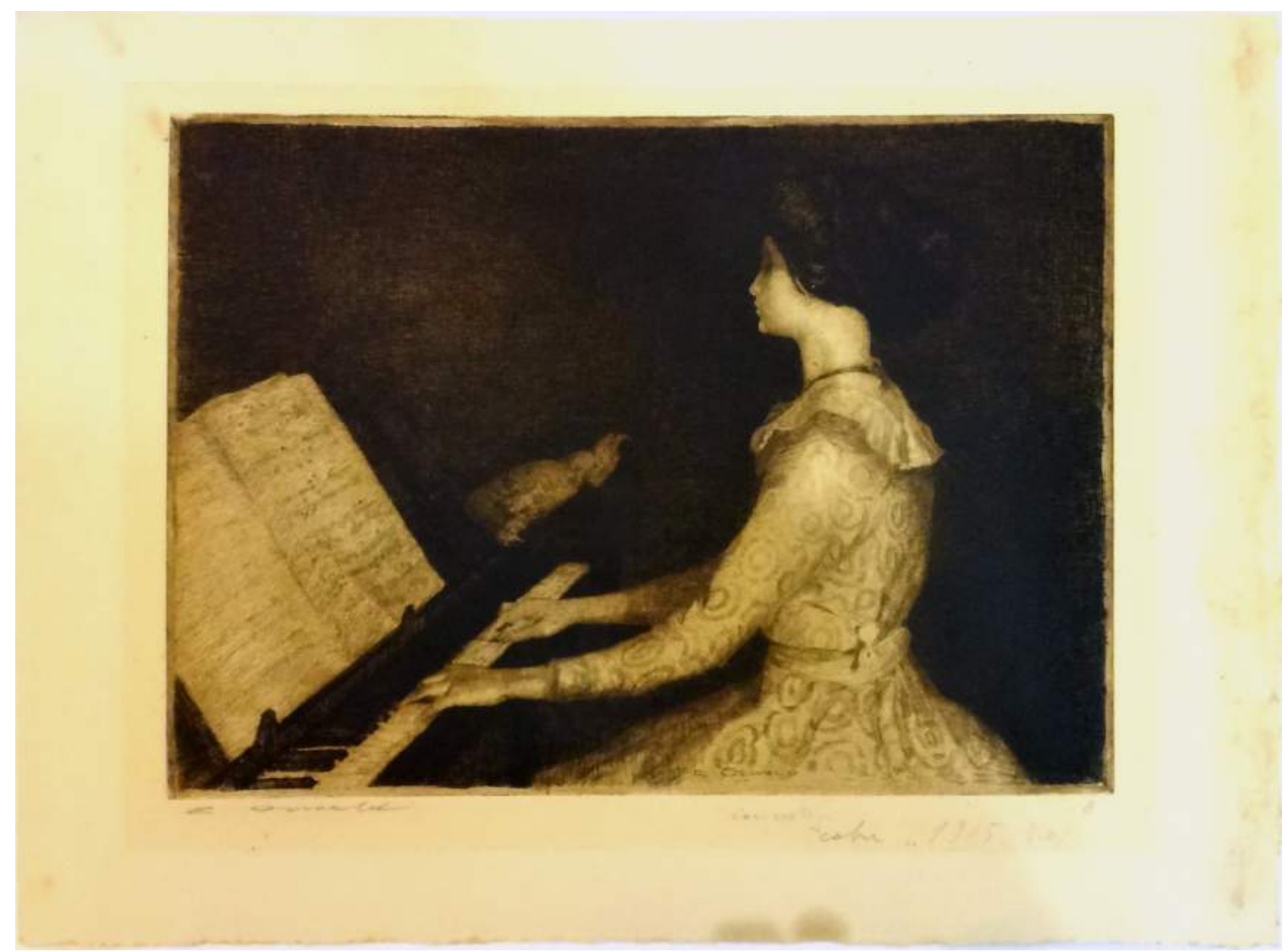

Fig. 65.A

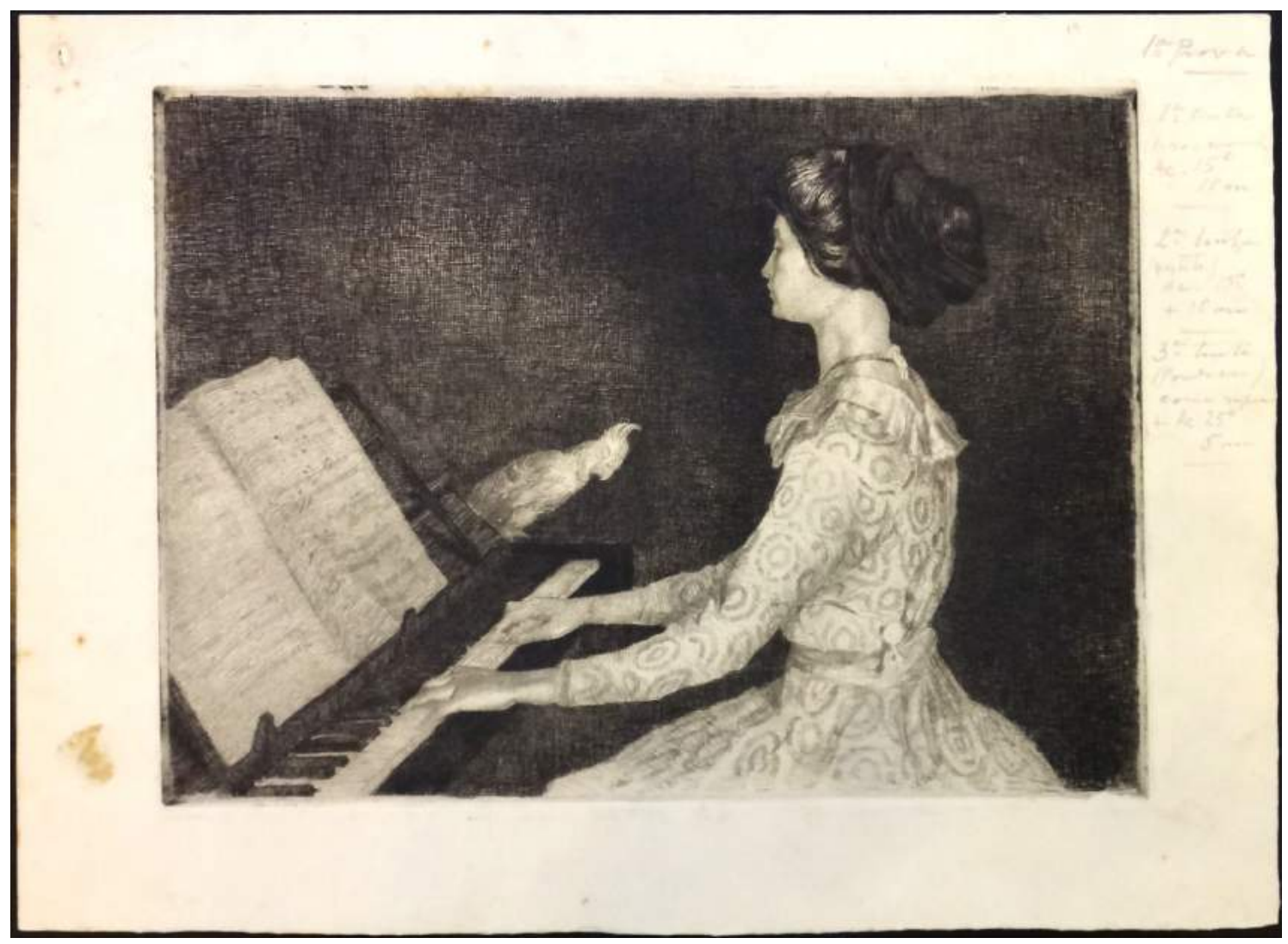

Fig. 65.C 


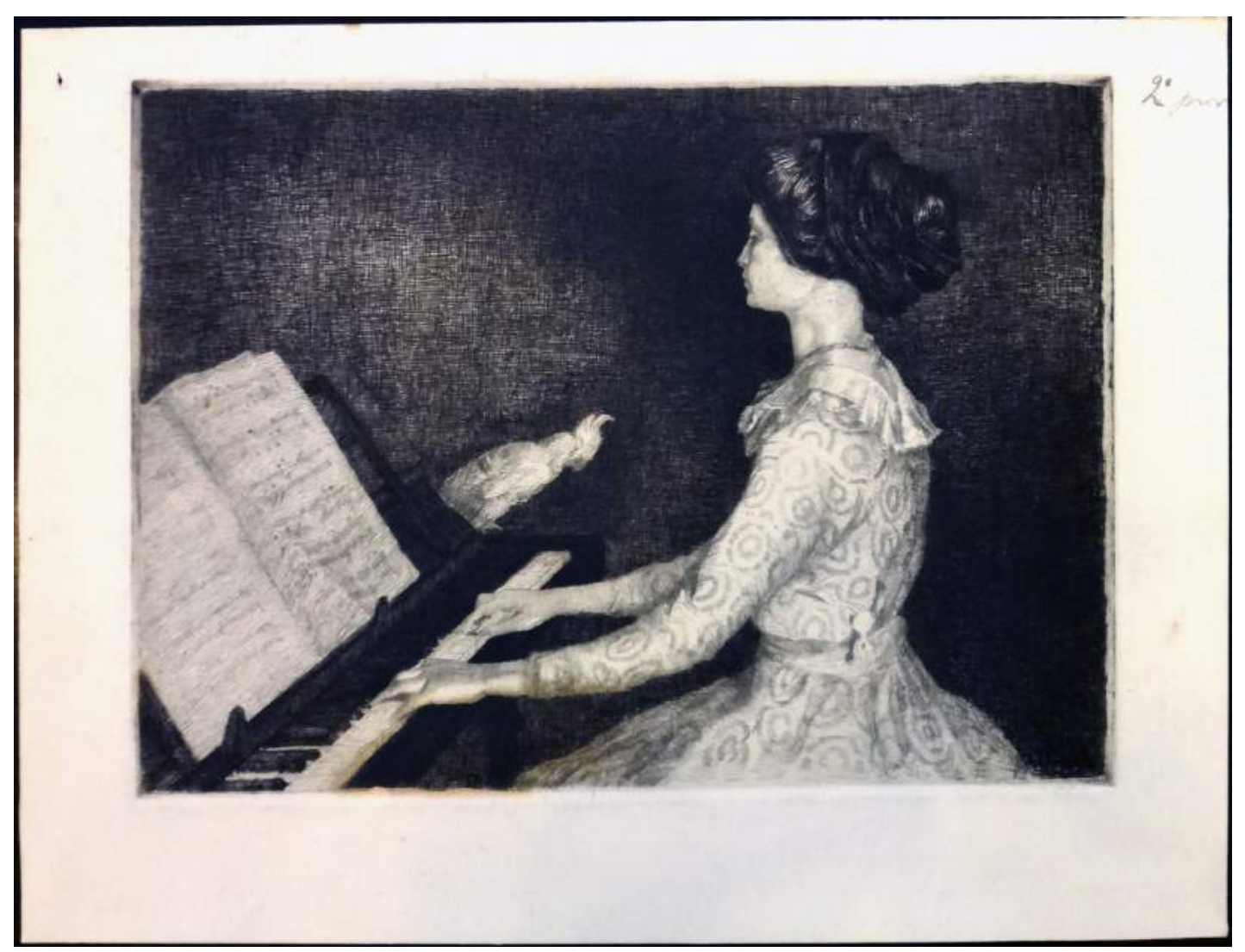

Fig. 65.D

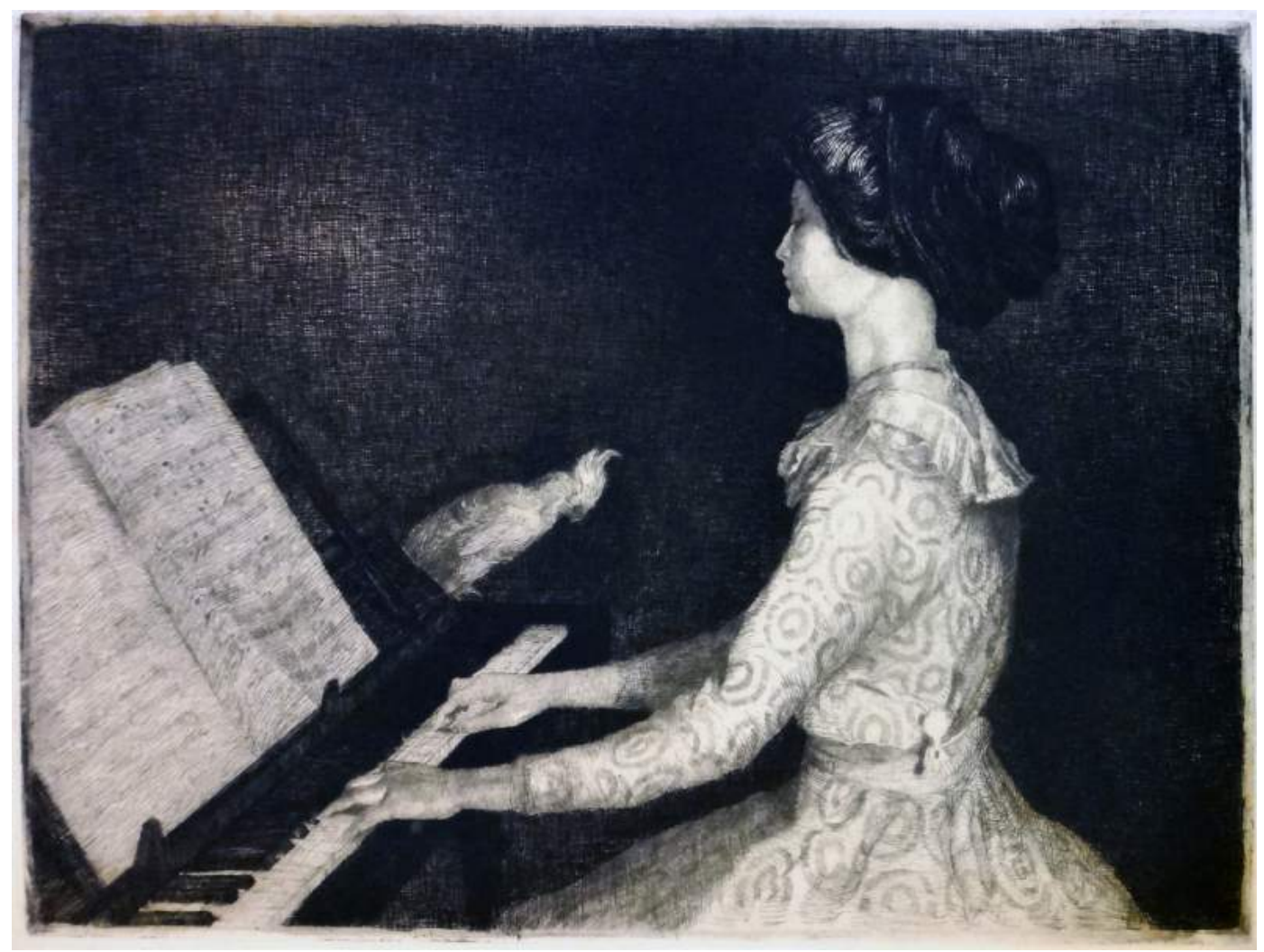

Fig. 65.E 


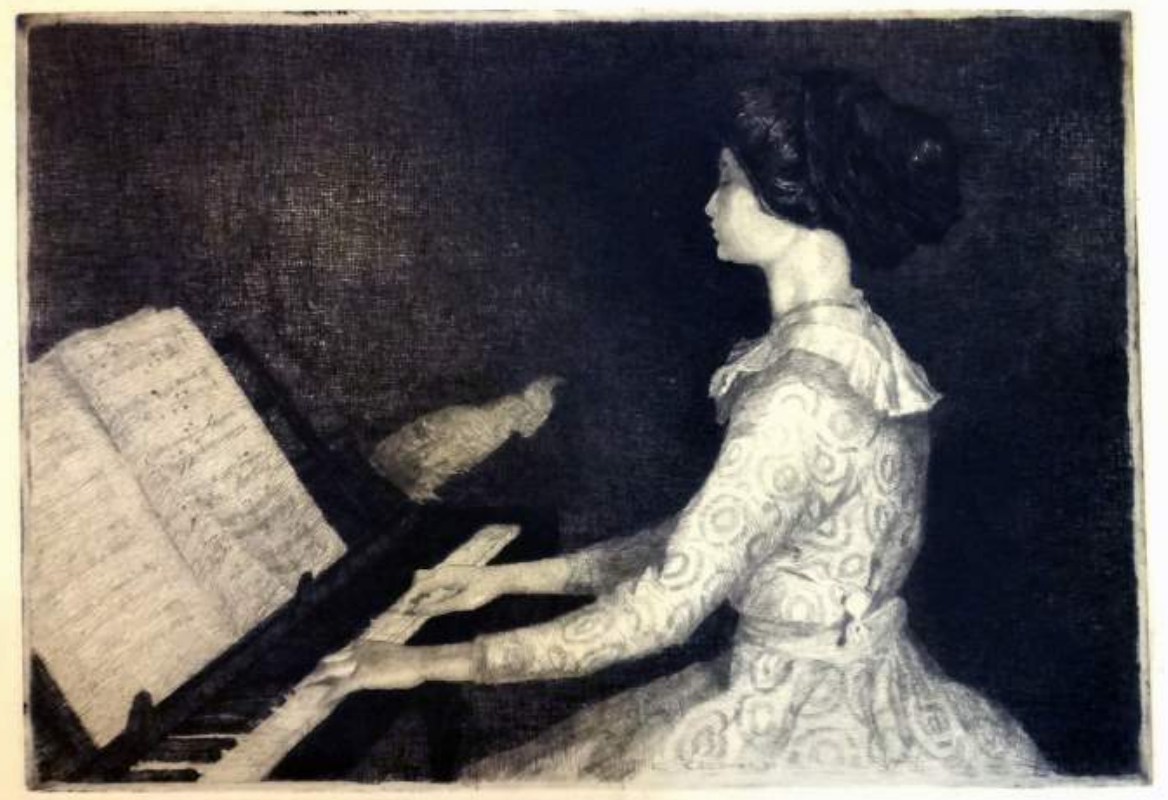

Fig. 65.F

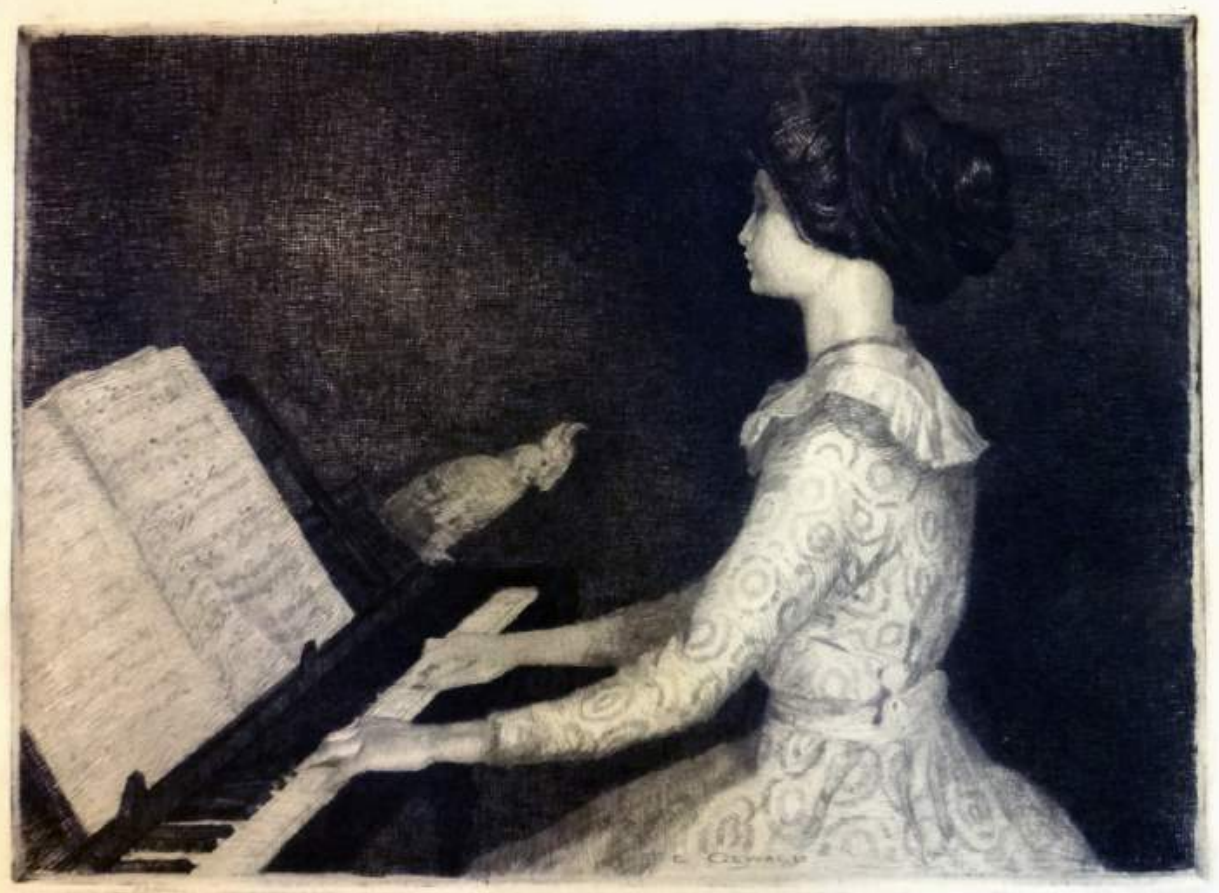

Fig. 65.G 


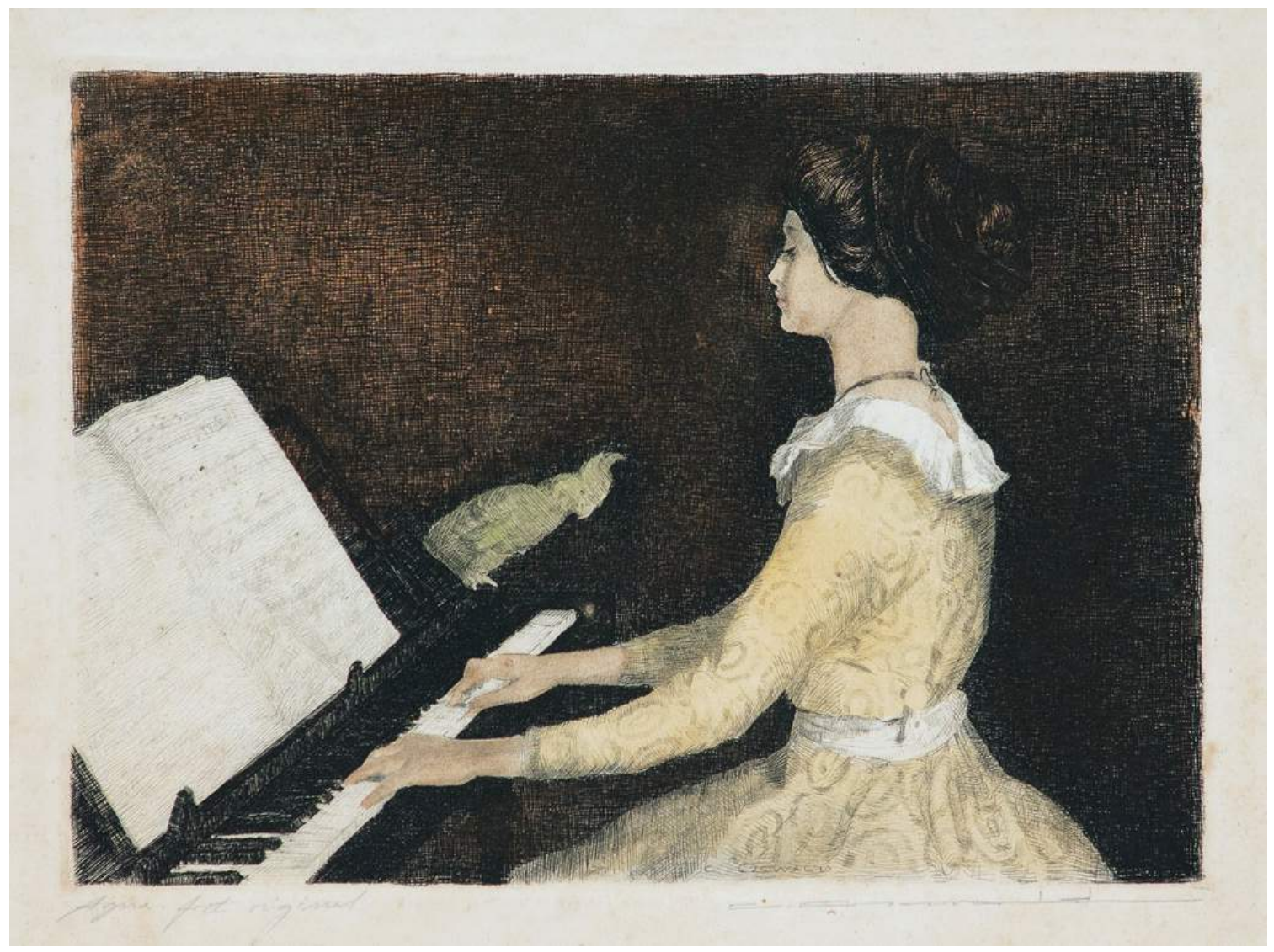

Fig. 67

66. TÍTULOS: Concerto; Tocando Debussy. VARIANTE: Tocando piano; Menina ao piano; Pianista.

DATA: 1914. TÉCNICA: Água-forte. MEDIDAS: 19,6 x 27,5 cm (mancha); 32,7 x 47,9 cm (papel). IMPRESSÃO: em preto, com algumas áreas em cores. ASSINATURA: "C. Oswald" gravado no centro da margem inferior da mancha, "C. Oswald" no canto inferior direito do papel. COLEÇÃO Museu Nacional de Belas Artes/IBRAM/MinC. PROVENIÊNCIA: Carlos Oswald, compra, 1963.

67. TÍTULOS: Concerto; Tocando Debussy. VARIANTE: Tocando piano; Menina ao piano; Pianista.

DATA: 1915. TÉCNICA: Água-forte. MEDIDAS: 19,5 x $27 \mathrm{~cm}$ (mancha), 25,3 x 32,5 cm (papel). IMPRESSÃO: em cores. ASSINATURA: "C. Oswald" gravado no centro da margem inferior da mancha, "C. Oswald" no canto inferior direito do papel. COLEÇÃO particular. FONTE: Evandro Carneiro Leiloeiro, disponível em: <http://www.evandrocarneiroleiloes. com/145675? artistId=88060> , acesso em 13/8/2017. 


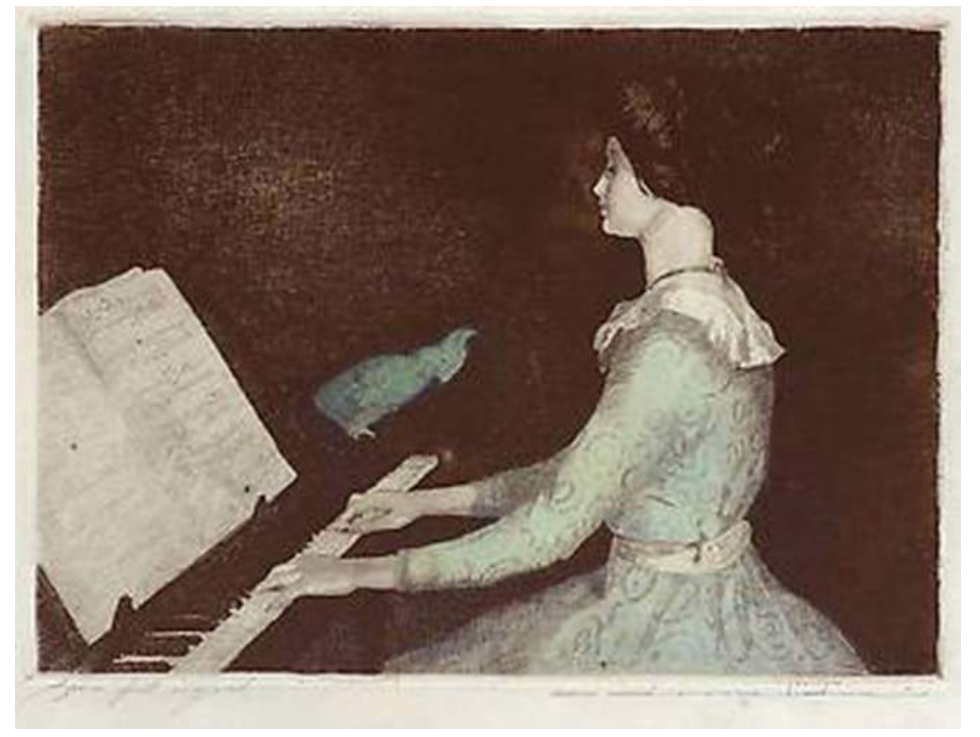

Fig. 68

68. TÍTULOS: Concerto; Tocando Debussy. VARIANTE: Tocando piano; Menina ao piano; Pianista.

DATA: 1915. TÉCNICA: Água-forte. MEDIDAS: 19,5 x $27 \mathrm{~cm}$ (mancha), 27,5 x $37 \mathrm{~cm}$ (papel). IMPRESSÃO: em preto, aquarelada. ASSINATURA: “C. Oswald” gravado no centro da margem inferior da mancha, "C. Oswald" no canto inferior direito do papel. COLEÇÃO particular. FONTE: Evandro Carneiro Leiloeiro, disponível em: <http://www.evandrocarneiroleiloes.com/145675? artistId=88060 > , acesso em 13/8/2017. 


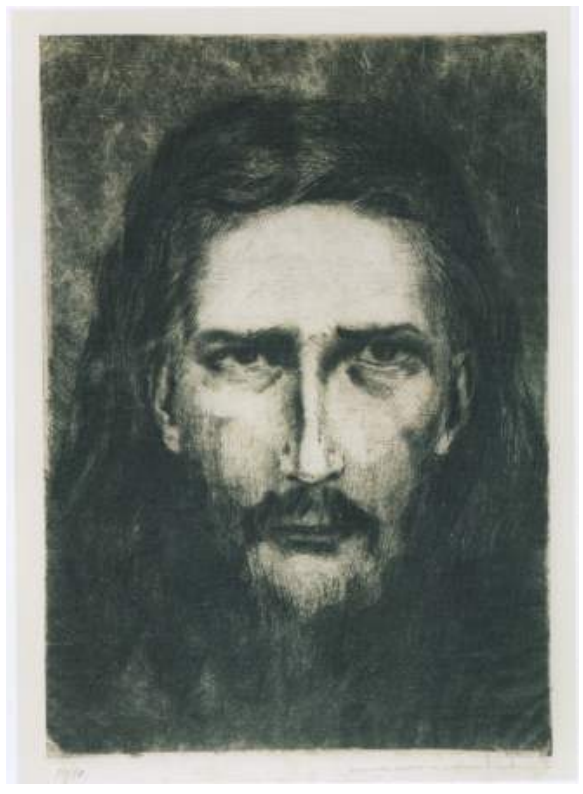

Fig. 69.B

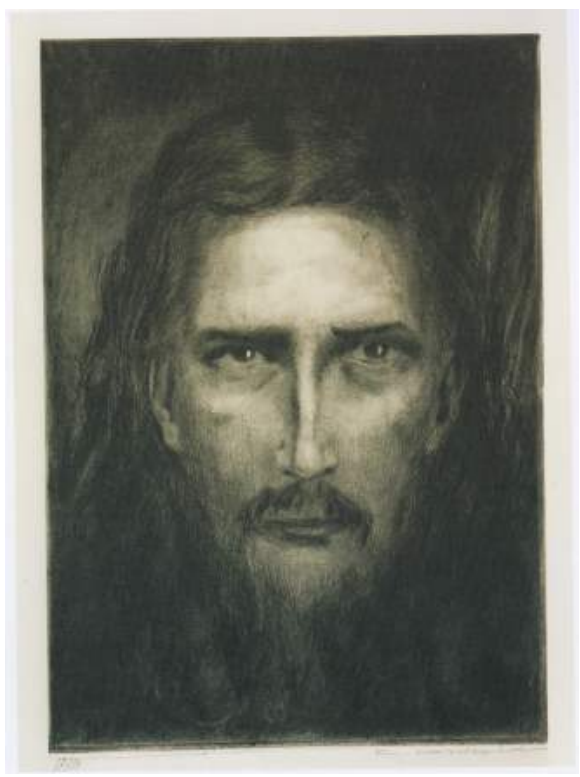

Fig. 69.C

69. TÍTULOS: Cristo; Iocahanann. VARIANTES: Cabeça de Cristo; São João Baptista; Yocahanann; Cabeça de São João Batista.

A. DATA: 1915. TÉCNICA: Ponta seca. MEDIDAS: 27,2 x $20 \mathrm{~cm}$ (mancha), 40,3 x $25 \mathrm{~cm}$ (papel). IMPRESSÃO: em preto. ASSINATURA: monograma "CO" no canto inferior esquerdo da mancha, "C. Oswald" no canto inferior esquerdo do papel. ACERVO Fundação Biblioteca Nacional. PROVENIÊNCIA: obra registrada no acervo em 1961, com a indicação de que já pertencia a ele antes.

B. DATA: 1914. TÉCNICA: Ponta seca. MEDIDAS: 27,2 x 19,3 cm (mancha). IMPRESSÃO: em preto. ASSINATURA: monograma "CO" no canto inferior esquerdo da mancha, "C. Oswald" no canto inferior esquerdo do papel. COLEÇÃO Maria Isabel Oswald Monteiro. FONTE: Vergolino, 2011, p. 60.

C. DATA: 1914. TÉCNICA: Ponta seca. MEDIDAS: 27,2 x 19,3 cm (mancha). IMPRESSÃO: em preto. ASSINATURA: monograma "CO" no canto inferior esquerdo da mancha, "C. Oswald" no canto inferior esquerdo do papel. COLEÇÃO Josafá Vilarouca Jr.. FONTE: Vergolino, 2011, p. 61.

LITERATURA: O Paiz, RJ, 7/7/1916 (nota); Almeida, O Malho, RJ, 4/10/1919 (artigo); Illustração Brasileira, 6/1921, p. 19 (rep.); Correio Paulistano, SP, 12/12/1923 (nota); Silva, Para todos, RJ, 16/11/1956 (ref.); Oswald, 1957, p. 211 (ref.); Silva, 1969 (ref.); Exp. Carlos Oswald: o resgate de um mestre, Caixa Cultural, Brasília/Curitiba, 2011, p. 60 - 61 (rep.). 


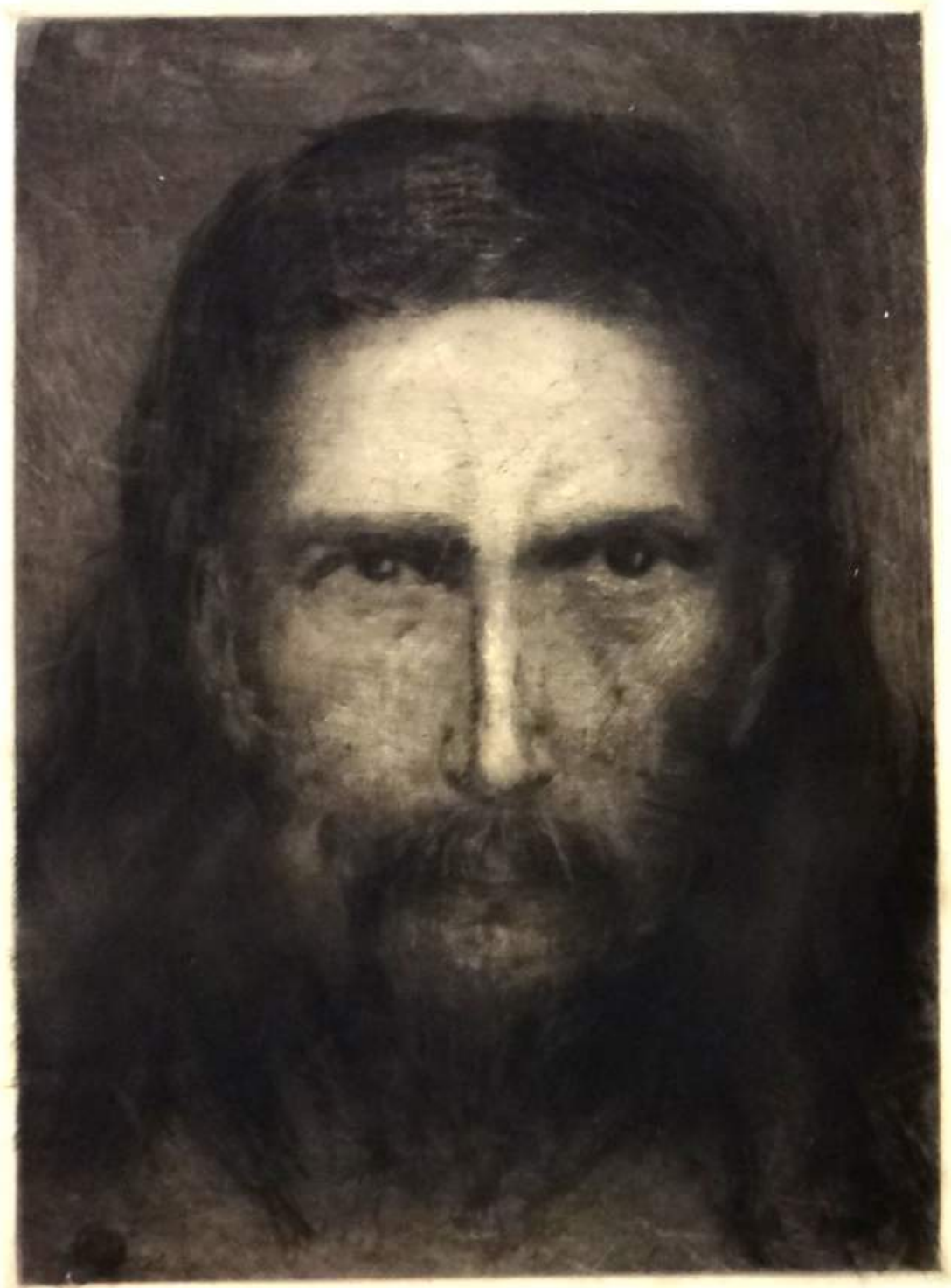

Fig. 69.A 


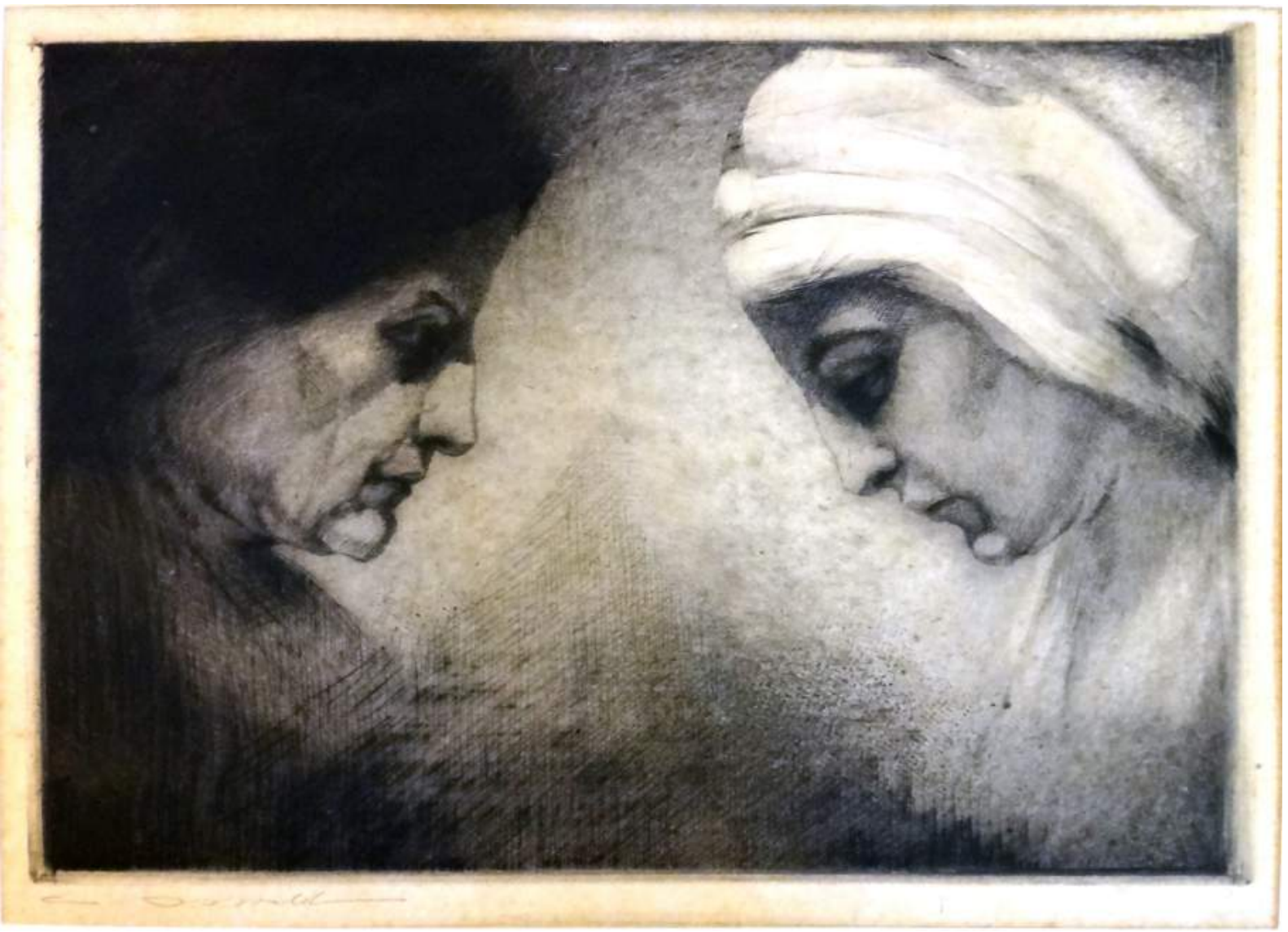

Fig. 70.A

70. TÍTULOS: Maria e Sta Isabel; A Visitação.

A. DATA: 1915. TÉCNICA: Água-forte e ponta seca. MEDIDAS: 19,7 x $28 \mathrm{~cm}$ (mancha), 32,5 x $50 \mathrm{~cm}$ (papel). IMPRESSÃO: em preto. ASSINATURA: “C. Oswald” no canto inferior esquerdo do papel. ACERVO Fundação Biblioteca Nacional. PROVENIÊNCIA: Carlos Oswald, compra, 1916.

B. DATA: 1913. TÉCNICA: Água-forte e ponta seca. MEDIDAS: 19,3 x 27,8 cm (mancha); 26,5 x 36,4 cm (papel). IMPRESSÃO: em preto. ASSINATURA: "C. Oswald" no canto inferior direito do papel. COLEÇÃO Museu Nacional de Belas Artes/IBRAM/MinC. PROVENIÊNCIA: Carlos Oswald, compra, 1963. Assinada C. Oswald.

LITERATURA: O Paiz, RJ, 7/7/1916 (nota); Almeida, O Malho, RJ, 4/10/1919 (artigo, rep.); Illustração Brasileira, RJ, 4/1921, p. 26 (artigo); Silva, 1969 (ref., datada 1914); Oswald, 1957, p. 211 (ref., datada 1914); Exp. Carlos Oswald: o resgate de um mestre, Caixa Cultural, Brasília/Curitiba, 2011, p. 59 (rep.). 


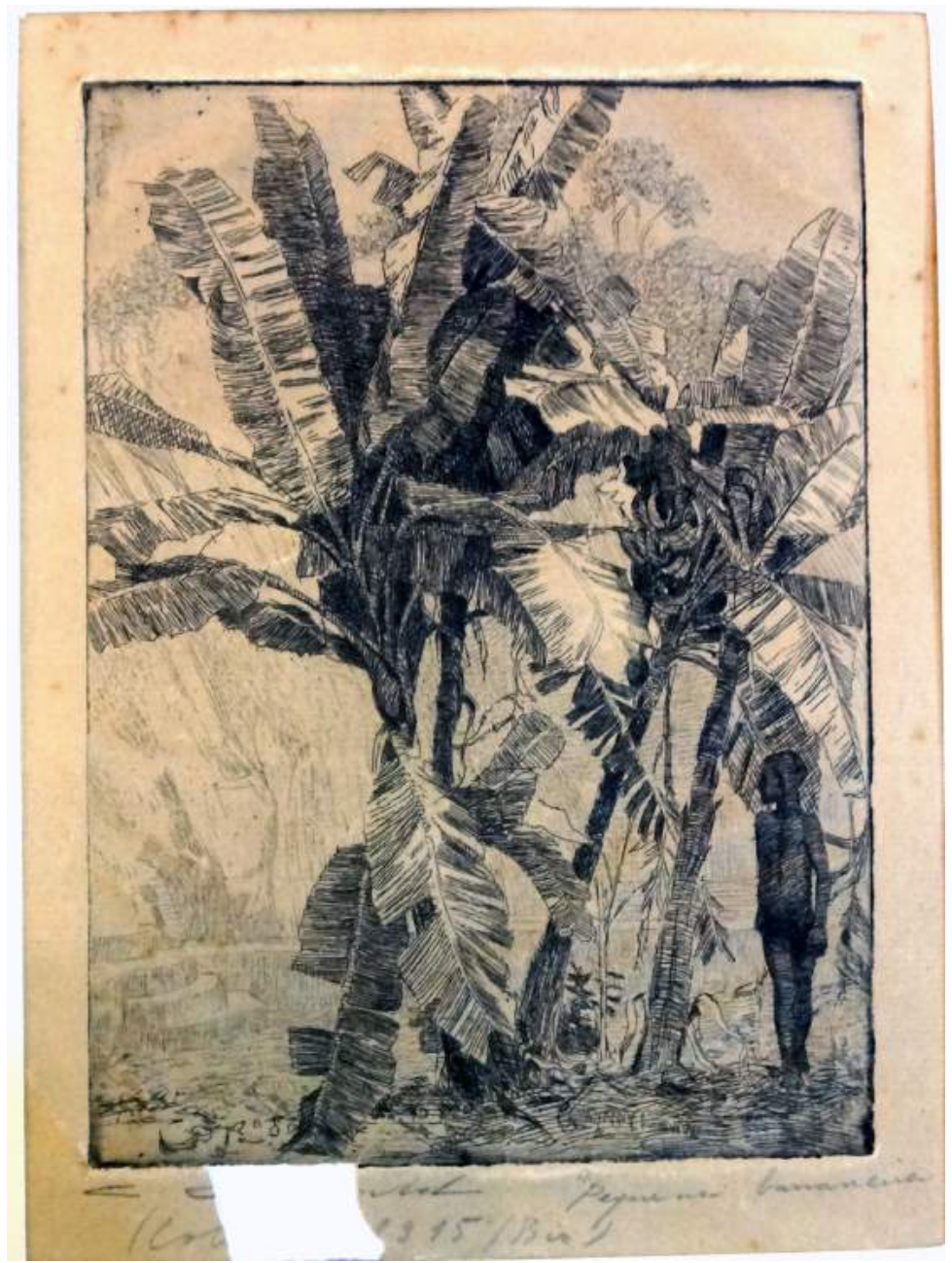

Fig. 71.A

71. TÍTULO: Pequena Bananeira.

A. DATA: 1915. TÉCNICA: Água-forte. MEDIDAS: 20 x 14 cm (mancha). IMPRESSÃO: em preto. MATRIZ: cobre. ASSINATURA: "C. Oswald" no canto inferior esquerdo do papel [rasgado]. ACERVO Fundação Biblioteca Nacional. PROVIDÊNCIA: Carlos Oswald, compra, 1916.

B. DATA: 1975. TÉCNICA: Água-forte. IMPRESSÃO: póstuma, em preto. MATRIZ: cobre. ACERVO Fundação Biblioteca Nacional. PROVENIÊNCIA: registrada em 1975 no acervo. [Dois exemplares.]

C. DATA: 1913. TÉCNICA: Água-forte. MEDIDAS: 19,7 x 14,1 cm (mancha); 33,4 x 22,1 cm (papel). IMPRESSÃO: em preto. MATRIZ: cobre. ASSINATURA: "C. Oswald” no papel. COLEÇÃO Museu Nacional de Belas Artes/IBRAM/MinC. PROVENIÊNCIA: Carlos Oswald, compra, 1963.

D. [matriz] DATA: 1915. TÉCNICA: Água-forte. MATRIZ: cobre. Sem assinatura. ACERVO Fundação Biblioteca Nacional. PROVENIÊNCIA: registrada no acervo em 1975.

LITERATURA: Silva, 1969 (ref., datada 1913); Exp. Carlos Oswald: o resgate de um mestre, Caixa Cultural, Brasília/Curitiba, 2011, p. 54 (rep.). 
72. TÍTULO: Brincando com a chama.

A. DATA: 1915. TÉCNICA: Água-forte, água-tinta e ponta seca. MEDIDAS: 28 x 19,7 cm (mancha), 52 x 33,5 cm (papel). IMPRESSÃO: em vermelho e em azul. ASSINATURA: "C. Oswald" no canto inferior esquerdo do papel. ACERVO Fundação Biblioteca Nacional. PROVENIÊNCIA: Carlos Oswald, compra, 1916.

B. [Prova matriz claro e escuro] DATA: 1915. TÉCNICA: Água-forte, água-tinta e ponta seca. MEDIDAS: 28 x 19,7 cm (mancha), 40,1 x 28 cm (papel). IMPRESSÃO: em preto. Sem assinatura. ACERVO Fundação Biblioteca Nacional. PROVENIÊNCIA: Carlos Oswald, compra, 1916.

C. [Prova matriz azul] DATA: 1915. TÉCNICA: água-tinta. MEDIDAS: c. 27 x16 cm (papel). IMPRESSÃO: em azul. Sem assinatura. ACERVO Fundação Biblioteca Nacional. PROVENIÊNCIA: Carlos Oswald, compra, 1916.

D. [Prova matriz vermelha] DATA: 1915. TÉCNICA: Água-forte, água-tinta e ponta seca. MEDIDAS: 28 x 19,7 cm (mancha), 37,9 x 27,7 cm (papel). IMPRESSÃO: em vermelho, amarelo e preto. Sem assinatura. ACERVO Fundação Biblioteca Nacional. PROVENIÊNCIA: Carlos Oswald, compra, 1916.

E. [1 $1^{\circ}$ estado] DATA: 1915. TÉCNICA: Água-forte, água-tinta e ponta seca. MEDIDAS: 28 x $19,7 \mathrm{~cm}$ (mancha), 37 x 27,3 cm (papel). IMPRESSÃO: em vermelho, azul e preto. Sem assinatura. ACERVO Fundação Biblioteca Nacional. PROVENIÊNCIA: Carlos Oswald, compra, 1916.

F. DATA: 1915. TÉCNICA: Água-forte, água-tinta e ponta seca. MEDIDAS: 27 x 19,3 cm (mancha); 32,4 x 27 cm (papel). IMPRESSÃO: em vermelho e em azul. ASSINATURA: "C. Oswald" no canto inferior esquerdo do papel. COLEÇÃO Museu Nacional de Belas Artes/ IBRAM/MinC. PROVENIÊNCIA: Carlos Oswald, compra, 1963.

LITERATURA: Illustração Brasileira, RJ, 1/1921, p. 24 (rep.); Illustração Brasileira, RJ, 4/1921, p. 27 (artigo); Oswald, 1957, p. 211 (ref., datada 1914); Silva, 1969 (ref.); Monteiro, 2000, p.108 (rep. em fotografia); Exp. Carlos Oswald: o resgate de um mestre, Caixa Cultural, Brasília/Curitiba, 2011, p. 37 (rep.). 


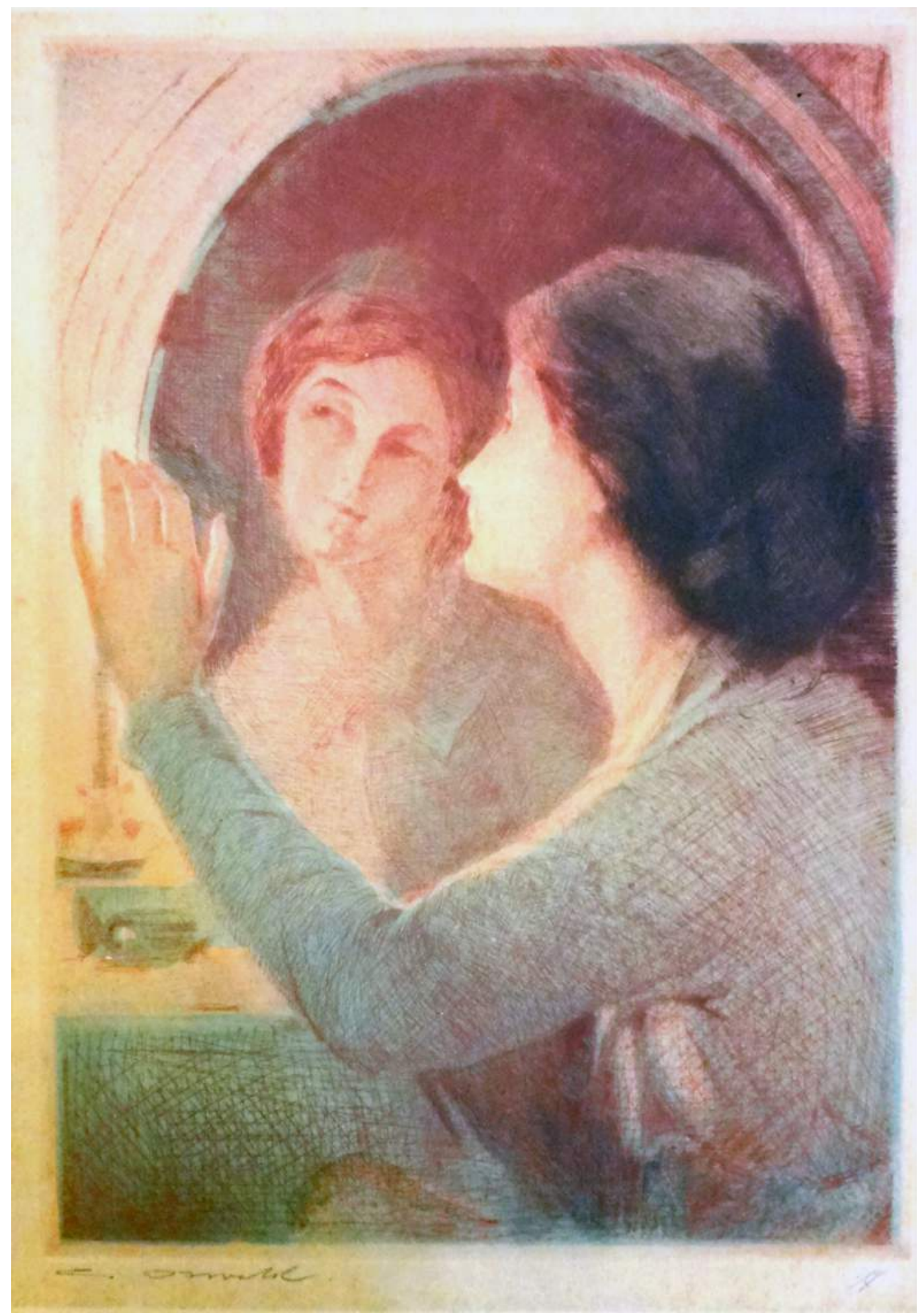

Fig. 72.A 


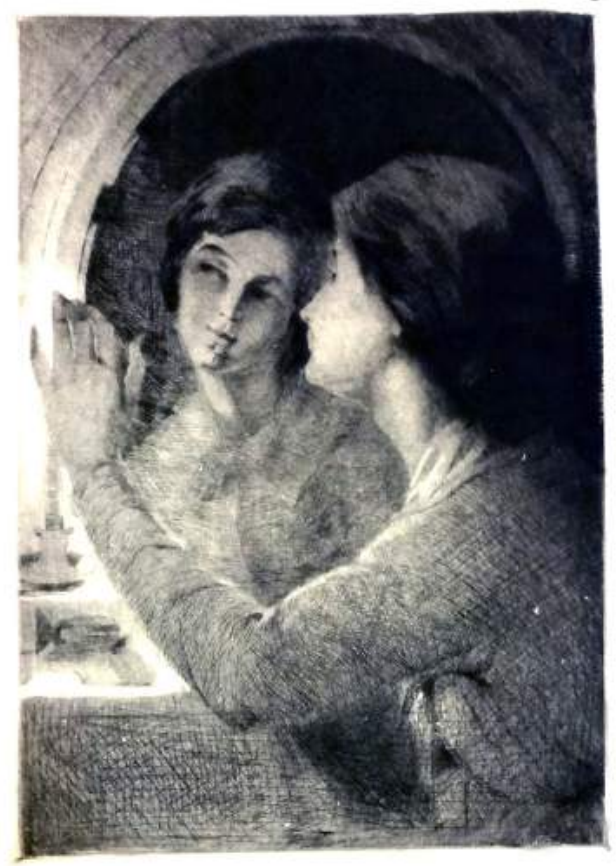

Fig. 72.B

Fig. 72.C

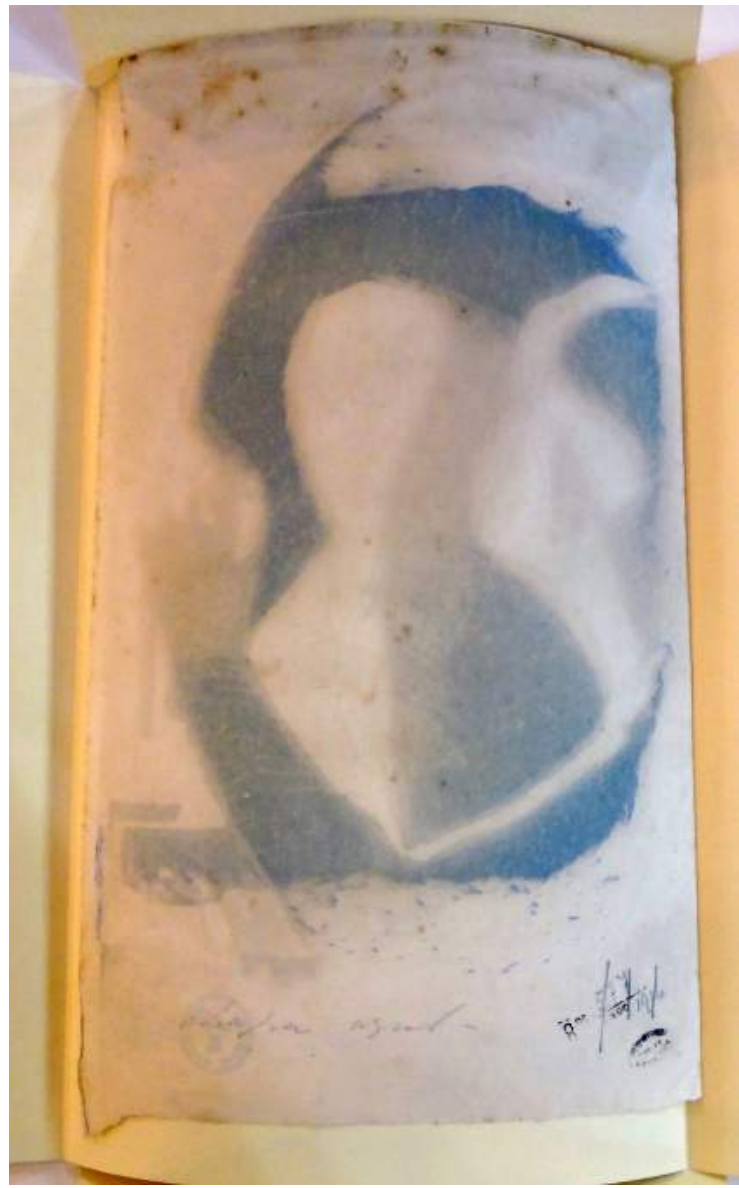




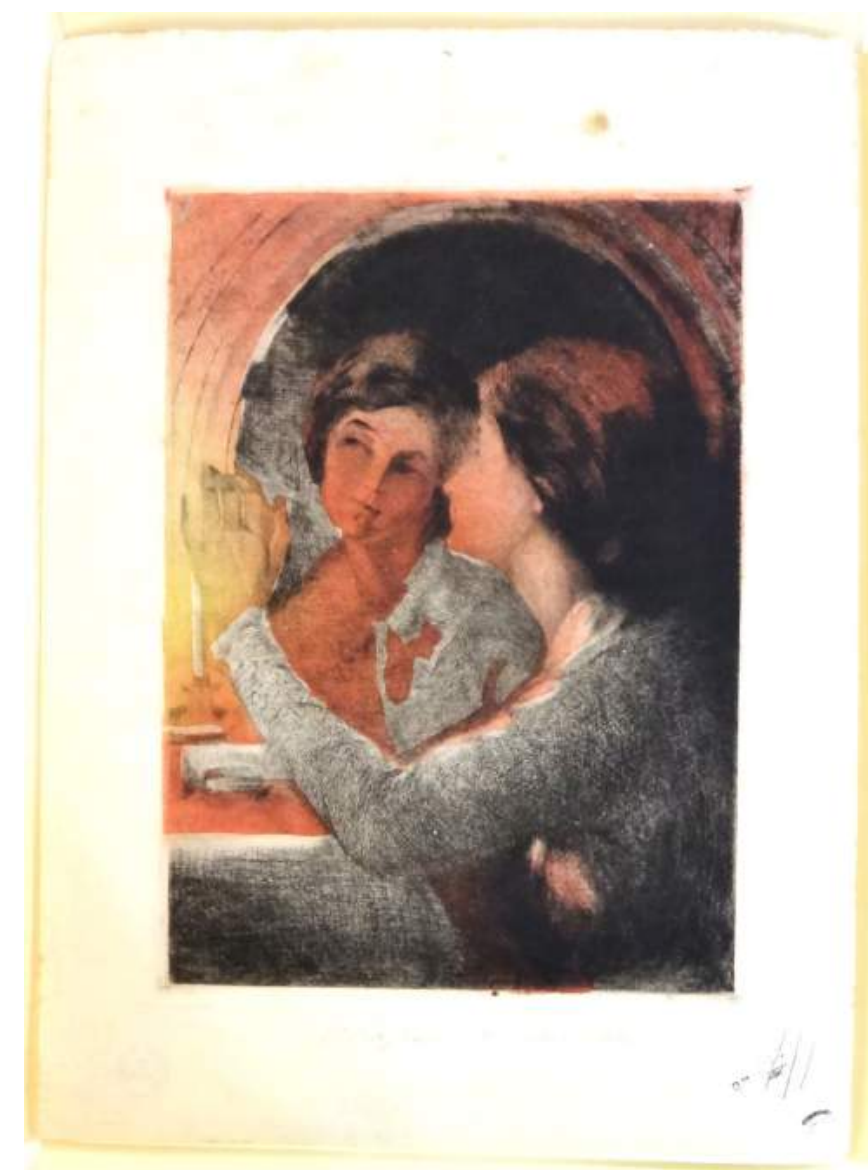

Fig. 72.D

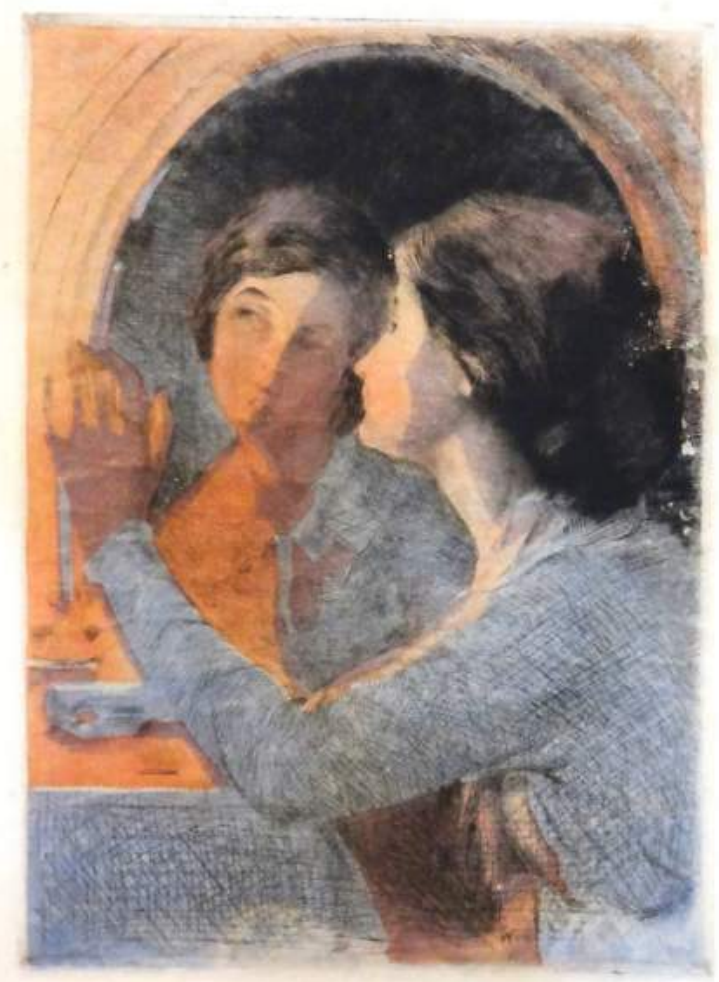

Fig. 72.E 
73. TÍTULO: Carlos Gomes.

A. DATA: 1915. TÉCNICA: Água-forte. MEDIDAS: 27,5 x $20 \mathrm{~cm}$ (mancha), 36 x 27,1 cm (papel). IMPRESSÃO: em preto. MATRIZ: cobre. MEDIDAS DA MATRIZ: 28,1 x 20,1 cm. ASSINATURA: monograma "CO" gravado na lateral esquerda da mancha, "C. Oswald" no canto inferior esquerdo do papel. ACERVO Fundação Biblioteca Nacional. PROVENIÊNCIA: registrada no acervo em 1916.

B. DATA: 1915. TÉCNICA: Água-forte. MEDIDAS: 27,5 x $20 \mathrm{~cm}$ (mancha), 36,4 x 27,5 cm (papel). IMPRESSÃO: em preto. MATRIZ: cobre. MEDIDAS DA MATRIZ: 28,1 x 20,1 cm. ASSINATURA: monograma "CO" gravado na lateral esquerda da mancha. ACERVO Fundação Biblioteca Nacional. PROVENIÊNCIA: registrada no acervo em 1916.

C. DATA: 1915. TÉCNICA: Água-forte. MEDIDAS: 26,8 x 19,5 cm (mancha); 34,9 x 24,5 cm (papel). IMPRESSÃO: em preto. MATRIZ: cobre. MEDIDAS DA MATRIZ: 28,1 x 20,1 cm. ASSINATURA: monograma "CO" gravado na lateral esquerda da mancha, "C. Oswald" no canto inferior direito do papel. COLEÇÃO Museu Nacional de Belas Artes/IBRAM/MinC. PROVENIÊNCIA: Carlos Oswald, compra, 1963.

D. [matriz] DATA: 1915. TÉCNICA: Água-forte. MATRIZ: cobre. MEDIDAS DA MATRIZ: 28,1 x 20,1 cm. ASSINATURA: monograma "CO" gravado na lateral direita da matriz. COLEÇÃO Museu Nacional de Belas Artes/IBRAM/MinC. PROVENIÊNCIA: Carlos Oswald, doação, 1962.

LITERATURA: O Paiz, RJ, 7/7/1916 (nota); O Jornal, RJ, 21/5/1921 (ref.); Correio da Manhã, RJ, 25/11/1933 (artigo); Correio da Manhã, RJ, 6/12/1935 (nota expo.); Oswald, 1957, p. 213 (ref., datada 1916); Silva, 1969 (ref., datada 1914); Exp. Carlos Oswald: o resgate de um mestre, Caixa Cultural, Brasília/Curitiba, 2011, p. 44 (rep.). 


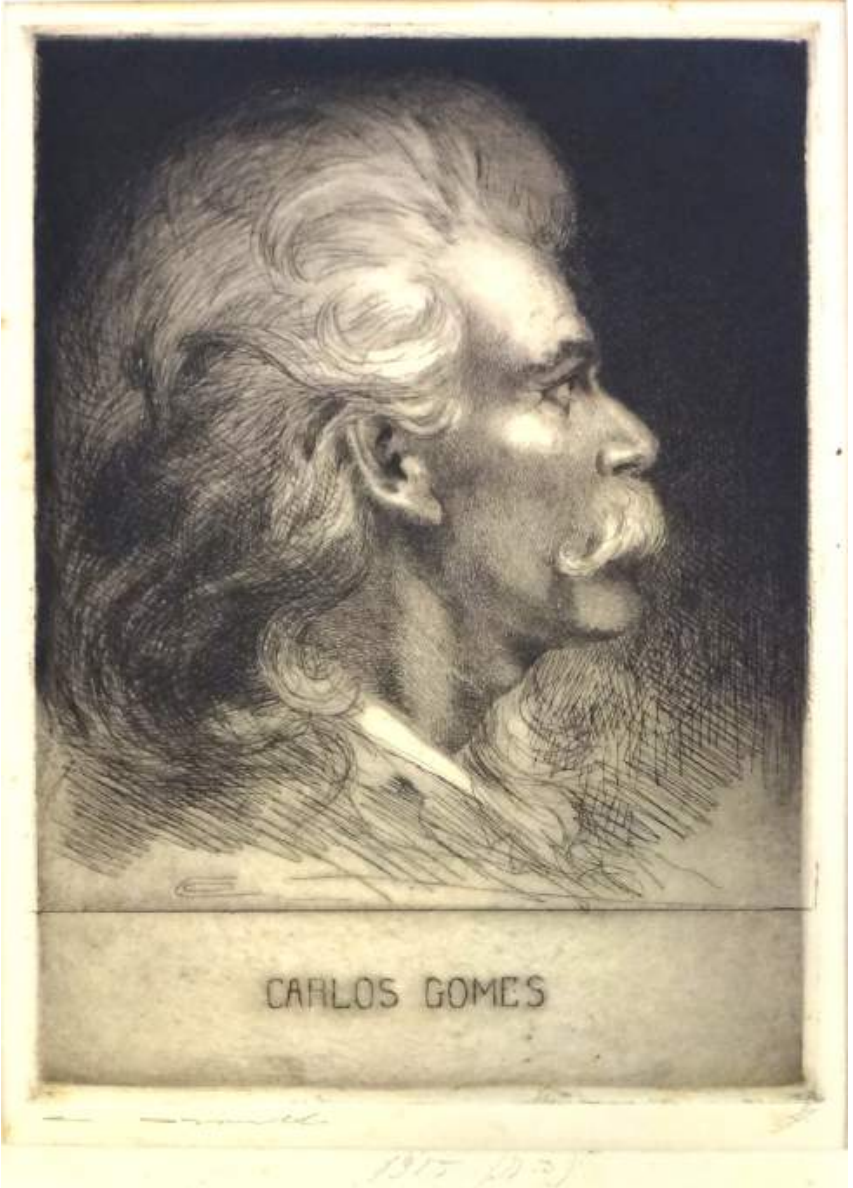

Fig. 73. A

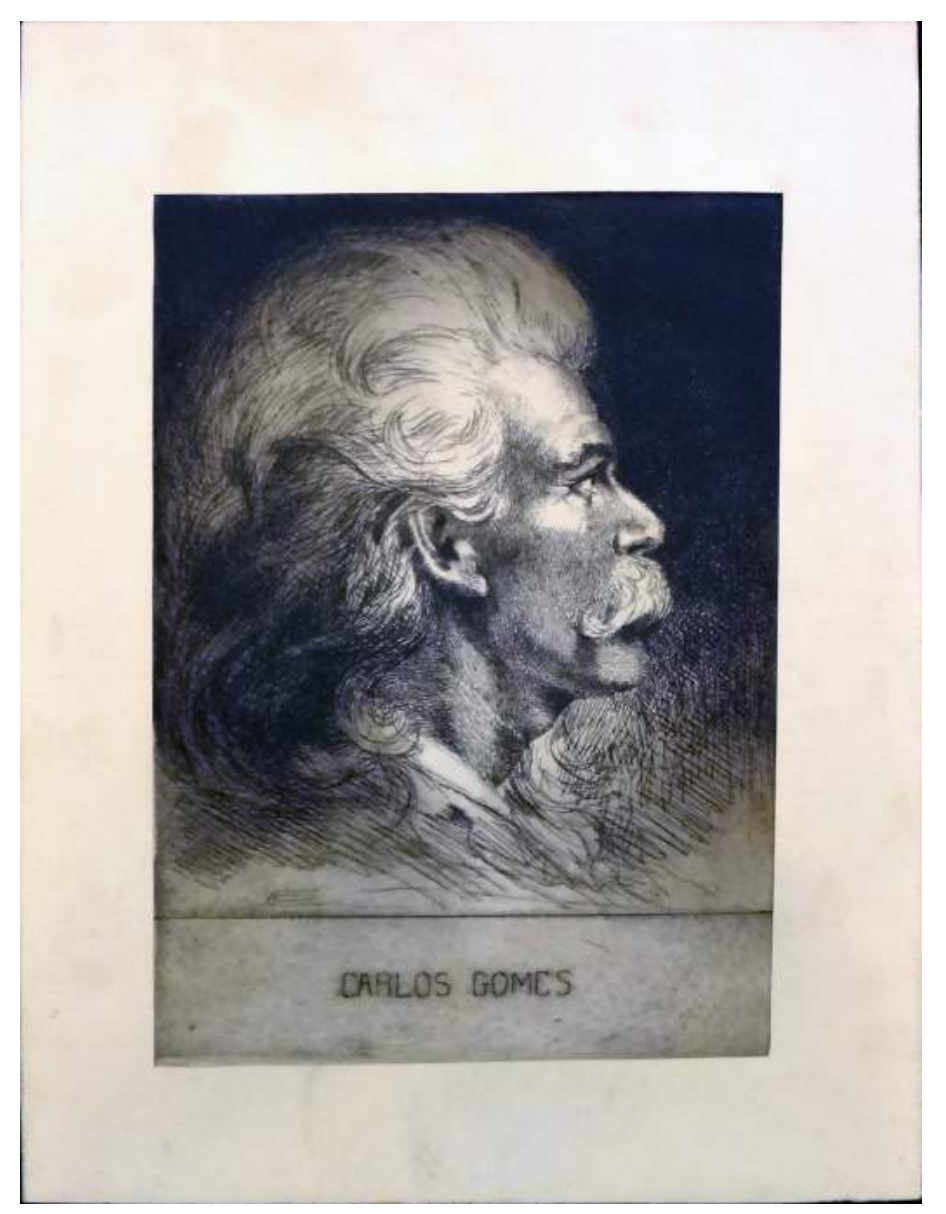

Fig. 73.B 


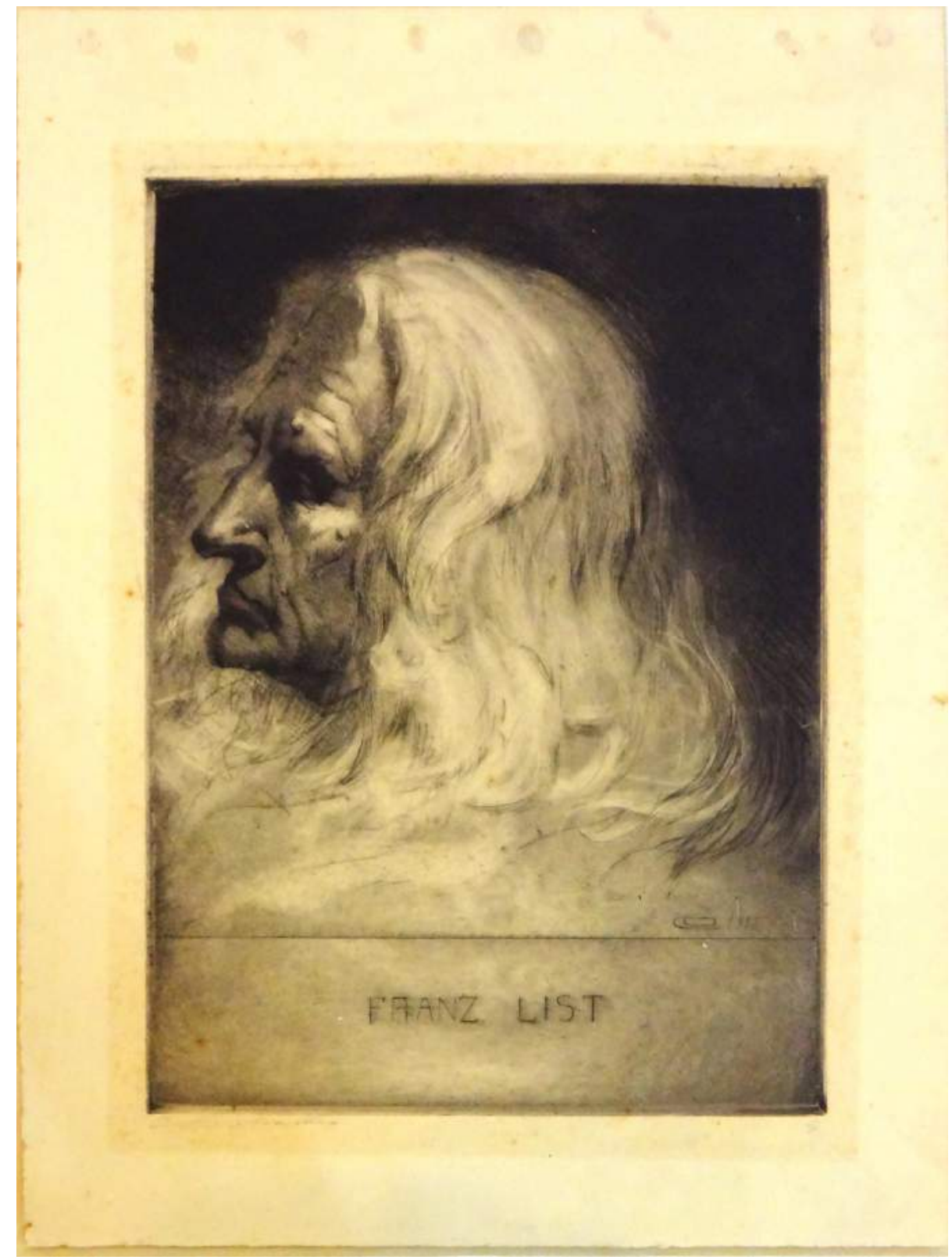

Fig. 74

74. TÍTULO: Franz List.

DATA: 1915. TÉCNICA: Água-forte. MEDIDAS: 27,3 x 19,9 cm (mancha), 36,2 x 27 cm (papel). IMPRESSÃO: em preto. ASSINATURA: monograma "CO 1915" no canto inferior direito da mancha, "C. Oswald" no canto inferior esquerdo do papel. ACERVO Fundação Biblioteca Nacional. PROVENIÊNCIA: registrada em 1916 na coleção.

LITERATURA: O Paiz, RJ, 7/7/1916 (nota); Correio Paulistano, SP, 8/2/1918 (nota); Almeida, O Malho, RJ, 4/10/1919 (artigo); Silva, 1969 (ref.). 


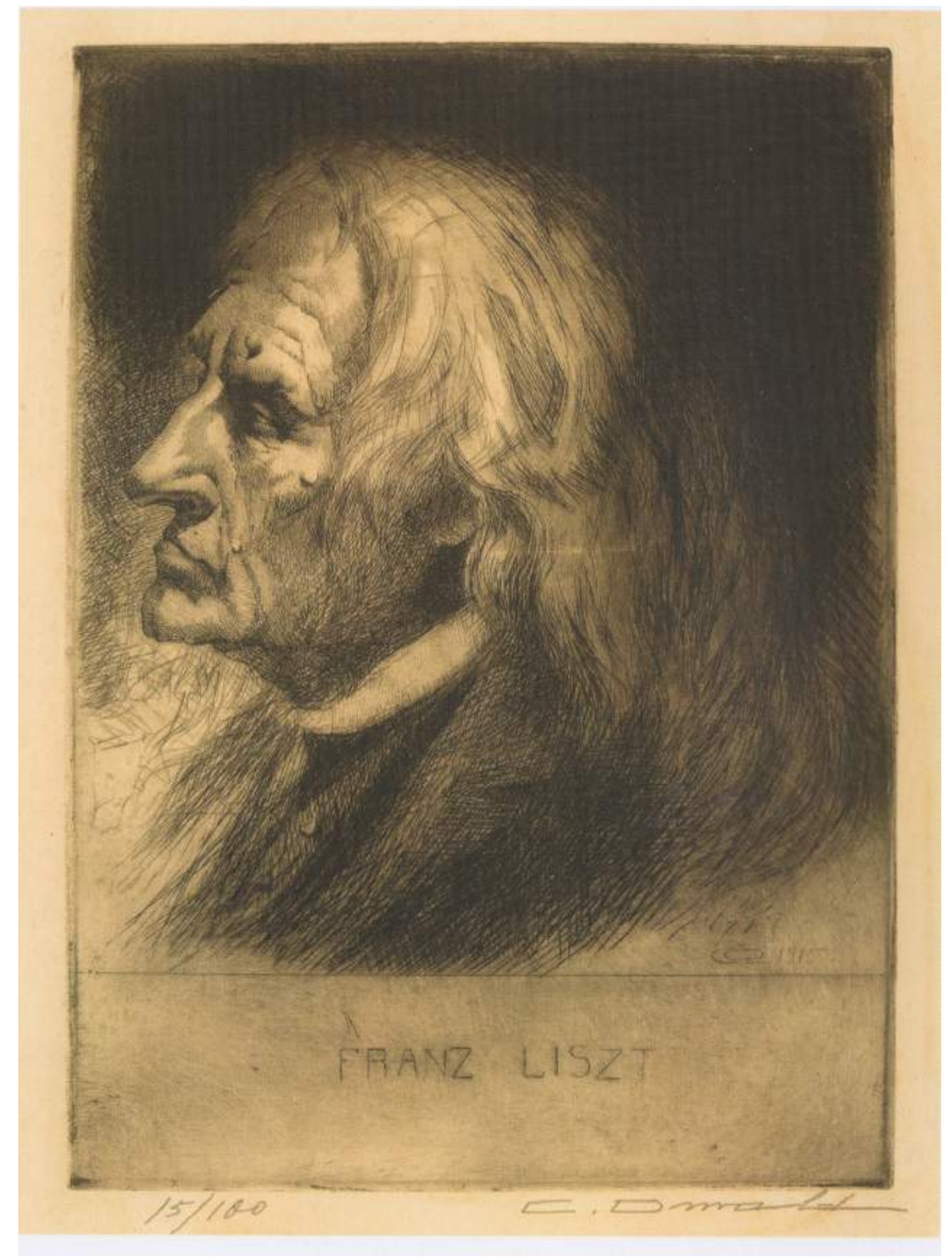

Fig. 75

75. TÍTULO: Franz Liszt.

DATA: 1915. TÉCNICA: Água-forte. MEDIDAS: 27,8 x 19,5 cm (mancha); 56,1 x 37,1 cm (papel). IMPRESSÃO: em preto. ASSINATURA: monograma "CO 1915" no canto inferior direito da mancha, "C. Oswald" no canto inferior direito do papel. COLEÇÃO Museu Nacional de Belas Artes/IBRAM/MinC. PROVENIÊNCIA: Carlos Oswald, compra, 1963. FONTE: Vergolino, 2011, p. 47.

LITERATURA: O Paiz, RJ, 7/7/1916 (nota); Correio Paulistano, SP, 8/2/1918 (nota); Almeida, O Malho, RJ, 4/10/1919 (artigo); Oswald, 1957, não p. (rep.); Silva, 1969 (ref.); Exp. Carlos Oswald: o resgate de um mestre, Caixa Cultural, Brasília/Curitiba, 2011, p. 47 (rep.). 
76. TÍTULO: [Retrato do compositor francês Claude] Debussy.

[matriz] DATA: 1915. TÉCNICA: água-forte. MATRIZ: latão. MEDIDAS DA MATRIZ: 94,7 x 17,4 cm. Sem assinatura. COLEÇÃO Museu Nacional de Belas Artes/IBRAM/MinC. PROVENIÊNCIA: Maria Isabel Oswald Monteiro, doação, 1983. FONTE: Museu Nacional de Belas Artes. 


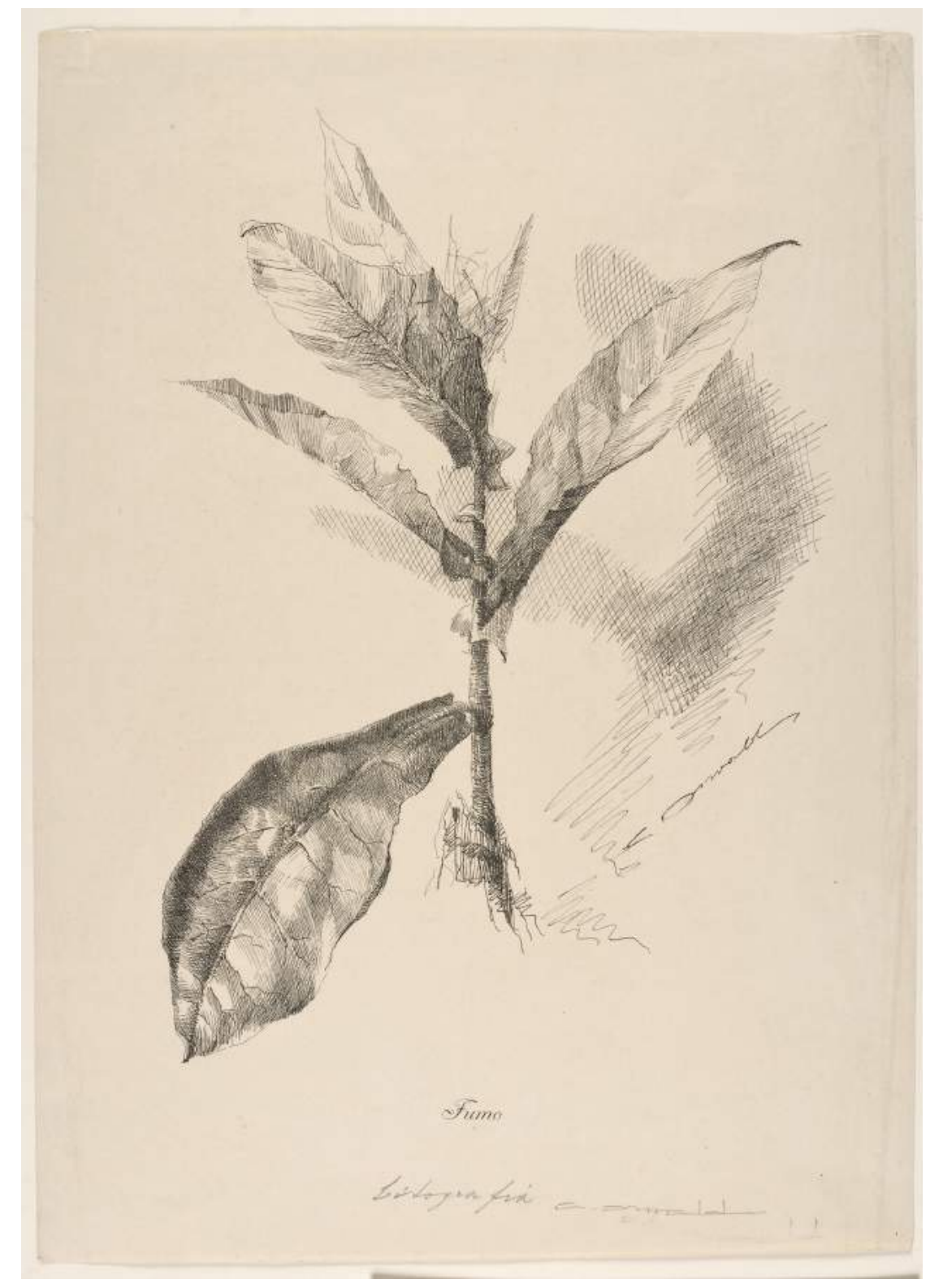

Fig. 77

77. TÍTULO: Fumo. VARIANTE: Estudo da folha de fumo.

A. DATA: 1915. TÉCNICA: Litografia. MEDIDAS: 34,8 x 23,5 cm (mancha), 46 x 32,5 cm (papel). ASSINATURA: "C. Oswald" na margem direita da mancha, "C. Oswald" no canto inferior direito do papel. COLEÇÃO Museu Nacional de Belas Artes/IBRAM/MinC. PROVENIÊNCIA: Carlos Oswald, compra, 1963. FOTOGRAFIA: Acervo Museu Nacional de Belas Artes/IBRAM/MinC.

LITERATURA: Silva, 1969 (ref.); Exp. Carlos Oswald: o resgate de um mestre, Caixa Cultural, Brasília/Curitiba, 2011, p. 39 (rep.). 


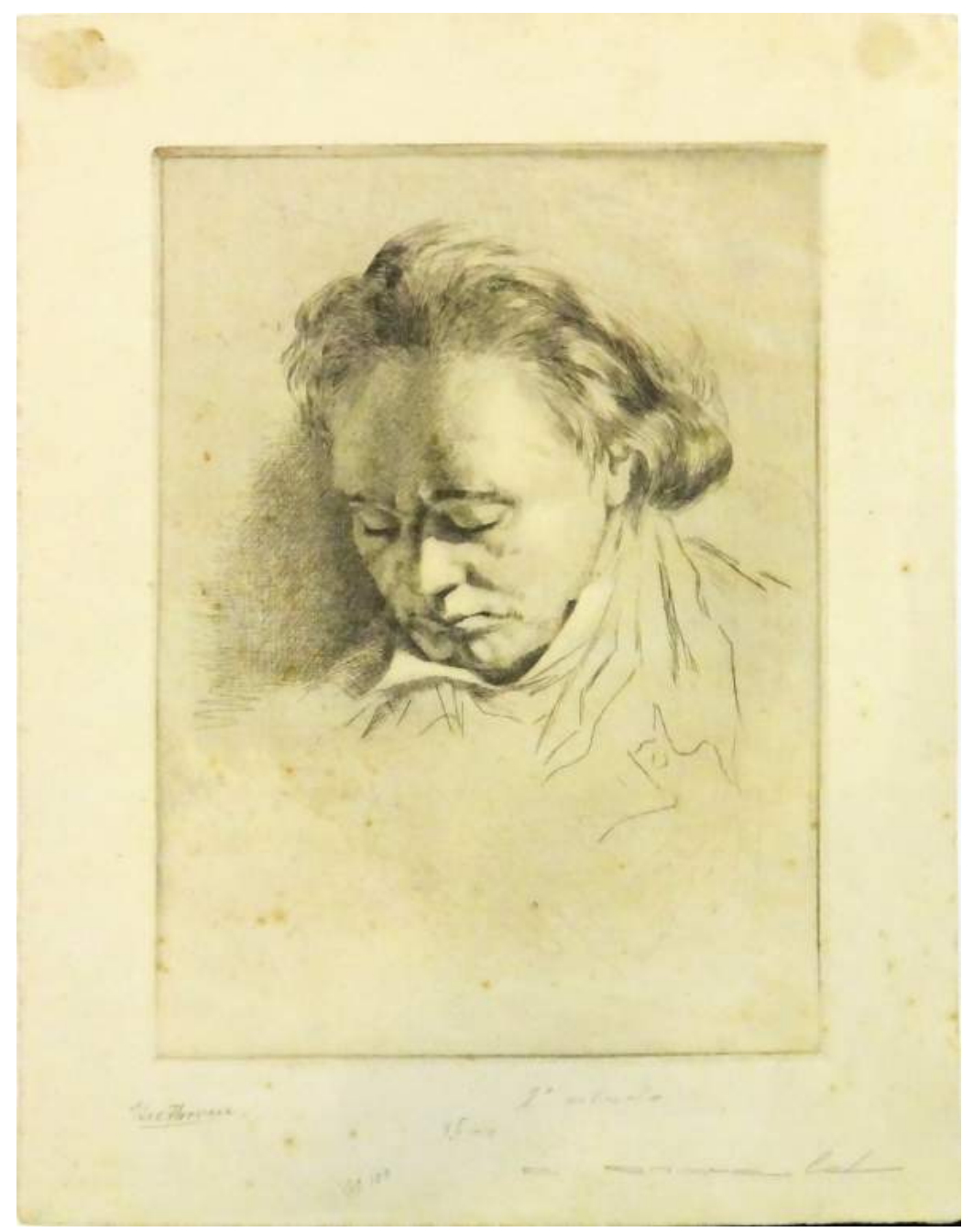

Fig. 78. C

78. TÍTULO: Beethoven.

A. DATA: 1919. TÉCNICA: Água-forte. MEDIDAS: 27,4 x 19,9 cm (mancha); 36 x 27,5 cm (papel). IMPRESSÃO: em preto. ASSINATURA: monograma “CO” gravado no canto inferior direito da mancha. COLEÇÃO Museu Nacional de Belas Artes/IBRAM/MinC. PROVENIÊNCIA: Carlos Oswald, compra, 1963.

B. DATA: 1919. TÉCNICA: Água-forte. MEDIDAS: 27,4 x 20 cm (mancha). IMPRESSÃO: em preto. MATRIZ: cobre. ASSINATURA: monograma "CO" gravado no canto inferior direito da mancha, "C. Oswald" no canto inferior direito do papel. COLEÇÃO Melina e Fábio Eleres. FONTE: Vergolino, 2011, p. 53.

C. [2 estado] DATA: 1919. TÉCNICA: Água-forte. MEDIDAS: 27,3 x 19,5 cm (mancha); 36,1 x 27,4 cm (papel). IMPRESSÃO: em preto. MATRIZ: cobre. ASSINATURA: "C. Oswald" no canto inferior direito do papel. ACERVO Fundação Biblioteca Nacional. PROVENIÊNCIA: registrada no acervo em 1920.

LITERATURA: Correio Paulistano, SP, 21/1/1923 (nota); Oswald, 1957, p. 215 (ref. e rep.); Silva, 1969 (ref.); Exp. Carlos Oswald: o resgate de um mestre, Caixa Cultural, Brasília/Curitiba, 2011, p. 53 (rep.). 


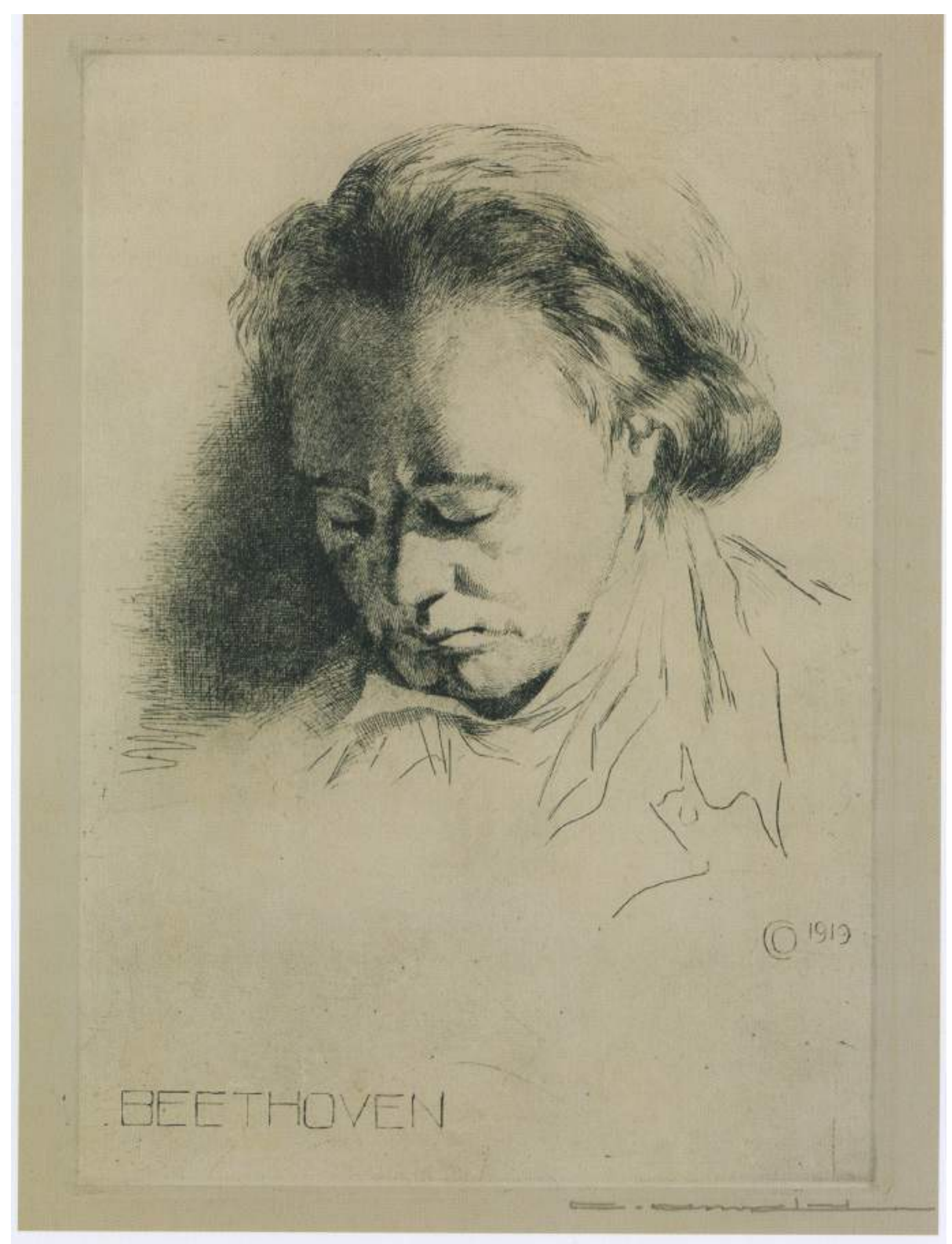

Fig. 78. B 


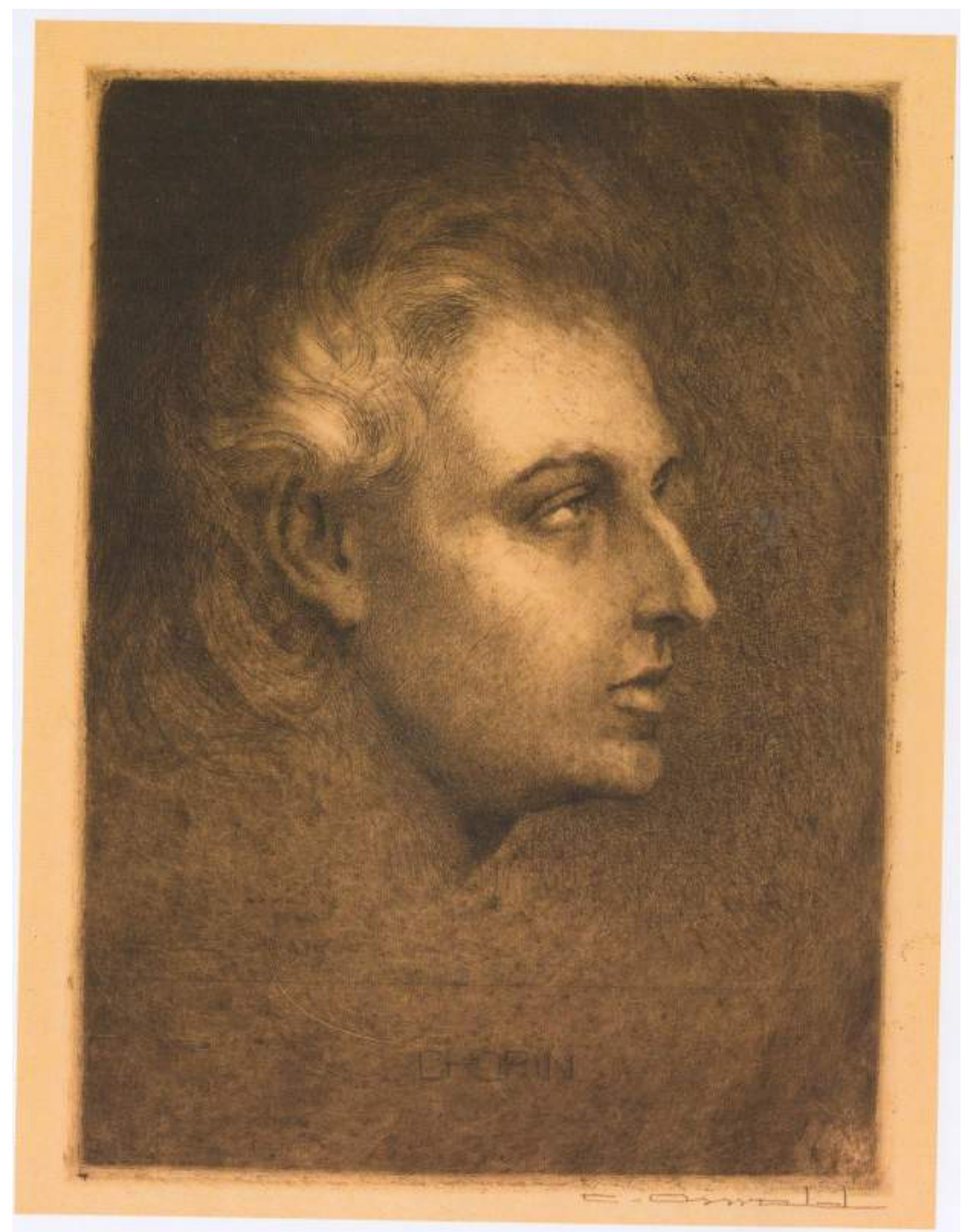

Fig. 79. A

79. TÍTULO: Chopin.

A. DATA: 1919. TÉCNICA: Água-forte. MEDIDAS: 26,5 x 19,5 cm (mancha), 36,4 x 28 cm (papel). IMPRESSÃO: em preto. ASSINATURA: monograma “CO” gravado na lateral esquerda da mancha, "C. Oswald" no canto inferior direito do papel. COLEÇÃO Museu Nacional de Belas Artes/IBRAM/MinC. PROVENIÊNCIA: Carlos Oswald, compra, 1963. FONTE: Vergolino, 2011, p. 50.

B. [1 estado] DATA: 1919. TÉCNICA: Água-forte. MEDIDAS: 27,6 x 20 cm (mancha), 39,1 x 28,2 cm (papel). IMPRESSÃO: em preto. ASSINATURA: monograma "CO” gravado na lateral esquerda da mancha. ACERVO Fundação Biblioteca Nacional. PROVENIÊNCIA: registrada no acervo em 1920.

LITERATURA: Almeida, O Malho, RJ, 4/10/1919 (artigo); O Jornal, RJ, 23/12/1921 (nota); Correio Paulistano, SP, 21/1/1923 (nota); Oswald, 1957, p. 216 (ref.); Silva, 1969 (ref.); Exp. Carlos Oswald: o resgate de um mestre, Caixa Cultural, Brasília/Curitiba, 2011, p. 50 (rep.). 


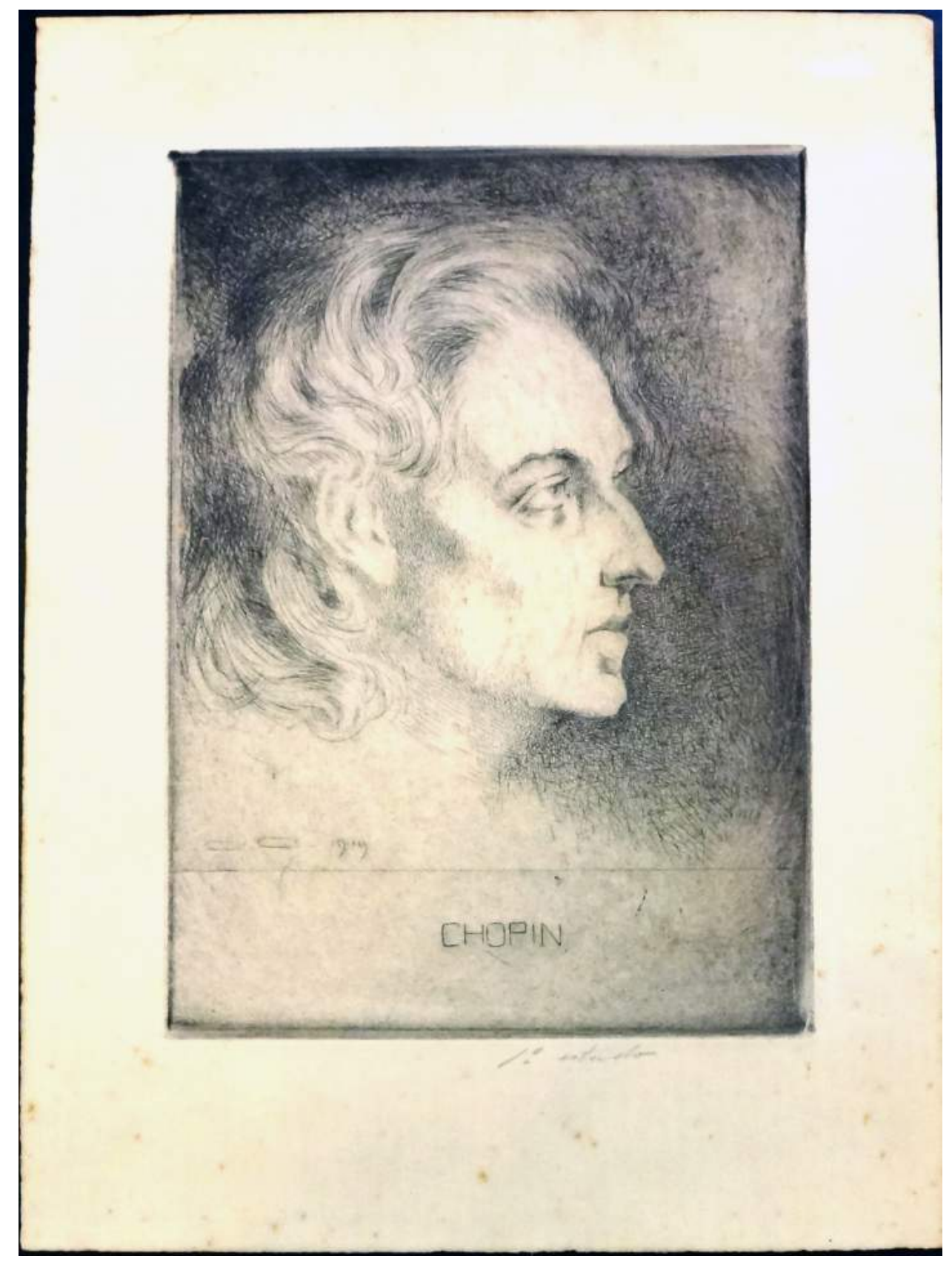

Fig. 79. B 


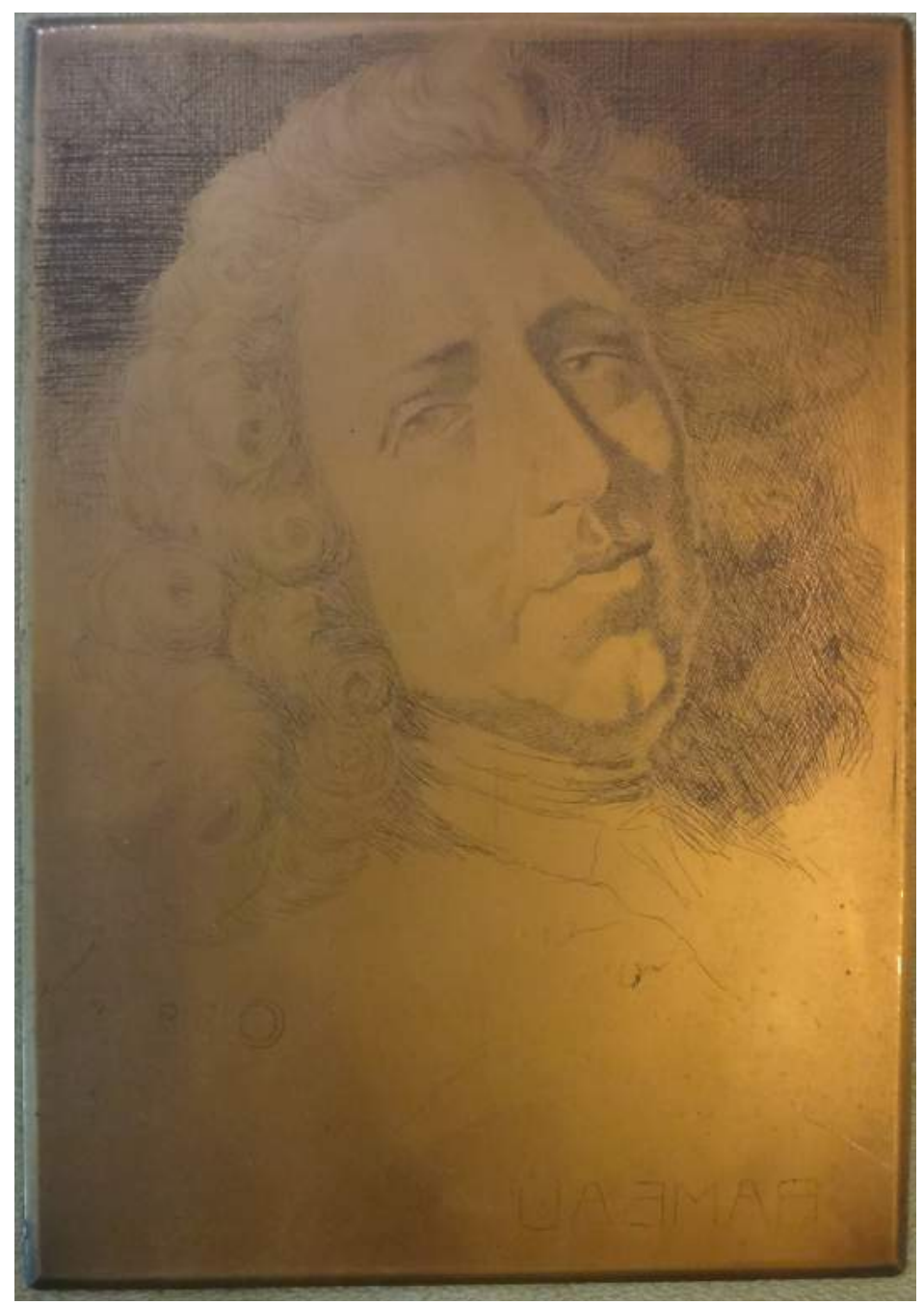

Fig. 80. C

80.TÍTULO: Rameau.

A. DATA: 1919. TÉCNICA: Água-forte. MEDIDAS: 19,8 X 14 cm (mancha), 34,9 x 25,7 cm (papel). IMPRESSÃO: em preto. MATRIZ: cobre. ASSINATURA: monograma "CO” na lateral direita da mancha, "C. Oswald" no canto inferior direito do papel. ACERVO Fundação Biblioteca Nacional. PROVENIÊNCIA: registrada no acervo em 1920.

B. DATA: 1919. TÉCNICA: Água-forte. MEDIDAS: 20 X 13,7 cm (mancha), 37,5 x 28,5 cm (papel). IMPRESSÃO: em preto. MATRIZ: cobre. ASSINATURA: monograma "CO” gravado na lateral direita da mancha, "C. Oswald" no papel. COLEÇÃO Museu Nacional de Belas Artes/IBRAM/MinC. PROVENIÊNCIA: Carlos Oswald, compra, 1963.

C. [matriz] DATA: 1919. TÉCNICA: Água-forte. MATRIZ: cobre. ASSINATURA: monograma "CO" na lateral esquerda. ACERVO Fundação Biblioteca Nacional.

LITERATURA: Oswald, 1957, p. 215 (ref.); Silva, 1969 (ref.). 


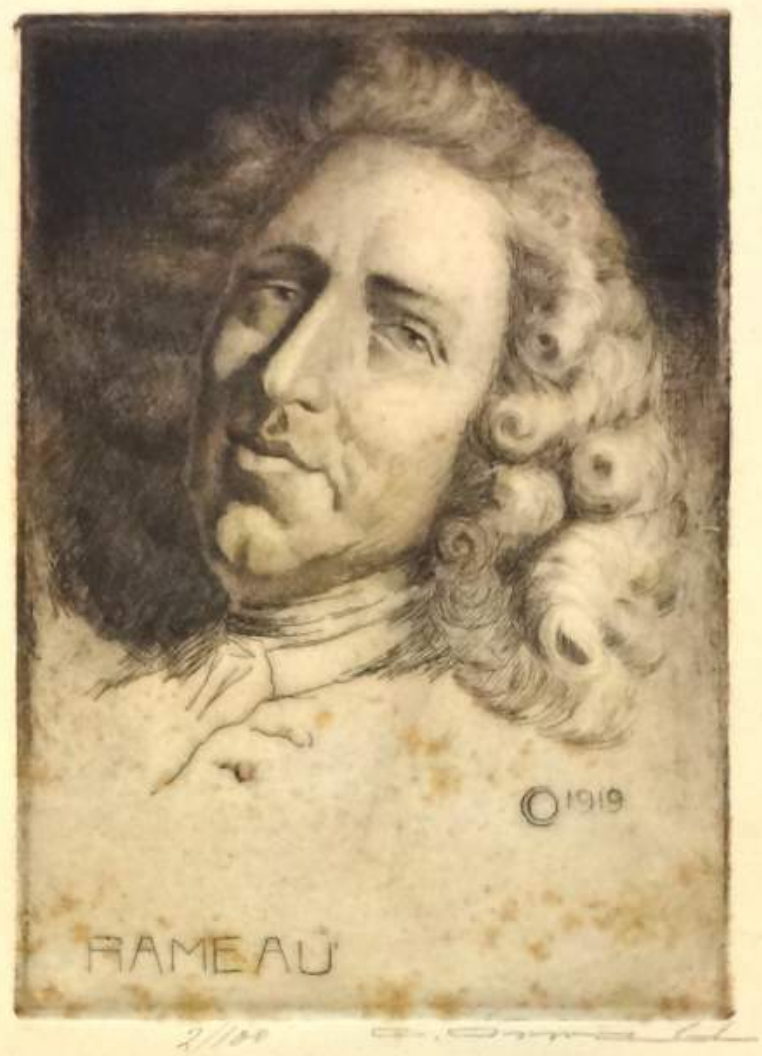

Fig. 80. A 
81. TÍTULO: Dante.

DATA: 1919. TÉCNICA: Água-forte. MEDIDAS: 27,5 x 19,5 cm (mancha); 30,3 x 21,7 cm (papel). IMPRESSÃO: em preto. ASSINATURA: monograma "CO" gravado na lateral direita da mancha, "C. Oswald" no canto inferior direito do papel. COLEÇÃO Museu Nacional de Belas Artes/IBRAM/MinC. PROVENIÊNCIA: Carlos Oswald, compra, 1963.

LITERATURA: O Jornal, RJ, 23/12/1921 (nota); A Gazeta, SP, 24/1/1923 (nota); Oswald,1957, p. 216 (ref.); Silva, 1969 (ref.); Exp. Processo de trabalho Carlos Oswald 1882-1982: Estudo e Desenhos, Solar Grandjean de Montigny, RJ, 1982, p. 44 (rep.); Exp. Carlos Oswald: o resgate de um mestre, Caixa Cultural, Brasília/Curitiba, 2011, p. 50 (rep.). 


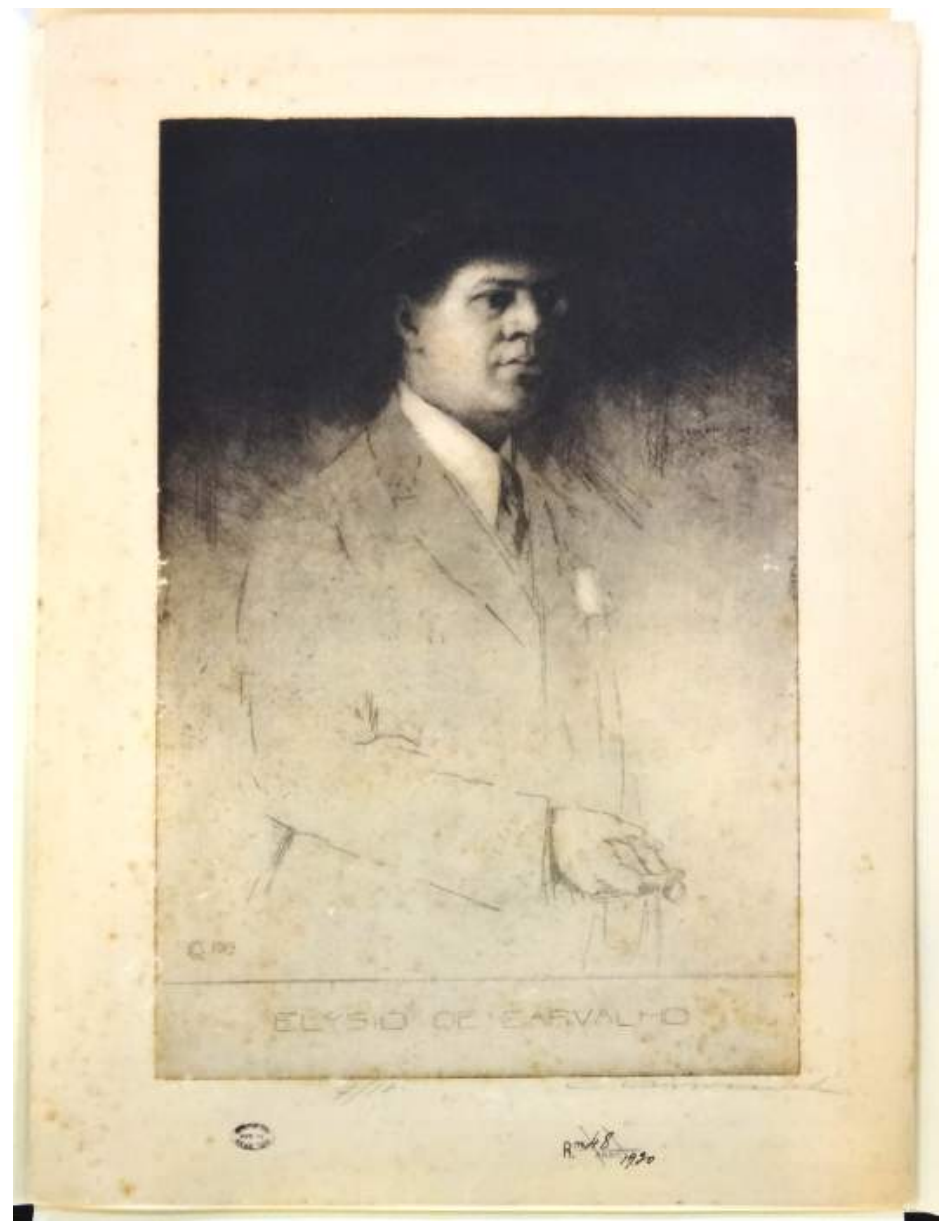

Fig. 82. A

82. TÍTULO: Elysio de Carvalho.

A. DATA: 1919. TÉCNICA: Água-forte. MEDIDAS: 29,5 X 19,5 cm (mancha), 36,6 x 26,7 cm (papel). IMPRESSÃO: em preto. MATRIZ: zinco. MEDIDAS DA MATRIZ: 30,2 x 19,7 cm. ASSINATURA: monograma "CO" gravado na lateral esquerda da mancha, "C. Oswald" no canto inferior direito do papel. ACERVO Fundação Biblioteca Nacional. PROVENIÊNCIA: registrada no acervo em 1920.

B. DATA: 1919. TÉCNICA: Água-forte. MEDIDAS: 30 X 19,2 cm (mancha), 33,8 x 21,4 cm (papel). IMPRESSÃO: em preto. MATRIZ: zinco. MEDIDAS DA MATRIZ: 30,2 x 19,7 cm. ASSINATURA: monograma "CO" gravado na lateral esquerda da mancha, "C. Oswald" no papel. COLEÇÃO Museu Nacional de Belas Artes/IBRAM/MinC. PROVENIÊNCIA: Carlos Oswald, compra, 1963.

C. [matriz] DATA: 1919. TÉCNICA: Água-forte. MATRIZ: zinco. MEDIDAS DA MATRIZ: 30,2 x 19,7 cm. ASSINATURA: monograma "CO” na lateral direita. COLEÇÃO Museu Nacional de Belas Artes/IBRAM/MinC. PROVENIÊNCIA: Maria Isabel Oswald Monteiro, doação, 1982.

LITERATURA: Illustração Brasileira, RJ, 15/8/1922, (rep.); Oswald, 1957, p. 215 (ref.); Silva, 1969 (ref.). 


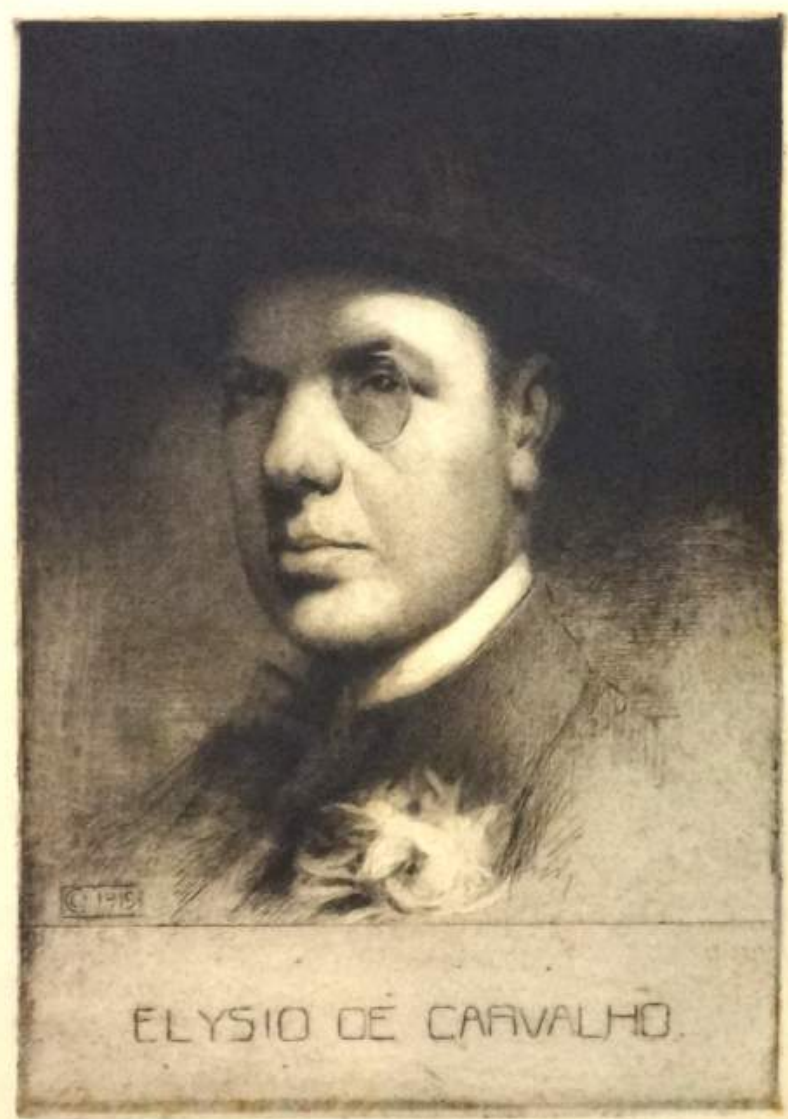

Fig. 83. A

83. TÍTULO: Elysio de Carvalho.

A. DATA: 1919. TÉCNICA: Água-forte. MEDIDAS: 27,7 X 19,5 cm (mancha), 54,5 X 36,3 cm (papel). IMPRESSÃO: em preto. ASSINATURA: monograma "CO” gravado na lateral esquerda da mancha, "C. Oswald" no canto inferior direito do papel. ACERVO Fundação Biblioteca Nacional. PROVENIÊNCIA: registrada no acervo em 1920.

B. DATA: 1919. TÉCNICA: Água-forte. MEDIDAS: 27,7 X $20 \mathrm{~cm}$ (mancha), 55,2 x 36,5 cm (papel). IMPRESSÃO: em preto. ASSINATURA: monograma “CO” gravado na lateral esquerda da mancha, "C. Oswald" no papel. COLEÇÃO Museu Nacional de Belas Artes/IBRAM/ MinC. PROVENIÊNCIA: Carlos Oswald, compra, 1963.

C. DATA: 1919. TÉCNICA: Água-forte. MEDIDAS: 27,7 X $20 \mathrm{~cm}$ (mancha), 32,5 x $25 \mathrm{~cm}$ (papel). IMPRESSÃO: em preto. ASSINATURA: "C. Oswald" embaixo no centro do papel. COLEÇÃO Museu Nacional de Belas Artes/IBRAM/MinC. PROVENIÊNCIA: Carlos Oswald, compra, 1963.

LITERATURA: Oswald, 1957, p. 215 (ref.); Silva, 1969 (ref.). 


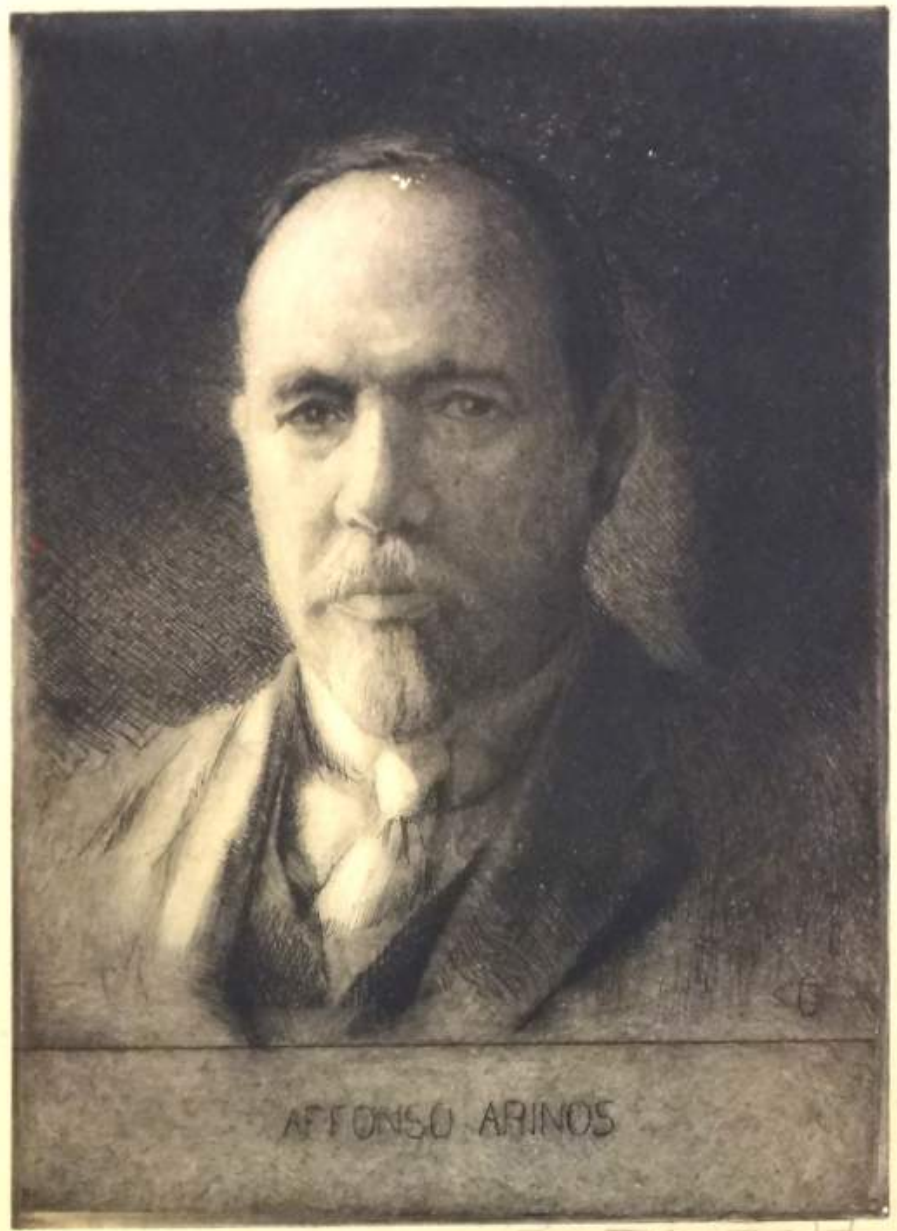

Fig. 84.A

84. TÍTULO: Affonso Arinos.

A. DATA: 1918. TÉCNICA: Água-forte. MEDIDAS: 27,9 x 19,6 cm (mancha), 39,1 x 28,5 cm (papel). IMPRESSÃO: em preto. ASSINATURA: monograma "CO” gravado na lateral direita da mancha, "C. Oswald" no canto inferior direito do papel. ACERVO Fundação Biblioteca Nacional. PROVENIÊNCIA: registrada no acervo em 1940.

B. DATA: 1919. TÉCNICA: Água-forte. MEDIDAS: 27,8 x 19,6 cm (mancha), 29,4 x 22,1 cm (papel). IMPRESSÃO: em preto. ASSINATURA: monograma "CO” gravado na lateral direita da mancha, "C. Oswald” no papel. COLEÇÃO Museu Nacional de Belas Artes/IBRAM/MinC. PROVENIÊNCIA: Carlos Oswald, compra, 1963.

C. DATA: 1919. TÉCNICA: Água-forte. MEDIDAS: 27,8 x 19,6 cm (mancha). IMPRESSÃO: em preto. ASSINATURA: monograma "CO" gravado na lateral direita da mancha, "C. Oswald" no canto inferior esquerdo do papel. COLEÇÃO Teca e Oswaldo Vergolino. FONTE: Vergolino, 2011, p. 52.

LITERATURA: Silva, 1969 (ref.); Exp. Carlos Oswald: o resgate de um mestre, Caixa Cultural, Brasília/Curitiba, 2011, p. 52 (rep.). 


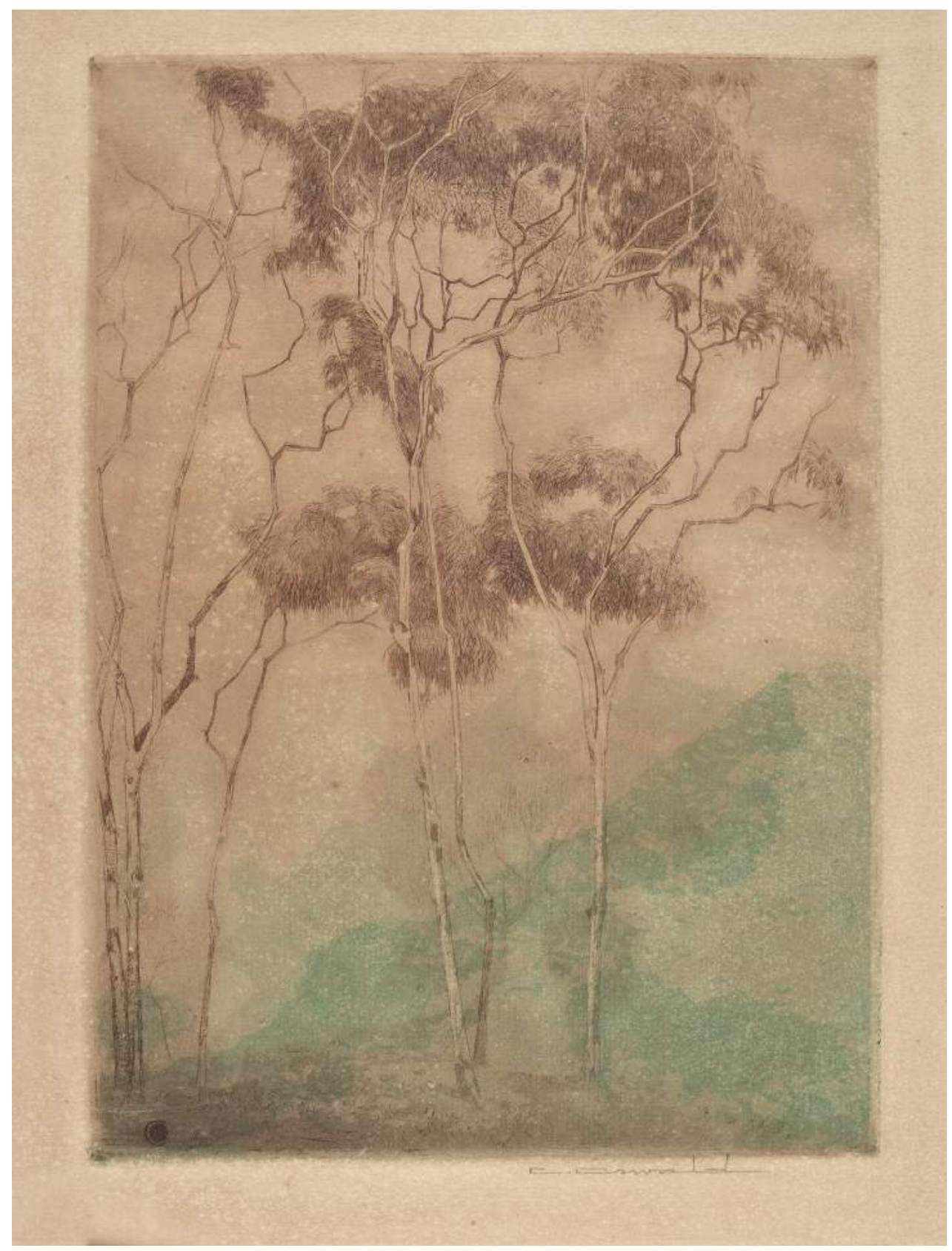

Fig. 85

85. TÍTULO: Árvore na Tijuca. VARIANTE: Troncos.

DATA: 1919. TÉCNICA: Água-forte e água-tinta. MEDIDAS: 27,9 x 19,8 cm (mancha); 47,5 x $35,7 \mathrm{~cm}$ (papel). IMPRESSÃO: em cores. ASSINATURA: monograma “CO” gravado no canto inferior esquerdo da mancha, "C. Oswald" no canto inferior direito do papel. COLEÇÃO Museu Nacional de Belas Artes/IBRAM/MinC. PROVENIÊNCIA: Carlos Oswald, compra, 1963. FOTOGRAFIA: Acervo Museu Nacional de Belas Artes/IBRAM/MinC.

LITERATURA: Silva, 1969 (ref., afirma que a gravura tem duas matrizes); Exp. Carlos Oswald: o resgate de um mestre, Caixa Cultural, Brasília/Curitiba, 2011, p. 74 (rep.). 


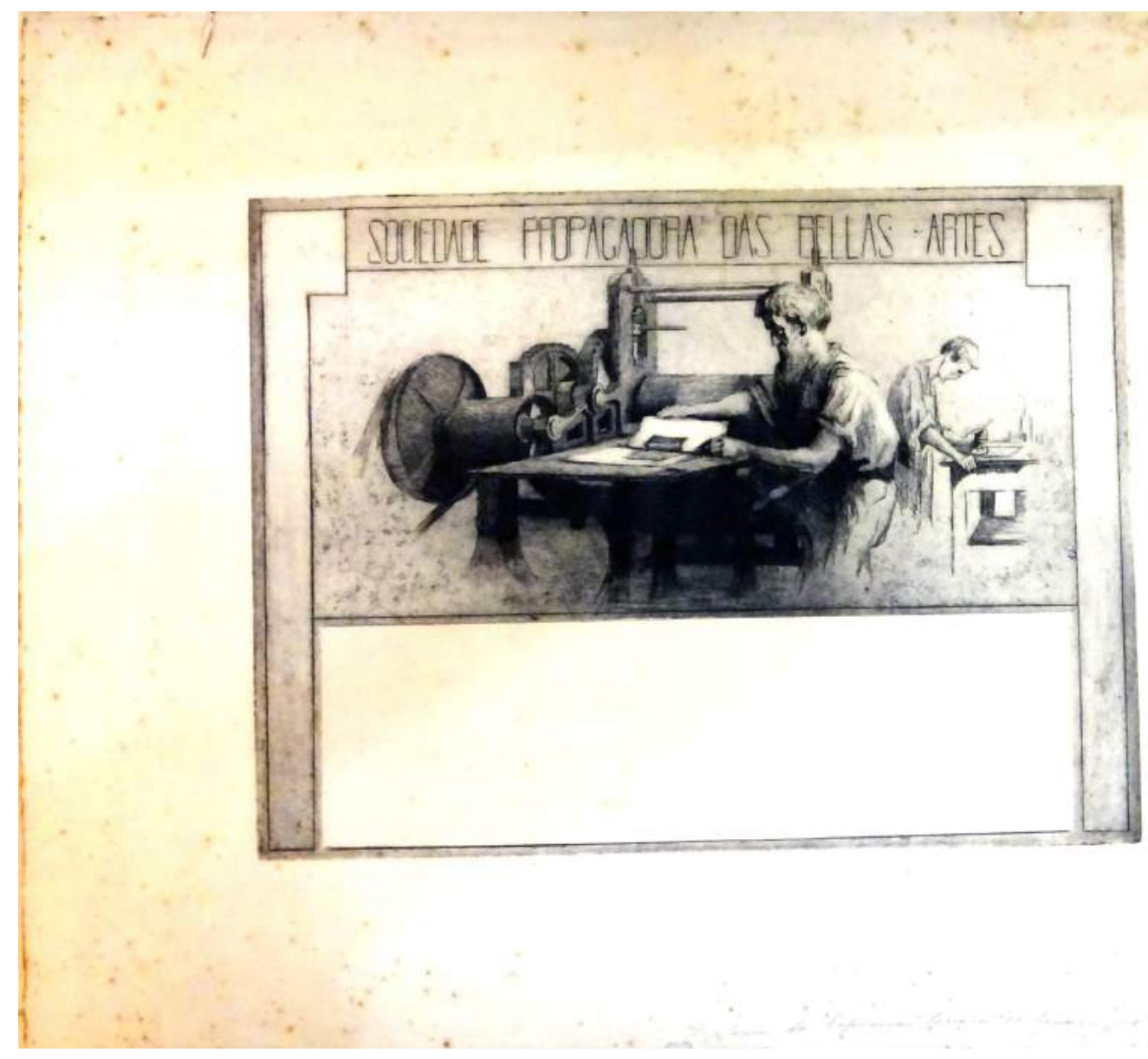

Fig. 86. A

86. TÍTULO: Sociedade Propagadora das Bellas Artes, Diploma da "Exposição de Águas-fortes".

A. DATA: 1919. TÉCNICA: Água-forte. MEDIDAS: 30 x $40 \mathrm{~cm}$ (mancha), 49,8 x $62 \mathrm{~cm}$ (papel). IMPRESSÃO: em preto. Sem assinatura. ACERVO Fundação Biblioteca Nacional. PROVENIÊNCIA: Carlos Oswald, doação, 1920.

B. DATA: 1932 [?]. TÉCNICA: Água-forte. MEDIDAS: 30,2 x 40,3 cm (mancha); 50,1 x 62,3 cm (papel). ASSINATURA: "C. Oswald" no papel. COLEÇÃO Museu Nacional de Belas Artes/IBRAM/MinC. PROVENIÊNCIA: Carlos Oswald, compra, 1963.

LITERATURA: Silva, 1969 (ref., datada 1930). 


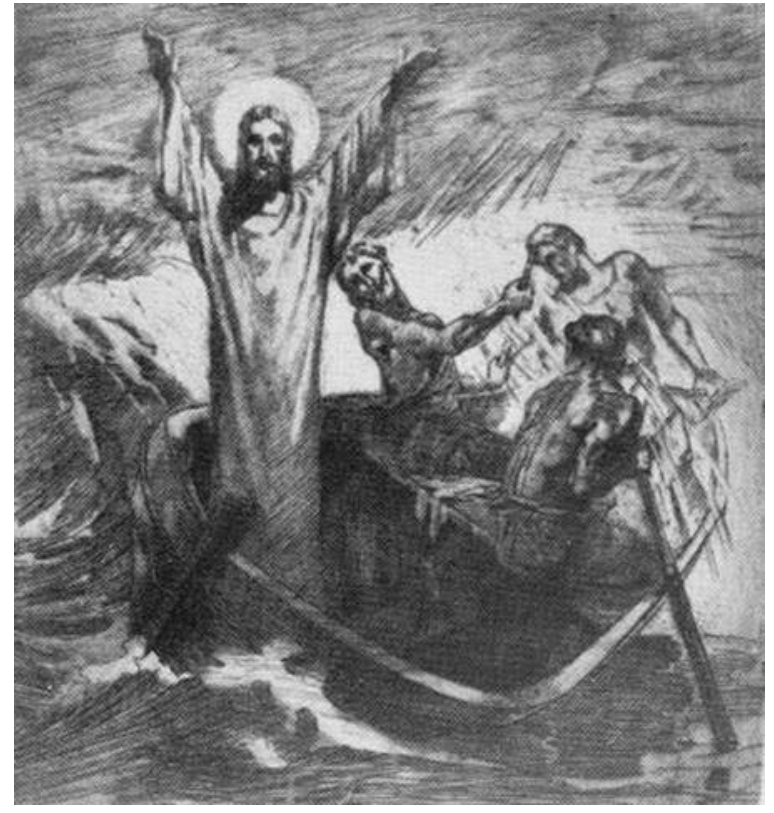

Fig. 87

87. TÍTULO: Jesus acalma a tempestade.

DATA: 1920. TÉCNICA: Água-forte. MEDIDAS: 37,5 x 35 cm (mancha); 51 x 45,5 cm (papel). IMPRESSÃO: em preto. ASSINATURA: "C. Oswald” no papel. COLEÇÃO Museu Nacional de Belas Artes/IBRAM/MinC. PROVENIÊNCIA: Carlos Oswald, compra, 1963. FOTOGRAFIA: Acervo Museu Nacional de Belas Artes/IBRAM/MinC.

LITERATURA: Oswald, 1957, p. 226 (ref., afirma que essa água-forte foi realizada a partir do quadro de mesmo título); Silva, 1969 (ref., datada 1944). 


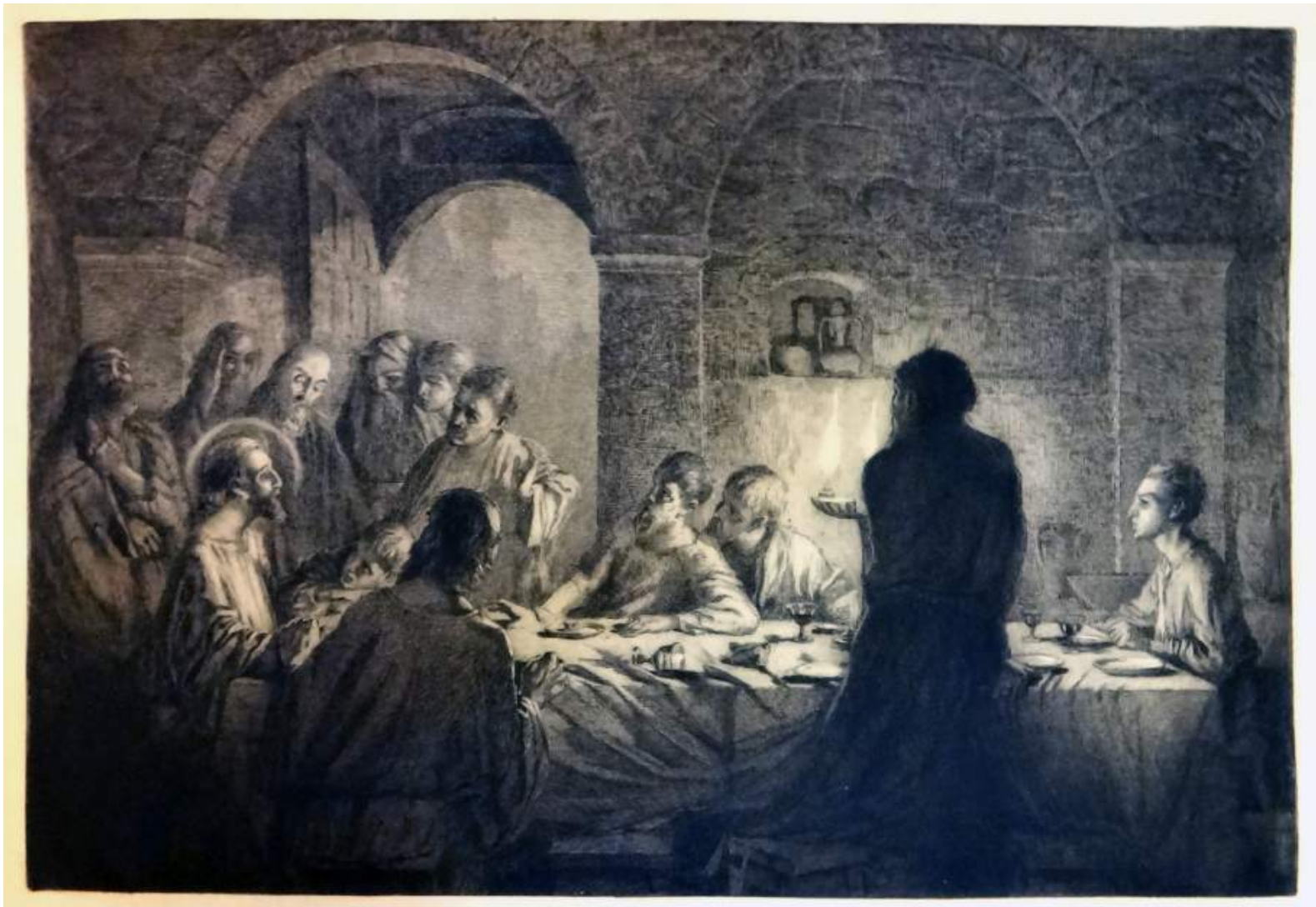

Fig. 88. A

88. TÍTULO: Última Ceia.

A. DATA: 1923[?]. TÉCNICA: Água-forte e água-tinta. MEDIDAS: 42 x $62 \mathrm{~cm}$ (mancha), 55,5 x 86,5 cm (papel). IMPRESSÃO: em preto. ASSINATURA: “C. Oswald” no canto inferior direito do papel. ACERVO Fundação Biblioteca Nacional. PROVENIÊNCIA: registrada no acervo em 1923.

B. DATA: 1923. TÉCNICA: Água-forte e água-tinta. MEDIDAS: 40 x $62 \mathrm{~cm}$ (mancha), 55 x $70 \mathrm{~cm}$ (papel). IMPRESSÃO: em marrom. ASSINATURA: "C. Oswald" no canto inferior direito do papel. COLEÇÃO Museu Nacional de Belas Artes/IBRAM/MinC. PROVENIÊNCIA: Carlos Oswald, compra, 1963.

C. [1 estado] DATA: 1923[?]. TÉCNICA: Água-forte e água-tinta. MEDIDAS: 49 x 63,5 cm (mancha), 55 x 72,5 cm (papel). IMPRESSÃO: em preto. Sem assinatura. ACERVO Fundação Biblioteca Nacional. PROVENIÊNCIA: registrada no acervo em 1923.

LITERATURA: Illustração Brasileira, RJ, 4/1924, (rep.); Mattos, Illustração Brasileira, RJ, 8/1924 (ref., artigo); Silva, 1969 (ref., datada 1923); Exp. Carlos Oswald: o resgate de um mestre, Caixa Cultural, Brasília/Curitiba, 2011, p. 66 (rep.). 


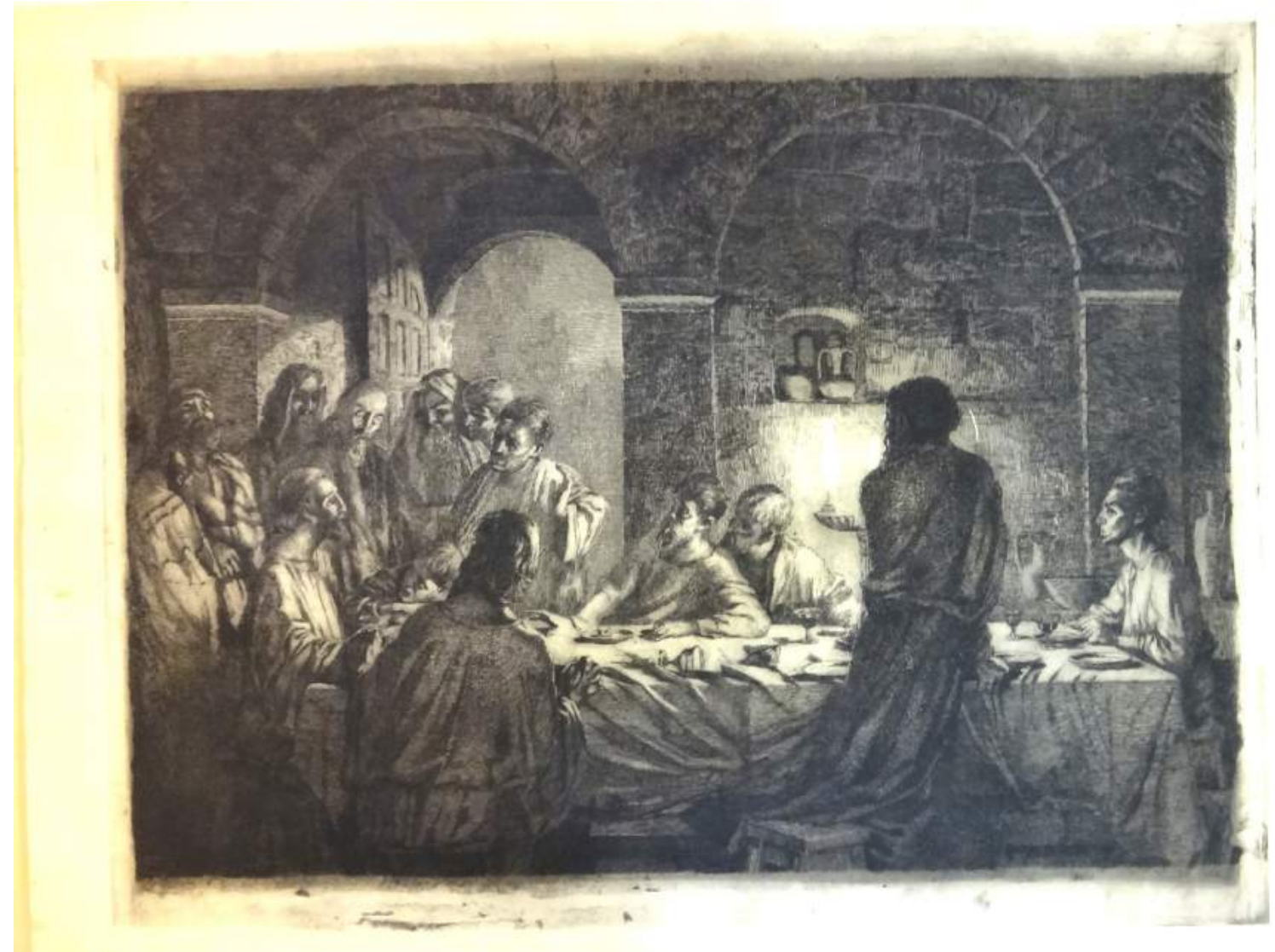

Fig. 88.C 


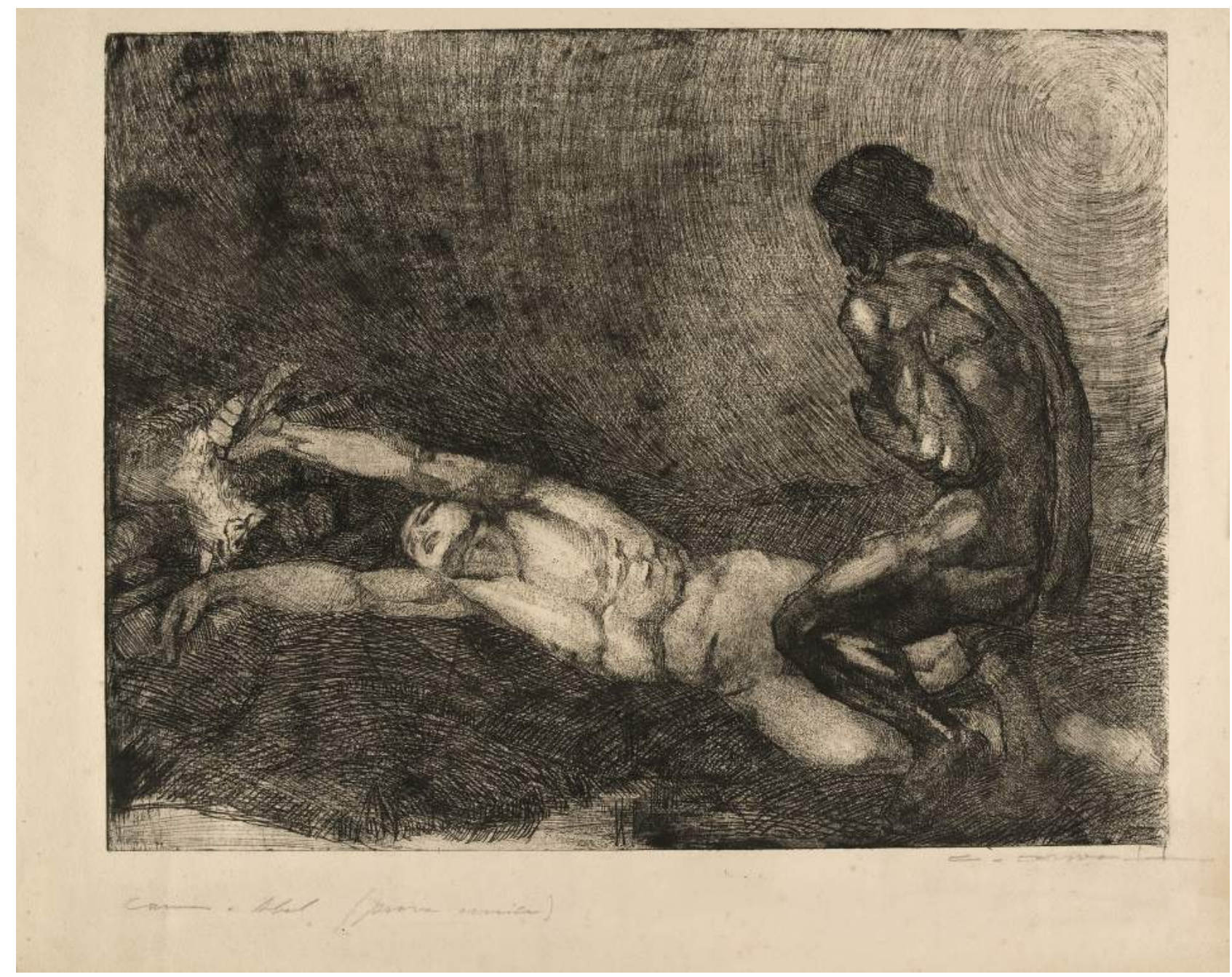

Fig. 89

89. TÍTULO: Caim e Abel.

DATA: 1925. TÉCNICA: Água-forte e água-tinta. MEDIDAS: 42,9 x 32,7 cm (mancha); 54,1 x 44,5 cm (papel). IMPRESSÃO: em preto. ASSINATURA: "C. Oswald" no canto inferior direito do papel. COLEÇÃO Museu Nacional de Belas Artes/IBRAM/MinC. PROVENIÊNCIA: Carlos Oswald, compra, 1963. FOTOGRAFIA: Acervo Museu Nacional de Belas Artes/ IBRAM/MinC.

LITERATURA: Silva, 1969 (ref.); Exp. Carlos Oswald: o resgate de um mestre, Caixa Cultural, Brasília/Curitiba, 2011, p. 67 (rep.). 


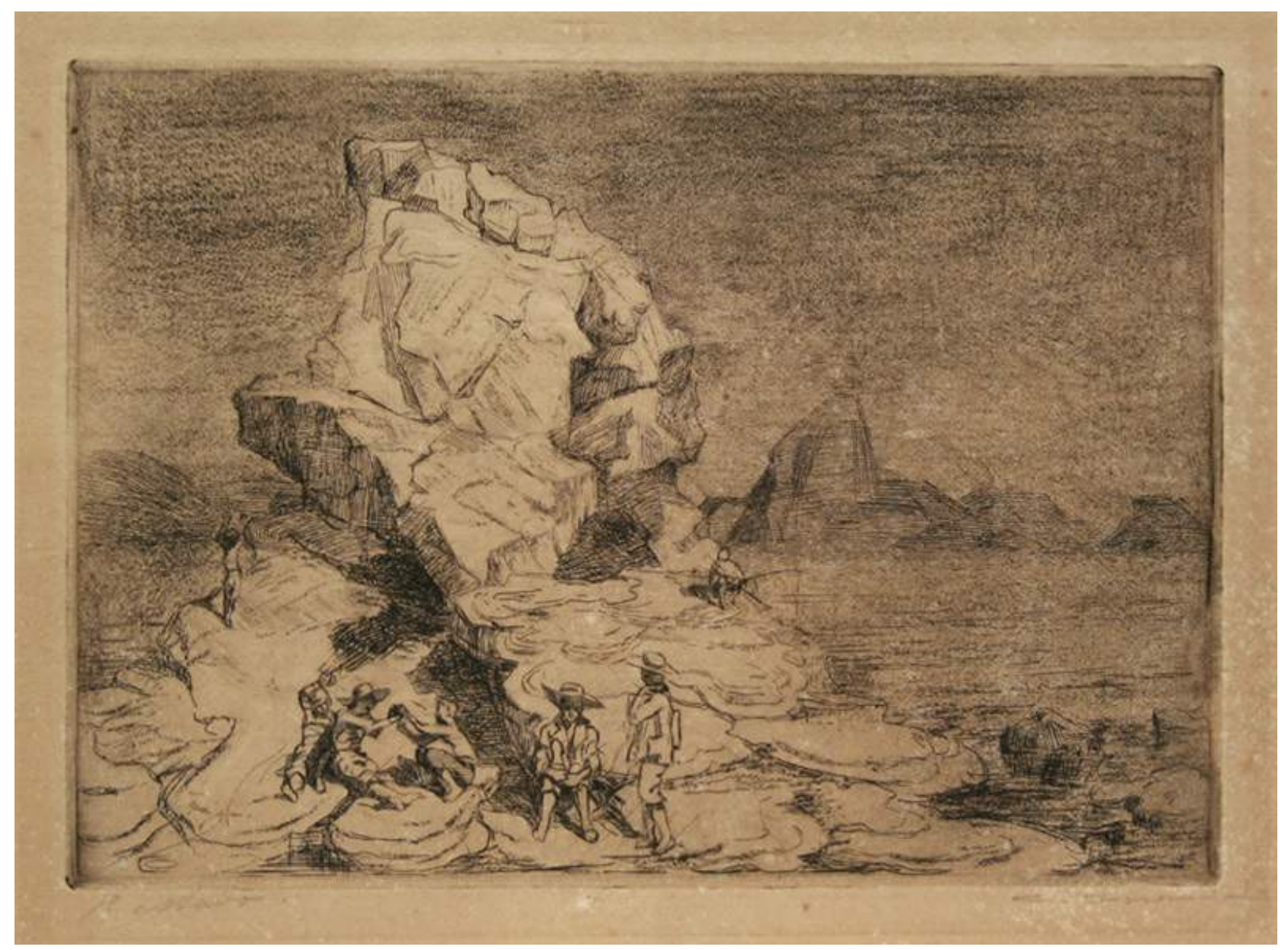

Fig. 90

90. TÍTULO: Pedra de Itapuca, Icaraí, Niterói, RJ.

DATA: 1925. TÉCNICA: Água-forte e verniz-mole. MEDIDAS: 19,8 x 28 cm (mancha); 28,7 x 39,4 cm (papel). IMPRESSÃO: em preto. ASSINATURA: monograma "CO" no canto inferior esquerdo da mancha, "C. Oswald" no canto inferior direiro do papel. COLEÇÃO Museu Nacional de Belas Artes/IBRAM/MinC. PROVENIÊNCIA: Carlos Oswald, compra, 1963. FOTOGRAFIA: Acervo Museu Nacional de Belas Artes/IBRAM/MinC.

LITERATURA: Silva, 1969 (ref.). 
91. TÍTULO: Teresópolis.

A. DATA: 1925. TÉCNICA: Água-forte, água-tinta e ponta seca. MEDIDAS: 20 x 27,3 cm (mancha); 32,5 x 50,5 cm (papel). IMPRESSÃO: em cores. MATRIZ: duas matrizes de latão. MEDIDAS DA MATRIZ: 20,2 x 28,2 cm. ASSINATURA: "C. Oswald" no canto inferior direito do papel. COLEÇÃO Museu Nacional de Belas Artes/IBRAM/MinC. PROVENIÊNCIA: Carlos Oswald, compra, 1963. FOTOGRAFIA: Acervo Museu Nacional de Belas Artes/ IBRAM/MinC.

B. DATA: 1979. TÉCNICA: Água-forte, água-tinta e ponta seca. IMPRESSÃO: póstuma, em cores, por Marcello Grassmann e Roberto Grassmann. MATRIZ: duas matrizes de latão. MEDIDAS DA MATRIZ: 20,2 x 28,2 cm. Sem assinatura. FONTE: Carlos Oswald: gravuras, Graphus, 1979.

C. [matriz] DATA: 1925. TÉCNICA: Água-forte, água-tinta. MATRIZ: latão. MEDIDAS DA MATRIZ: 20,2 x 28,2 cm. Sem assinatura. COLEÇÃO Museu Nacional de Belas Artes/ IBRAM/MinC. PROVENIÊNCIA: Maria Isabel Oswald Monteiro, doação, 1982.

D. [matriz] DATA: 1925. TÉCNICA: Água-forte, água-tinta e ponta seca. MATRIZ: latão. MEDIDAS DA MATRIZ: 20,2 x 28,2 cm. Sem assinatura. COLEÇÃO Museu Nacional de Belas Artes/IBRAM/MinC. PROVENIÊNCIA: Maria Isabel Oswald Monteiro, doação, 1983.

LITERATURA: Silva, 1969 (ref.); Artistas gravadores do Brasil, 1984, p. 19 (rep.); Buti, Letycia, 2000, p. 49 (rep.); Exp. Carlos Oswald: o resgate de um mestre, Caixa Cultural, Brasília/Curitiba, 2011, p. 80 (rep.).

92. TÍTULO: Teresópolis.

DATA: 1925. TÉCNICA: Água-forte, água-tinta e ponta seca. MEDIDAS: 19,5 x $28 \mathrm{~cm}$ (mancha); 25,7 x $34 \mathrm{~cm}$ (papel). IMPRESSÃO: em preto. MATRIZ: duas matrizes em latão. MEDIDAS DA MATRIZ: 20,2 x 28,2 cm. ASSINATURA: "C. Oswald" no papel. COLEÇÃO Museu Nacional de Belas Artes/IBRAM/MinC. PROVENIÊNCIA: José Lucas Oswald, compra, 1968.

93. TÍTULO: Teresópolis.

DATA: 1925. TÉCNICA: Água-forte e água-tinta. MEDIDAS: 19,7 x $28 \mathrm{~cm}$ (mancha); 25,7 x 32,8 cm (papel). IMPRESSÃO: em preto. MATRIZ: latão. MEDIDAS DA MATRIZ: 20,2 x $28,2 \mathrm{~cm}$. ASSINATURA: "C. Oswald" no papel. COLEÇÃO Museu Nacional de Belas Artes/ IBRAM/MinC. PROVENIÊNCIA: José Lucas Oswald, compra, 1968. FOTOGRAFIA: Acervo Museu Nacional de Belas Artes/IBRAM/MinC. 


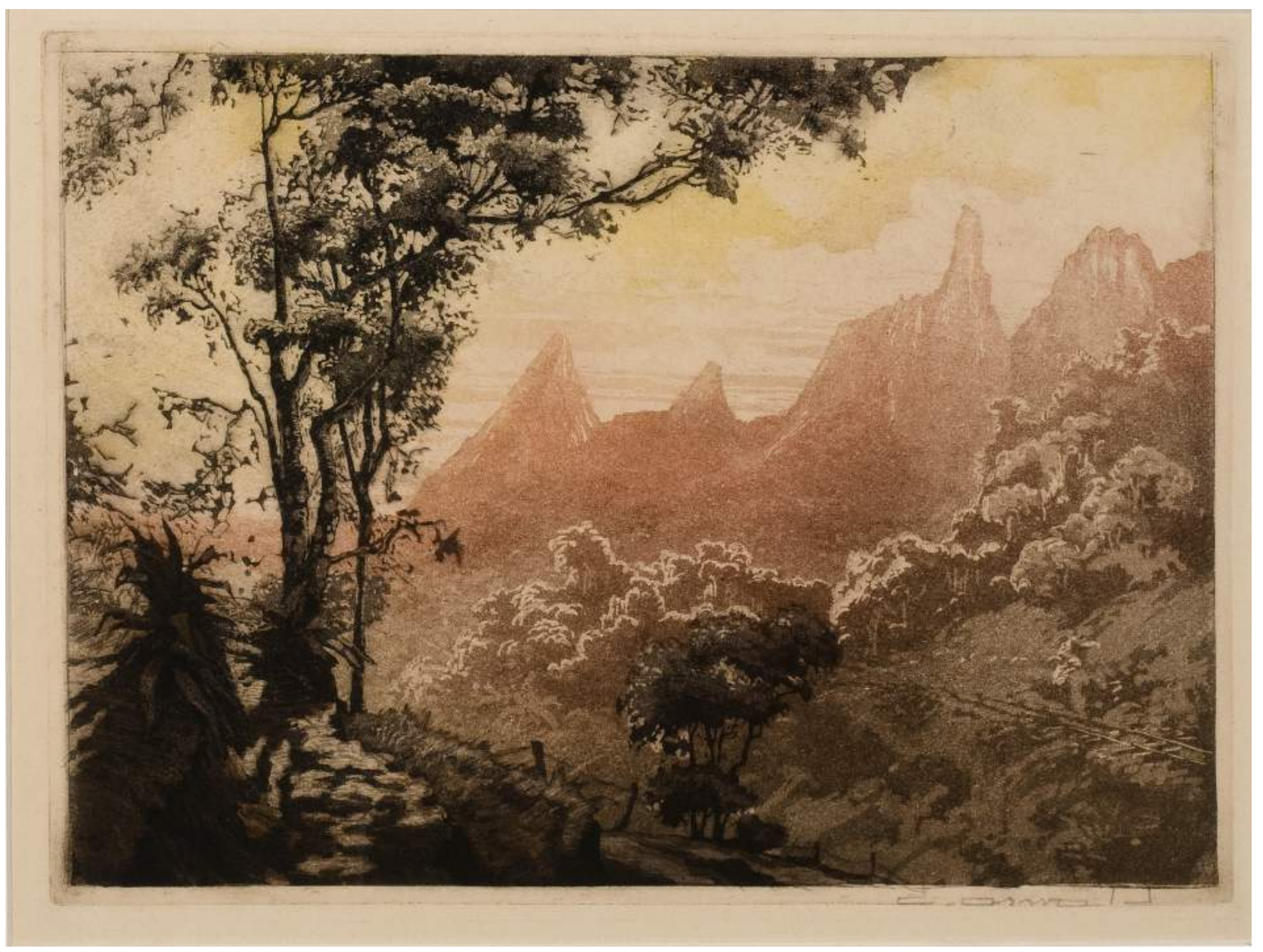

Fig. 91.A

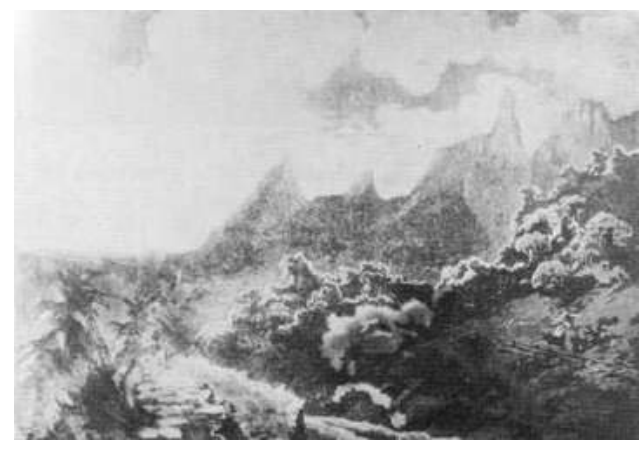

Fig. 93

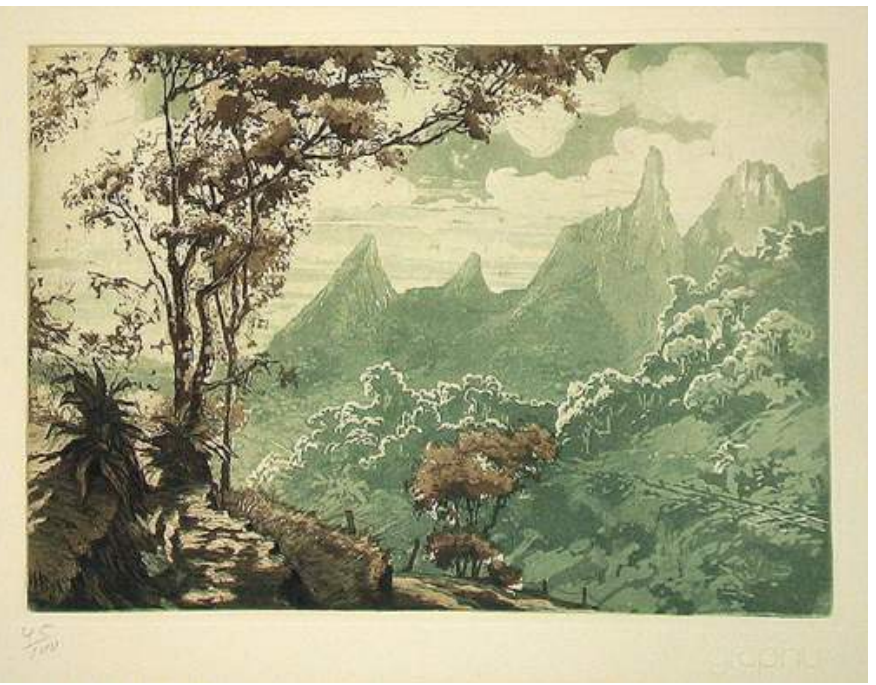

Fig. 91. B 


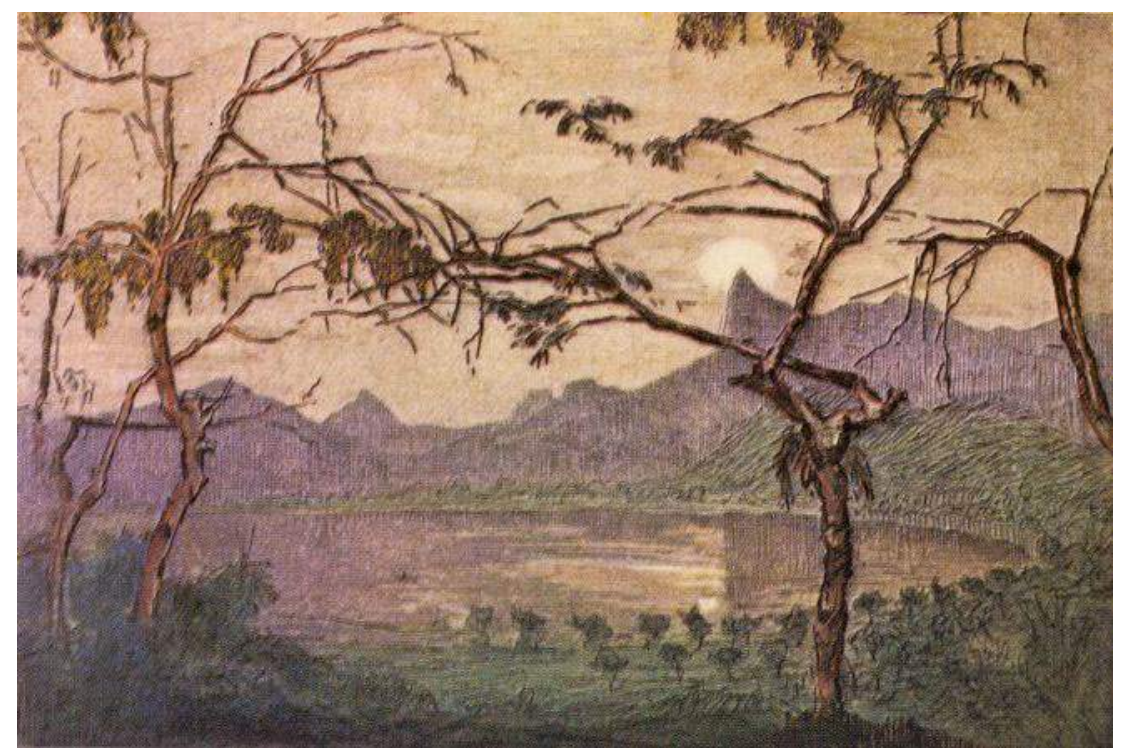

Fig. 94

94. TÍTULO: Corcovado.

DATA: 1925. TÉCNICA: Água-forte. MEDIDAS: 19,5 x 27,8 cm (mancha); 25,5 x 31,8 cm (papel). IMPRESSÃO: obra aquarelada. ASSINATURA: "C. Oswald" no canto inferior direito do papel. COLEÇÃO Museu Nacional de Belas Artes/IBRAM/MinC. PROVENIÊNCIA: Carlos Oswald, compra, 1963. FOTOGRAFIA: Acervo Museu Nacional de Belas Artes/IBRAM/ MinC.

LITERATURA: Oswald, 1957, p. 286 (ref.); Silva, 1969 (ref.); Exp. Carlos Oswald no Museu Nacional de Belas Artes, RJ, MNBA, 1982, capa (rep.). 
95. TÍTULO: Gávea. VARIANTE: Pedra da Gávea.

A. DATA: 1925. TÉCNICA: Água-forte, água-tinta e ponta seca. MEDIDAS: 27,3 x $20 \mathrm{~cm}$ (mancha); 45,9 x 32,5 cm (papel). IMPRESSÃO: em cores. MATRIZ: duas matrizes de latão. MEDIDAS DA MATRIZ: 28 x 20,1 cm. ASSINATURA: “C. Oswald” no canto inferior direito do papel. COLEÇÃO Museu Nacional de Belas Artes/IBRAM/MinC. PROVENIÊNCIA: Carlos Oswald, compra, 1963. FOTOGRAFIA: Acervo Museu Nacional de Belas Artes/IBRAM/ MinC.

B. DATA: 1979. TÉCNICA: Água-forte, água-tinta e ponta seca. IMPRESSÃO: póstuma, em cores, por Marcello Grassmann e Roberto Grassmann. MATRIZ: duas matrizes de latão. MEDIDAS DA MATRIZ: 28 x 20,1 cm. Sem assinatura. FONTE: Carlos Oswald: gravuras, Graphus, 1979.

C. [matriz] DATA: 1925. TÉCNICA: Água-forte, água-tinta e ponta seca. MATRIZ: latão. MEDIDAS DA MATRIZ: 28 x 20,1 cm. Sem assinatura. COLEÇÃO Museu Nacional de Belas Artes/IBRAM/MinC. PROVENIÊNCIA: Maria Isabel Oswald Monteiro, doação, 1982.

D. [matriz] DATA: 1925. TÉCNICA: Água-forte e água-tinta. MATRIZ: latão. MEDIDAS DA MATRIZ: 28 x 20,1 cm. Sem assinatura. COLEÇÃO Museu Nacional de Belas Artes/IBRAM/ MinC. PROVENIÊNCIA: Maria Isabel Oswald Monteiro, doação, 1983.

LITERATURA: Oswald, 1957, não p. (rep.); Silva, 1969 (ref.); Artistas gravadores do Brasil, 1984, p. 17 (rep.); Monteiro, 2000, p. 188 (rep.); Buti, Letycia, 2002, p. 55 (rep.); Exp. Carlos Oswald: o resgate de um mestre, Caixa Cultural, Brasília/Curitiba, 2011, p. 75 (rep.).

96. TÍTULO: Gávea. VARIANTE: Pedra da Gávea.

DATA: 1925. TÉCNICA: Água-forte, água-tinta e ponta seca. MEDIDAS: 27,4 x $20 \mathrm{~cm}$ (mancha); 47,6 x 32,1 cm (papel). IMPRESSÃO: em preto. MATRIZ: duas matrizes de latão. MEDIDAS DA MATRIZ: 28 x 20,1 cm. ASSINATURA: "C. Oswald” no canto inferior direito do papel. COLEÇÃO Museu Nacional de Belas Artes/IBRAM/MinC. PROVENIÊNCIA: Carlos Oswald, compra, 1963. FOTOGRAFIA: Acervo Museu Nacional de Belas Artes/IBRAM/ MinC.

97. TÍTULO: Gávea. VARIANTE: Pedra da Gávea.

DATA: 1925. TÉCNICA: Água-forte, água-tinta e ponta seca. MEDIDAS: 26,5 x $18 \mathrm{~cm}$ (mancha); 35 x 26 cm (papel). IMPRESSÃO: em cores. MATRIZ: duas matrizes de latão. MEDIDAS DA MATRIZ: 28 x 20,1 cm. ASSINATURA: “C. Oswald” no canto inferior direito do papel. COLEÇÃO particular. FONTE: Evandro Carneiro Leiloeiro, disponível em: <http://www. evandrocarneiroleiloes.com/145675 ?artistId=88060 > , acesso em 13/8/2017. 

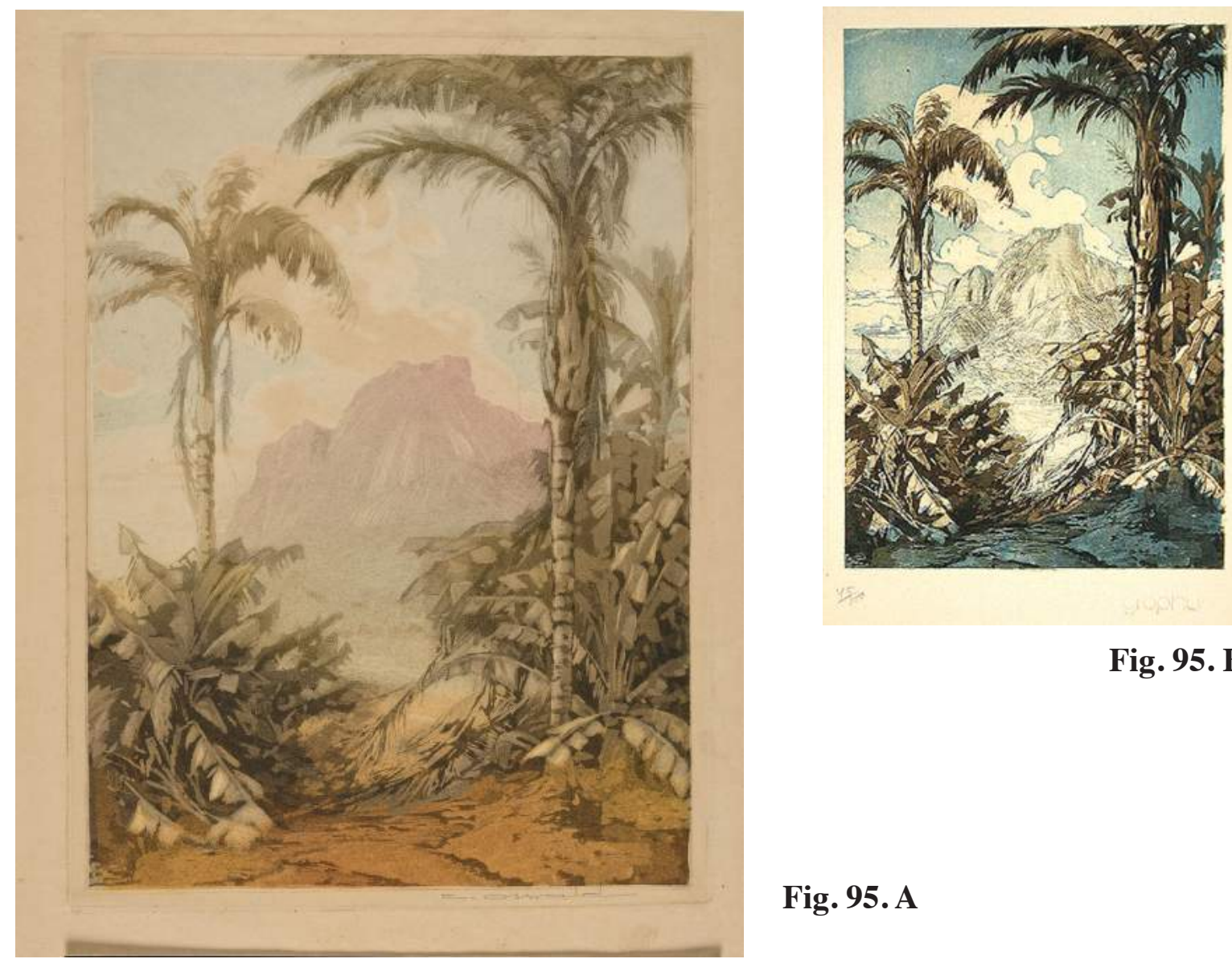

Fig. 95. B

Fig. 95. A

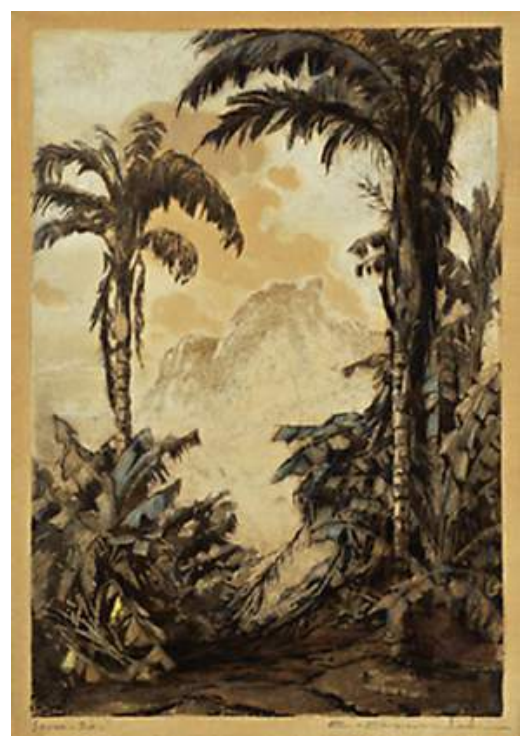

Fig. 97

Fig. 96

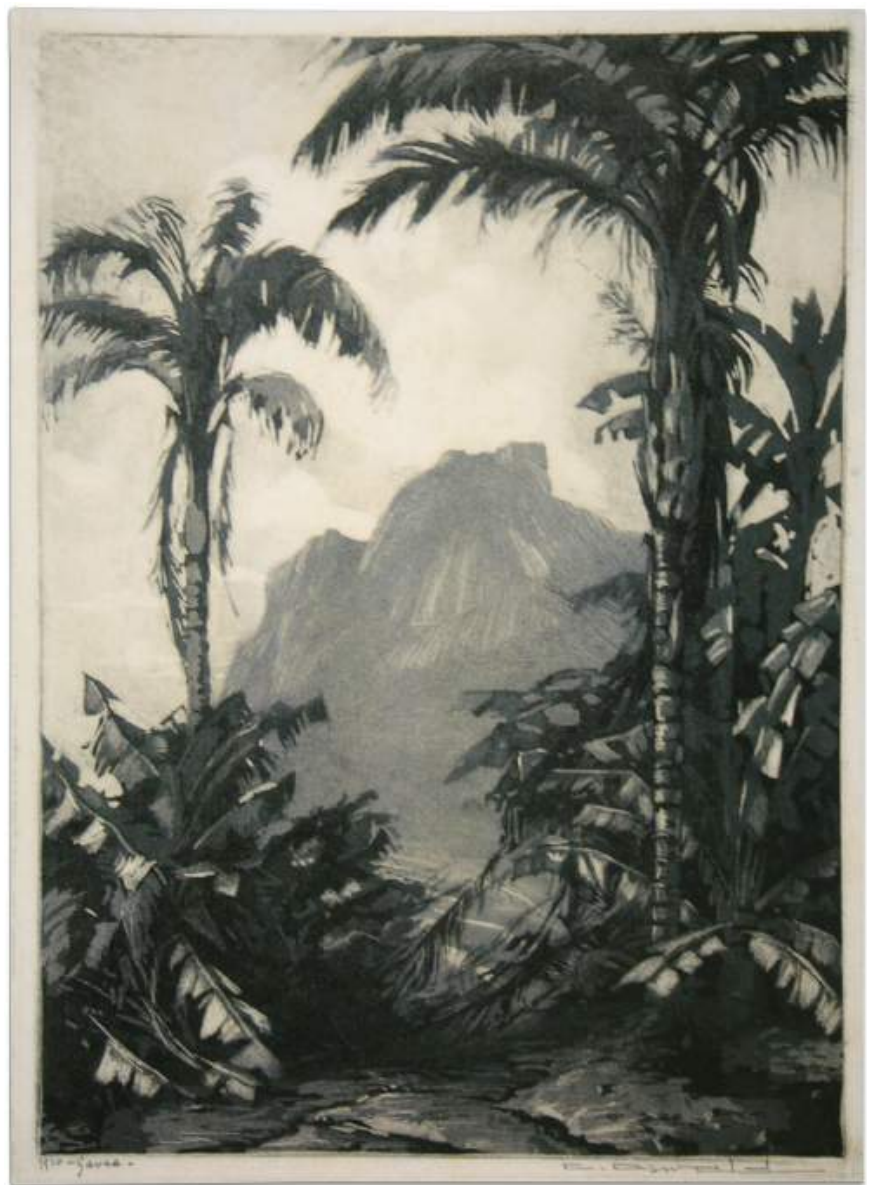




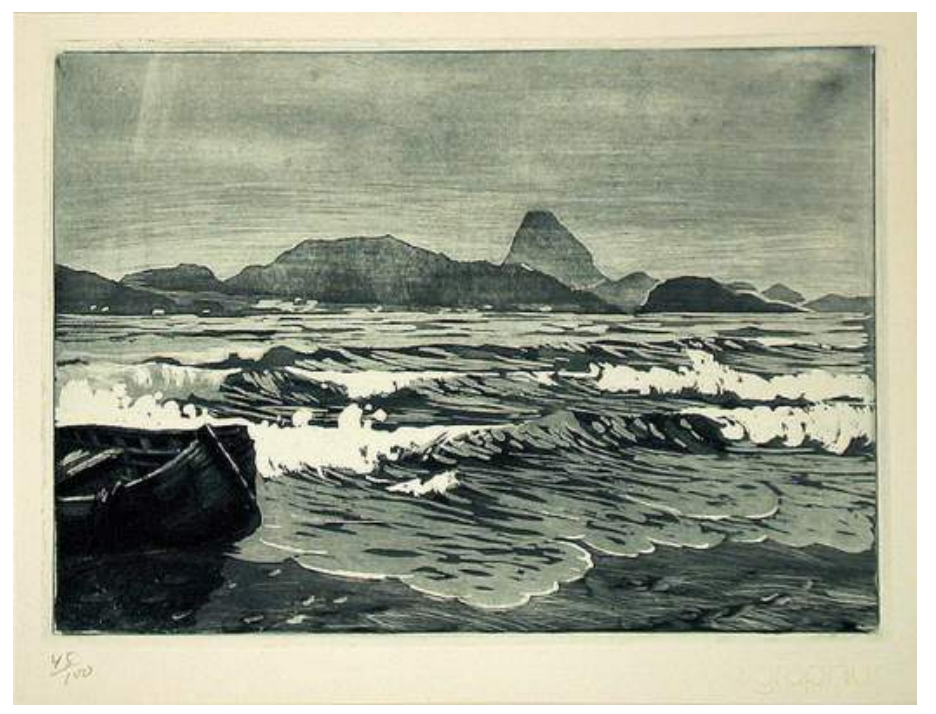

Fig. 98.B

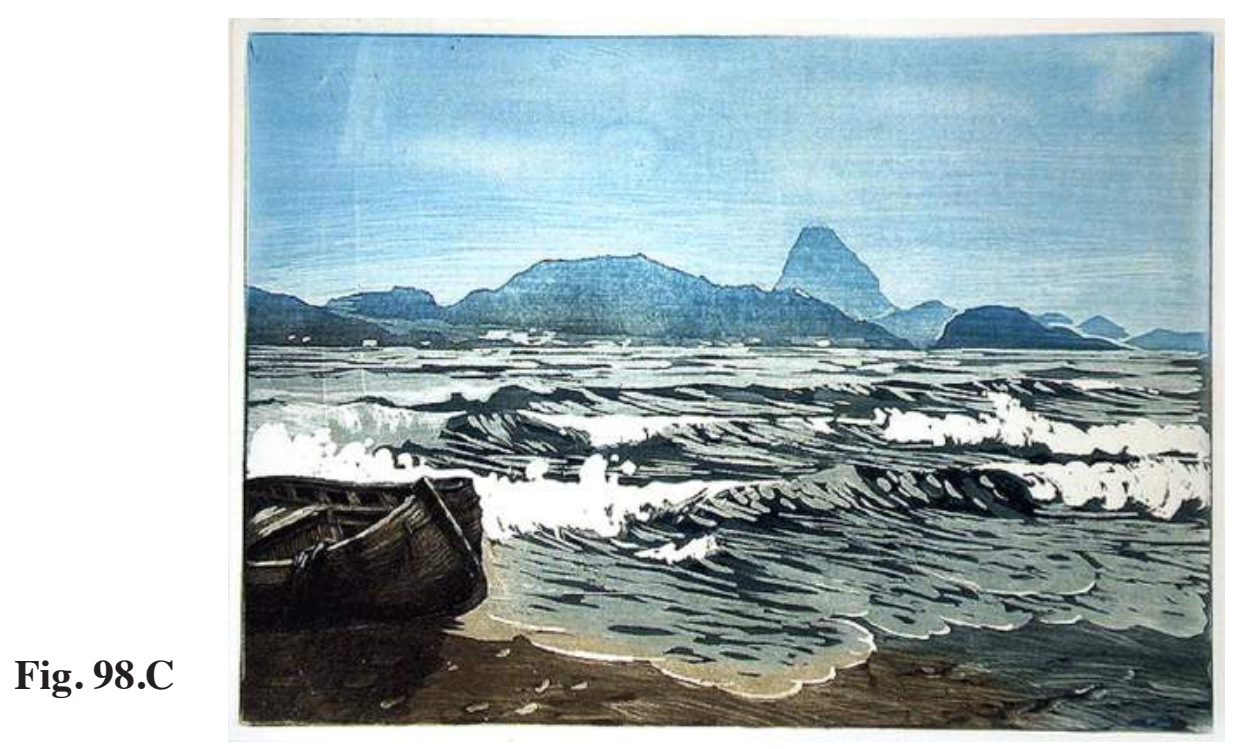

98. TÍTULO: Praia de Botafogo.

A. [matriz] DATA: 1925. TÉCNICA: Água-forte e água-tinta. MATRIZ: latão. MEDIDAS DA MATRIZ: 20,2 x $28 \mathrm{~cm}$. Sem assinatura. COLEÇÃO Museu Nacional de Belas Artes/IBRAM/ MinC. PROVENIÊNCIA: Maria Isabel Oswald Monteiro, doação, 1982.

B. DATA: 1979. TÉCNICA: Água-forte, água-tinta. IMPRESSÃO: póstuma, em preto azulado, por Marcello Grassmann e Roberto Grassmann. MATRIZ: latão. MEDIDAS DA MATRIZ: 20,2 x 28 cm. Sem assinatura. FONTE: Carlos Oswald: gravuras, Graphus, 1979.

C. DATA: 1979. TÉCNICA: Água-forte, água-tinta. IMPRESSÃO: póstuma, em cores, por Marcello Grassmann e Roberto Grassmann. MATRIZ: latão. MEDIDAS DA MATRIZ: 20,2 x $28 \mathrm{~cm}$. Sem assinatura. FONTE: Carlos Oswald: gravuras, Graphus, 1979.

LITERATURA: Silva, 1969 (ref.); Buti, Letycia, 2002, p. 47 (rep.). 


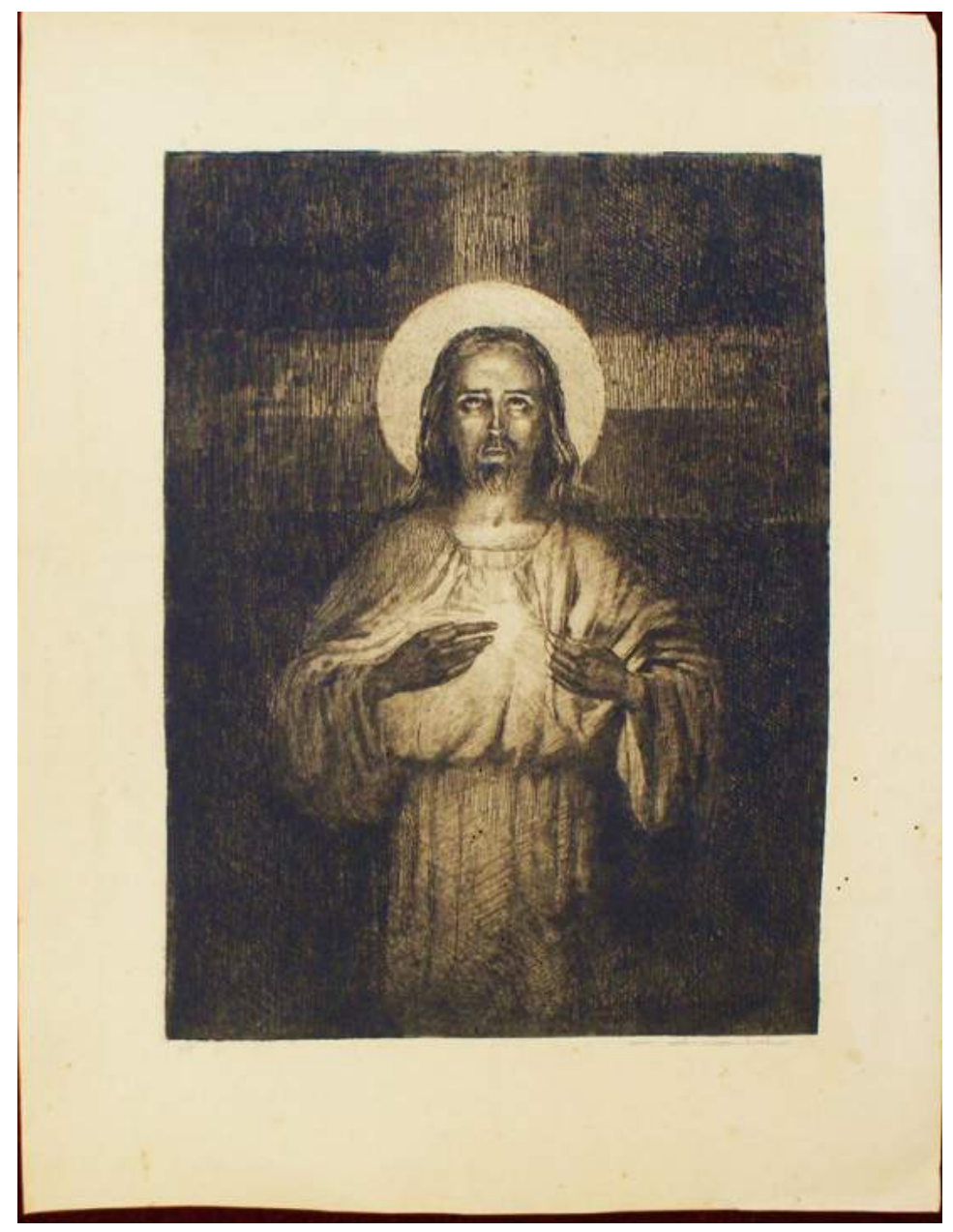

Fig. 99.B

99. TÍTULO: Sagrado coração de Jesus.

A. DATA: 1925. TÉCNICA: Água-forte e água-tinta. MEDIDAS: 39 x 28,1 cm (mancha); 56 x 34,5 cm (papel). IMPRESSÃO: em preto. MATRIZ: zinco. MEDIDAS DA MATRIZ: 39,6 x 29,7 cm. ASSINATURA: "C. Oswald" no canto inferior direito do papel. COLEÇÃO Museu Nacional de Belas Artes/IBRAM/MinC. PROVENIÊNCIA: Carlos Oswald, compra, 1963. FONTE: Museu Nacional de Belas Artes.

B. DATA: 1925. TÉCNICA: Água-forte e água-tinta. IMPRESSÃO: em cores. MATRIZ: zinco. MEDIDAS DA MATRIZ: 39,6 x 29,7 cm. ASSINATURA: "C. Oswald" no canto inferior direito do papel. COLEÇÃO Família Oswald.

C. [matriz] DATA: 1925. TÉCNICA: Água-forte e água-tinta. MATRIZ: zinco. MEDIDAS DA MATRIZ: 39,6 x 29,7 cm. Sem assinatura.. COLEÇÃO Museu Nacional de Belas Artes/ IBRAM/MinC. PROVENIÊNCIA: Maria Isabel Oswald Monteiro, doação, 1982. FONTE: Museu Nacional de Belas Artes.

LITERATURA: Silva, 1969 (ref.). 

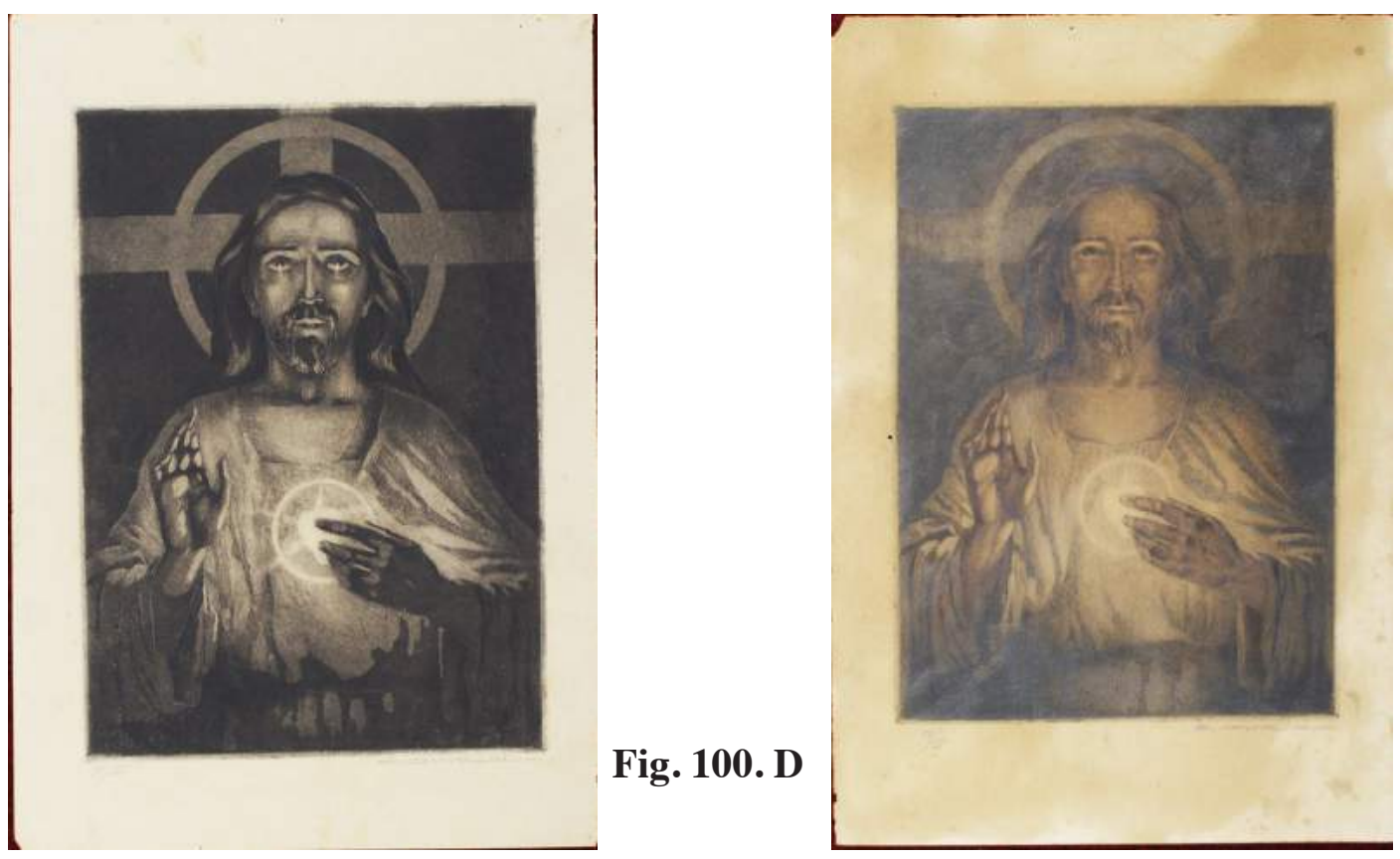

Fig. 101

100. TÍTULO: Sagrado coração de Jesus.

A. DATA: 1925. TÉCNICA: Água-forte e água-tinta. MEDIDAS: 27,4 x $22 \mathrm{~cm}$ (mancha), 36,4 x 25,5 cm (papel). IMPRESSÃO: em preto. ASSINATURA: "C. Oswald" no papel, "C.Oswald" gravado embaixo no centro da mancha. COLEÇÃO Museu Nacional de Belas Artes/ IBRAM/MinC. PROVENIÊNCIA: Carlos Oswald, compra, 1963.

B. DATA: 1925. TÉCNICA: Água-forte e água-tinta. MEDIDAS: 27,2 x 20 cm (mancha), 36,4 x 25,5 cm (papel). IMPRESSÃO: em preto. ASSINATURA: "C. Oswald” no canto inferior direito do papel, "C. Oswald” gravado embaixo no centro da mancha. COLEÇÃO Museu Nacional de Belas Artes/IBRAM/MinC. PROVENIÊNCIA: Carlos Oswald, compra, 1963. FONTE: Museu Nacional de Belas Artes.

C. DATA: 1925. TÉCNICA: Água-forte e água-tinta. MEDIDAS: 27,2 x $20 \mathrm{~cm}$ (mancha). IMPRESSÃO: em preto. ASSINATURA: "C. Oswald" no canto inferior direito do papel. COLEÇÃO Teca e Oswaldo Vergolino. FONTE: Vergolino, 2011, p. 62.

D. DATA: 1925. TÉCNICA: Água-forte e água-tinta. IMPRESSÃO: em preto. ASSINATURA: "C. Oswald" no canto inferior direito do papel. COLEÇÃO Família Oswald.

LITERATURA: Exp. Carlos Oswald: o resgate de um mestre, Caixa Cultural, Brasília/Curitiba, 2011, p. 62 (rep.).

101. TÍTULO: Sagrado coração de Jesus.

DATA: 1925. TÉCNICA: Água-forte e água-tinta. IMPRESSÃO: em cores. ASSINATURA: "C. Oswald" no canto inferior direito do papel, "C. Oswald" embaixo no centro da mancha. COLEÇÃO Família Oswald. 
102. TÍTULO: Adoração ao Menino Jesus.

[matriz] DATA: 1925. TÉCNICAS: Água-forte e água-tinta. MATRIZ: zinco. MEDIDAS DA MATRIZ: 22,7 x 32,4 cm. Sem assinatura. COLEÇÃO Museu Nacional de Belas Artes/ IBRAM/MinC. PROVENIÊNCIA: Maria Isabel Oswald Monteiro, doação, 1982. FONTE: Museu Nacional de Belas Artes.

103. TÍTULOS: Velhas Figueiras; Figueiras.

A. DATA: 1930. TÉCNICA: Água-forte. MEDIDAS: 29,2x 39,5cm (mancha). IMPRESSÃO: em preto. MATRIZ: zinco. MEDIDAS DA MATRIZ: 30 x 39,8 cm. ASSINATURA: "C. Oswald" no canto inferior direito do papel. ACERVO Fundação Biblioteca Nacional. PROVENIÊNCIA: registrada no acervo em 1974.

B. DATA: 1979. TÉCNICA: Água-forte. IMPRESSÃO: póstuma, em preto, por Marcello Grassmann e Roberto Grassmann. MATRIZ: zinco. MEDIDAS DA MATRIZ: 30 x 39,8 cm. Sem assinatura. FONTE: Carlos Oswald: gravuras, Graphus, 1979.

C. [matriz] DATA: 1930. TÉCNICA: Água-forte. MATRIZ: zinco. MEDIDAS DA MATRIZ: 30 x 39,8 cm. Sem assinatura. COLEÇÃO Museu Nacional de Belas Artes/IBRAM/MinC. PROVENIÊNCIA: Maria Isabel Oswald Monteiro, doação, 1982.

LITERATURA: Silva, 1969 (ref.); Buti, Letycia, 2002, p. 57 (rep.).

104. TÍTULOS: Velhas Figueiras; Figueiras.

DATA: 1930. TÉCNICA: Água-forte. MEDIDAS: 29,8 x 39,3 cm (mancha); 35 x 42,7 cm (papel). IMPRESSÃO: em preto, cópia aquarelada. MATRIZ: zinco. MEDIDAS DA MATRIZ: 30 x 39,8 cm. ASSINATURA: “C. Oswald” no canto inferior direito do papel. COLEÇÃO Museu Nacional de Belas Artes/IBRAM/MinC. PROVENIÊNCIA: Carlos Oswald, compra, 1963. FOTOGRAFIA: Acervo Museu Nacional de Belas Artes/IBRAM/MinC.

LITERATURA: Silva, 1969 (ref.); Exp. Carlos Oswald: o resgate de um mestre, Caixa Cultural, Brasília/Curitiba, 2011, p. 76 (rep.). 


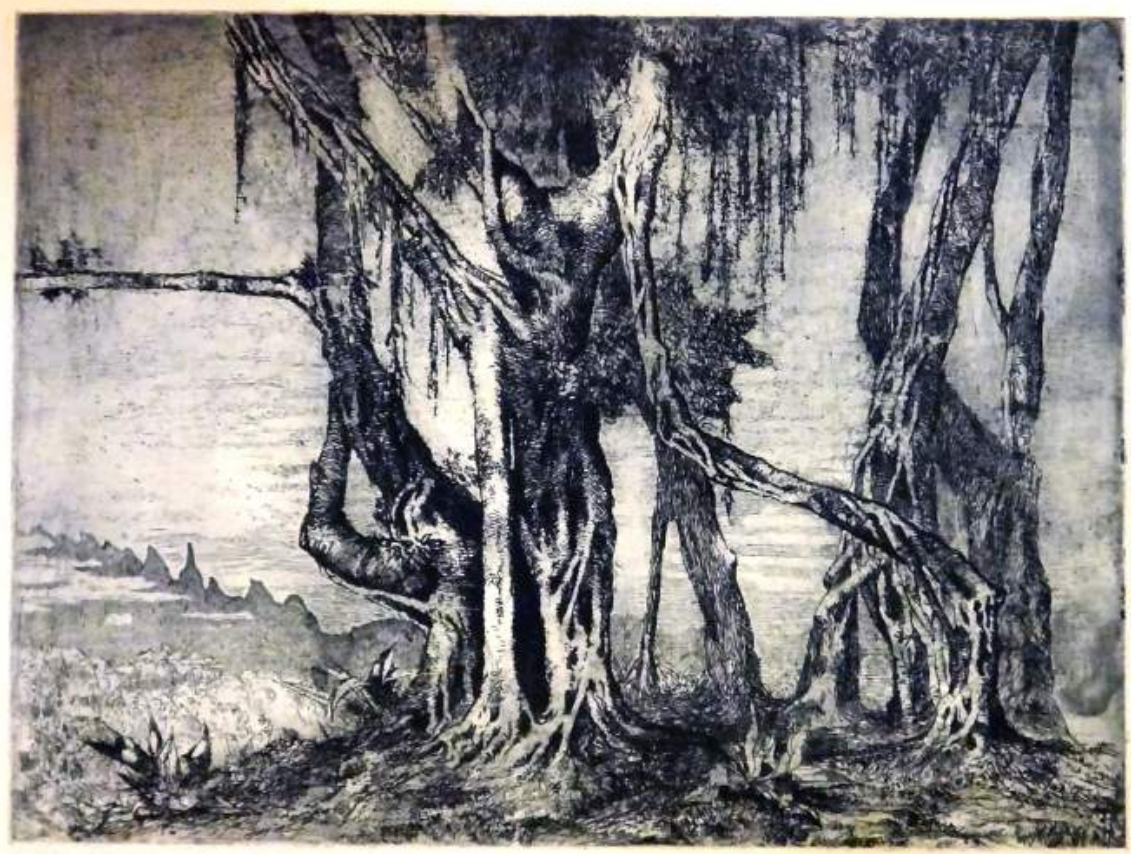

Fig. 103. A

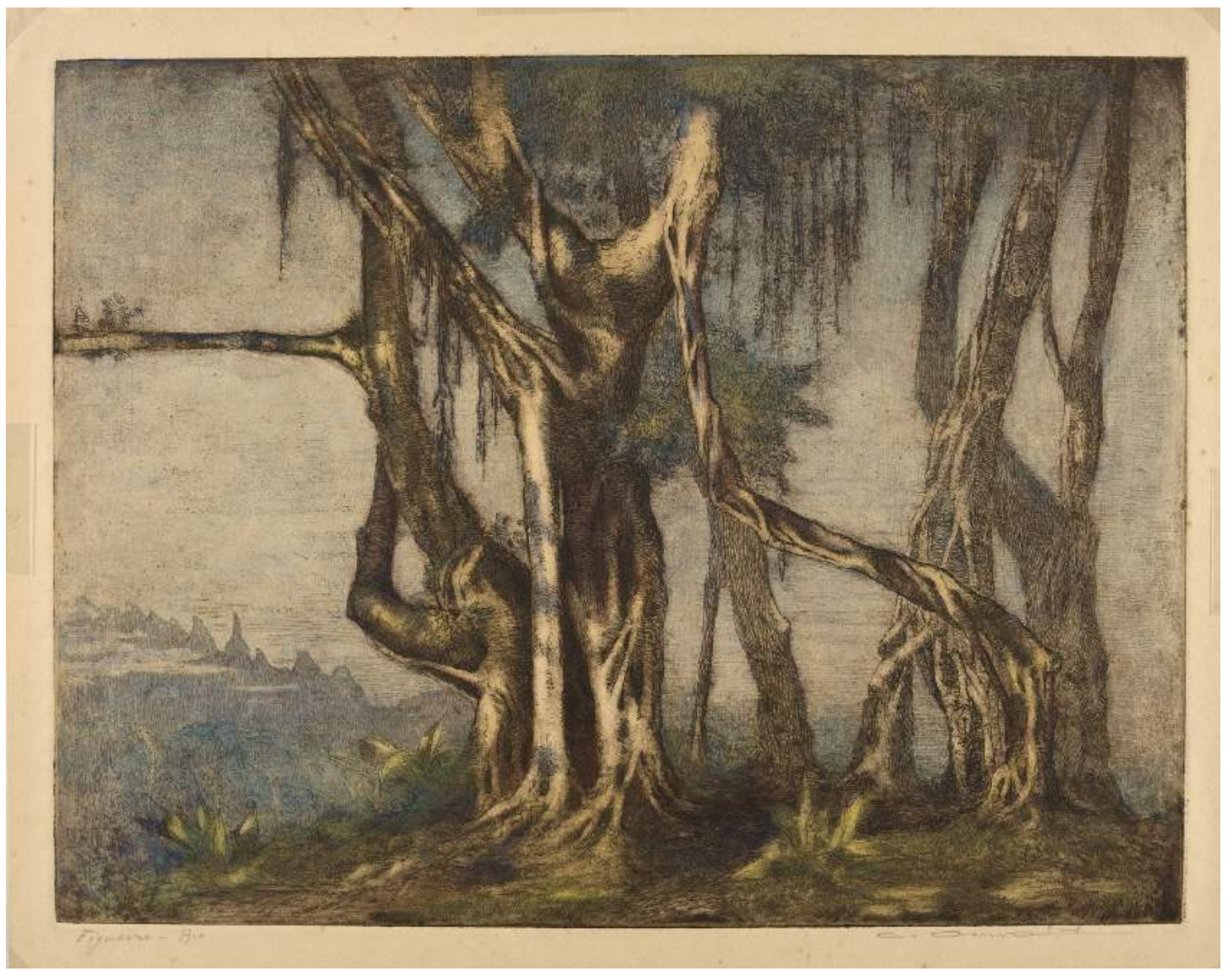

Fig. 104 


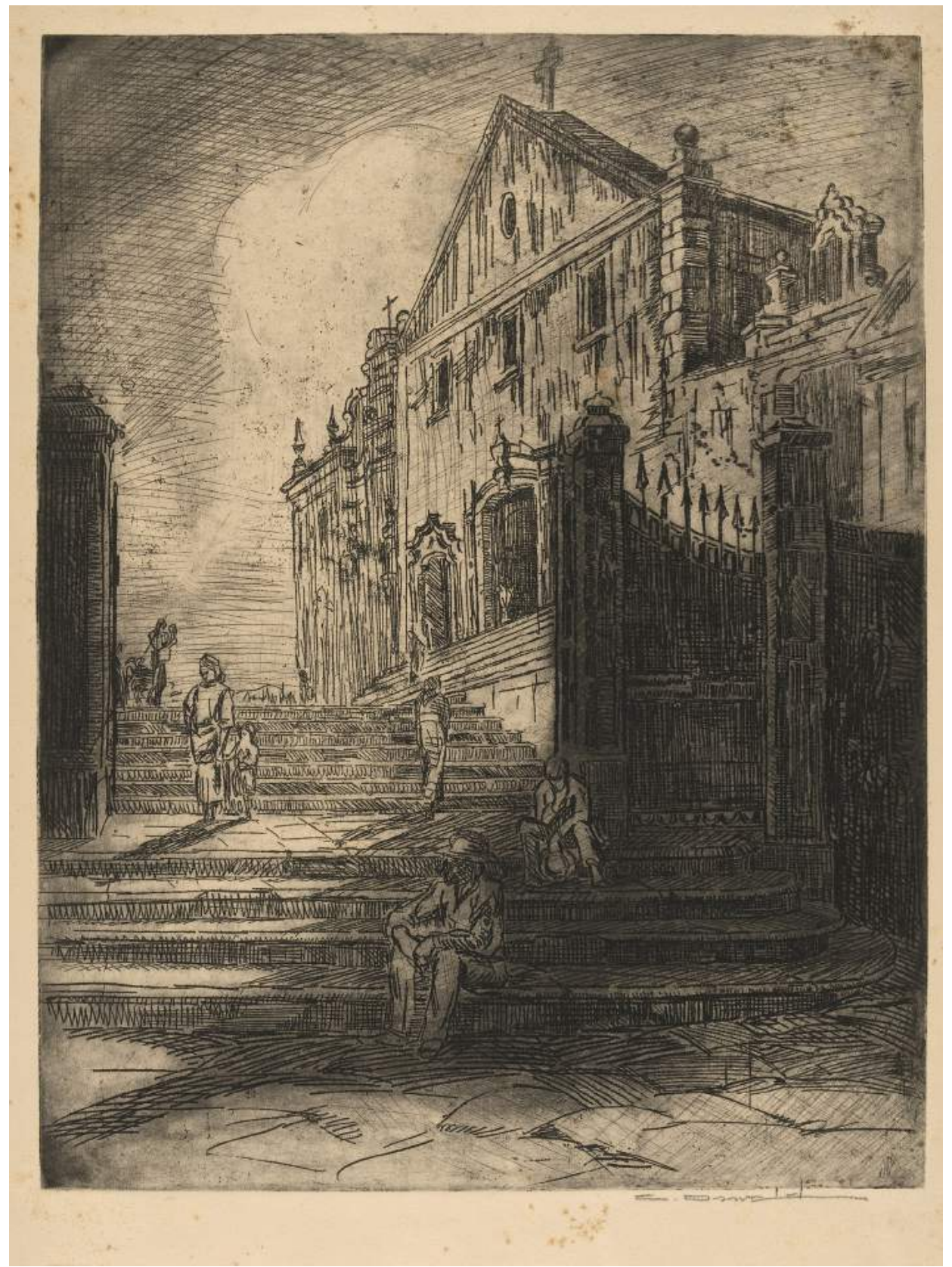

Fig. 105

105. TÍTULO: Fachada da Igreja de Santo Antônio.

DATA: 1930. TÉCNICA: Água-forte. MEDIDAS: 43 x 32,3 cm (mancha), 57,5 x 39,6 cm (papel). IMPRESSÃO: em preto. ASSINATURA: "C. Oswald” no canto inferior direito do suporte. COLEÇÃO Museu Nacional de Belas Artes/IBRAM/MinC. PROVENIÊNCIA: Carlos Oswald, compra, 1963. FOTOGRAFIA: Acervo Museu Nacional de Belas Artes/IBRAM/MinC.

LITERATURA: Silva, 1969 (ref.); Exp. Carlos Oswald: o resgate de um mestre, Caixa Cultural, Brasília/Curitiba, 2011, p. 68 - 69 (rep.). 


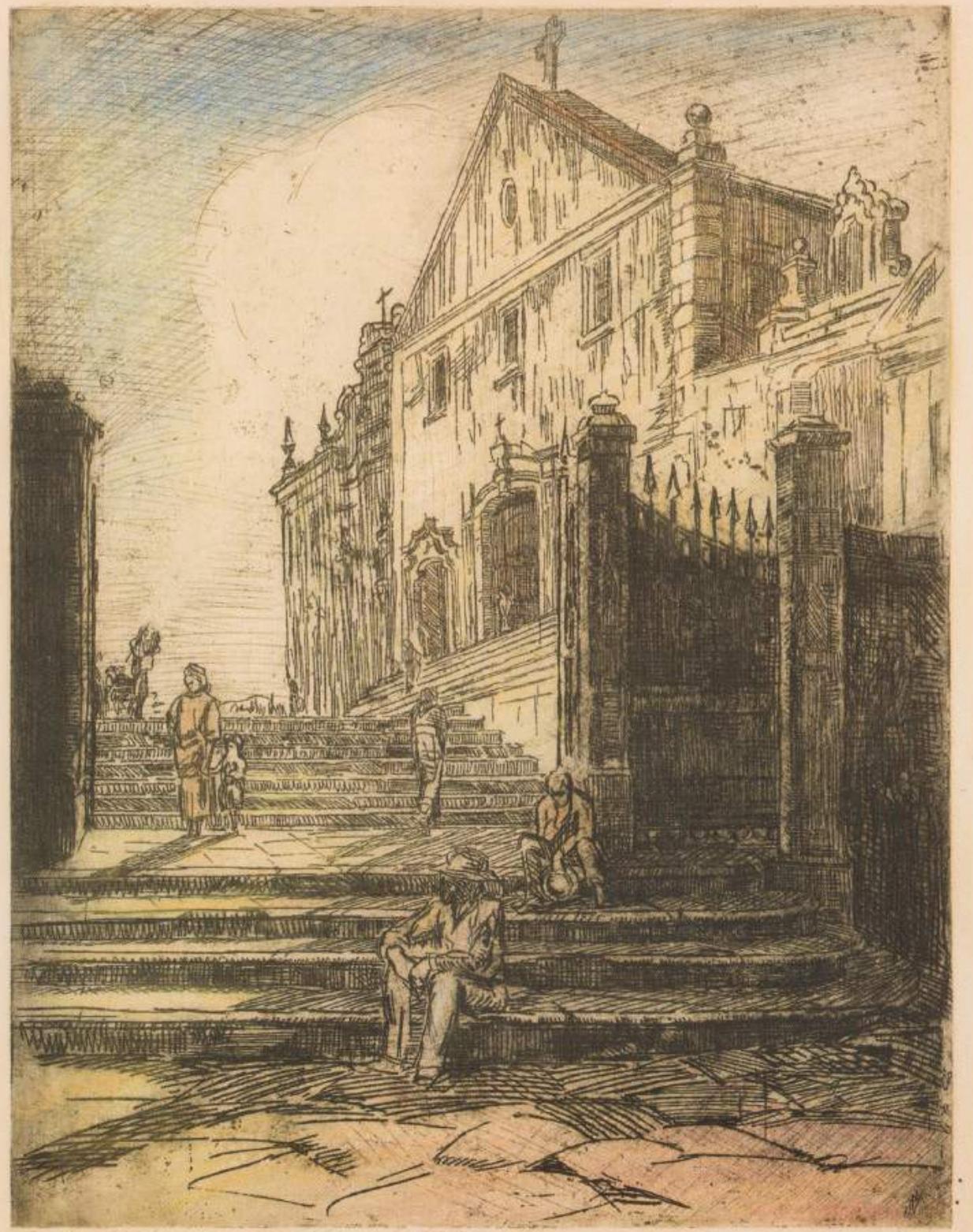

Fig. 106

106. TÍTULO: Fachada da Igreja de Santo Antônio.

DATA: 1930. TÉCNICA: Água-forte. MEDIDAS: 43 x 32,3 cm (mancha). IMPRESSÃO: em preto com algumas áreas em cores. ASSINATURA: "C. Oswald" no canto inferior direito do suporte. COLEÇÃO Teca e Oswald Vergolino. FONTE: Vergolino, 2011, p. 69.

LITERATURA: Silva, 1969 (ref.); Exp. Carlos Oswald: o resgate de um mestre, Caixa Cultural, Brasília/Curitiba, 2011, p. 68 - 69 (rep.). 
107. TÍTULO: Sagrado coração de Maria.

A. DATA: 1930. TÉCNICA: verniz mole. MEDIDAS: 27,6 x $20 \mathrm{~cm}$ (mancha); 36,7 x 27,5 cm (papel). MATRIZ: latão. MEDIDAS DA MATRIZ: 28,2 x 20,2 cm. ASSINATURA: “C. Oswald" no canto inferior direito do suporte. COLEÇÃO Museu Nacional de Belas Artes/ IBRAM/MinC. PROVENIÊNCIA: Carlos Oswald, compra, 1963.

B. [matriz] DATA: 1930. TÉCNICA: verniz mole. MATRIZ: latão. MEDIDAS DA MATRIZ: 28,2 x 20,2 cm. Sem assinatura. COLEÇÃO Museu Nacional de Belas Artes/IBRAM/MinC. PROVENIÊNCIA: Maria Isabel Oswald Monteiro, doação, 1982.

LITERATURA: Silva, 1969 (ref.); Exp. Carlos Oswald: o resgate de um mestre, Caixa Cultural, Brasília/Curitiba, 2011, p. 63 (rep.). 


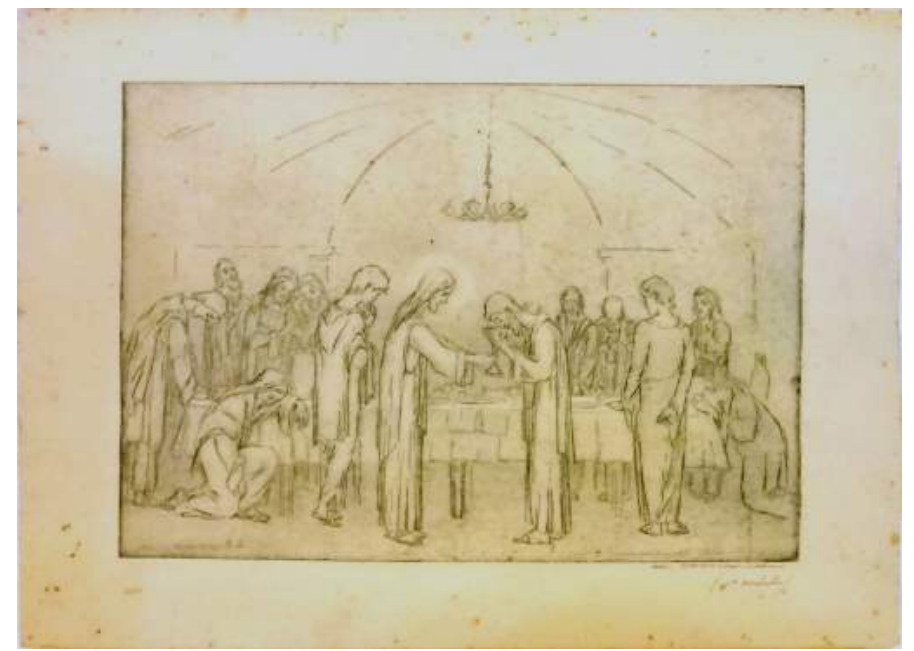

Fig. 108. B

108. TÍTULO: A última ceia. VARIANTES: A última ceia do senhor, A última ceia em pé.

A. DATA: 1932. TÉCNICA: Água-forte e água-tinta. MEDIDAS: 28 x 39 cm (mancha). IMPRESSÃO: em preto. ASSINATURA: "C. Oswald" no canto inferior direito do papel, "C. Oswald" gravado no canto inferior esquerdo da mancha. ACERVO Fundação Biblioteca Nacional. PROVENIÊNCIA: registrada no acervo em 1940.

B. [1 $1^{\circ}$ estado] DATA: 1932. TÉCNICA: Água-forte. MEDIDAS: 28 x $39 \mathrm{~cm}$ (mancha). IMPRESSÃO: em preto. ASSINATURA: "C. Oswald" no canto inferior direito do papel, "C. Oswald" gravado no canto inferior esquerdo da mancha. ACERVO Fundação Biblioteca Nacional. PROVENIÊNCIA: registrada no acervo em 1940.

C. DATA: 1932. TÉCNICA: Água-forte. MEDIDAS: 28 x $39 \mathrm{~cm}$ (mancha), 36,5 x 54,7 cm (papel). IMPRESSÃO: em preto. ASSINATURA: "C. Oswald" no papel, "C. Oswald" gravado no canto inferior esquerdo da mancha. COLEÇÃO Museu Nacional de Belas Artes/IBRAM/ MinC. PROVENIÊNCIA: Carlos Oswald, compra, 1963.

D. DATA: 1932. TÉCNICA: Água-forte. MEDIDAS: 28 x $39 \mathrm{~cm}$ (mancha), 36,5 x 54,7 cm (papel). IMPRESSÃO: em preto. ASSINATURA: “C. Oswald” no papel, “C. Oswald” gravado no canto inferior esquerdo da mancha. COLEÇÃO Museu Nacional de Belas Artes/IBRAM/ MinC. PROVENIÊNCIA: Carlos Oswald, compra, 1963.

LITERATURA: Silva, 1969 (ref.); Oswald, 1957, p. 224 (ref.).

109. TÍTULO: A última ceia. VARIANTES: A última ceia do senhor, A última ceia em pé.

DATA: 1932. TÉCNICA: Água-forte e água-tinta. MEDIDAS: 28 x 39 cm (mancha). IMPRESSÃO: em vermelho. ASSINATURA: "C. Oswald" no canto inferior direito do papel, "C. Oswald” gravado no canto inferior esquerdo da mancha. COLEÇÃO Família Oswald. 


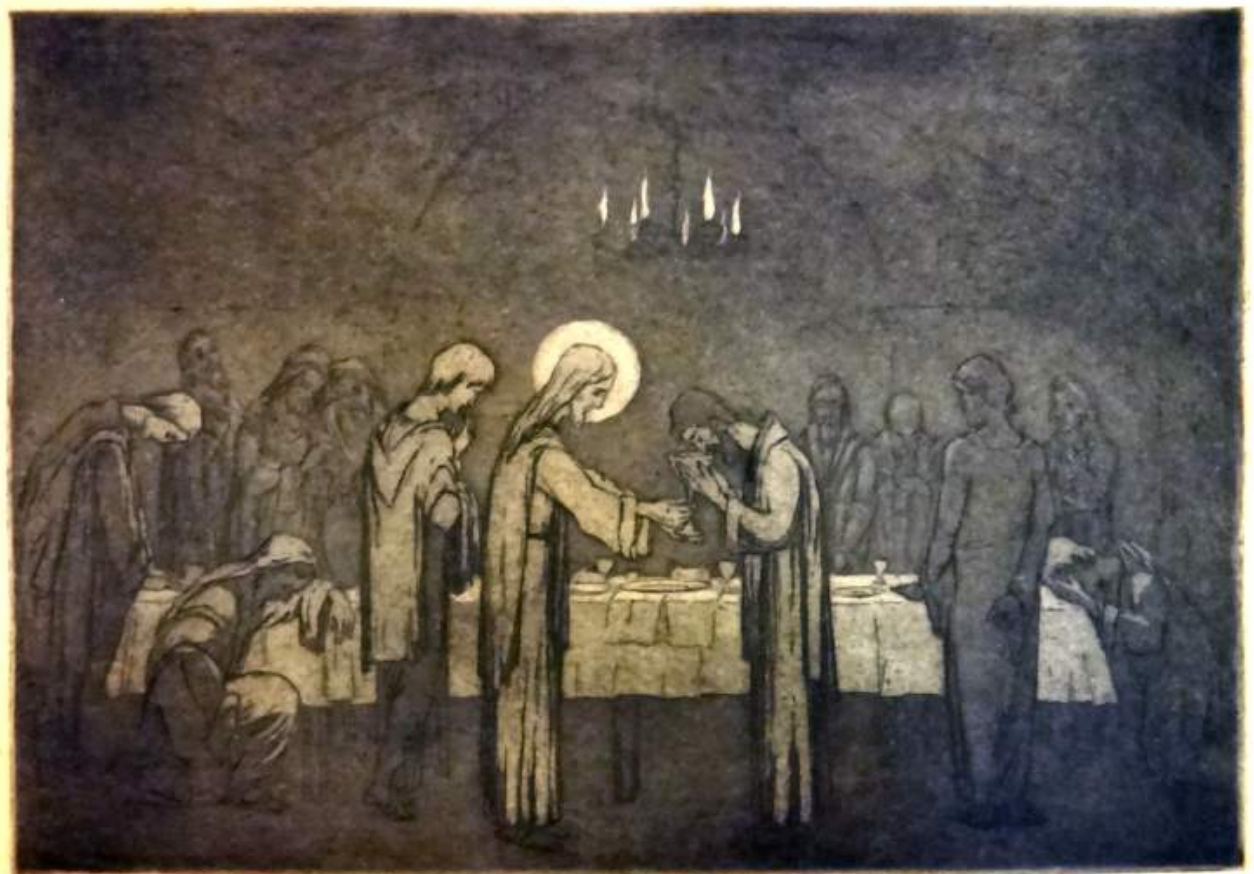

Fig. 108. A

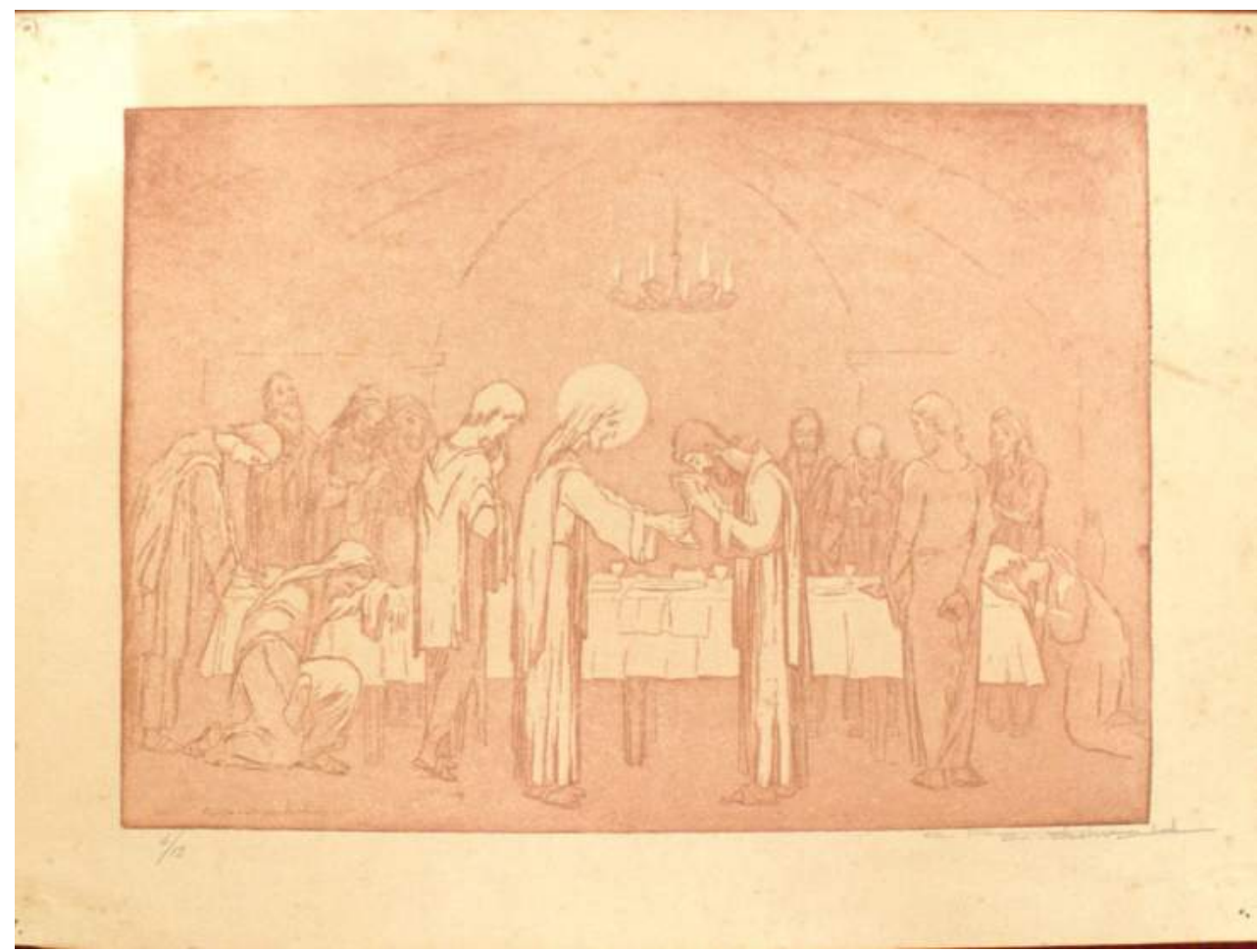

Fig. 109 


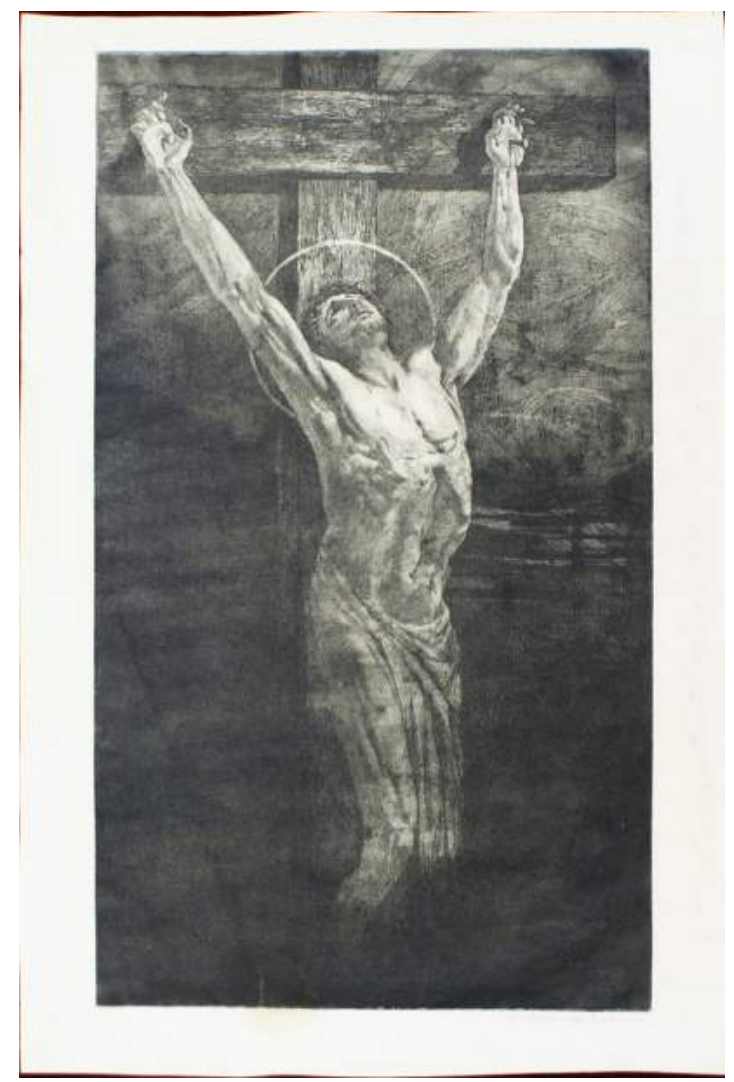

Fig. 110. B

110. TÍTULO: Crucificado.

A. DATA: 1932. TÉCNICA: Água-forte. MEDIDAS: 64,5 x 37,6 cm (mancha); 74,4 x 54,7 cm (papel). IMPRESSÃO: em preto. MATRIZ: zinco. MEDIDAS DA MATRIZ: 65,1 x 38,2 cm. ASSINATURA: "C. Oswald" no papel, "C. Oswald" no canto superior direito da mancha. COLEÇÃO Museu Nacional de Belas Artes/IBRAM/MinC. PROVENIÊNCIA: Carlos Oswald, compra, 1963.

B. DATA: 1932. TÉCNICA: Água-forte. IMPRESSÃO: em preto. MATRIZ: zinco. MEDIDAS DA MATRIZ: 65,1 x 38,2 cm. ASSINATURA: "C. Oswald" no canto superior direito da mancha. COLEÇÃO Famíla Oswald.

C. [matriz] DATA: 1932. TÉCNICA: Água-forte. MATRIZ: zinco. MEDIDAS DA MATRIZ: 65,1 x 38,2 cm. Sem assinatura. COLEÇÃO Museu Nacional de Belas Artes/IBRAM/MinC. PROVENIÊNCIA: Maria Isabel Oswald Monteiro, doação, 1982.

LITERATURA: Oswald, 1957, p. 224 (ref. e rep.); Silva. 1969, não p. (ref.). 
Fig. 111. B

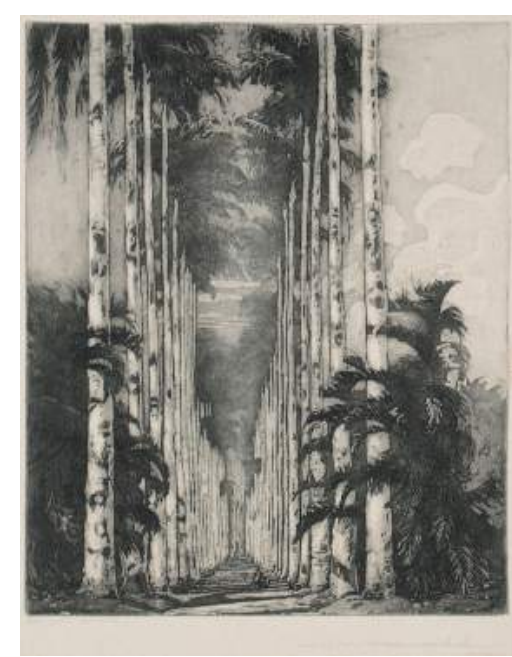

111. TÍTULO: Palmeiras. VARIANTE: Palmeiras no Jardim Botânico.

A. DATA: 1932. TÉCNICA: Água-forte, água-tinta e ponta-seca. MEDIDAS: 28 x 21,8 cm (mancha); 36,6 x 27,4 cm (papel). IMPRESSÃO: em preto. MATRIZ: zinco. MEDIDAS DA MATRIZ: 28,1 x 22,2 cm. ASSINATURA: "C. Oswald" no canto inferior direito do papel. COLEÇÃO Museu Nacional de Belas Artes/IBRAM/MinC. PROVENIÊNCIA: Carlos Oswald, compra, 1963. FOTOGRAFIA: Acervo Museu Nacional de Belas Artes/IBRAM/MinC.

B. DATA: 1932. TÉCNICA: Água-forte, água-tinta e ponta-seca. MEDIDAS: 28 x 22,5 cm (mancha); 36,5 x 26,5 cm (papel). IMPRESSÃO: em preto. MATRIZ: zinco. MEDIDAS DA MATRIZ: 28,1 x 22,2 cm. ASSINATURA: "C. Oswald" no canto inferior direito do papel. COLEÇÃO particular. FONTE: Evandro Carneiro Leiloeiro, disponível em: <http://www.evandrocarneiroleiloes.com/145675? artistId=88060> , acesso em 13/8/2017.

C. [matriz] DATA: 1932. TÉCNICA: Água-forte e água-tinta. MATRIZ: zinco. MEDIDAS DA MATRIZ: 28,1 x 22,2 cm. Sem assinatura. COLEÇÃO Museu Nacional de Belas Artes/ IBRAM/MinC. PROVENIÊNCIA: Maria Isabel Oswald Monteiro, doação, 1982.

LITERATURA: Oswald, 1957, p. 224 (ref.); Silva, 1969 (ref.); Exp. Guignard e o Oriente: China, Japão e Minas, Instituto Tomie Ohtake, SP, 2010, p. 24 (rep.); Exp. Carlos Oswald: o resgate de um mestre, Caixa Cultural, Brasília/Curitiba, 2011, p. 63 (rep.).

112. TÍTULO: Palmeiras no Jardim Botânico.

A. DATA: 1986. TÉCNICA: ponta seca. MEDIDAS: 27 x 18,3 cm (mancha); 35,8 x 18,3 cm (papel). IMPRESSÃO: póstuma. MATRIZ: plástico. MEDIDAS DA MATRIZ: 27,5 x 18,4 cm. Sem assinatura. COLEÇÃO Museu Nacional de Belas Artes/IBRAM/MinC. PROVENIÊNCIA: registrada na coleção em 1986.

B. [matriz] DATA: 1935[?]. TÉCNICA: ponta seca. MATRIZ: plástico. MEDIDAS DA MATRIZ: 27,5 x 18,4 cm. Sem assinatura. COLEÇÃO Museu Nacional de Belas Artes/IBRAM/ MinC. PROVENIÊNCIA: Maria Isabel Oswald Monteiro, doação, 1982. [Obra realizada a partir de Palmeiras.]

LITERATURA: Silva, 1969 (ref.). 


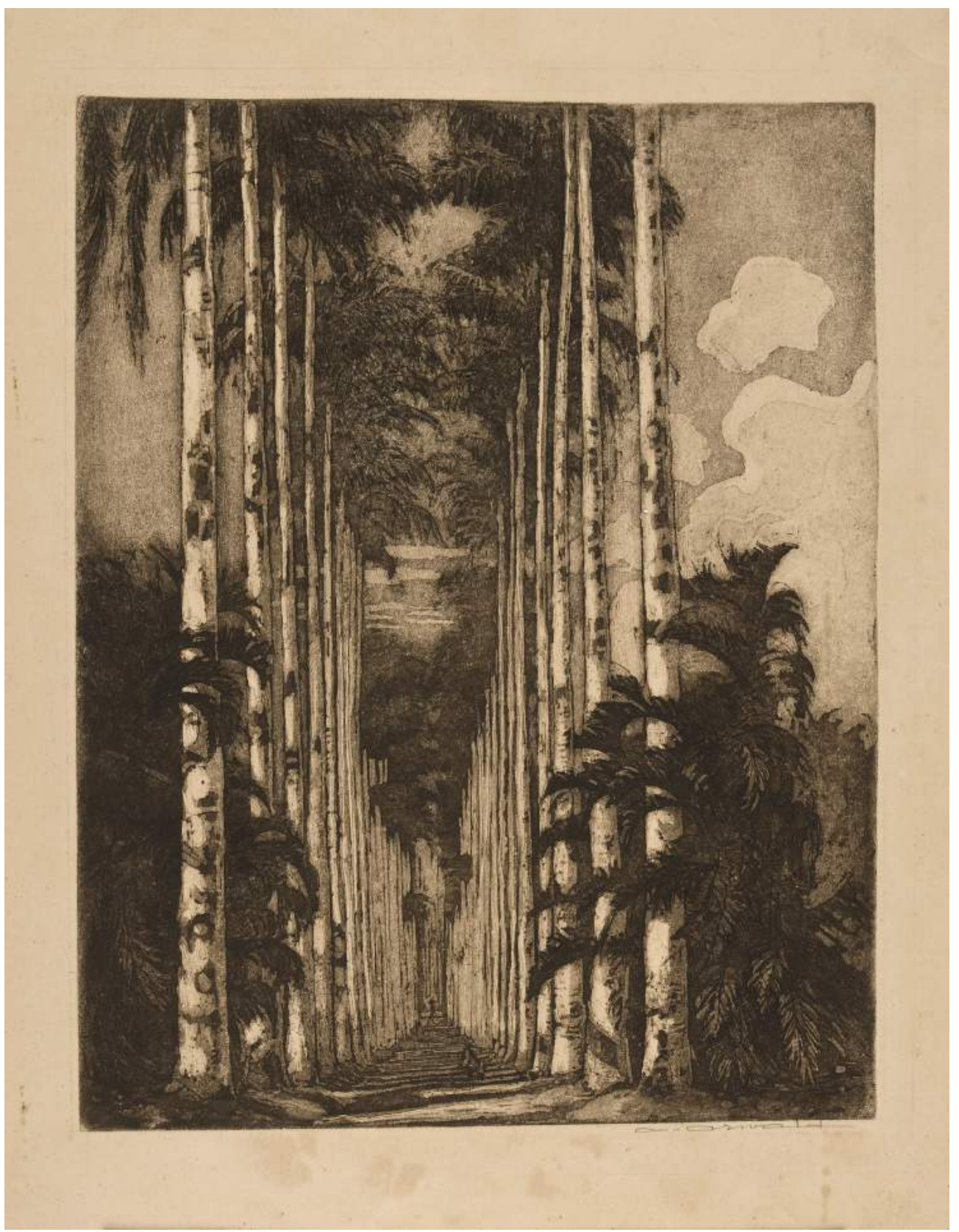

Fig. 111. A 


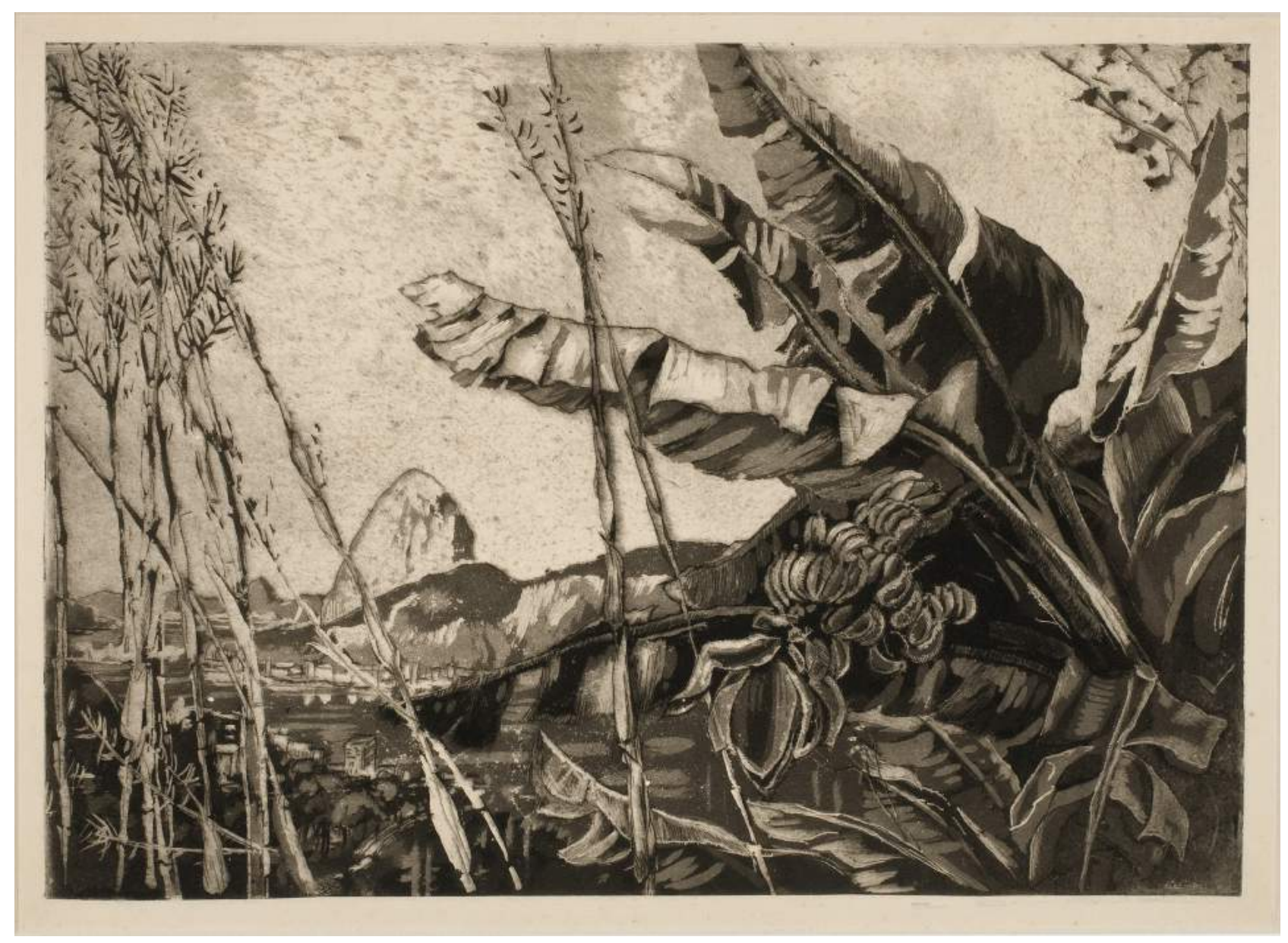

Fig. 113

113. TÍTULO: Pão de Açúcar.

DATA: 1933. TÉCNICA: Água-tinta. IMPRESSÃO: em preto. ASSINATURA: "C. Oswald" no canto inferior direito do suporte. COLEÇÃO Museu Nacional de Belas Artes/IBRAM/MinC. PROVENIÊNCIA: Carlos Oswald, compra, 1963. FOTOGRAFIA: Acervo Museu Nacional de Belas Artes/IBRAM/MinC.

LITERATURA: Silva, 1969 (ref.); Exp. Carlos Oswald: o resgate de um mestre, Caixa Cultural, Brasília/Curitiba, 2011, p. 77 (rep.). 


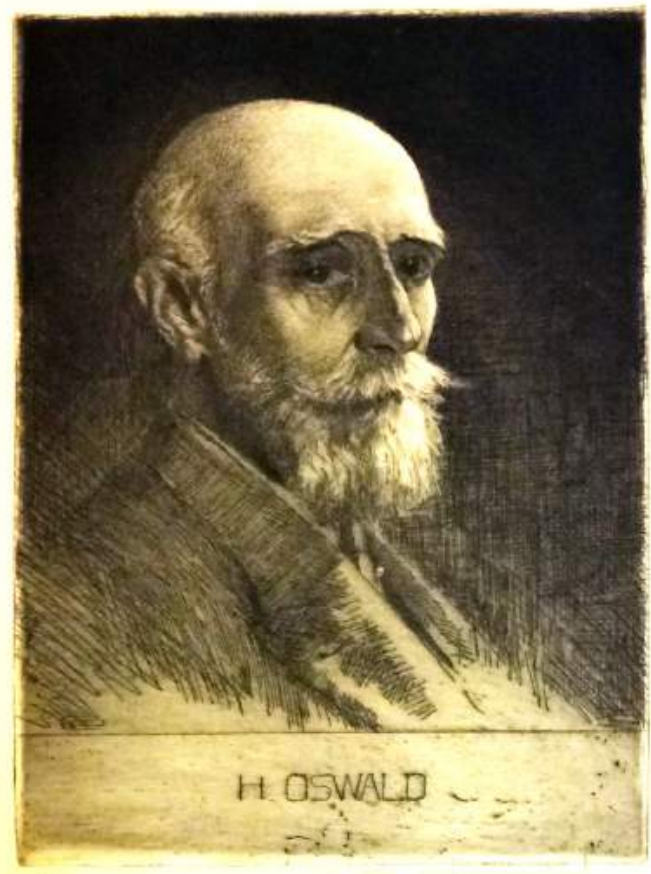

Fig. 114. A

114. TÍTULO: H. Oswald.

A. DATA: 1933. TÉCNICA: Água-forte é água-tinta. MEDIDAS: 26,5 X 19,4 cm (mancha), 38,1 x 28 cm (papel). IMPRESSÃO: em preto. MATRIZ: zinco. MEDIDAS DA MATRIZ: 28,1 x 19,6 cm. ASSINATURA: "C. Oswald" no canto inferior direito do papel, monograma "CO" gravado na lateral esquerda da mancha. ACERVO Fundação Biblioteca Nacional. PROVENIÊNCIA: registrada no acervo em 1940.

B. DATA: 1933. TÉCNICA: Água-forte e água-tinta. MEDIDAS: 27,6 x $19 \mathrm{~cm}$ (mancha); 35,1 x 24,8 cm (papel). IMPRESSÃO: em preto. MATRIZ: zinco. MEDIDAS DA MATRIZ: 28,1 x 19,6 cm. ASSINATURA: “C. Oswald” no papel, monograma "CO” gravado na lateral esquerda da mancha. COLEÇÃO Museu Nacional de Belas Artes/IBRAM/MinC. PROVENIÊNCIA: Carlos Oswald, compra, 1963.

C. [matriz] DATA: 1933. TÉCNICA: Água-forte e água-tinta. MATRIZ: zinco. MEDIDAS DA MATRIZ: 28,1 x 19,6 cm. ASSINATURA: monograma "CO" no canto inferior direito. COLEÇÃO Museu Nacional de Belas Artes/IBRAM/MinC. PROVENIÊNCIA: Maria Isabel Oswald Monteiro, doação, 1982.

LITERATURA: Correio da Manhã, RJ, 25/11/1933 (nota, inauguração da galeria de compositores do Instituto de Educação); Oswald, 1957 p. 224 (ref. e rep.); Silva, 1969 (ref.). 


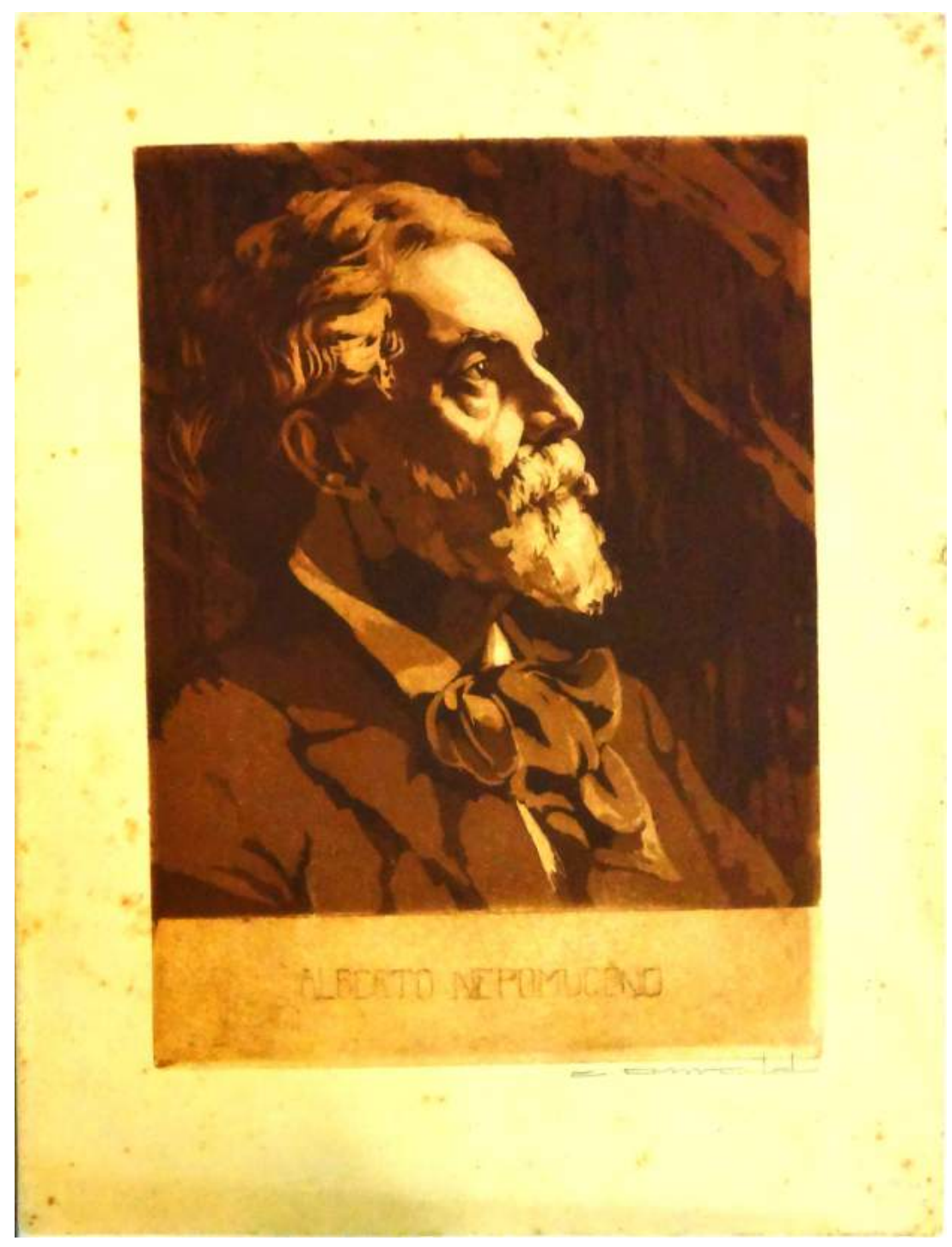

Fig. 115

115. TÍTULO: Alberto Nepomuceno.

DATA: 1933. TÉCNICA: Água-tinta. MEDIDAS: 27,5 X $20 \mathrm{~cm}$ (mancha), 36,5 x 27,4 cm (papel). IMPRESSÃO: em marrom. ASSINATURA: "C. Oswald” no canto inferior direito do papel. ACERVO Fundação Biblioteca Nacional. PROVENIÊNCIA: registrada no acervo em 1940.

LITERATURA: Correio da Manhã, RJ, 25/11/1933 (nota, inauguração da galeria de compositores do Instituto de Educação); Oswald, 1957, p. 224 (ref. e rep.); Silva, 1969 (ref.).

116. TÍTULO: Alberto Nepomuceno.

DATA: 1933. TÉCNICA: Água-tinta. MEDIDAS: 27,3 x 19,7 cm (mancha); 50 x 32,5 cm (papel). IMPRESSÃO: em cores. ASSINATURA: "C. Oswald" no papel. COLEÇÃO Museu Nacional de Belas Artes/IBRAM/MinC. PROVENIÊNCIA: Carlos Oswald, compra, 1963. 


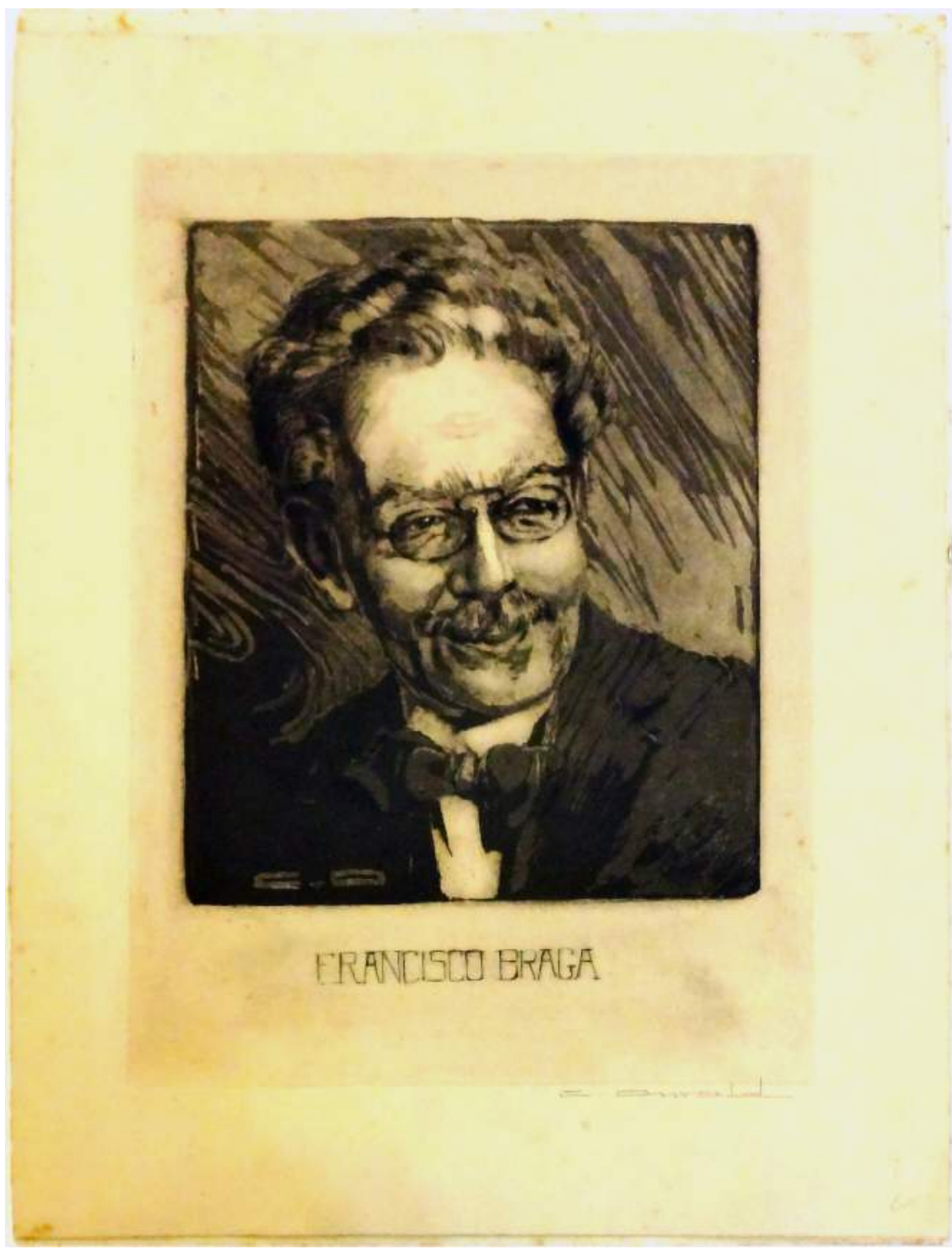

Fig. 117. A

117. TÍTULO: Francisco Braga.

A. DATA: 1933. TÉCNICA: Água-tinta. MEDIDAS: 27,5 x $20 \mathrm{~cm}$ (mancha), 35,2 x 27,4 cm (papel). IMPRESSÃO: em preto. ASSINATURA: "C. Oswald" no canto inferior direito do papel, monograma "CO" gravado no canto inferior esquerdo da mancha. ACERVO Fundação Biblioteca Nacional. PROVENIÊNCIA: registrada no acervo em 1940.

B. DATA: 1933. TÉCNICA: Água-tinta. MEDIDAS: 28 x 19,7 cm (mancha), 36,5 x 27,6 cm (papel). IMPRESSÃO: em preto. ASSINATURA: "C. Oswald" no papel, monograma "CO" gravado no canto inferior esquerdo da mancha. COLEÇÃO Museu Nacional de Belas Artes/ IBRAM/MinC. PROVENIÊNCIA: Carlos Oswald, compra, 1963.

LITERATURA: Correio da Manhã, RJ, 25/11/1933 (nota, inauguração da galeria de compositores do Instituto de Educação); Oswald, 1957, p. 224 (ref.); Silva, 1969 (ref.). 


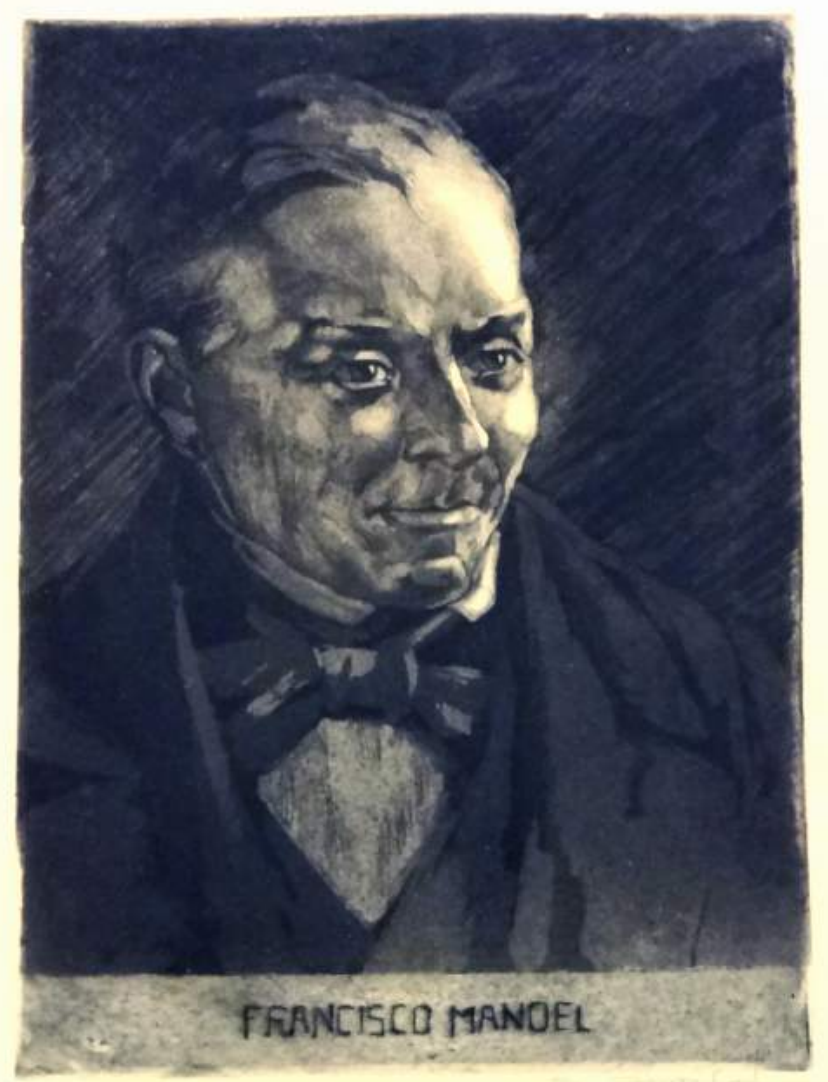

Fig. 118. A

118. TÍTULO: Francisco Manoel.

A. DATA: 1933. TÉCNICA: Água-tinta e água-forte. MEDIDAS: 26,5 x $19 \mathrm{~cm}$ (mancha), 38 x $28 \mathrm{~cm}$ (papel). IMPRESSÃO: em preto. ASSINATURA: "C. Oswald" no canto inferior direito do papel. ACERVO Fundação Biblioteca Nacional. PROVENIÊNCIA: registrada no acervo em 1940.

B. DATA: 1933. TÉCNICA: Água-tinta e água-forte. MEDIDAS: 27,5 x 19,5 cm (mancha), 35 x 25,3 cm (papel). IMPRESSÃO: em preto. ASSINATURA: "C. Oswald" no canto inferior direito do papel. COLEÇÃO Museu Nacional de Belas Artes/IBRAM/MinC. PROVENIÊNCIA: Carlos Oswald, compra, 1963.

LITERATURA: Correio da Manhã, RJ, 25/11/1933 (nota, inauguração da galeria de compositores do Instituto de Educação); Oswald, 1957, p. 224 (ref.); Silva, 1969 (ref.). 


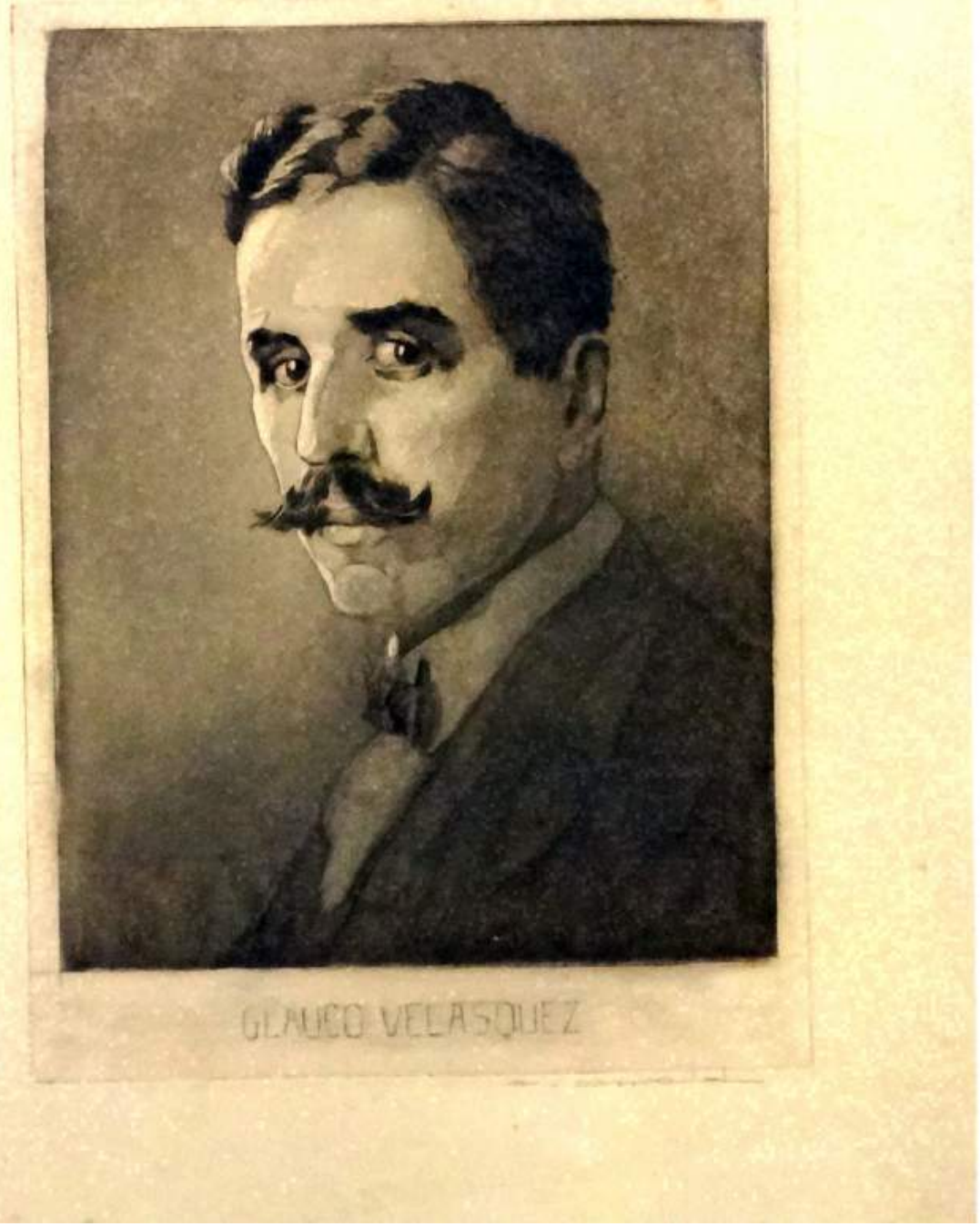

Fig. 119.A

119. TÍTULO: Glauco Velasquez.

A..DATA: 1933. TÉCNICA: Água-tinta e água-forte. MEDIDAS: 27,8 x 19,6 cm (mancha), 36,5 x 28,1 cm (papel). IMPRESSÃO: em preto. ASSINATURA: "C. Oswald" no canto inferior direito do papel. ACERVO Fundação Biblioteca Nacional. PROVENIÊNCIA: registrada no acervo em 1940.

B. DATA: 1933. TÉCNICA: Água-tinta e água-forte. MEDIDAS: 23,5 x 18,3 cm (mancha), 38,5 x 24 cm (papel). IMPRESSÃO: em verde. ASSINATURA: "C. Oswald" no canto inferior direito do papel. COLEÇÃO Museu Nacional de Belas Artes/IBRAM/MinC. PROVENIÊNCIA: Carlos Oswald, compra, 1963.

LITERATURA: Correio da Manhã, RJ, 25/11/1933 (nota, inauguração da galeria de compositores do Instituto de Educação); Oswald, 1957, p. 224 (ref.); Silva, 1969 (ref.). 


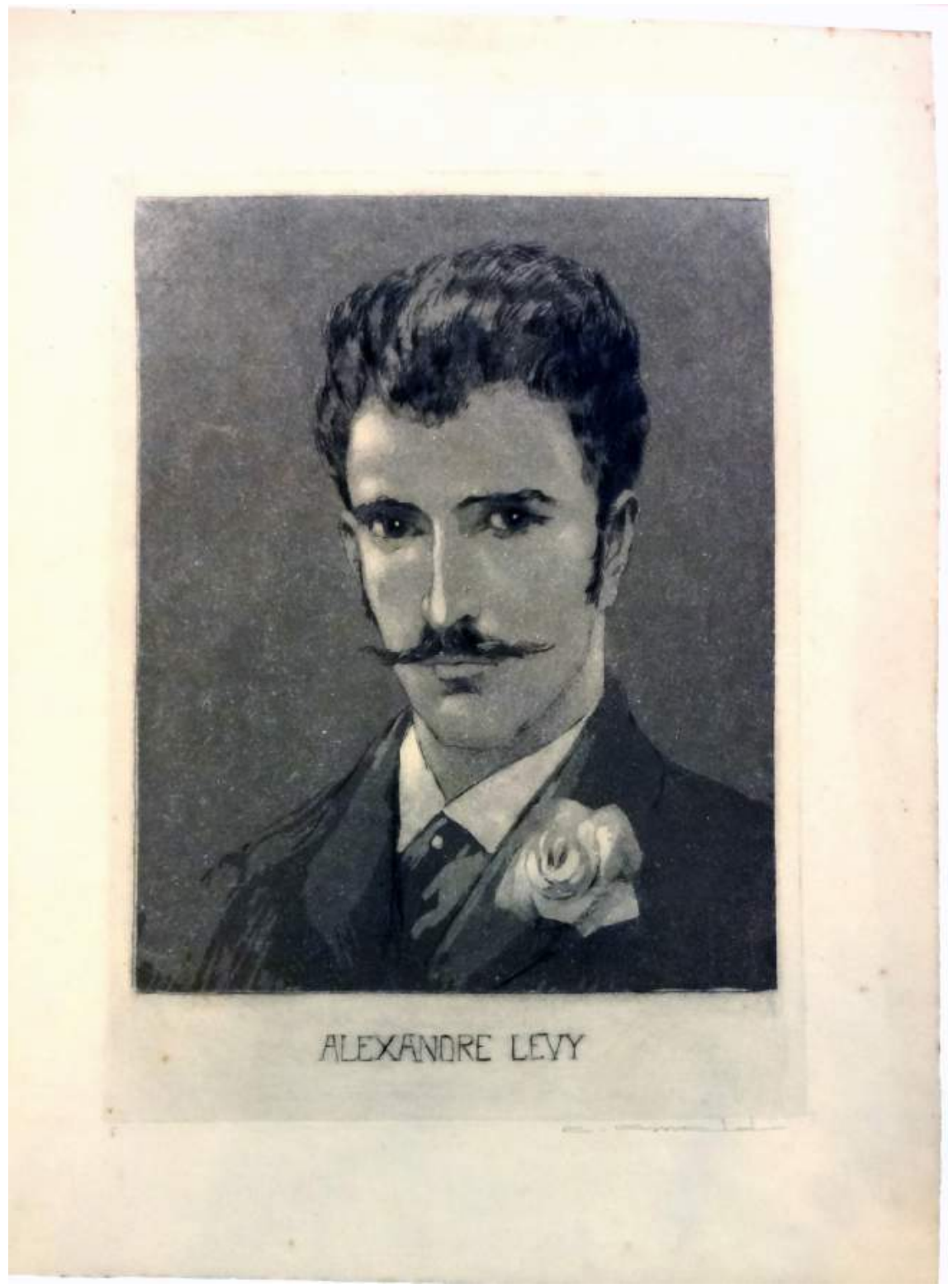

Fig. 120. A

120. TÍTULO: Alexandre Levy.

A. DATA: 1933. TÉCNICA: Água-tinta e água-forte. MEDIDAS: 27,5 x $20 \mathrm{~cm}$ (mancha), 36,5 x 28,2 cm (papel). IMPRESSÃO: em preto. MATRIZ: latão. MEDIDA DA MATRIZ: 28 x 20 cm. ASSINATURA: "C. Oswald" no canto inferior direito do papel. ACERVO Fundação Biblioteca Nacional. PROVENIÊNCIA: registrada no acervo em 1940.

B. [matriz] DATA: 1933. TÉCNICA: Água-tinta e água-forte. MATRIZ: latão. MEDIDA DA MATRIZ: 28 x $20 \mathrm{~cm}$. Sem assinatura. COLEÇÃO Museu Nacional de Belas Artes/IBRAM/ MinC. PROVENIÊNCIA: Maria Isabel Oswald Monteiro, doação, 1982.

LITERATURA: Correio da Manhã, RJ, 25/11/1933 (nota, inauguração da galeria de compositores do Instituto de Educação); Oswald, 1957, p. 224 (ref.); Silva, 1969 (ref.). 


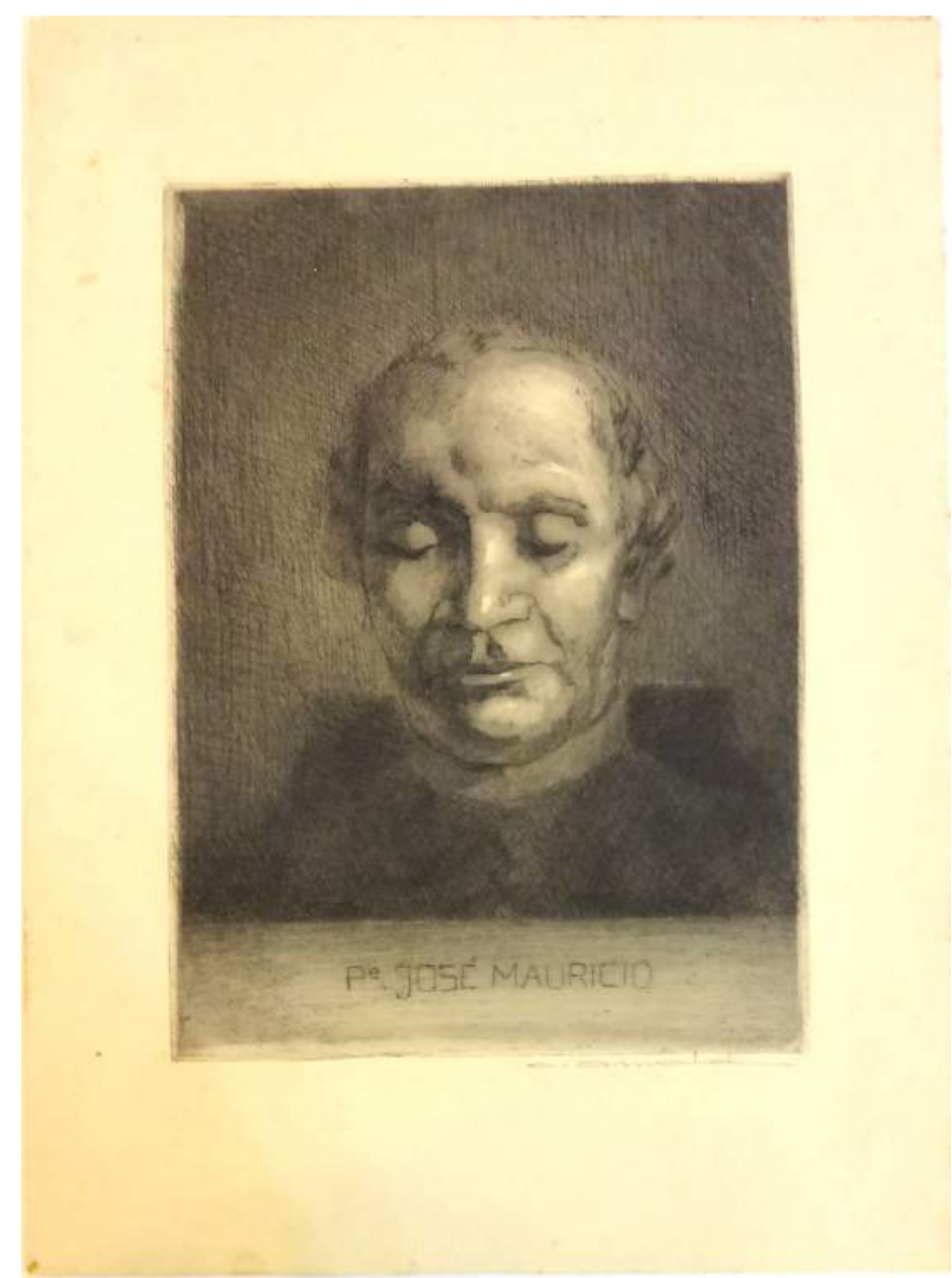

Fig. 121. A

121. TÍTULO: Pe. José Maurício.

A. DATA: 1933. TÉCNICA: Água-forte e água-tinta. MEDIDAS: 26,8 x 19,4 cm (mancha), 38,4 x 28 cm (papel). IMPRESSÃO: em preto. MATRIZ: zinco. MEDIDA DA MATRIZ: 27,9 x $19,5 \mathrm{~cm}$. ASSINATURA: “C. Oswald” no canto inferior direito do papel, monograma "CO"gravado na parte inferior da mancha. ACERVO Fundação Biblioteca Nacional. PROVENIÊNCIA: registrada no acervo em 1940.

B. DATA: 1933. TÉCNICA: Água-forte e água-tinta. MEDIDAS: 27,1 x 18,7 cm (mancha), 31 x 22,6 cm (papel). IMPRESSÃO: em preto. MATRIZ: zinco. MEDIDA DA MATRIZ: 27,9 x $19,5 \mathrm{~cm}$. ASSINATURA: "C. Oswald" no papel, monograma "CO"gravado na parte inferior da mancha. COLEÇÃO Museu Nacional de Belas Artes/IBRAM/MinC. PROVENIÊNCIA: Carlos Oswald, compra, 1963. [O MNBA possui mais um exemplar da obra].

C. [matriz] DATA: 1933. TÉCNICA: Água-forte e água-tinta. MATRIZ: zinco. MEDIDA DA MATRIZ: 27,9 x 19,5 cm. ASSINATURA: monograma "CO"na parte inferior. COLEÇÃO Museu Nacional de Belas Artes/IBRAM/MinC. PROVENIÊNCIA: Maria Isabel Oswald Monteiro, doação, 1982.

LITERATURA: Correio da Manhã, RJ, 25/11/1933 (nota, inauguração da galeria de compositores do Instituto de Educação); Oswald, 1957, p. 224 (ref.); Silva, 1969 (ref.). 


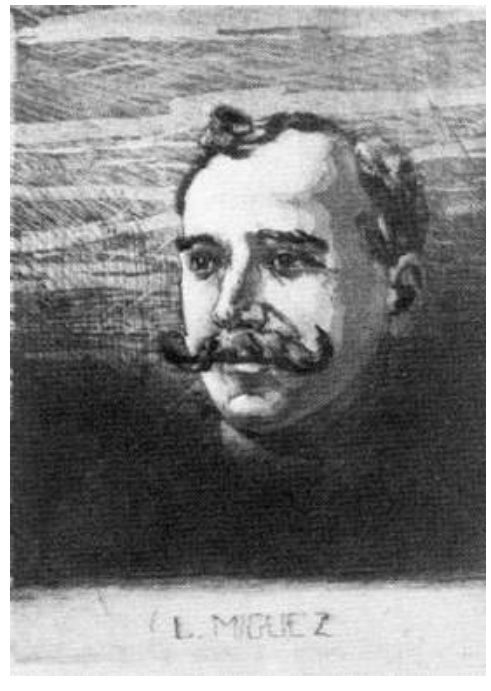

Fig. 122
122. TÍTULO: L. Miguez.

DATA: 1933. TÉCNICA: Água-forte. MEDIDAS: 26,7 x $20 \mathrm{~cm}$ (mancha), 38 x 27,8 cm (papel). IMPRESSÃO: em preto. ASSINATURA: "C. Oswald" no papel. COLEÇÃO Museu Nacional de Belas Artes/IBRAM/MinC. PROVENIÊNCIA: Carlos Oswald, compra, 1963. FOTOGRAFIA: Acervo Museu Nacional de Belas Artes/IBRAM/MinC.

LITERATURA: Correio da Manhã, RJ, 25/11/1933 (nota, inauguração da galeria de compositores do Instituto de Educação); Silva, 1969 (ref.).

123. TÍTULO: Luciano Gallet.

DATA: 1933. TÉCNICA: Água-tinta. MEDIDAS: 23,5 x 17,7 cm (mancha), 32 x $22 \mathrm{~cm}$ (papel). IMPRESSÃO: em preto. ASSINATURA: "C. Oswald” no papel. COLEÇÃO Museu Nacional de Belas Artes/IBRAM/MinC. PROVENIÊNCIA: Carlos Oswald, compra, 1963.

LITERATURA: Correio da Manhã, RJ, 25/11/1933 (nota, inauguração da galeria de compositores do Instituto de Educação); Silva, 1969 (ref.); Exp. Carlos Oswald: o resgate de um mestre, Caixa Cultural, Brasília/Curitiba, 2011, p. 51 (rep.). 


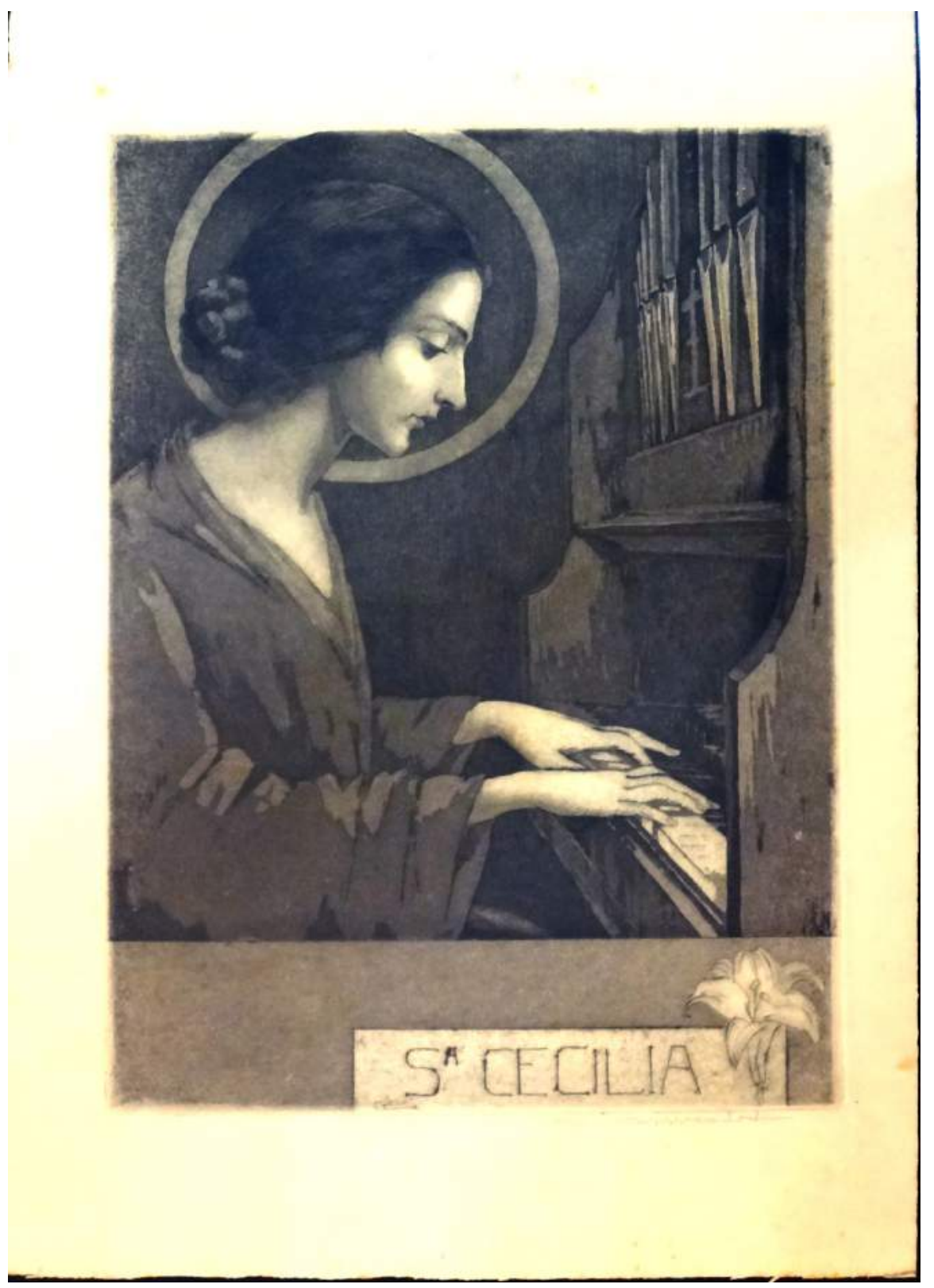

Fig. 124

124. TÍTULO: $\mathrm{S}^{\mathrm{a}}$ Cecília.

DATA: 1933[?]. TÉCNICA: Água-tinta e água-forte. MEDIDAS: 27 x 19 cm (mancha). IMPRESSÃO: em preto. ASSINATURA: "C. Oswald" no canto inferior direito do papel. ACERVO Fundação Biblioteca Nacional. PROVENIÊNCIA: registrada no acervo em 1940.

LITERATURA: Silva, 1969 (ref.). 
125. TÍTULO: Autorretrato.

A. DATA: 1935. TÉCNICA: Verniz mole e ponta seca. MEDIDAS: 20 x 13,3 cm (mancha), 30 x 21,5 cm (papel). IMPRESSÃO: em preto. MATRIZ: latão. MEDIDAS DA MATRIZ: 20,1 x 13,9 cm. ASSINATURA: "C. Oswald" no canto inferior direito do papel. ACERVO Fundação Biblioteca Nacional. PROVENIÊNCIA: registrada no acervo em 1940.

B. DATA: 1935. TÉCNICA: Verniz mole e ponta seca. MEDIDAS: 19,3 x 13,7 cm (mancha), 21,8 x 18,2 cm (papel). IMPRESSÃO: em preto. MATRIZ: latão. MEDIDAS DA MATRIZ: 20,1 x 13,9 cm. ASSINATURA: "C. Oswald” no papel. COLEÇÃO Museu Nacional de Belas Artes/IBRAM/MinC. PROVENIÊNCIA: Carlos Oswald, compra, 1963.

C. DATA: 1935. TÉCNICA: Verniz mole e ponta seca. MEDIDAS: 20 x 13,3 cm (mancha), 32,5 x 26,4 cm (papel). MATRIZ: latão. MEDIDAS DA MATRIZ: 20,1 x 13,9 cm. ASSINATURA: "C. Oswald” no papel. COLEÇÃO Museu Nacional de Belas Artes/IBRAM/MinC. PROVENIÊNCIA: José Lucas Oswald, compra, 1968.

D. DATA: 1986. TÉCNICA: Verniz mole e ponta seca. MEDIDAS: 19,7 x $13 \mathrm{~cm}$ (mancha), 36,2 x 26,4 cm (papel). IMPRESSÃO: póstuma. MATRIZ: latão. MEDIDAS DA MATRIZ: 20,1 x 13,9 cm. Sem assinatura. COLEÇÃO Museu Nacional de Belas Artes/IBRAM/MinC. PROVENIÊNCIA: registrada na coleção em 1986.

E. DATA: 1935. TÉCNICA: Verniz mole e ponta seca. MEDIDAS: 20 x 13,3 cm (mancha), 27,9 x 19,2 cm (papel). IMPRESSÃO: em preto. MATRIZ: latão. MEDIDAS DA MATRIZ: 20,1 x 13,9 cm. Sem assinatura. ACERVO Fundação Biblioteca Nacional. PROVENIÊNCIA: registrada no acervo em 1940.

F. DATA: 1935. TÉCNICA: Verniz mole e ponta seca. MEDIDAS: 20 x 13,5 cm (mancha), 32,9 x 22,8 cm (papel). MATRIZ: latão. MEDIDA DA MATRIZ: 20,1 x 13,9 cm. ASSINATURA: "C. Oswald” no papel. COLEÇÃO Museu Nacional de Belas Artes/IBRAM/MinC. PROVENIÊNCIA: Carlos Oswald, compra, 1963.

G. [matriz] DATA: 1935. TÉCNICA: Verniz mole e ponta seca. MATRIZ: latão. MEDIDA DA MATRIZ: 20,1 x 13,9 cm. Sem assinatura. COLEÇÃO Museu Nacional de Belas Artes/ IBRAM/MinC. PROVENIÊNCIA: Maria Isabel Oswald Monteiro, doação, 1982.

LITERATURA: Illustração Brasileira, RJ, 8/1950 (rep.); Silva, 1969 (ref.); Exp. Carlos Oswald: o resgate de um mestre, Caixa Cultural, Brasília/Curitiba, 2011, p. 88 (rep.). 


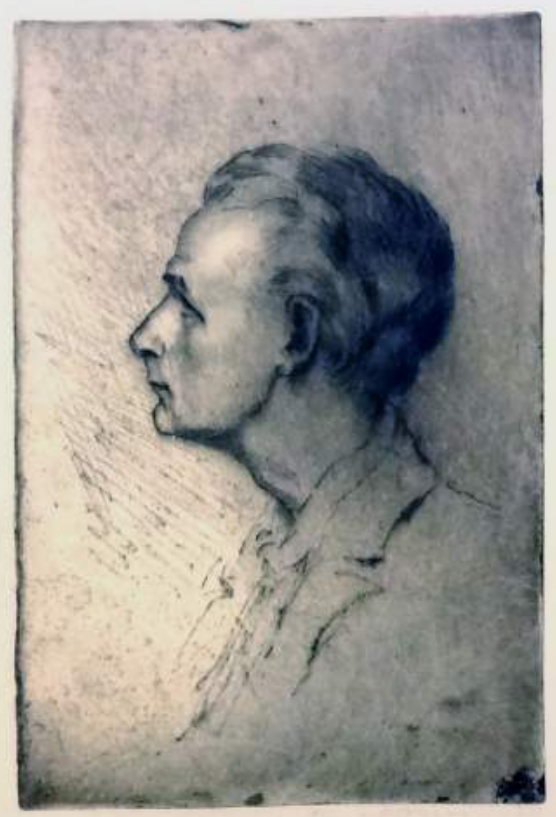

Fig. 125. A

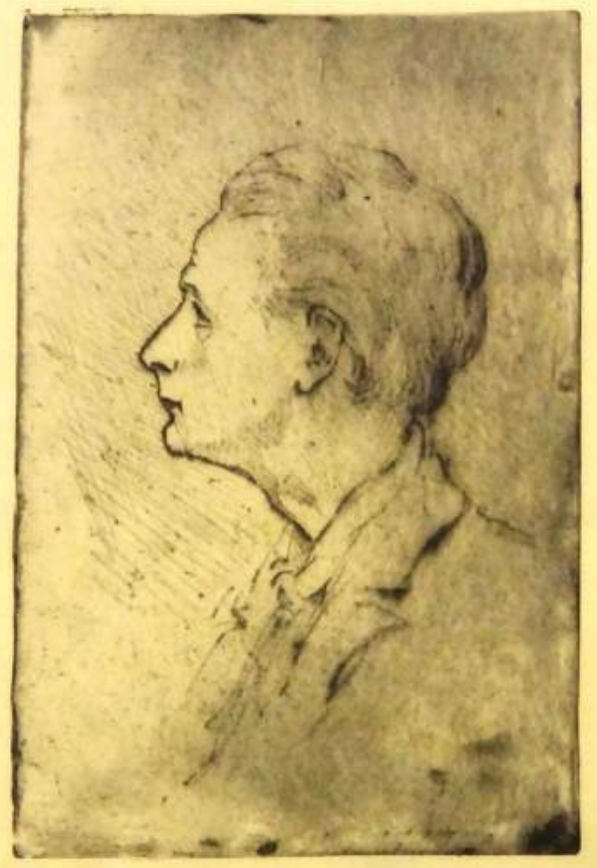

Fig. 125. E 


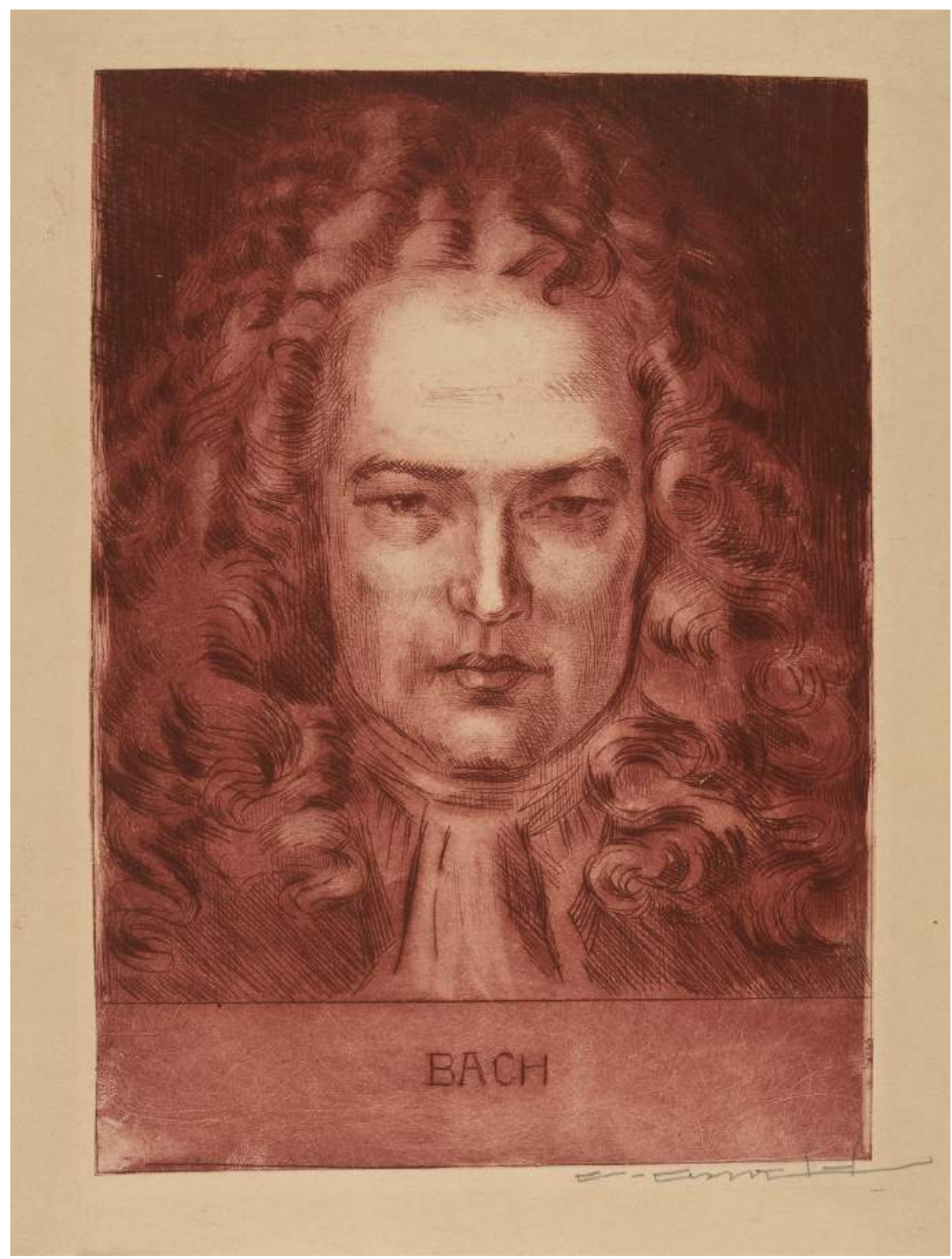

Fig. 126.A

126. TÍTULO: Bach.

A. DATA: 1935[?]. TÉCNICA: Ponta seca. MEDIDAS: 27,4 x 19,5 cm (mancha), 36,3 x 28,5 cm (papel). IMPRESSÃO: em magenta. MATRIZ: plástico. MEDIDAS DA MATRIZ: 27,9 x 19,6 cm. ASSINATURA: “C. Oswald” no canto inferior direito do papel. COLEÇÃO Museu Nacional de Belas Artes/IBRAM/MinC. PROVENIÊNCIA: Carlos Oswald, compra, 1963. FOTOGRAFIA: Acervo Museu Nacional de Belas Artes/IBRAM/MinC.

B. [matriz] DATA: 1935[?]. TÉCNICA: Ponta seca. MATRIZ: plástico. MEDIDAS DA MATRIZ: 27,9 x 19,6 cm. Sem assinatura. COLEÇÃO Museu Nacional de Belas Artes/IBRAM/ MinC. PROVENIÊNCIA: Maria Isabel Oswald Monteiro, doação, 1982.

LITERATURA: Silva, 1969 (ref.); Exp. Carlos Oswald: o resgate de um mestre, Caixa Cultural, Brasília/Curitiba, 2011, p. 51 (rep.). 


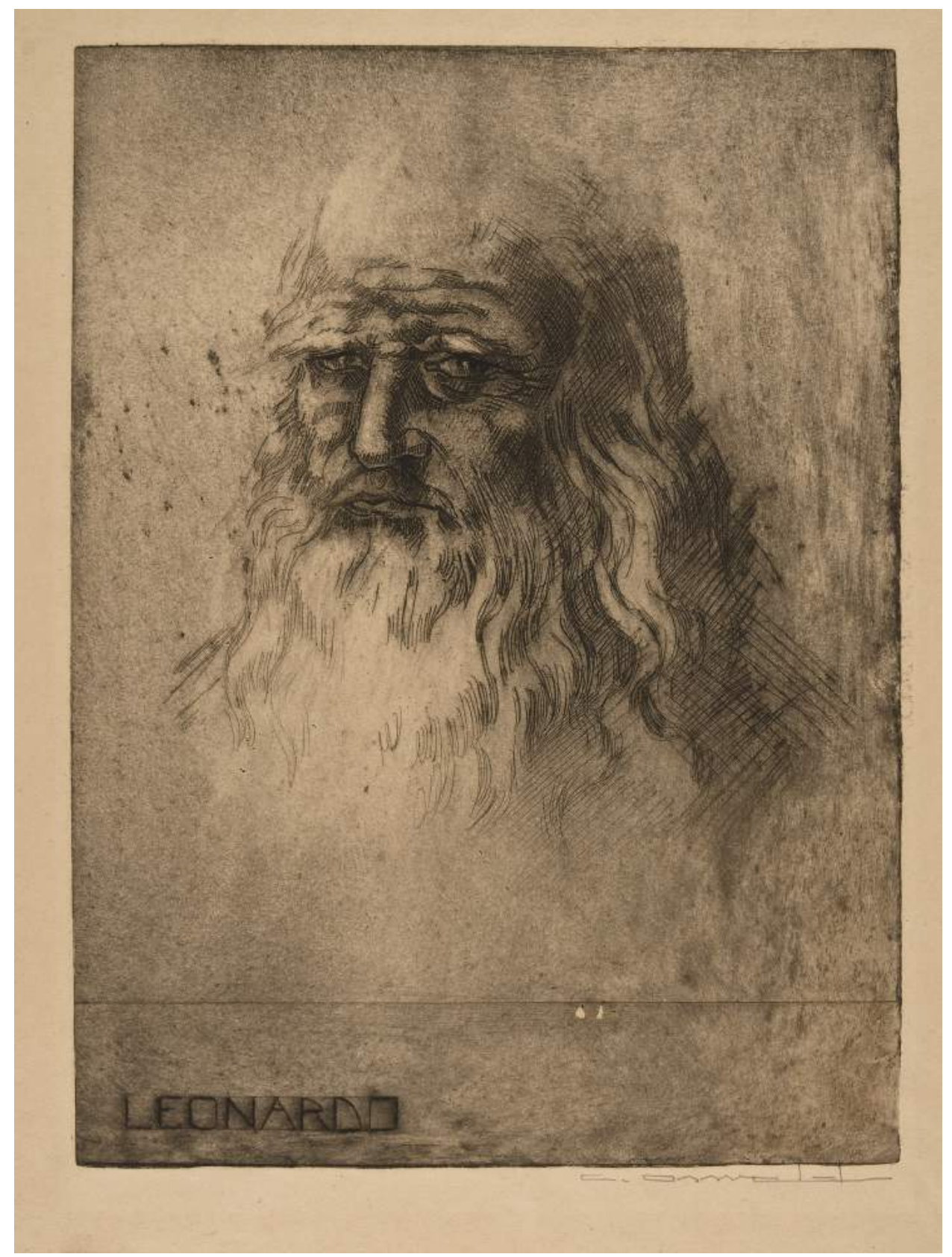

Fig. 127.A

127. TÍTULO: Leonardo [Da Vinci].

A. DATA: 1935[?]. TÉCNICA: Água-forte. MEDIDAS: 27,3 x 20,1 cm (mancha), 36,6 x 28,3 cm (papel). IMPRESSÃO: em preto. MATRIZ: latão. MEDIDAS DA MATRIZ: 28 x 20,3 cm. ASSINATURA: “C. Oswald” no canto inferior direito do papel. COLEÇÃO Museu Nacional de Belas Artes/IBRAM/MinC. PROVENIÊNCIA: Carlos Oswald, compra, 1963. FOTOGRAFIA: Acervo Museu Nacional de Belas Artes/IBRAM/MinC.

B. [matriz] DATA: 1935[?]. TÉCNICA: Água-forte. MATRIZ: latão. MEDIDAS DA MATRIZ: 28 x 20,3 cm. Sem assinatura. COLEÇÃO Museu Nacional de Belas Artes/IBRAM/ MinC. PROVENIÊNCIA: Maria Isabel Oswald Monteiro, doação, 1982.

LITERATURA: Silva, 1969 (ref.); Exp. Carlos Oswald: o resgate de um mestre, Caixa Cultural, Brasília/Curitiba, 2011, p. 42 (rep.). 


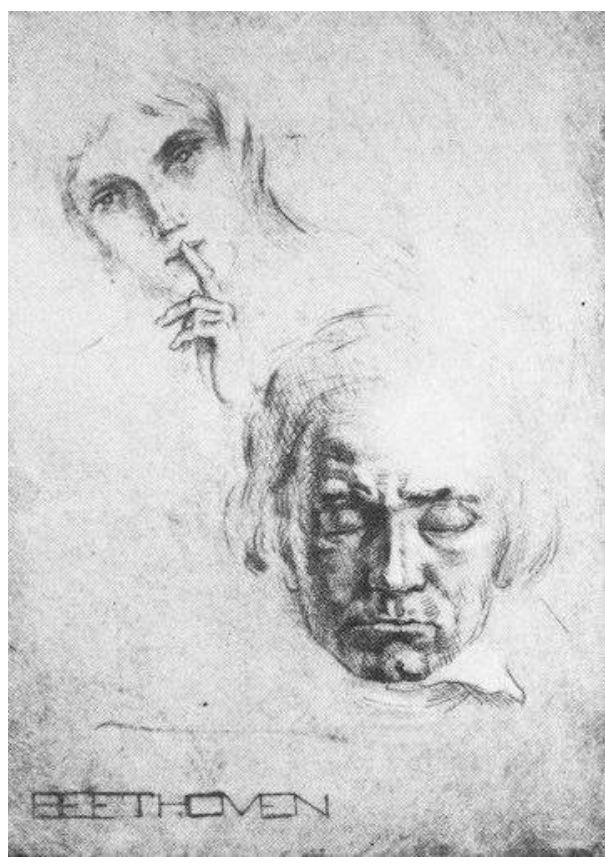

Fig. 128.A LITERATURA: Silva, 1969 (ref.).

128. TÍTULO: Beethoven. nal de Belas Artes/IBRAM/MinC. bel Oswald Monteiro, doação, 1982.

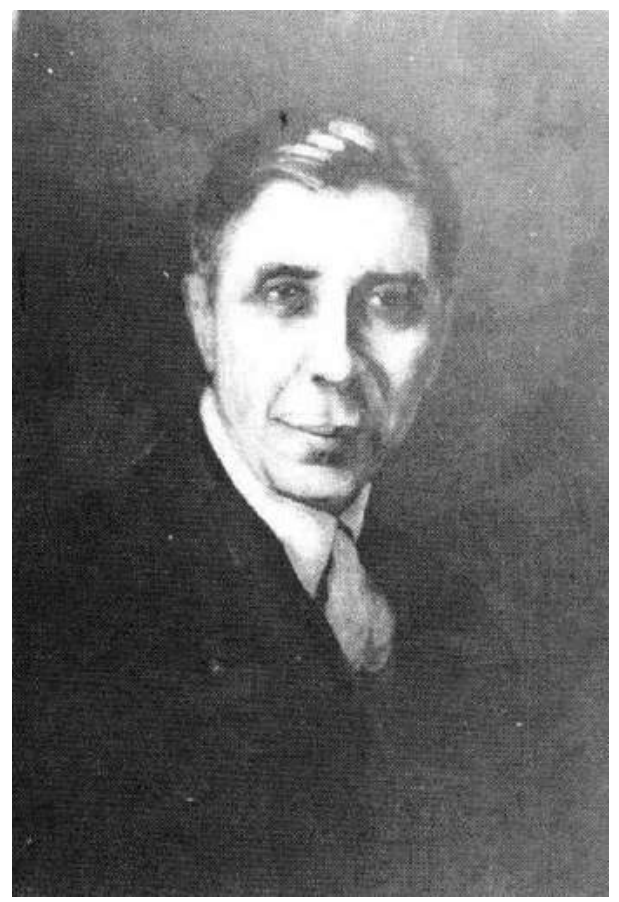

A. DATA: 1935. TÉCNICA: Verniz mole. MEDIDAS: 19,8 x 14,3 cm (mancha), 36,9 x 27,6 cm (papel). IMPRESSÃO: em preto. MATRIZ: latão. MEDIDAS DA MATRIZ: 20 x 14,2 cm. ASSINATURA: "C. Oswald" no papel. COLEÇÃO Museu Nacional de Belas Artes/ IBRAM/MinC. PROVENIÊNCIA: Carlos Oswald, compra, 1963. FOTOGRAFIA: Acervo Museu Nacio-

B. [matriz] DATA: 1935. TÉCNICA: Água-forte. MATRIZ: latão. MEDIDAS DA MATRIZ: 20 x 14,2 cm. Sem assinatura. COLEÇÃO Museu Nacional de Belas Artes/IBRAM/MinC. PROVENIÊNCIA: Maria Isa-

129. TÍTULO: Retrato de um político mineiro [?].

A. DATA: 1935. TÉCNICA: Água-tinta. MEDIDAS: 19,7 x 15,1 cm (mancha), 23,1 x 18,5 cm (papel). IMPRESSÃO: em preto. ASSINATURA: "C. Oswald" no canto inferior direito do papel. COLEÇÃO Museu Nacional de Belas Artes/IBRAM/MinC. PROVENIÊNCIA: Carlos Oswald, compra, 1963. FOTOGRAFIA: Acervo Museu Nacional de Belas Artes/ IBRAM/MinC.

LITERATURA: Silva, 1969 (ref.).

Fig. 129 
130. TÍTULO: Bois molestados pelas moscas.

A. DATA: 1935. TÉCNICA: Água-forte. MEDIDAS: 19,8 x 28 cm (mancha), 32,9 x 47,8 cm (papel). IMPRESSÃO: em preto. MATRIZ: latão. MEDIDAS DA MATRIZ: 20,1 x 28,3 cm. ASSINATURA: "C. Oswald" no canto inferior direito do papel. COLEÇÃO Museu Nacional de Belas Artes/IBRAM/MinC. PROVENIÊNCIA: Carlos Oswald, compra, 1963.

B. DATA: 1935. TÉCNICA: Água-forte. MEDIDAS: 19,8 x 27,8 cm (mancha), 29,8 x $38 \mathrm{~cm}$ (papel). MATRIZ: latão. MEDIDAS DA MATRIZ: 20,1 x 28,3 cm. Sem assinatura. COLEÇÃO Museu Nacional de Belas Artes/IBRAM/MinC. PROVENIÊNCIA: Maria Isabel Oswald Monteiro, doação, 1986.

C. [matriz] DATA: 1935. TÉCNICA: Água-forte. MATRIZ: latão. MEDIDAS DA MATRIZ: 20,1 x 28,3 cm. Sem assinatura. COLEÇÃO Museu Nacional de Belas Artes/IBRAM/MinC. PROVENIÊNCIA: Maria Isabel Oswald Monteiro, doação, 1982.

LITERATURA: Oswald, 1957 (rep.); Silva, 1969 (ref.); Exp. Carlos Oswald: o resgate de um mestre, Caixa Cultural, Brasília/Curitiba, 2011, p. 42 (rep.). 


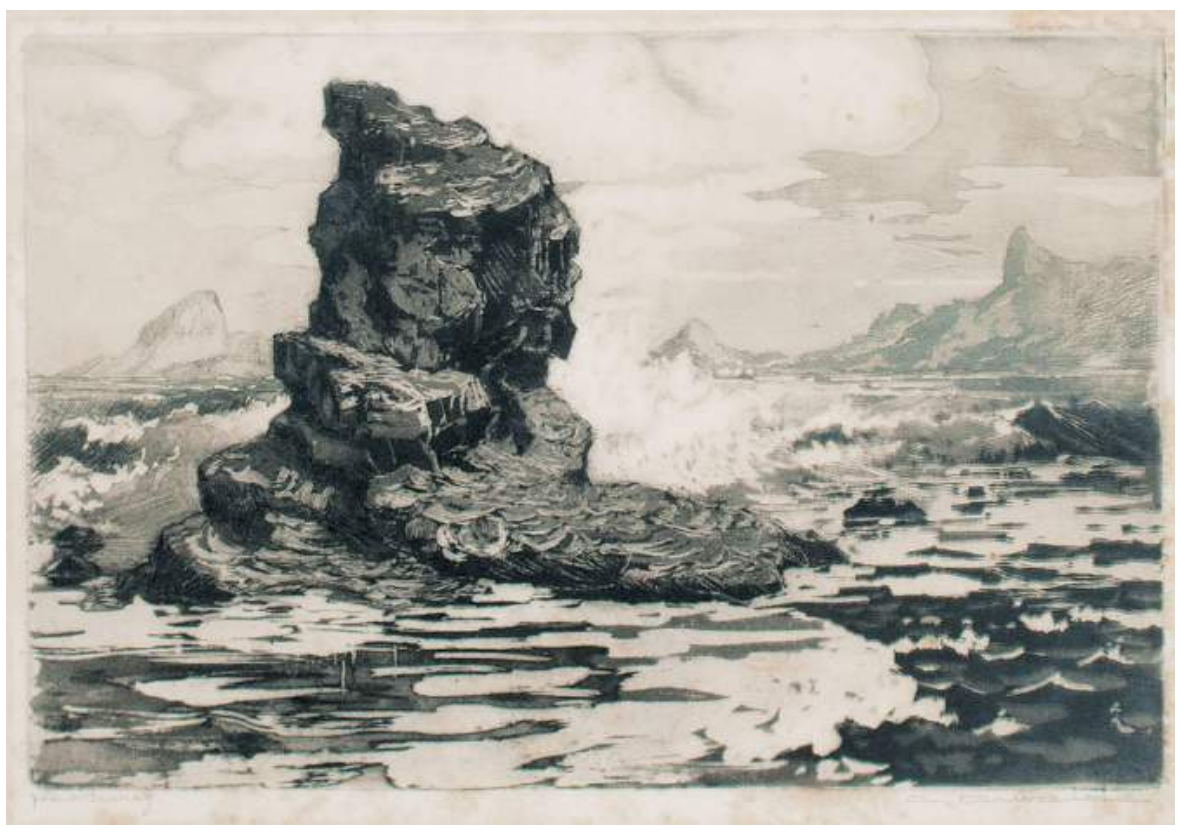

Fig. 131. B

131. TÍTULO: Pedra de Itapuca, Icaraí. VARIANTE: Praia de Icaraí.

A. DATA: 1940. TÉCNICA: Água-forte e água-tinta. MEDIDAS: 18,5 x 27,5 cm (mancha), 25,2 x 32,2 cm (papel). IMPRESSÃO: em preto, aquarelada. MATRIZ: latão. MEDIDAS DA MATRIZ: 19,2 x 27,9 cm. ASSINATURA: “C. Oswald” no canto inferior direito do papel. COLEÇÃO Museu Nacional de Belas Artes/IBRAM/MinC. PROVENIÊNCIA: Carlos Oswald, compra, 1963. FOTOGRAFIA: Acervo Museu Nacional de Belas Artes/IBRAM/MinC.

B. DATA: 1940. TÉCNICA: Água-forte e água-tinta. MEDIDAS: 19 x $28 \mathrm{~cm}$ (mancha), 24 x $31 \mathrm{~cm}$ (papel). IMPRESSÃO: em preto. MATRIZ: latão. MEDIDAS DA MATRIZ: 19,2 x 27,9 cm. ASSINATURA: “C. Oswald” no canto inferior direito do papel. COLEÇÃO particular. FONTE: Evandro Carneiro Leiloeiro, disponível em: <http://www.evandrocarneiroleiloes. com/145675 ?artistId=88060> , acesso em 13/8/2017.

C. DATA: 1979. TÉCNICA: Água-forte e água-tinta. IMPRESSÃO: póstuma, em preto, por Marcello Grassmann e Roberto Grassmann. MATRIZ: latão. MEDIDAS DA MATRIZ: 19,2 x 27,9 cm. Sem assinatura. FONTE: Carlos Oswald: gravuras, Graphus, 1979.

D. DATA: 1987[?]. TÉCNICA: Água-forte e água-tinta. MEDIDAS: 19,9 x 27,2 cm (mancha). IMPRESSÃO: póstuma, em preto, por Noemi Silva Ribeiro para o Gabinete de Gravura do MNBA. MATRIZ: latão. MEDIDAS DA MATRIZ: 19,2 x 27,9 cm. Sem assinatura. ACERVO Fundação Biblioteca Nacional. PROVENIÊNCIA: Gabinete de Gravura do MNBA, doação, 1987.

E. [matriz] DATA: 1940. TÉCNICA: Água-forte e água-tinta. MATRIZ: latão. MEDIDAS DA MATRIZ: 19,2 x 27,9 cm. Sem assinatura. COLEÇÃO Museu Nacional de Belas Artes/ IBRAM/MinC. PROVENIÊNCIA: Maria Isabel Oswald Monteiro, doação, 1982.

LITERATURA: Exp. Seventy-five Latin American Prints, Corcoran Gallery, EUA, 1944; Oswald, 1957, p. 229 (ref.); Silva, 1969 (ref.); Buti, Letycia, 2002, p. 53 (rep.); Exp. Carlos Oswald: o resgate de um mestre, Caixa Cultural, Brasília/Curitiba, 2011, p. 81 (rep.). 


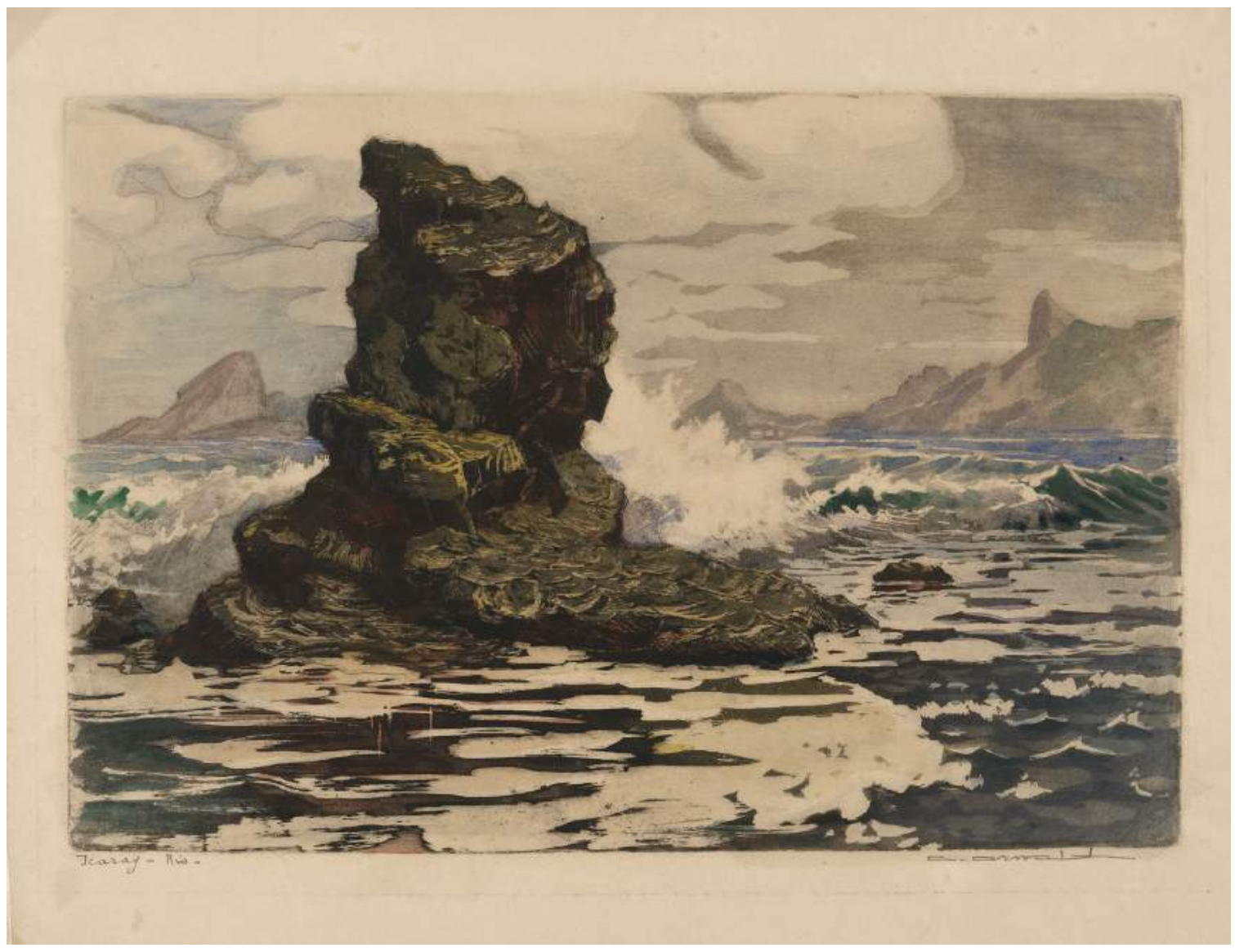

Fig. 131.A

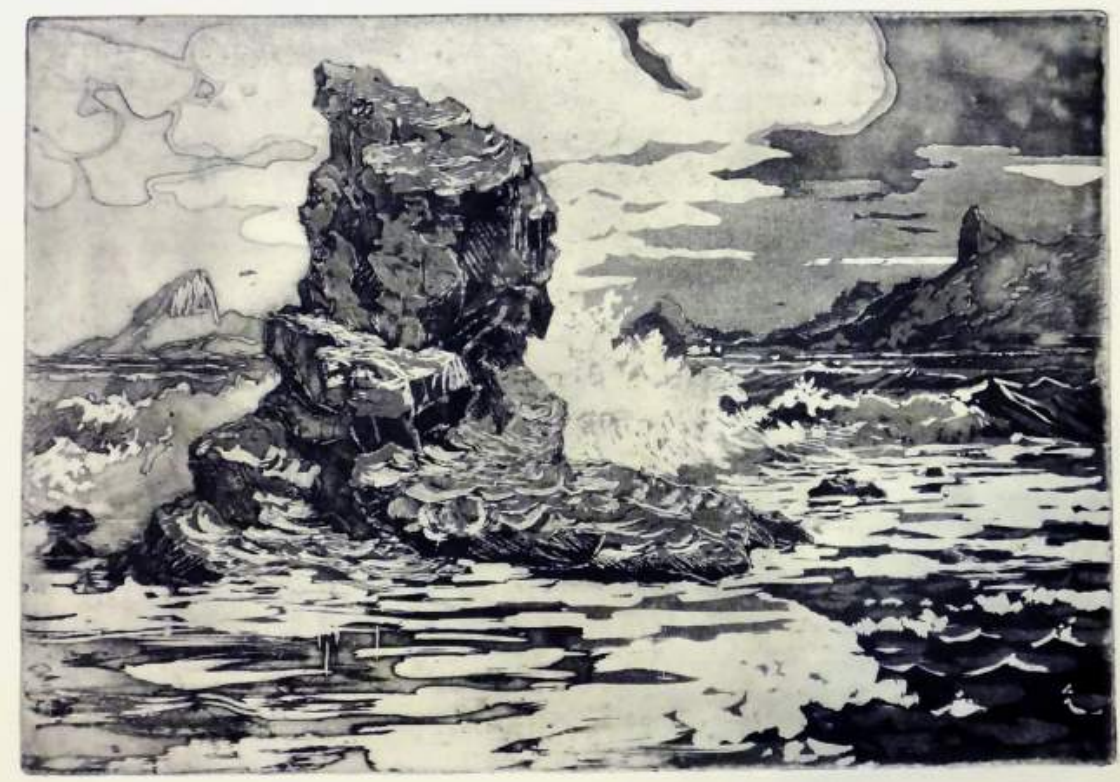




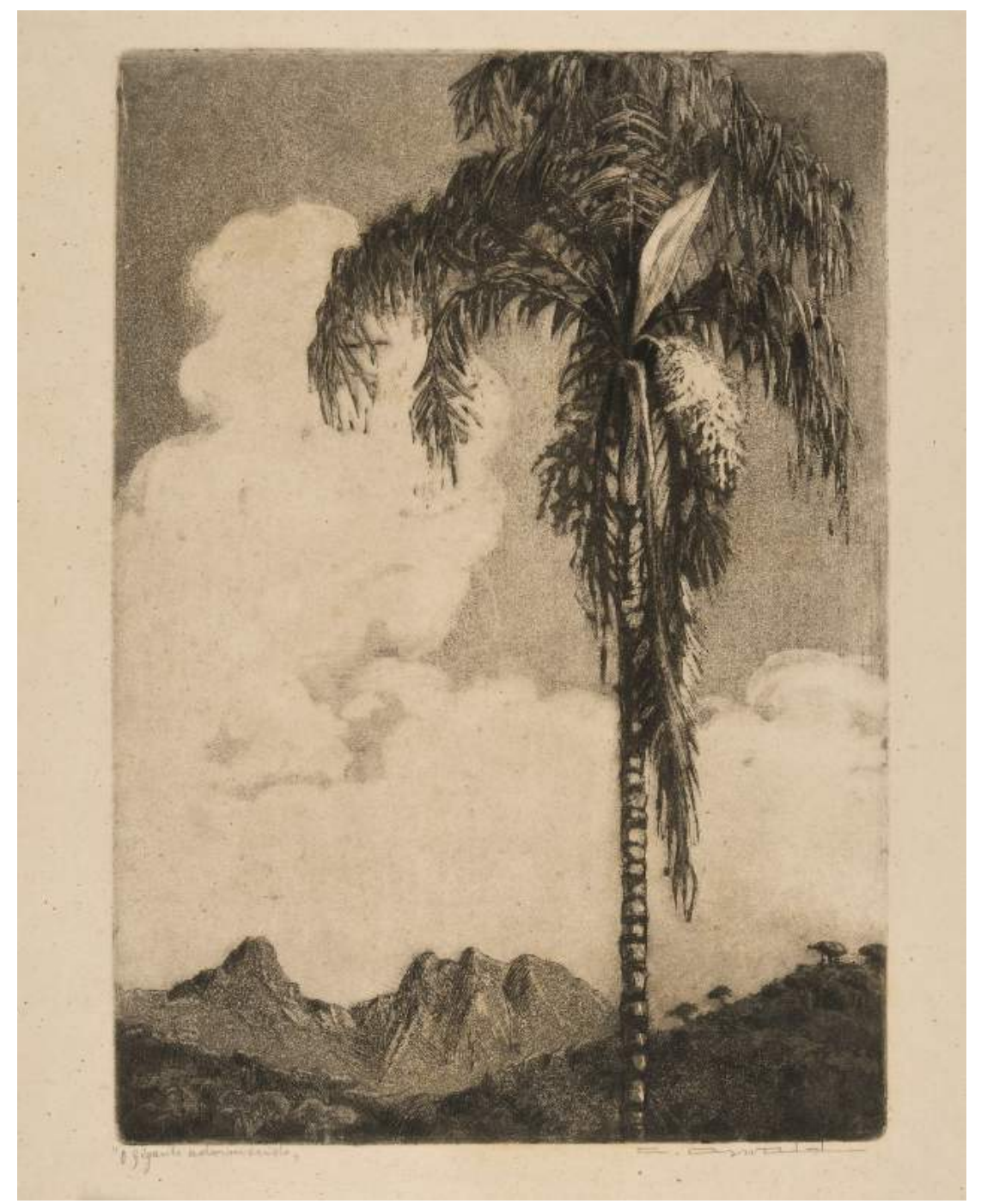

Fig. 132. A

132. TÍTULOS: O gigante adormecido; O gigante adormecido (a Tijuca).

A. DATA: 1940. TÉCNICA: Água-forte e água-tinta. MEDIDAS: 27,5 x $19 \mathrm{~cm}$ (mancha), 36,5 x 27,3 cm (papel). IMPRESSÃO: em preto. MATRIZ: latão. MEDIDAS DA MATRIZ: 27,9 x 19,2 cm. ASSINATURA: "C. Oswald" no canto inferior direito do papel. COLEÇÃO Museu Nacional de Belas Artes/IBRAM/MinC. PROVENIÊNCIA: Carlos Oswald, compra, 1963. FOTOGRAFIA: Acervo Museu Nacional de Belas Artes/IBRAM/MinC.

B. DATA: 1979. TÉCNICA: Água-forte e água-tinta. IMPRESSÃO: póstuma, em preto, por Marcello Grassmann e Roberto Grassmann. MATRIZ: latão. MEDIDAS DA MATRIZ: 27,9 x 19,2 cm. Sem assinatura. FONTE: Carlos Oswald: gravuras, Graphus, 1979.

C. [matriz] DATA: 1940. TÉCNICA: Água-forte e água-tinta. MATRIZ: latão. MEDIDAS DA MATRIZ: 27,9 x 19,2 cm. Sem assinatura. COLEÇÃO Museu Nacional de Belas Artes/ IBRAM/MinC. PROVENIÊNCIA: Maria Isabel Oswald Monteiro, doação, 1982.

LITERATURA: Oswald, 1957, p. 229 (ref.); Silva, 1969 (ref.); Buti, Letycia, 2002, p. 51 (rep.); Exp. Carlos Oswald: o resgate de um mestre, Caixa Cultural, Brasília/Curitiba, 2011, p. 79 (rep.). 


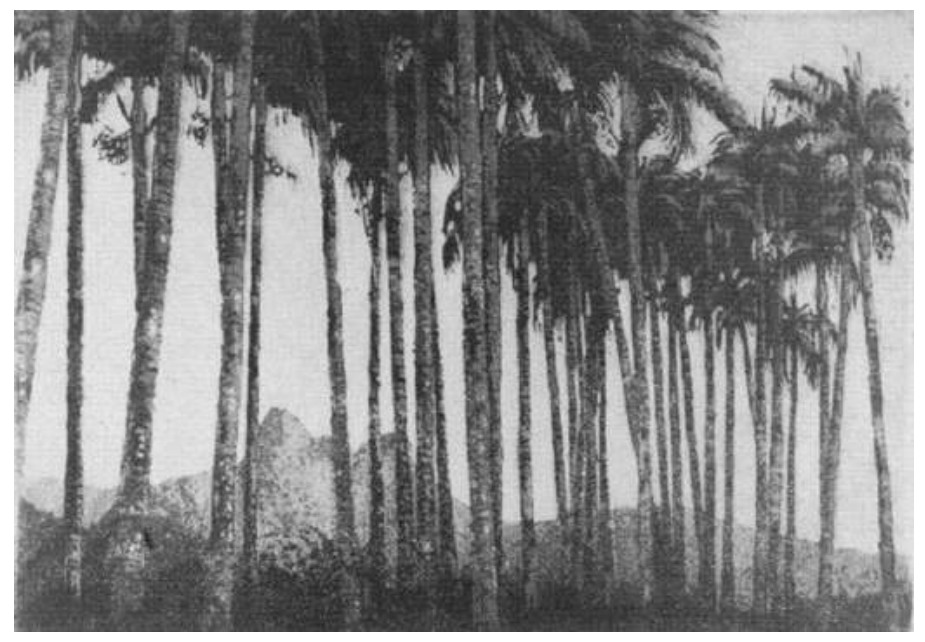

Fig. 133

133. TÍTULO: Palmeiras na Tijuca; Rio, Tijuca.

DATA: 1940. TÉCNICA: Água-tinta. MEDIDAS: 19,4 x 27,8 cm (mancha), 25 x 32,1 cm (papel). IMPRESSÃO: em preto. ASSINATURA: "C. Oswald” no canto inferior direito do papel. COLEÇÃO Museu Nacional de Belas Artes/IBRAM/MinC. PROVENIÊNCIA: Carlos Oswald, compra, 1963. FOTOGRAFIA: Acervo Museu Nacional de Belas Artes/IBRAM/MinC.

LITERATURA: Oswald, 1957, p. 229 (ref.); Silva, 1969 (ref.).

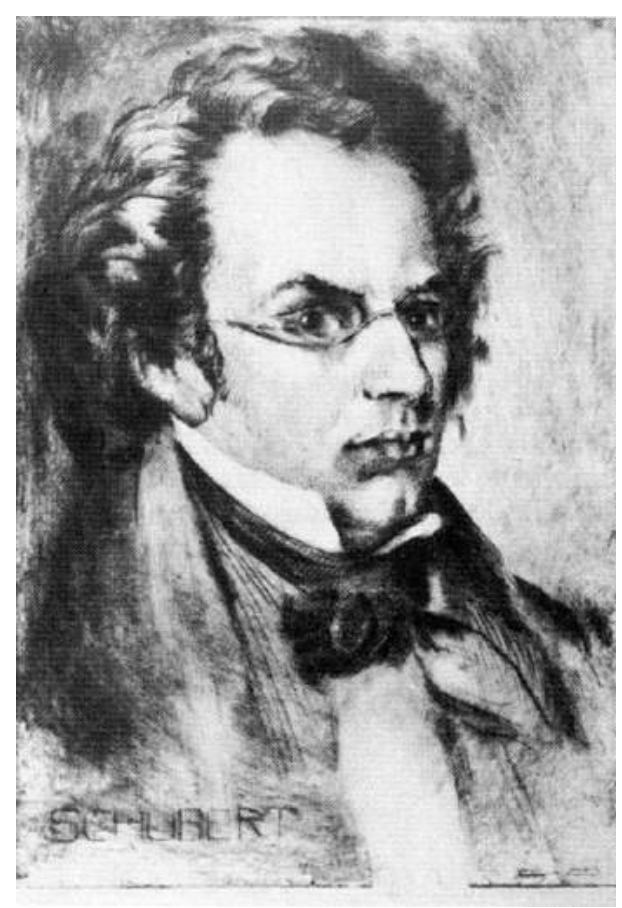

Fig. 1341982.
134. TÍTULO: Schubert.

A. DATA: 1943. TÉCNICA: Ponta seca. MEDIDAS: 27,9 x 19,5 cm (mancha), 32,4 x 24,9 cm (papel). IMPRESSÃO: em preto. MATRIZ: latão. MEDIDAS DA MATRIZ: 28,2 X 20,1 cm. ASSINATURA: "C. Oswald" no papel, monograma "CO" gravado no canto inferior direito da mancha. COLEÇÃO Museu Nacional de Belas Artes/IBRAM/MinC. PROVENIÊNCIA: Carlos Oswald, compra, 1963. FOTOGRAFIA: Acervo Museu Nacional de Belas Artes/IBRAM/MinC.

B. [matriz] DATA: 1943. MATRIZ: latão. MEDIDAS DA MATRIZ: 28,2 X 20,1 cm. ASSINATURA: monograma "CO" no canto inferior esquerdo. COLEÇÃO Museu Nacional de Belas Artes/IBRAM/MinC. PROVENIÊNCIA: Maria Isabel Oswald Monteiro, doação,

LITERATURA: Silva, 1969 (ref.). 


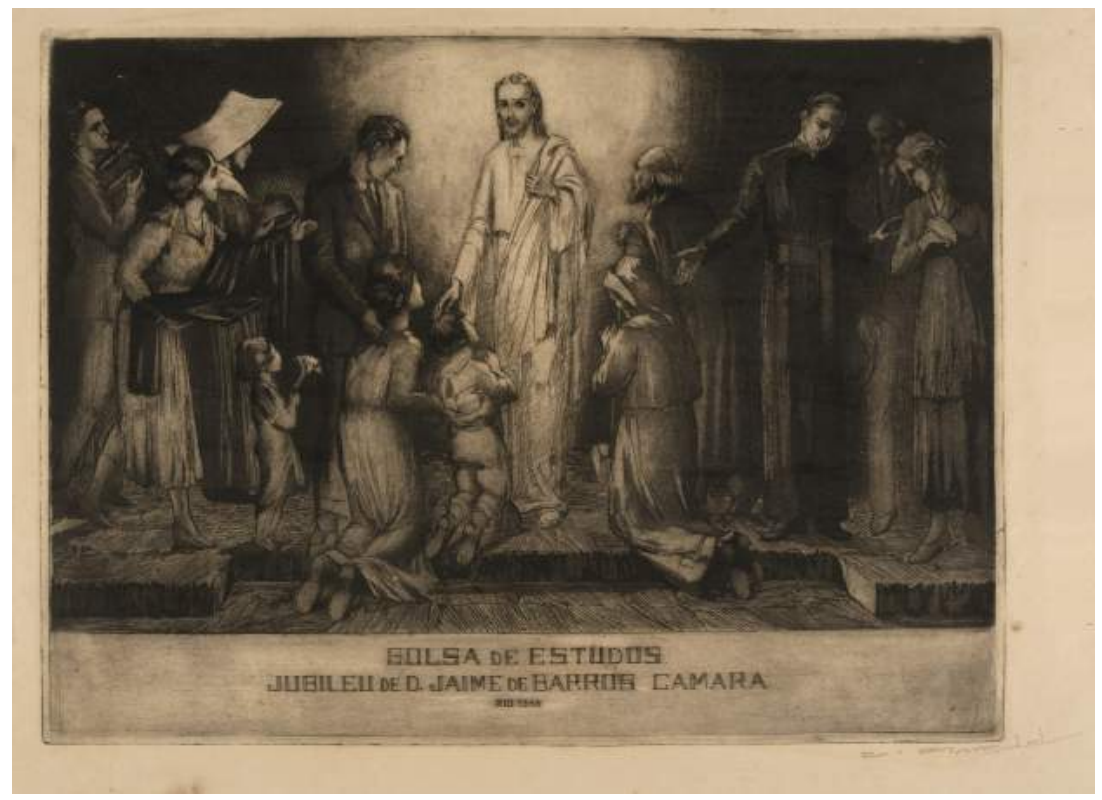

Fig. 135.A

135. TÍTULO: Bolsa de Estudos Jubileu de D. Jaime de Barros Camara [Diploma das Vocações Sacerdotais]

A. DATA: 1945 [?]. TÉCNICA: água-forte e água-tinta. MEDIDAS: 29,2 x 39,8 cm (mancha); 40,5 x $66 \mathrm{~cm}$ (papel). IMPRESSÃO: em preto. MATRIZ: latão. MEDIDAS DA MATRIZ: 20 x 40,1 cm. ASSINATURA: "C. Oswald" no canto inferior direito do papel. COLEÇÃO Museu Nacional de Belas Artes/IBRAM/MinC. PROVENIÊNCIA: Carlos Oswald, compra, 1963. FOTOGRAFIA: Acervo Museu Nacional de Belas Artes/IBRAM/MinC. [O MNBA possui mais dois exemplares da gravura].

B. DATA: 1945 [?]. TÉCNICA: água-forte e água-tinta. MEDIDAS: 29 x 39,5 cm (mancha); 43,5 x 56,5 cm (papel). IMPRESSÃO: em preto. MATRIZ: latão. MEDIDAS DA MATRIZ: 20 x 40,1 cm. ASSINATURA: "C. Oswald” no papel. COLEÇÃO Museu Nacional de Belas Artes/IBRAM/MinC. PROVENIÊNCIA: Guilherme Schubert, doação, 1985.

E. [matriz] DATA: 1945 [?]. TÉCNICA: água-forte e água-tinta. MATRIZ: latão. MEDIDAS DA MATRIZ: 20 x 40,1 cm. Sem assinatura. COLEÇÃO Museu Nacional de Belas Artes/ IBRAM/MinC. PROVENIÊNCIA: Maria Isabel Oswald Monteiro, doação, 1982.

LITERATURA: Silva, 1969 (ref.); Exp. Carlos Oswald: o resgate de um mestre, Caixa Cultural, Brasília/Curitiba, 2011, p. 71 (rep.). 


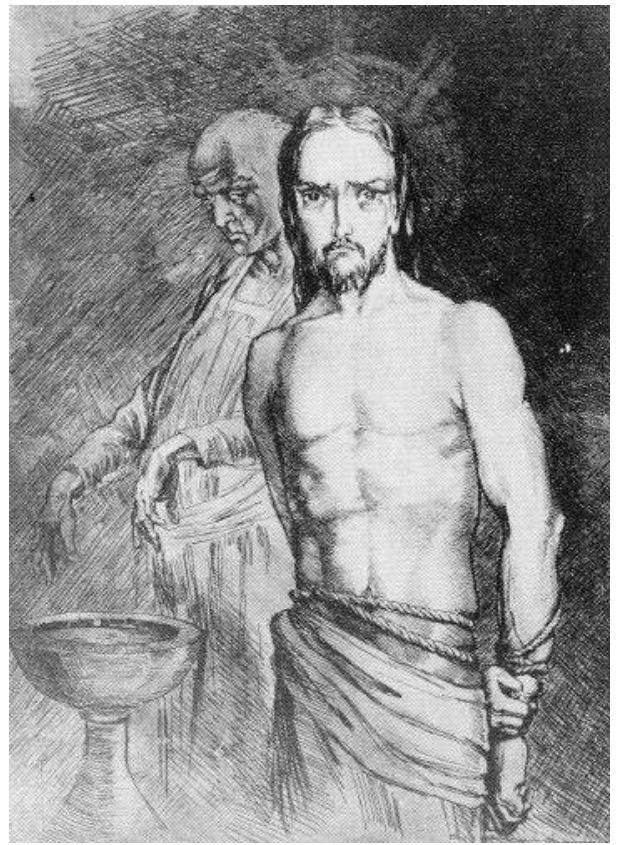

Fig. 136. A

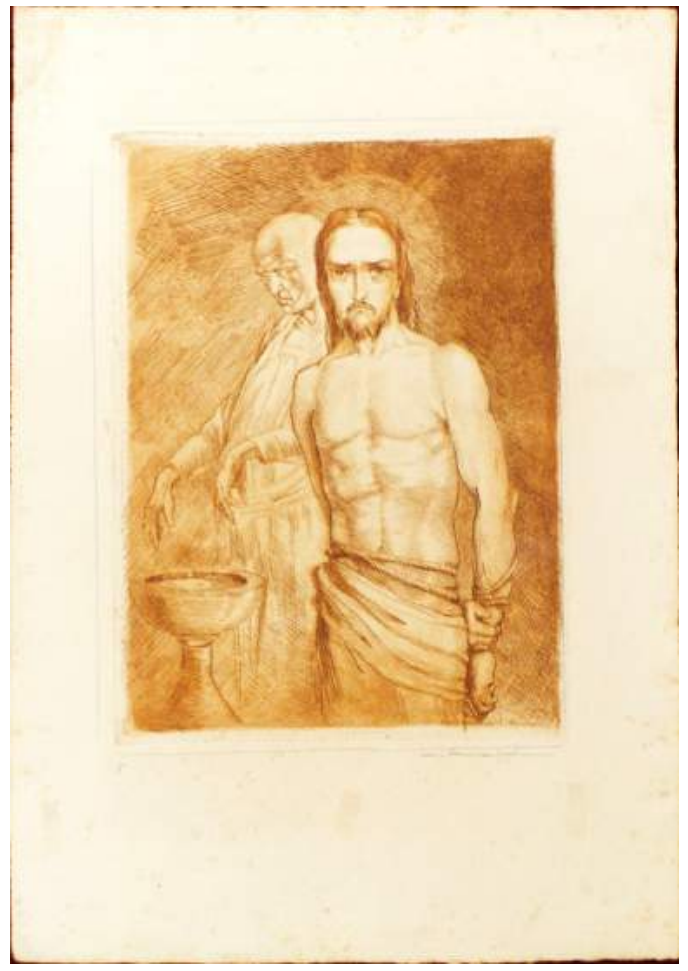

Fig. 137

136. TÍTULO: Via Sacra [ $1^{\mathrm{a}}$ estação - Jesus Condenado]. VARIANTE: Jesus condenado.

A. DATA: 1946. TÉCNICA: Água-forte. MEDIDAS: 35,8 x 26,2 cm (mancha); 51,1 x 34,1 cm (papel). IMPRESSÃO: em preto. MATRIZ: latão. MEDIDAS DA MATRIZ: 37,2 x 27,1 cm. ASSINATURA: "C. Oswald" no papel, "C. Oswald" no canto inferior direito da mancha. COLEÇÃO Museu Nacional de Belas Artes/IBRAM/MinC. PROVENIÊNCIA: Carlos Oswald, compra, 1963. FOTOGRAFIA: Acervo Museu Nacional de Belas Artes/IBRAM/MinC.

B. DATA: 1946. TÉCNICA: Água-forte. IMPRESSÃO: em preto. MATRIZ: latão. MEDIDAS DA MATRIZ: 37,2 x 27,1 cm. ASSINATURA: "C. Oswald" no canto inferior direito do papel, "C. Oswald" no canto inferior direito da mancha. COLEÇÃO Família Oswald.

C. [matriz] DATA: 1946. TÉCNICA: Água-forte. MATRIZ: latão. MEDIDAS DA MATRIZ: 37,2 x 27,1 cm. ASSINATURA: "C. Oswald" no canto inferior esquerdo. COLEÇÃO Museu Nacional de Belas Artes/IBRAM/MinC. PROVENIÊNCIA: Maria Isabel Oswald Monteiro, doação, 1982.

LITERATURA: Correio da Manhã, RJ, 18/6/1950 (ref.); A Cruz, RJ, 6/8/1950 (artigo); Silva, Para todos, RJ, 16/11/1956 (artigo); Oswald, 1957, p.231 (ref.); Silva, 1969 (ref.).

137. TÍTULO: Via Sacra [1ª estação - Jesus Condenado]. VARIANTE: Jesus condenado.

DATA: 1946. TÉCNICA: Água-forte. IMPRESSÃO: em marrom. MATRIZ: latão. MEDIDAS DA MATRIZ: 37,2 x 27,1 cm. ASSINATURA: "C. Oswald" no canto inferior direito do papel, "C. Oswald" no canto inferior direito da mancha. COLEÇÃO Família Oswald. 


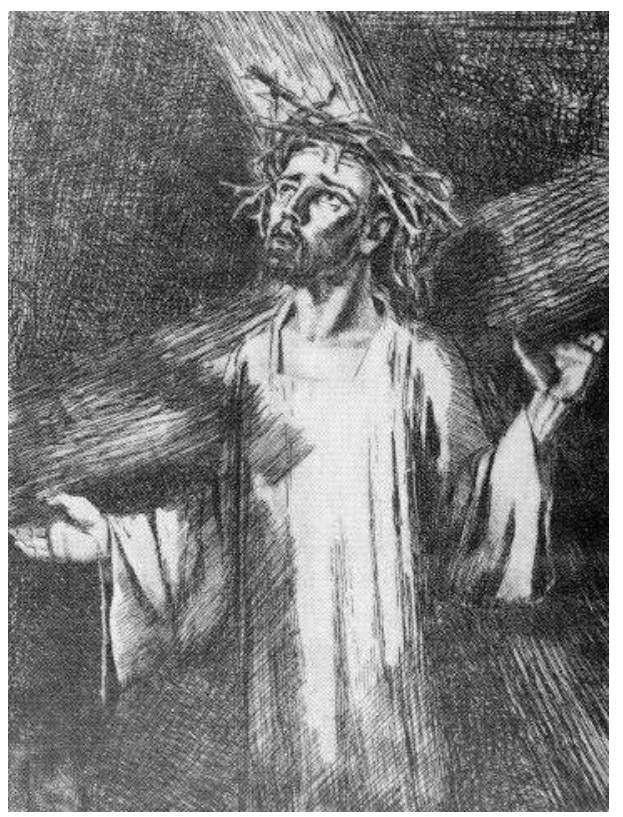

Fig. 138.A

138. TÍTULO: Via Sacra [2 $2^{\mathrm{a}}$ estação - Jesus carregando a Cruz]. VARIANTE: Jesus carregando a Cruz.

A. DATA: 1946. TÉCNICA: Água-forte. MEDIDAS: 35,8 x 26,5 cm (mancha); 50 x 35 cm (papel). IMPRESSÃO: em preto. MATRIZ: latão. MEDIDAS DA MATRIZ: 37,2 x 27,1 cm. ASSINATURA: "C. Oswald” no papel, "C. Oswald” gravado no canto inferior esquerdo da mancha. COLEÇÃO Museu Nacional de Belas Artes/IBRAM/MinC. PROVENIÊNCIA: Carlos Oswald, compra, 1963. FOTOGRAFIA: Acervo Museu Nacional de Belas Artes/IBRAM/MinC.

B. [matriz] DATA: 1946. TÉCNICA: Água-forte. MATRIZ: latão. MEDIDAS DA MATRIZ: 37,2 x 27,1 cm. ASSINATURA: "C. Oswald" no canto inferior direito. COLEÇÃO Museu Nacional de Belas Artes/IBRAM/MinC. PROVENIÊNCIA: Maria Isabel Oswald Monteiro, doação, 1982.

LITERATURA: Illustração Brasileira, RJ, 2/1948, não p. (rep.); Correio da Manhã, RJ, 18/6/1950 (ref.); A Cruz, RJ, 6/8/1950 (artigo); Silva, Para todos, RJ, 16/11/1956 (artigo); Illustração Brasileira, RJ, 7/1957, p. 15 (rep.); Oswald, 1957, p.231 (ref.); Silva, 1969 (ref.). 


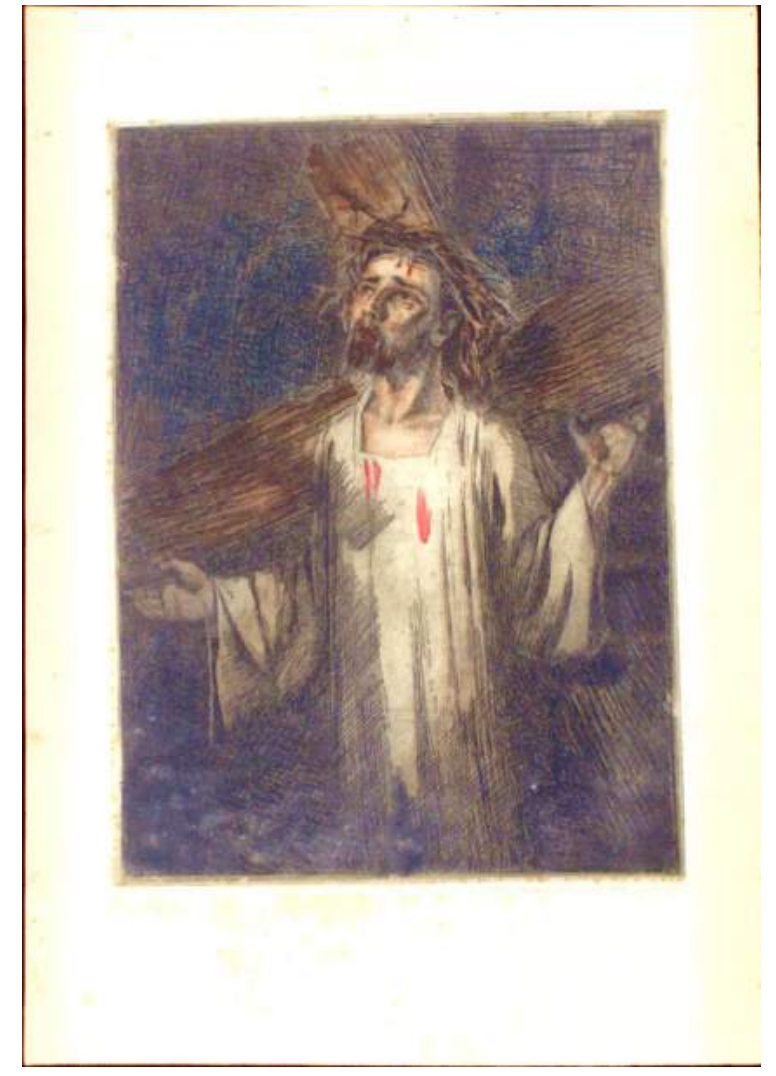

Fig. 139

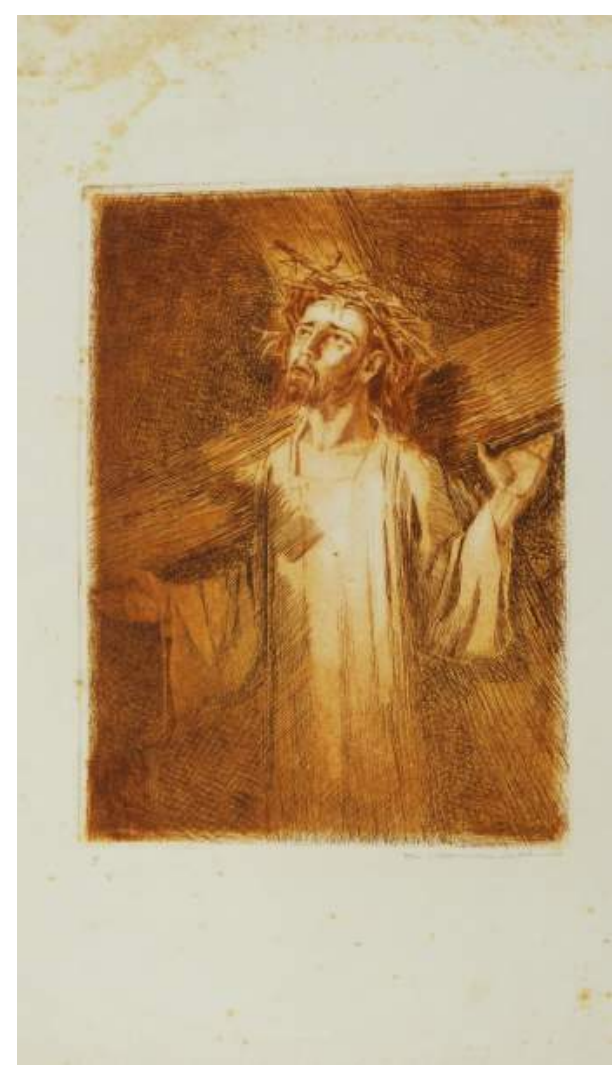

Fig. 140

139. TÍTULO: Via Sacra [2 $2^{\text {a }}$ estação - Jesus carregando a Cruz]. VARIANTE: Jesus carregando a Cruz.

DATA: 1946. TÉCNICA: Água-forte. IMPRESSÃO: em cores. MATRIZ: latão. MEDIDAS DA MATRIZ: 37,2 x 27,1 cm. ASSINATURA: "C. Oswald" no canto inferior direito do papel. COLEÇÃO Famíla Oswald.

140. TÍTULO: Via Sacra [2a estação - Jesus carregando a Cruz]. VARIANTE: Jesus carregando a Cruz.

DATA: 1946. TÉCNICA: Água-forte. IMPRESSÃO: em marrom. MATRIZ: latão. MEDIDAS DA MATRIZ: 37,2 x 27,1 cm. ASSINATURA: “C. Oswald” no canto inferior direito do papel. COLEÇÃo Família Oswald. 


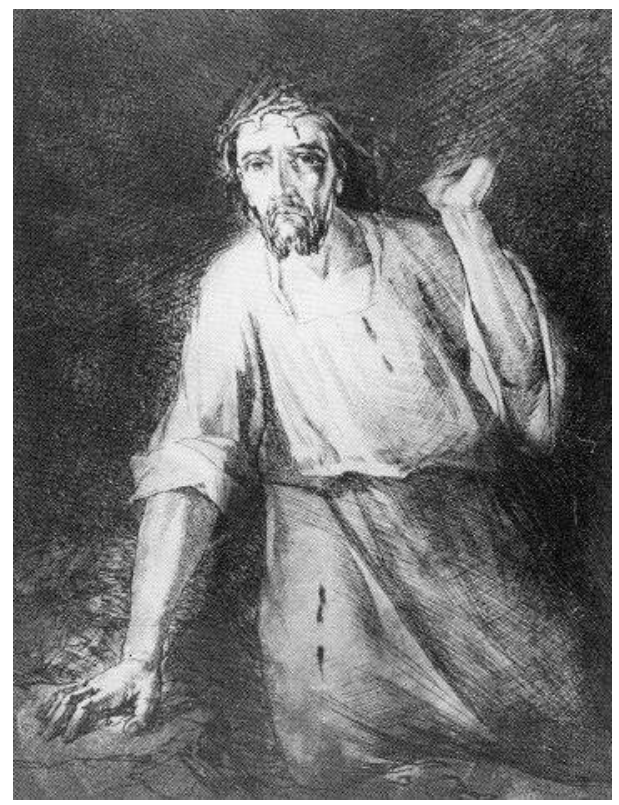

Fig. 141.A

141. TÍTULO: Via Sacra [ $3^{\mathrm{a}}$ estação - Jesus cai pela primeira vez]. VARIANTE: Jesus cai pela primeira vez.

A. DATA: 1946. TÉCNICA: Água-forte e água-tinta. MEDIDAS: 35,1 x 26 cm (mancha); 51,2 x 34,3 cm (papel). IMPRESSÃO: em preto. MATRIZ: cobre. MEDIDAS DA MATRIZ: 36,9 x $27 \mathrm{~cm}$. ASSINATURA: "C. Oswald" no papel, "C. Oswald” gravado no canto inferior esquerdo da mancha. COLEÇÃO Museu Nacional de Belas Artes/IBRAM/MinC. PROVENIÊNCIA: Carlos Oswald, compra, 1963. FOTOGRAFIA: Acervo Museu Nacional de Belas Artes/IBRAM/MinC.

B. [matriz] DATA: 1946. TÉCNICA: Água-forte e água-tinta. MATRIZ: cobre. MEDIDAS DA MATRIZ: 36,9 x 27 cm. ASSINATURA: "C. Oswald” na matriz. COLEÇÃO Museu Nacional de Belas Artes/IBRAM/MinC. PROVENIÊNCIA: Maria Isabel Oswald Monteiro, doação, 1982.

LITERATURA: Correio da Manhã, RJ, 18/6/1950 (ref.); A Cruz, RJ, 6/8/1950 (artigo); Silva, Para todos, RJ, 16/11/1956 (artigo); Oswald, 1957, p.231 (ref.); Silva, 1969 (ref.). 


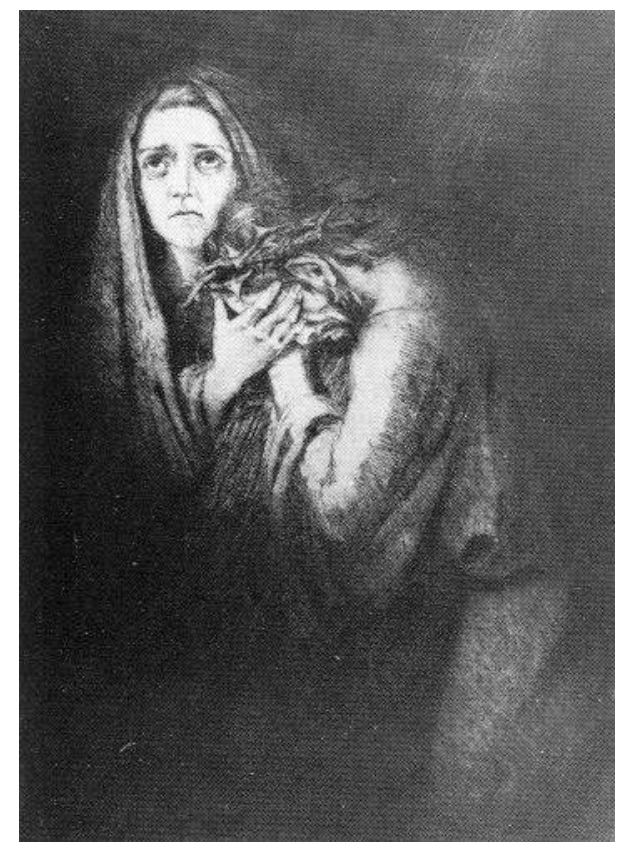

Fig. 142.A

142. TÍTULO: Via Sacra [4 $4^{\mathrm{a}}$ estação - O encontro]. VARIANTE: O encontro.

A. DATA: 1946. TÉCNICA: Água-forte e água-tinta. MEDIDAS: 35,3 x 25,6 cm (mancha); 51,2 x 34,1 cm (papel). IMPRESSÃO: em preto. MATRIZ: latão. MEDIDAS DA MATRIZ: 37,2 x 26,9 cm. ASSINATURA: "C. Oswald” no papel. COLEÇÃO Museu Nacional de Belas Artes/IBRAM/MinC. PROVENIÊNCIA: Carlos Oswald, compra, 1963. FOTOGRAFIA: Acervo Museu Nacional de Belas Artes/IBRAM/MinC.

B. [matriz] DATA: 1946. TÉCNICA: Água-forte e água-tinta. MATRIZ: cobre. MEDIDAS DA MATRIZ: 37,2 x 26,9 cm. ASSINATURA: “C. Oswald”. COLEÇÃO Museu Nacional de Belas Artes/IBRAM/MinC. PROVENIÊNCIA: Maria Isabel Oswald Monteiro, doação, 1982.

LITERATURA: Correio da Manhã, RJ, 18/6/1950 (ref.); A Cruz, RJ, 6/8/1950 (artigo); Silva, Para todos, RJ, 16/11/1956 (artigo); Oswald, 1957, p.231 (ref.); Silva, 1969 (ref.). 


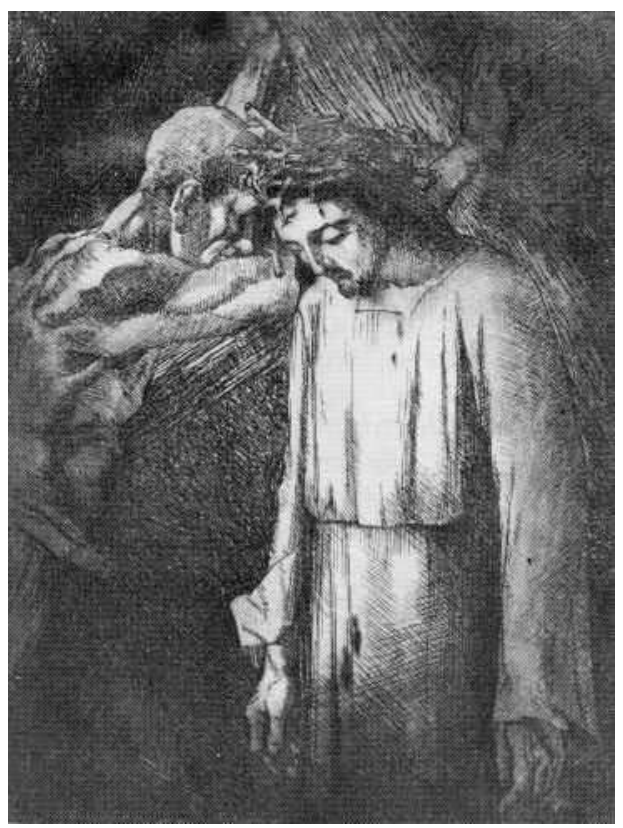

Fig. 143. A

143. TÍTULO: Via Sacra [5 $5^{\text {a }}$ estação - O Cirineu]. VARIANTE: O Cirineu.

A. DATA: 1946. TÉCNICA: Água-forte. MEDIDAS: 34,5 x 25,3 cm (mancha); 50,7 x 36 cm (papel). IMPRESSÃO: em preto. MATRIZ: cobre. MEDIDAS DA MATRIZ: 36,9 x $27 \mathrm{~cm}$. ASSINATURA: "C. Oswald" no papel, "C. Oswald" no canto inferior esquerdo da mancha. COLEÇÃO Museu Nacional de Belas Artes/IBRAM/MinC. PROVENIÊNCIA: Carlos Oswald, compra, 1963. FOTOGRAFIA: Acervo Museu Nacional de Belas Artes/IBRAM/MinC. B. [matriz] DATA: 1946. TÉCNICA: Água-forte. MATRIZ: cobre. MEDIDAS DA MATRIZ: 36,9 x 27 cm. ASSINATURA: "C. Oswald” no canto inferior direito. COLEÇÃO Museu Nacional de Belas Artes/IBRAM/MinC. PROVENIÊNCIA: Maria Isabel Oswald Monteiro, doação, 1982.

LITERATURA: Correio da Manhã, RJ, 18/6/1950 (ref.); A Cruz, RJ, 6/8/1950 (artigo); Silva, Para todos, RJ, 16/11/1956 (artigo); Oswald, 1957, p.231 (ref.); Silva, 1969 (ref.). 


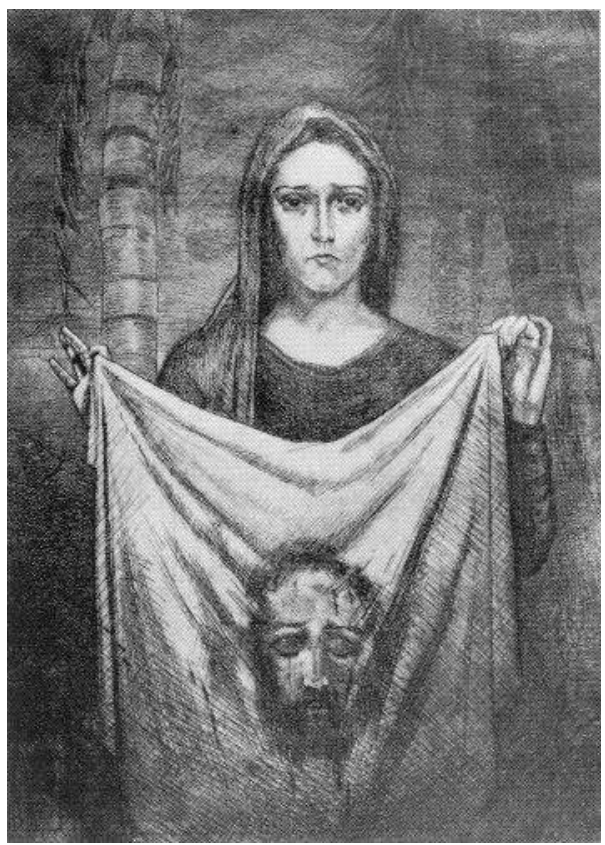

Fig. 144.A

144. TÍTULO: Via Sacra [6 $6^{\mathrm{a}}$ estação - Verônica]. VARIANTE: Verônica.

A. DATA: 1946. TÉCNICA: Água-forte. MEDIDAS: 35,5 x 26,7 cm (mancha); 50 x 34,8 cm (papel). IMPRESSÃO: em preto. MATRIZ: latão. MEDIDAS DA MATRIZ: $37 \mathrm{x} 27,1 \mathrm{~cm}$. ASSINATURA: "C. Oswald" gravado no canto inferior esquerdo da mancha. COLEÇÃO Museu Nacional de Belas Artes/IBRAM/MinC. PROVENIÊNCIA: Carlos Oswald, compra, 1963. FOTOGRAFIA: Acervo Museu Nacional de Belas Artes/IBRAM/MinC.

B. [matriz] DATA: 1946. TÉCNICA: Água-forte. MATRIZ: latão. MEDIDAS DA MATRIZ: 37 x 27,1 cm. ASSINATURA: "C. Oswald” no canto inferior direito. COLEÇÃO Museu Nacional de Belas Artes/IBRAM/MinC. PROVENIÊNCIA: Maria Isabel Oswald Monteiro, doação, 1982.

LITERATURA: Correio da Manhã, RJ, 18/6/1950 (ref.); A Cruz, RJ, 6/8/1950 (artigo); Silva, Para todos, RJ, 16/11/1956 (artigo); Oswald, 1957, p.231 (ref.); Silva, 1969 (ref.). 


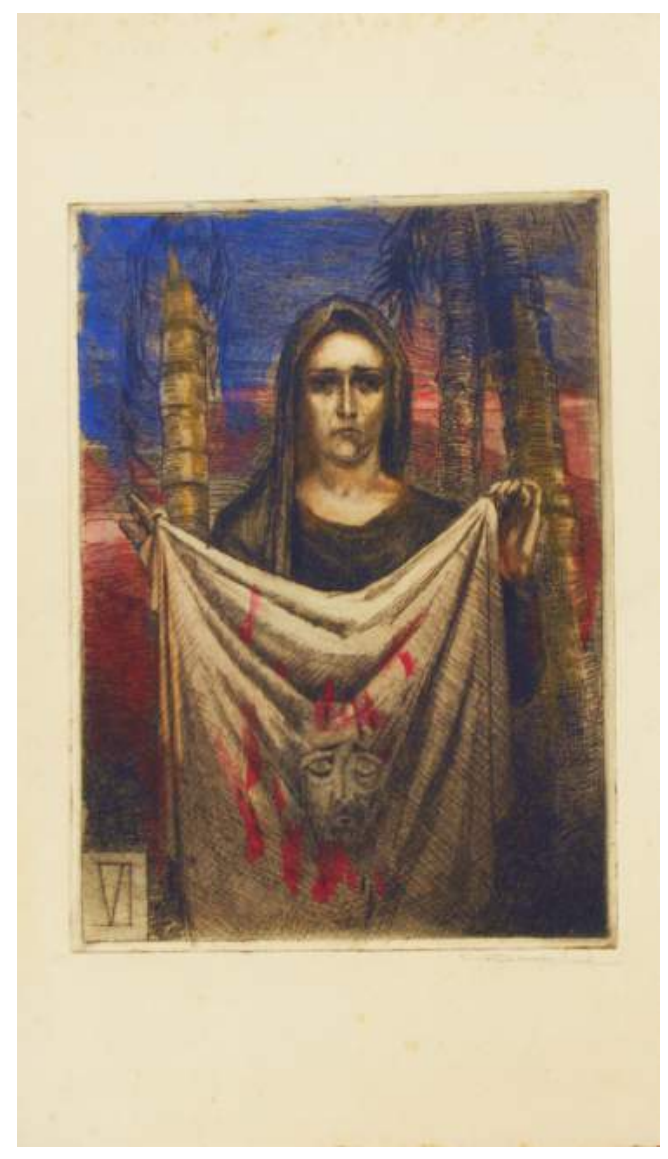

Fig. 145

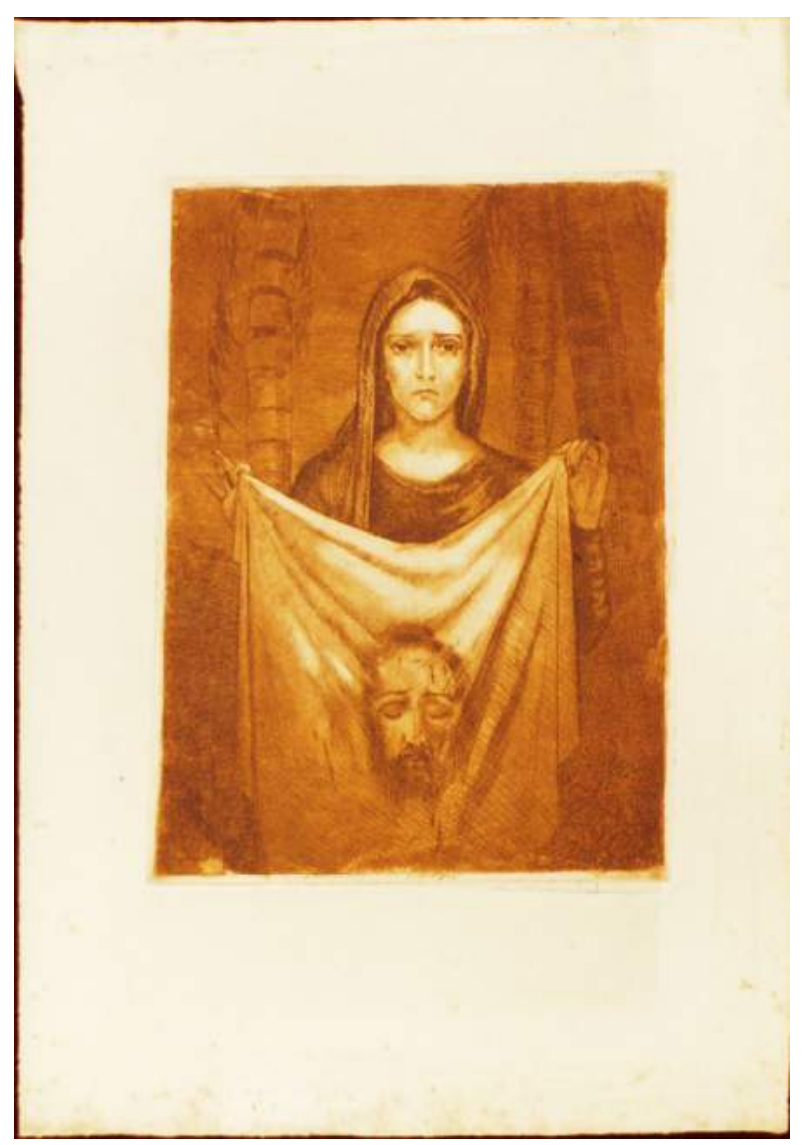

Fig. 146

145. TÍTULO: Via Sacra [6 $6^{\mathrm{a}}$ estação - Verônica]. VARIANTE: Verônica.

DATA: 1946. TÉCNICA: Água-forte. IMPRESSÃO: em preto, impressão pintada. MATRIZ: cobre. MEDIDAS DA MATRIZ: 37 x 27,1 cm. ASSINATURA: "C. Oswald” no canto inferior direito do papel; com o número "VI" gravado no canto inferior esquerdo da mancha. COLEÇÃO Família Oswald.

146. TÍTULO: Via Sacra [6 ${ }^{a}$ estação - Verônica]. VARIANTE: Verônica.

DATA: 1946. TÉCNICA: Água-forte. IMPRESSÃO: em marrom. MATRIZ: cobre. MEDIDAS DA MATRIZ: 37 x 27,1 cm. ASSINATURA: "C. Oswald" no canto inferior direito do papel. COLEÇÃO Família Oswald. 


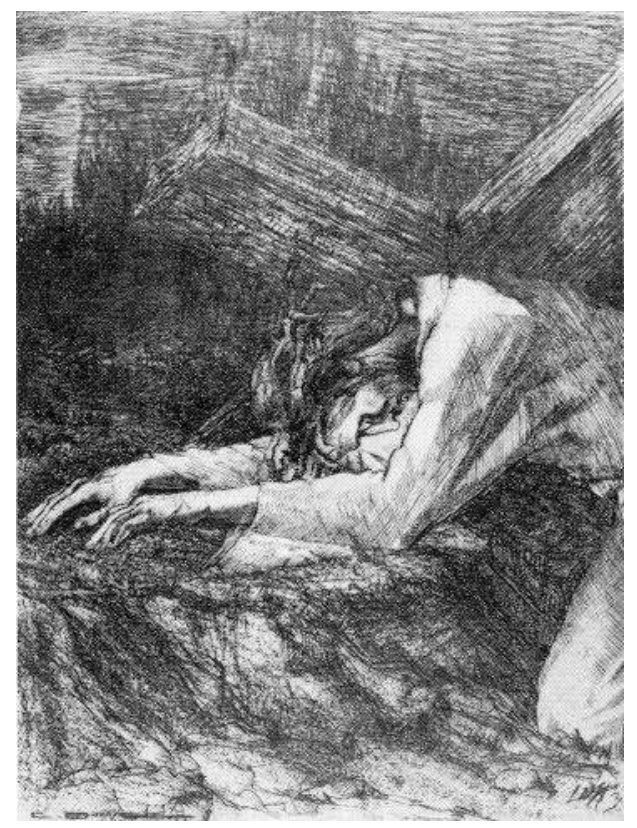

Fig. 147.A

147. TÍTULO: Via Sacra [7 $7^{\text {a }}$ estação - Jesus cai pela segunda vez]. VARIANTE: Jesus cai pela segunda vez.

A. DATA: 1946. TÉCNICA: Água-forte e água-tinta. MEDIDAS: 35 x $26 \mathrm{~cm}$ (mancha); 50,2 x $35 \mathrm{~cm}$ (papel). IMPRESSÃO: em preto. MATRIZ: latão. MEDIDAS DA MATRIZ: 37,1 x 27,1 cm. ASSINATURA: "C. Oswald" no papel, "C. Oswald” no canto inferior esquerdo da mancha. COLEÇÃO Museu Nacional de Belas Artes/IBRAM/MinC. PROVENIÊNCIA: Carlos Oswald, compra, 1963. FOTOGRAFIA: Acervo Museu Nacional de Belas Artes/IBRAM/ MinC.

B. [matriz] DATA: 1946. TÉCNICA: Água-forte e água-tinta. MATRIZ: latão. MEDIDAS DA MATRIZ: 37,1 x 27,1 cm. ASSINATURA: “C. Oswald” no canto inferior direito. COLEÇÃO Museu Nacional de Belas Artes/IBRAM/MinC. PROVENIÊNCIA: Maria Isabel Oswald Monteiro, doação, 1982.

LITERATURA: Correio da Manhã, RJ, 18/6/1950 (ref.); A Cruz, RJ, 6/8/1950 (artigo); Silva, Para todos, RJ, 16/11/1956 (artigo); Oswald, 1957, p.231 (ref.); Silva, 1969 (ref.). 


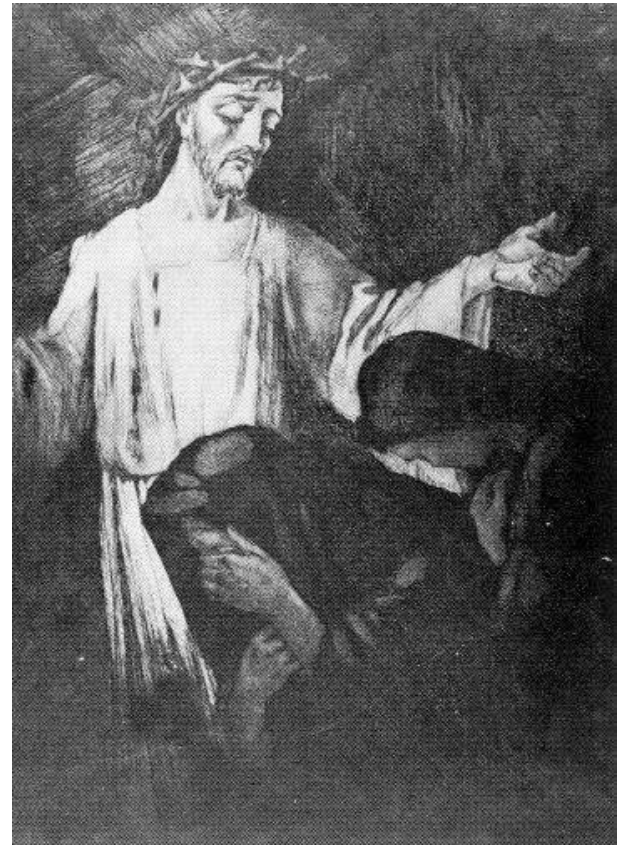

Fig. 148

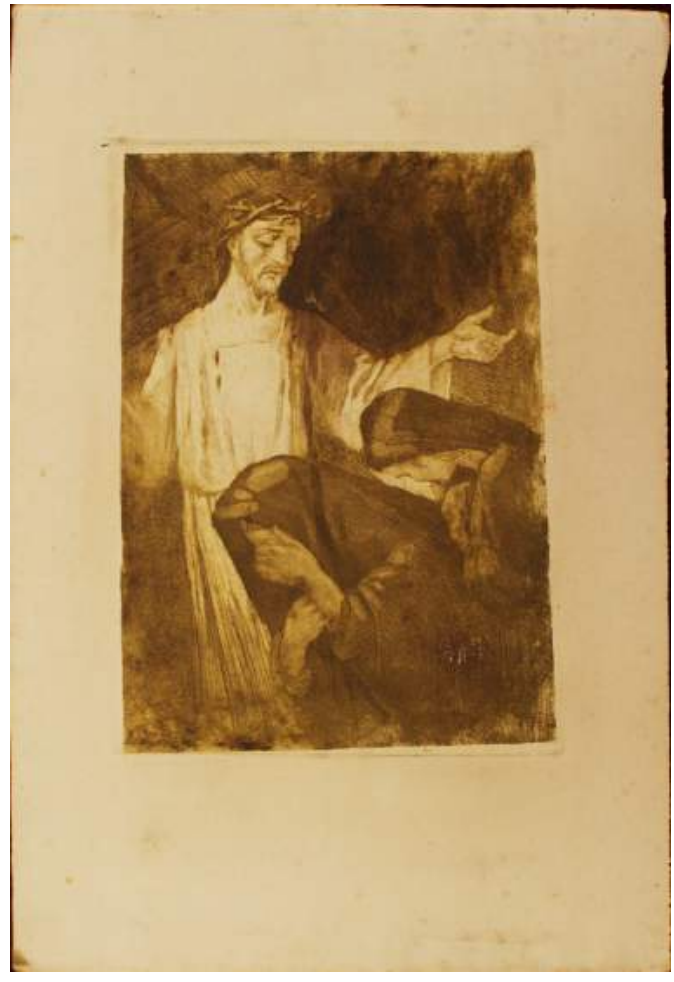

Fig. 149

148. TÍTULO: Via Sacra [8 $8^{\text {a }}$ estação - Jesus entre as mulheres de Jerusalém]. VARIANTE: Jesus entre as mulheres de Jerusalém.

A. DATA: 1946. TÉCNICA: Água-forte e água-tinta. MEDIDAS: 36 x 25,6 cm (mancha); 48 x 33,1 cm (papel). IMPRESSÃO: em preto. MATRIZ: latão. MEDIDAS DA MATRIZ: 37 x 27,1 cm. ASSINATURA: "C. Oswald" no canto inferior esquerdo da mancha, "C. Oswald" no papel. COLEÇÃO Museu Nacional de Belas Artes/IBRAM/MinC. PROVENIÊNCIA: Carlos Oswald, compra, 1963. FOTOGRAFIA: Acervo Museu Nacional de Belas Artes/ IBRAM/MinC.

B. [matriz] DATA: 1946. TÉCNICA: Água-forte e água-tinta. MATRIZ: latão. MEDIDAS DA MATRIZ: 37 x 27,1 cm. Sem assinatura. COLEÇÃO Museu Nacional de Belas Artes/ IBRAM/MinC. PROVENIÊNCIA: Maria Isabel Oswald Monteiro, doação, 1982.

LITERATURA: Correio da Manhã, RJ, 18/6/1950 (ref.); A Cruz, RJ, 6/8/1950 (artigo); Silva, Para todos, RJ, 16/11/1956 (artigo); Oswald, 1957, p.231 (ref.); Silva, 1969 (ref.).

149. TÍTULO: Via Sacra [ $8^{\text {a }}$ estação - Jesus entre as mulheres de Jerusalém]. VARIANTE: Jesus entre as mulheres de Jerusalém.

DATA: 1946. TÉCNICA: Água-forte e água-tinta. IMPRESSÃO: em marrom. MATRIZ: latão. MEDIDAS DA MATRIZ: 37 x 27,1 cm. Sem assinatura. COLEÇÃO Família Oswald. 


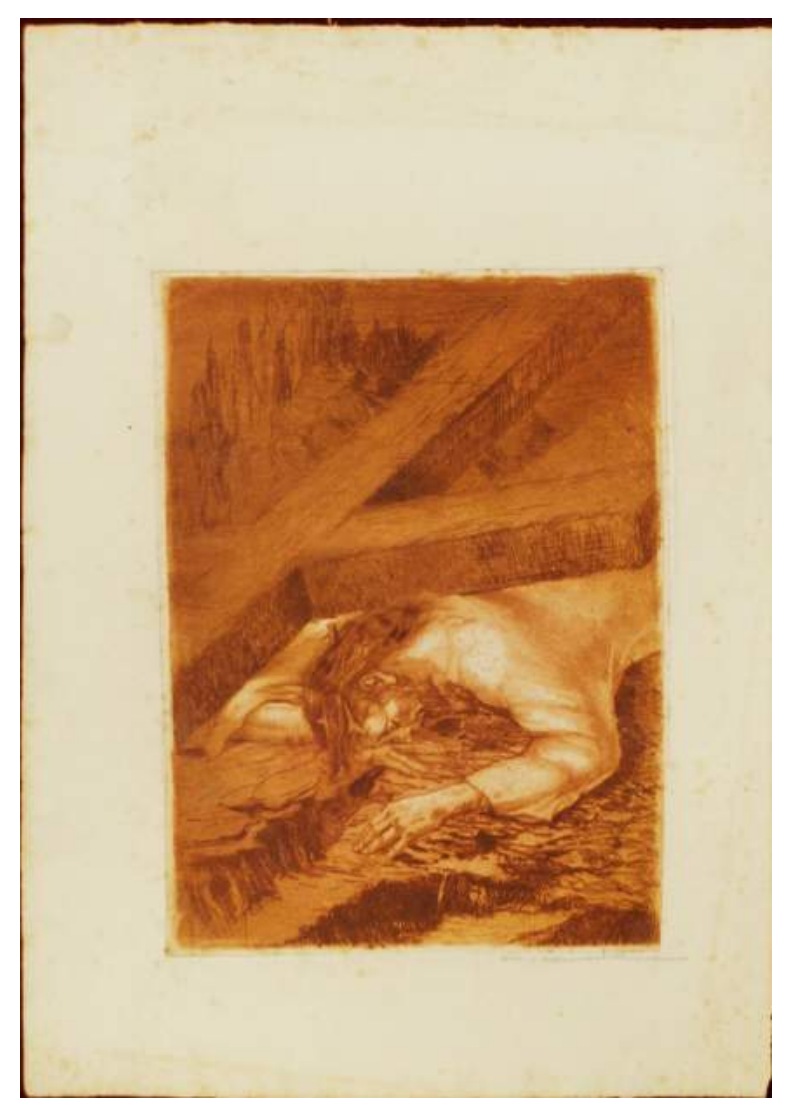

Fig. 151

150. TÍTULO: Via Sacra [9a estação - Jesus cai pela terceira vez]. VARIANTE: Jesus cai pela terceira vez; Terceira queda.

A. DATA: 1946. TÉCNICA: Água-forte. MEDIDAS: 35,7 x 26,2 cm (mancha); 50 x $34 \mathrm{~cm}$ (papel). IMPRESSÃO: em preto. MATRIZ: latão. MEDIDAS DA MATRIZ: 36,8 x $27,1 \mathrm{~cm}$. ASSINATURA: "C. Oswald" no canto inferior esquerdo da mancha, "C. Oswald" no papel. COLEÇÃO Museu Nacional de Belas Artes/IBRAM/MinC. PROVENIÊNCIA: Carlos Oswald, compra, 1963.

B. [matriz] DATA: 1946. TÉCNICA: Água-forte. MATRIZ: latão. MEDIDAS DA MATRIZ: 36,8 x 27,1 cm. ASSINATURA: "C. Oswald" no canto inferior direito. COLEÇÃO Museu Nacional de Belas Artes/IBRAM/MinC. PROVENIÊNCIA: Maria Isabel Oswald Monteiro, doação, 1982.

LITERATURA: Correio da Manhã, RJ, 18/6/1950 (ref.); A Cruz, RJ, 6/8/1950 (artigo); Silva, Para todos, RJ, 16/11/1956 (artigo); Oswald, 1957, p.231 (ref.); Silva, 1969 (ref.).

151. TÍTULO: Via Sacra [9a estação - Jesus cai pela terceira vez]. VARIANTE: Jesus cai pela terceira vez; Terceira queda.

DATA: 1946. TÉCNICA: Água-forte. IMPRESSÃO: em marrom. MATRIZ: latão. MEDIDAS DA MATRIZ: 36,8 x 27,1 cm. ASSINATURA: “C. Oswald” no canto inferior direito do papel. COLEÇÃO Família Oswald. 


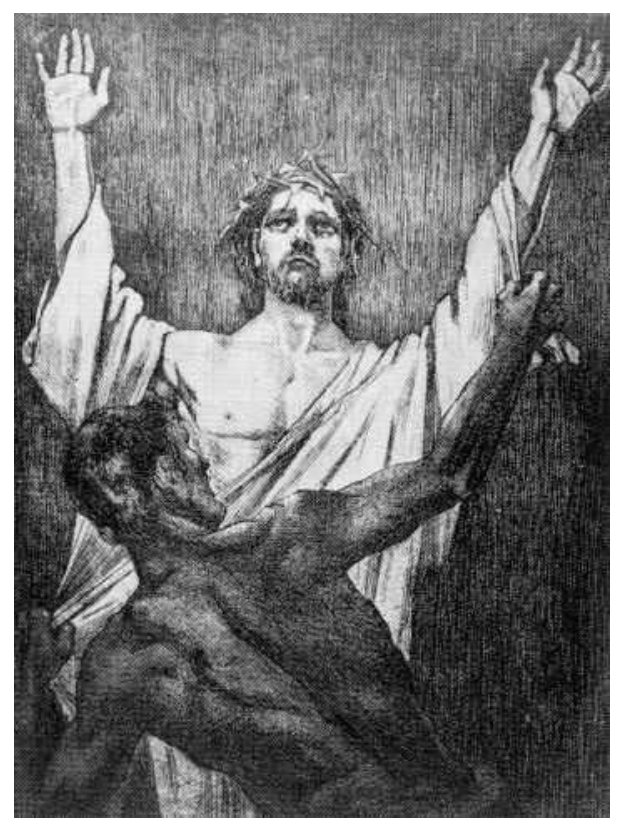

Fig. 152. A

152. TÍTULO: Via Sacra [10a estação - Jesus despido]. VARIANTE: Jesus despido.

A. DATA: 1946. TÉCNICA: Água-forte e água-tinta. MEDIDAS: 35,5 x $26 \mathrm{~cm}$ (mancha); 50 x 35 cm (papel). IMPRESSÃO: em preto. MATRIZ: latão. MEDIDAS DA MATRIZ: 37,1 x 27,1 cm. ASSINATURA: "C. Oswald" no canto inferior direito da mancha, "C. Oswald" no papel. COLEÇÃO Museu Nacional de Belas Artes/IBRAM/MinC. PROVENIÊNCIA: Carlos Oswald, compra, 1963. FOTOGRAFIA: Acervo Museu Nacional de Belas Artes/IBRAM/MinC. B. [matriz] DATA: 1946. TÉCNICA: Água-forte. MATRIZ: latão. MEDIDAS DA MATRIZ: 37,1 x 27,1 cm. ASSINATURA: "C. Oswald" no canto inferior esquerdo. COLEÇÃO Museu Nacional de Belas Artes/IBRAM/MinC. PROVENIÊNCIA: Maria Isabel Oswald Monteiro, doação, 1982.

LITERATURA: Correio da Manhã, RJ, 18/6/1950 (ref.); A Cruz, RJ, 6/8/1950 (artigo); Silva, Para todos, RJ, 16/11/1956 (artigo); Oswald, 1957, p.231 (ref.); Silva, 1969 (ref.). 


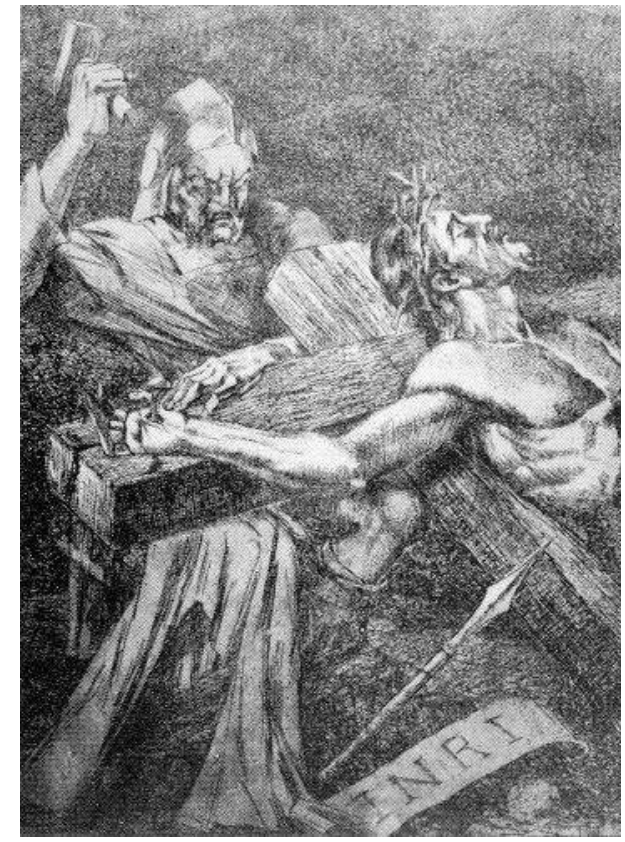

Fig. 153.A

153. TÍTULO: Via Sacra [11 a estação - Crucificação]. VARIANTE: Crucificação.

A. DATA: 1947. TÉCNICA: Água-forte e água-tinta. MEDIDAS: 34,3 x 25,7 cm (mancha); 50,7 x 36,4 cm (papel). IMPRESSÃO: em preto. MATRIZ: latão. MEDIDAS DA MATRIZ: 37,1 x 27,1 cm. ASSINATURA: "C. Oswald" no canto inferior direito da mancha, "C. Oswald" no papel. COLEÇÃO Museu Nacional de Belas Artes/IBRAM/MinC. PROVENIÊNCIA: Carlos Oswald, compra, 1963. FOTOGRAFIA: Acervo Museu Nacional de Belas Artes/IBRAM/ MinC.

B. [matriz] DATA: 1947. TÉCNICA: Água-forte e água-tinta. MATRIZ: latão. MEDIDAS DA MATRIZ: 37,1 x 27,1 cm. ASSINATURA: "C. Oswald" no canto inferior esquerdo. COLEÇÃO Museu Nacional de Belas Artes/IBRAM/MinC. PROVENIÊNCIA: Maria Isabel Oswald Monteiro, doação, 1982.

LITERATURA: Correio da Manhã, RJ, 18/6/1950 (ref.); A Cruz, RJ, 6/8/1950 (artigo); Silva, Para todos, RJ, 16/11/1956 (artigo); Oswald, 1957, p.231 (ref., datada 1946); Silva, 1969 (ref.). 


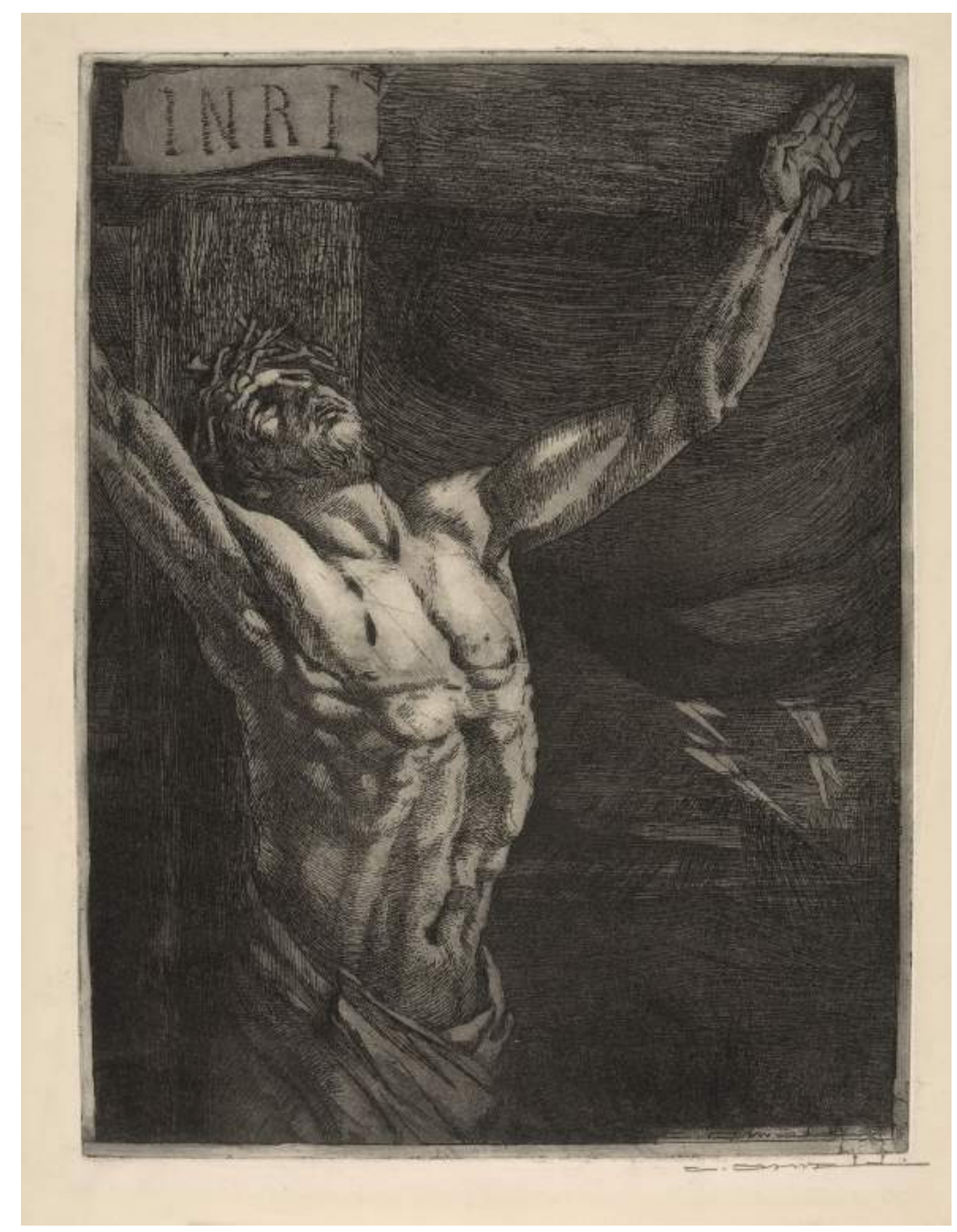

Fig. 154.A

154. TÍTULO: Via Sacra [12 estação - Morte de Jesus]. VARIANTE: Morte de Jesus; A morte de Jesus; Jesus morre na Cruz.

A. DATA: 1947. TÉCNICA: Água-forte. MEDIDAS: 34,9 x 25,7 cm (mancha); 50 x 25,7 cm (papel). IMPRESSÃO: em preto. MATRIZ: latão. MEDIDAS DA MATRIZ: 37,1 x 27,1 cm. ASSINATURA: "C. Oswald" no canto inferior direito da mancha, "C. Oswald" no canto inferior direito do papel. COLEÇÃO Museu Nacional de Belas Artes/IBRAM/MinC. PROVENIÊNCIA: Carlos Oswald, compra, 1963. FOTOGRAFIA: Acervo Museu Nacional de Belas Artes/IBRAM/MinC.

B. [matriz] DATA: 1947. TÉCNICA: Água-forte. MATRIZ: latão. MEDIDAS DA MATRIZ: 37,1 x 27,1 cm. ASSINATURA: "C. Oswald" no canto inferior esquerdo. COLEÇÃO Museu Nacional de Belas Artes/IBRAM/MinC. PROVENIÊNCIA: Maria Isabel Oswald Monteiro, doação, 1982.

LITERATURA: Exp. Arte Sacra Contemporânea, Ministério da Educação, RJ, 1947; Correio da Manhã, RJ, 18/6/1950 (ref.); A Cruz, RJ, 6/8/1950 (artigo); Illustração Brasileira, RJ, 12/1950, p. 104 (rep.); Silva, Para todos, RJ, 16/11/1956 (artigo); Oswald, 1957, p.231 (ref., datada 1946); Silva, 1969 (ref.). 


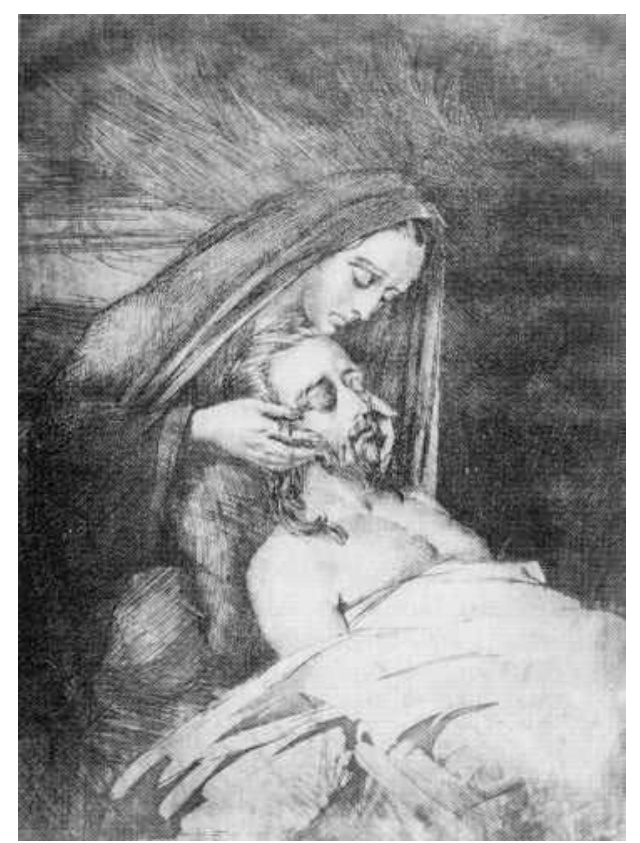

Fig. 155. A

155. TÍTULO: Via Sacra [13 ${ }^{a}$ estação - Deposição da Cruz]. VARIANTE: Deposição da Cruz.

A. DATA: 1946. TÉCNICA: Água-forte e água-tinta. MEDIDAS: 36,5 x 27 cm (mancha); 52 x $37 \mathrm{~cm}$ (papel). IMPRESSÃO: em preto. MATRIZ: latão. MEDIDAS DA MATRIZ: 36,5 x $27 \mathrm{~cm}$. ASSINATURA: "C. Oswald" no canto inferior esquerdo da mancha, "C. Oswald" no papel. COLEÇÃO Museu Nacional de Belas Artes/IBRAM/MinC. PROVENIÊNCIA: Carlos Oswald, compra, 1963. FOTOGRAFIA: Acervo Museu Nacional de Belas Artes/IBRAM/ MinC.

B [matriz] DATA: 1946. TÉCNICA: Água-forte e água-tinta. MATRIZ: latão. MEDIDAS DA MATRIZ: 36,5 x $27 \mathrm{~cm}$. ASSINATURA: "C. Oswald" no canto inferior direito. COLEÇÃO Museu Nacional de Belas Artes/IBRAM/MinC. PROVENIÊNCIA: Maria Isabel Oswald Monteiro, doação, 1982.

LITERATURA: Correio da Manhã, RJ, 18/6/1950 (ref.); A Cruz, RJ, 6/8/1950 (artigo); Silva, Para todos, RJ, 16/11/1956 (artigo); Oswald, 1957, p. 231 (ref.); Silva, 1969 (ref.). 


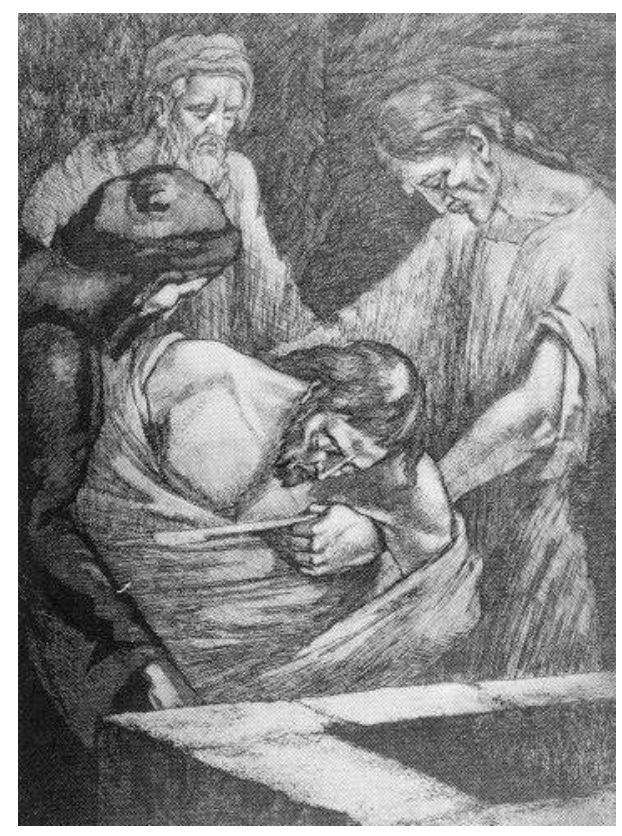

Fig. 156

156. TÍTULO: Via Sacra [14 a estação - Sepultamento de Jesus]. VARIANTE: Sepultamento de Jesus.

DATA: 1947. TÉCNICA: Água-forte e água-tinta. MEDIDAS: 35,8 x 25,7 cm (mancha); 47,8 x 32,8 cm (papel). IMPRESSÃO: em preto. ASSINATURA: “C. Oswald” no canto inferior direito da mancha, "C. Oswald" no papel. COLEÇÃO Museu Nacional de Belas Artes/IBRAM/ MinC. PROVENIÊNCIA: Carlos Oswald, compra, 1963. FOTOGRAFIA: Acervo Museu Nacional de Belas Artes/IBRAM/MinC.

LITERATURA: Correio da Manhã, RJ, 18/6/1950 (ref.); A Cruz, RJ, 6/8/1950 (artigo); Silva, Para todos, RJ, 16/11/1956 (artigo); Oswald, 1957, p. 231 (ref., datada 1946); Silva, 1969 (ref.). 


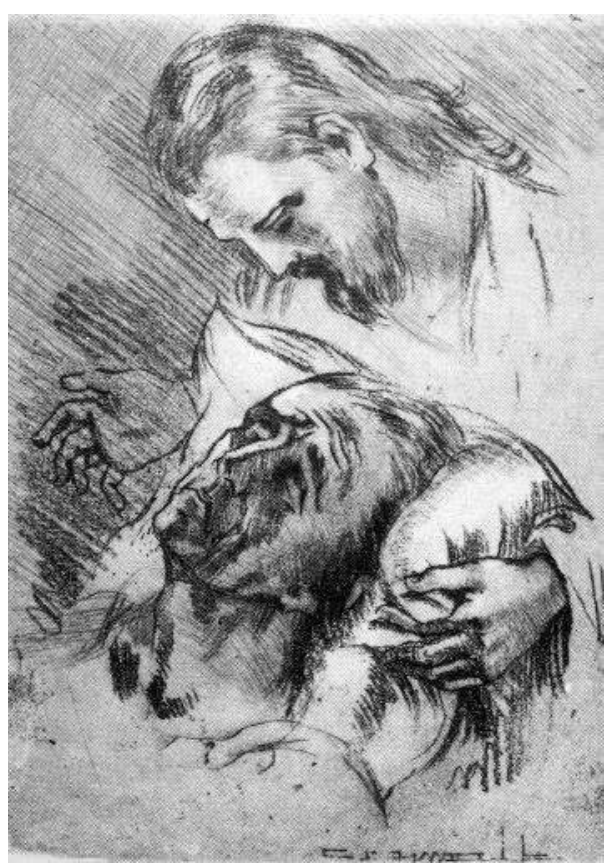

Fig. 157

157. TÍTULO: Jesus e o doente.

A. DATA: 1947. TÉCNICA: Verniz mole e ponta seca. MEDIDAS: 20 x 14,7 cm (mancha); 34,2 x 25,7 cm (papel). MATRIZ: latão. MEDIDAS DA MATRIZ: 20,2 x 15,1 cm. ASSINATURA: "C. Oswald" no canto inferior direito do papel e na mancha. COLEÇÃO Museu Nacional de Belas Artes/IBRAM/MinC. PROVENIÊNCIA: Carlos Oswald, compra, 1963. FOTOGRAFIA: Acervo Museu Nacional de Belas Artes/IBRAM/MinC.

B. [matriz] DATA: 1947. TÉCNICA: Verniz mole e ponta seca. MATRIZ: latão. MEDIDAS DA MATRIZ: 20,2 x 15,1 cm. ASSINATURA: "C. Oswald”. COLEÇÃO Museu Nacional de Belas Artes/IBRAM/MinC. PROVENIÊNCIA: Maria Isabel Oswald Monteiro, doação, 1982.

LITERATURA: Oswald, 1957, p. 234 (ref., afirma que a gravura foi comercializada pelo Atelier de Arte); Silva, 1969 (ref.). 


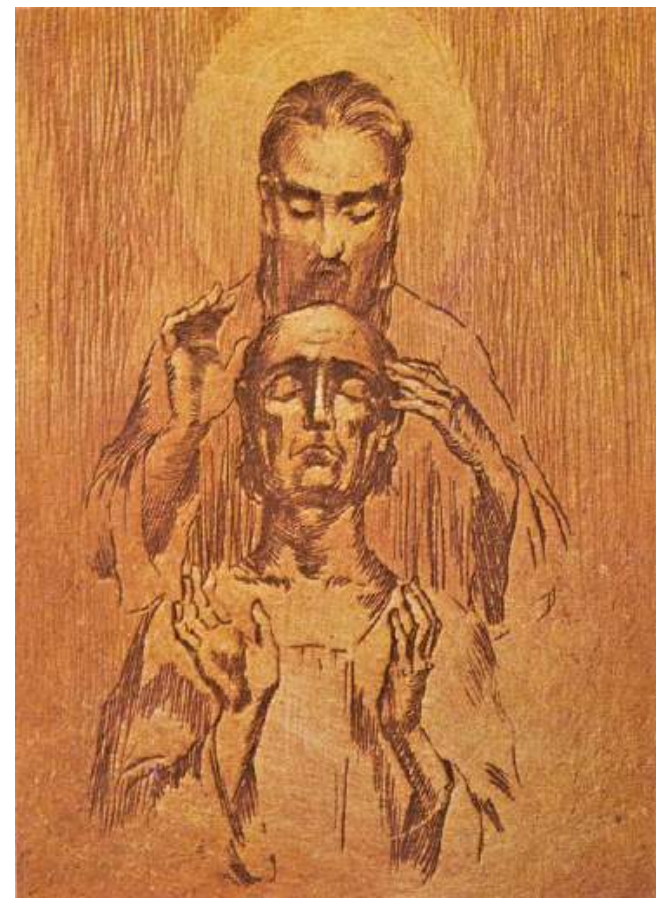

Fig. 158

158. TÍTULO: Senhor! Que eu veja!

A. DATA: 1947. TÉCNICA: Verniz mole e ponta seca. MEDIDAS: 20,7 x 15,1 cm (mancha); 34,3 x 25,6 cm (papel). IMPRESSÃO: em marrom. MATRIZ: latão. MEDIDAS DA MATRIZ: 20,7 x 15,1 cm. ASSINATURA: "C. Oswald” no papel. COLEÇÃO Museu Nacional de Belas Artes/IBRAM/MinC. PROVENIÊNCIA: Carlos Oswald, compra, 1963. FOTOGRAFIA: Acervo Museu Nacional de Belas Artes/IBRAM/MinC.

B. [matriz] DATA: 1947. TÉCNICA: Verniz mole e ponta seca. MATRIZ: latão. MEDIDAS DA MATRIZ: 20,7 x 15,1 cm. Sem assinatura. COLEÇÃO Museu Nacional de Belas Artes/ IBRAM/MinC. PROVENIÊNCIA: Maria Isabel Oswald Monteiro, doação, 1982.

LITERATURA: Oswald, 1957, p. 234 (ref., afirma que a gravura foi comercializada pelo Atelier de Arte); Silva, 1969 (ref.). 


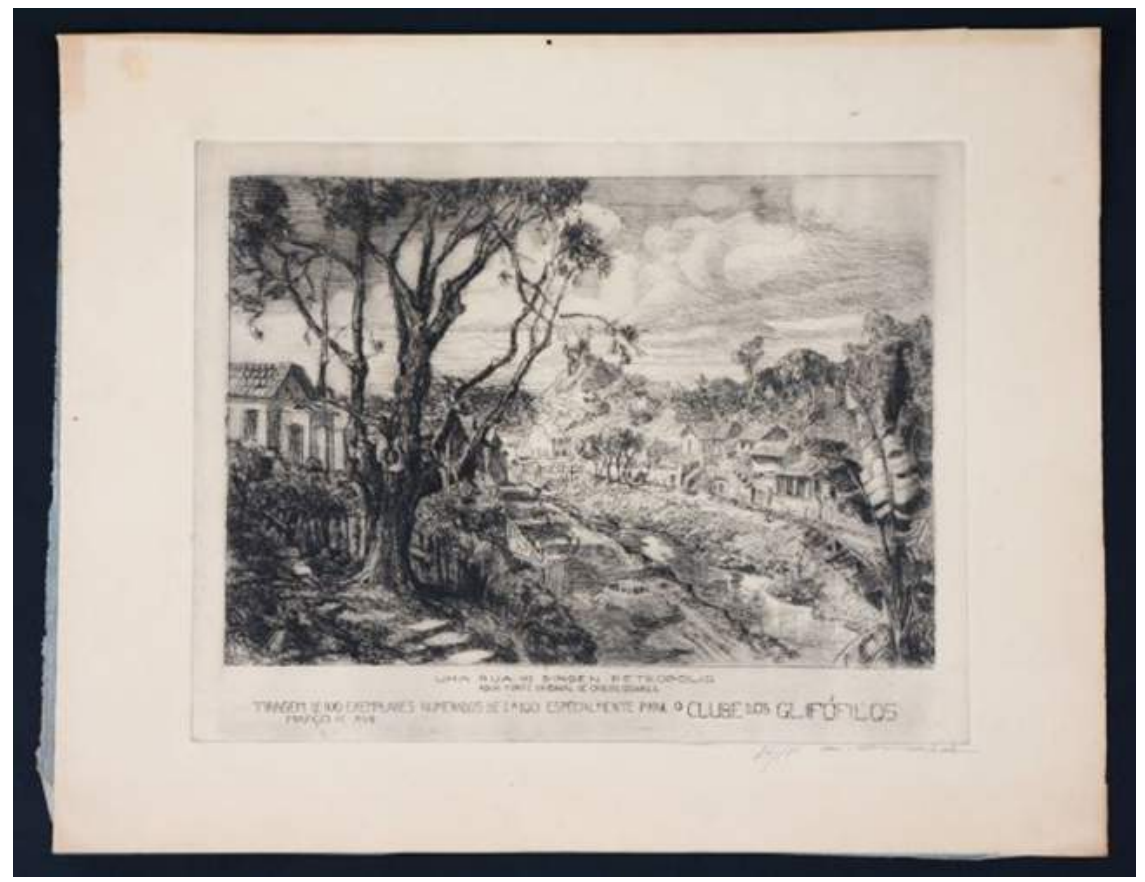

Fig. 159. A

159. TÍTULO: Uma rua no Bingen Petrópolis.

A. DATA: 1949. TÉCNICA: Água-forte. IMPRESSÃO: em preto. MATRIZ: cobre. MEDIDAS DA MATRIZ: 27,1 x 34,9 cm. ASSINATURA: “Água-forte original de Carlos Oswald” gravado no centro embaixo da matriz, "C. Oswald" no canto inferior direito do papel. FONTE: Antonio Ferreira - Leiloeiro Público, Lote 214, disponível em <https://www.antonioferreira.lel.br/ peca.asp?ID=102085> , acesso em 12/08/2017. [Gravura realizada para o Clube do Glifófilos, tiragem de cem cópias, março de 1949].

B. [matriz] DATA: 1949. TÉCNICA: Água-forte. MATRIZ: cobre. MEDIDAS DA MATRIZ: 27,1 x 34,9 cm. ASSINATURA: “Água-forte original de Carlos Oswald” gravado no centro embaixo da matriz. COLEÇÃO Museu Nacional de Belas Artes/IBRAM/MinC. PROVENIÊNCIA: Maria Isabel Oswald Monteiro, doação, 1982.

LITERATURA: Diário Carioca, RJ, 18/3/1949 (nota); A Noite, RJ, 9/5/1949 (nota); Oswald, 1957, p. 233 (ref.); Silva, 1969 (ref.).. 


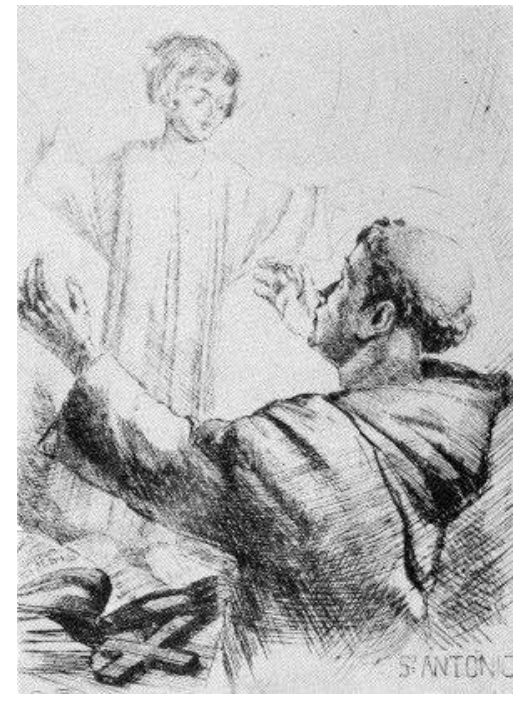

Fig. 160
160. TÍTULO: So. Antonio.

DATA: 1950. TÉCNICA: Água-forte. MEDIDAS: $20 \mathrm{x}$ $14,9 \mathrm{~cm}$ (mancha); 37,2 x $28 \mathrm{~cm}$ (papel). ASSINATURA: "C. Oswald" no papel e monograma "CO" no canto inferior esquerdo. COLEÇÃO Museu Nacional de Belas Artes/ IBRAM/MinC. PROVENIÊNCIA: Carlos Oswald, compra, 1963. FOTOGRAFIA: Acervo Museu Nacional de Belas Artes/IBRAM/MinC.

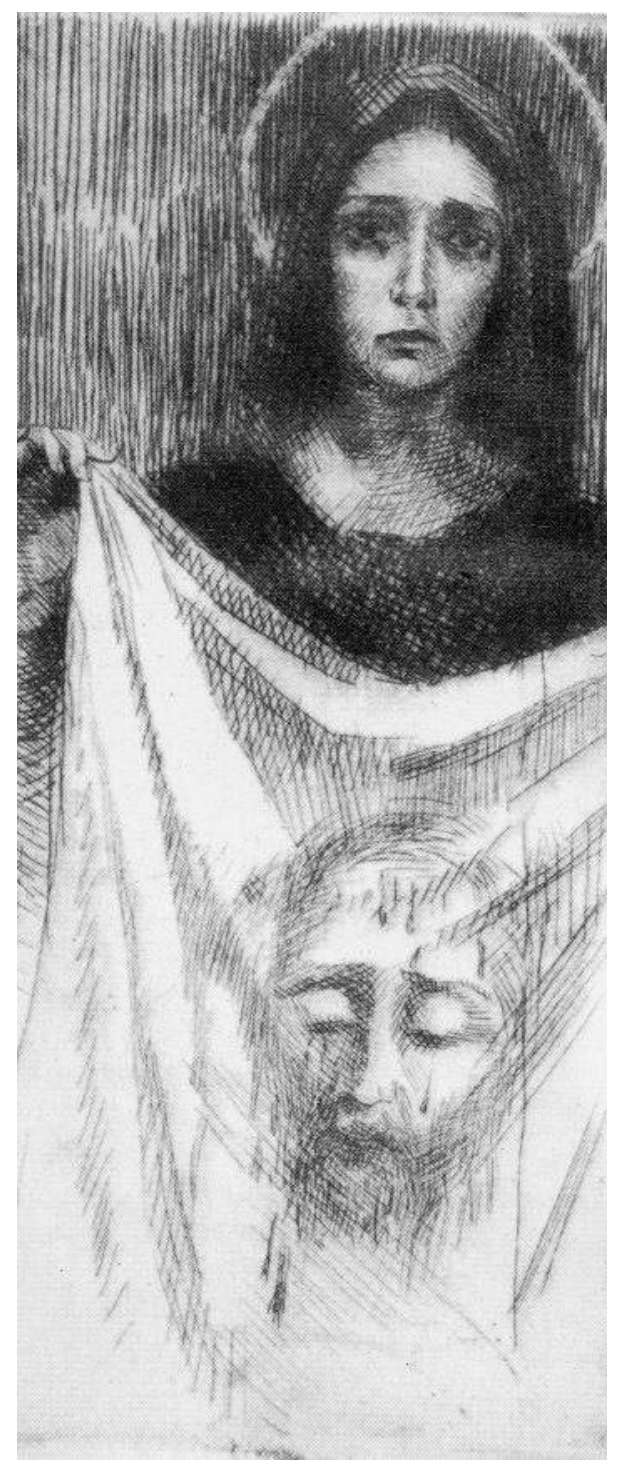

161. TÍTULOS: Verônica; Santa Verônica.

DATA: 1950. TÉCNICA: Ponta seca. MEDIDAS: 16 x 7,6 cm (mancha); 25,3 x $15 \mathrm{~cm}$ (papel). ASSINATURA: "C. Oswald" no cento embaixo no papel. COLEÇÃO Museu Nacional de Belas Artes/IBRAM/MinC. PROVENIÊNCIA: Carlos Oswald, compra, 1963. FOTOGRAFIA: Acervo Museu Nacional de Belas Artes/ IBRAM/MinC.

LITERATURA: Oswald, 1957, p. 222 (ref.); Silva. 1969 (ref.)..

Fig. 161 


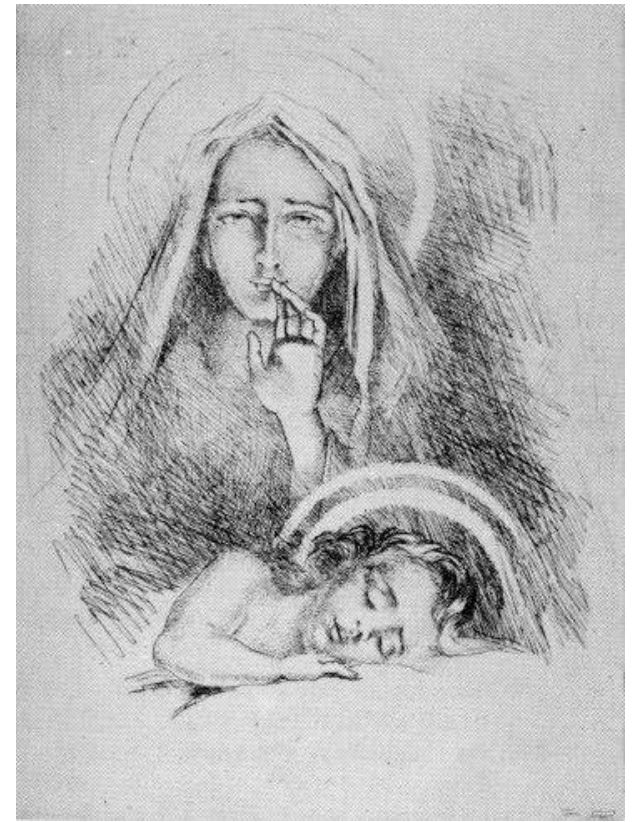

Fig. 162.A

162. TÍTULO: A Virgem do Silêncio.

A. DATA: 1951. TÉCNICA: Água-forte. MEDIDAS: 20 x 14,9 cm (mancha); 28 x 18,6 cm (papel). MATRIZ: latão. MEDIDAS DA MATRIZ: 20,3 x 15,2 cm. ASSINATURA: monograma "CO” gravado na mancha, "C. Oswald” no papel. COLEÇÃO Museu Nacional de Belas Artes/ IBRAM/MinC. PROVENIÊNCIA: Carlos Oswald, compra, 1963. FOTOGRAFIA: Acervo Museu Nacional de Belas Artes/IBRAM/MinC.

B. [matriz] DATA: 1951. TÉCNICA: Água-forte. MATRIZ: latão. MEDIDAS DA MATRIZ: 20,3 x 15,2 cm. Sem assinatura. COLEÇÃO Museu Nacional de Belas Artes/IBRAM/MinC. PROVENIÊNCIA: Maria Isabel Oswald Monteiro, doação, 1982.

LITERATURA: Oswald, 1957, p. 234 (ref., afirma que foi realizada para o Atelier de Arte); Silva, 1969 (ref.). 


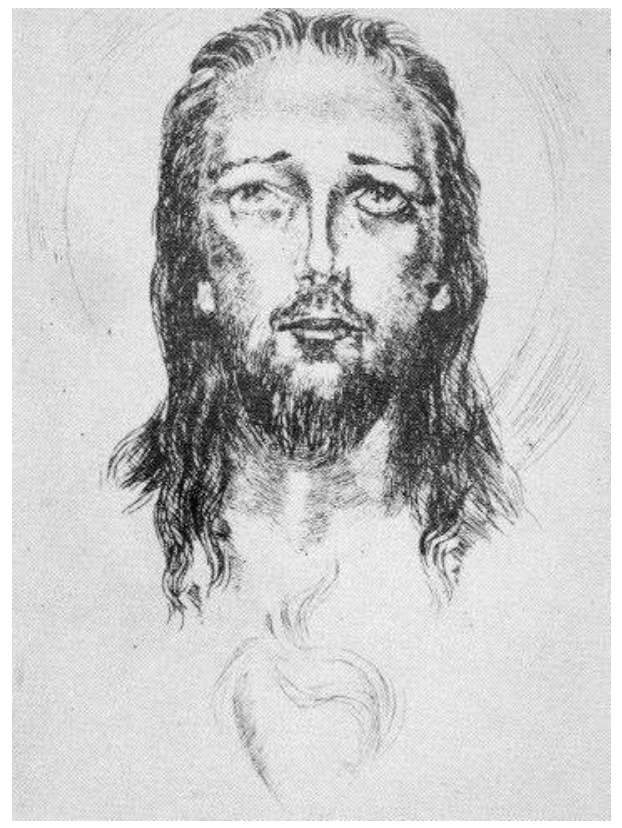

Fig. 163

163. TÍTULO: A cabeça do Sagrado Coração de Jesus. VARIANTE: Sagrado Coração de Jesus.

A. DATA: 1951. TÉCNICA: Água-forte. MEDIDAS: 27,6 x 19,5 cm (mancha); 37,3 x $28 \mathrm{~cm}$ (papel). ASSINATURA: "C. Oswald" no canto inferior direito do papel. COLEÇÃO Museu Nacional de Belas Artes/IBRAM/MinC. PROVENIÊNCIA: Carlos Oswald, compra, 1963. FOTOGRAFIA: Acervo Museu Nacional de Belas Artes/IBRAM/MinC. [A coleção possui outra cópia dessa gravura doada por Guilherme Schubert em 1988]

LITERATURA: Oswald, 1957, p. 234 (ref., afirma que a gravura foi realizada para o Atelier de Arte); Silva, 1969 (ref.). 


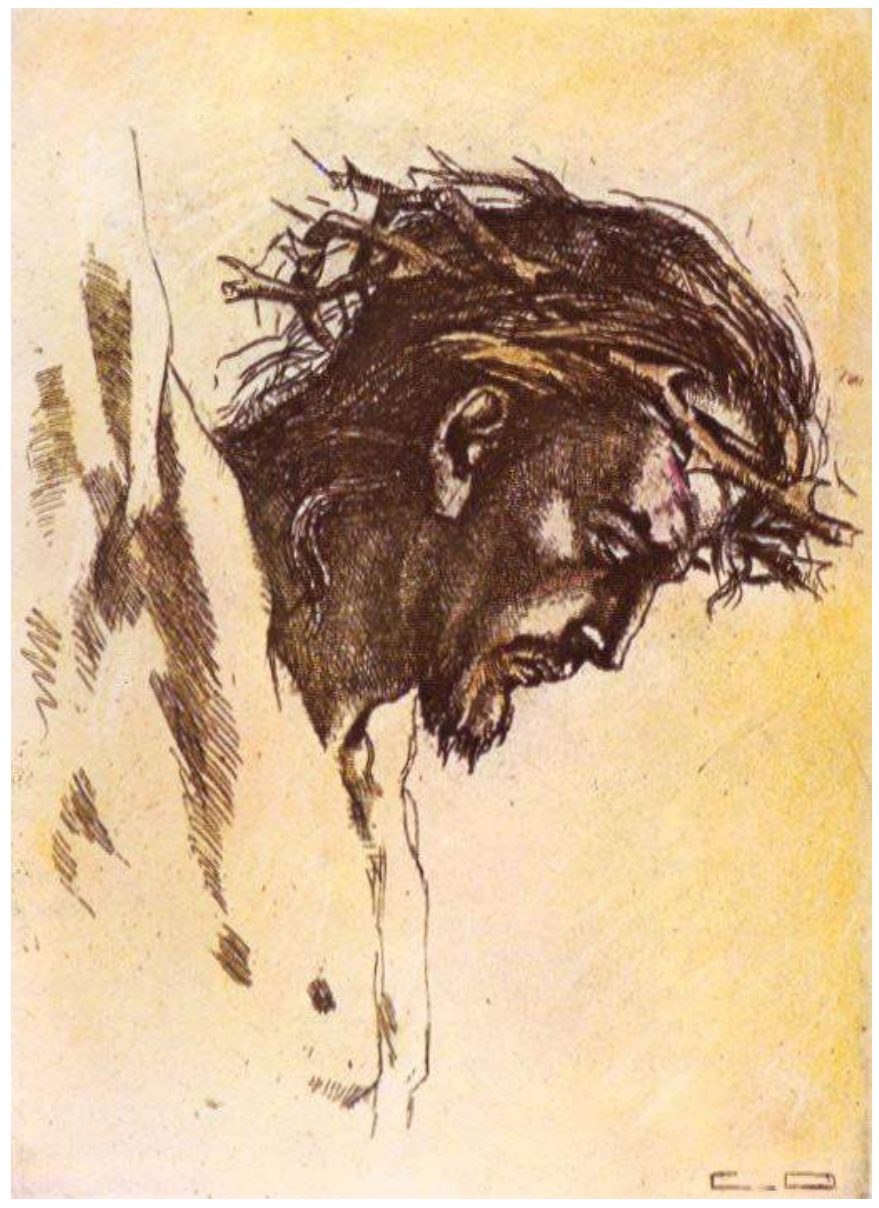

Fig. 164.A

164. TÍTULO: Perfil de Cristo Crucificado.

A. DATA: 1951. TÉCNICA: Água-forte. MEDIDAS: 24,6 x 17,6 cm (mancha); 37,2 x 28 cm (papel). MATRIZ: cobre. ASSINATURA: "C. Oswald" no papel, monograma "CO" no canto inferior direito da mancha. COLEÇÃO Museu Nacional de Belas Artes/IBRAM/MinC. PROVENIÊNCIA: Carlos Oswald, compra, 1963. FOTOGRAFIA: Acervo Museu Nacional de Belas Artes/IBRAM/MinC.

B. DATA: 1951. TÉCNICA: Água-forte. MEDIDAS: 24,7 x 17,6 cm (mancha); 37,6 x 27,5 cm (papel). MATRIZ: cobre. ASSINATURA: "C. Oswald" no papel, monograma "CO" no canto inferior direito da mancha. COLEÇÃO Museu Nacional de Belas Artes/IBRAM/MinC. PROVENIÊNCIA: Guilherme Schubert, doação, 1988.

C. DATA: 1951. TÉCNICA: Água-forte. MEDIDAS: 24,7 x 17,6 cm (mancha). IMPRESSÃO: em preto. MATRIZ: cobre. ASSINATURA: "C. Oswald" no canto inferior direito do papel, monograma "CO" no canto inferior direito da mancha. COLEÇÃO Josafá Vilarouca Jr. FONTE: Vergolino, 2011, p.64.

LITERATURA: Oswald, 1957, p. 234 (ref., afirma que a gravura foi realizada para o Atelier de Arte); Silva, 1969 (ref.); Exp. Carlos Oswald: o resgate de um mestre, Caixa Cultural, Brasília/ Curitiba, 2011, p. 64 (rep.). 


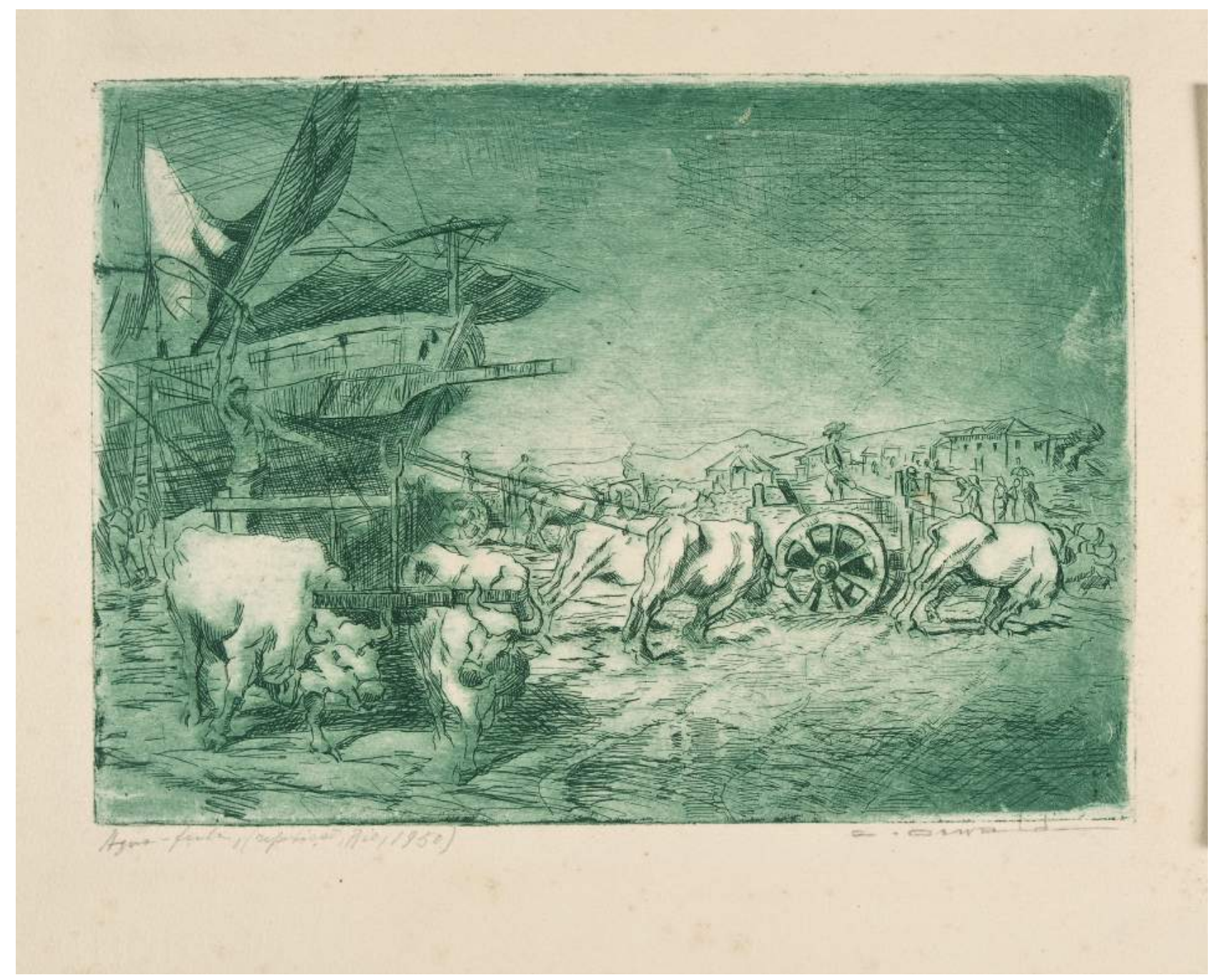

Fig. 165

165. TÍTULO: O Supremo esforço. VARIANTE: Supremo esforço.

DATA: 1950. TÉCNICA: Água-forte. MEDIDAS: 19,7 x 27,5 cm (mancha); 29,5 x 39,5 cm (papel). IMPRESSÃO: em verde. MATRIZ: cobre. ASSINATURA: “C. Oswald” no canto inferior direito do papel. COLEÇÃO Museu Nacional de Belas Artes/IBRAM/MinC. PROVENIÊNCIA: Carlos Oswald, compra, 1963. FOTOGRAFIA: Acervo Museu Nacional de Belas Artes/IBRAM/MinC.

LITERATURA: Oswald, 1957, p. 234 (ref., datada 1951, afirma que a gravura foi realizada para o Atelier de Arte e é uma repetição em menor tamanho de Bois puxando um navio); Silva, 1969 (ref.); Exp. Carlos Oswald: o resgate de um mestre, Caixa Cultural, Brasília/Curitiba, 2011, p. 82 (rep.). 


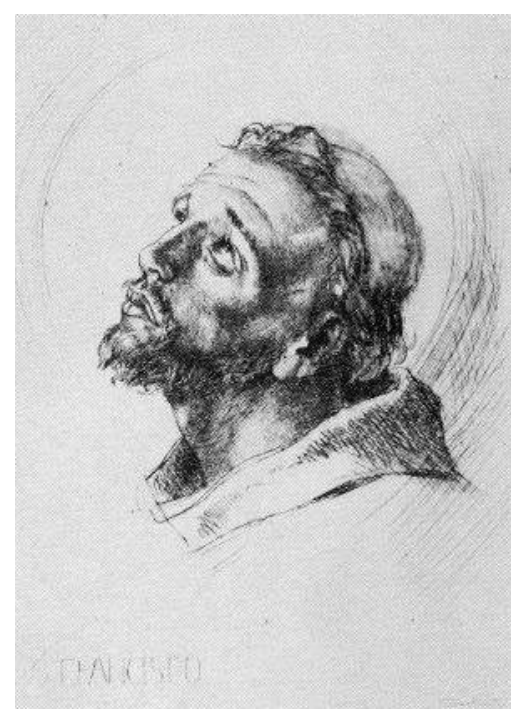

Fig. 166
166. TÍTULOS: Cabeça de São Francisco; S. Francisco. VARIANTE: São Francisco.

A. DATA: 1951. TÉCNICA: Água-forte. MEDIDAS: 27,3 x 19,6 cm (mancha); 37,6 x 27,3 cm (papel). MATRIZ: cobre. ASSINATURA: "C. Oswald" no papel; monograma "CO" no canto inferior direito da mancha. COLEÇÃO Museu Nacional de Belas Artes/IBRAM/MinC. PROVENIÊNCIA: Carlos Oswald, compra, 1963.FOTOGRAFIA: Acervo Museu Nacional de Belas Artes/IBRAM/MinC.

B. DATA: 1951. TÉCNICA: Água-forte. MEDIDAS: 27,5 x $20 \mathrm{~cm}$ (mancha); 37,7 x 27,4 cm (papel). MATRIZ: cobre. ASSINATURA: "C. Oswald" no papel; monograma "CO" no canto inferior direito da mancha. COLEÇÃO Museu Nacional de Belas Artes/IBRAM/MinC. PROVENIÊNCIA: Guilherme Schubert, doação, 1988.

LITERATURA: Oswald, Correio da Manhã, RJ, 20/1/1952 (rep.); Oswald, 1957, p. 234 (ref., datada 1952, afirma que a gravura foi encomendada pelo Atelier de Arte); Silva, 1969 (ref.).

167. TÍTULO: Santo Antônio e o Santo Menino. VARIANTE: So Antônio.

DATA: 1951. TÉCNICA: Água-forte. MEDIDAS: 25,5 x 19,9 cm (mancha); 37,6 x 27,5 cm (papel). MATRIZ: cobre. ASSINATURA: "C. Oswald" no papel, monograma "CO" no canto inferior esquerdo da mancha. COLEÇÃO Museu Nacional de Belas Artes/IBRAM/MinC. PROVENIÊNCIA: Guilherme Schubert, doação, 1988. FONTE: Museu Nacional de Belas Artes.

LITERATURA: Oswald, 1957,p. 234 (ref., datada 1952, afirma que a gravura foi realizada para o Atelier de Arte); Silva, 1969 (ref.). 


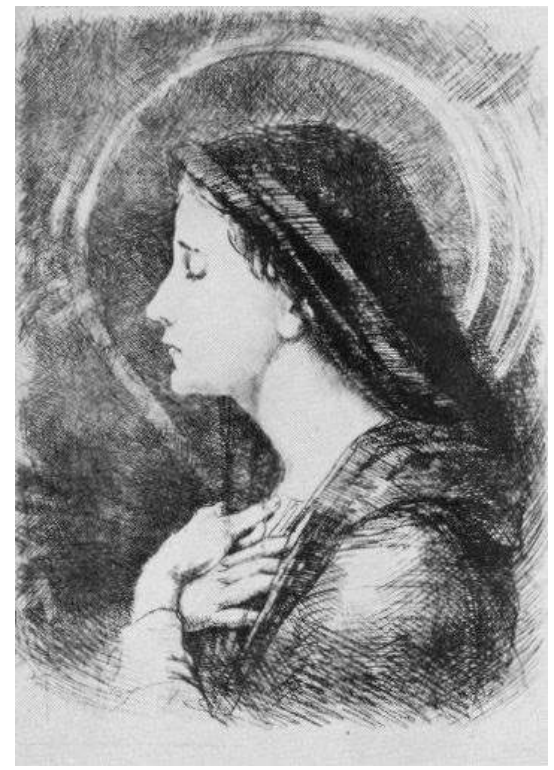

Fig. 168

168. TÍTULO: Perfil de Nossa Senhora das Dores.

A. DATA: 1952. TÉCNICA: Água-forte. MEDIDAS: 24,1 x 17,8 cm (mancha); 34,3 x 24,1 cm (papel). MATRIZ: cobre. MEDIDAS DA MATRIZ: 25 x $18 \mathrm{~cm}$. ASSINATURA: "C. Oswald" no papel. COLEÇÃO Museu Nacional de Belas Artes/IBRAM/MinC. PROVENIÊNCIA: Carlos Oswald, compra, 1963. FOTOGRAFIA: Acervo Museu Nacional de Belas Artes/IBRAM/ MinC.

B. [matriz] DATA: 1952. TÉCNICA: Água-forte. MATRIZ: cobre. MEDIDAS DA MATRIZ: 25 x $18 \mathrm{~cm}$. Sem assinatura. COLEÇÃO Museu Nacional de Belas Artes/IBRAM/MinC. PROVENIÊNCIA: Maria Isabel Oswald Monteiro, doação, 1982.

LITERATURA: Oswald, 1957, p. 234 (ref., afirma que a gravura foi realizada para o Atelier de Arte); Silva, 1969 (ref.). 


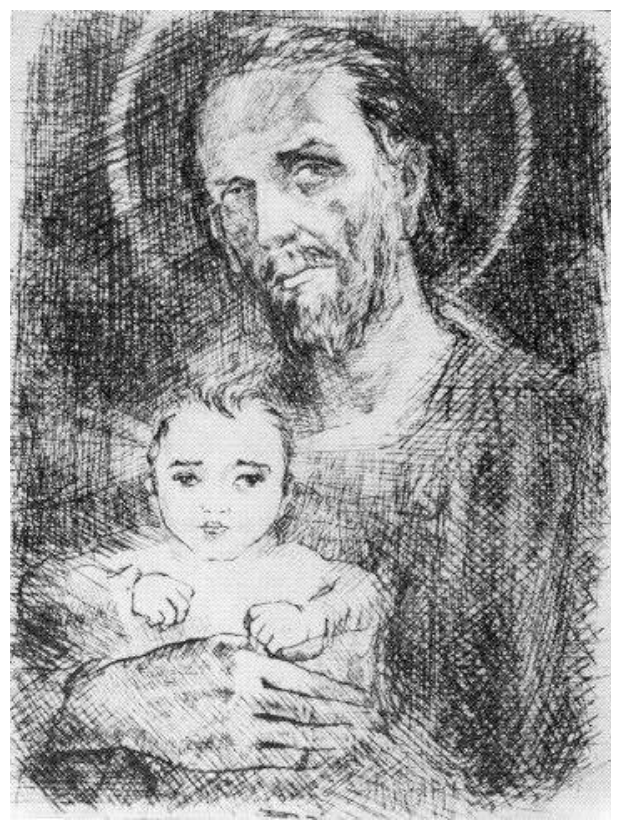

Fig. 169

169. TÍTULO: São José e o Santo Menino. VARIANTES: São José com Menino; São José e o Menino Jesus.

A. DATA: 1952. TÉCNICA: Água-forte e ponta seca. MEDIDAS: 20 x $15 \mathrm{~cm}$ (mancha); 28 x $18,5 \mathrm{~cm}$ (papel). ASSINATURA: "C. Oswald” no papel. COLEÇÃO Museu Nacional de Belas Artes/IBRAM/MinC. PROVENIÊNCIA: Carlos Oswald, compra, 1963. FOTOGRAFIA: Acervo Museu Nacional de Belas Artes/IBRAM/MinC.

B. DATA: 1952. TÉCNICA: Água-forte e ponta seca. MEDIDAS: 20 x 14,9 cm (mancha); 37,2 x $28 \mathrm{~cm}$ (papel). ASSINATURA: "C. Oswald" no canto inferior direito do papel. COLEÇÃO Museu Nacional de Belas Artes/IBRAM/MinC. PROVENIÊNCIA: Guilherme Schubert, doação, 1988.

LITERATURA: Oswald, 1957,p. 234 (ref., datada 1952, afirma que a gravura foi encomendada pelo Atelier de Arte); Silva, 1969 (ref.). 
Fig. 170. B

170. TÍTULO: Trecho de procissão.

A. DATA: 1955. TÉCNICA: Água-forte. MEDIDAS: 19,5 x 27,2 cm (mancha); 34,1 x 27,2 cm (papel). IMPRESSÃO: em preto. ASSINATURA: "C. Oswald" no canto inferior direito do papel. COLEÇÃO Museu Nacional de Belas Artes/IBRAM/MinC. PROVENIÊNCIA: Carlos Oswald, compra, 1963.

B. DATA: 1955. TÉCNICA: Água-forte. IMPRESSÃO: em preto. ASSINATURA: “C. Oswald" no canto inferior direito do papel. COLEÇÃO Família Oswald.

C. DATA: 1964. TÉCNICA: Água-forte. MEDIDAS: 19,5 x 27,2 cm (mancha); 34,1 x 27,2 cm (papel). IMPRESSÃO: em preto. ASSINATURA: "C. Oswald" no papel. ACERVO Fundação Biblioteca Nacional. PROVENIÊNCIA: registrada na coleção em 1970.

Obra pertencente ao álbum "Carlos Oswald cinco gravuras originais", impresso pela Gravura de Arte Editora, em 1964.

LITERATURA: Oswald, 1957, p. 236 (ref., afirma que foi realizada para a Associação Amigos da Gravura e, em 1957, ainda não havia sido editada); Silva, 1969 (ref.); Exp. A moderna gravura brasileira, Biblioteca Nacional, RJ, 1974, p. 15-16 (ref.); Jornal do Brasil, RJ, 18/11/1977 (rep., nota expo.); Exp. Carlos Oswald: o resgate de um mestre, Caixa Cultural, Brasília/Curitiba, 2011, p. 85 (rep.). 
171. TÍTULO: Jesus acalma a tempestade. VARIANTE: Jesus acalmando a tempestade.

[matriz] DATA: 1956. TÉCNICA: Ponta seca. MATRIZ: acrílico. MEDIDAS DA MATRIZ: 7 x 6,3 cm. Sem assinatura. COLEÇÃO Museu Nacional de Belas Artes/IBRAM/MinC. PROVENIÊNCIA: Maria Isabel Oswald Monteiro, doação, 1982. FONTE: Museu Nacional de Belas Artes.

LITERATURA: Oswald, 1957, p. 226 e p. 237 (ref., afirma que essa "ponta seca em miniatura" foi realizada a partir do quadro de mesmo título); Silva, 1969 (ref.).

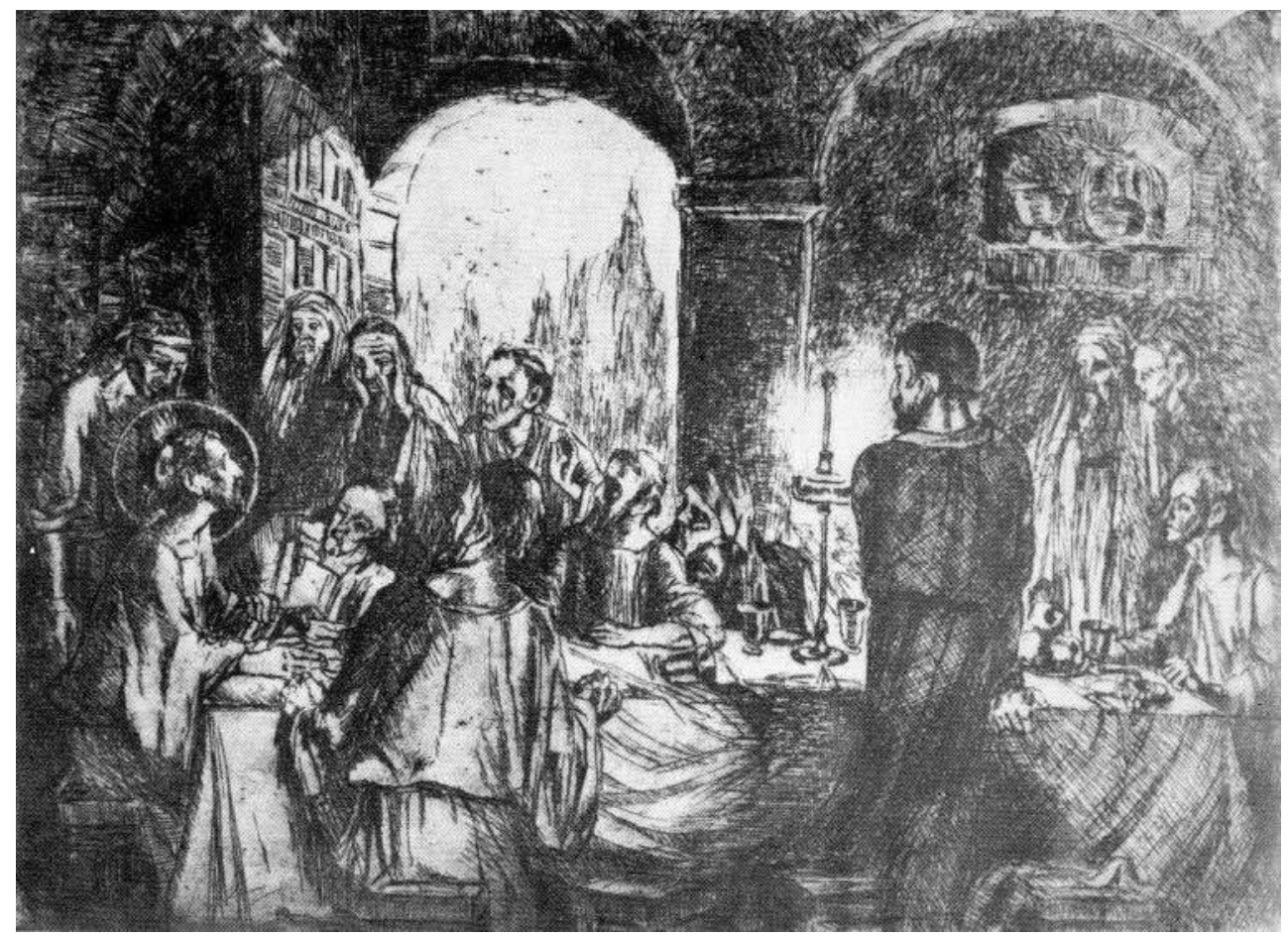

Fig. 172

172. TÍTULO: Última Ceia.

DATA: 1958/1959. TÉCNICA: Água-forte. MEDIDAS: 30 x $41 \mathrm{~cm}$ (mancha), 45 x 56,5 cm (papel). IMPRESSÃO: em preto. ASSINATURA: "C. Oswald" no canto inferior do papel. COLEÇÃO Museu Nacional de Belas Artes/IBRAM/MinC. PROVENIÊNCIA: Carlos Oswald, compra, 1963. FOTOGRAFIA: Acervo Museu Nacional de Belas Artes/IBRAM/MinC.

LITERATURA: Silva, 1969 (ref.). 


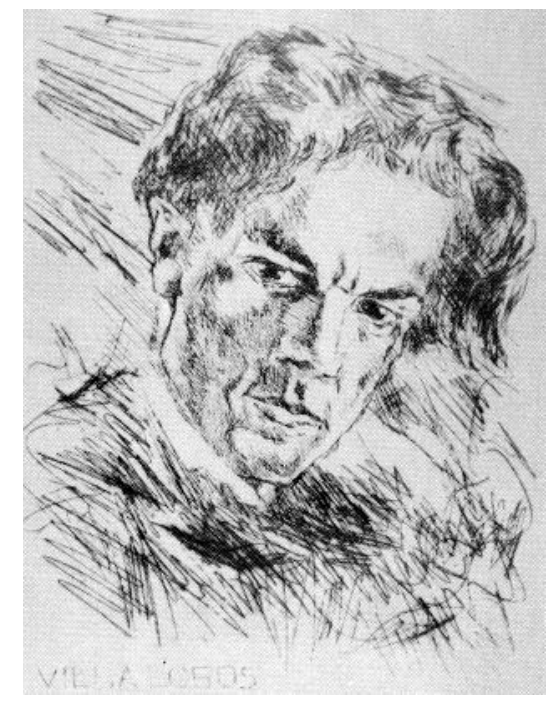

Fig. 173

173. TÍTULO: Villa-Lobos.

DATA: 1963. TÉCNICA: Água-forte. MEDIDAS: 27,2 x 19,8 cm (mancha), 50 x 31,3 cm (papel). IMPRESSÃO: em preto. ASSINATURA: “C. Oswald” no papel. COLEÇÃO Museu Nacional de Belas Artes/IBRAM/MinC. PROVENIÊNCIA: Carlos Oswald, compra, 1963. FOTOGRAFIA: Acervo Museu Nacional de Belas Artes/IBRAM/MinC.

LITERATURA: Silva, 1969 (ref.). 


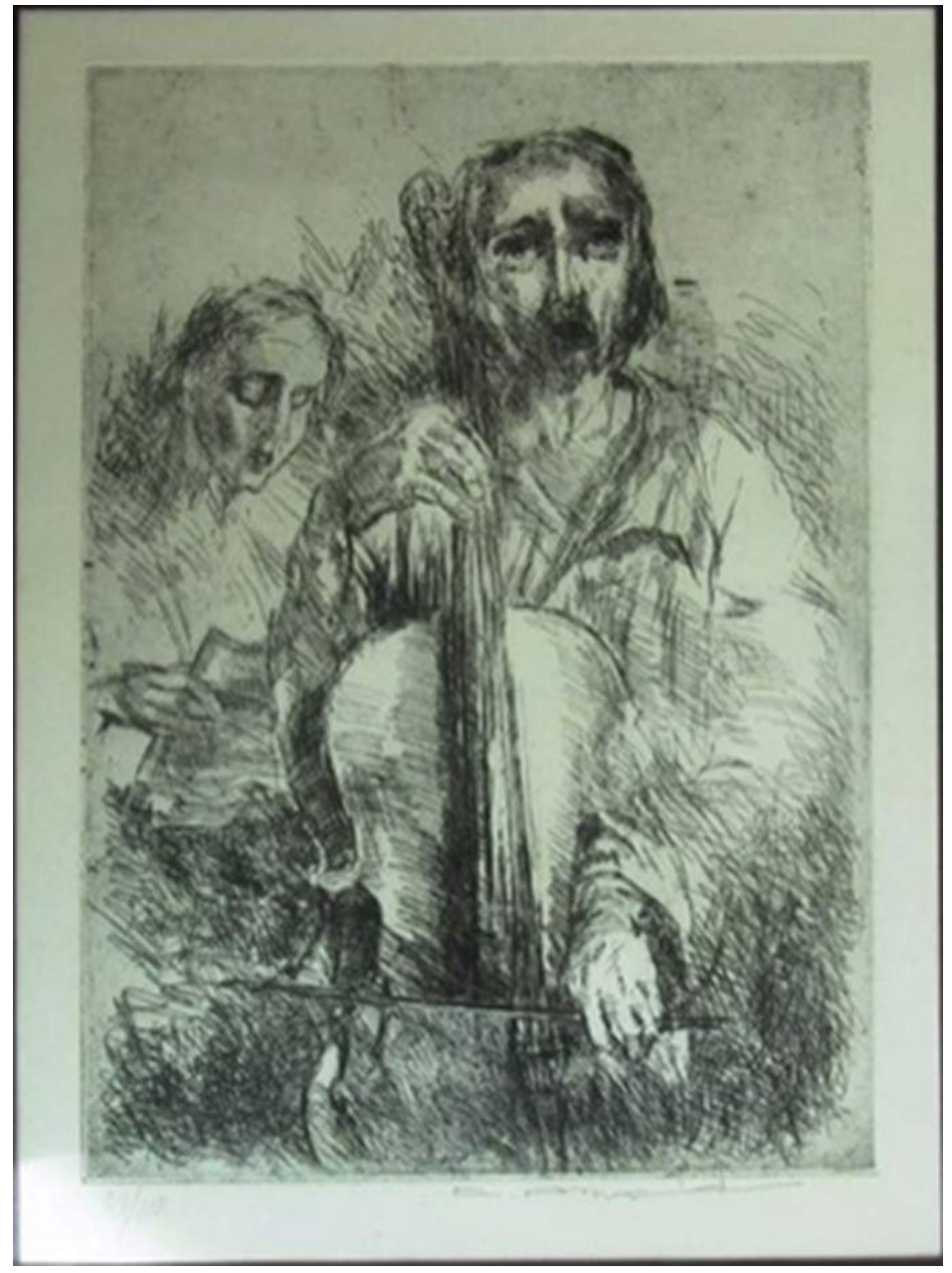

Fig. 174.B

174. TÍTULO: Andante da Quinta Sinfonia de Tchaikovsky.

A. DATA: 1963. TÉCNICA: Água-forte. MEDIDAS: 27,7 x 19,7 cm (mancha); 50 x 31,5 cm (papel). IMPRESSÃO: em preto. MATRIZ: cobre. MEDIDAS DA MATRIZ: $28,1 \mathrm{x} 20 \mathrm{~cm}$. ASSINATURA: "C. Oswald” no papel. COLEÇÃO Museu Nacional de Belas Artes/IBRAM/ MinC. PROVENIÊNCIA: Associação dos Amigos do Museu Nacional de Belas Artes, doação, 1963.

B. DATA: 1963. TÉCNICA: Água-forte. IMPRESSÃO: em preto. MATRIZ: cobre. MEDIDAS DA MATRIZ: 28,1 x $20 \mathrm{~cm}$. ASSINATURA: "C. Oswald" no canto inferior direito do papel. COLEÇÃO particular. FONTE: < http://produto.mercadolivre.com.br/MLB-761055869-carlos -oswald-gravuraandante-da-quinta-sinfonia-_JM> , acesso em 15/8/2017.

C. [matriz] DATA: 1963. TÉCNICA: Água-forte. MATRIZ: cobre. MEDIDAS DA MATRIZ: 28,1 x $20 \mathrm{~cm}$. Sem assinatura. COLEÇÃO Museu Nacional de Belas Artes/IBRAM/MinC. PROVENIÊNCIA: Associação dos Amigos do Museu Nacional de Belas Artes, doação, 1964. 


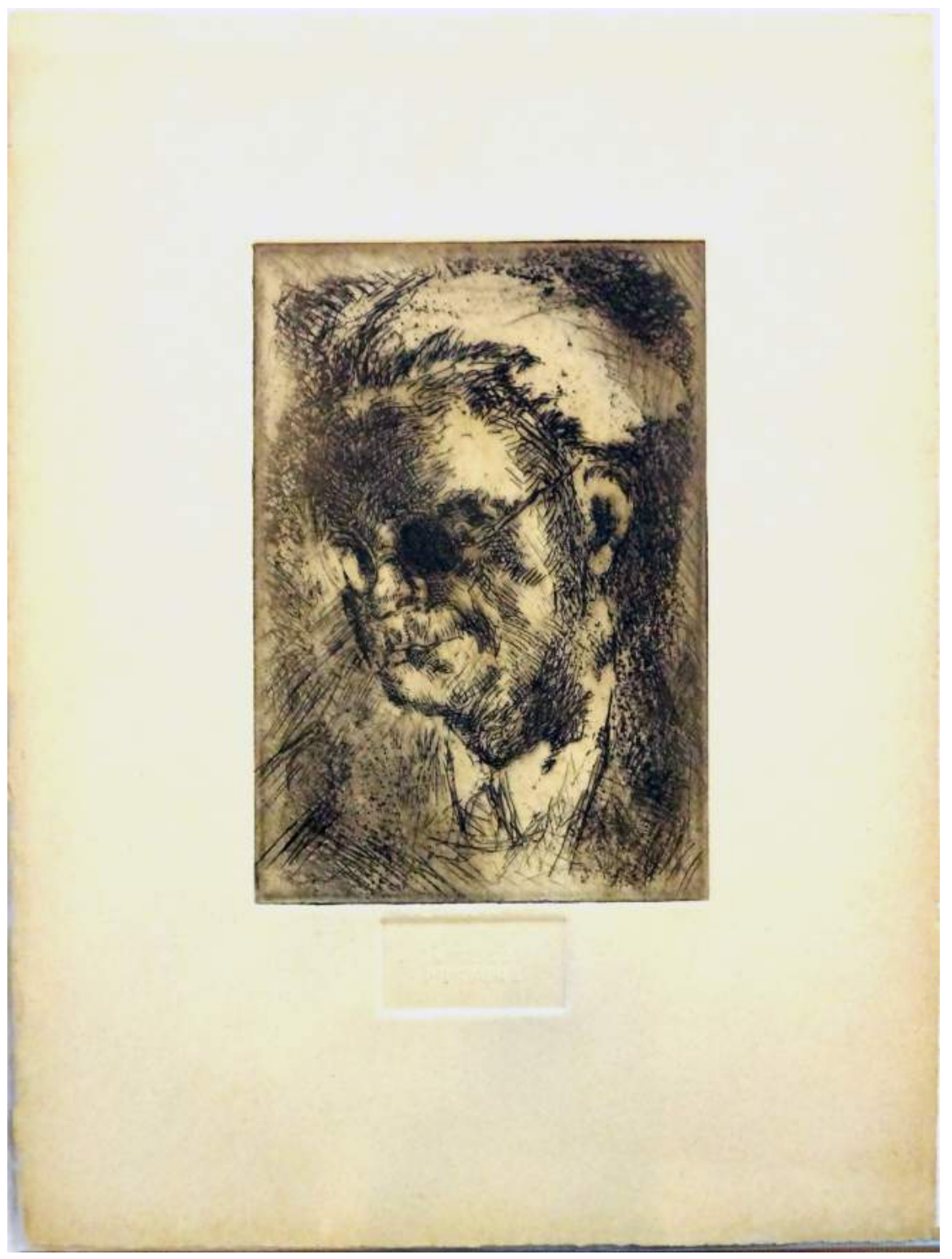

Fig. 175. A

175. TÍTULO: Autorretrato.

A. DATA: 1978 [?]. TÉCNICA: Água-forte. MEDIDAS: 10 x $15 \mathrm{~cm}$ (mancha). IMPRESSÃO: póstuma, em preto. Sem assinatura, marca d'água "Impressão póstuma". ACERVO Fundação Biblioteca Nacional. PROVENIÊNCIA: registrada no acervo 1978.

B. DATA: 1978 [?]. TÉCNICA: Água-forte. MEDIDAS: 10 x 15 cm (mancha); 28,3 x 20,4 cm (papel). IMPRESSÃO: póstuma, em preto. Sem assinatura, marca d'água "Impressão póstuma”. COLEÇÃO Museu Nacional de Belas Artes/IBRAM/MinC. PROVENIÊNCIA: Orlando Joaquim Correia da Silva, doação, 1978.

LITERATURA: Silva, 1969 (ref.); Exp. Carlos Oswald: o resgate de um mestre, Caixa Cultural, Brasília/Curitiba, 2011, p. 89 (rep.). 


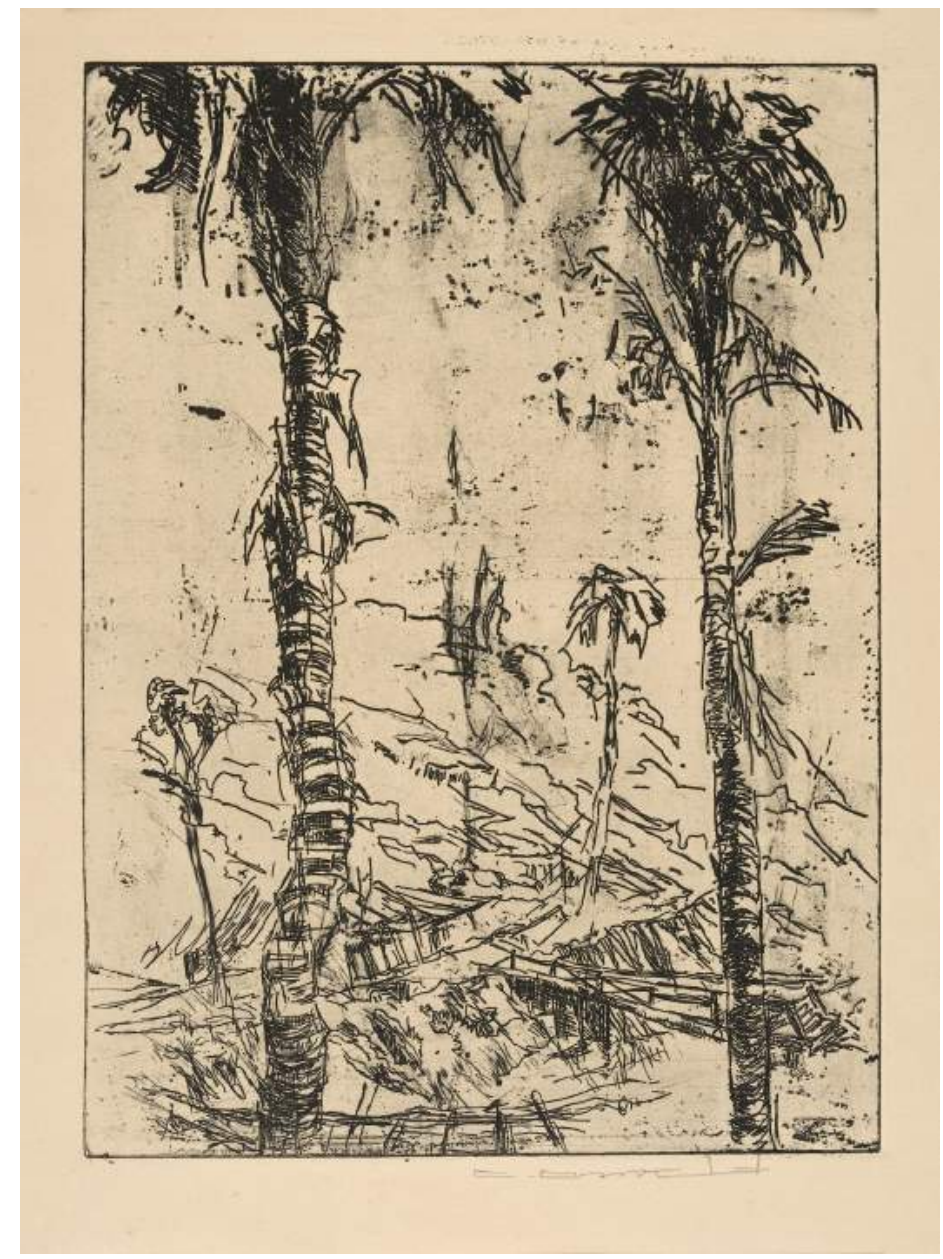

Fig. 176. A

176. TÍTULO: Paisagem com palmeiras.

A. DATA: 1964. TÉCNICA: Água-forte. MEDIDAS: 27,5 x 19,9 cm (mancha); 50 x 31,5 cm (papel). IMPRESSÃO: em preto. ASSINATURA: "C. Oswald" no canto inferior direito do papel. COLEÇÃO Museu Nacional de Belas Artes/IBRAM/MinC. FOTOGRAFIA: Acervo Museu Nacional de Belas Artes/IBRAM/MinC.

B. DATA: 1964. TÉCNICA: Água-forte. MEDIDAS: 27,5 x 19,8 cm (mancha); 50 x 31,6 cm (papel). IMPRESSÃO: em preto. ASSINATURA: "C. Oswald" no canto inferior direito do papel. COLEÇÃO Museu Nacional de Belas Artes/IBRAM/MinC. PROVENIÊNCIA: José Lucas Oswald, compra, 1968.

C. DATA: 1964. TÉCNICA: Água-forte. MEDIDAS: 28 x 19,9 cm (mancha). IMPRESSÃO: em preto. ASSINATURA: "C. Oswald” no canto do papel. ACERVO Fundação Biblioteca Nacional. PROVENIÊNCIA: registrada na coleção em 1970.

Obra pertencente ao álbum "Carlos Oswald cinco gravuras originais", impresso pela Gravura de Arte Editora, em 1964.

LITERATURA: Silva, 1969; Exp. A moderna gravura brasileira, Biblioteca Nacional, RJ, 1974, p. 15-16 (ref.); Exp. Carlos Oswald: o resgate de um mestre, Caixa Cultural, Brasília/Curitiba, 2011, p. 83 (rep.). 


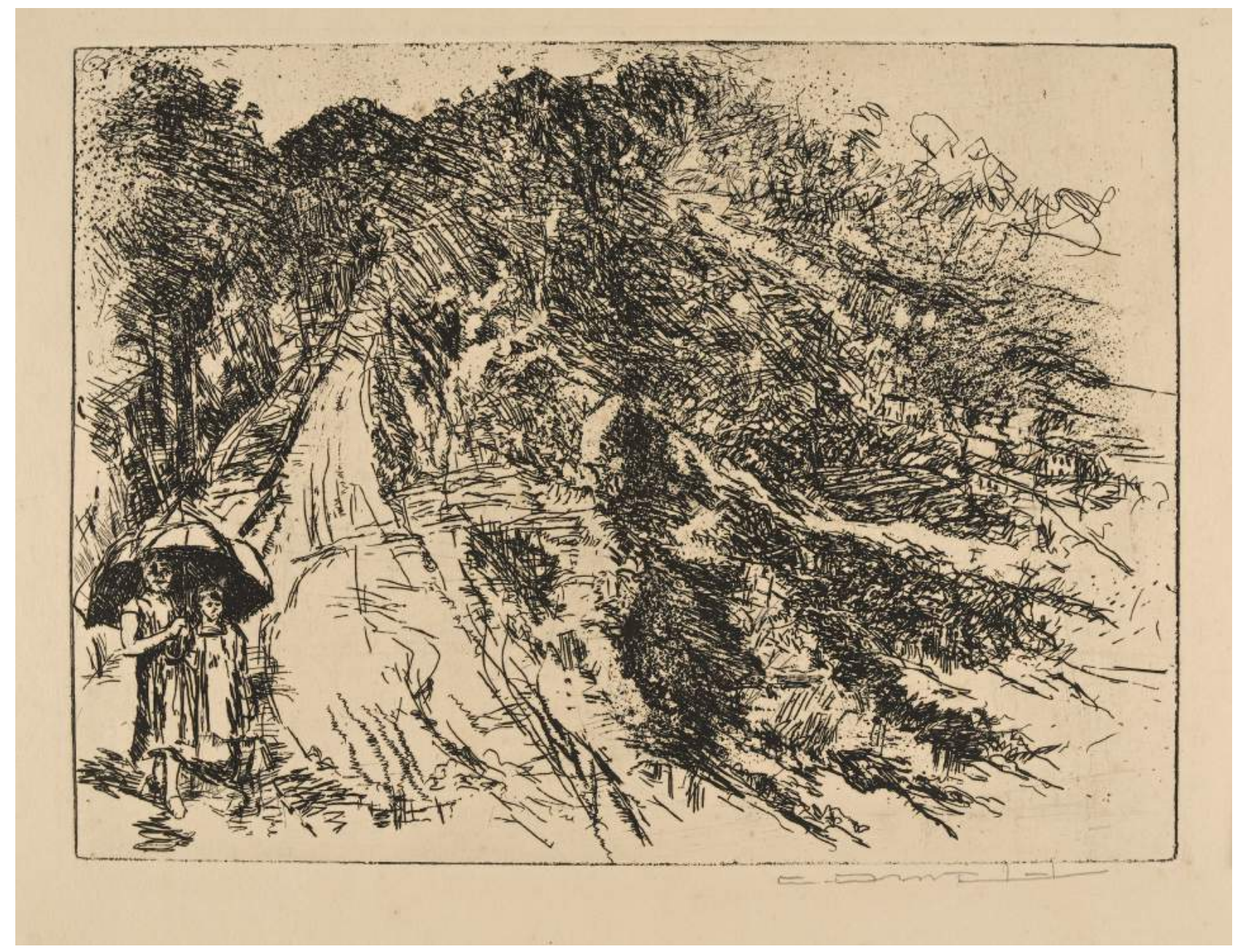

Fig. 177.A

177. TÍTULO: Dia chuvoso em Petrópolis [?]. VARIANTE: Paisagem.

A. DATA: 1964. TÉCNICA: Água-forte. MEDIDAS: 20 x 27,2 cm (mancha); 33,6 x 50 cm (papel). IMPRESSÃO: em preto. ASSINATURA: "C. Oswald" no canto inferior direito do papel. COLEÇÃO Museu Nacional de Belas Artes/IBRAM/MinC. FOTOGRAFIA: Acervo Museu Nacional de Belas Artes/IBRAM/MinC.

B. DATA: 1964. TÉCNICA: Água-forte. MEDIDAS: 19,9 x 27,7 cm (mancha). IMPRESSÃO: em preto. ASSINATURA: "C. Oswald” no canto do papel. ACERVO Fundação Biblioteca Nacional. PROVENIÊNCIA: registrada na coleção em 1970.

Obra pertencente ao álbum "Carlos Oswald cinco gravuras originais", impresso pela Gravura de Arte Editora, em 1964.

LITERATURA: Silva, 1969; Exp. A moderna gravura brasileira, Biblioteca Nacional, RJ, 1974, p. 15-16 (ref.); Exp. Carlos Oswald: o resgate de um mestre, Caixa Cultural, Brasília/Curitiba, 2011, p. 86 (rep.). 


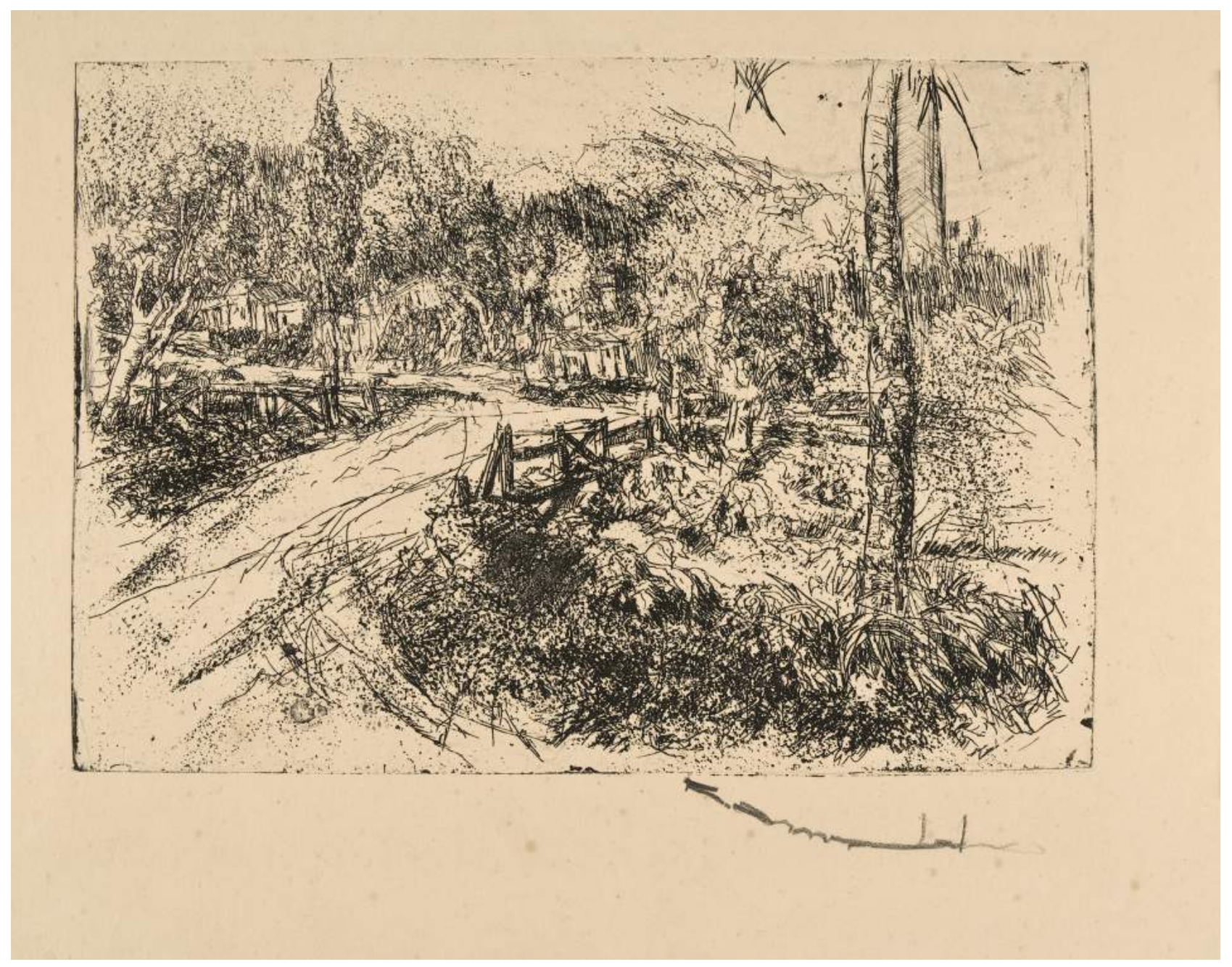

Fig. 178. A

178. TÍTULO: Ponte no Bingen [?]. VARIANTE: Paisagem.

A. DATA: 1964. TÉCNICA: Água-forte. MEDIDAS: 20,1 x 28,5 cm (mancha); 31,5 x 50,1 cm (papel). IMPRESSÃO: em preto. ASSINATURA: "C. Oswald" no canto inferior direito do papel. COLEÇÃO Museu Nacional de Belas Artes/IBRAM/MinC. PROVENIÊNCIA: Maria Isabel Oswald Monteiro, doação, 1982. FOTOGRAFIA: Acervo Museu Nacional de Belas Artes/IBRAM/MinC.

B. DATA: 1964. TÉCNICA: Água-forte. MEDIDAS: 20,1 x 29 cm (mancha). IMPRESSÃO: em preto. ASSINATURA: "C. Oswald” no canto do papel. ACERVO Fundação Biblioteca Nacional. PROVENIÊNCIA: registrada na coleção em 1970.

Obra pertencente ao álbum "Carlos Oswald cinco gravuras originais", impresso pela Gravura de Arte Editora, em 1964.

LITERATURA: Silva, 1969; Exp. A moderna gravura brasileira, Biblioteca Nacional, RJ, 1974, p. 15-16 (ref.); Exp. Carlos Oswald: o resgate de um mestre, Caixa Cultural, Brasília/Curitiba, 2011, p. 87 (rep.). 


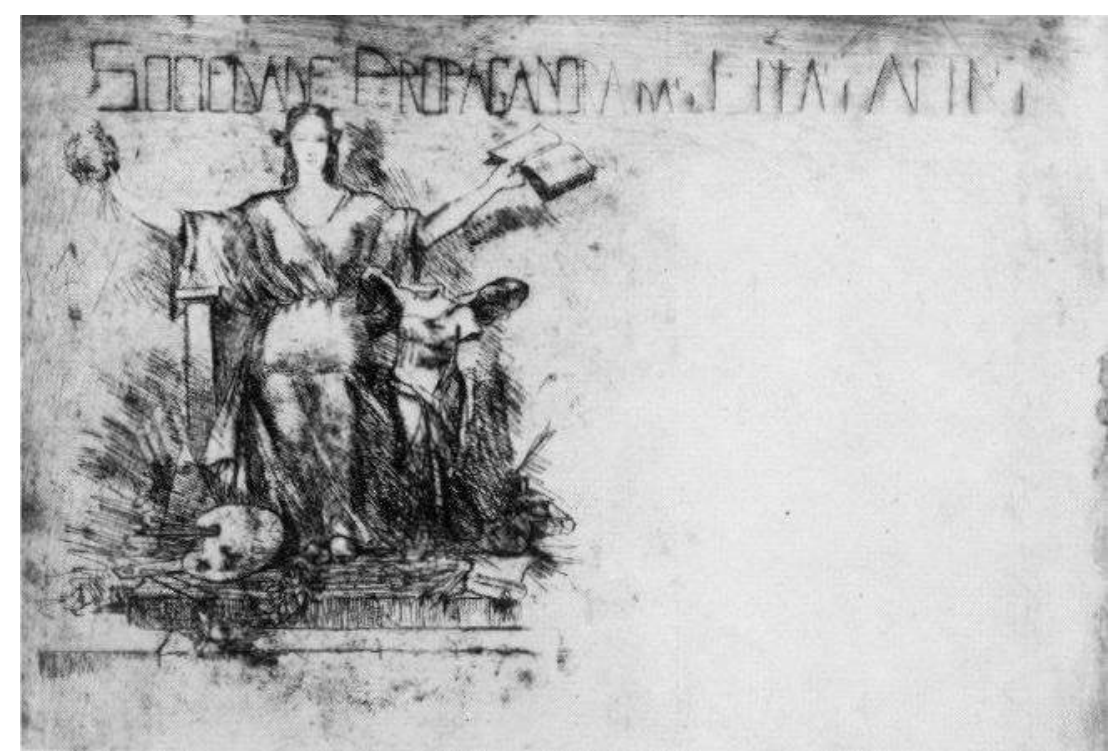

Fig. 179

179. TÍTULO: Diploma para a "Sociedade Propagadora de Bellas Artes".

DATA: 1931/1940 [?]. TÉCNICA: Água-forte e ponta seca. MEDIDAS: 27,5 x 40,3 cm (mancha); 37,5 x 54,9 cm (papel). IMPRESSÃO: em preto. ASSINATURA: "C. Oswald" no papel. COLEÇÃO Museu Nacional de Belas Artes/IBRAM/MinC. PROVENIÊNCIA: Carlos Oswald, doação, 1963. FOTOGRAFIA: Acervo Museu Nacional de Belas Artes/IBRAM/MinC. 


\section{Referências bibliográficas}

\section{Livros, monografias, trabalhos acadêmicos}

ACCIOLY, Godiva. Um pintor na Ordem de São Gregório. Revista Brasileira de História da Educação, Maringá-PR, v. 15, n. 2 (38), p. 247-278, maio/ago. 2015. Disponível em: http://www.rbhe.sbhe.org.br/index.php/rbhe. Acesso em: 6/10/2017.

AMARAL, Aracy. Arte para quê? A preocupação social na arte brasileira 1930 - 1970. São Paulo: Nobel, 1984.

AMARAL, Cláudio Silveira. Rui Barbosa e John Ruskin: a política do ensino do desenho. Arquitextos, São Paulo, ano 11, n. 121.07, Vitruvius, jun. 2010. Disponível em: $<$ http://www.vitruvius.com.br/revistas/read/arquitextos/10.121/3467>. Acesso em: 17/6/2017.

AMERICAN NATIONAL COMMITTEE OF ENGRAVING. Seventy-Five Latin American Prints: A survey of contemporary printmaking in eighteen countries of Central and South America. [EUA]: [Corcoran Gallery, American National Committee of Engraving], [1944]. Catálogo de exposição.

ARNONE, Marianne F.. A gravura como difusora da arte: um estudo sobre a gravura brasileira no final do século XIX a partir da análise dos textos e produção crítica de Félix Ferreira. 2014. 220f. Dissertação (Mestrado em Artes Visuais) - Universidade de São Paulo, Escola de Comunicações e Artes, 2014.

ARTISTAS gravadores do Brasil = Brazilian engravers = Grafische Kuenstler Brasiliens. S.l., Volkswagen do Brasil, 1984.

AYALA, Walmir (coord.). Dicionário de Artistas Plásticos: arquitetura, escultura, pintura, desenho, gravura, artes aplicadas. Vol. 3 (M a P). Brasília: Instituto Nacional do Livro, MEC, 1973.

BARDI, P. M.. História da arte brasileira: pintura, escultura, arquitetura, outras artes. São Paulo: Ed. Melhoramentos, 1975.

BARROS, Álvaro Paes de. O Liceu de Artes e Ofícios e seu fundador. Rio de Janeiro: [s.n.], 1956.

BIBLIOTECA NACIONAL - Brasil. A moderna gravura brasileira. Organizado por Eunice de Manso Cabral. Rio de Janeiro: Biblioteca Nacional, 1974. Catálogo de exposição.

BIELINSKI, Alba Carneiro. O Liceu de Artes e Ofícios: sua história de 1856 a 1906. 19\&20, Rio de Janeiro, v. IV, n. 1, jan. 2009. Disponível em: $<$ http://www.dezenovevinte.net/ensino_artistico/liceu_alba.htm>. Acesso em: 5/10/2017.

BOSSE, Abraham. Tratado da gravura à água forte, e a buril, e em maneira negra com o modo de construir as prensas modernas e de imprimir em talho doce. Tradução de José Joaquim Viegas de Menezes. Lisboa: Typographia Chalcographica, Typoplastica e Literaria do Arco do Cego, 1801.

BOTELhO, Adir et al. Gravura Brasileira. Hoje. Depoimentos. Coordenação Heloísa Pires Ferreira, Maria Luisa Luz Távora e Adamastor Camará. Rio de Janeiro: Oficina de Gravura SESCTijuca, 1996, v.2.

BÜRGER, W.. Un mot sur l'eau-forte. In: SOCIÉTÉ DES AQUA-FORTISTES, Eaux-Fortes modernes: oeuvres inédites et originales. Paris: Cadart \& Luquet, 1864.

BUTI, Marco. LETYCIA, Anna (org.). Gravura em metal. São Paulo: Editora da Universidade de São Paulo, Impressa Oficial do Estado, 2002. 
CAIXA CULTURAL. A gravura brasileira na Coleção Mônica e George Kornis. Textos de Mônica e George Kornis e Rubem Grilo. São Paulo et al.: Caixa Cultural, 2007. Catálogo de exposição

CAMPINA, Eugenio. Construzioni idrauliche e jiraulica tecnica, basi scientifiche, applicazioni teoniche, studi speciali. Milano: U. Hoepli, 1933.

CENTRO CULTURAL BANCO DO BRASIL. Rembrandt e a arte da gravura. Textos de Eva Ornstein-Van Slooten, Marijke Holtrop e Peter Schatborn. Curadores Ed de Heer, Pieter Tjabbes, Aernoud Hagen. Brasília: Centro Cultural Banco do Brasil, 2002. Catálogo de exposição.

DUQUE-ESTRADA, Luiz Gonzaga. Contemporaneos (pintores e esculptores). Rio de Janeiro, Benedicto de Souza, 1929.

ESCOLA NACIONAL DE BELAS ARTES. Catalogo da exposição Geral de Bellas Artes: inaugurada em $1^{\circ}$ outubro de 1894. Rio de Janeiro: Typographia Hildebrandt, 1894. Acervo do Museu Nacional de Belas Artes/IBRAM/MinC. Disponível em: < http://docvirt.com/docreader.net/DocReader.aspx?bib=bib redarte\&pagfis $=4300 \quad>$. Acesso em: 20/06/2017.

ESCOLA NACIONAL DE BELlAS ARTES. Catalogo da $3^{\text {a }}$ Exposição Geral de Bellas Artes. Rio de Janeiro: $\quad$ [s.n.], 1896. $\quad$ Disponível em: http://docvirt.com/docreader.net/DocReader.aspx?bib=bib redarte\&pagfis $=4300>$. Acesso em: 09/6/2017.

FERNANDES, Cybele Vidal Neto. O Ensino de Pintura e Escultura na Academia Imperial das Belas Artes. 19\&20, Rio de Janeiro, v. II, n. 3, jul. 2007. Disponível em: $<$ http://www.dezenovevinte.net/ensino_artistico/aiba_ensino.htm>. Acesso em: 26/5/2017.

FERREIRA, Félix. Pequenas exposições: I - Do Liceu de Artes e Ofícios em 1882. In: Belas Artes: estudos e apreciações. 2.ed. Porto Alegre, RS: Zouk, 2012.

FERREIRA, Orlando da Costa. Imagem e letra: Introdução à Bibliologia Brasileira: A imagem gravada. $2^{\text {a }}$ ed.. São Paulo: Editora da Universidade de São Paulo, 1994.

FONTANA, Carla Fernanda. O Desenho de Letras em Capas de Livros: Edgar Koetz e a Seção de Desenho da Livraria do Globo de Porto Alegre. Livro, São Paulo, Núcleo de Estudos do Livro e da Edição - USP, nº 5, 2016.

. O trabalho de Poty Lazzarotto como Ilustrador. 2010. 132p. Dissertação (Mestrado) - Faculdade de Filosofia Letras e Ciências Humanas - USP, São Paulo, 2010.

GALERIA DE ARTE BANERJ. Axl Leskoschek e seus alunos: Brasil/1940-1948. Curadoria Frederico Morais; texto Frederico Morais. Rio de Janeiro: Galeria de Arte Banerj, 1985. Catálogo de exposição.

GAUTIER, Théophile. Un mot sur l'eau-forte. In: SOCIÉTÉ DES AQUA-FORTISTES, Eaux-Fortes modernes: oeuvres inédites et originales. Paris: Cadart \& Luquet, $1862-1863$. Société des Aquafortistes, Eaux-Fortes modernes, 1863.

HADEN, Francis Seymour. The relative claims of etching and engraving to rank as fine arts, and to be represented as such in the Royal Academy of Arts. London: Matchim and Son, 1883.

INSTITUTO TOMIE OHTAKE. Guignard e o Oriente: China, Japão e Minas. Curadoria Paulo Herkenhoff. São Paulo: Instituto Tomie Ohtake, 2010. Catálogo de exposição. 
KOSSOVITCH, Leon. LAUDANNA, Mayra. Gravura: Arte Brasileira do Século XX. Apres. Ricardo Ribenboim. São Paulo: Cosac \& Naify/ Itáu Cultural, 2000.

LE BRUN Charles. Conference de Monsier Le Brun premier peintre du Roy de France, chancelier et directeur de l'Academie de Peinture et Sculpture. Paris: E. Picart le Rom, 1698.

LEITE, José Roberto Teixeira. A gravura brasileira contemporânea. Rio de Janeiro: Ed. Expressão e Cultura, 1966.

MARINI, Giorgio. L'incisione a Firenze a ridosso della Grande Guerra: spunti per gli esordi di Carlo Sbisà. In: CABURLOTTO, Luca. DE GRASSI, Massimo (a cura di). Carlo Sbisà: 'ai quadri miei non dan libero passo'. Trieste: EUT Edizioni Università di Trieste, 2014, pp. 69-96. Disponível em: $<$ https://www.academia.edu/> . Acesso em: 04/07/2017.

MARTINS, José E.. Henrique Oswald: músico de uma saga romântica. São Paulo: Editora da Universidade de São Paulo, 1995.

MELIS-MARINI, Felice. L'Acquaforte - Manuale Pratico con 10 tavole e 15 prove originali. Milão, Itália: Ulrico Hoepli, 1916.

MONTEIRO, Maria Isabel Oswald. Carlos Oswald (1882 - 1971): Pintor da Luz e dos Reflexos. Rio de Janeiro: Casa Jorge, 2000.

. Carlos Oswald. Henrique Oswald. Site. [S.1]: [S.n.], [S.d]. Disponível em: $<$ http://www.oswald.com.br/site2010/carlos1.htm $>$. Acesso em 23/03/17.

MÜNCHENER KÜNSTLERGENASSENCHAFT. Offizieller Katalog der Münchener JahresAusstellung im KGL. Glaspalast. München: Münchener Künstlergenassenchaft, 1910.

MURASSE, Celina M.. A educação para a ordem e o progresso do Brasil: O Liceu de Artes e Ofícios do Rio de Janeiro (1856-1888). 2001. 184f. Tese (Doutorado) - Universidade Estadual de Campinas, Faculdade de Educação, Campinas, 2001.

MUSÉE DES BEAUX-ARTS DE DIJON. Portrait présumé de Jean-Philippe Rameau. Collections du Musée des Beaux-arts de Dijon. Site. Disponível em: http://mbacollections.dijon.fr/ow4/mba/voir.xsp?id=00101-451\&qid=sdx_q0\&n=2\&e= Acesso em 12/09/2017.

MUSÉE DU LOUVRE. Rembrandt et la figure du Christ. Site. Disponível em: < http://rembrandt.louvre.fr/fr/html/r13.html >. Acesso em 2/09/2017.

MUSEU NACIONAL DE BELAS ARTES. Carlos Oswald no Museu Nacional de Belas Artes do Rio de Janeiro-1982. Texto de Orlando da Silva. Rio de Janeiro: Museu Nacional de Belas Artes, 1982. Catálogo de exposição.

OSWALD, Carlos. Gravuras. Textos de Lívio Abramo e Maria Izabel Oswald Monteiro. Álbum contendo gravuras originais e autenticadas de Carlos Oswald. São Paulo: Graphus, 1979.

OSWALD, Maria Gertrudes M.B. (org). Processo de trabalho. Carlos Oswald, 1882- estudos \& desenhos. Exposição organizada por Maria Gertrudes M.B. Oswald. Rio de Janeiro: Solar Grandjean de Montigny, 1982. Catálogo de exposição.

PEREIRA, Ricardo A. B.. A ENBA da primeira metade do século XX vista pela obra de alguns dos seus professors: uma gradual transição para o moderno. 19\&20, Rio de Janeiro, v. VIII, n. 1, jan./jun. 2013. Disponível em: <http://www.dezenovevinte.net/ensino_artistico/ensino_enba_rp.htm $>$. Acesso em: 5/10/2017. 
PIZA, Maria A. de T. B.. A Poética da Luz na Obra de Carlos Oswald. 2004. Tese (Doutoramento em Artes). Faculdade de Arquitetura, Artes e Comunicação, UNESP, Bauru, 2004.

PONTUAL, Roberto. Dicionário das Artes Plásticas no Brasil. Rio de Janeiro: Ed. Civilização Brasileira, 1969.

RIFFAULIDES HÊTRE, Jean René Denis, 1752-1826. Nouveau manuel complet dy peintre en batiments, du gabricant de couleurs, du doreur, du vernisseur, du vitrier et de l'argenteur. Paris: Lib. encyclopédique de Roret, 1843.

SILVA, M. Nogueira da. Dois grandes Artistas. In Artistas de Hoje. Rio de Janeiro: Editora Brasileira Lux, 1925.

SILVA, Orlando da. Carlos Oswald o gravador - Catálogo "raisonné". Rio de Janeiro: Gravura de Arte Editora, 1969.

SILVA, Orlando da. GRASSMANN, Marcelo. A arte maior da gravura. São Paulo: Edição Espade, 1976.

TÁVORA, Maria L. Luz. A gravura artística na Escola Nacional de Belas Artes - anos 50/60: tensões e conquistas na atualização do seu ensino de arte. In: COLÓQUIO DO COMITÊ BRASILEIRO DE HISTÓRIA DA ARTE, 24, 204, Belo Horizonte. Anais... Belo Horizonte: [s.n.], 2004. Disponível em: http://www.cbha.art.br/coloquios/2004/textos/76 maria luisa luz tavora.pdf. Acesso em: $04 / 04 / 2017$.

. A gravura no Liceu de Artes e Ofícios - RJ: tensão entre métier e meio expressivo. In: ENCONTRO DA ASSOCIAÇÃO NACIONAL DE PESQUISADORES EM ARTES PLÁSTICAS, 16, 2007, Florianópolis, SC. Anais... Florianópolis, SC: ANPAP, UDESC, Clicdata Multimídia, 2007. p.381-390. Disponível em: $<$ http://anpap.org.br/anais/2007/2007/artigos/039.pdf $>$. Acesso em: 8 mar. 2017.

Experiência Moderna: gravura no Curso de Desenho de Propaganda e de Artes Gráficas - Fundação Getúlio Vargas 1946. In: ENCONTRO NACIONAL DA ASSOCIAÇÃO NACIONAL DE PESQUISADORES DE ARTES PLÁSTICAS, 21, 2012, Rio de Janeiro. Anais... Rio de Janeiro: ANPAP, 2012. p.1608-1619. Disponível em:< http://www.anpap.org.br/anais/2012/pdf/simposio9/maria luisa tavora.pdf> Acesso em: 8 mar. 2017.

VALLE, Arthur Gomes. A pintura da Escola Nacional de Belas Artes na $1^{\text {a }}$ República (18901930): da formação do artista aos seus modos estilísticos. Tese (Doutorado em História e Crítica da Arte) - Universidade Federal do Rio de Janeiro, Programa de Pós-Graduação em Artes Visuais, PPGAV. Rio de Janeiro: [s.n], 2007. [Versão não revisada]. Disponível em: < https://www.academia.edu/24168944/2007_-

A_Pintura_da_Escola_Nacional_de_Belas_Artes_na_1a_Rep\%C3\%BAblica_1890-

1930_Da_Forma\%C3\%A7\%C3\%A30_do_Artista_aos_seus_Modos_Esti1\%C3\%ADsticos_Tese_de_ Doutorado_Vers\%C3\%A3o_N\%C3\%Ä3o_Revisada_> . Acesso em 31/3/17.

VERGOLINO, Paulo Leonel Gomes (cur). Carlos Oswald: o resgate de um mestre. Brasília, Curitiba: Caixa Cultural, 2011. Catálogo de exposição.

O olhar estrangeiro: A obra gravada de Hans Steiner como recorte-modelo para o resgate da História da Gravura no Brasil. 2015. 156f. Dissertação (Mestrado) Universidade Estadual de Campinas, Instituto de Artes. Campinas, SP: [s.n.], 2015. 


\section{Documentos, leis, decretos}

ANTONIO NICOLAU TOLENTINO. In: ACERVO Arquivológico do Museu D. João VI/EBA/UFRJ. Disponível em: <http://www.museu.eba.ufrj.br/>. Acesso em: 25/05/2017.

BRASIL. Lei n. 1.331-A, de 17 de fevereiro de 1854. Approva o regulamento para a reforma do ensino primario e secundário do Municipio da Côrte. Portal da Câmara dos Deputados. Disponível em: < http://www2.camara.leg.br/legin/fed/decret/1824-1899/decreto-1331-a-17-fevereiro-1854590146-publicacaooriginal-115292-pe.html>. Acesso em: 6/10/2017.

. Decreto n. 3.012, de 28 de novembro de 1862. Approva os estatutos da Sociedade Propagadora das Bellas Artes. Portal da Câmara dos Deputados. Disponível em:< http://www2.camara.leg.br/legin/fed/decret/1824-1899/decreto-3012-28-novembro-1862-555891publicacaooriginal-75401-pe.html>. Acesso em: 10/06/2017.

Lei n. 3.141, de 30 de outubro de 1882. Fixa a Despeza Geral do Imperio para os exercícios de 1882-1883 e 1883-1884, e dá outras providencias. Collecção das Leis do Imperio do Brazil de 1882. Rio de Janeiro: Imprensa Nacional, 1883. Parte I - Tomo XXIX, v. 1, p. 105. Disponível em: http://www2.camara.leg.br/atividade-legislativa/legislacao/publicacoes/doimperio/colecao8.html. Acesso em: 6/10/2017.

Decreto n. 8.802, de 16 de dezembro de 1882. Crêa na Academia de Bellas-Artes a cadeira de xylographia. Colleç̧ão dos Actos do Poder Executivo do Imperio do Brazil de 1882. Rio de Janeiro: Typographia Nacional, 1883. Parte II, Tomo XLV, V. II, p.537.

. Decisões do Ministerio do Imperio n.47, de 26 de julho de 1884. Approva, com modificações, o programma para o concurso da nova cadeira de xylographia da Academia das Bellas Artes. Colleç̧ão das Decisões do Imperio do Brazil de 1884. Rio de Janeiro: Typographia Nacional, 1885, p. 23. Disponível em: $<$ http://www2.camara.leg.br/atividadelegislativa/legislacao/publicacoes/doimperio/colecao8.html>. Acesso em 6/10/2017.

Decreto n. 983, de 8 de novembro de 1890. Approva os estatutos para a Escola Nacional de Bellas-Artes. Portal da Câmara dos Deputados. Disponível em: $<$ http://www2.camara.leg.br/legin/fed/decret/1824-1899/decreto-983-8-novembro-1890-517808publicacaooriginal-1-pe.html>. Acesso em: 09/06/2017.

Lei n. 191-B, de 30 de setembro de 1893. Fixa a despeza geral da Republica dos Estados Unidos do Brazil para o exercicio de 1894, e dá outras providencias. Portal da Câmara dos Deputados. Disponível em: < http://www2.camara.leg.br/legin/fed/lei/1824-1899/lei-191-b-30setembro-1893-541013-publicacaooriginal-42740-pl.html>. Acesso em: 10/6/2017.

Decreto n. 3.987, de 13 abril 1901. Approva o regulamento para a Escola Nacional de Bellas Artes. Diário Oficial da União, Rio de Janeiro, 18 abr. 1901.

Decreto $\mathrm{n}^{\circ}$ 8.659, de 5 de Abril de 1911. Approva a lei Organica do Ensino Superior e do Fundamental na Republica. Portal da Câmara dos Deputados. Disponível em:< http://www2.camara.leg.br/legin/fed/decret/1910-1919/decreto-8659-5-abril-1911-517247publicacaooriginal-1-pe.html>. Acesso em: 8/10/2017.

. Decreto n. 9.919, de 7 de dezembro de 1912. Abre ao Ministerio da Agricultura, Industria e Commercio o credito de 300:000\$ para auxiliar a construcção do novo edificio do Lycen de Artes e Officios do Rio de Janeiro. Portal da Câmara dos Deputados. Disponível em: $<$ http://www2.camara.leg.br/legin/fed/decret/1910-1919/decreto-9919-7-dezembro-1912-520178publicacaooriginal-1-pe.html>. Acesso em: 10/6/2017. 
Decreto $\mathrm{n}^{\circ} 16.967$, de $1^{\circ}$ de julho de 1925. Concede á Sociedade Propagadora das Bellas Artes o direito de emittir "debentures", para resgate de emprestimo emittido para a construcção do edificio do Lyceu de Artes e Officios. Portal da Câmara dos Deputados. Disponível em: < http://www2.camara.leg.br/legin/fed/decret/1920-1929/decreto-16967-1-julho-1925-514370publicacaooriginal-1-pe.html $>$. Acesso em 6/10/2017.

Decreto-lei $\mathrm{n}^{\circ}$ 1.604, de 14 de setembro de 1939. Autoriza o Prefeito do Distrito Federal a contratar com a Sociedade Propagadora das Belas Artes a cessão de benfeitorias de sua propriedade à Prefeitura nas condições que menciona. Portal da Câmara dos Deputados. Disponível em: http://www2.camara.leg.br/legin/fed/declei/1930-1939/decreto-lei-1604-14-setembro-1939-411628publicacaooriginal-1-pe.html. Acesso em 6/10/2017.

. Universidade do Brasil. Regimento da Escola Nacional de Belas Artes, de 08 de agosto de 1947. Diário Oficial da União, Seção 1, Rio de Janeiro, 08 ago. 1947, p.12.

GIRARDET, Augusto Giorgio. In: ACERVO Arquivológico do Museu D. João VI/EBA/UFRJ. Disponível em: $<$ http://www.museu.eba.ufrj.br/>. Acesso em 25/05/2017.

GRAVURA DE MEDALHAS E PEDRAS PRECIOSAS. In: ACERVO Arquivológico do Museu D. João VI/ EBA/UFRJ. Disponível em: <http://www.museu.eba.ufrj.br/>. Acesso em 25/05/2017.

LAZZAROTTO, Napoleon Potyguara. [Carta] Jul. 195X, São Paulo [para] OSWALD, Carlos. Rio de Janeiro. 1f. Arquivo Histórico do Museu Nacional de Belas Artes/IBRAM/MinC.

LAZZAROTTO, Napoleon Potyguara. [Carta] Set. 194X, Paris [para] OSWALD, Carlos. Petrópolis. 1f. Arquivo Histórico do Museu Nacional de Belas Artes/IBRAM/MinC.

MAIA, Ernesto Gomes M.. Academia Imperial das Bellas-Artes. Rio de Janeiro: Academia Imperial das Bellas Artes, 17 abr. 1884. Relatório manuscrito. Arquivo do Museu D. João VI/EBA/UFRJ.

MORRIS, Peter. [Carta] 07 jul. 1952, Rio de Janeiro [para] OSWALD, Carlos. Rio de Janeiro. 1f. Arquivo Histórico do Museu Nacional de Belas Artes/IBRAM/MinC.

RESENDE, Antônio de Pádua Assis. Relatorio sobre os trabalhos da Commissão do Brazil na Exposição Turim-Roma de 1911 e propaganda do café no estrangeiro. Turim: [s.n.], 1911, p.94.

ROSA, Tomás de. [Carta] 14 fev. 1946, Rio de Janeiro [para] OSWALD, Carlos. Rio de Janeiro. 2 f. Arquivo Histórico do Museu Nacional de Belas Artes/IBRAM/MinC.

ROSA, Tomás de. [Carta] 19 jan. 1946, Rio de Janeiro [para] OSWALD, Carlos. Rio de Janeiro. 2 f. Arquivo Histórico do Museu Nacional de Belas Artes/IBRAM/MinC.

SILVA, M. Nogueira da. [Álbum de fotografias de artistas brasileiros e estrangeiros]. [Rio de Janeiro], [1920]. Fotografia, 212p. Biblioteca Nacional (Brasil).

SOCIEDADE PROPAGADORA DE BELLAS ARTES. A Sociedade Propagadora das BellasArtes e o Lycêo de Artes e Officios do Rio de Janeiro. Rio de Janeiro: Typographia Hildebrandt, 1883.

STEINER, Hans. [Carta] 06 ago. 1948, Porto Alegre [para] OSWALD, Carlos. Rio de Janeiro. 1f. Arquivo Histórico do Museu Nacional de Belas Artes/IBRAM/MinC.

STEINER, Hans. [Carta] 20 abr. 1955, Teresópolis [para] OSWALD, Carlos. Rio de Janeiro. 1f. Arquivo Histórico do Museu Nacional de Belas Artes/IBRAM/MinC. 
TOlentino, Antônio Nicolau. Relatorio do Director da Academia das Bellas-Artes. Rio de Janeiro: Academia Imperial das Bellas Artes, 26 abr. 1883. Documento datiloscrito. Arquivo do Museu D. João VI/EBA/UFRJ.

XILOGRAFIA. In: ACERVO Arquivológico do Museu D. João VI/EBA/UFRJ. Disponível em: $<$ http://www.museu.eba.ufrj.br/>. Acesso em 25/05/2017.

\section{Periódicos}

“A Noticia” no "Salon”. A Notícia, Rio de Janeiro, 3 set. 1913.

A eleição do Lyceo - Sociedade Propagadora de Bellas Artes. O Seculo, Rio de Janeiro, 28 set. 1911, p.3.

A exposição do livro. A Manhã, Rio de Janeiro, 13 mai. 1927

A exposição do pintor e agua-fortista Carlos Oswald. A Gazeta, São Paulo, 11 dez. 1923.

A Exposição Oswald na Escola de Bellas Artes. Correio da Noite, Rio de Janeiro, 23 maio 1913, p.1.

A grande exposição de Arte da Casa dos Artistas. O Jornal, Rio de Janeiro, 23 dez. 1921.

A inauguração da galeria de compositores brasileiros já falecidos no Instituto de Educação. Correio da Manhã, Rio de Janeiro, 25 nov. 1933.

Algumas impressões sobre a exposição Latour-Oswald. Correio da Manhã, Rio de Janeiro, 04 jun. 1913.

A próxima semana. Jornal do Brasil, Rio de Janeiro, 18 nov. 1977.

A.M. O que é a gravura a água-forte. Leitura para todos, Rio de Janeiro, nov. 1920.

A.V.. Á proposito do 'Salão de 1913'. Suplemento d'A Notícia, Rio de Janeiro, 18 out. 1913.

A.V.. Salão de 1909. A Notícia, Rio de Janeiro, 31 ago. 1909.

ALMEIDA, Renato. Um artista interior. O Malho, Rio de Janeiro, 04 out. 1919.

AMADOR, Bueno. Belas Artes. O Salão de 1906. Jornal do Brasil, Rio de Janeiro, 26 set. 1906, p.2.

AMADOR, Bueno. Belas-Artes. Jornal do Brasil, Rio de Janeiro, 15 set. 1908, p.4.

AMADOR, Bueno. Belas-artes. Jornal do Brasil, Rio de Janeiro, 18 set. 1908, p.6.

AMADOR, Bueno. Bellas Artes Salão de 1909. Jornal do Brasil, Rio de Janeiro, 4 set. 1909.

AMADOR, Bueno. O Salão de 1906. Jornal do Brasil, Rio de Janeiro, 10 set. 1906.

A repercussão da obra de um artista patrício no estrangeiro. Gazeta de Notícias, Rio de Janeiro, 12 jun. 1927.

Artes e Artistas. Circulo de Bellas Artes. O Paiz, Rio de Janeiro, 21 nov. 1909.

As Artes - Notícias Diversas. Diário Carioca, Rio de Janeiro, 18 mar. 1949, p.6. 
As Artes. Diário Carioca, Rio de Janeiro, 10 fev. 1949, p. 6.

As Artes. Diário Carioca, Rio de Janeiro, 18 mar. 1949, p. 6.

As Artes. Diário Carioca, Rio de Janeiro, 24 jun. 1949, p. 6.

A Exposição Geral de Bellas Artes. A Federação, Porto Alegre, 30 set. 1913

A Ultima Ceia: Agua-forte de Carlos Oswaldo. Illustração Brasileira, Rio de Janeiro, abr. 1924.

Bellas Artes. Correio da Manhã, Rio de Janeiro, 06 dez. 1935.

Bellas Artes. Revista da Semana, Rio de Janeiro, 18 ago. 1917.

BENTO, Antonio. Alunos da F.G.V. na A.B.I. Diário Carioca, Rio de Janeiro, 11 mar. 1947.

BENTO, Antonio. Desaparecerá o curso da F.G.V?. Diário Carioca, Rio de Janeiro, 14 fev. 1947.

BENTO, Antonio. O curso da "Fundação Getúlio Vargas". Diário Carioca, Rio de Janeiro, 13 fev. 1947.

BENTO, Antonio. Uma geração de gravadores. Diário Carioca, Rio de Janeiro, 16 fev. 1947.

CALZINI, Raffaele. Esposizioni e Concorsi: La Mostra Nazionale dell'Incisione. Emporium, Bergamo, Itália, mar. 1915, pp.181-191.

CAPRIN, Giulio. Arte contemporânea: Giovani ritrattisti toscani. Emporium, Bergamo, Itália, mai. 1913.

CARLOS, J.. Velho Amador. O Jornal, Rio de Janeiro, 22 nov. 1919.

Carlos Oswald. Correio Paulistano, São Paulo, 20 jan. 1918.

Centenario da parochia do Braz. Correio Paulistano, São Paulo, 31 jan. 1918.

CHIMINELLI, R.. Acqueforti ed Acquafortisti: Emanuele Brugnoli. Emporium, Bergamo, Itália, nov. 1922, pp. 262-275.

Clube dos Glifófilos. Correio da Manhã, Rio de Janeiro, 17 abr. 1949, p. 15.

Congresso Eucharistico de Lourdes. O Paiz, Rio de Janeiro, 23 jun. 1914.

Correio Musical Brasileiro. O Jornal, Rio de Janeiro, 21 mai. 1921

Cristo na inspiração de seis artistas. Illustração Brasileira, Rio de Janeiro, jul. ago. 1957.

Democratização da Arte. Jornal do Brasil, Rio de Janeiro, 12 fev. 1952.

DUQUE, Gonzaga. Salão de 1906. Kosmos, Rio de Janeiro, set. 1906.

DUQUE, Gonzaga. Salão de 1907. Kosmos, Rio de Janeiro, set. 1907.

E. de M.. Exposição Carlos Oswald. A Noite, Rio de Janeiro, 28 mar. 1917.

Em favor das belas artes. A Manhã, Rio de Janeiro, 3 fev. 1953. 
Escola de Bellas Artes - Salão de 1907 - "Vernissage". Correio da Manhã, Rio de Janeiro, $1^{\circ}$ set. 1907.

Exposição Carioca de Lithographia. O Jornal, Rio de Janeiro, 3 nov. 1919.

Exposição Carlos Oswald. A Gazeta, São Paulo, $1^{\circ}$ fev. 1923.

Exposição Carlos Oswald. A Gazeta, São Paulo, 24 jan. 1923.

Exposição Carlos Oswald. Correio Paulistano, São Paulo, 8 fev. 1918.

Exposição Carlos Oswald. Correio Paulistano, São Paulo, 21 jan. 1923.

Exposição Carlos Oswald. Correio Paulistano, São Paulo, $1^{\circ}$ fev. 1923.

Exposição Carlos Oswald. Correio Paulistano, São Paulo, 12 dez. 1923.

Exposição Carlos Oswald. O Paiz, Rio de Janeiro, 7 jul. 1916.

Exposição Carlos Oswald. O Paiz, Rio de Janeiro, 30 mar. 1917.

Exposição Carlos Oswald. O Imparcial, Rio de Janeiro, 12 abr. 1917.

Exposição das Bellas Artes. Gazeta de Notícias, Rio de Janeiro, 12 set. 1904.

Exposição de Águas-fortes. Correio da Manhã, Rio de Janeiro, 30 maio 1952.

Exposição de Arte Sacra. Correio da Manhã, Rio de Janeiro, 18 jun. 1950.

Exposições do mês. Illustração Brasileira, Rio de Janeiro, ago. 1950.

Exposição Juventas. A Notícia, Rio de Janeiro, 16 out. 1915.

Fallencia denegada. O Paiz, Rio de Janeiro, 30 out. 1915.

Fallencia. O Paiz, Rio de Janeiro, 10 ago. 1916.

FELIX, E.. Illustração Brasileira, Rio de Janeiro, 1º jun. 1913, p. 180 - 182.

Galeria Artística. Correio Paulistano, São Paulo, 14 fev. 1918.

GIOVANOLA, Luigi. Acqueforti ed Acquafortisti: Vico Viganò. Emporium, Bergamo, Itália, mar. 1912, pp. 195-212.

GOMES, Tapajós. Exposição Carlos Oswald. Correio da Manhã, Rio de Janeiro, 08 dez. 1935.

Gravura de Carlos Oswald. Illustração Brasileira, Rio de Janeiro, fev. 1948.

GULLAR, Ferreira. "A confusão é grande e a gravura não vai lucrar nada com isso". Entrevista com Oswaldo Goeldi. Jornal do Brasil, Rio de Janeiro, 01 dez. 1957.

Illustração Brasileira. Rio de Janeiro: Sociedade Anonyma O Malho, set. de 1920.

Illustração Brasileira. Rio de Janeiro: Sociedade Anonyma O Malho, out. 1920. 
Illustração Brasileira. Rio de Janeiro: Sociedade Anonyma O Malho, nov. 1920.

Illustração Brasileira. Rio de Janeiro: Sociedade Anonyma O Malho, jan. 1921.

Illustração Brasileira. Rio de Janeiro: Sociedade Anonyma O Malho, fev. 1921.

Illustração Brasileira. Rio de Janeiro: Sociedade Anonyma O Malho, mar. 1921.

Illustração Brasileira. Rio de Janeiro: Sociedade Anonyma O Malho, abr. 1921.

Illustração Brasileira. Rio de Janeiro: Sociedade Anonyma O Malho, jun. 1921.

Illustração Brasileira. Rio de Janeiro: Sociedade Anonyma O Malho, dez. de 1921.

Illustração Brasileira. Rio de Janeiro: Sociedade Anonyma O Malho, abr. 1922.

Illustração Brasileira. Rio de Janeiro: Sociedade Anonyma O Malho, ago. 1922.

Inaugurada fábrica que é única na América. Tribuna da Imprensa, Rio de Janeiro, $1^{\circ}$ ago. 1955.

Inaugurou-se hontem a exposição de pintura Carlos Oswald. Gazeta de Notícias, Rio de Janeiro, 24 maio 1916.

J.M.. Bellas-Artes - Exposição Águas-fortes. O Paiz, Rio de Janeiro, 24 nov. 1919.

LEITE, J. R. Teixeira. Clubes de Gravura. Diário de Notícias, Rio de Janeiro, 29 ago. 1963.

Letras e Artes. A Noite, Rio de Janeiro, 9 maio 1949.

Lyceu de Artes e Officios. Correio da Manhã, Rio de Janeiro, $1^{\circ}$ mar. 1914.

MAURÍCIO, Virgílio. O Salão Nacional de Bellas Artes. A Época, Rio de Janeiro, 15 ago. 1918.

MATTOS, Adalberto. A gravura à "Agua-forte” no Rio de Janeiro. Para todos, Rio de Janeiro, 25 set. 1926.

MATTOS, Adalberto. A gravura à água-forte no Rio de Janeiro. Illustração Brasileira, dez. 1922.

MATTOS, Adalberto. A gravura à Agua-forte. Para todos, 02 out. 1926.

MATTOS, Adalberto. Impressões de Arte. A Epoca, Rio de Janeiro, 27 jun. 1916.

MATTOS, Adalberto. O Salão de MCMXXIV. Illustração Brasileira, Rio de Janeiro, ago. 1924.

Movimento Artístico - Carlos Oswald. Revista do Brasil, São Paulo, fev. 1918, p. 172 - 179.

Notas de arte - Exposição Juventas. A Notícia, Rio de Janeiro, 16 out. 1915.

Notas de arte - Exposição Oswald. Jornal do Commercio, São Paulo, 25 jan. 1918.

Notas de arte. Jornal do Commercio, Rio de Janeiro, 1 set. 1906, p. 3.

Notas de arte. Jornal do Commercio, Rio de Janeiro, 12 set. 1902, p.3. 
Notas de arte. Jornal do Commercio, Rio de Janeiro, 13 set. 1903, p.3.

Notas de arte. Jornal do Commercio, Rio de Janeiro, 13 set. 1904, p.3.

Notas de arte. Jornal do Commercio, Rio de Janeiro, $1^{\text {o }}$ ago. 1915, p.6.

Notas de arte. Jornal do Commercio, Rio de Janeiro, 15 ago. 1915, p.2.

Notas de arte. Jornal do Commercio, Rio de Janeiro, 26 ago. 1916, p.6-7.

Notas de arte. Jornal do Commercio, Rio de Janeiro, 16 ago. 1914, p.6.

Notas de arte. Jornal do Commercio, Rio de Janeiro, 23 set. 1906, p.4.

Notas de arte. Jornal do Commercio, Rio de Janeiro, 26 ago. 1916, p.6-7.

Notas de arte. Jornal do Commercio, Rio de Janeiro, 27 maio 1913.

Notas de arte. Jornal do Commercio, Rio de Janeiro, 7 set. 1909, p. 7.

Notas de arte. Jornal do Commercio, Rio de Janeiro, 8 set. 1907, p.4.

Notas sobre arte. Jornal do Commercio, Rio de Janeiro, 1 set. 1895, p.2.

Notas sobre arte, Jornal do Commercio, Rio de Janeiro, 4 set. 1900, p.3.

Notas sobre arte. Jornal do Commercio, Rio de Janeiro, 10 set. 1901, p.3.

Notas sobre arte. Jornal do Commercio, Rio de Janeiro, $1^{\text {o }}$ set. 1895, p.2.

Notas sobre arte. Jornal do Commercio, Rio de Janeiro, 4 set.1900, p.3.

O “salon” de 1913 - Carlos Oswald - Luiz Cristhophe. O Imparcial, Rio de Janeiro, 9 set. 1913.

O salão de Bellas-Artes. Revista da Semana, Rio de Janeiro, 18 out. 1908.

OCTAVIO FILHO, Rodrigo. O "Salão" de 1918. Revista do Brasil, São Paulo, ano III, nov. 1918, n. 35, p.305-310.

O Salão de 1915. A Notícia, Rio de Janeiro, 25 jul. 1915.

Os amigos da gravura. Museus Castro Maya. Rio de Janeiro, IBRAM, 2017. Disponível em: < http://museuscastromaya.com.br/museu-da-chacara-do-ceu/exposicao-do-museu-da-chacara-doceu/os-amigos-da-gravura/>. Acesso em: 10 mar. 2017.

Os nossos artistas. Gazeta de Notícias, Rio de Janeiro, 13 ago. 1907.

PADILHA, Moacyr. Carlos Oswald, o Apóstolo da Gravura Artística no Brasil. Diário de Pernambuco, Pernambuco, 6 jan. 1952.

PAPINI, Roberto. Stampe Moderne D’Ogni Paese Alla Mostra di Firenze. Emporium, Bergamo, Itália, jun. 1927, pp.338-356.

PEDROSA, Mario. Curso de Desenho e Artes Gráficas. Correio da Manhã, Rio de Janeiro, 15 fev. 1947. 
PEDROSA, Mario. Selvageria a la Goering. Correio da Manhã, Rio de Janeiro, 21 fev. 1947.

Primeira exposição carioca de gravura a agua forte. A Noite, Rio de Janeiro, 19 out. 1919.

Primeira Exposição Carioca de Gravura a agua forte. Correio da Manhã, Rio de Janeiro, 30 out. 1919.

Registro de Artes - Carlos Oswald. Correio Paulistano, São Paulo, 29 jul. 1913.

SILVA, Orlando da. A obra de Carlos Oswald. Para todos, Rio de Janeiro, 16 nov. 1956.

SOCIEDADE PROPAGADORA DE BELAS ARTES. O Brazil Artistico: Revista da Sociedade

Propagadora das Bellas-Artes do Rio de Janeiro. Rio de Janeiro, Typographia Leuzinger, $1^{\circ}$ Trimestre - 25 mar. 1911.

Sociedade Propagadora de Bellas Artes. Jornal do Commercio, Rio de Janeiro, 27 set. 1911.

TORMENTA, Vera. Os gravadores discutem acaloradamente. Para todos, Rio de Janeiro, 01 nov. 1956.

Trabalho de um Pintor Brasileiro. A Cruz, Rio de Janeiro, 06 ago. 1950.

Tragédia Florentina. Illustração Brasileira, Rio de Janeiro, 15 ago. 1922.

Várias Notícias. Jornal do Commercio, Rio de Janeiro, 26 set. 1951

\section{Escritos de Carlos Oswald}

OSWALD, Carlos. Como me tornei pintor. Petrópolis, RJ: Ed. Vozes, [1957].

. A água-forte no Rio de Janeiro. Correio da Manhã, Rio de Janeiro, 20 jan. 1952.

- A água-forte no Rio de Janeiro. Documento datilografado, [s/d]. Arquivo Histórico do Museu Nacional de Belas Artes/IBRAM/MinC, Rio de Janeiro.

. A "Ceia de Emmaus" de Rembrandt. Documento datilografado, [s/d]. Arquivo Histórico do Museu Nacional de Belas Artes/IBRAM/MinC, Rio de Janeiro.

. Tocando Debussy. Illustração Brasileira, Rio de Janeiro, out. 1925.

. Praça da Senhoria. Illustração Brasileira, Rio de Janeiro, set. 1924.

. Os grandes problemas da arte. Jornal do Brasil, Rio de Janeiro, 09 dez. 1936.

. Arte, Religião e Moral. Vozes de Petrópolis, Petrópolis, c.1933, p.430-433.

. Arte Sacra. Vozes de Petrópolis, Petrópolis, c.1934, p.646-649.

. A linha na obra de arte. Vozes de Petrópolis, Petrópolis, ago 1938, p.481-488.

.Decoração sacra. Vozes de Petrópolis, Petrópolis, mai/jun 1943, p.344-347.

.Decoração sacra (II). Vozes de Petrópolis, Petrópolis, jul/ago 1943, p.500-507. 
. Arte Cristã. Vozes de Petrópolis, Petrópolis, jan/fev 1944, p.70-78.

385.

. Epifania na Alma do Artista. Vozes de Petrópolis, Petrópolis, mai/jun 1944, p.380-

.Artistas Cristãos: II) Henrique Oswald e seu Filho Alfredo. Vozes de Petrópolis, Petrópolis, jan/fev 1945, p.60-78.

. Água-Forte. Vozes de Petrópolis, Petrópolis, mai/jun 1945, p.300-306.

p.611-616.

.Um Programa Cultural Artístico. Vozes de Petrópolis, Petrópolis, set/out 1945,

. A Beleza da Matéria. Vozes de Petrópolis, Petrópolis, jan/fev 1947, p.51-59.

344. . Problemas de Arte Cristã. Vozes de Petrópolis, Petrópolis, maio/jun 1947, p.334$\overline{1947, \text { p.616-623. }}$

. A Sociedade Brasileira de Arte Cristã. Vozes de Petrópolis, Petrópolis, set/out

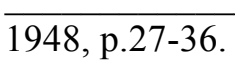

.Exposição de Arte Sacra Contemporânea. Vozes de Petrópolis, Petrópolis, jan/fev

.Objetos de Arte e Colecionadores. Vozes de Petrópolis, Petrópolis, mar/abr 1948,

p.169-175.

. Crise na Arte Moderna. Vozes de Petrópolis, Petrópolis, jul/ago 1948, p.473-478.

. Arte Abstrata. Vozes de Petrópolis, Petrópolis, set/dez 1948, p.662-667.

. Arte para a Igreja. Vozes de Petrópolis, Petrópolis, jan/fev 1949, p.47-54.

.Insistir. Vozes de Petrópolis, Petrópolis, jul/ago 1949, p.426-431.

585.

.Técnicas de Arte: o Vitral. Vozes de Petrópolis, Petrópolis, set/dez 1949, p.579-

. Arte Sacra Moderna. Vozes de Petrópolis, Petrópolis, mar/abr 1950, p.159-169.

1950, p.274-285.

. Sociedade Brasileira de Arte Cristã. Vozes de Petrópolis, Petrópolis, maio/jun

550, p.32-42.

. Imagens de Nossa Senhora. Vozes de Petrópolis, Petrópolis, set/dez 1950, p.540-

Imagens de Jesus. Vozes de Petrópolis, Petrópolis, jan/fev 1951,p.32-42.

. Decoração Sacra. Vozes de Petrópolis, Petrópolis, maio/jun 1951, p.276-284.

set/out 1951, p.477-485.

Atividades da Sociedade Brasileira de Arte Cristã. Vozes de Petrópolis, Petrópolis, . A Propósito da Bienal. Vozes de Petrópolis, Petrópolis, jan/fev 1952, p.46-52. 
p.159-166.

Santificado Seja o Vosso Nome. Vozes de Petrópolis, Petrópolis, mar/abr 1952, set/out 1952, p.493-497.

A propósito do Salão Nacional de Arte Moderna. Vozes de Petrópolis, Petrópolis, 638.

S. Francisco e a Arte Sacra. Vozes de Petrópolis, Petrópolis, nov/dez 1952, p.629-

Adorno e Religião. Vozes de Petrópolis, Petrópolis, jan/fev 1953, p.31-39.

Arte e Fé. Vozes de Petrópolis, Petrópolis, mar/abr 1953, p.168-175.

398. Arte Sacra no Século XX. Vozes de Petrópolis, Petrópolis, jul/ago 1953, p.393O Artista Cristão. Vozes de Petrópolis, Petrópolis, maio/jun 1954, p.244-252.

. S. Pio X e a Arte. Vozes de Petrópolis, Petrópolis, set/out 1954, p.473-479.

Matisse. Vozes de Petrópolis, Petrópolis, jan/fev 1955, p.29-35.

1955, p.257-262.

. A Oficina de Gravura a Água-forte. Vozes de Petrópolis, Petrópolis, maio/jun

Arte Plástica Cristã Simbólica. Vozes de Petrópolis, Petrópolis, jul/ago 1955,

p.389-396.

Como me tornei pintor (Notas Autobiográficas). Vozes de Petrópolis, Petrópolis,

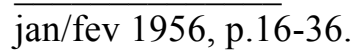

. Como me tornei pintor. Vozes de Petrópolis, Petrópolis, mar/abr 1956, p.149-166.

. Como me tornei pintor. Vozes de Petrópolis, Petrópolis, maio/jun 1956, 264-285.

385.

. Como me tornei pintor (IV). Vozes de Petrópolis, Petrópolis, jul/ago 1956, p.367-

. Como me tornei pintor. Vozes de Petrópolis, Petrópolis, set/out 1956, p.487-505.

. Como me tornei pintor. Vozes de Petrópolis, Petrópolis, ano 51, jan. 1957, p.23-

43. 1957, p.176-188.

. Notas Autobiográficas de um Pintor. Vozes de Petrópolis, Petrópolis, ano 51, mar. 1957, p.254-261.

Notas Autobiográficas de um Pintor. Vozes de Petrópolis, Petrópolis, ano 51, abr. 1957, p.342-351.

Notas Autobiográficas de um Pintor. Vozes de Petrópolis, Petrópolis, ano 51, maio 